
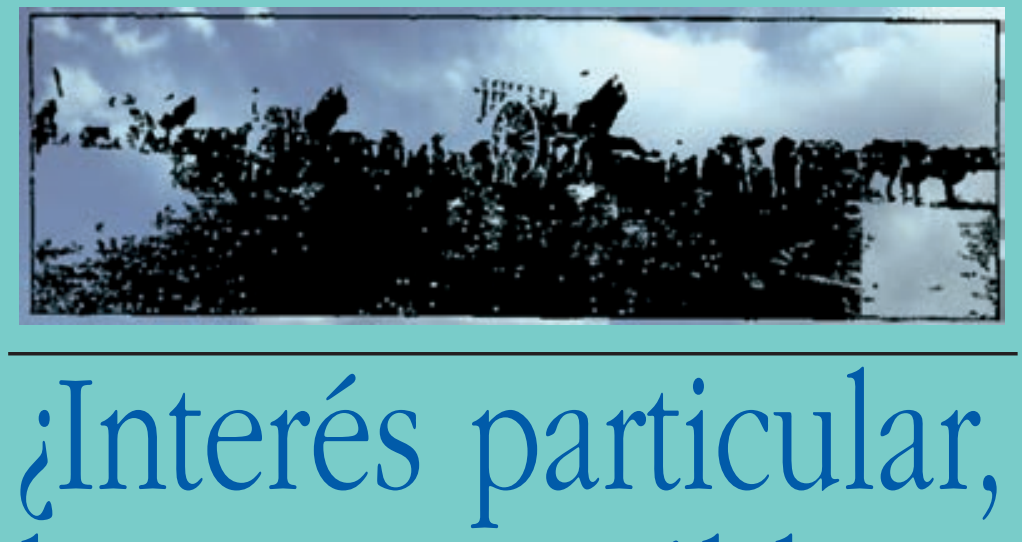
bienestar público? Grandes patrimonios y reformas agrarias

Ricardo Robledo y Santiago López (editores)

\title{
pers
}

Prensas Universitarias de Zaragoza 

¿INTERÉS PARTICULAR, BIENESTAR PÚBLICO?

Grandes patrimonios y reformas agrarias 



\section{¿INTERÉS PARTICULAR, BIENESTAR PÚBLICO? \\ Grandes patrimonios y reformas agrarias}

Ricardo Robledo y Santiago López

(editores) 


\section{FICHA CATALOGRÁFICA}

¿INTERÉS particular, bienestar público? : grandes patrimonios y reformas agrarias / Ricardo Robledo y Santiago López (editores). — Zaragoza : Prensas Universitarias de Zaragoza, 2007

581 p. ; $22 \mathrm{~cm}$. - (Ciencias sociales ; 62)

ISBN 978-84-7733-892-5

1. Reforma agraria-España-S. XIX-XX. 2. Reforma agraria-América latina-S. XIX-XX. I. Robledo, Ricardo. II. López, Santiago. III. Prensas Universitarias de

Zaragoza. IV. Serie: Ciencias sociales (Prensas Universitarias de Zaragoza) ; 62

332.021.8:63(460+8)«18/19»"

$338.43 .02(460+8) \ll 18 / 19 »$

No está permitida la reproducción total o parcial de este libro, ni su tratamiento informático, ni la transmisión de ninguna forma o por cualquier medio, ya sea electrónico, mecánico, por fotocopia, por registro u otros métodos, ni su préstamo, alquiler o cualquier forma de cesión de uso del ejemplar, sin el permiso previo y por escrito de los titulares del Copyright.

(C) Los autores

(C) De la presente edición, Prensas Universitarias de Zaragoza

1. ${ }^{\mathrm{a}}$ edición, 2007

Ilustración de la cubierta: José Luis Cano

Colección Ciencias Sociales, n. ${ }^{\circ} 62$

Director de la colección: Pedro Rújula López

Prensas Universitarias de Zaragoza. Edificio de Ciencias Geológicas, c/ Pedro Cerbuna, 12 50009 Zaragoza, España. Tel.: 976761 330. Fax: 976761063

puz@unizar.es http://puz.unizar.es

Prensas Universitarias de Zaragoza es la editorial de la Universidad de Zaragoza, que edita e imprime libros desde su fundación en 1542.

Impreso en España

Imprime: Línea 2015

D.L.: Z-1782-2007 


\title{
INTRODUCCIÓN: TIEMPO, INSTITUCIONES \\ Y REFORMAS*
}

\author{
Ricardo Robledo y Santiago López \\ (Universidad de Salamanca)
}

And in leaving out institutions, history, and distributional considerations, neoclassical economics leaves out the heart of development economics $[. .$.$] We are at least at the stage at which we know that we$ do not know. That is, perhaps, a good way to begin the new century.

K. Hoff y J. Stiglitz (2001), pp. 390 y 428

Como habrá reconocido el lector, hemos titulado el libro con una variación de la célebre frase de Mandeville «Los vicios privados hacen la prosperidad pública», subtítulo de su controvertida Fábula de las abejas, que escandalizó a los contemporáneos medio siglo antes de que A. Smith propugnara los beneficios de la mano invisible para lograr la riqueza de las naciones. ${ }^{1}$ Los signos de interrogación cuestionan aquella correlación y

* Proyecto de investigación de la Junta de Castilla y León, SA041A06 y Acción Especial del Ministerio de Educación y Ciencia (BHA 2002-1264-E). Agradecemos las observaciones de J. Carmona, D. Gallego, I. Iriarte y E. Tello, a quienes no hacemos responsables de los posibles errores que perciba el lector.

1 El libro se consideró «una indecencia pública» (Mandeville [1729] 1982). En el reciente libro de Roncaglia se matiza alguna de las lecturas simplistas que se hacen de este autor (Roncaglia, 2006), p. 129. 
dejan al lector la oportunidad de que, al acabar la lectura de estas páginas, siga manteniendo los interrogantes con más escepticismo o simplemente los quite siguiendo las lecturas más doctrinarias de los orígenes de la economía política. ${ }^{2}$ Las dos partes del libro ayudan a tomar esa decisión desde la perspectiva micro del estudio de los patrimonios y de la actuación macro de las políticas de reforma agraria.

En este libro se reúnen dos temas que no suelen ir juntos, gestión de patrimonios y reformas agrarias, de modo que una de sus ventajas consiste en acercar discursos que pueden enriquecerse mutuamente. Los especialistas de ambos temas no acostumbran a mezclarse, en parte porque la reforma agraria dejó de ser un tema estelar en la agenda del investigador hacia 1980. Pero la mezcla gran patrimonio-reforma es una de las asociaciones más socorridas para el historiador que suele basarse en la eficiencia/ineficiencia de la gran explotación para negar o justificar la reforma agraria.

Hace tiempo que los economistas españoles de ayer (pongamos que desde 1902, cuando Canalejas planteó el problema en las Cortes), como los historiadores de hoy, debaten sobre los males y virtudes del latifundismo. La investigación en historia agraria ha ido perfilando argumentos, muy debatidos por cierto, para explicar las características del capitalismo agrario español, que no puede quedar bien parado si la principal vara de medir es la inferioridad de la productividad agrícola respecto a las agriculturas atlánticas. Distinto es el diferencial que marca la desigual distribución de la propiedad, pero cuando se tienen en cuenta esas dos variables de las restricciones ambientales-tecnológicas y de la racionalidad económica del gran propietario, resulta complicado mantener la tesis más tradicional de la correlación latifundismo-atraso de la economía española. Ahora bien, la consideración de estas variables (sustentadas en un buen número de investigaciones) no significa compartir la idea de que, teniendo en cuenta una dotación ambiental inicial, el mercado se encarga de generar el desarrollo mejor esperable, o que son los impedimentos institu-

2 No hará falta recurrir a la «simpatía» de Smith en su Teoría de los sentimientos morales para corregir este sesgo, pero sí al importante papel concedido por Smith a la intervención del gobierno para apoyar el funcionamiento del mercado como institución social (Irwin, 1996), p. 78. 
cionales al libre mercado los que imposibilitan un mayor desarrollo.

Recientemente R. Garrabou y M. González Molina, al poner en un primer plano los factores ambientales, han demostrado que, teniendo en cuenta el nivel tecnológico y un determinado desarrollo de los mercados, la agricultura española difícilmente podía alcanzar las tasas de crecimiento de la producción y de la productividad que registraron algunos países europeos. Pero eso no quiere decir que la agricultura española contemporánea hubiera apurado sus posibilidades de crecimiento. Existían unos márgenes para mejorar los resultados, dicen estos autores, que dependían de las relaciones sociales y del marco institucional. Entre otros factores, una redistribución de la propiedad y la implantación de formas de tenencia más favorables a los cultivadores, al estimular procesos de especialización, hubieran podido mejorar los resultados, aunque sin llegar a los niveles de crecimiento de las agriculturas atlánticas europeas. ${ }^{3}$

Es decir, no es incompatible la aceptación de la restricción ambientalista-tecnológica y de la racionalidad económica con la incorporación de factores institucionales, porque aquellas variables no constituyen el fardo de inercias del pasado que condena a los brazos caídos, sino factores, no inmutables, que señalan los márgenes de actuación de los grupos humanos. Los grupos se dotan a sí mismos de instituciones que les permiten sacar más o menos rendimiento económico a un medio físico en función de un medio humano (entendemos por medio humano el resto de instituciones), sin tener toda la información de ambos. No es la dotación de factores del medio físico la que directamente determina el rendimiento económico, sino que es la relación que las instituciones permiten que las personas tengan con el medio (físico y humano) la que determina directamente el rendimiento económico, tal y como demostraron Acemoglu, Johnson y Robinson (2004). Obviamente, los grupos tendrán más incentivos para moverse y trabajar en zonas con recursos donde sea fácil lograr los mayores rendimientos económicos con instituciones sencillas.

Sacarle partido a un medio físico sólo se logra si el entramado institucional está diseñado para apoyar el crecimiento económico. Son las instituciones las que dan origen a la riqueza. Ahora bien, lograr la riqueza

3 Garrabou y González Molina (2006), p. 431. 
(estar cada vez mejor todos y cada uno) es un hecho difícil de conseguir, y ante este tipo de complejidad los humanos reaccionamos creando instituciones, porque facilitan la toma de decisiones.

Como ha indicado C. Knudsen las instituciones existen para resolver el problema de la toma de decisiones ante situaciones con información imperfecta y asimétrica. ${ }^{4}$ Las instituciones son el fruto de nuestras carencias de competencias a la hora de afrontar las dificultades. Cuanto mayor es la dificultad y menor es la información con la que contamos, mayor es la complejidad. En esta situación, crear o mantener, pero, en cualquier caso, seguir una regla es una forma de reducir la complejidad. Si la regla es buena permitirá incluso que la institución se acomode o supere el medio físico y humano. La eficiencia de las instituciones no sólo está en reducir costes de transacción e incertidumbres, sino en tener el grado de libertad suficiente para transformarse-evolucionar, permitir innovaciones y ampliar la capacidad de negociación interna de sus miembros. Consecuentemente, no compartimos la aplicación de algunas lecturas de la nueva economía institucional (NEI) como un "corpus» intemporal que se ha quedado cristalizado en la aceptación del cambio institucional adscrito a las reformas agrarias liberales, cuestionando en cambio intervenciones como las de la reforma agraria de carácter redistributivo o la realizada con criterios políticos de ampliación del acceso a la propiedad o uso de la tierra. ${ }^{5}$ Una reforma no deja de ser una regla, una institución que permite transformar, innovar y ampliar la capacidad de negociación de la sociedad. Aunque no sea la intención de sus mentores, una aplicación o lectura restrictiva de la NEI lleva directa o indirectamente a la legitimación sin más del statu quo con el argumento de que intentar modificar algo que funciona es empeorarlo. ${ }^{6}$ Creemos que

4 Knudsen (1993).

5 Sin profundizar más aquí, hay que señalar, como indican Toboso y Compés (2003), que los neoinstitucionalistas tienden a ignorar también el hecho de que la organización o entorno institucional existente suele ser a menudo el resultado de estratégicos conflictos distributivos entre diferentes grupos sociales.

6 Curiosamente el respaldo intelectual suele ser la mano invisible de Smith («persiguiendo su propio interés promueve el de la sociedad de forma más efectiva que si realmente intentase promoverlo»), pero esto es extrapolar un argumento nada conservador, pues iba dirigido contra el predominio del sistema mercantil o, como nos ha advertido V. Llombart, contra el hábito de los comerciantes e industriales (empresarios y capitalistas) que se dedicaban si podían a conspirar contra el bien público. Smith ([1776] 1988), tomo I, pp. 503-504. 
merece la pena explorar las alternativas que pudieran existir en la explotación y gestión de la gran propiedad, examinar la viabilidad o no de las reformas agrarias, sin descuidar algunas cuestiones metodológicas sobre la economía institucional, que es en lo que se centra esta introducción. ${ }^{7}$

\section{La eficiencia económica y la naturaleza de las instituciones}

Frente a lecturas esquemáticas del pasado, muy condicionadas por una visión estrecha de la eficiencia propia de la economía neoclásica, las nuevas interpretaciones de la economía institucional sostienen que una identificación directa entre la existencia de una institución y su duración atribuida a la eficiencia es errónea. No toda institución, por el hecho de existir, reduce costes, y menos aún de forma permanente a lo largo del tiempo. Los modernos institucionalistas, con North a la cabeza, reconocen actualmente el mal uso que se ha hecho y hace de esa asociación. ${ }^{8}$ Además, es una asociación antinatural para los historiadores, porque tan sólo es una suposición que se puede asumir si estuviéramos hablando de mundos sin cambios, sin

7 La Nueva Economía Institucional (NEI) no presenta un corpus cerrado; en esta misma introducción se acude a autores de la NEI (North, Ostrom...) que critican algunos de sus planteamientos, actitud que responde a las fronteras movedizas de esta escuela, pero también a su capacidad para recomponer razonamientos ante el reto de nuevos problemas. Por tanto, una lectura errónea de estas páginas sería la de una descalificación de la NEI, que sólo mantenemos cuando se utilizan varas de medir, por ejemplo la definición de los derechos de propiedad, como una panacea. La segunda edición del libro de Furubotn y Richter integra dos nuevos campos en la NEI: primero, la teoría de juegos de carácter evolutivo — además, conectada a ella estarían los análisis del pasado encabezados por Greif- y segundo, las teorías de la acción colectiva de Olson, entre otros. A estas perspectivas también cabe sumar en un segundo plano de importancia los desarrollos que la NEI ha encontrado en la Sociología y la Ciencia Política (Furubotn y Richter, 2005), pp. 34-40.

8 North (2005), p. 15. El análisis institucional histórico y comparativo (AIHC) de Greif acentúa aún más estas críticas, que el mismo North admite en su obra más reciente (North, 2005). Para las diferencias entre NEI y AIHC, véase Caballero (2004); cf. también Toboso y Compés (2003) y Tello (2005), pp. 113-117. Los economistas del desarrollo han marcado a menudo sus distancias con varias proposiciones de la NEI; además de las referencias que figuran más adelante, véanse por ejemplo Bardhan (1989) y Nabli y Nugent (1989); pese al comedimiento de sus críticas, estos autores no eluden hablar en ciertos casos de «funcionalismo ahistórico» e incluso de "vulgar darwinismo» de varios cultivadores de la NEI y de la dificultad de aplicar en los países en desarrollo políticas inspiradas en tal metodología. 
transformaciones, de mundos absolutamente estables. Posiblemente eso explique la prevención con que la mayoría de los historiadores, agrarios o no, han recibido el análisis de la NEI, especialmente por las primeras formulaciones que se fueron conociendo con motivo de la aparición del libro de Thomas y North y su roma interpretación del feudalismo.

Asumir que las instituciones son fruto de transformaciones y transformables, implica desprenderse de la hipótesis de que el mal funcionamiento de normas y organismos está en función de la desviación respecto a la institución de referencia tomada como modelo estándar. Tal modelo no existe desde el momento en que admitimos, como hace el propio North, que las instituciones tienen una naturaleza cambiante. Entonces ¿por qué ha habido confusión entre la existencia de instituciones y su eficiencia económica?

La clave radica en confundir la eficiencia de una institución con el hecho de que la eficiencia económica debería determinar la existencia y permanencia de toda institución en todo momento. Lo que debe ser no tiene por qué ser. Veamos por separado eficiencia y permanencia:

1) La eficiencia de una institución es su capacidad para reducir los costes de transacción y los costes de producción. Profundicemos un poco más. La eficiencia institucional es la reducción de los costes de producción gracias a que se facilitan las transacciones y consiguiéndolo a precios más bajos, es decir, elevando el bienestar material. La eficiencia establece, por tanto, una relación relativa entre unos y otros costes a favor de un descenso de los ligados a los factores de producción, mientras que a su vez la bajada del coste total (producción y transacción) ha de darse en términos absolutos.

2) La existencia y permanencia de una institución está ligada a su capacidad para disminuir la incertidumbre en el conjunto de los agentes implicados en ella. Si una institución permanece, es que estará consiguiendo que los que participan en ella puedan tomar decisiones más conscientes de sus repercusiones futuras. Es decir, una institución que reduce la incertidumbre aumenta la capacidad de adaptación o de reacción de sus componentes y de ella misma.

Por consiguiente, una institución capaz de reducir los costes de producción y de transacción, así como la incertidumbre, sería eficiente y tendría las bases para permanecer, porque no debería tener rival. Y desde una 
perspectiva de individualismo metodológico, además, no debería tener rival porque todo individuo tiene en su curva de utilidad los objetivos de reducir la incertidumbre para rebajar la tensión cotidiana (capacidad de predicción) y conseguir más y mejores productos a menores costes (maximizar-optimizar).

No parece, por tanto, que hubiera mucho lugar para controversias. El objetivo debería ser descubrir qué hace que unas instituciones aparezcan y sobrevivan sin ser eficientes económicamente. En este sentido se pueden apuntar dos razones:

Primera, las instituciones se cargan de rémoras. Las instituciones pueden desarrollar su capacidad de predicción, de reducción de la incertidumbre, en función de cosas muy diversas; lo pueden hacer utilizando desde creencias religiosas hasta conocimientos científicos, más o menos experimentados, más o menos hipotéticos. Consecuentemente, las instituciones se cargan de rémoras (concepciones equivocadas de la realidad o que no facilitan la relación con el entorno físico y humano, tanto institucional como tecnológico, lo que se da en llamar path dependence $)^{9}$ que hacen que se ralentice o incluso se detenga la optimización, ocasionando su decadencia o su desaparición más o menos violenta. Por tanto, las rémoras son consubstanciales a las instituciones si partimos de que la información es imperfecta e incompleta (no conocemos todo del universo, y lo que sabemos tiene equivocaciones). A esta perspectiva "pesimista» se le suele hacer la crítica de que en un mundo moderno, de economía de mercado y libre empresa, las rémoras sólo pueden proceder de no estar en la frontera de los conocimientos científicos: bastaría con innovar. Pero también tiene su contrarréplica el optimismo innovador: por un lado, las creencias son persistentes y desmantelar las instituciones en las que están presentes tiene profundos y ocultos costes (sunk costs). Por otro lado, la propia búsqueda de la eficiencia tiene su propia rémora, porque en muchas ocasiones ello supone anteponer la consecución de la amortización del capital instalado a la destrucción creativa que implican las innovaciones. Si se es eficiente a corto plazo - amortizando al máximo—, se suele ser ineficiente a largo plazo

9 Definimos path dependence en su acepción mínima, que vendría a decir que los procesos de aprendizaje por los cuales creamos hoy nuestros instrumentos e instituciones condicionarán nuestras decisiones futuras. 
—no dando entrada a tiempo a las innovaciones.

Segunda, la reducción de la incertidumbre y de los costes son hechos relativos que afectan más a unos u otros individuos vinculados a las instituciones. Sobre este aspecto profundizaremos en el siguiente epígrafe.

En conclusión, la cualidad que guía a toda institución — la eficiencia- no se debe confundir con el hecho de que toda institución exista y permanezca. Con lo expresado se evita caer en la idea de que las instituciones inevitablemente llegan a un estado de funcionamiento perfecto antes o después, y que, por tanto, el statu quo o el dejar hacer son aceptables como si fueran ya el mejor de los mundos posibles. Una norma o institución puede ser aparentemente "perfecta», pero no ser efectiva porque un marco de creencias erróneo crea otras normas que impiden su funcionamiento. ${ }^{10}$ Son tantos los ejemplos históricos de inadaptación, de fracaso en trasplantar marcos institucionales occidentales a los países en desarrollo, que no merece la pena pormenorizarlos.

\section{Eficiencia relativa y entornos cambiantes}

La eficiencia es un hecho relativo dentro de una institución. Unos individuos pueden sentir que la institución está ganando en eficiencia mientras otros opinan lo contrario. Ninguna institución tiene conciencia y menos puede optimizar y predecir. ${ }^{11}$ Estas funciones son humanas, y si la institución las «tiene» es porque las instituciones las rigen los individuos. Se es miembro de un organismo que es gobernado por unas normas que son admitidas. Esto nos lleva a plantearnos que la reducción de la incertidumbre es un hecho individual. La suma positiva de las reducciones - la incertidumbre colectiva - es la reducción de la incertidumbre que da una insti-

10 Como indican Greif, Hoff y Stiglitz, la capacidad para que se apliquen correctamente las normativas depende del medio socioeconómico, de la cultura y de factores políticos; por tanto, lo que podemos esperar es que un sistema en particular de una sociedad específica presente ineficiencias económicas (Hoff y Stiglitz, 2001, p. 445).

11 Si bien es cierto, como ha señalado Hodgson (1999), que las instituciones no sólo establecen restricciones o convenciones y proporcionan información; también los individuos pueden ser modelados y formados por las instituciones sociales. 
tución a cada individuo que la comparte o utiliza. Pues bien, no conviene olvidar que la reducción de la incertidumbre colectiva suele hacerse a costa de que para algunos de los participantes su incertidumbre particular se eleve, porque su mundo es el que se está cambiando. Así, por ejemplo, una institución que permita una definición de los derechos de propiedad sobre la tierra basada en títulos formales (registros de la propiedad, catastros... y contratos escritos) reduce la incertidumbre por la carga de información que conllevan dichos títulos, pero aumenta la incertidumbre entre los que tenían títulos basados en la costumbre y la tradición oral. Estos últimos son títulos más inciertos porque son más costosos de comprobar, no porque no sean legítimos, legales o verdaderos. Además, la existencia de derechos consuetudinarios de los de abajo, de acceso al «común», por ejemplo, contradice la idea de que la naturaleza de la propiedad se reconozca por su disfrute exclusivo; es decir, la definición de derechos no tiene sólo una intención de clarificación, neutra socialmente. Los que espigaban en los cercados ingleses en 1788 fueron acusados de recortar los beneficios del agricultor, como aseguraba la naciente economía política, y de incitar al fraude. ${ }^{12}$

En una situación de alteración del entorno humano o físico, los individuos que dan forma a la institución tendrán diferentes percepciones de la eficiencia de ésta y del grado de incertidumbre que reduce o provoca. Esas diferencias, asentadas en las diferentes creencias y conocimientos que tienen los individuos, los legitiman para tomar decisiones en pro o en contra de la institución, de su permanencia o de su reforma. Precisamente es este hecho el que nos interesa, porque toda reforma agraria está ligada a situaciones de rápido cambio de los entornos, defensa o ataque de unas creencias y conocimientos y tomas de decisión antitéticas, pero que cada individuo entiende como acertadas, adecuadas e incluso justas. Como señalan Acemoglu, Johnson y Robinson (2004, pp. 3-31), cuando se da un conflicto económico de intereses, bien entre grupos bien entre el individuo y el grupo, acerca de las decisiones a tomar, prevalecerá el de

12 Sancionar esa costumbre «abriría la puerta al fraude, porque los peones estarían tentados de esparcir el trigo para mejorar el espigueo de sus esposas, hijos y vecinos [...] aumentaría la insolencia de los pobres» (Thompson, 1995), p. 164. Los jueces ingleses, que se oponían al socorro consuetudinario de los pobres, necesitaban justificar la imposición de la ley sobre la norma consuetudinaria con una frescura que hoy queda disimulada en muchas formulaciones de la economía, institucional o no. 
aquel que tenga mayor poder político. Este hecho da a la reforma agraria un aparente sesgo de no racionalidad económica, cuando lo que sucede es que las instituciones económicas dependen de los pesos de los poderes políticos. Por supuesto, el que tiene el poder político puede tomar conscientemente una decisión económica no eficiente.

La realidad de nuestro mundo es que lo que hoy era eficiente puede no serlo mañana, porque los entornos, tanto el físico como el humano - nuevos conocimientos, nuevas tecnologías y nuevas instituciones-, varían. Al incluir el tiempo, al incluir la historia, nos encontramos con que las instituciones están en una permanente situación de pérdida-ganancia de eficiencia y pérdida-ganancia de capacidad de adaptación al entorno, de captación y gestión de una información creciente. Por tanto, la eficiencia y capacidad de reducción de incertidumbre son cuestiones relativas con respecto a la intensidad de cambio que proporciona el entorno.

\section{Las reformas agrarias y las instituciones}

Las reformas a las que se refiere este libro pueden acogerse al calificativo de reformas distributivas, si bien el tipo de propiedad objeto de la intervención es tan distinto como las instituciones del Antiguo Régimen o una hacienda de principios del siglo XX en América Latina. Todas se incluyen, pues, en un marco de mayor o menor intervención del Estado, que no por eso anula el marco liberal por el que se rige la economía. Si la intervención se produce es porque el grado de disfuncionalidad o de degradación de las instituciones (incluyendo las normas) bloquea el crecimiento económico o la estabilidad social, entre otros motivos.

El aparato analítico de la NEI no es la mejor herramienta para enfrentarse al tema de un cambio como el de las reformas agrarias, una vez consolidado el marco liberal; sirva como ejemplo que, en un libro dedicado al desarrollo económico, la brevísima intervención de D. C. North lleve como título «Needed: A Theory of Change»; siguen sin poder contestarse aceptablemente las preguntas de Gustafsson de cómo y por qué cambian las instituciones y de qué depende el que los resultados de esos cambios

13 Un resumen, en Tello (2005), p. 112. 
institucionales obstaculicen la eficiencia económica y la igualdad social. ${ }^{13}$ Aunque las instituciones dejen de ser variables exógenas para la NEI y se supere un análisis unidependiente del sistema de precios, muchos de sus cultivadores siguen sintiéndose más cómodos con los conceptos de racionalidad y de equilibrio, con más o menos imperfecciones, que con los opuestos. Si a lo anterior se añade la conveniencia de un marco liberal que permita la movilidad de los factores de producción, resulta complicado explicar el éxito de las reformas agrarias excepcionalmente exitosas: las de China, Japón, Corea, Taiwan se produjeron precisamente en un entorno autoritario o dictatorial donde el Estado cumplía algo más que la mera función de garante de los derechos de propiedad, y ahora sus economías agrarias presentan los menores grados de desigualdad del mundo. ${ }^{14}$

Este aspecto de los derechos de propiedad, de su consabida definición, se ha convertido, si no en un fetiche, casi en un comodín que sirve para explicar éxitos y fracasos en todo tiempo y lugar, ${ }^{15}$ si se acepta en la versión convencional de Demsetz-Coase de que, bien definidos los derechos de propiedad, se facilitan arreglos institucionales (internalizar externalidades) para conseguir resultados óptimos sin necesidad de impuestos o regulaciones por parte del Estado. Acemoglu (2003) defiende lo que él denomica «Modified Political Coase Theorem», que supone la inclusión de la ideología como previo determinante de la elección de unas u otras instituciones y decisiones. Creemos que es interesante para el historiador acercarse a otras versiones menos esquemáticas, como las de Deininger (2003, p. 25), que en la definición y seguridad de los derechos de propiedad incluye la duración de los derechos, la identificación de los límites, la capacidad de aplicación de los contratos a la hora de resolver los conflictos, la

14 Los países del mundo que ofrecen un desarrollo económico más equitativo suelen tener una correlación alta con haber realizado profundas reformas agrarias de carácter redistributivo (Frankema, 2006), pp. 9 y 10.

15 Con un marco institucional mejor definido, Argentina habría acortado distancias con respecto a Australia y Canadá, según han planteado L. Prados e I. Sanz-Villarroya (2004). Gelman (2005), p. 483, ha quitado hierro a tal hipótesis exponiendo que la disputa por los derechos de propiedad reflejaba más una querella por la distribución de los beneficios de ese crecimiento que una discusión sobre las posibilidades del crecimiento en sí. Bardahn (2001a), p. 275, opina que a menudo los seguidores de la escuela de los derechos de propiedad «displayed a naive presumption of the survival of the "fittest" institution". 
consideración de sujetos de derechos individuales y comunales y la evolución de los derechos según varíen las escaseces relativas. Es decir, en esta definición se detectan dos variables heterodoxas: los derechos no individuales y el tiempo.

La inclusión de los derechos comunales supone un ataque a la línea de flotación de la escuela de los derechos de propiedad, que basa precisamente en la privatización del común el mecanismo de la eficiencia para evitar «tragedias» y «gorrones». En la literatura internacional sobre el desarrollo, en efecto, se atribuyen al comunal virtudes públicas que parecían reservadas a los vicios privados, por seguir la expresión de Mendeville. Se ha demostrado que en el mundo comunal se puede conseguir una clara definición de los límites a los que están sometidos los usufructuarios, unas reglas transparentes de apropiación, una vigilancia efectiva y unos mecanismos para la resolución de los conflictos. Por el contrario, la aplicación efectiva de los derechos de propiedad privada, al convertir el comunal en mercancía, rompe los mecanismos de cooperación consuetudinarios y desincentiva inversiones dirigidas al mantenimiento de los recursos o a lograr objetivos comunes, como los costes de información derivados de la experimentación con nuevos cultivos. Que no se trata de idealización alguna se comprueba cuando vemos que se le asignan al comunal, según determinados contextos medioambientales, funciones que no cubriría nunca la iniciativa privada haciendo realidad equidad y desarrollo. ${ }^{16}$

La inserción de la variable tiempo en la definición no convencional de los derechos de propiedad se hace precisa para poder dar respuesta a los cambios sociales y económicos relacionados con el incremento demo-

16 La referencia habitual es la de Ostrom (1990); Runge y Defrancesco (2006), pp. 1723-1724, reconocen las características exitosas del comunal en la Magnifica Comunitá di Fiemme; Gibson et ál. (2005) analizan las razones del éxito en la gestión del común con un amplio estudio empírico; Deininger (2003), pp. 28-31; Bardahn (2001a), pp. 282-283; A. Berry (2002), p. 61, advierte del peligro de que, cuando en África subsahariana los sistemas comunales den lugar a derechos de propiedad occidentalizados, se produzca un tipo latinoamericano de concentración de la tierra. Las limitaciones de la NEI para explicar la pervivencia del comunal fueron expuestas ya por Iriarte Goñi (1998), pp. 117-122. Son muchos los historiadores españoles dedicados al estudio de los comunales que han sabido marcar distancias adecuadas con la NEI. Por citar el último trabajo, Iriarte y Lana (2006), y a nivel internacional Demélas y Vivier (dirs.) (2003), donde puede consultarse el trabajo de M. ${ }^{\text {T }}$ T. Pérez Picazo. 
gráfico o las oportunidades del comercio, lo que supone reinterpretar la tradición del «común» o las normas legales para hacer frente a las circunstancias cambiantes. ${ }^{17}$ Pero la inclusión del tiempo tiene otro horizonte que el de adecuar derechos a entornos cambiantes en la línea argumentativa expuesta en el apartado 2. Los derechos de propiedad pueden estar bien definidos, pero sustentando una institución de tal rigidez que se estén comprometiendo escenarios futuros. Una alta desigualdad en la distribución de la riqueza de la que se parte inicialmente puede reproducirse a sí misma de un periodo al siguiente. Del mismo modo que se plantea el asunto de la asignación intergeneracional de recursos en la economía ecológica, una gran desigualdad hoy puede limitar el crecimiento de modo permanente. ${ }^{18}$

Ante tal horizonte, el que relaciona desigualdad de la renta con crecimiento económico, ${ }^{19}$ es comprensible que los economistas del desarrollo replantearan la intervención del Estado en la distribución de la riqueza, sobre todo si se acepta la premisa de que son inseparables distribución, instituciones y eficiencia. ${ }^{20}$ Es otra de las divergencias respecto a neoclásicos y a buena parte de los neoinstitucionalistas, que miran con recelo la actuación redistributiva del Estado por suponer que favorecen creaciones improductivas de rentas.

Sin embargo, algunas de las intervenciones del Estado y algunas de las reformas agrarias han derivado del hecho de que no había una buena definición de los derechos de propiedad desde el momento en que las élites políticas podían usar su poder para expropiar los bienes y la producción de los que no formaban parte de la élite. Una buena definición de los derechos de propiedad, según Acemoglu, Johnson y Robinson (2004, p. 48), debería comenzar por constreñir y vigilar el uso del poder político por

17 Deininger (2003), p. 35.

18 Hoff y Stiglitz (2001), p. 394. Véase en este sentido el trabajo de Frankema (2006), pp. 16 y ss.

19 Entre la abundante literatura, pueden consultarse los trabajos de Domínguez Martín (2002) y Alonso (2005).

20 «La moderna teoría económica enfatiza que los costos de transacción dependen de las instituciones, que las instituciones son endógenas y que la distribución de la riqueza afecta a la eficiencia económica tanto directamente como a través de su efecto sobre las instituciones» (Hoff y Siglitz, 2001), p. 393. 
parte de las élites políticas.

Dentro de las intervenciones del Estado, la reforma agraria, que a fines de los 70 había dejado de estar en la agenda del investigador como en la de diversos grupos, volvió a ser motivo de preocupación en la década de los 90 para organismos como el Banco Mundial, aunque fuera con políticas de market friendly land reform. ${ }^{21}$ Motivos adicionales a tener en cuenta para entender el citado giro han sido el protagonismo de los movimientos sociales en América Latina, especialmente en Brasil, México, Bolivia y Perú, que testimoniaban la discrepancia con las políticas neoliberales, como afirman Víctor Bretón y Elisa Botella más adelante. Hasta en un país como Argentina, cuyo alicorto recorrido en las reformas de la tierra, según plantean Marta Valencia y Mónica Blanco, no era como para alimentar una tradición agrarista, ha vuelto a plantearse en el verano de 2006 la reforma agraria con medidas legislativas de expropiación y algún acto de tanto simbolismo como el protagonizado por un diputado peronista con el corte de alambradas de las estancias que el magnate estadounidense Douglas Tompkins había adquirido en el departamento de Corrientes. ${ }^{22}$

La perspectiva de que disponen los analistas de las reformas agrarias, de éxito desigual, ha ido enriqueciendo su tratamiento hacia la integración en una amplia estrategia de desarrollo rural con la incorporación de variables medioambientales o de género, mucho más evidentes y necesarias hoy que en el periodo de entreguerras, cuando el acceso a la tierra tenía un protagonismo ineludible. A pesar del escepticismo que haya podido generar

21 «Land reform is a many-splendoured thing». Así se iniciaba el trabajo "Poverty and the distribution of land» de K. Griffin, A. R. Khan y A. Ickowitz (2002). Puesto que el principal firmante, Griffin, había planteado la oportunidad de las reformas agrarias en los años 70, podría decirse que este trabajo simbolizaba el retorno a aquellos planteamientos después del paréntesis de la aplicación de políticas derivadas del Consenso de Washington.

22 Véanse las informaciones de Clarín o Página 12 el 17 de agosto de 2006, o de La Nación el 4 de septiembre de 2006; el diputado es el subsecretario de Tierras para el Hábitat, Luis D'Elía. La diputada kirchnerista Araceli Méndez fue la encargada de dar detalles del proyecto, que apunta "contra la concentración y extranjerización de la tierra». La legisladora remarcó dos aspectos estratégicos de las tierras sobre las que se pide la expropiación: «Están sobre el acuífero Guaraní (una de las reservas de agua potable más importantes del mundo) y a 700 kilómetros de la pista aérea de lo que será la futura base militar norteamericana Mariscal Estigarribia, en la república del Paraguay» (Página 12, 18-VIII-2006). 
la evolución de algunas reformas, cuya casuística desborda claramente esta introducción, parece haber acuerdo en valorar los efectos de las reformas en aspectos difícilmente cuantificables pero tan decisivos como articular redes sociales horizontales, que se hacen posibles cuando la reforma cambia la estructura del poder local; esto es lo que permite dar «voz» a los pobres (en la acepción de Hirschman) involucrándose en la gestión de las instituciones locales. ${ }^{23}$ Estos aspectos, minusvalorados con frecuencia por el análisis económico, ayudan a entender, sensu contrario, situaciones conflictivas que hacen fracasar la reforma por la oposición de los terratenientes a la pérdida de rentas políticas y sociales. La línea argumental desarrollada por Badhuri o A. Sen, a los que se refiere D. Gallego en el primer capítulo de este libro, respalda lo que decimos desde otro ángulo.

En resumidas cuentas, la herramienta de las instituciones se utiliza de muy diverso modo, señal de que es un concepto casi oceánico. Quizá, como sugiere Chang (2004), convenga cambiar el grado de conexión habitual entre instituciones y crecimiento hasta el punto de verlas más como resultado que como causa del crecimiento, y por tanto no tiene sentido generalizar una «actualización institucional» necesariamente uniforme y benéfica para todos los países.

\section{Reformas agrarias en España y América Latina}

La historia-plantilla tiene pocas dificultades para explicar el éxito o fracaso del crecimiento económico. Una vez aceptado el modelo exitoso occidental como norma e identificadas las variables institucionales que lo posibilitan (libertad, orden, justicia, bienes públicos...), es cuestión de mirar a otros universos (China o al Imperio árabe) para detectar las carencias institucionales occidentales y explicar el fracaso. Este modo de proceder ha sido cuestionado de forma convincente con argumentos que obli-

23 Bardahn (2001a), p. 282, y (2001b); véase también Deininger (2003), pp. 143156, A. Berry (2002), Griffin et ál. (2002), y Bernstein (2004).

24 Muchos de los temas se discuten en el libro colectivo de Brook y Blue (eds.) (1999), especialmente en las colaboraciones de F. Bray y Bin Wong; también, en Chang (2004). En Goody (2005), pp. 30-64, se encuentra una de las críticas más sistemáticas de los tópicos que alimentan la visión eurocéntrica (más bien anglocéntrica) de D. Landes; y más recientemente, en Hobson (2006), pássim, especialmente pp. 45-49. 
gan a repensar la historia económica que suele explicarse. ${ }^{24}$ Desde la economía del desarrollo, Bardahn (2001b) ha sido más directo al cuestionar el ideario de pacto surgido tras la Revolución política inglesa del siglo XVII - que garantizaba derechos de propiedad privada, empresa privada y mercado de capitales - como garantía del crecimiento, afirmando que esos factores no son ni suficientes (dada la importancia de los factores tecnológicos o de otro tipo) ni necesarios, como sugieren los triunfos del este asiático, basados más en las relaciones que en las normas.

La historia agraria española del siglo XIX sirve de contraejemplo a la historia-plantilla desde otro ángulo. Aunque alguna vez se ha elucubrado sobre la falta de definición de los derechos de propiedad, la flexibilidad del mercado laboral, la de los contratos de arrendamiento y la seguridad que concedía el Registro de la Propiedad desde 1861, bien podrían figurar como trípode de la definición más convencional de los derechos de propiedad. La constatación de este esquema liberal en el mercado de la tierra nos obligó hace tiempo a contestar a la pregunta de cómo conciliar la estrategia del propietario rentista con el desarrollo del capitalismo agrario en España, ${ }^{25}$ un caso que hoy podría plantearse desde el ángulo de la ineficiencia de las instituciones, de sus inercias y rigideces para adaptarse a los cambios demográficos, económicos o culturales, tal como se ha aludido anteriormente.

En España hubo que esperar a que se produjera el cambio de relación de fuerzas que supuso la llegada de la Segunda República para que se pudiera alterar la situación institucionalizada en las Cortes de Cádiz y corregir una desigualdad que sin duda tenía efectos económicos y sociales negativos. ${ }^{26} \mathrm{Y}$ sin duda esta alteración, especialmente en el primer

25 Se plantea en el epílogo de Robledo (1984), pp. 217-229. Un análisis sistemático, en Pujol et ál. (2001), con el debate recogido en Historia Agraria (2002), n. ${ }^{\circ}$ 28, pp. 179228, Carmona y Simpson (2003), Robledo (2004) y Pinilla (2004).

26 La cuestión es saber cuál era el margen que había para la intensificación, que unos ven muy reducido y otros no tanto; como advierte A. López Estudillo, «una estructura social agraria más igualitaria — con mayor peso de la explotación familiar y un nivel superior de los jornales - habría estimulado en el periodo aquí estudiado [1870-1930] unas pautas de especialización socialmente más favorables y con resultados económicos más dinámicos por la modificación en la distribución de la renta y en las pautas de la demanda, por sus efectos en los niveles de instrucción de la población» (López Estudillo, 2002), p. 171. También, González de Molina (1996) y las observaciones finales en el capítulo de Gallego. 
bienio republicano y después de febrero de 1936, al proporcionar a un mismo tiempo «salida» y «voz» a los menos pudientes (jurados de revisiones de rentas, jurados mixtos, comunidades de campesinos...), implicó no sólo una fuerte caída de la renta de la tierra, sino también una gran pérdida de rentas políticas y sociales. Aunque la República, a través del IRA (Instituto de Reforma Agraria), garantizara al terrateniente la renta de las fincas ocupadas o se las pagara a precio de mercado, cuando se aprobó la ley de contrarreforma de 1935, lo que no podía era compensar la pérdida de influencia política y social de los terratenientes. Probablemente esta disminución de los beneficios políticos derivados del cambio en la tenencia de la tierra y de la regulación del mercado de trabajo agrario fueron los que forzaron al derribo del cambio institucional manu militari. ${ }^{27}$

No es el momento de polemizar sobre la viabilidad de las reformas agrarias. Los capítulos de la segunda parte se encargan de ofrecer perspectivas no siempre coincidentes. En el capítulo 10, Luis E. Espinoza, R. Robledo, M. ${ }^{a}$ Pilar Brel y J. Villar se centran en la fuente del censo de campesinos, que tuvo en su origen, más que una motivación estadística, un objetivo político y social, pues de su inclusión o exclusión dependía acceder o no a los asentamientos. Cualquier estudioso de la historia social y económica de los años 30 sacará provecho de la información del número de jornaleros, pequeños propietarios, arrendatarios y sociedades obreras, que por primera vez se exponen a escala de partido judicial para la mayoría de las provincias españolas.

En el texto de J. Carmona y J. Simpson se presenta una visión más bien crítica de la reforma agraria, apoyándose en la estructura creada por la evolución histórica del latifundio. Este problema se vio reforzado por el predominio de la producción extensiva de cereales y ganado, un hecho que habría requerido grandes cambios si se hubiese deseado crear empleo suficiente, con el agravante de que muchos de los posibles beneficiarios de la reforma agraria carecían de experiencia y medios, pues, según los autores,

27 Robledo (1996), pp. 329-338. Los cambios en la tenencia de la tierra sólo fueron relevantes a partir del triunfo del Frente Popular, pues hasta octubre de 1933 no se empezó a asentar a campesino alguno. En la tesis de Francisco Espinosa (2006) se documenta la importancia de la reforma a partir de febrero de 1936. 
no habían sido arrendatarios antes de su redistribución. Las dificultades que habría supuesto la conversión de los latifundios andaluces en pequeñas explotaciones orientadas hacia el mercado habrían sido inmensas.

Muy diferente es la versión que ofrece la investigación de S. Riesco, resultado de su tesis doctoral, referida a Extremadura. La aplicación de los decretos de intensificación de 1932 y de yunteros de 1936 resultó una alternativa muy eficaz a la ley de bases. Se demostró que con voluntad política se podía pasar por encima de las trabas de los propietarios. Las iniciativas de la intensificación y también de la «declaración de utilidad social» durante 1936 demostraban que era posible otra reforma agraria. Aunque muy limitados por su aplicación en el tiempo y por la escasez de lotes para los asentados, los resultados de los decretos promulgados en un contexto de grave crisis social merecen ser analizados, ampliando así la visión de una reforma agraria orientada exclusivamente al aumento de la productividad agraria.

Los capítulos referidos a las reformas de América Latina antes de la guerra mundial se refieren a Argentina y México. En el primer caso, Marta Valencia analiza las discusiones y resultados del marco legal que rigió durante ochenta años en la provincia de Buenos Aires sobre las tierras que se incorporaron a la estructura productiva después de haber sido conquistadas, y que eran del dominio de los aborígenes; economía e ideología se mezclan en el contexto de la frontera y de la necesidad del poblamiento del «desierto». A pesar de los límites rigurosos que impuso la ley general de tierras públicas sancionada en 1876 para promover la subdivisión de la propiedad, la debilidad de las instituciones que debían controlar el proceso de parcelamiento y los intereses de los hacendados convirtieron en poco efectiva aquella legislación. Por su parte, Alejandro Tortolero analiza la influencia de las tesis de la ineficiencia de la gran propiedad proclamada por los liberales, fundamento ideológico de los planteamientos reformistas de la Revolución mexicana que sancionó la Constitución de 1917. Pero, según este autor, la ineficiencia no es tal si tomamos en cuenta su inserción regional y su vinculación con los mercados, y se trata más bien de un mito elaborado principalmente por Andrés Molina Enríquez. De ahí que explore también el impacto negativo de la reforma agraria sobre algunos grandes patrimonios situados en la región de Chalco, caracterizados durante siglos por ser la cuna de una de las agri- 
culturas más productivas de todo México.

El tratamiento de la reforma agraria a partir de los años cuarenta del siglo XX se explora primero en el trabajo de Mónica Blanco, que estudia el proceso de transformaciones en la estructura de tenencia de la tierra en la provincia de Buenos Aires (como representativa de la región pampeana) durante la particular coyuntura económica y política de las décadas de 1940 y 1960. Asimismo, se muestran las contradicciones generadas entre el discurso y la práctica legislativa, alrededor de la implementación de la prometida reforma agraria. Un recorrido parlamentario, legislativo y estadístico le permite concluir que el carácter revolucionario que se intenta dar al proceso de reforma en el agro pampeano deriva en un discurso político del peronismo que enfatiza el cambio, pero que no se traduce en una práctica legislativa igualmente innovadora.

Los tres tipos de reformas a los que se refiere este libro - la liberal del siglo XIX, las del periodo de entreguerras y las posteriores a la Segunda Guerra Mundial— se sitúan en contextos socioeconómicos e ideológicos muy distintos; el marco liberal en una fase mayoritariamente expansiva de la economía corresponde a las reformas agrarias del siglo XIX, lo cual contrasta con las que tienen lugar en el periodo de entreguerras, donde se acentúa la crisis del liberalismo tanto en lo económico como en la organización política. Las reformas que se extienden a lo largo de la segunda mitad del siglo XX responden a situaciones muy dispares, pero si hay que señalar una característica ausente en las anteriores habrá que aludir al factor de internacionalización, mucho más cuando concluía el siglo XX que anteriormente, bien por la participación de organismos internacionales a distintos niveles o por no poder eludir los países afectados las condiciones de la globalización.

Los dos últimos capítulos nos acercan a esta problemática de la globalización, desde cuya perspectiva aborda Víctor Bretón las aportaciones de las reformas de los años 70-80. No se trata tanto de proponer un balance exhaustivo de lo que supuso la era reformista, como de señalar sus «luces» — su contribución a la modernización de las estructuras agrariasy sus «sombras» - la situación en que quedó un porcentaje significativo de la población campesina-. Más allá de las interpretaciones convencionales, se pretende analizar algunos de los efectos nunca previstos - sobre todo en el ámbito de la redefinición de los actores sociales- y se plantea 
lo que hay de retórico o de razonable en el argumento de considerar obsoletas este tipo de medidas redistributivas, de nuevo reconsideradas por instituciones como el Banco Mundial como estrategia plausible de cara al futuro inmediato.

En el último capítulo, Elisa Botella analiza la importancia de los asuntos agrarios y rurales en las agendas de desarrollo de América Latina. Tras lo que Stiglitz acuñó como el post-Washington Consensus y las exitosas experiencias de industrialización del este asiático posteriores a la Segunda Guerra Mundial, en las que la agricultura y redistribución de la tierra tuvieron un papel muy significativo, el desarrollo agrario y rural y los procesos de reforma agraria en América Latina han recibido una renovada atención. Bajo el contexto actual de la globalización, surgen interesantes alternativas agrarias que debemos observar atentamente a la hora de elaborar políticas y agendas de desarrollo agrario y rural no sólo en las economías menos desarrolladas, sino también en los países industrializados. Este capítulo introducirá como ejemplos el caso de Brasil y el rol de los movimientos sociales en la promoción de la agroecología, y el modelo de agricultura sostenible nacido en Cuba como respuesta a la crisis de los 90 tras la caída del bloque socialista.

\section{Los grandes patrimonios agrarios}

Como decíamos al principio, no suelen juntarse patrimonios y reformas agrarias; de hecho, ésta es la primera vez que en un congreso de Historia Económica se le ha dedicado una sesión a la reforma agraria y podría decirse casi lo mismo de la Historia Agraria, pensando en el XII Congreso de la Sociedad Española de Historia Agraria (SEHA) de Córdoba de 2008. El lector tendrá ocasión de comprobar como se entrelazan ambos temas enriqueciéndose el análisis del cambio social y de las instituciones.

La propia inclusión de ambos aspectos muestra también, como afirma Domingo Gallego, que partimos de la hipótesis de que el cambio en el contexto social, provocado por una reforma agraria o por otras acciones, puede a su vez transformar los tipos de empresas, sus modos de gestión, así como las implicaciones de ambos aspectos sobre el desarrollo económico y sobre su viabilidad ambiental. De ahí que el autor recurra a la lite- 
ratura económica de carácter institucional para entender por qué, en algunos casos, las empresas son fuentes de nuevas posibilidades individuales o sociales, mientras que en otros se convierten en depredadoras de capacidades humanas y recursos naturales. En las características de las sociedades podemos encontrar algunas de las claves para explicar que los derechos de propiedad de unos sean un freno para el desarrollo de las capacidades de otros o un elemento que, junto a otros, den mayor seguridad a los procesos productivos y más transparencia a las relaciones comerciales, sin entorpecer las posibilidades de los que sólo poseen patrimonios muy reducidos.

Algunos de estos planteamientos teóricos se concretan en la investigación micro de los grandes patrimonios. Se trata de ocho trabajos, donde casi todas las regiones españolas están representadas, y en los que se ofrecen nuevas perspectivas sobre el cambio liberal en la propiedad y en la gestión de la gran propiedad. Además, tres de ellos, en un arco temporal que no suele ser habitual, llegan hasta la Segunda República, con lo que se analizan las repercusiones de la reforma agraria en el patrimonio de forma bien precisa, tanto económicamente como en otros aspectos sociales. Resumiremos las principales aportaciones en torno a cuatro temas:

1) Evolución de la renta de la tierra. Aunque en todos los capítulos se ofrecen indicaciones sobre la evolución de la renta, hay tres o cuatro que permiten un estudio a largo plazo, como el de Moreno para la casa de Bornos (1800-1924) y el de López Estudillo para el cabildo catedral de Córdoba (1700-1840). En el capítulo de A. Presedo se distingue la renta pactada y la efectivamente pagada, y cómo los impagos se integran en la contabilidad de los patrimonios de la hidalguía gallega. La llegada de la crisis agraria abre una doble vía: la de la erosión de la renta, que documenta bien Saguer en Gerona, y la que se percibe en las investigaciones de Moreno sobre la casa de Bornos y de Gastón y Lana sobre Zaldívar en Navarra, que aprecian una recuperación rentista a principios del XX con las consiguientes complicaciones de legitimidad a la llegada de la Segunda República en Navarra.

2) Efectos del cambio liberal: quien quiera interpretar el cambio decimonónico lejos de plantillas preconcebidas sobre la perfección de la propiedad, o sobre la imposición de la ley sobre la norma, hallará argumentos en varios capítulos. En el de J. Bonales se demuestra como el individualismo agrícola y el establecimiento de las normas del juego económico por 
parte de la comunidad rural en el Antiguo Régimen conformaban un marco de relaciones económicas, pero también sociales y políticas, en el que los grandes propietarios se veían obligados a negociar continuamente con las comunidades. La posibilidad de cambio que introdujeron las reformas liberales se vio atenuada por la obligación de mantener la negociación dentro del nuevo marco jurídico y por la capacidad de resistencia de las comunidades. Por su parte, A. Morey comprueba que el comportamiento de la antigua nobleza mallorquina ante la ley de abolición de vínculos y fideicomisos de 1841 no ha de valorarse tanto por la cantidad de tierras enajenadas como por las estrategias de la nobleza para evitar perder, precisamente, su condición de grupo terrateniente hegemónico. Interesa también el análisis de la parcelación selectiva de esta gran propiedad a través de un tipo de contrato de transmisión específico que exigía la conservación del dominio directo. Por último, debe fijarse también la atención sobre los fenómenos de recomposición patrimonial a los que se refieren Bonales, Morey y Gastón y Lana.

3) Sistemas de tenencia. Además del fenómeno de la persistencia, a contracorriente, de la aparcería en el patrimonio, estudiado por E. Saguer, y de los establecimientos enfitéuticos en Mallorca, A. López Estudillo presenta la aplicación de la cláusula de esterilidad (riesgos compartidos ante accidentes calamitosos), que transformó la cesión de los cortijos en una peculiar aparcería frente a las rentas fijas imperantes en los demás tipos de explotaciones cordobesas. La adecuación de esta fórmula frente a otras reglas y usos menos colaborativos, a menudo presentados como óptimos para la asignación de factores en todo tiempo y circunstancia, sirve de contrapunto histórico al excesivo grado de abstracción que a veces suele hacerse de la teoría de los contratos.

4) Gestión del patrimonio. Los cambios liberales afectaron a la gestión. A. Presedo se centra en la figura del mayordomo o administrador general, que adquirió nuevas responsabilidades: se perfeccionaron los mecanismos de registro de ingresos y se intensificó la comunicación epistolar entre el hidalgo propietario y los subalternos encargados de la administración de sus patrimonios. A. Morey explica la sustitución de los «parientes administradores» por los «administradores profesionales». Javier Moreno analiza como los Bornos redujeron sustancialmente los gastos de administración, adoptaron los organigramas de gestión de la intendencia 
militar y sometieron a mayor control a los administradores. Gastón y Lana exponen una trayectoria más amplia: tras una apuesta decidida por la inversión y la administración directa durante la fase expansiva de la segunda mitad del siglo XIX, las nuevas condiciones del capitalismo agrario tras la crisis finisecular condujeron a un viraje en las estrategias de gestión. J. Bonales acude a la teoría de la agencia para comprender la tendencia a la venta o cesión del patrimonio por parte del principal, y E. Saguer expone la orientación de un gran propietario, reformista social, dedicada a mejorar las viviendas de sus masoveros y a apoyar la inversión. Finalmente, en la comunicación de R. Serrano se nos presenta el declive de un gran patrimonio, ya extremadamente mermado a principios del siglo XX. Más que la contabilidad que refleja ingresos menguantes, conviene ver la influencia política de la administración cuando lo que se disputa es el liderazgo de la gente de orden en una comarca castellana: obtener el apoyo del duque o la desautorización por parte de su administrador no era asunto baladí en la reorganización y liderazgo de las fuerzas de la derecha en la Segunda República.

Sólo dos apuntes para concluir: desde que en 1973, en el primer congreso de Historia Económica, se presentara la comunicación de J. F. de la Peña y A. M. Bernal sobre la formación de una gran propiedad, hasta este octavo congreso, se ha ido acumulando un notable esfuerzo en la investigación sobre grandes patrimonios agrarios, que tal vez sobrepasa el centenar de monografías. Posiblemente ha llegado el momento de intentar captar la varianza (la variedad de aptitudes y situaciones de la población de grandes propietarios), frente a la media (el arquetipo representativo de propietario capitalista). En cuanto a la reforma agraria, la recuperación del tema de las reformas agrarias distributivas debería animar al análisis del difícil equilibrio entre eficiencia y equidad en el observatorio de la reforma de la Segunda República y de las reformas en América Latina.

Agradecemos a la Asociación de Historia Económica de España el que aceptara este tema de los grandes patrimonios y reformas agrarias dentro

28 Cambio institucional en la agricultura: modificaciones en la gestión de los grandes patrimonios y reforma agraria, sesión 18 del VIII Congreso de la Asociación de Historia Económica, celebrado en Santiago en septiembre de 2005. 
de las sesiones del VIII Congreso, celebrado en Santiago de Compostela. ${ }^{28}$ Esto ha permitido completar y ampliar las perspectivas y la metodología de otra sesión celebrada en el anterior congreso de Zaragoza, que dio origen a un libro publicado al poco tiempo (Casado y Robledo, 2002). El agradecimiento se hace extensivo a la Universidad de Salamanca, a la Junta de Castilla y León y también al Ministerio de Educación, por la concesión de la Acción Especial, que hicieron posible la celebración de una sesión preparatoria en noviembre de 2004 en la Biblioteca de la Hospedería Fonseca (Simposio Internacional «Gestión de Patrimonios Agrarios y Reformas Agraria». Finalmente, sin la generosa respuesta que recibimos de los autores a la invitación para participar en el congreso este libro hubiera sido imposible. Debemos destacar la labor de Elisa Botella, que asumió la tediosa tarea de confeccionar una bibliografía general. 


\section{I \\ GRANDES PATRIMONIOS}





\section{LAS EMPRESAS Y LOS DERECHOS DE PROPIEDAD. PROPUESTAS DESDE LA ECONOMÍA INSTITUCIONAL*}

Domingo Gallego Martinez

(Universidad de Zaragoza)

\section{Introducción}

El objetivo de este trabajo es mostrar, desde una perspectiva teórica, como el modo de funcionamiento de las empresas y las implicaciones que pueden tener los derechos de propiedad son muy dependientes del contexto social en el que unas actúan y los otros se ejercen.

Ello nos conduce a preocuparnos por las características de las sociedades, pues en ellas podemos encontrar algunas de las claves que permitan explicarnos el que los derechos de propiedad de unos sean un freno para el desarrollo de las capacidades de otros o que, por el contrario, sean un elemento que, junto a otros, dé mayor seguridad a los procesos productivos y más transparencia a las relaciones comerciales, sin entorpecer por ello las posibilidades de los que sólo poseen patrimonios muy reducidos. De modo similar, el análisis de la sociedad nos

* Este texto se basa principalmente en los apartados 2.1.2, 3.3 y 3.5 de un libro en proceso de elaboración. 
podrá dar pistas para entender por qué, en algunos casos, las empresas son fuentes de nuevas posibilidades para quienes participan o se relacionan con ellas, así como para el conjunto de la sociedad, o, en otros, se convierten en depredadoras de capacidades humanas y recursos naturales.

Para enfrentarnos a esta tarea, el primer paso va a ser utilizar la literatura económica de carácter institucional para poder llegar a alguna conclusión sobre cuáles son los rasgos básicos de una sociedad que induce a depredar a los otros y a la naturaleza y cuáles los que inducen a ser considerados con los intereses de los demás. Éste será el objetivo del apartado primero. En el segundo se presentará un concepto de empresa que permita identificar los caminos a través de los cuales las características de su entorno social y ambiental afectan a su modo de funcionamiento. A su vez, para poder pensar en las implicaciones de los derechos individuales de propiedad, será necesario situar estos derechos en la sociedad en la que se ejercen, es decir, en el contexto de otros modos de acceso a los recursos y en el de las formas en las que los propietarios hacen operativas las potencialidades productivas de los bienes por ellos poseídos. Éste será el objetivo del apartado tercero.

El hacer una reflexión muy general y desde una perspectiva teórica sobre estas cuestiones resulta, a mi entender, muy apropiado en el contexto de un libro en el que se analizan históricamente las consecuencias para el desarrollo económico de los modos de gestión empresarial y de las reformas agrarias. La propia inclusión de ambos aspectos (la gestión y las reformas agrarias) en un mismo texto muestra que los editores parten de la hipótesis de que el cambio en el contexto social, que puede ser provocado por una reforma agraria o por otras acciones, puede a su vez transformar los tipos de empresas y sus modos de gestión, así como las implicaciones de ambos aspectos sobre el desarrollo económico y sobre su viabilidad ambiental.

Para intentar ser funcional con este enfoque de los editores, el trabajo termina con un epílogo (parte cuarta) en el que se reflexiona, ya de modo más histórico que teórico, sobre las reformas agrarias y los modos de gestión empresarial, utilizando los instrumentos analíticos presentados en los epígrafes anteriores. 


\section{El peso de la historia: las inercias del pasado}

Dos autores tan distintos como North y Bhaduri coinciden en otorgar un considerable protagonismo a las instituciones como factores primarios inductores de las inercias sociales, aunque a través de dos perspectivas muy dispares. Las inercias estarían explicadas, según North ([1990] 1993), por el sistema de incentivos inducido por las normas y valores de una sociedad y, según Bhaduri ([1983] 1987 y 1998), por las relaciones de poder dominantes en ella entre los individuos y las organizaciones. En las páginas siguientes se tratará brevemente de las propuestas de estos dos autores, así como del enfoque adoptado en este trabajo.

Desde la perspectiva de North ([1990] 1993), el comportamiento se rige por valores y normas formales e informales asumidas consciente o inconscientemente por los individuos y los grupos. En la medida en que sean pautas de comportamiento generalmente aceptadas, las propias inclinaciones personales tenderán a ir en esa dirección, pero también la autocoacción, la del entorno inmediato y, en su caso, la coacción de la autoridad pública conducirán a su cumplimiento. Este marco de valores y normas es generador de incentivos y restricciones que afectarán tanto al comportamiento individual como al de las organizaciones (familias, explotaciones, empresas u organismos no mercantiles públicos o privados). Así, la impresión inicial es que los valores y las normas producen los incentivos que dan lugar a la constitución de organizaciones con objetivos y características compatibles con las normas y valores generales.

North no sólo señala la fuerza de los valores y normas sociales para inducir comportamientos, sino que además identifica el tipo de valores inductores del progreso. Éstos se concretan en el respeto a los derechos individuales, incluidos lógicamente los derechos de propiedad, pues este respeto, en la medida en que forme parte de los valores sociales, inducirá a que sólo se pueda contar con las capacidades o el patrimonio de otro a través de acuerdos mutuamente consentidos; y este consentimiento sólo se alcanzará, en el contexto de unas pautas hedonistas de comportamiento, si el acuerdo es beneficioso para todas las partes implicadas. Cualquier restricción que no sea mutuamente acordada o que se intente aplicar a agentes que no han intervenido directa o indirectamente en la negociación, 
supondría un riesgo de expropiación directa del patrimonio de los agentes excluidos y también un riesgo de que se recorten otros de sus derechos individuales. Estas situaciones, de hacerse efectivas, podrían ir debilitando las conexiones entre los intereses individuales y los colectivos, a causa de los incentivos para la constitución de organizaciones con objetivos más confiscatorios que productivos y para la introducción de restricciones a la competencia, es decir, a la libertad de movimientos de mercancías, personas y empresas.

Estas posibilidades de acumular unos a costa de otros afectarían negativamente a los otros y al conjunto de la sociedad, y es según North una de las principales razones que explican la persistencia del atraso en algunas sociedades. ${ }^{1}$ Pero el respeto a los derechos individuales, si está profundamente asentado, dificultará esos comportamientos parasitarios y tenderá a preservar la coherencia entre los objetivos e intereses individuales y los generales, pues, en este contexto social respetuoso con los derechos de los otros, para obtener cosas que no se poseen el único camino será producir, intercambiar o pactar redistribuciones de la renta o la riqueza. Todo ello, dada la existencia de costes de transacción, supondría también alcanzar acuerdos sobre las normas que definan los derechos de propiedad y sobre las que regulen los contratos a través de los cuales se organiza la cooperación. Los costes de transacción también inducirán a los particulares a la constitución de organizaciones de carácter público que coordinen los procesos de negociación social y garanticen la puesta en práctica de lo acordado. ${ }^{2}$ A su vez, a través de las empresas se organizará una cooperación directa entre los agentes que sustituirá y complementará, en aquellos casos en que los costes de transacción lo hagan conveniente, a la cooperación indirecta a través del mercado. Los derechos individuales serían así los principales inductores tanto de la cooperación productiva como de la formación de instituciones públicas respetuosas con los intereses de todos, como de la persistencia de la competencia, inductora a su vez de modos eficientes de cooperación.

1 Véase el tratamiento que North ([1990] 1993), pp. 121-136, hace de los casos de Estados Unidos y de Latinoamérica para ejemplificar las potencialidades de los valores individualistas.

2 Véase Coase ([1937] 1994) y ([1960] 1994). 
Olson ([2000] 2001, pp. 1-32) coincide con Coase ([1960] 1994, pp. 121-164) y North en la necesidad de un contexto institucional adecuado, pero ve inviable que sea a través del acuerdo entre los particulares como se logre construir, ya que las potencialidades de cooperación voluntaria en un mundo en el que rigen los valores individuales es efectiva tan sólo para la provisión de bienes privados a través del mercado, pero, en general, no para la provisión de bienes públicos, pues los individuos y las organizaciones tenderán, guiados por sus intereses egoístas, a beneficiarse de ellos evitando, al ser bienes de acceso libre, sufragar los costes de producirlos. Olson señala como alternativa la acción coactiva del Estado, condicionada a su vez por los intereses de quienes lo controlan. Estos últimos, aunque sean déspotas autoritarios, al tener intereses coincidentes con el conjunto de la sociedad (viven de ella, luego tienen que protegerla), tienden a estar motivados a modular la presión impositiva y a devolver a la sociedad parte de lo recaudado financiando la provisión de bienes públicos que faciliten la cooperación mercantil entre los particulares. Los estados que actúan en el contexto de sistemas políticos democráticos pueden ser, según Olson, particularmente eficientes en el logro de estos resultados, pues las mayorías sociales, al hacerse con el control del Estado, tenderán a combinar sus intereses individuales como propietarios con sus intereses como controladores del sector público. $\mathrm{Si}$, además, esas mayorías son inclusivas (están muy vinculadas por motivos económicos y culturales con los demás grupos sociales), sus intereses tenderán a incluir a los de las minorías. En estos casos los intereses de las mayorías como controladoras del estado irán confluyendo con sus intereses como ciudadanos y con los del conjunto de la población, tendiendo así a extraer vía impuestos justo la magnitud de recursos necesarios para producir los bienes públicos que la sociedad reclama.

En resumen, combinando las perspectivas de North, Coase y Olson, resulta que la interacción entre derechos individuales y Estado democrático creará las condiciones más adecuadas para el desarrollo económico, pues se complementarán las condiciones favorables para el funcionamiento del mercado y del Estado, es decir, para la complementaria producción de bienes privados y públicos. Para Olson ([1982] 1986), permanecería, sin embargo, el riesgo de que los grupos de presión orientaran al Estado a seguir sendas favorables para ellos, pero contradictorias con los intereses 
generales. Sólo en una sociedad dinámica estos riesgos podrán atenuarse al reducir el peso económico de los sectores maduros de la economía, que para Olson serían los más proclives a invertir en organizarse para condicionar la acción del Estado.

Pero Bhaduri ([1983] 1987 y 1998) señala además que la complementariedad entre intereses particulares y colectivos se puede romper, tanto en el ámbito mercantil como en el político, como consecuencia de la existencia de graves desequilibrios sociales, pues estos desequilibrios acabarán provocando serias contradicciones entre lo que es eficiente para la prosperidad general y lo que es eficiente para un grupo social concreto. Es decir, distingue entre eficiencia general y de clase y analiza en qué contextos pueden darse contradicciones graves entre ambas.

El núcleo de su argumentación se sitúa en las características de las organizaciones que operan en el mercado, para apreciar si participan en él de modo voluntario o forzado, pues en este segundo caso la relación entre intercambio y ganancia mutua se rompe y con ello también la relación entre intereses personales y generales, pese a que las organizaciones actúen en una sociedad mercantil en la que reine la propiedad privada de los recursos y las libertades individuales. ${ }^{3}$

Bhaduri da gran importancia en los ejemplos que utiliza a la posibilidad de elegir entre participar en el mercado y producir para autoabastecerse. En la medida en que esta posibilidad sea efectiva, la participación en el mercado será voluntaria y en la medida en que esta posibilidad disminuya, la participación en el mercado será forzada. Su ejemplo de comercialización forzada es el de unas explotaciones agrarias muy endeudadas que tienen que renunciar a combinaciones entre producción para la venta y producción para el autoconsumo, o entre producción para vender hoy o en el futuro, que les podrían ser más favorables. La causa de esta disminu-

3 El razonamiento sostenido por Bhaduri ([1983] 1987) se realiza bajo el supuesto de que está analizando sociedades donde los mercados de trabajo, productos y crédito aún no han tomado formas plenamente capitalistas. En el texto, sin embargo, se extienden sus planteamientos a mercados bajo condiciones institucionales propias de sociedades capitalistas, incluso al caso de sociedades capitalistas desarrolladas y democráticas. 
ción de su campo de posibilidades de elección será la necesidad de hacer frente a las obligaciones a las que su elevado endeudamiento les obliga, endeudamiento que tampoco mejora sus campos de posibilidades, pues sólo le permite financiar, y de modo muy precario, sus gastos corrientes de consumo y producción. En este contexto, el propio nivel de endeudamiento será también forzado, existiendo otras combinaciones de financiación externa e interna a las que no tiene acceso a causa de que sus urgencias y sus limitadas garantías le inducen a utilizar los servicios del crédito en condiciones muy onerosas, condiciones que provocan la reproducción de lo que Bhaduri denomina comercio forzado.

En estas condiciones, una de las partes puede perder con el intercambio y, a su vez, también la sociedad en su conjunto, en la medida en que esta situación afecte a grupos sociales amplios y dificulte su capitalización personal y empresarial. Por otro lado, si la actividad de préstamo y compra de las cosechas resulta rentable para prestamistas, propietarios o intermediarios, invertirán recursos en esta dirección, colapsando de este modo la mejora del capital físico y humano en el conjunto del sistema social. Es decir, Bhaduri indica con este ejemplo como el margen de maniobra de quienes participan en el mercado condiciona la capacidad de esta institución de inducir al desarrollo general combinando los intereses individuales.

Esta línea argumental se puede generalizar, pues implícitamente lo que señala Bhaduri es que los resultados de las negociaciones mercantiles serán tanto más coherentes con los intereses de cada una de las partes si cada una dispone de un campo de elección efectivo, es decir, si dispone de otras alternativas viables. El tamaño del campo de elección accesible para los distintos individuos, grupos y organizaciones será, por lo tanto, clave para que, mediante la negociación mercantil (y el caso es similar para la negociación política), se vaya alcanzando cierto grado de coherencia entre intereses particulares y generales. Es decir, no sólo son necesarios unos derechos de propiedad bien definidos y la interacción de los propietarios a través del mercado para inducir al progreso, sino, además, márgenes de maniobra amplios para todos, que eviten la prepotencia de unos y la falta de posibilidades de elección de otros tanto en la negociación mercantil como en la política, como en las que puedan darse en otros ámbitos de la vida social. 
Pero es que además los derechos de propiedad que propician estos equilibrios (es decir, cierta diversidad de opciones para todos) no tienen por qué ser exclusivamente los derechos individuales de propiedad, pues, por ejemplo, en no pocos casos históricos los derechos de propiedad colectivos cohesionan a los grupos reforzando su capacidad de negociación política y mercantil. Estos derechos colectivos ofrecen a su vez alternativas al mercado para proveerse de recursos, dando además mayor seguridad a los más débiles, en la medida en que es una propiedad inalienable y, por lo tanto, independiente de la situación económica de las familias. Las redes sociales que se tejen en torno a la gestión de la propiedad comunal facilitan también la cooperación y la transmisión de información entre los vecinos, lo que impulsa sus capacidades y, por lo tanto, aumenta su campo de elección.

Este ejemplo nos remite a su vez a que en cualquier sociedad existen diversos modos de organizar la cooperación, y cada uno de ellos con campos de eficiencia distinta en cada momento concreto. Es decir, en las sociedades no sólo hay mercados y organizaciones privadas que se proveen en el mercado y producen para vender. Encontramos también familias, organizaciones de carácter comunal o vecinal con su patrimonio y sus normas para aprovecharlo; encontramos instituciones públicas con muy diversos patrimonios y sistemas de captación de recursos vía impuestos que desarrollan a su vez una más o menos amplia diversidad de funciones institucionales y productivas. Existen también variadas redes sociales que enlazan a individuos, familias, vecinos, empresas, y que ofrecen a quienes están integrados en ellas nuevas oportunidades de cooperación. En casi todas estas organizaciones, al igual que en el mercado, el elemento central para que en los modos de cooperación estén conectados los intereses individuales y colectivos es la existencia de margen de maniobra efectivo para las partes que negocian entre sí en los diversos ámbitos considerados.

Resultará así, y ésta es la perspectiva asumida en este trabajo, que las claves para inducir unas inercias positivas en la evolución de una sociedad serán un conjunto de valores y normas sociales, combinadas con organizaciones de carácter privado, colectivo o público, que propicien al mismo tiempo un campo de elección relevante para los miembros de la sociedad y unas posibilidades abiertas y no excluyentes de utilización de los distintos ámbitos que permiten organizar la cooperación social. En estas condi- 
ciones, los distintos modos de cooperación se potenciarán mutuamente al potenciar las capacidades y los campos de elección de todos y cada uno de los miembros de la sociedad. ${ }^{4}$

En definitiva, la garantía más segura para los derechos individuales y colectivos es que los distintos agentes dispongan de un margen de elección relevante, lo que impedirá a unos imponer sus intereses a otros, pues los otros dispondrán de alternativas que les permitan no aceptar las propuestas de cooperación que no sean coherentes con sus propios intereses. Este margen de maniobra de unos y otros tenderá a influir favorablemente en todos los órdenes de la vida social en la medida en que se extienda a todos los implicados en cualquier forma de cooperación, sea familiar, vecinal, empresarial, comercial, sindical o política. Es decir, los valores, las normas y las organizaciones respetuosas con los intereses de todos se forman y se reproducen en contextos en los que los agentes sólo aceptan lo que les resulta ventajoso al tener un amplio campo de posibilidades de elección. Por el contrario, las normas aparentemente respetuosas con los derechos individuales, e incluso las instituciones democráticas, tenderán a desvirtuarse en contextos en los que el escaso margen de maniobra de unos les fuerce a aceptar las propuestas de los otros sin poder matizarlas para que sean consideradas con sus intereses.

Las potencialidades del modelo de sociedad resultante de las interacciones concretas que se den en cada caso entre individuos y organizaciones se verán a su vez favorecidas en su desarrollo si coinciden con unas condiciones ambientales no muy agresivas para la vida humana ${ }^{5}$ y que ofrezcan a su vez ciertas potencialidades productivas. ${ }^{6}$ Estos factores son

4 El acceso a un campo amplio de opciones, Sen ([1999] 2000), pp. 15-53, lo sintetiza en el concepto de libertad en el que se condensa la capacidad de acción, y por lo tanto también de negociación de las personas. La libertad se concreta así en el acceso a la salud, a la cultura, a los recursos y a la coordinación con otros a través de la integración en las redes y organizaciones sociales disponibles en una sociedad.

5 Véase Landes ([1998] 1999), pp. 19-30.

6 Estas interacciones pueden darse también en sentido inverso, pues son abundantes los ejemplos históricos de sociedades que por sus características no han sido capaces de aprovechar las posibilidades del medio natural en el que se asentaban o las potencialidades derivadas de la relación con otras sociedades. La incapacidad para limitar usos depredadores de seres humanos y condiciones ambientales, con sus consiguientes efectos negativos para el bienestar general, también estará relacionada con el tipo de sociedad, es decir, por la relación entre los campos de elección de sus miembros y organizaciones. 
particularmente relevantes si tenemos en cuenta que el desencadenamiento de las inercias positivas (y el de las negativas también) nos remite frecuentemente a periodos preindustriales o a épocas en las que aún la agricultura orgánica tenía un imponente peso en el empleo y en el suministro de alimentos y materias primas. ${ }^{7}$ Desde luego, el creciente papel que van a ir teniendo desde las primeras fases de la industrialización los recursos del subsuelo en la provisión de energía y materiales que sustituyan a los de origen agrario, sitúa también a estos componentes de la dotación de recursos naturales en un lugar clave para explicar el desenvolvimiento de las potencialidades de los sistemas sociales. ${ }^{8}$

Además, no puede perderse de vista, como impulsor de inercias primarias, el factor localización, $\mathrm{u}$ otros que propicien las relaciones entre sociedades distintas, ${ }^{9}$ pues los procesos de desarrollo necesitan también interacciones entre las sociedades que faciliten el trasvase de experiencias tecnológicas, organizativas y culturales. Este aspecto nos remite a observar que el desarrollo no es un proceso que pueda entenderse a nivel local, regional o nacional, pues las interacciones que lo hacen posible requieren de su paralelismo en varios espacios que se potencien mutuamente. Claro que, a su vez, este aprovechamiento de las inercias positivas que vienen de fuera requerirá unas condiciones sociales y ambientales locales que permitan su asimilación y aprovechamiento, y en este contexto se explica la diversidad de resultados dentro de espacios globalmente prósperos. En lo que respecta a la localización concreta de centros dinámicos en las sociedades prósperas, pueden darse algunos elementos de casualidad que inducen a procesos acumulativos, pero para que estas casualidades prendan suelen ser necesarias condiciones apropiadas que las hagan viables. ${ }^{10}$

7 Véase Sieferle (2001) y González de Molina (2001), pp. 43-50.

8 Para los modos de interacción entre naturaleza, sociedad y economía, véase Georgescu-Roegen ([1971] 1996), pp. 45-68 y 380-390, y Wrigley ([1988] 1993).

9 Hay factores que pueden paliar o neutralizar las consecuencias negativas de ubicaciones aparentemente perversas; es el caso, por ejemplo, de un idioma o de una cultura compartida o de la integración en países o en organizaciones económicas internacionales dotadas globalmente de condiciones favorecedoras del desarrollo.

10 Una reflexión sobre la relación entre la casualidad y la localización industrial puede encontrase en Krugman (1992). 
Así, desde la perspectiva de las inercias primarias, los desequilibrios sociales parecen difícilmente superables, así como los efectos que generan: una sociedad y un sistema económico poco integrados y poco diversificados. Es decir, existen valores excluyentes y discriminatorios, así como profundas desigualdades en el acceso a los recursos, que, al reproducirse, sostienen a unos sistemas sociales muy desequilibrados que dificultan la generación de recursos productivos y su utilización para el logro de objetivos de interés general.

Las condiciones favorables (sobre todo si son tanto de carácter social como ambiental) tenderán, por el contrario, a despertar las potencialidades de los individuos y de la colaboración entre ellos, logrando así modos más eficaces de aprovechamiento de los recursos humanos y naturales. Es decir, existen sistemas de valores que cohesionan al conjunto de miembros de la sociedad, y relaciones no muy desequilibradas entre ellos que, al tender a mantenerse, permiten la reproducción de unos sistemas sociales que facilitan la generación de recursos productivos y un aprovechamiento de sus potencialidades coherente con el interés general. ${ }^{11}$

La fuerza de las inercias se matiza si tenemos en cuenta que, al menos potencialmente, existen en las sociedades, incluso en las más desequilibradas, un conjunto de incentivos y de fuerzas que inducen a la negociación para mejorar las capacidades del grupo y de sus miembros e incluso a tener en cuenta, en el logro de estos objetivos, los requerimientos y restricciones del medio natural sobre el que actúan. La fuente principal de esos incentivos será la existencia de relaciones sociales densas y continuadas entre los miembros de una sociedad, pues ellas son el soporte en el que se desarrolla y se descubre la mutua utilidad o solidaridad de unos respecto a otros. El cambio, entendido como corrección de inercias negativas o potenciación de

11 En el texto se reflexiona desde la perspectiva de las inercias primarias, pero una vez puestas éstas en marcha generan valores, tipos de empresas y sistemas políticos que inducen a inercias evolutivas derivadas de una combinación interactiva de las distintas características de una sociedad. Para una reflexión sobre los distintos conceptos de evolución manejados explícita o implícitamente por las distintas corrientes de pensamiento económicos, véase Hodgson ([1993] 1995), en particular el capítulo 3. En López y Valdaliso (1999), pp. 32-35, puede encontrarse una útil síntesis de las inercias implícitas en las teorías evolutivas; y en Vara, Turmo y Rodríguez (2005), una presentación de las distintas tendencias de esta línea de pensamiento. 
las positivas, será inducido precisamente por estas fuerzas que conducen a tener en cuenta los intereses de los otros, pues gracias a ellas se podrá ir ampliando progresivamente el campo de elección efectiva de los miembros de la comunidad y de sus organizaciones. Pero en este trabajo no se va a tratar de las fuerzas que inducen al cambio, sino de las consecuencias, en un momento dado, de una combinación concreta de inercias sobre el funcionamiento de la empresa y sobre los modos de acceso a los recursos.

\section{La empresa en la sociedad}

Las empresas son uno de los modos de organizar la cooperación directa entre las personas y, en el caso de las economías de mercado, una de las principales razones de su existencia se deriva de las dificultades de poner en marcha (por motivos tecnológicos y comerciales) determinados tipos de actividades productivas a través tan sólo de la cooperación indirecta de carácter mercantil. Es decir, tras la existencia de las empresas están los requerimientos en cooperación directa de algunas actividades productivas y las características de los mercados, en la medida en que induzcan a costes de transacción más o menos elevados en relación con los que puedan resultar de la gestión directa.

Las relaciones de la empresa con el exterior se sitúan en el contexto de falta de transparencia e insuficiencias de la cooperación indirecta: según sean los mercados en los que actúe, y su implicación en cada uno de ellos, dedicará más o menos recursos a organizarlos, ya sea negociando normas y pautas de comportamiento que los regulen (o adaptándose a las existentes), ya tejiendo, de modo más o menos formal, relaciones con proveedores, clientes o suministradores de mano de obra (o aprovechándose de las relaciones previamente existentes entre ellos). Estos contactos sistemáticos con otras organizaciones podrán ser además la base sobre la que se apoyen pautas de cooperación que influyan en la organización interna de la empresa y en sus planes a largo plazo.

En las empresas y en los mercados existen caminos similares a través de los cuales el sistema social y ambiental condiciona su funcionamiento. Tanto las relaciones de las empresas con el exterior como su organización 
interna se verán afectadas por estas circunstancias. Las interacciones entre las empresas y el contexto en el que actúan se perciben con particular claridad en cuanto dejamos de pensar en la gestión empresarial como una mera planificación centralizada transmitida de arriba abajo en forma de órdenes imperativas. ${ }^{12}$ Efectivamente, se aprecia con bastante nitidez como las características de la sociedad en la que la empresa está instalada afectan a la coordinación empresarial en cuanto observamos el plan del empresario como un acuerdo negociado directa o indirectamente: el plan se adaptará en parte a unos hábitos, cualidades profesionales y capacidades de presión de la plantilla, de los proveedores y de los clientes, así como a las características del entorno social en la que la actividad productiva se desenvuelva. Las condiciones ambientales también abrirán posibilidades e impondrán restricciones a cualquier proyecto empresarial.

Suponer que el plan del empresario es un acuerdo negociado resulta bastante verosímil si introducimos en la argumentación las relaciones de agencia que afectan al interior de cualquier organización y a sus relaciones con otras organizaciones u otros agentes externos. El concepto agencia recoge las dificultades del principal para controlar las actividades de sus subordinados e implica que estos últimos tienen un margen de maniobra autónomo derivado de las peculiaridades técnicas de su actividad, de la información específica que tengan sobre ella y de los contactos propios que desarrollen en el desempeño de su trabajo o en otras actividades. Todo ello le da al agente autonomía y capacidad de utilizarla para el cumplimiento de sus propios objetivos, pero también le da capacidad de negociación frente a los otros agentes y frente al principal. En este contexto resulta bastante razonable proponer que el plan del empresario es un acuerdo negociado incluso en su aplicación al interior de la empresa.

Con respecto a las relaciones de las empresas con el exterior, la necesidad de negociar aún es más evidente, pues, aun en el caso de relaciones subordinadas entre empresas, el margen de maniobra de las dependientes

12 Sobre la evolución histórica de los modelos de empresa, véase Piore y Sabel ([1984] 1990) y Valdaliso y López (2000). Sobre los distintos tipos de organizaciones y las fronteras entre empresa y mercado, véase Salas (1996), pp. 15-47. 
suele ser bastante mayor que el de la mayoría de los agentes internos. La necesidad del empresario de negociar dentro y fuera de la empresa aún será más clara si sumamos a la relación de agencia la existencia de conexiones más o menos sólidas entre los agentes de una misma empresa y sus posibles contactos con redes externas de carácter familiar, sindical, político o empresarial. Otro tanto les puede ocurrir a las empresas subordinadas respecto a la principal, pues pueden estar conectadas entre ellas, integradas en organizaciones sectoriales o disponer de otros contactos comerciales o políticos. Todas estas circunstancias de agentes y empresas potencian su capacidad de negociación y les abren nuevas alternativas de empleo o de mercado.

En cualquier caso, las relaciones de agencia y las circunstancias que potencian el margen de maniobra de los agentes no sólo deben interpretarse como un problema que, para solucionarlo, requiere gastos en control y supervisión, sino también como un elemento que puede aumentar la capacidad de las organizaciones y de las relaciones entre ellas, pues induce a combinar en los acuerdos de gestión las distintas problemáticas de los distintos departamentos y empresas y los intereses de los distintos sujetos privados y colectivos que cooperan en el funcionamiento de una empresa o de una red de empresas. ${ }^{13}$ Es decir, el margen de maniobra de los agentes y organizaciones permite que en la actividad empresarial se pueda combinar el desarrollo de un proyecto con la potenciación de las capacidades de las organizaciones y agentes que colaboran en él, e incluso se puede llegar a controlar más eficazmente las consecuencias ambientales de lo acordado.

El concepto de agencia aplicado a la relación del empresario con las condiciones ambientales puede ser también operativo. En unos casos, a través de la capacidad de acción autónoma de quienes se vean afectados por las consecuencias ambientales de las actividades desarrolladas por la empresa, ya

13 Como se señalaba en el apartado 1 siguiendo la línea argumental de Bhaduri (1998), el resultado de los procesos de negociación será tanto más representativo de los intereses generales cuanto más amplio sea el margen de maniobra de las personas u organizaciones implicadas en la negociación. Hay que resaltar que el uso que en el texto se hace del concepto "agencia» es poco habitual, pues combina la dificultad de control del agente por el principal con la idea de Sen ([1999] 2000), pp. 34-36, de que esa libertad de agencia es inductora de capacidades de acción y de negociación que pueden ser productivas para el agente y para la organización en la que actúa. 
sean trabajadores, otras empresas o grupos no conectados directamente con la actividad empresarial, pero sí con sus consecuencias. Pero también la propia naturaleza puede por sí misma tomarse (forzando el concepto) como un agente con el que el empresario coopera. Es decir, al tener la naturaleza su propio campo de maniobra autónomo (su propia lógica de funcionamiento), tendrá que ser considerada por sí misma en el plan del empresario para evitar enfrentarse a degradaciones de suelos, a insuficiencias de recursos hídricos, a riesgos de inundaciones o de derrumbamientos o, en general, a procesos de contaminación ambiental de distinta intensidad.

Presentar el plan del empresario como algo que se va fraguando en un proceso de negociación conduce a su vez a pensar que las partes que participan en él se ven incentivadas a organizarse de modo más o menos formal y a definir sus propias estrategias de negociación. En este sentido, se aprecia cierta simetría entre el interior y el exterior de la empresa, pues los modos en que se organizan quienes participan en ella van a tener repercusiones en ambos ámbitos, y en ambos ámbitos hay necesidades objetivas de organizarse para actuar en buenas condiciones como comprador, vendedor, empresario o trabajador por cuenta ajena, ya se sea directivo, técnico, administrativo o personal poco cualificado.

La constitución de una empresa en este contexto supondrá un acoplamiento técnico, organizativo y político entre las personas que la componen y entre las empresas con las que se relaciona, y de todo ello con el medio ambiental en el que se actúe. Este acoplamiento se irá validando y consolidando con la experiencia e irá caracterizando a cada empresa como una organización dotada de sus peculiares capacidades. La clave de su reproducción y expansión será que sus particulares capacidades sean comercialmente relevantes y suficientemente flexibles para aprovechar las oportunidades que vayan apareciendo en los mercados. Pero debemos tener en cuenta que las capacidades y limitaciones de estas organizaciones no son algo que se pueda explicar tan sólo desde ellas mismas, pues muchas de sus características son consecuencia de la sociedad y del medio natural en el que actúan, ya que precisamente su viabilidad como organización dependerá de adecuarse a las condiciones del medio en el que se desenvuelven para aprovecharlas mejor. Al hacerlo podrán atenuar la agresividad ambiental de sus actuaciones y también potenciar las capacidades 
de los agentes y organizaciones con los que cooperan directa o indirectamente. Las empresas pueden también intentar adaptar su entorno a sus necesidades, pero incluso su capacidad de hacerlo dependerá de la relación entre sus posibilidades y las de los otros grupos que pujarán como ella por adecuar el marco institucional a sus peculiares necesidades. ${ }^{14}$ En la medida en que esta puja no sea en exceso desequilibrada, se podrá combinar el cambio con los intereses generales.

La acción exterior de las empresas será a su vez de gran trascendencia en los procesos de negociación que van configurando la organización de los mercados, pues no en vano una gran parte de quienes negocian en ellos son empresas. Pero no perdamos de vista que no sólo las empresas participan en esta negociación social; también participan en ella (directamente o a través de sus organizaciones o de la intermediación del sector público) las explotaciones familiares, los trabajadores, los consumidores y una gran diversidad de asociaciones profesionales. Las propias características de las administraciones públicas y del sistema político en que se desenvuelvan afectarán considerablemente a los resultados que se deriven del funcionamiento de la economía de mercado.

En definitiva, el marco en el que actúan las empresas repercutirá en sus capacidades, pero también en las consecuencias que su despliegue como organización tenga sobre el medio natural y sobre las capacidades de las personas y organizaciones con las que se relacione. En el próximo apartado se mostrará como los modos de acceso a los recursos que rigen en una sociedad afec-

14 La visión de la empresa que se ha utilizado en este apartado ha tenido como principal objetivo mostrar sus conexiones con el entorno en el que actúa. Para lograr este objetivo se han utilizado, matizándolos, conceptos que Valdaliso y López (2000), pp. 28-60, incluyen en las que denominan economía de los costes de transacción y economía de las relaciones de agencia. La virtud de estas perspectivas para el objetivo señalado es que ven a la empresa en su contexto más que en ella misma. El problema es que dejan fuera algunos aspectos vitales, como son las características y potencialidades de los distintos tipos de organizaciones, que explican una parte relevante de su dinámica. Para paliar este problema se ha hecho hincapié en el carácter productivo de las organizaciones, es decir, de las empresas, señalando que mediante ellas se pueden hacer cosas que serían inviables con la sola coordinación mercantil, por muy transparentes que fuesen los mercados. Esta matización creo que facilita la inclusión de algunas de las aportaciones de las teorías que ven a la empresa como «recipiente de capacidades». 
tarán a las capacidades de los que en ella se desenvuelven, a los modos de gestión de las empresas, así como a sus consecuencias sociales y ambientales.

\section{De los derechos de propiedad y de otros modos de acceso a los recursos}

Los derechos de propiedad permiten a quienes los ejercen acceder a los recursos poseídos, y en su caso comerciar con ellos o con los servicios que generan. En la medida en que el acceso a los recursos es un paso inevitable para el consuno o para organizar cualquier tipo de proceso productivo, y teniendo en cuenta que en los intercambios se requiere al menos un mutuo reconocimiento de los derechos de posesión sobre las mercancías intercambiadas, se hace evidente que los derechos de propiedad ocupan un lugar clave en el funcionamiento de cualquier economía y, por supuesto, también en las economías de mercado. Por los mismos motivos, tienen también una elevada trascendencia las normas que regulan el uso de los derechos de propiedad sobre los distintos tipos de bienes, así como las que regulan los contratos de cesión de la propiedad o del usufructo de los recursos poseídos.

No nos puede extrañar, por lo tanto, que sea frecuente situar los derechos de propiedad individuales como el núcleo explicativo de las potencialidades de los mercados: su generalidad, la precisión en su definición y la seguridad en su posesión y disfrute se suelen convertir en piezas clave para explicar las potencialidades del mercado, particularmente si se tiene en cuenta que las decisiones con más capacidad de inducir al crecimiento económico son las de inversión y éstas, al suponer grandes desfases entre los desembolsos y los resultados, son especialmente sensibles a la seguridad en la posesión y a las expectativas de un escrupuloso cumplimiento de los contratos. ${ }^{15}$

15 Véanse particularmente las mejoras en la eficiencia en las negociaciones mercantiles gracias a una adecuada definición de derechos de propiedad (Coase, [1960] 1994) y la importancia de la seguridad en los acuerdos no autoliquidables (Olson, [2000] 2001), pp. 216-235. Una visión general de los derechos de propiedad desde esta perspectiva neoclásica, puede encontrarse en Eggertsson ([1990] 1995). 
Pero el desenvolvimiento de las potencialidades del mercado requiere a su vez, como se ha sugerido en los apartados anteriores, de otros ámbitos que le nutren de recursos humanos y materiales, y también de información, criterios, normas y organizaciones vitales para mantener la interacción mercantil entre particulares y empresas. En esos otros ámbitos es frecuente que la propiedad no sea el camino único (y, en no pocos casos, ni el principal) para el acceso a los recursos y a su aprovechamiento. Es decir, es frecuente que en la cooperación no mercantil los propietarios no sean los únicos con acceso a los bienes que poseen, sino que también otras personas accedan a ellos por estar de algún modo vinculadas con los propietarios. A su vez es también muy habitual que los propietarios no gestionen directamente los recursos poseídos, sino que lo hagan a través de organizaciones de distinto tipo, por lo que de las características de estas últimas dependerá buena parte de los resultados alcanzados. En definitiva, los modos en que se organiza el acceso a los recursos de los que no son propietarios, y las formas de organizar la gestión de sus recursos por los propietarios, pasan a ser elementos que condicionan las potencialidades de unos derechos de propiedad dados y que explican, a su vez, la persistencia y reproducción de su diversidad en las distintas sociedades capitalistas, incluidas las más desarrolladas. En los párrafos siguientes me voy a ocupar con mayor detenimiento de estas cuestiones.

Es evidente que una parte considerable de los bienes a los que accedemos no son de nuestra propiedad, ni accedemos a ellos previa operación de intercambio o contrato de cesión de su usufructo. En primer lugar estarían aquellos bienes a los que, siendo propiedad particular de algún o algunos individuos concretos, otros tienen también acceso de modo más o menos restringido y regulado, pero sin ningún tipo de contrato de arrendamiento o cesión temporal. Efectivamente, en algunos casos disponemos de bienes que no son de nuestra propiedad por el mero hecho de pertenecer a nuestros abuelos, padres, cónyuges, hermanos, es decir, accedemos a ellos como miembros de un grupo familiar, dentro del cual se irán organizando, de modo más o menos formal, los modos de acceso a los correspondientes recursos. Dentro de este mismo grupo de bienes de propiedad particular, pero de uso colectivo, pueden incluirse algunos de los que son propiedad de amigos, vecinos o conocidos, que en ciertas circunstancias 
facilitan el acceso a ellos, generalmente de modo más restringido que cuando se trata de familiares. Algunos servicios son suministrados incluso sin ningún tipo de relación entre las partes, que pueden estar ligadas simplemente por lazos de solidaridad de carácter general o vinculados por alguna característica del beneficiario que sensibilice al propietario: origen, edad, sexo, aspecto, situación, religión, raza.

Otro tipo de bienes o servicios a los que pueden acceder particulares, profesionales y empresas sin ser propietarios son los pertenecientes a asociaciones profesionales o empresariales de distinto tipo, a sindicatos, grupos políticos, organizaciones asistenciales (las ONG entre ellas), órdenes religiosas. En algunos casos, para acceder a ellos o a los servicios que prestan se requiere pertenecer o estar relacionado de algún modo con la organización propietaria; en otros, el acceso a sus servicios puede ser libre o estar restringido a personas o empresas con alguna peculiaridad específica. Los bienes a los que se accede o los servicios que se reciben a través de este tipo de organizaciones pueden ser muy diversos. Unos, ligados al esparcimiento o a la formación: zonas deportivas, lugares de reunión, servicios religiosos, espectáculos, clases, bibliotecas. Otros pueden facilitar servicios básicos a personas en situaciones extremas: alojamiento, ropa, alimentos, protección, información. Otros pueden facilitar el acceso al mercado a personas o empresas: información laboral, contactos comerciales o asesoramiento legal, tecnológico o financiero. Es a su vez frecuente que, en paralelo a la prestación de algunos de los bienes o servicios mencionados, el mero contacto entre personas con similares problemas induzca a modos de cooperación interpersonal o interempresarial, tanto para el desarrollo de actividades políticas o reivindicativas como para la organización de nuevas actividades mercantiles, como para la mutua prestación de servicios no mercantiles complementarios a los suministrados por las organizaciones que han facilitado el contacto. Estos modos de acceso a los recursos, como los ejemplos comentados indican, no son sólo propios de particulares o de la provisión de ocio, cultura o formación, sino que también las empresas, los profesionales y los trabajadores por cuenta ajena pueden acceder mediante estos modos no mercantiles de cooperación a recursos útiles para el desarrollo de sus procesos de producción y comercialización. 
También una buena parte de los bienes propiedad de las distintas administraciones públicas formarían parte del grupo al que se accede sin ser propietario. En general los bienes propiedad de las administraciones públicas son de acceso más o menos regulado a la totalidad de la población o a algunos segmentos de ella: calles, parques, espacios naturales de titularidad pública, carreteras, bibliotecas, centros cívicos, colegios y hospitales públicos, centros públicos para la prestación de servicios a empresas o a particulares. A ello se añaden los servicios de carácter general prestados por los funcionarios públicos en orden a la limpieza o a la seguridad. A todos ellos se accede como ciudadano o como ciudadano con algún tipo de perfil particular. El acceso supondrá generalmente el cumplimiento de unas normas impuestas por la administración, pero también, frecuentemente, por los demás usuarios.

En una posición intermedia entre la propiedad de organizaciones privadas y la propiedad pública estarían los bienes propiedad de instituciones vecinales, que sólo son accesibles a los vecinos de un lugar o incluso a tan sólo una parte de ellos. Sería el caso de los espacios comunales o vecinales antes de que pasasen a ser propiedad municipal, e incluso después, pues tras el cambio de titularidad suele perdurar la restricción para su uso a personas no censadas en la localidad. En este caso, las normas para el uso de esos espacios o de los servicios de algunas instalaciones (molinos, batanes, prensas, acequias, almacenes, locales) suelen dar lugar a estatutos y a control mutuo entre los vecinos de los modos de aprovechamiento de los recursos.

Usamos también recursos naturales no apropiados ni por particulares ni por ningún tipo de organismo público o privado. El caso del aire o las aguas internacionales es uno de los más evidentes. Pero incluso en estos casos, pese a la no apropiación, existen normas que regulan su aprovechamiento; así, orientan a usar determinados tipos de combustibles o motores, indican pautas a seguir respecto a la limpieza de las cisternas de los buques y, por lo tanto, nos remiten a instituciones, nacionales e internacionales o a acuerdos entre ellas, que regulan estos comportamientos. Es decir, en este caso el uso del recurso, pese a no estar apropiado, responde a normas y a usos sociales y, por lo tanto, la adecuación de su uso a los intereses generales dependerá de las características y capacidades de las ins- 
tituciones que regulan su aprovechamiento, así como de los valores que condicionan el comportamiento de los usuarios.

Es evidente, por lo tanto, que a una parte muy considerable de los bienes y servicios que utilizamos no accedemos ni en calidad de propietarios ni de adquirientes de los bienes o de los servicios que generan. Estas posibilidades son factibles por la existencia de las diversas formas de propiedad que se han ido presentando indirectamente en los párrafos anteriores: propiedad privada individual de uso familiar; propiedad privada individual abierta a terceros con los que se tienen vínculos distintos a los familiares; propiedad privada de organizaciones que abren a otros el uso de sus recursos; propiedad colectiva de grupos de empresas o particulares para la prestación mutua de servicios fuera del ámbito del mercado; propiedades en manos de las distintas administraciones públicas, abiertas de modo más o menos general a personas, empresas y otras organizaciones; propiedades vecinales, como punto intermedio entre la pública y la de las organizaciones no mercantiles; espacios o recursos no apropiados por nadie (ni personas ni organizaciones) y de uso más o menos regulado por acuerdos entre quienes suelen utilizarlos. Las variantes de cada uno de estos tipos de propiedad, combinadas con los distintos modos de regular el acceso a los recursos, abre una gama de posibilidades aún más amplia que la aquí considerada.

Estas formas abiertas de propiedad y de ejercer la propiedad implican que, junto a los propietarios legales (particulares u organizaciones de distinto carácter), otras personas, grupos u organizaciones inciden (al acceder a ellos) en sus formas de uso, de tal modo que los posibles objetivos de la propiedad se combinan con los de otros sujetos en la medida en que tengan acceso y algún grado de control efectivo sobre los recursos poseídos por otros. Así, los modos de uso efectivos de la propiedad individual tenderán a combinar objetivos individuales, familiares e incluso vecinales en algunos casos; los objetivos de organizaciones públicas o privadas, con los de los usuarios concretos (individuales o colectivos) que de hecho tengan acceso a los bienes o servicios poseídos o gestionados por aquéllas. Es decir, estos modos abiertos de propiedad facilitan la posibilidad de sostener formas de cooperación distintas a la mercantil que son vitales para el propio funcionamiento de la economía de mercado. La perseverancia de 
esas otras formas de propiedad y cooperación se debe, por lo tanto, a la necesidad de organizar el mercado y a la existencia inevitable de circuitos no mercantiles, los naturales evidentemente, pero también la familia, las administraciones públicas y otros muchos modos no mercantiles de organizar la cooperación humana. Su importante presencia, particularmente en las sociedades capitalistas más desarrolladas (tanto en el inicio de su andadura hacia el capitalismo como en la actualidad), nos muestra que su desarrollo se ha sustentado y se sustenta, entre otras razones, en su capacidad de combinar una amplia diversidad de modos de cooperación. ${ }^{16}$

Pero es que, además, la utilización de la propiedad individual para la puesta en marcha de actividades productivas con objetivos meramente mercantiles implica, en la inmensa mayoría de los casos, dar entrada a otros en el manejo de los recursos propios. Con ellos entrarán no sólo sus habilidades y capacidades productivas, sino también sus particulares intereses, que en alguna medida acabarán impregnando al conjunto de la organización empresarial y a sus objetivos. Las formas que pueden tomar estas participaciones son muy variadas, pero lo más frecuente en estos casos es que la participación de terceros se realice mediante contratos mercantiles de compraventa de servicios. En unos casos serán contratos de trabajo que implicarán la incorporación con distintas funciones y condiciones de trabajadores con sus particulares competencias profesionales. En otros se combinarán los contratos laborales con la cesión del usufructo de parte del patrimonio de la empresa a otros trabajadores o empresas, a través de diversos contratos en los que se establecen obligaciones recíprocas. Este último sería el caso de los distintos tipos de contratos de cesión de fincas en arrendamiento o aparcería, o de cesión del uso de redes comerciales, de marcas, de sistemas de fabricación.

16 No resulta adecuado, a mi juicio, hablar de fallos del mercado, del Estado o de la familia para explicar la convivencia entre unos u otros modos de cooperación. El hecho es que, dada la complejidad de las sociedades actuales (y de la mayoría de las anteriores), ninguna forma de cooperación por sí misma tiene capacidad de hacer frente a la provisión de todas las necesidades individuales y colectivas. Las creencias en posibles únicos caminos aumentan riesgos y restan efectividad, pues la eficiencia de cada modo de cooperación depende de la de los demás. 
Todos estos contratos darán lugar a que, aunque el propietario tuviese unos objetivos iniciales exclusivamente individuales para organizar la puesta en marcha de una nueva empresa, la puesta en marcha efectiva de sus proyectos termine combinando los suyos con los de otros para poder dar viabilidad a sus planes. Y también, en cierta forma, a través de este mecanismo, parte de la influencia económica y política implícita en la posesión de esos bienes pasará a quienes de hecho tienen cierto control sobre ellos sin llegar a ser propietarios. Este último resultado, aunque es de carácter general, se aprecia de modo particularmente claro en el caso de las personas que, sin ser propietarios, ocupan puestos relevantes en la gestión de una empresa. ${ }^{17}$

Es decir, también a través de las empresas gestionadas con objetivos mercantiles, personas que no son propietarias acceden a los recursos poseídos por otros para poder desarrollar las tareas que se les encomienden, pero también, en parte, para poder atender a sus propios objetivos. En la medida en que estos agentes puedan disponer de cierto margen de autonomía respecto al principal, su capacidad de hacer que cuenten sus objetivos particulares será mayor $\mathrm{y}$, en ese sentido, sus intereses y criterios incidirán en los modos de utilizar bienes poseídos por otros. Incluso su influencia social y profesional y su remuneración puede verse afectada por esta circunstancia. La actividad empresarial consistirá en este contexto en hacer compatibles los requerimientos de sacar adelante un determinado proyecto con las distintas capacidades y objetivos de los distintos propietarios y agentes que tienen que participar en él para hacerlo viable.

\section{Consecuencias de los distintos modos de acceso a los recursos}

De este recorrido resulta que es mucho más frecuente de lo que puede parecer el acceso a recursos de los que no se es propietario y, a su vez,

17 Si los propietarios son diversos, esta combinación de objetivos e intereses a la que se alude en el texto aún será más evidente. Si la propiedad y la gestión están separadas, la combinación de intereses distintos en el proyecto empresarial todavía será más clara. 
menos frecuente de lo que aparenta el uso particular por su propietario de los recursos por él poseídos. ${ }^{18}$ Es decir, las capacidades de los individuos y de las organizaciones y su posibilidad de utilizarlas no dependen sólo del acceso a los bienes que posean, sino también de las posibilidades abiertas de acceder a los recursos de otros, y a los naturales no apropiados, por vías mercantiles y no mercantiles. Las condiciones en las que se realice este acceso tendrán también gran importancia, pues de ellas dependerá que los objetivos e intereses de los no propietarios tengan mayor o menor incidencia en el uso dado a los recursos. Claro que estas posibilidades y sus consecuencias son y han sido muy distintas en unas y otras sociedades.

En la actualidad hay sociedades con administraciones públicas de gran envergadura que prestan servicios de muy distinto tipo a los particulares, a las empresas y a otras organizaciones. Sociedades que suelen tener además una amplia articulación no mercantil entre sus miembros por la pujanza de organizaciones y redes de carácter familiar, vecinal, sindical, político y asociativo de distinto tipo. Sociedades que cuentan también con sistemas empresariales caracterizados por la existencia de amplias trabazones entre las empresas que los integran, que dan lugar a vínculos estables entre ellas, así como a la existencia de organizaciones sectoriales que les facilitan el acceso a mercados, a servicios, a técnicas o a influencia institucional.

En este contexto, la gran magnitud del patrimonio poseído particularmente por algunos individuos o empresas será un factor que indudablemente condicionará positivamente su margen de maniobra, pero el potencial de ese patrimonio será resultado del uso de las capacidades de quienes se incorporan a colaborar con él como asalariados, como empresas asociadas mediante vínculos más o menos sólidos o como proveedores y clientes más circunstanciales. Los usos de los recursos públicos y de los

18 Pese a todo, hay pequeños talleres y comercios cuyo propietario es el único operario y utiliza directamente los recursos que posee. Hay no pocas personas que viven solas y no comparten sus bienes de uso doméstico con nadie y, en fin, cada uno tenemos un limitado conjunto de bienes de propiedad y uso particular. Todo ello nos remite a ámbitos o a actividades en las que la cooperación interpersonal es muy débil o transcurre, en mayor medida que en otros casos, a través del mercado. 
servicios de las organizaciones en las que esté integrado serán otros tantos factores que potenciarán sus resultados. Pero al desenvolverse en una sociedad donde los otros, además de capacidades productivas, tienen capacidad negociadora, la cooperación con ellos requerirá integrar en los proyectos propios los intereses y objetivos de los demás agentes. Es decir, la cooperación directa con los otros aumentará la capacidad productiva de los recursos poseídos e inducirá a combinar objetivos particulares con los generales. Incluso aquellas decisiones empresariales guiadas sólo por los precios tenderán a adecuarse mejor, en sociedades de este tipo, a los intereses generales en la medida en que el acceso extendido y no muy desigual a la renta haga que las necesidades de todos se reflejen a través de la demanda directa de los particulares, o mediante su demanda indirecta reflejada en los criterios de gasto de las organizaciones no mercantiles que nutren a particulares y empresas de bienes y servicios.

A su vez, en este tipo de sociedades la debilidad del patrimonio poseído resta margen de maniobra, pero pese a ello es posible acceder a un relevante desarrollo físico, intelectual, profesional o empresarial. El acceso a recursos y a conexiones por vías no mercantiles podrá completar las obtenidas vía renta y mercado. La formación, los recursos y las conexiones con otros adquiridas por diversas vías suministrarán margen de maniobra a la hora de elegir, y también capacidad negociadora. La existencia de una gran diversidad de organizaciones empresariales o de otro tipo con las que cooperar directa o indirectamente es, además de una fuente de oportunidades, una baza adicional al negociar con ellas. Todo ello, y las normas y valores generales que en estos contextos suelen equilibrar las relaciones entre las partes, facilitará que, al incorporarse o relacionarse con otras organizaciones, éstas se vean abocadas a tener en cuenta en cierto grado los objetivos e intereses de la otra parte.

Es decir, el desigual reparto de la propiedad de la riqueza genera desigualdades relevantes incluso en sociedades muy trabadas socialmente, pero esa trabazón, al potenciar los modos de cooperación no mercantiles y al inducir a considerar los objetivos de los demás en las formas mercantiles de cooperación, provoca que las desigualdades patrimoniales personales se vean ampliamente reducidas en términos de renta y de bienestar. Todo ello tenderá a limitar tanto los desequilibrios sociales como los 
ambientales, al disponer los posibles afectados por ellos de capacidades para manifestar sus problemas y para poner en marcha negociaciones que intenten paliarlos.

Pero la propiedad de otros pasará a ser un factor de exclusión en el acceso a los recursos, o inductora de modos de acceso a ellos muy desfavorables para los no propietarios, cuando se combine la fuerte desigualdad en la distribución personal de la propiedad con la débil presencia de modos de cooperación no mercantiles. En sociedades de este tipo, la propiedad privada se convierte en la fuente principal de capacidades y oportunidades y la exclusión de la propiedad, en la causa principal de la posible marginalidad social de unos o de las carencias serias de otros, pese a que puedan estar integrados de un modo u otro en las empresas organizadas por los poseedores de los recursos productivos. Esta situación dificultará la capacidad de respuesta de los sectores excluidos de la propiedad ante los problemas de todo tipo con los que se vayan encontrando, ya sean de carácter social o ambiental.

Es decir, pese a que la cooperación mercantil sea inductora de otros modos de cooperación y tienda a aumentar sus potencialidades al combinarse con ellos, no todas las sociedades tienen capacidad de responder con similar intensidad a estos incentivos que de una u otra forma sienten asalariados, profesionales, empresarios de distinto rango o consumidores, de tal modo que en unos casos resultan sistemas económicos complejos por las formas de acceso a los recursos y por los tipos de derechos de propiedad que los sostienen, y en otros nos encontramos con una menor relevancia de esas otras formas de cooperación social.

Los factores que pueden inducir a potenciar o debilitar la respuesta a esos incentivos nos pueden remitir a las pautas de distribución de la propiedad privada o a la existencia de otros modos de propiedad y cooperación en las etapas previas a la industrialización, pero también a las características del sistema social en sus aspectos políticos, culturales o institucionales, en la medida en que frenen o potencien las posibilidades de los distintos grupos sociales de organizarse para cooperar en la producción, en el acceso a los mercados o, en general, en la defensa de sus intereses. Es decir, nos remiten a las fuerzas que dificultan o facilitan la cooperación social. 
En definitiva, la diversidad institucional, y en concreto la diversidad en las formas de posesión y acceso a los bienes, es propia de sociedades capitalistas avanzadas o en camino de serlo, e incluso de las relaciones económicas internacionales que mantienen entre ellas. Pero también es propio de ellas la precisión, la seguridad y la amplia regulación de los distintos tipos de derechos de propiedad existentes. Es decir, tras mercados eficientes suelen existir sociedades complejas que les suministran seguridad y estímulos adecuados y los nutren de recursos y tramas sociales densas que conectan de forma directa a quienes negocian en ellos. Mutilar o frenar el desarrollo de las redes sociales no mercantiles existentes en un país para potenciar con ello la cooperación mercantil, puede ser por lo tanto contraproducente si el objetivo que se pretende es allanar el camino hacia un bienestar razonable y generalizado, pero deteriorar las condiciones que permiten el desarrollo de las actividades mercantiles también puede tener efectos negativos sobre los demás modos de cooperación.

El problema es como las sociedades eligen en cada momento qué combinación de modos de cooperación les resulta más adecuada. Este problema nos remite a la productividad de la negociación y a las condiciones que permiten descubrirla por los agentes y organizaciones implicados. La productividad de la negociación remite a su vez a que, en un contexto dado, los distintos modos de cooperación son productivos en distinta medida y, en el caso de que en la sociedad se den las circunstancias para ir percibiendo estas diferencias, habrá incentivos en todas las partes implicadas para establecer negociaciones que permitan ir seleccionando paulatinamente, y tras múltiples experiencias, aquellos modos de cooperación que sean más adecuados para organizar los distintos tipos de actividades. Las condiciones adecuadas para el desarrollo de estos procesos de selección serán las que mantengan los márgenes de maniobra de todos los agentes implicados, pues ésta es una condición que induce a que sus particulares intereses y capacidades sean considerados y potenciados. Estos márgenes favorecerán y se verán favorecidos por la existencia de amplios campos de interacción entre los distintos individuos y organizaciones que permitan la circulación de información y la evaluación de las experiencias obtenidas con los distintos modos de organizar la cooperación. 


\section{La historia desde la teoría}

La argumentación desarrollada en los párrafos anteriores sobre la gestión empresarial y el acceso a los recursos, creo que pueden inducir a algunas reflexiones operativas para el análisis de las reformas agrarias y del papel de la agencia en la explicación del funcionamiento de la empresa.

Las reformas agrarias redistributivas (la de la Segunda República española, por ejemplo) pueden tener especial relevancia para romper inercias negativas en el caso de sociedades rurales con parco desarrollo de otras actividades productivas, sin suficiente presencia de formas de cooperación distintas al mercado y con fuerte concentración de los recursos en una exigua minoría de propietarios que los explota directamente. El efecto de la redistribución puede ser más favorable en el caso de que el cambio abra nuevas formas de aprovechamiento del medio natural, pero, aunque no se derivasen de ello cambios sustanciales en la producción ni en las formas de uso del medio, la reforma sería razonable al facilitar un reequilibrio de la correlación de fuerzas sociales que a largo plazo podría acabar incidiendo favorablemente en las capacidades de los individuos y en el funcionamiento de todos los modos de cooperación social, ayudando quizá con ello al desarrollo de actividades no agrarias en las zonas rurales.

Pero debe tenerse en cuenta que para alcanzar ese resultado no sería suficiente con la redistribución de la tierra. Sería necesario además apoyo a los nuevos propietarios o explotaciones bajo la forma de crédito y asesoramiento técnico y comercial. Este último aspecto abre además otro campo de reflexión: ¿no podía ser más razonable poner en marcha reformas en la legislación que indujesen a la gestión indirecta de los grandes patrimonios? Estas medidas se podrían completar, a su vez, con otras de carácter financiero, comercial o tecnológico que pudiesen mejorar las capacidades y oportunidades de los nuevos arrendatarios y de los pequeños y medianos campesinos presentes, en mayor o menor grado, en casi todas las sociedades rurales.

En cualquier caso, la opción entre modificar la distribución de la propiedad o potenciar otros modos de acceso a los recursos distintos a 
la propiedad no hace de ellas prácticas excluyentes, sino complementarias. Pero, de tener que elegir entre una y otra, resulta claramente más potente la de potenciar otros modos de acceso a los recursos, pues tierra sin capacidades tecnológicas, sin financiación, sin salidas comerciales puede ser un camino sin futuro. Pero capacidades nuevas sin acceso a la tierra (o con un acceso como arrendatario en condiciones muy gravosas) pueden ser también insuficientes, particularmente para los sectores sociales con menores recursos, en sociedades con poca diversificación sectorial de sus economías. En otras circunstancias menos extremas, las capacidades nuevas impulsadas por las reformas podrían utilizarse también en otras direcciones distintas a la agraria, como la emigración o el empleo en otros sectores. Quizá el desarrollo de las actividades no agrarias fuese posible como consecuencia de la dinámica económica inducida por la reforma agraria.

De todos modos, en la valoración de un camino u otro, o de la posible combinación entre ellos, la clave está en diferenciar el camino del objetivo. Los caminos pueden ser variados, pero el objetivo irrenunciable: mejorar y equilibrar las capacidades y posibilidades de los miembros más débiles de la sociedad. La discusión debe orientarse, pues, sobre en qué medida unas u otras decisiones son o fueron funcionales (y lo serán en distinto grado según las circunstancias históricas concretas) en el logro de ese objetivo, que a mi entender tiene capacidad tanto de mejorar las relaciones de la sociedad con la naturaleza como de ir conformando sociedades más equilibradas y a largo plazo más prósperas.

Conviene también tener en cuenta que un tipo u otro de reforma agraria requiere cierto grado de consenso para llevarla a cabo. Además, ese consenso no es tan sólo un condicionante político inevitable, sino también una condición para que desde el punto de vista económico la reforma pueda tener éxito. Es decir, considerar los intereses de otros (en el caso de una reforma agraria, los de los propietarios de distinto nivel, los de los colonos a ellos ligados, así como los de industriales, comerciantes, prestamistas o banqueros que actúen en el mundo rural) implica también la posibilidad de dar continuidad a las actividades productivas, financieras y comerciales gestionadas por ellos. La creación de nuevas posibilidades para unos debería ser compatible, para ser viable, con la continuidad de 
bastantes de los sistemas de producción, comercialización y financiación anteriores. Al menos, con todos aquellos que no fueran claramente contradictorios con los nuevos caminos que se pretende abrir con la reforma. La nueva correlación de fuerzas sociales inducida por la reforma agraria puede a su vez ir modificando los modos de actuación, en las instituciones, en los mercados y en sus empresas, de los agentes prepotentes en la etapa anterior.

De estas últimas reflexiones se deduce que la eficacia para el logro de los objetivos de una reforma agraria mejorará si ésta, además de unas medidas de carácter general, ofrece flexibilidad para adaptarlas a las condiciones particulares (sociales y ambientales) de los distintos espacios.

A la vista de lo señalado para el caso de las reformas redistributivas, parece bastante razonable que las reformas agrarias liberales combinaran, es el caso de España, cambios con continuidades en distinta medida según las características de cada una de las sociedades afectadas. Las razones de esta duplicidad serían múltiples; en las que quiero insistir ahora es en las relacionadas con la continuidad de anteriores modos de cooperación no mercantiles: su continuidad era un requisito, no sólo para mantener cierto grado de consenso entre los miembros de cada sociedad rural, y entre éstos y el poder central, sino también para mantener modos de cooperación que fueron de hecho complementarios con la expansión de la economía de mercado. Los foros, la enfiteusis, el comunal y sus modos colectivos de gestión, las relaciones clientelares, las redes familiares, la profunda personalización de las relaciones comerciales (para arrendar, prestar, vender, contratar braceros o administradores), todas ellas fueron formas de cooperación no mercantiles que, combinadas con las mercantiles, pudieron mejorar la eficiencia de estas últimas, completándolas y organizándolas con los instrumentos de que cada sociedad disponía. Es decir, las continuidades en no pocos casos fueron una palanca impulsora del mercado y en bastantes casos, no siempre, desde luego, indujeron a unas relaciones mercantiles menos desequilibradas socialmente de lo que hubieran sido en su ausencia. Además, teniendo en cuenta que la ruptura tecnológica con la agricultura orgánica no llegó, en el caso de España, hasta avanzado el siglo XX, 
estas instituciones contribuyeron a transmitir y reproducir modos de manejo del medio natural adecuados a las distintas condiciones ambientales. Con ello pudieron contribuir a mantener los equilibrios ambientales que sostenían la capacidad productiva de la agricultura orgánica y, consiguientemente, los flujos productivos que abastecían los mercados.

Se ha presentado en las páginas anteriores la actividad empresarial como una combinación entre la planificación y la intermediación. En el caso de ser relevante este último aspecto, el efecto agencia cobrará fuerza y con ella (es la propuesta que se hace en el texto) los objetivos de la actividad empresarial tenderán a adaptarse en cierto grado a los intereses de su entorno y de quienes participan directamente en ella. El riesgo podría ser que este mayor equilibrio negociador diera lugar a pérdidas de competitividad, pero la hipótesis que se plantea es que, por el contrario, ese modelo de empresa más acoplado al entorno (desde un punto de vista social y ambiental) acabará potenciando las capacidades productivas y el campo de opciones disponibles de la empresa y del sistema social.

Por el contrario, una empresa que se sitúa en un contexto ambiental y social dado con muy alta capacidad de imponer los objetivos de la propiedad sobre las demás personas y grupos implicados en el proceso productivo, puede provocar graves efectos ambientales y sociales en su entorno, ya sea socavando el capital ambiental o humano o dificultando la realización de algunas de las potencialidades de la sociedad y de la naturaleza en la que se inserta.

En la mayoría de los casos (como en el de los distintos ejemplos históricos de explotaciones agrarias), nos encontramos con combinaciones matizadas entre el papel del empresario como planificador e intermediario. Pero lo que creo que de este trabajo se deriva es que la necesidad de buscar consenso entre sus agentes por parte del empresario es un factor que tenderá a mejorar las capacidades de los sujetos, de las organizaciones y del conjunto del sistema social. Por ello, las condiciones sociales que inducen a esa adaptación (campo de maniobra amplio de los agentes o de las organizaciones con los que el empresario pretende cooperar) no son un problema, sino un factor inductor de un tipo de empresas que tien- 
den a utilizar más adecuadamente las características del medio humano y natural en el que actúan. ${ }^{19}$

Compárese, a modo de ejemplo, los distintos modos de gestión patrimonial que se van gestando en sociedades donde el propietario se enfrenta a braceros pobres y sin muchas alternativas de empleo, respecto al que negocia con arrendatarios que tienen tierras propias y otras alternativas de empleo para ellos o sus hijos. Véase la diversidad de casos que presenta Ramón Garrabou (2000) y reflexiónese sobre los distintos modos de gestión a los que dan lugar y las consecuencias que pueden tener para el desarrollo económico.

19 Pero la agencia puede convertirse en un problema cuando se concentra en un solo agente o en unos pocos. Es el caso frecuentemente manejado en la historiografía cuando se trata de administradores de grandes propietarios en sociedades muy desequilibradas socialmente. En estas circunstancias, el amplio margen de maniobra del administrador frente al propietario, y también frente a colonos y braceros, puede provocar un desequilibrio en la capacidad de ejercer como agencia de unos y otros que puede terminar descapitalizando al propietario y dificultando la acumulación campesina. Es decir, la agencia, para provocar los resultados favorables que se señalan en el texto, requiere que tengan capacidad de ejercerla los distintos tipos de agentes que participan en la explotación, porque así con ello se tenderán a conseguir unos resultados coherentes, en distinto grado, con los intereses de todos. 


\title{
2. EL ARRENDAMIENTO DE LATIFUNDIOS A PARTES DE FRUTOS: CONTRATOS Y GESTIÓN PATRIMONIAL DEL CABILDO DE LA CATEDRAL DE CÓRDOBA (1700-1840**
}

\author{
Antonio López Estudillo \\ (Universitat de Girona)
}

El presente estudio se inicia con una aproximación a la composición y evolución de los ingresos del cabildo cordobés, y se centra en adelante en el análisis de los contratos con renta sujeta a esterilidad con que arrendaba sus cortijos, un peculiar "contrato de aparcería». Además de los antecedentes y cláusulas de esos contratos, a corto plazo pero renovados con frecuencia, se analizará la gestión efectiva en 34 cortijos de ese gran patrimonio rústico entre 1700 y $1840 .{ }^{1}$ El contraste de esas prácticas con otros ejemplos próximos contribuirá a destacar la importancia de las formas de gestión y otros condicionantes históricos, al definir un tipo de contrato como óptimo para la asignación de factores y el uso (socialmente) más eficiente de los recur-

* La realización de este estudio ha gozado de financiación a cargo de los proyectos de investigación SEC 2003-08449-C04-02 y MEC HUM 2005-04731/HIST.

1 Esos 34 cortijos reunían 11362 ha en 1700. Prescindo de otros 4 cortijos (Torremocha, Fontalva, Pardillo Bajo y Luis Díaz) en propiedad proindivisa, en los que el cabildo poseyó 1099,3 ha. El cabildo gestionaba además el patrimonio de unas 40 obras pías, y otros. Agradezco las facilidades recibidas en el Archivo de la Catedral de Córdoba (en lo sucesivo, A.C.C.) y en otros de la ciudad, cruciales para quien reside lejos. 
sos. En el contexto investigado, los contratos y experiencias de gestión que alentaron comportamientos colaborativos estimularon un aprovechamiento más intensivo y regular de los recursos, y proporcionaron rentas más elevadas y estables, que prácticas alternativas que otorgaron mayor primacía a la competencia formal a través del mercado entre arrendatarios. Éstas buscaron con subastas públicas frecuentes a labradores que ofrecían las rentas fijas más elevadas y aportaban garantías hipotecarias mayores en previsión de impagos, pero, lejos de asegurar la regularidad en los pagos, originaron más pleitos, desahucios y ejecución de bienes de los arrendatarios, sin ventaja para la producción ni para los propietarios, salvo la posibilidad de prescindir de un control atento de la explotación de sus tierras. Las imperfecciones de los mercados, la selección de los labradores y las relaciones establecidas con ellos distaron de ser aspectos secundarios. En cualquier caso, nuestro estudio aporta nuevas perspectivas al análisis de la aparcería, pues los numerosos modelos teóricos formulados se han centrado en explotaciones familiares, con colonos que tenían por alternativa el trabajo asalariado, y resultan por ello parcialmente inadecuados para analizar a labradores con cientos de hectáreas en cultivo, por encima de una decena de asalariados en las épocas de baja intensidad en las labores y un considerable capital de explotación, que incluía abundante ganado de labor y crianza. ${ }^{2}$

\section{Evolución del patrimonio e ingresos de la mesa capitular}

La catedral de Córdoba fue dotada desde la conquista cristiana de importantes privilegios y bienes, que se multiplicaron en el Medievo con nuevas donaciones y compras. Hacia 1470, la mesa capitular había acu-

2 Una síntesis de gran número de modelos interpretativos sobre la aparcería, en Colin (ed.) (2003), pp. 21-46. Me limitaré al contraste entre tipos de contratos y formas de gestión. Evitaré la alternativa entre cultivo directo o indirecto, pues las imperfecciones en los mercados y barreras psicosociales limitaron el cultivo directo en los cortijos de Córdoba a una escala irrelevante hasta la Revolución liberal. Tampoco compararé el cultivo al tercio con la explotación familiar con aprovechamientos más intensivos, ni en cuanto a la eficiencia (social) del sistema de explotación — base de las propuestas de sucesivos reformismos agrarios-, ni por sus resultados potenciales como estrategia de gestión global por los grandes propietarios del Antiguo Régimen, que en la comarca rehuyeron por sistema esa alternativa. 
mulado con esas adquisiciones y numerosas permutas un patrimonio de alrededor de 14000 ha., integrado muy mayoritariamente por grandes fincas de cereal, que habían sido escasas en la dotación inicial aportada por los reyes. También disponía de percepciones y privilegios fiscales y de más de 450 casas, tiendas u otras instalaciones (mesones, molinos, carnicerías, hornos....). ${ }^{3}$ Desde entonces, la incorporación o permuta de fincas fue menor y fruto de donaciones testamentarias, preferentemente de prebendados del cabildo, y de compras como la del cortijo Casillas en la primera mitad del siglo XVI y la de medio cortijo Luís Díaz en 1804.

El cuadro 1 muestra una aproximación a la composición y evolución de las rentas de la mesa capitular, expresando su valor en fanegas de pan terciado (dos de trigo por cada una de cebada). En tiempos del catastro de Ensenada, en el que he comprobado que sus ingresos rústicos se registraron con muy leve ocultación, el ingreso bruto del cabildo equivalía a una cuarta parte del montante anual de todo el diezmo eclesiástico de la diócesis en 1750-1759. Unas rentas cuantiosas en las que tenían un peso reducido antiguos tributos cedidos por la Corona, como el almojarifazgo o diezmo de la aduana de Córdoba y su término, y el grueso de las instalaciones comerciales e industriales que desde el Medievo ejercieron en régimen casi monopólico: la venta de productos de alfarería, los mesones y el gran número de tiendas y molinos que antaño pertenecieron a la mesa capitular. ${ }^{4}$

3 Parto de Sanz (2000), pp. 252-257, que enumera las 30 fincas mayores. Las medidas que aporta de 29 de ellas hacia 1470 (575 yugadas y 563 aranzadas) equivalen a unas 13170 ha; no indica las del cortijo del Chanciller ( 510 ha en el siglo XIX) ni de las fincas menores (olivares, viñas, hazas y huertas). Junto a los cortijos, los inmuebles urbanos fueron el segmento del patrimonio con mayor incremento, acelerado en épocas de hundimiento demográfico. De 1380 a 1440 el cabildo pasó de poseer 247 a 448 casas, tiendas y mesones, y su número siguió creciendo. Véase también Vázquez (1987), pp. 9-22, Moya (1978), pp. 243-246, Nieto (1979) y Ladero (1999), p. 210.

4 Las vicisitudes terminales del almojarifazgo y el monopolio de la alfarería, en Moya (1978), pp. 249-250. Hacia 1750 sólo restaban 2 de los 10 molinos de harina y 4 de los 33 mesones que poseía en el siglo XV, y 1 taberna, 1 horno de pan, 7 carnicerías y 2 mataderos. López Ontiveros (1990), pp. 101, 114 y 151-153; Muñoz (1988), p. 380. 


\section{CUADRO 1}

APROXIMACIÓN A LAS RENTAS DE LA MESA CAPITULAR,1746-1826 (renta bruta convertida a fanegas de pan terciado a precios corrientes) ${ }^{5}$

\begin{tabular}{|l|rr|rr|rr|rr|}
\hline Años & \multicolumn{2}{|c|}{$1746-1750$} & \multicolumn{2}{|c|}{$1805-1807$} & \multicolumn{2}{|c|}{$1811-1816$} & \multicolumn{2}{|c|}{$1822-1826$} \\
\hline Cortijos & 19306 & $41,4 \%$ & 12376 & $36,1 \%$ & 9426 & $38,7 \%$ & 10325 & $39,5 \%$ \\
Hazas & 321 & $0,7 \%$ & 1019 & $3,0 \%$ & 22 & $0,1 \%$ & 321 & $1,2 \%$ \\
Olivares & 76 & $0,2 \%$ & 26 & $0,1 \%$ & 23 & $0,1 \%$ & 36 & $0,1 \%$ \\
Huertas & 1117 & $2,4 \%$ & 783 & $2,3 \%$ & 155 & $0,6 \%$ & 177 & $0,7 \%$ \\
Casas & 8512 & $18,2 \%$ & 5093 & $14,9 \%$ & 3514 & $14,4 \%$ & 5568 & $21,3 \%$ \\
Molino & 1719 & $3,7 \%$ & - & - & - & - & - & - \\
Censos y juros & 575 & $1,2 \%$ & 210 & $0,6 \%$ & 120 & $0,5 \%$ & 179 & $0,7 \%$ \\
Situados & 2324 & $5,0 \%$ & 1239 & $3,6 \%$ & 1343 & $5,5 \%$ & 1030 & $3,9 \%$ \\
Diezmos & 8035 & $17,2 \%$ & & & & & & \\
Carnicerías & 4703 & $10,1 \%$ & & & & & & \\
Diezmos+carnicerías & & & 12956 & $37,8 \%$ & 9547 & $39,2 \%$ & 7804 & $29,9 \%$ \\
Aniversarios... & - & - & 564 & $1,6 \%$ & 201 & $0,8 \%$ & 678 & $2,6 \%$ \\
Total & 46670 & & 34266 & & 24351 & & 26118 & \\
\hline
\end{tabular}

Desde 1746-1750 los ingresos de la mesa capitular conocieron oscilaciones moderadas que les condujeron a un nivel superior a fines del siglo XVIII. Principalmente por el ascenso del diezmo, que obtuvo en la diócesis uno de sus mejores registros en la década final del siglo XVIII, y en que el trigo y la cebada creció más en la campiña próxima a la capital, en la que el cabildo percibía una mayor proporción de él. Pero también la renta de sus cortijos en 1790-1796, incluidas las hazas en que se parcela-

5 A.C.C., legajos 2747, 3162, 3184; la información sobre cortijos del cabildo empleada en este estudio se concentra en A.C.C., legajos 2023 a 2024, 2359 a 2373 y 2481 a 2483, Muñoz (1988), p. 392 y López Ontiveros (1990), pp. 101, 114 y 151152. Reemplazo los precios del grano de las cuentas originales, muy infravalorados según práctica iniciada siglos atrás (Vázquez, 1987), p. 447. Tomo los precios de Ponsot (1986), pp. 517-521 y 531-532, completando sus vacíos con precios de conventos de Córdoba; para las décadas de 1810 y 1820 adopto los precios mensuales que proporcionó la mesa capitular al Ayuntamiento de Córdoba, y precios compilados por éste en adelante. En 1746-1750 no cuento con el desglose anual del diezmo, y evito conversiones a partir de promedios quinquenales. Al aplicar el precio del grano de la fuente para convertir las rentas en metálico de 1746-1750, se incrementa levemente el ingreso bruto y el peso relativo en él de casas y carnicerías. La corrección en la valoración de los granos mejora las cuentas originales, aunque por su origen parafiscal podrían incluir otras infravaloraciones. 
ron dos de ellos, superaba la percibida en 1746-1750, con un leve ascenso en pan terciado, cuya capacidad de compra en otros bienes y servicios se acrecentó. Por ese mismo motivo, la renta de sus numerosísimas casas descendió una tercera parte (en pan terciado), por el gradual ajuste a la inflación conforme se renovaban sus contratos, de renta fija y muy larga duración en general. En conjunto, los ingresos del cabildo fines de siglo superaban los de 1746-1750. En 1793-1797 se repartían a sus prebendados por diezmos y rentas alrededor de dos millones de reales, que no pueden compararse de modo directo con los datos expresados en el cuadro, pues falta añadirles los gastos generales de la institución y corregir la infravaloración de los granos, que formaban gran parte de lo distribuido a los prebendados. ${ }^{6}$

Desde los años del cambio de siglo se inició un brusco descenso en los ingresos del cabildo, por el hundimiento de las rentas decimales principalmente. A fines del siglo XVIII el diezmo había alcanzado un máximo muy por encima de los niveles considerados en el cuadro 1, pero el siglo concluyó con la detracción del noveno por el Estado y la posterior erosión del diezmo. Además, en la década posterior a 1826, fecha en que concluye el cuadro, el diezmo se hundió mucho más que el resto de los ingresos. Por otro lado, hay descensos en otras partidas, debidos al hundimiento de las rentas decimales capturadas por el cabildo. El situado era un pago fijo satisfecho por el marquesado de Priego a la mesa capitular por lo que correspondía a ésta en el diezmo del término indiviso de Aguilar, Montilla y otros pueblos, percibido por entero por el marqués. Su cuantía fue objeto de conflictos y concordias en el pasado, y mediado el siglo XVIII consistía en 2000 fanegas de pan terciado y 2000 ducados, que se vieron reducidos a la mitad en el primer cuarto del siglo XIX: 1000 fanegas de pan terciado y poco más de doce mil reales al año, y con algún impago. Mayor pérdida supuso el final del privilegio que eximía de diezmar al patrimonio rústico de la mesa capitular. La exención se traducía en la percepción de unas rentas más elevadas por sus predios, en las que se incluía el diezmo, que el cabildo no repartía con otros per-

6 Lo repartido en 1793-1797, la mitad de ello por diezmos, en Muñoz (1988), pp. 365-366, 390-391, 398 y 403-406. Los gastos generales sumaron 337605 rs. anuales en 1805-1807. A.C.C., legajo 3162. Moya (1978), pp. 248-249, para las casas. 
ceptores. Pero desde 1797 sus labradores debieron pagar todo el diezmo a la administración, que lo aplicó desde 1801 a la extinción de vales reales. ${ }^{7}$ Este aspecto se visualiza en el cuadro 1 como un descenso de la renta de sus tierras, que ese factor redujo en alrededor de una cuarta parte, aunque no de inmediato gracias a los elevados rendimientos de 1797-1802.

Mayor aún fue el declive del único monopolio medieval que producía elevadas rentas hacia 1750. El producto de las carnicerías de Córdoba cayó hasta el último tercio de siglo a poco menos de la mitad en términos nominales, y se hundió tras las primeras etapas del liberalismo: en 1822-1826 sólo alcanzaba un 4,4\% de su valor en el quinquenio 1746-1750 (en pan terciado). ${ }^{8}$ En cambio, la renta de los inmuebles urbanos siguió afectada por el tardío ajuste de sus contratos a la evolución de los precios, y la deflación posterior a 1812 permitió recuperar el nivel de renta (en pan terciado) de mediados del siglo XVIII hacia 1820; en 1830 era un tercio superior, y después comenzó a descender al cesar la deflación, desamortizarse algunas casas y perderse otras por insuficiencias en las reparaciones, dada la inseguridad de la mesa capitular en preservar su titularidad.

La renta de los cortijos experimentó un intenso descenso. Un hito clave fue la pérdida del diezmo desde 1797, pero se produjo además un declive desde el máximo alcanzado hacia 1745-1760, con una fase de bonanza en los años noventa por buenas cosechas y efímeras innovaciones en sus contratos (el pegujal de los ministros). Las malas cosechas de 1804 y otras, y la Guerra de la Independencia con sus requisas, pertur-

7 Sí diezmaban los cortijos considerados casa excusada: Aborroz (pila de la catedral), Camarero (parroquia de Montoro) y Monteruelo Alto y Bajo (San Pedro), y eran fuente de conflictos entre el cabildo y Hacienda por motivos que la contabilidad permite aclarar: en 1766 la cosecha bruta de Monteruelo Bajo fue de 1212 fanegas de pan terciado y el diezmo se limitó a 94 fanegas $(7,76 \%)$, por restar el cabildo su renta (2/9) antes de diezmar. A.C.C., legajos 2363 y 2365, años 1765 a 1769. Muñoz (1984), Sanz (1995), p. 87, y Vázquez (1987), p. 442.

868900 rs. de media en 1746-1750; 36275 rs. de media en los años de fines del siglo, citados por Moya (1978), p. 250; 26987 rs. en 1808, un tercio menos en 1811 ó 1815, y 6552 rs. en 1822-1826. A.C.C., legajos 3162 y 3184, y Archivo Municipal de Córdoba (en adelante A.M.C.), caja 1723. 
bación en los mercados y baja en las rentas por decreto, provocaron un fuerte descenso. ${ }^{9}$ A partir de ahí, las fluctuaciones se harían alrededor de ese nivel muy inferior, alcanzándose un nuevo mínimo en los años treinta. En 1835-1838 la renta anual de los cortijos equivalía a 7283 fanegas de pan terciado, menos de la mitad que en 1797-1802, siendo irrelevantes los cambios en la composición de esas fincas. ${ }^{10} \mathrm{El}$ descenso de la renta de las huertas, olivares y hazas se debió por el contrario a la precoz venta de las fincas en cultivo más intensivo al desamortizarse el séptimo eclesiástico. Así, tras un fuerte ascenso en la renta de las hazas debida a la parcelación de dos cortijos en Castro del Río en 1761-1770, su desamortización hundió la renta de las hazas de Castro y Córdoba, de 51371 reales anuales en 1805-1807, a sólo 1335 reales en $1811 .^{11}$

En suma, los ingresos de la mesa capitular conocieron desde 1797 un profundo declive debido en gran medida a las circunstancias políticas. A pesar de todo, las pérdidas en su patrimonio rústico fueron moderadas, lo que junto a sus numerosos inmuebles urbanos hizo del cabildo cordobés,

9 Una rebaja de la cuarta parte de la renta fue decretada el 27-VI-1811 por el conde de Montarco, comisario general y regio en Andalucía de la Administración bonapartista. La guerra implicó otras severas pérdidas al cabildo: 2,5 millones de rs. saqueados por las tropas francesas en sus oficinas, un préstamo de dos millones y un donativo de uno a la Administración josefina (Vázquez, 1993), p. 138. Expulsados ya los franceses, por 15 meses de contribución extraordinaria de guerra (X-1812 a XII-1813) se liquidó al cabildo 1225136 rs. por sus rentas y la masa decimal de la diócesis. (A.M.C., caja 1504). Los pagos extraordinarios citados, que no son todos los satisfechos, y alguno no gravó en exclusiva a la mesa capitular, equivalen a la renta neta del cabildo en el "quinquenio" 1805-1807 y 1815-1816. El potencial contributivo imputado al cabildo se advierte en el reparto de 796 acciones de 1000 rs. entre la élite local (4-X-1811) para evitar apremios militares a la ciudad por sus atrasos. Al cabildo le tocaron 80 acciones, por 115 al conjunto de la nobleza titulada - excepto el marqués de la Vega y algún otro, que tenían incautados sus patrimonios por su militancia antibonapartista-, 15 al obispo o 12 a la principal casa mercantil y bancaria (Ochaita y Pariza). A.M.C., caja 1722.

10 Se incorporó en 1804 medio cortijo Luís Díaz (176,3 ha) de la obra pía de Beatriz Victoria Páez de Guzmán, de la que fue patrono el duque de Alba, adquirido en 1804 por 319332 rs.; y en la desamortización del séptimo eclesiástico se perdió el cortijo Magdalena de D. Leopoldo (183,6 ha), que adquirió por 300000 rs. el marqués de Benamejí (2-IV-1808).

11 A.C.C., Manuales de Cortijos de años diversos, y legajo 3162; Muñoz (1984), p. 128. 
conforme avanzaba el hundimiento del diezmo, uno de los más ricos de España. $^{12}$

Como titular y administrador directo de ese patrimonio, el cabildo cordobés no afrontó el cultivo directo de sus cortijos, y el olivar o la viña alcanzaron menor peso entre sus bienes que en los restantes cabildos béticos. El predominio de las grandes explotaciones cerealistas no se debió a las donaciones recibidas, y sí a su estrategia de permutas y compras en el Medievo y a su nula participación en las importantes inversiones en plantación de olivar - y construcción de molinos- que emprendieron otras instituciones eclesiásticas vecinas, incluida la mesa episcopal, en La Guijarrosa, Alameda del Obispo, Adamuz, Montoro, etc. ${ }^{13}$ La gestión patrimonial del cabildo de Córdoba se redujo por ello a la cesión en arriendo de sus tierras, pero en esa faceta alcanzó una pericia muy destacada.

\section{Los contratos a esterilidad o la vigencia de rentas a partes de frutos en cortijos béticos}

Llegados a este punto procede estudiar los contratos a esterilidad, ${ }^{14}$ el manejo de sus cláusulas por el cabildo para adaptarlos a las coyunturas y los condicionantes que imponían a las prácticas de cultivo. El contrato de

12 Así se afirmó por varios diputados al debatirse la cuantía del subsidio que debería pagar como tributo la Iglesia. Diario de Sesiones de Cortes, sesión del 8-X-1820, p. 1505 (Cuesta), y sesión del 20-V-1821, p. 1730 (García Page). Ya decidida la desamortización de sus bienes, la dotación mínima y máxima aplicable a Córdoba aprobada en 1822 por las Cortes suponía por prebendado, en relación al importe repartido en 1793-1797, de un 18 a un $27 \%$ por cada dignidad, de un 39 a un $58 \%$ por canónigo, de un 32 a un $48 \%$ por racionero, y de un 53 a un $85 \%$ por medio racionero, expresado en pan terciado a precios locales de 1793-1797 y 1818-1822. Íd., sesión del 29-VI-1822, pp. 2244-2245 y 2248.

13 Muchos baldíos enajenados por la Corona fueron roturados y plantados de olivar por conventos cordobeses. El convento de la Coronada plantó de olivar en Aguilar más de 250 fanegas de tierra en al menos 6 de sus fincas, con particular intensidad de 1819 a 1834 . La antigua jurisdicción de La Alameda, perteneciente al obispo, transformó de 1750 a su desamortización su cereal extensivo y pastos en predominio del olivar y regadío, y al menos hacia 1812 era objeto de cultivo directo. A.M.C., caja 1723. Ello no fue inusual en Andalucía. López Martínez (1997), pp. 721-722.

14 Referencias a esos contratos, en Mata (1987), vol. I, pp. 249-264, López Estudillo (1996), Grupo de Historia Social Agraria Andaluza (1997), pp. 406-409, y Muñoz, Mata y Gamero (2003). 
un cortijo de la mesa capitular incluía decenas de cláusulas. En general se establecía por 3 a 6 años, con raras excepciones de contratos por 9 ó 12 años, una y dos vidas. ${ }^{15}$ Fijaba la superficie de tercio que cada año era obligado sembrar de trigo o cebada sobre barbechos con tres labores de aramía, más cohecho y siembra. A veces se establecían los periodos en que debían darse esas rejas, para evitar la práctica oportunista, detectada en algún labrador en grande que cultivaba simultáneamente otras fincas, de labrar otras tierras en las épocas más favorables y las del cabildo cuando sus yuntas quedaban libres. Se señalaba también el número de fanegas de tierra que podían sembrarse en la hoja de barbecho y en la de manchón que permanecía de pasto, las semillas permitidas en cada hoja, el régimen particular de renta en esas siembras cuando difería de la aplicada en el tercio, y la penalización por sembrar más superficie de la autorizada en el contrato, que pocas veces superó el $12 \%$ de la extensión de esas dos hojas. También debía el colono mantener las lindes, evitar la consolidación de servidumbres y reducir procesos erosivos, conservando cañizares y alamedas en los márgenes de cursos fluviales o impidiendo la formación de arroyos. Se fijaban además los plazos en que debía dejar libre parte del cortijo al colono entrante - pues cada uno sembraba sobre barbechos labrados por sí, y para ello el entrante iniciaba sus labores cuando el saliente acababa de sembrar su última cosecha en la hoja de tercio-, así como la paja y las casas que debía entregar a éste para sus ganados y obreros, quien se las pagaría al arrendatario saliente con los aprecios de costumbre por ser de su propiedad. ${ }^{16}$ Unas condiciones orientadas a reducir los comportamientos

15 Contratos de 9 años, en Arcas (1769-1777 y 1778-1786) y Hazas de la Iglesia (1746-1754); de 12 años, en Montefrío Bajo (1756-1767); por dos vidas, la del labrador y la de quien él determinase, en Hazas de Argote (1743-1770) en dos contratos abandonados por sus colonos; por una vida, en Montefrío Alto (1710-1718) a Josefa de Arroyo y Pineda, cuya familia lo labraba desde 1675 y la sucedió en él por más de un siglo tras su fallecimiento.

16 La propiedad de las casas implicaba plena responsabilidad en su mantenimiento y recuperación de las mejoras. En general, los muros de obra, cuando existían, correspondían al propietario, y el arrendatario entrante pagaba al saliente el valor por aprecio de las maderas y sus techos pajizos, y de otros equipos fijos ocasionalmente. Un pago mayor habría supuesto una barrera al acceso de nuevos labradores, y redundado en detrimento de la renta, como sucedió a inicios del siglo XIX en el cortijo del Ingeniero, al construir un labrador casas de obra muy costosas y poco adecuadas al sistema ordinario de aprovechamiento, que obstaculizaron la entrada de nuevos arrendatarios. 
oportunistas, de graves efectos sobre la renta al negociar la cesión a nuevos labradores, así como destinados a aminorar la inversión, riesgo y costes de supervisión al propietario. Por último, el contrato establecía los pagos de su renta mixta, fechas de abono, lugar al que debían transportarse los pagos en especie y las garantías ante el impago, limitadas en general a los ganados, aperos, barbechos y casas en el cortijo, que en caso de quiebra solía adquirir un labrador entrante pagando al saliente y asumiendo sus débitos.

La renta incluía dos pagos fijos ligados en teoría al aprovechamiento de los pastos del cortijo. Uno de ellos satisfecho en dinero, aunque la cifra acordada aparecía en los contratos expresada de modo ritual en carneros, cerdos y queso, a precios constantes en todo el periodo. El otro, un par de gallinas por cada cahíz (12 fanegas) de renta íntegra. Muy superiores eran los pagos por las tierras sembradas. El contrato citaba una cuantía dada, o bien las fanegas de pan terciado a pagar por cada una de las fanegas de tierra que compondría el tercio de siembra obligada, así como pequeñas cuantías de paja; ${ }^{17}$ pero el pago de ambas especies quedaba sujeto a esterilidad.

La cláusula de esterilidad remitía a la legislación medieval de Las Partidas, y perseguía que los colonos no asumiesen todos los riesgos, muy elevados con rendimientos tan fluctuantes como los del cereal de secano bético en cultivo extensivo. Su aplicación estuvo muy generalizada en la Época Moderna en Andalucía (Jaén, Córdoba, áreas de Sevilla, Huelva...), en ocasiones sin cita expresa en los contratos y aplicada según usos locales, como se advierte en la intensa fluctuación de las rentas anuales en grano en las contabilidades patrimoniales. ${ }^{18}$ Las condiciones de los contratos a

17 Un halda de paja por cada cahíz de renta efectiva. En la práctica, un real por halda, pues era ineficiente acarrear pequeñas cargas y gestionar su recepción y formación de almiares. Sólo en algunos cortijos seleccionados por su ubicación se exigía el pago efectivo de cierto número de carros de paja, que sus colonos llevaban a las cuadras del molino de harina de Lope García, propiedad del cabildo.

18 La aplicación de la esterilidad en Jaén en los siglos XVI y XVII, incluso sin citarse en los contratos, en Coronas (1994), pp. 265-271. En Sevilla se citaba en el siglo XVI en contratos de Carmona y el Aljarafe, quedaba implícita en otros contratos a partes de frutos, la fluctuación anual de las rentas del Monasterio de San Clemente (Sevilla) parece denotar su empleo en otras áreas —Borrero (2003), pp. 157-162_, y su uso perduró al menos en 
esterilidad fueron diversas en distintas zonas y épocas, teniendo en común el reducir la renta respecto a la establecida en el contrato cuando la cosecha no alcanzaba un nivel dado por causas no imputables al colono. En la Sevilla de inicios del siglo XVI la cláusula consistía a veces en la condonación de la renta el año en que se perdía la cosecha y la prórroga del contrato en un año; en otros pueblos o fincas, en el pago como renta de 1/5, 1/8 ó 1/12 de lo producido; y en Huelva, 1/6 en el siglo XVII. Era infrecuente el explicitar las condiciones que permitían alegar esterilidad, y cuando se hizo se citó el no alcanzar rendimientos superiores a 6 granos por simiente unas veces, 7 a 1, u 8 a 1 en otras. En los cortijos de la mesa capitular de Córdoba, hacia 1620 se aplicaba la esterilidad cuando el rendimiento por semilla sembrada era inferior a 7 , pero ese dato dejó de citarse y el estudio de las rentas satisfechas en 1700-1840 muestra que el umbral para reclamar esterilidad pasó a ser diferente en cada caso, e implícito en otra cláusula del contrato. De todos los umbrales citados se deriva que la esterilidad regiría en la gran mayoría de los años, transformando un contrato en el que se citaba una cuantía dada de grano como renta en otro a partes de frutos. ${ }^{19}$

La renta a esterilidad en los cortijos de Córdoba obligaba al labrador a pagar 2/9 de la cosecha bruta - 3/10 en los de la mesa capitular hasta 1797, por incluir el diezmo-, y el umbral para reclamar esterilidad era variable, pues existía derecho a ella cuantos años esa proporción de la cosecha fuese inferior a la renta en grano fijada en el contrato. No era común citar un rendimiento mínimo del trigo para su aplicación,

Écija. En Huelva, los contratos con esterilidad eran mayoritarios en el cereal en el siglo XVII, un $60,9 \%$, por un $14,1 \%$ en que el colono desistía de su derecho a reclamarla, y un $24,8 \%$ que no citaba nada al respecto. Pulido (1982), p. 25, y Pulido (1988). En Córdoba las rentas a partes de frutos o en esterilidad abundaban hacia 1750 por toda la campiña en las fincas de cereal, y preferentemente en las extensas. Cerrato (2000), pp. 76-84 y 201-205, incluye una amplia muestra de las tierras de cereal arrendadas por los conventos femeninos de la provincia, y 8307 ha (un 77,3\%) de ella se cedían a partes de frutos o esterilidad, por 2433 ha $(22,7 \%)$ arrendadas con rentas fijas en metálico, grano o mixtas.

19 La esterilidad era aplicable en 1620 hasta los $8,8 \mathrm{hl} / \mathrm{ha}$, dada la práctica de siembra de los cortijos del cabildo. Más tarde dependería de la renta fijada en cada contrato. En umbral máximo, en los contratos de Montefrío Bajo de 1750 a 1779 habría esterilidad hasta los 13,6 hl/ha. A.C.C., Manuales de Cortijos, Borrero (2003), pp. 158-159, Coronas (1994), p. 269, Mata (1987), vol. I, pp. 258-259, Pulido (1982), p. 26. 
pues era el conjunto de la cosecha el que hacía alcanzar o no ese umbral, con sumas ponderadas de granos diversos, tanto en el tercio como en extensiones variables de las otras dos hojas de labor. En otros términos, la renta en grano del contrato fijaba un máximo, muy variable según la coyuntura y rentabilidad histórica estimada a cada cortijo. Los contratos a esterilidad reducían el riesgo asumido por el colono evitando el muy oneroso pago de rentas fijas en grano en los años de mala cosecha. Pero fijaban además un umbral máximo de renta en grano que introducía un mayor incentivo a una labranza esmerada que la aparcería. A la estrecha supervisión de la intensidad de sus labores, común en los contratos a partes de frutos para evitar el riesgo moral, ${ }^{20}$ unía el interés por superar el umbral de cosecha implícito en la renta fijada en el contrato por medio de buenas labores, pues la parte extra cosechada quedaba libre de satisfacer los 2/9 de renta y, en los cortijos de la mesa capitular, también de pagar diezmo por ella. La cuantía y probabilidad de ese premio era variable, según el nivel al que se fijara la renta en contrato y su relación con la calidad de la tierra, y la situación del mercado. Esa práctica definía un incentivo bien diseñado a la intensificación de las labores, pero la elevación de la renta en contrato podía concluir por anularlo. Si su nivel era tan elevado que sólo en años muy excepcionales dejaba libre de renta partes minúsculas de la cosecha, la renta a esterilidad perdía ese incentivo adicional respecto a la aparcería, y en última instancia podía favorecer labores menos esmeradas y algún descenso en los rendimientos medios. ${ }^{21}$

La cláusula de esterilidad introducía una intensa y variable disparidad entre la renta en grano fijada en contrato y la exigible al colono. En

20 La supervisión de la intensidad en el cultivo era más necesaria en los contratos a partes de frutos y forjó en los propietarios afectados hábitos más interesados por el cuadro técnico de las labores —Garrabou, Planas y Saguer (2001a), pp. 55-59, y (2002), pp. 309310 - o se aplicó cuando las competencias e información entre propietarios y colonos estaban más equilibradas, según perspectivas más estáticas de la nueva economía institucional. Colin (ed.) (2003), p. 41.

21 A un nivel elevado de renta, la crítica marshalliana a la aparcería frente al arrendamiento o el cultivo directo podía adquirir sentido. A saber, que al aparcero le interesaba alcanzar un inferior nivel óptimo de intensidad en las labores, pues satisfacía todo el costo marginal y sólo participaba del producto marginal en la proporción fijada en el contrato. 
GRÁFICO 1

RENTA EN GRANOS A ESTERILIDAD

(promedio cortijos Hinojosa, Pangía y Villaviciosa)

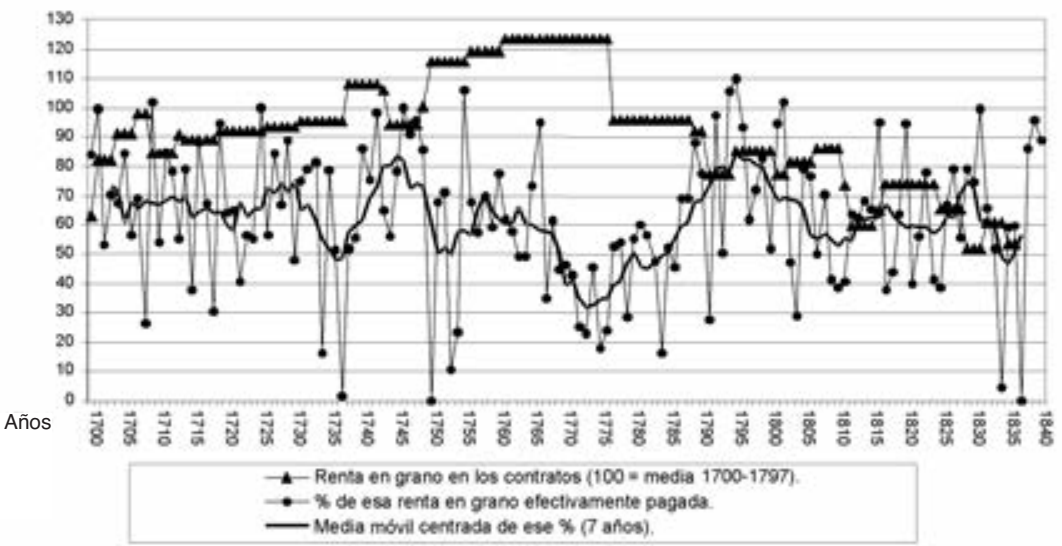

ausencia de cambios en los rendimientos medios, la elevación de la renta en grano en el contrato capturaba parte del excedente que la cláusula reservaba en los años buenos al labrador aplicado. Como pagaría más renta en los años de buena cosecha, pero la misma proporción que antes en los demás, la renta efectiva tendería en promedio a distanciarse de la fijada en contrato, como se advierte en el gráfico 1. Por ello, las series de renta construidas a partir de contratos sujetos a esterilidad, ya lo indiquen sus cláusulas o se aplique ésta sin ese requisito por estar contemplada en la legislación castellana, adolecen de graves vicios: a) elevan el nivel de la renta, b) prescinden de la fluctuación anual de ésta, y c) exageran los cambios a medio plazo de la renta, pues al elevarse la renta en grano fijada en contrato se reducía la proporción de ésta que era efectivamente pagada, y viceversa.

Al estímulo de labores esmeradas para hacer más frecuentes y elevadas las buenas cosechas, por quedar para el labrador las partes de frutos que excediesen de la renta citada en contrato, se añadía el relativo a la producción de excedentes pecuarios en los cortijos. Por los pastos se pagaba un tanto fijo en metálico, y el labrador era dueño de sus ganados y adoptaba todas las decisiones al respecto, asumiendo todo el riesgo y los beneficios de esa actividad. Un aspecto habitual en otros contratos con renta a 
partes de frutos, ${ }^{22}$ y que en el cultivo al tercio, con su reserva de una hoja con pastos y elevada presión de rentas y diezmos sobre sus granos, podía aportar una fracción muy elevada del excedente retenido para sí por los grandes labradores arrendatarios cordobeses.

La renta a esterilidad exigía cada año una tazmía o estimación detallada de la cosecha prevista. Poco antes de la recolección, los tazmiadores enviados por el cabildo visitaban cada cortijo y estimaban los rendimientos y superficies sembradas de trigo, cebada y otras semillas. Sus informes precisaban además las siembras perdidas, para dar fe de que el colono sembró la superficie que exigía el contrato, e indicaban si se incumplieron labores fijadas en sus cláusulas o las siembras en el rastrojo y el barbecho superaban las autorizadas, aspectos que incrementarían la renta del año con las penalizaciones previstas por el contrato o la costumbre. Como la renta se pagaba en fanegas de pan terciado, y la cosecha incluía diversas semillas con superficies sembradas y rendimientos cambiantes, la tazmía debía calcular el equivalente de la cosecha bruta de todas esas semillas en fanegas de pan terciado.

El cuadro 2 muestra una tazmía simplificada con los coeficientes de conversión habituales. Cada fanega de trigo equivalía a 2 fanegas de cebada y a 2 fanegas colmadas de escaña, habas, garbanzos, yeros, alverjones y otras semillas. Como la fanega colmada medía alrededor de 1,25 fanegas rasas, un litro de cebada equivalía a 0,5 de trigo y un litro de escaña, habas o garbanzos, a 0,4 de trigo. Esa conversión se aproximaba a los precios relativos en los cereales pienso, y divergía en las habas, garbanzos, lentejas y otras semillas, que eran muy infravaloradas. La antigüedad de la práctica y la limitación por contrato de sus siembras en los barbechos parecen

22 En el ganado primó la libre asunción de riesgos frente a la supervisión, menos eficiente en el control de actividades que implican laboriosidad, de muchas decisiones de resultado incierto (proporción entre las especies de renta a criar, entre lechones a vender y a retener para criarlos con subproductos del cortijo sin otro uso, momento en que los vacunos de labor envejecidos debían engordarse para su venta como carne...) y efectos sobre la calidad. En los contratos de masoverías y aparcerías catalanas, el ganado también quedó en general al margen. Garrabou y Planas (1997), p. 398, Congost et ál. (1997). Los pagos en metálico adicionales a las partes de frutos se han interpretado como un medio cómodo de participación del rentista en productos de difícil control y división. M. C. Thaize-Challier (2003), p. 60. 
indicar que ello no se introdujo para potenciar las leguminosas por su función fertilizante. ${ }^{23} \mathrm{Su}$ infravaloración respondía quizás a los bajos rendimientos que esas leguminosas alcanzaban en los barbechos de los cortijos, y al elevado coste que suponía la semilla y los 3/10 por renta y diezmo, por lo que se sembraban en escasa cuantía y apenas quedaban excedentes tras servir de alimento a los ganados y al personal del cortijo. Para concluir la tazmía, las fanegas equivalentes a trigo se convertían en fanegas de pan terciado $^{24}$ y de esa cosecha bruta en pan terciado se calculaban los 2/9 de ella, se informaba al labrador por escrito y se le invitaba a acudir a la catedral para ajustar la renta con diputados del cabildo. Un ajuste repetido cada recolección con los prebendados elegidos cada año para representar a la institución propietaria, que constituía un símbolo de la estrecha supervisión que el cabildo ejercía de modo colectivo sobre sus cortijos. ${ }^{25} \mathrm{Si}$ la cosecha correspondía a un año favorable, el resultado de la renta a esterilidad según la tazmía excedía a la renta íntegra fijada en el contrato, y era ésta la que se pagaba, quedando parte de la cosecha libre de los $2 / 9$, lo que podía elevar muy significativamente el excedente neto del arrendatario. ${ }^{26}$

Si el labrador no creía aceptable el acuerdo propuesto por el cabildo, podía reclamar el pago en fieldad, bien por considerar excesiva la cosecha prevista en la tazmía o bien por estimar que, dados los precios corrientes de cada producto en ese año y la composición de su cosecha, le eran lesi-

23 Seguramente sí favoreció su siembra el conde de Fernán Núñez en las hazas en que parceló el grueso de sus cortijos hacia 1775 en Fernán Núñez, unas a renta fija y otras a esterilidad (con renta de $2 / 6$ de la cosecha, las más frecuentes), al establecer una proporción muy inferior de renta en las leguminosas recolectadas. Naranjo (1995).

2412 fanegas de pan terciado se componen de 8 de trigo y de 4 de cebada (que valen como 2 de trigo). De ahí que se utilizase como conversor 1,2:1, dado que cada 10 fanegas de trigo valían como 12 fanegas de pan terciado.

25 El ajuste concluía, en general, con la rebaja de algunas fanegas de renta respecto al cálculo por tazmía. Asumo la interpretación sobre la administración directa y colectiva por el cabildo expresada por Sanz (2000), pp. 202-206.

26 La renta establecida en el contrato del ejemplo (350 fanegas) fijaba el umbral de producción para satisfacer la renta íntegra sin esterilidad en 1575 fanegas de pan terciado $(350 \times 9 / 2)$. Un umbral superable con labores esmeradas, que ese año permitió al labrador que 357 fanegas cosechadas (1932-1575) quedaran libres de pago de los 2/9. Así, la renta en grano fue del $18,48 \%$ del producto bruto, en lugar de $2 / 9(22,22 \%)$, y aunque parezca un diferencial menor en relación a la cosecha bruta, el beneficio neto del labrador pudo elevarse en $1 / 5$ o más gracias a ello. 


\section{CUADRO 2}

\section{TAZMÍA Y ESTIMACIÓN DE LA RENTA EN GRANO DE UN CORTIJO}

1. Renta en contrato: 2 fanegas de pan terciado por cada una de las 175 fanegas de tierra en la hoja de tercio (máximo: 350 fanegas de pan terciado).

2. Tazmía de la cosecha a recolectar (20 de mayo de 1817).

Hoja del tercio

Trigo 105 fanegas de tierra a 10 fanega

Trigo 25 fanegas de tierra a 8 fanegas.

Trigo 18 fanegas de tierra a 6 fanegas.

Trigo 12 fanegas de tierra con la cosecha perdida

Hoja de rastrojo:

Escaña 15 fanegas de tierra a 10 fanegas colmadas

Hoja de barbecho:

Habas 3 fanegas de tierra a 4 fanegas colmadas.

Garbanzos 2 fanegas de tierra a 3 fanegas colmadas

Yeros 3 fanegas de tierra a 6 fanegas colmadas.

Alverjones 3 fanegas de tierra a 6 fanegas colmadas.

Totales.

3. Cálculo de la renta, de regir el pago de renta a esterilidad.

a) 1358 fanegas de trigo +252 fanegas equivalentes a trigo ( 504 fanegas de otras semillas $/ 2)=1610 \mathrm{f}$. equivalentes a trigo.

b) 1610 fanegas equivalentes a trigo $\times 1,2=1932$ fanegas de pan terciado.

c) renta a esterilidad $1932 \times 2 / 9=429$ fanegas y 4 celemines de pan terciado.

4. Renta en fanegas de pan terciado a satisfacer en el año 1817.

350 fanegas de pan terciado, "renta íntegra» por contrato, por ser ésta inferior a la calculada a esterilidad (2/9) en ese año.

vas las equivalencias implícitas en su cálculo y su pago en pan terciado. A veces, el problema radicaba en la buena calidad del grano exigido en las rentas a esterilidad por el cabildo, al estimar el labrador que la baja calidad de su cosecha le haría muy costoso seleccionar esos granos entre los por él recolectados o, incluso, adquirir en el mercado grano bueno para la renta. ${ }^{27}$ Cuando el labrador no deseaba ajustarse por la tazmía y solici-

27 «Me he resuelto a traer fiel [...] no teniéndome cuenta entrar por la tazmía, sea la que fuese, no es tanto lo que a ello me mueve la escasez, como la calidad de cuanto grano se recoja, pues siendo pésimo me sería de mucha pérdida la entrega ahí» (carta del labrador del cortijo Magdalena en 1783). 
taba pagar en fieldad, el cabildo nombraba a un hombre de su confianza ( fiel) al que hacía firmar un contrato con sus obligaciones, y éste permanecía en la finca y vigilaba día y noche los trabajos de era hasta su conclusión, penalizándose la extracción de grano no autorizada del cortijo con el pago de la renta íntegra sin esterilidad. ${ }^{28}$ En los cortijos en fieldad, la renta consistía en 2/9 de los granos de todo tipo recolectados y de los residuos de grano de la era. El cabildo accedía en general con contrariedad al pago en fieldad, por el oportunismo que revelaba en los labradores que la reclamaban, los obstáculos que introducía en el complejo sistema de reparto de la renta en granos entre sus prebendados (por sorteo entre ellos de fracciones de la renta de los cortijos con pagos a esterilidad) o por los mayores costes que suponía la conservación y venta de semillas con salida mercantil más difícil. ${ }^{29}$

\section{El cabildo y la gestión de sus cortijos, tratos y contratos}

El cabildo se comportó como un propietario rentista, atento a la maximización de sus ingresos, poco dado a participar en la financiación de inversiones en sus fincas y refractario al cultivo directo. Pero distó de actuar como algunos propietarios absentistas de patrimonio fragmentado y disperso, que adoptaron contratos más rígidos y decisiones prefijadas e inflexibles ante impagos de rentas, garantías exigidas a los colonos y otras, muy condicionados por su falta de información e incapacidad para diferenciar los problemas de liquidez de colonos cumplidores de otros impa-

28 "Lo que ha de hacer el fiel, que va a cortijo, conforme a las condiciones del contrato", en A.C.C., legajo 2362. El fiel era pagado por el labrador: en 1771 el del cortijo Pan Giménez Bajo permaneció 46 días y cobró 4 rs. diarios en metálico y 2,5 rs. en comida; en 1800 el del cortijo Cuadrado permaneció 77 días y cobró 6 rs. diarios en metálico más manutención.

29 La contrariedad del cabildo con la fieldad se advierte en cartas de distintos colonos: los de Cuadradillo y Fontalva, en 1783, al pedir alguna rebaja de renta «en atención a lo fatal del año, y a que siempre rehusamos traer fiel»; el del cortijo Aldea de don Gil en $1812 \ldots$ Para evitar el último problema que cito en el texto, ya fijada la renta en fieldad, distintos pagos en semillas podían convertirse en trigo o cebada por acuerdo bilateral, considerando o no los precios del año. 
gos concebidos por sus autores como estrategia para forzar la bajada de las rentas. ${ }^{30}$

El cabildo cordobés dispuso de elevado poder de negociación por su peso en el mercado local de cesión de tierras, dada la dimensión de los patrimonios que administraba y la seguridad que le otorgaban otros ingresos (arriendo de casas, diezmos) y los cuantiosos fondos en metálico de obras pías para asumir discontinuidades a corto plazo en sus rentas, e incluso para ofrecer rebajas de rentas y préstamos a sus labradores más leales en circunstancias excepcionales. Su poder de negociación derivaba también de su información privilegiada sobre las cosechas y los mercados de productos y factores en la comarca, a la que no era ajena su participación directa en la recaudación de diezmos y en la distribución del subsidio entre instituciones religiosas. Su información sobre la capacidad productiva de cada uno de sus cortijos, la situación del mercado al negociar nuevos arriendos o la intensidad y resultados de las labores de cada uno de sus colonos, distaba mucho de la información asimétrica con la que otros propietarios acudían a negociar con sus arrendatarios.

Esa información permitiría al cabildo anticiparse a otros patrimonios en la adopción de decisiones estratégicas sobre su parcelario, para atenuar la reducción en la renta de sus tierras en cuanto ésta comenzó a descender hacia 1760 del máximo en que se hallaba desde mediados de siglo. Por una parte, parceló los cortijos Cerro Aceituno (1761-1763) y Hazas de Argote (1770), ambos de los más pequeños que poseía, próximos a Castro del Río, de calidad inferior a la media a tenor de su renta, y al primero de los cuales se negó en 1746 el privilegio de cerramiento con que de facto se

30 Carmona y Simpson (2003), pp. 129 y 133-134, contraponen a absentistas y titulares de patrimonios concentrados y gran influencia local. No obstante, hubo dueños de patrimonios dispersos y con información limitada, acostumbrados a la supervisión más atenta requerida por los contratos a partes de frutos, que, tras tantear, adoptaron decisiones cooperativas más exitosas allí donde mantenían contratos de renta fija. Al impago de ésta en sus cortijos de Colomera (Granada) respondió el marqués de Sentmenat con ejecuciones judiciales en la crisis finisecular. Pero advirtió de inmediato que arruinaba a sus colonos sin apenas provecho propio, por los costes asumidos. Ordenó suspenderlas, accedió a escalonar el pago de atrasos, e incluso a condonaciones parciales, y evitó que sus tierras quedasen sin arrendar y gravadas con tributos elevados, como sucedió a otros grandes propietarios en la comarca. Archivo de la Corona de Aragón, Fondo Marqués de Sentmenat, Patrimonio Patiño, legajos 48 a 54. 
CUADRO 3

DIVISIÓN DE LOS CORTIJOS MÁS EXTENSOS Y REPERCUSIÓN EN SU RENTA

\begin{tabular}{|l|c|c|c|}
\hline $\begin{array}{l}\text { Cortijo (ha) y año } \\
\text { de su división }\end{array}$ & $\begin{array}{c}\text { a. Renta en la década posterior } \\
\text { a su división (100= su renta } \\
\text { en la década previa) }\end{array}$ & $\begin{array}{c}\text { b. Idem en los } \\
\text { 34 cortijos } \\
\text { estudiados }\end{array}$ & $\begin{array}{c}\text { Diferencia } \\
\text { imputable } \\
\text { a su división } \\
\text { (a-b) } \times 100 / b\end{array}$ \\
\hline Torre Juan Gil (596), 1757 & 138,1 & 115,9 & 19,2 \\
Coronadas (687) 1765 & 123,8 & 84,1 & 47,2 \\
Pan Jiménez (650) 1766 & 97,8 & 77,6 & 26,0 \\
Rivillas (481) 1767 & 72,1 & 81,0 & $-11,0$ \\
Rinconada (657) 1768 & 131,6 & 86,5 & 52,1 \\
Camarero (640) 1770 & 79,7 & 83,9 & $-5,0$ \\
Coronadas (687) 1801 & 88,8 & 77,3 & 14,9 \\
\hline
\end{tabular}

venía explotando. El resultado fue una intensa elevación de sus rentas: las tierras parceladas en 1761 en el cortijo Cerro Aceituno, en su mayoría en hazas de 4 fanegas (2,44 ha), pagaron más del doble que en el decenio previo, justo cuando la renta de los cortijos tendía a descender.

Por otro lado, subdividió sus 6 cortijos más extensos en 12 de medidas inferiores, pues aquéllos requerían labradores con mucho ganado, equipo y liquidez, poco numerosos en la campiña de Córdoba, que imponían condiciones al arrendarlos ${ }^{31}$ que anticipó en ellos la percepción del cambio de coyuntura. El efecto de esa operación sobre sus rentas lo muestro en el cuadro 3, en el que presento en números índices (a) la evolución de la renta de cada cortijo que fue objeto de subdivisión en la década posterior a su partición, respecto al nivel medio de su renta en la década previa, y lo contrasto con (b) el promedio de la renta por fanega de los 34 cortijos estudiados en idénticos años. La subdivisión no consiguió invertir la tendencia general de la renta, salvo en los dos mayores, pues ésta respondía a causas generales, pero sus rentas evolucionaron de modo más favorable. En el promedio de las 7 experiencias, la evolución de sus rentas res-

31 Coronadas era el más extenso y de baja calidad. La escasez de labradores en grande obligó al cabildo a aceptar la reducción de la superficie de siembra obligada en su tercio de 366 a 250 fanegas desde 1744, y a que se sembrasen 50 fanegas exentas de renta en 1759-1764. Al dividirlo en 1765 recuperó la superficie de siembra y elevó su renta. Cuando su renta reinició su descenso, la mesa volvió a reunificarlo en 1778-1800, para dividirlo definitivamente en 1801 . 
pecto a la década previa a su división fue en estas fincas un 20,5\% mejor que en el promedio de los 34 cortijos, ${ }^{32}$ por cambios en sus cláusulas favorables al cabildo, y una mejor evolución en sus rendimientos por haber sido objeto antes de su partición de cultivo menos esmerado. El cabildo capturó así una renta diferencial gracias a la reducción de las barreras para acceder a su cultivo. Una práctica que los agrónomos locales aconsejaban en sus informes a otros patrimonios, y que a largo plazo había conducido a una mayor homogeneidad de las dimensiones de los cortijos, por subdivisión de los más extensos, ${ }^{33}$ no dejando en las cercanías de Córdoba cortijos tan extensos como los mayores de Sevilla o Jerez.

La información detallada sobre sus fincas — crucial en rentas a partes de frutos y con colonos que podían tener interés en aminorar la intensidad de las labores - o dejar las peores tierras como pastos, pues sus productos no satisfacían rentas proporcionales, permitió al cabildo un estrecho control de las prácticas de cultivo en sus cortijos. Esa supervisión tuvo bajo coste por unidad de renta por la participación directa de prebendados en el ajuste de rentas, negociación de contratos, contabilidad y archivo, ${ }^{34}$ por el corto número de esas fincas y su elevada concentración espacial, al ser muchas de ellas colindantes, ${ }^{35}$ y por el pago por los colonos por

32 Renta total satisfecha, convertida en fanegas de pan terciado. Si la comparación se realiza con la evolución de la renta de los cortijos que no fueron subdivididos, y no con los 34 cortijos, la renta diferencial conseguida se acrecienta, y sólo es negativa en Rivillas, el menos extenso con diferencia de los divididos.

33 Francisco Salcedo aseguraba en un informe de 1800 al Ayuntamiento que, subdividiendo en dos o tres cada uno de los grandes cortijos de propios, desaparecerían los problemas para encontrar colonos y obtendrían una renta al menos una cuarta parte superior, que compensaría sobradamente la inversión en casas y pozos requerida al segregar las nuevas fincas. Sin salir del patrimonio de la mesa capitular, los cortijos Rinconada, Montefrío, Cuadrado, Aldea de Gil Crespo y Cascajar superaban hacia 1470 las dimensiones de las mayores fincas del siglo XVIII, y se subdividieron antes.

34 La estructura contable dificulta precisar ese coste, que en los cortijos pudo ser inferior a una tercera parte que en los patrimonios estudiados por Garrabou, Planas y Saguer (2002), p. 312, sin incluir valoración monetaria del trabajo de los prebendados ni de los propietarios rurales catalanes.

35 Lindaban entre sí Villaviciosa, Aldea de don Gil, Cisneros, Cuadradillo, Cuadrado, Hinojosa y Gamonosa; Monteruelo Alto y Bajo, Luís Díaz, Sancho Martín y Marchante; Ventosilla de los Prados con Montefrío Alto y Bajo; Camarero Alto y Bajo con Pangía, etc. Esa concentración es deudora de la estrategia seguida en los siglos XIII al XV, cuando se formaron esos grandes compactos por compras y permutas de cortijos y agregación de fincas menores. 
tazmías y fieldad cuando su actuación anómala o el disenso respecto a la renta del año acrecentaba los costes. ${ }^{36}$

Ejemplo de su atención por los aprovechamientos agrícolas de sus cortijos fue el seguimiento de las variedades de trigo sembradas, que a inicios del siglo XVIII conocieron cambios al tiempo que se elevaron substancialmente sus rendimientos. Así, en 1700 ó 1701 unos cortijos sembraban trigo blanquillo y otros bujalanceño en proporciones semejantes, pero ya en 1703 se citaban otras variedades (fimia en Montefrío Alto, alonso en Casillas) y el trigo raspinegro había comenzado su irrupción, alcanzando fracciones de 9 cortijos. Antes de concluir la década, el raspinegro ocupaba 15 cortijos por entero y 20 cortijos en 1716, por 8 de blanquillo y 4 de trigo bujalanceño, en un proceso de ensayos y substitución muy generalizado. ${ }^{37}$

El cabildo se comportó como un propietario con arraigo e influencia local, gran pericia en la manipulación de las cláusulas de sus contratos y especial interés en las relativas a la intensidad del cultivo y en aminorar los costes de transacción que la supervisión y aplicación de sanciones suponía a la mesa capitular y también a sus labradores. Las penalizaciones serían graduales en forma de pagos adicionales a la renta del año regulados en su cuantía por sistemas fijados en los contratos o por la costumbre local, y con mecanismos de resolución poco costosos cuando persistía el disenso (fieldad). Todo ello facilitó la adecuación de las labores a coyunturas cambiantes, redujo al mínimo los costes judiciales y también limitó los ligados a la incertidumbre del labrador ante la eventualidad de sufrir un desahucio y a sus efectos de pérdida de reputación y lesión económica en un mer-

36 Los contratos de 1828 incluían que los labradores de los cortijos donde «se encuentren defectos notables de labores o excesos en sus libertades» pagarían al perito 60 rs. por su trabajo, y ya he citado su pago al fiel. Además de los técnicos contratados, el trato con gran número de labradores y aperadores al negociar el ajuste anual de cada renta proporcionó al cabildo valiosa información sobre las prácticas de cultivo y rentabilidad potencial de sus fincas.

37 En 1716 mantenían trigo bujalanceño Aldea de don Gil, Magdalena, Rivillas y Villaviciosa, todos ellos de elevada fertilidad. Sembraban blanquillo Arcas, Cuadradillo, Cuadrado, Montefrío Alto y Bajo, Monteruelo Bajo, Pangía y Ventosilla. Fruto de los ensayos, el blanquinegro se abandonó tras haberse sembrado en varios cortijos (como Arcas o Monteruelo Bajo), y otros que iniciaron el siglo con trigo bujalanceño pasaron a sembrarse con blanquillo. 
cado en el que sólo cambiaban de labrador cada año dos o tres decenas de cortijos, de un número de propietarios inferior aún.

De la intensidad con que se supervisó las prácticas de cultivo da cuenta la casuística de los vicios detectados y sometidos a pagos. Por una parte, las siembras en las hojas de rastrojo y barbecho por encima de las autorizadas en contrato, muy frecuentes, detectadas por las tazmías que fijaban su extensión y cosecha prevista, y aceptadas sin reticencias a cambio de renta en proporción a sus frutos. ${ }^{38}$ La tolerancia con esos excesos aportó un margen de flexibilidad a los labradores, y un plus a las rentas, que contrasta con las amenazas de desahucio insertas en otros contratos y formas de gestión menos aptos para controlar y someter a pago esas prácticas. Por otra parte, la vigilancia y las sanciones al labrador que incumplía las tres rejas más cohecho y siembra obligadas en la hoja de tercio en los contratos, ${ }^{39} \mathrm{o}$ al que no sembraba toda la superficie de tercio fijada en el contrato. ${ }^{40}$ Ambas faltas eran muy graves en contratos a partes de frutos, infrecuentes, e indicio de un oportunismo inaceptable desde la lógica de este contrato, o de problemas como la carencia de recursos de los colonos por la reiteración de malas cosechas, su pérdida de cuota en los excedentes del cortijo o la falta de rentabilidad de las siembras en las peores tierras de labor de ciertos cortijos en coyunturas depresivas.

38 En general con la renta aplicable al tercio de labor, pero con una casuística de rebajas discrecionales muy variada.

39 Falta difícil de probar, aunque no de advertir y sancionar con la no renovación del contrato, si la coyuntura facilitaba el reemplazo de labrador. Varios ejemplos: a) penalización de 35 fanegas de pan terciado al labrador de Doña Urraca "por no haber labrado bien este cortijo en la cosecha de este año» (1757); b) pago de renta íntegra en todo el cortijo Gamonosa (1770) por no haber hecho los barbechos con 3 rejas y cohecho a estilo de buenos labradores, según declaración de los peritos J. Salcedo y J. González Vega en autos judiciales; c) pago de la renta íntegra sin esterilidad por 56 de las fanegas del tercio del cortijo Casillas, al aceptar su colono el certificado del perito J. Salcedo, que reconoció sus barbechos y «habiéndolo medido hallé que de las ciento y sesenta de su tercio las ciento y cuatro están labradas con arreglo a las condiciones de dicha escritura y las restantes cincuenta y seis no están como corresponde por haber treinta y ocho fanegas de una reja, y dieciocho sin labrar, por lo que las referidas cincuenta y seis deben quedar sujetas a la pena que impone la escritura de dicho arrendamiento» (1771).

40 Falta penalizada a veces con el pago de la renta íntegra por cada fanega no sembrada, como en el cortijo Torre Juan Gil (1751), y otras con la renta media de las sembradas en el resto del tercio, como en el cortijo Coronadas (1751 y 1774). En ambos cortijos, de los mayores del cabildo, por dos labradores privilegiados que por rara excepción se negaron al pago exigido y suscitaron pleitos, que concluyeron con el embargo de sus aperos y barbechos. 


\section{GRAFICO 2}

\section{CAMBIOS EN LA EXTENSIÓN DE SIEMBRA OBLIGADA EN LA HOJA DEL AÑO \\ (100 = siembra de su hoja de tercio completa)}

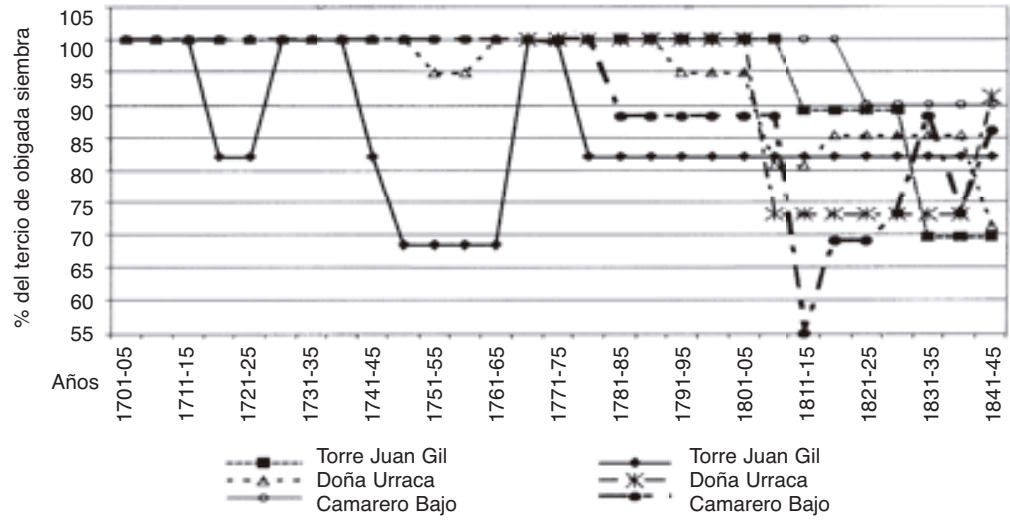

El cabildo tomó buena nota y negoció la reducción del tercio de siembra obligada en ciertos cortijos, como muestro en el gráfico 2. Fue ésta una decisión difícil, pues el cabildo hizo lo imposible para que todos sus cortijos se mantuviesen en cultivo y no se aprovechasen como dehesas de secano. De hecho, al evitar a sus labradores incurrir en pérdidas con labores y siembras en tierras marginales de algunas fincas, en épocas de precios relativos desfavorables, mantuvo el cultivo en aquellos cortijos que incluían tierras poco fértiles (Coronadas, Doña Urraca, Torre Juan Gil Alto); en otros ello fue condición para el mantenimiento sin interrupción de los contratos a esterilidad (Camarero Bajo, Pan Giménez, Torremocha); y en todos ellos permitió que sus rentas bajasen menos que sin su pericia y flexibilidad en la negociación de las cláusulas contractuales.

Pero la capacidad de ajuste de los contratos a esterilidad no era ilimitada, pues la modificación excesiva de sus cláusulas tendía a desnaturalizar el juego de incentivos y riesgos compartidos. Tanto si se aminoraban en demasía los pagos fijos como si se aumentaban aquéllos y se reducía la renta en grano establecida como umbral en los contratos - lo que multiplicaba los años en que se pagaría esa renta en grano íntegra, compartiendo riesgos el cabildo en las malas cosechas-, o si se incrementaban las libertades o superficies de siembra libres de renta, en las que los labradores tenderían a concentrar el estiércol disponible para acrecentar la fracción de la cosecha 


\section{GRÁFICO 3}

TIPO DE RENTA VIGENTE EN LOS CORTIJOS

DE LA MESA CAPITULAR DE CÓRDOBA, 1790-1980

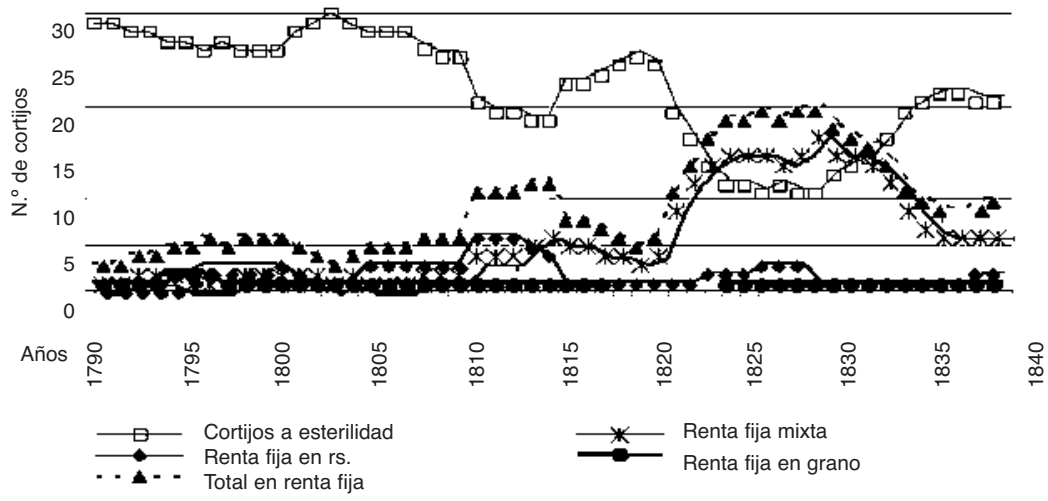

exenta de renta. Todo ello se ensayó, pero el margen de ajuste era limitado, pues dejando subsistentes los 2/9 de la renta a esterilidad, y añadido el diezmo, la semilla y otros costes, la rentabilidad de su cultivo en las coyunturas depresivas se veía cuestionada, y cuando el ganado lanar perdió gran parte de su rentabilidad se dificultó compensarlo mediante los excedentes pecuarios. De ahí que, al acentuarse las dificultades, se optase temporalmente por contratos de renta fija en bastantes cortijos, ${ }^{41}$ con niveles de renta inferiores a los precedentes, dejando al labrador mayores riesgos y también flexibilidad para reducir sus siembras y adaptarse a una coyuntura menos apropiada a los exigentes requisitos de los contratos a esterilidad.

No obstante, hasta la crisis en la labranza de los cortijos que comenzó en Córdoba en la segunda década del siglo XIX no fueron generales las alteraciones contractuales que implicasen aminorar la intensidad en el cultivo. Con anterioridad, el alza de los precios relativos del grano en la segunda mitad del siglo XVIII animó a introducir pequeños cambios en los contratos,

41 Los contratos a renta fija fueron más frecuentes en las primeras etapas liberales, quizás por temor a una pérdida de control respecto a las cosechas cuando el diezmo acentuó su erosión, o por afirmarse ideas favorables a la asunción de riesgo, por los colonos. En los años treinta no ocurrió lo mismo. 
o en su aplicación, que supusieron moderadas intensificaciones. El trigo fue desplazando a la cebada casi por completo de la hoja de tercio, y amplió sus siembras en las superficies autorizadas y sujetas a renta de los rastrojos, lo que antes había sido excepcional. ${ }^{42}$ Además, el cabildo introdujo en los años noventa una práctica que perduró unos tres lustros, el pegujal de los ministros, por el que la mesa proporcionaba la semilla y los colonos debían cultivar y recolectar una pequeña parcela de trigo en el rastrojo y entregar su producto al cabildo, deducido el diezmo. Las siembras en el rastrojo y barbecho crecieron en el siglo XVIII, principalmente en porciones de siembra autorizada y libre de renta, no incluidas en las tazmías, a menudo como contrapartida a otras exigencias a los labradores. ${ }^{43}$ En conjunto, la porción sembrada en esas hojas se mantuvo reducida, aunque su avance acumulado añadió en el siglo XVIII varios cientos de hectáreas de sembradío en los cortijos de la mesa capitular, siendo el trigo el cultivo más beneficiado.

La gestión del cabildo se caracterizó por una participación muy reducida en las inversiones requeridas por sus cortijos, puesto que los ganados, aperos y hasta las partes perecederas de las casas de los cortijos pertenecían a los labradores. Entre las inversiones en las que participó, se cuentan la construcción de un gran pozo de ladrillo para proveer de agua al cortijo Cisneros; la formación de una alameda en el cortijo Casillas (1780-1800); la construcción de nuevas casas en Casillas y Rinconada; o la reconstrucción de casas y almiares destruidos por incendios en Monteruelo Alto y Bajo y Camarero Alto. Concentrada en su gran mayoría a fines del siglo XVIII, la aportación se limitó en esos casos a la concesión de moderadas rebajas de renta en sus contratos, aumento de superficies de siembra libres de renta o pequeños préstamos sin interés. ${ }^{44}$

42 Tomando como muestra 6 cortijos (Aldea de don Gil, Aborroz, Pangía, Cañuelo, Arcas y Casillas), en las superficies de rastrojo sujetas a renta se cosecharon 2156 fanegas de trigo en 1700-1750, por 10960 en 1751-1800. La progresión es tan evidente como reducidas sus cuantías: sólo en los cuatro primeros habría alcanzado a proveer de pan a sus obreros fijos. Los años sin tazmía, por no aplicarse esterilidad, por buena cosecha, procedo a una estimación defectiva.

43 La autorización de esas siembras exentas de renta se practicaba de antiguo, pero se amplió y generalizó como contrapartida a la exigencia de satisfacer el diezmo a otras administraciones (1797) y al pegujal de los ministros. Pese a su reducida superficie, bien estercoladas y exentas de renta, esas libertades pudieron aportar parte relevante del excedente agrícola capturado por el labrador.

44 Todo ello, en A.C.C., Manuales de Cortijos. 
Pero esa reducida participación en las inversiones fue paralela a prácticas que implicaron rebajas de renta tras años calamitosos, tolerancia con el mantenimiento de ciertos débitos en coyunturas depresivas y, excepcionalmente, la concesión de elevados préstamos a sus arrendatarios. Todo ello con carácter discrecional y condicionado, ${ }^{45}$ favoreciendo a los labradores más comprometidos con la mesa capitular, y con rebajas de renta diseñadas para incentivar a sus labradores a extender sus siembras e intensidad del cultivo tras cosechas catastróficas, para que recuperasen en breve plazo su mermado capital de explotación... y llenasen en lo sucesivo los graneros de la mesa capitular.

Un ejemplo de esas prácticas se percibe en el año agrícola 1737-1738. En 1734 se perdió la cosecha. La de 1735 fue excelente y compensó parte de los daños, pero fue seguida de otra deficiente en 1736, y la de 1737 se perdió por entero. Era preciso romper esa dinámica que provocó pérdidas severas a los labradores, y que pronto se tradujo en abandonos de la labor que forzaron al cabildo a firmar contratos con rentas inferiores. Pero el elevadísimo precio de las semillas en los años de escasez, y la alta porción que renta y diezmo se llevarían de la cosecha venidera, no propiciaban que los labradores forzasen una salida a esa situación, arriesgando cuanto les restaba y solicitando préstamos si era preciso. El cabildo contribuiría a definir los incentivos precisos para salir de la situación, anunciando rebaja en las rentas de 1738 con un diseño adecuado. La rebaja no fue igual en todos los cortijos, pues se alcanzaron acuerdos parciales para sembrar cuanto fuese posible en los rastrojos, dejando a salvo los barbechos para no afectar la cosecha del año siguiente. En muchos cortijos la renta en grano se redujo en una tercera parte en la hoja de tercio, ${ }^{46}$ y tan sólo al diezmo en las extensas siembras en los rastrojos.

Con ocasión de otras cosechas calamitosas el cabildo adoptó comportamientos diversos. En 1751 redujo la renta al diezmo, e incluso menos, en las

45 En conjunto, un entramado de estímulos y compensaciones complejo, como el que definen Calatayud, Millán y Romeo (1997), pp. 340-341 y 343, y (2002), pp. 77 y 79.

46 Es decir, al diezmo y 1/10 adicional como renta. La cosecha fue excelente, y la rebaja se aplicó también en los cortijos en que tocó pagar la renta íntegra de contrato, que pagaron por ello menos de $2 / 10$ por renta y diezmo. 
extensas siembras en los rastrojos de algunos labradores, ${ }^{47}$ aun sin haber sido autorizadas con antelación, al tiempo que a quienes no sembraron todo el tercio tras la pérdida de la cosecha precedente (Coronadas, Torre Juan Gil), pese a disponer de recursos, les impuso fuertes pagos que concluyeron en embargo y ejecución de su equipo de labranza. Dos años después hubo otra cosecha perdida, y el cabildo rescató sus propuestas más cooperativas para incentivar una rápida recuperación del capital de explotación. En 1754 autorizaron superficies de siembra extensísimas fuera de la hoja del tercio —o se presionó a ampliar esas siembras, que a veces ocuparon todo el rastrojo-, limitando al diezmo el pago por lo cosechado en ellas. Como la cosecha fue mediocre y no se cumplieron los objetivos, en 1755 volvieron a repetirse siembras muy extensas que contribuyeron a una cosecha formidable.

En circunstancias más excepcionales, cuando la cosecha perdida se insertaba en una coyuntura depresiva en la que aumentaba la dificultad de captar a nuevos labradores con recursos y aptitud idóneos, el cabildo añadió a esas prácticas mayor tolerancia con el retraso en los pagos y la cesión de préstamos a sus colonos. En parte para aportarles liquidez sin exponerlos a demandar otros más onerosos — que deberían pagar del excedente, retardarían la recuperación de su capital de explotación y llevarían a aminorar las rentas que podrían satisfacer, o a su quiebra y abandono del cortijo-, y en parte para escriturar y escalonar el pago de unos débitos ya contraídos. El ejemplo más destacado fue el préstamo de 400000 reales a sus labradores en 1804 , equivalente a $2 / 3$ de la renta anual de todos sus cortijos por entonces, el grueso de los cuales se acumuló por un puñado de labradores que mantenían antigua relación como arrendatarios de la mesa capitular. ${ }^{48}$

Hasta 1808 sus colonos retornaron casi la mitad del préstamo, pero la guerra paralizó los pagos y aceleró la retirada de muchos de los labrado-

47 El labrador de Gamonosa cosechó en el rastrojo 570 fanegas de trigo, aparte de las siembras a que estaba autorizado por contrato, y sólo pagó 50 fanegas de trigo por diezmo y renta de ellas. Un trato muy preferente al que no fue ajeno su compromiso con el patrimonio, pues desde 1717 labraba sin interrupción el cortijo.

48 «Nota del préstamo de 400000 rs. de las capillas de San Acacio y Sta. Inés a favor de la mesa capitular y de los que hizo ésta con los mismos fondos a los labradores de sus cortijos en el año de 1804, y actual estado de su reintegro en el de 1810» (A.C.C., legajo 3161). Hubo bastantes otros créditos menores. Además de las fechas que indico, buen número de los colonos beneficiados habían sucedido a sus familiares en ese u otros cortijos del cabildo. 
CUADRO 4

MAYORES BENEFICIARIOS DEL PRÉSTAMO DE 400000 REALES EN 1804

\begin{tabular}{|c|c|c|c|c|}
\hline $\begin{array}{l}\text { Cuantía del } \\
\text { préstamo }\end{array}$ & $\begin{array}{l}\text { Débito en } \\
\text { dic. } 1810\end{array}$ & Labrador & Cortijos & $\begin{array}{c}\text { Años de arriendo } \\
\text { en ese cortijo }\end{array}$ \\
\hline \multirow[t]{2}{*}{61117 rs. } & \multirow[t]{2}{*}{23401 rs. } & \multirow[t]{2}{*}{ Juan de Ayllón } & Camarero Bajo & $1788-1811$ \\
\hline & & & Torre Juan Gil Bj. & $1791-1810$ \\
\hline \multirow[t]{2}{*}{49600 rs. } & \multirow[t]{2}{*}{ ? } & \multirow[t]{2}{*}{ Diego Negrete } & Monteruelo Alto & $1774-1816$ \\
\hline & & & Monteruelo Bajo & $1780-1816$ \\
\hline 41489 rs. & 12239 rs. & Juan F. Botijón & Doña Urraca & $1796-1810$ \\
\hline 30000 rs. & - & María Ramírez & Chotón & $1795-1808$ \\
\hline 24000 rs. & 18000 rs. & Francisca Dávila & Montefrío Alto & $1748-1811$ \\
\hline 24000 rs. & 14100 rs & Alonso Velasco & Rivillas & $1789-1815$ \\
\hline 15000 rs. & - & Luís de Castro & Torremocha & 1779-1809 \\
\hline 12000 rs. & - & J.Coca Oblancas & Villaviciosa & $1790-1811$ \\
\hline 12000 rs. & 3677 rs. & Lorenzo Gavilán & Camarero Alto & $1788-1816$ \\
\hline 12000 rs. & 7133 rs. & Ana M.a Arellano & Cisneros & $1799-1810$ \\
\hline
\end{tabular}

res que el cabildo habría deseado preservar. En un nuevo contexto sociopolítico, en que el cabildo vería amenazada su posición social privilegiada y en riesgo sus rentas y patrimonio, y se hizo más difícil la captación de labradores solventes y adictos, su gestión tendió a ser más transigente con los débitos. ${ }^{49}$ Trató de escalonar los pagos, condonó pequeñas cantidades y toleró atrasos, cuidando de que el débito no excediese de la cuantía susceptible de ser compensada con los enseres de labor, si había que optar por ese recurso final. En definitiva, en ciertas épocas y con los labradores cuya continuidad deseaba preservar, el cabildo asumió una participación en los riesgos climáticos, de incendio, por requisas militares y otros, por encima de lo exigido por los contratos, y su actuación ganó la fidelidad de familias de labradores muy ligadas al cabildo, a algunas de las cuales salvó largo tiempo de la usura y la quiebra.

49 Diego Negrete dejó en 1816 Monterito Alto debiendo 11 658,74 rs. del préstamo de 1804, del que se hicieron cargo los nuevos labradores, que tomaron de él los ganados y aperos. Marina Ayllón recibió Camarero Bajo de Juan Ayllón comprometiéndose a pagar los 7000 rs. que éste debía aún. Alonso Velasco debía 28585 rs. de rentas de Rivillas a fines de 1810, y sus herederos arrastraron débitos hasta 1840, en que dejaron el cortijo y traspasaron sus aperos al colono entrante en pago del débito, etc. En la documentación municipal hay indicaciones de la acelerada rotación de arrendatarios en los cortijos del término (21-VIII-1811), y de las muchas fincas que estaban quedando sin labrador (oficio al prefecto, 27-V-1812). A.M.C., caja 1723. 
Los contratos a esterilidad y las prácticas de gestión del cabildo tendían a distribuir el elevado riesgo ligado a la fluctuación de las cosechas del cereal de secano en los cortijos béticos. La reducción de la renta en grano en los años de mala cosecha, en que ésta se hacía particularmente gravosa, reducía significativamente el capital circulante preciso para emprender la labor de un cortijo y la probabilidad de tener que recurrir al crédito, o a vender a bajo precio el ganado, para obtener liquidez. La aceptación como garantía hipotecaria de los ganados, aperos, casas del cortijo y labores de barbecho facilitaba el acceso a la labor a personas sin más bienes que los precisos para la labranza y el aprovechamiento ganadero del cortijo, e incluso cuando poseían otros inmuebles no fue inusual que el cabildo decidiese no levantar hipoteca sobre ellos, otorgando así a los labradores una suerte de responsabilidad limitada. Con todo ello, el cabildo ampliaba el número de potenciales arrendatarios, que no era crecido y obligaba a elegir, para arrendar los más de cuarenta cortijos de la mesa capitular y patrimonios anejos, entre candidatos no siempre idóneos, y reducía su dependencia de los escasos labradores acaudalados, que poseían mayor capacidad de negociación al fijar las condiciones contractuales y rentas y eran preferidos por otros propietarios por la seguridad que añadían a la satisfacción de sus pagos en los plazos previstos. La autorización de siembras muy extensas tras cosechas catastróficas y su incentivo con rebajas en su renta, así como el pago escalonado de débitos y otras prácticas beneficiosas al labrador, hacían más dependientes a los colonos del favor discrecional del cabildo, y más inclinados a aceptar sus exigencias respecto a la intensidad en las labores.

\section{Esterilidad y renta de la tierra, una aproximación de urgencia}

Pero la reducción del riesgo para el colono no debe llevar a confundir los contratos a esterilidad, ni otros a partes de frutos, con sistemas de cesión que implicasen menores rentas o menor presión sobre el producto bruto. ${ }^{50}$ Bien al contrario, las rentas de los cortijos del cabildo eran muy elevadas respecto a fincas análogas con otros tipos de contrato.

50 La renta en grano en 14 cortijos del patrimonio aquí estudiado equivalía en 1611 1617 al 30,86\% de sus cosechas, y un 24,43\% en 1830-1836, según cálculos de Ponsot (1981), p. 177. 


\section{CUADRO 5}

EVOLUCIÓN DE LA RENTA EN CORTIJOS DE LA MESA

CAPITULAR DE CÓRDOBA: ESTABILIDAD A MEDIO PLAZO

DE LAS RENTAS A ESTERILIDAD

\begin{tabular}{|lcc|}
\hline Periodos & Grupo A & Grupo B \\
\hline & (Renta total con inclusión de diezmo) \\
$1700-1769$ & $\frac{100}{86}$ & 100 \\
$1770-1789$ & $\frac{86}{73}$ & 92 \\
$1790-1796$ & (Renta total, el diezmo se paga a otros) \\
& 57 & 92 \\
$1797-1801$ & 66 & 75 \\
$1802-1806$ & 56 & 69 \\
$1807-1811$ & 38 & 57 \\
$1812-1816$ & 67 & 71 \\
$1817-1821$ & 55 & 64 \\
$1822-1826$ & 66 & 80 \\
$1827-1831$ & 56 & 52 \\
$1832-1836$ & 48 & 51 \\
$1837-1841$ & & \\
\hline
\end{tabular}

FUENTE: Rentas totales convertidas en pan terciado/ha $(100=$ media de 1700-1769). Grupo A: 14 cortijos $^{51}$ con 3781 ha que firmaron contratos de renta fija. Sus primeros índices los subrayo, pues tenían entonces contratos a esterilidad salvo excepción, y en 1790-1841 el índice sólo promedia los cortijos que en cada año tenían en vigor rentas fijas. El grupo B, 10 cortijos con 4127 ha que mantuvieron sus contratos a esterilidad.

Además, el interés del cabildo por mantener los contratos a esterilidad — visible por su recuperación al concluir las coyunturas políticas más desfavorables, su mantenimiento por los colonos más ligados a la institución o las alteraciones en sus cláusulas reduciendo el tercio de siembra obligada para hacerlos viables en etapas adversas - no fue ajeno a que, a pesar de las reducciones que se pactaron en la renta en grano en sus contratos a esterilidad, la evolución de sus pagos efectivos mantuvo, como muestro en el cuadro 5, mayor estabilidad y nivel que en los cortijos en

51 Grupo A: Alcaparra, Aldea de don Gil, Camarero Alto, Cañuelo, Casillas, Chotón, Cisneros, Coronadas Altas y Bajas, Cuadradillo, Monteruelo Alto y Bajo, Torre Juan Gil Alto y Hazas de la Iglesia. Grupo B: Camarero Bajo, Hinojosa, Pan Giménez, Pangía, Rivillas Bajas, Ventosilla, Villaviciosa, Gamonosa y Montefrío Alto y Bajo. Los demás cortijos no los he incluido en ninguno de los grupos, pues firmaron más de un contrato de renta fija, aunque por corto número de años. 
que se optó por rentas fijas, en los que se negociaron descensos de renta superiores.

El cabildo administró sus cortijos con gran habilidad en el manejo de las cláusulas contractuales, al servicio de la captación de rentas elevadas y bastante estables a medio plazo. La subdivisión de sus mayores cortijos en la década de 1760 fue su adaptación a las dificultades de arrendarlos en esos años, en parte ligada a los avatares en la formación paulatina del mercado interior. ${ }^{52} \mathrm{Su}$ flexibilidad respecto a los atrasos de renta en el primer tercio del siglo XIX fue una adaptación a la creciente dificultad para captar nuevos arrendatarios con solvencia y motivación para cultivar con intensidad los cortijos - condición precisa para la satisfacción del elevado nivel de rentas por unidad de superficie que caracterizó a este patrimonio-, y al nuevo contexto político más incierto para la institución, que hizo necesario estrechar alianzas con los labradores de la casa. Pero incluso en esos años, en que se asumieron costes por encima de lo habitual por decisiones ligadas a esa coyuntura agraria y política, y no sólo al sistema de esterilidad que se reemplazó en muchos cortijos al acrecentarse las dificultades, no se dudó en incautar los aperos y ganados de los arrendatarios que se arruinaron en la explotación de sus cortijos.

Incluso considerando la renegociación de los débitos en las fases más críticas de inicios del siglo XIX, los contratos a esterilidad, y la forma en que los gestionó el cabildo cordobés, entrañaron costes de transacción reducidos respecto a otros modelos de administración, para el cabildo y más aún para sus labradores. Todo ello con moderados y repartidos costes de supervisión, que repercutían en la alta intensidad de las labores, evitaban fijar sin información suficiente las rentas a exigir en nuevos

52 En 1771 el labrador del cortijo Vírgenes, de los propios de Córdoba, solicitó una fuerte baja en la renta que venía pagando desde enero de 1765, y afirmó que aquélla se elevó mucho por la extracción de granos de Córdoba a los puertos de Sevilla, Málaga y otros, con motivo de la escasez existente en España, y que la extracción se había reducido mucho y los precios descendido. Consiguió la rebaja, y el informe administrativo formado indicó que se hallaban "en el día muchos de los mejores cortijos y tierras sin labradores» (A.M.C., caja 126). La renta de los cortijos del cabildo evolucionó de modo semejante a las rentas señoriales valencianas expresadas en grano y medias móviles —Catalá (1995), p. 227, gráfico 4-, en tanto que rentas y precios de un proveedor alternativo, Tierra de Campos, fluctuaron en esta etapa a la inversa que en Córdoba. Yun (1987), pp. 516 y 519-522. 
contratos e identificaban siembras no autorizadas y cobraban por ellas pagos preestablecidos en lugar de imponer riesgos de desahucio; con sistemas de verificación en caso de disenso (fieldad); y con muy reducidos gastos judiciales.

El contraste de esa gestión con otro ejemplo local puede servir para alertar frente a la definición ahistórica de uno u otro tipo de contrato como óptimo. Los propios de Córdoba poseían 6 cortijos en distintos municipios de la campiña. De muy antiguo se arrendaron con renta fija en metálico y por tres años de contrato. Su aprovechamiento se efectuaba de facto como si tuviesen privilegio de cerramiento. Sus arrendatarios se seleccionaban por subasta, procedían de otras poblaciones y no parecen haber tenido relación previa con los munícipes de la capital. El concejo no incurrió en gastos de tazmías anuales, pero sí en otros informes pormenorizados sobre sus tierras e instalaciones para fijar la renta que podía exigirse en distintas coyunturas. La concurrencia de licitadores fue excitada mediante decenas de pregones por los pueblos. Formalmente, el sistema de contratación parece óptimo en teoría. Pero la realidad sería algo diferente, y sus rentas por hectárea rondaron la mitad que en los cortijos del cabildo, lo que sólo limitadamente respondía a divergencias en su fertilidad. Dada la excesiva extensión de varios de los cortijos de propios, las elevadas garantías hipotecarias que solían exigirse a sus colonos, la dispersión de los cortijos en 3 focos $^{53}$ y la carencia de relaciones suficientes con labradores de las poblaciones próximas a cada finca, rara vez eran más de dos quienes propusieron posturas sucesivas o acudieron a pujar en subasta. El Ayuntamiento cordobés desatendió los informes técnicos que aconsejaron subdividir sus fincas en cortijos de dimensión inferior para reducir barreras de acceso, facilitar una mayor concurrencia de colonos y elevar sus rentas. Tal vez le detuvo la penuria de medios para construir los pozos, abrevaderos e instalaciones que los peritos creyeron necesarios, o la desconfianza sobre su rápida amortización, además

53 El Ingeniero (942,6 ha), en Santaella y lindante con el término sevillano de Estepa, dista $56 \mathrm{~km}$ en línea recta de Paredones (583 ha), Butaguillos (500,7 ha), Vírgenes (376,1 ha) y Perestrella (340,3 ha), contiguos y repartidos entre los términos de Castro del Río y Baena, y limítrofes con el principal núcleo de cortijos del cabildo (Cuadrado, Gamonosa, etc.), cuyas rentas eran muy elevadas. El sexto cortijo, Haza Pedernales (131 ha), está en Córdoba. Otro cortijo de los propios de Córdoba, La Parrilla (915,1 ha), estaba en La Rambla y fue segregado del patrimonio para formar parte del espacio en el que se desarrolló la colonización carolina. 
del temor a que alterando su situación se alentaran las exigencias de reparto entre los vecinos de los términos en que radicaban. El sistema seguido para la subasta del arriendo producía a menudo la continuidad del labrador, pero no apoyada en una confianza creciente entre titular y colono que animara a éste a inversiones que tardasen en amortizarse y redujera costes de supervisión, sino por la ocasional falta de otros licitadores, reclamando y obteniendo entonces con frecuencia el colono rebajas en la renta. Sin embargo, otras veces concurrían varios interesados y las rentas se elevaban de modo súbito, alcanzando unas fluctuaciones de intensidad desconocida en los cortijos del cabildo. Junto al cambio en los mercados, los labradores adujeron dos razones respecto a esas elevaciones. Una era el retraso excesivo en la negociación, por el sistema de subastas y mejoras posteriores, formalmente intachable pero en la práctica un arma de doble filo. Evitar el retraso y la inseguridad que suponía podía alejar a competidores, pero también llevó a aceptar elevaciones en la renta a labradores que por ese retraso habían perdido la ocasión de arrendar otros cortijos y precisaban una finca para sus ganados y labranzas. En otras ocasiones se afirmó que las pujas alcanzaron rentas poco sostenibles por acaloramiento en la subasta. Las importantes fluctuaciones de renta de un contrato a otro, y su carácter de renta fija en el contexto de fuerte inestabilidad de las primeras décadas del siglo XIX, dieron origen a débitos más elevados que en los cortijos del cabildo. En teoría eran más tolerables, por las garantías hipotecarias más exigentes que se requirieron. Pero la lejana vecindad de los arrendatarios de sus mayores fincas y de los bienes que habían hipotecado, la quiebra de esos labradores y el retraso en las gestiones para su cobro en un contexto deflacionista derivaron en la acumulación de impagos abultados y definitivos, cuyos mayores beneficiarios fueron los empleados en litigios y gestiones, que generaron una voluminosa documentación. ${ }^{54}$

54 Manuel Valdés arrendó en 1817-1819 el cortijo del Ingeniero por 35000 rs., antes arrendado en 10000 . Hipotecó como garantía 61 aranzadas de olivar en Estepa valoradas en 124000 rs. y en tres años acumuló 80000 rs. de débitos por rentas y costas. Valdés edificó nuevas casas con techo de teja que generaron pleitos. Su viuda, residente en Puente Genil, exigiría que se tomaran como parte del débito - las casas se apreciaron en 27654 rs. en 1825, y en 37980 rs. en 1837-, pero el Ayuntamiento pleiteó por el pago íntegro del débito y no acertó a escalonar en varios años el pago de las casas por el arrendatario entrante, ni a administrar como propias las edificaciones. Al pretender que los colonos pagasen su valor al contado, creó una barrera de acceso que dejó sin arrendatario el cortijo varios años... Diego Escobar arrendó en 1833 Paredones y Medina, y en 1850 todavía se indaga- 
El cabildo eclesiástico de Córdoba se comportó como un propietario rentista. Pero muy atento al seleccionar a sus colonos y, al subdividir sus fincas para hacerlo posible, vigilante con sus formas de explotación, que no aceptó derivasen hacia el uso como dehesa, a diferencia de la administración de propios y otros titulares privilegiados — para quienes la renta ofrecida en subasta y con fianza hipotecaria fue un criterio más decisivo-, flexible cuando las circunstancias condujeron a pérdidas generalizadas en la explotación de sus fincas y diligente en la elección de contratos, la manipulación de sus cláusulas y la gestión diaria para evitar la judicialización del disenso. Naturalmente su pretensión era capturar el grueso de las ganancias derivadas de todo ello, y el resultado no le fue insatisfactorio. La contrapartida a la asunción compartida de riesgos y las bajas exigencias para el acceso a la labor respecto a cortijos semejantes, fue la imposición de prácticas de labranza exigentes y una participación en las cosechas que permitió al cabildo ingresar rentas muy elevadas y más regulares a medio y largo plazo que las de otros patrimonios béticos con cortijos arrendados a renta fija y, en general, objeto de una gestión menos atenta respecto a las prácticas de explotación y la producción de sus tierras.

En el cuadro 6 muestro el elevado nivel de renta por hectárea obtenido por el cabildo de Córdoba en sus cortijos, ${ }^{55}$ en relación con otras explotaciones béticas de idéntica orientación productiva, y la notable estabilidad de sus rentas respecto a otros patrimonios. Aparte de evoluciones atípicas de rentas como la de los donadíos de Trebujena y Sanlúcar - cuyo descenso en la segunda mitad del siglo XVIII parece excesivo-, la expresión de las rentas en litros de trigo evidencia los límites y la temprana inflexión de unas rentas que cuando se muestran en reales parecen no haber tenido freno. De hecho, frente a los cortijos del cabildo de Córdoba, ubicados en una de las áreas de Andalucía más densamente pobladas y cultivadas desde el siglo XVI y más favorables a las siembras del trigo

ban los bienes afectos a la fianza hipotecaria que presentó, pues no pagó los 27000 rs. de renta de los 3 años del contrato, la décima parte del valor del cortijo al cederlo a censo reservativo en 1842. Un ejemplo de intensa fluctuación en la renta, esta vez sin impago: el cortijo Vírgenes rentó 19531 rs. anuales en 1804-1807, por 7344 rs. anteriormente y 9000 rs. después (A.M.C., cajas 122, 123 y 126).

55 Un nivel no alejado del medio hl de trigo por ha en explotaciones menores cultivadas a año y vez en Tierra de Campos durante el grueso del siglo XVI. Yun Casalilla (1987), p. 171. 


\section{CUADRO 6}

EVOLUCIÓN DE LA RENTA EN CORTIJOS DE DISTINTAS

ÁREAS DE LA ANDALUCÍA BÉTICA

(rentas totales expresadas en litros de trigo por ha de superficie)

\begin{tabular}{|c|c|c|c|c|c|c|c|}
\hline & \multicolumn{3}{|c|}{ Córdoba } & \multicolumn{2}{|c|}{ Sevilla } & \multicolumn{2}{|c|}{ Cádiz } \\
\hline & \multicolumn{2}{|c|}{$\begin{array}{c}\text { Mesa } \\
\text { Capitular }\end{array}$} & $\begin{array}{l}\text { Propios de } \\
\text { la capital }\end{array}$ & Coronil & Utrera & $\begin{array}{l}\text { Trebujena } \\
\text { Sanlucar }\end{array}$ & Jerez \\
\hline N. ${ }^{\circ}$ cortijos & \multirow{2}{*}{\multicolumn{2}{|c|}{$\begin{array}{c}33 \\
10302\end{array}$}} & 6 & 21 & 6 & 6 & 5 \\
\hline Hectáreas & & & 2874 & 3365 & 4063 & 4609 & 2998 \\
\hline & A & B & & & & & C \\
\hline $1671-1690$ & & & $12,4 \mathrm{~b}$ & 8,4 & 6,9 & 41,3 & $(46,9)$ \\
\hline $1691-1710$ & $(62,6) a$ & $44,1 \mathrm{a}$ & $18,0 \mathrm{c}$ & 13,5 & 13,6 & 56,2 & $(63,5 \mathrm{~g})$ \\
\hline $1711-1730$ & $(69,6)$ & 50,8 & $34,2 \mathrm{~d}$ & 15,9 & 21,2 & 66,4 & $(49,7)$ \\
\hline $1731-1750$ & $(59,8)$ & 48,0 & $30,1 \mathrm{e}$ & 25,5 & 18,1 & 57,4 & $(46,9)$ \\
\hline $1751-1770$ & $(78,8)$ & 59,1 & $29,9 \mathrm{f}$ & 28,4 & 21,6 & 28,6 & \\
\hline $1771-1790$ & $(59,7)$ & 47,6 & 20,5 & 24,3 & 23,5 & 15,2 & $(56,0)$ \\
\hline $1791-1810$ & $(49,5)$ & 45,7 & 24,9 & 17,2 & 18,0 & 12,5 & $(41,2)$ \\
\hline $1811-1830$ & & 34,3 & 20,7 & 19,7 & & & $(36,2)$ \\
\hline
\end{tabular}

Los datos entre paréntesis incluyen el diezmo íntegro (Córdoba), o 2/3 de éste (Jerez). a: años 17001710; b: 1668-1672; c: 1700-1701; d: 1724-1730; e: 1731-1747; f: 1765-1770; g: 1690-1699.

FUENTES: Córdoba, en A.C.C., Manuales de Cortijos; A.M.C., cajas 122 a 126, y 131; Pozas (1995), p. 413 y (2001), pp. 393-401; y García Pozuelo (2001), pp. 195-200. Jerez, en A. L. López Martínez (1997), pp. 717-718. Las tres series restantes, en Bernal (1988), pp. 168-169. Para las medidas superficiales de cada término, Ferrer y González (1996). ${ }^{56}$

en secano, ${ }^{57}$ el nivel de la renta por hectárea de muchos cortijos de las mayores casas nobiliarias aparece como relativamente bajo. No en balde, muchas de sus tierras las consiguieron en el Medievo en la periferia de la campiña, alrededor de la accidentada y peligrosa franja morisca. De ahí que el intenso ascenso de las rentas de éstas desde inicios del siglo XVI, frente a la estabilidad muy superior de otras comarcas béticas, no se deba

56 Prescindo de Hazas de Argote entre los 34 cortijos del cabildo estudiados, pues no me es posible restar el diezmo. Precios de Ponsot (1986), pp. 519-521. Prescindo de la serie de renta de 32 cortijos de Córdoba de este autor, pues la estimo inverosímil. Pese a estar situados en términos de inferior fertilidad, en 1690-1750 su serie dobla la renta por unidad de superficie de los cortijos del cabildo, que pagaban 3/10 de su cosecha bruta más pagos en metálico. Quizás el autor tomó rentas a esterilidad por su valor íntegro en contrato.

57 La Campiña Baja de Córdoba ha tenido recientemente los mayores rendimientos medios del trigo en secano de Andalucía, junto a la Campiña de Cádiz y el Condado y Campiña de Huelva. Pérez García (1998), pp. 33-34. 
sólo al tipo de contrato ni al dinamismo vinculado al imperio de esas comarcas, y sí a la tardía colonización de esas áreas periféricas y la puesta en cultivo posterior y gradual de sus tierras.

Los contratos a esterilidad de los cortijos cordobeses vivieron su canto del cisne en los años 1830, decayendo a continuación hasta constituir rara excepción en la segunda mitad del siglo. Algunas circunstancias rodearon su extinción. Entre ellas, la aplicación de rentas fijas por la administración de bienes nacionales, que heredaron los compradores de esas fincas y sirvieron de ejemplo a otros; la compra de numerosos cortijos del cabildo y otras instituciones locales por propietarios residentes en Madrid u otros puntos distantes — un absentismo de nuevo cuño, hijo de la reforma agraria liberal—, no habituados a los sistemas de supervisión que requerían los contratos a esterilidad, que habrían generado obligaciones indeseadas a sus administradores y a los titulares problemas de agencia; un probable agravio fiscal en la estimación del líquido imponible de quien cedía tierras con esos contratos, que puedo documentar para Córdoba en ciertos años; la desaparición de la administración decimal, que proporcionaba información global sobre las cosechas con que contrastar tazmías efectuadas sin grandes costes, aceptando los agentes la compensación de los errores a lo largo del tiempo; o la falta de flexibilidad que existió para alterar las partes de frutos exigidas como renta y adecuarlas a coyunturas socioeconómicas cambiantes.

Sin una causalidad única ni suficiente, los contratos a esterilidad desaparecieron en un contexto de intensas transferencias de propiedad y renovación entre los arrendatarios. El ambiente de la revolución liberal, que en las dos primeras etapas constitucionales ya coincidió con un importante aunque efímero retroceso de esos contratos, acabaría por conducir a su abandono. En ocasiones, esos cortijos fueron adquiridos por propietarios que los cultivaron por sí, y a veces construyeron mejores pozos y otras instalaciones e intensificaron su explotación. Con menor excepcionalidad de lo que se admite, otros cortijos se parcelaron, aumentaron sus siembras de leguminosas y redujeron o eliminaron los barbechos. ${ }^{58}$ Pero, en su gran

58 En el siglo posterior a su desamortización, un tercio de los cortijos del cabildo cordobés se parceló o se segregaron parcelas de él, en dominio o en explotación. El proceso no siempre fue irreversible, pero las más de 400 parcelas en propiedad entre Montefrío Alto y Bajo hacia 1919 permiten hacerse idea de su potencial repercusión social. 
mayoría, en Córdoba se mantuvo su arriendo con renta fija en metálico, contratos de corta duración y mayores restricciones al incremento coyuntural de las siembras fuera de la hoja de tercio que cuando los administró el cabildo. ${ }^{59}$

La superioridad de los contratos a renta fija en metálico frente a los de renta mixta a esterilidad, u otros a partes de frutos con implicación inversora de los propietarios, o con mayor estabilidad y derechos del campesino, no resulta aceptable como afirmación atemporal. ${ }^{60}$ En su origen constituyó en cierto modo un mito eurocéntrico alimentado de prejuicios clasistas y urbanos frente a los saberes y esfuerzos del campesino pobre, al que se oponía un idealizado gran labrador con capital y conocimientos técnicos, en un mundo agrario identificado en general con los cultivos herbáceos en grandes llanuras, susceptibles de antiguo de economías de escala. Un planteamiento esquemático no asumido plenamente por los tratadistas prácticos, y cuya insuficiencia han intentado analizar múltiples aproximaciones desde la nueva economía institucional. ${ }^{61}$

Es bien cierto que, a largo plazo, de mantenerse contratos a partes de frutos se habría hecho conveniente la aportación inversora del propietario en abonos y equipo al ser reemplazado el ganado de labor y renta, que en los cortijos producía ingresos y no sólo costes a los colonos. También lo es que la fluctuación atenuada en los precios de los productos por la ampliación del mercado y en las cosechas por cambios en las labores, el acceso al crédito en mejores condiciones por los colonos, los seguros contra incendios y otros, y la propia acumulación de capital por los labradores, reduje-

59 Hasta la recuperación en el siglo XX de la antigua fórmula contractual a pasto $y$ labor, que dejaba más flexibilidad al colono, no vigilaba su intensidad en el cultivo y admitía potencialmente prácticas degradadoras de la fertilidad.

60 La aparcería ganó terreno en Italia en las décadas finales del siglo XIX e iniciales del XX. La visión pesimista sobre ese contrato abrió paso hace décadas a la aceptación de sus posibilidades de transformación y su reconocimiento como un instrumento de transformación agraria, por E. Sereni, L. Cafagna y otros. Biagioli (2003), pp. 69-70, 75-79 y 82. También J. Torras y otros han vinculado la especialización vitícola que impulsó la economía catalana moderna con la rabassa morta, cesión a partes de frutos con derechos mucho más sólidos del campesino, u otros contratos al uso.

61 J.S. Mill ya alertó frente a argumentos basados en prejuicios. Una síntesis sobre las interpretaciones sobre la aparcería de los clásicos a la nueva economía institucional, en Colin (ed.) (2003). 
ron imperfecciones en ciertos mercados y otras causas que hacían ventajosa la distribución de riesgos de los viejos contratos. No obstante, cuando se produjo la desaparición de los contratos de esterilidad cordobeses, estaban lejos de haberse consumado esos cambios, y su reemplazo por contratos con renta fija en metálico se acompañó de comportamientos más absentistas por los grandes propietarios rentistas. En ese contexto, los contratos de renta fija en metálico distaron mucho de contribuir a la perfección de los mercados. Al disociar la obtención de la renta por los propietarios de la estrecha supervisión del cuadro técnico de las labores, la producción y sus precios, se afirmó por el contrario una asimetría creciente entre la información de los rentistas y de los cultivadores. En algunas etapas, la fuerte presión para acceder al cultivo de la tierra contrarrestó los efectos que de ello cabría esperar. A más largo plazo, esa asimetría contribuiría a la degradación gradual del rentista. Incluso en la campiña de Córdoba, donde la renta de los cortijos conoció un notable ascenso en el primer tercio del siglo XX, los cambios en los sistemas de cultivo y los rendimientos, y en los precios relativos de sus productos y del trabajo, propiciaron varias coyunturas de acumulación por los grandes labradores, que, tardíamente, accedieron al fin a la propiedad de los cortijos cordobeses. 


\section{CAMBIOS HACENDÍSTICOS Y DE GESTIÓN EN LOS PATRIMONIOS DE LA HIDALGUÍA ACOMODADA GALLEGA EN EL SIGLO XIX* Antonio Presedo Garazo (Universidade de Santiago de Compostela)}

\section{Introducción}

Los patrimonios de la hidalguía gallega más acomodada, compuesta por una reducida elite de rentistas seculares que había alcanzado e incluso superado el nivel de ingresos de los rentistas excepcionales durante la Época Moderna, ${ }^{1}$ no se mantuvieron al margen de las transformaciones que experimentaron en el transcurso del siglo XIX, en el contexto peninsu-

* Una primera versión del presente texto fue presentada en el Simposio Internacional: Gestión de patrimonios agrarios y reformas agrarias (1800-1950), celebrado en la Biblioteca del Colegio Mayor Fonseca de la Universidad de Salamanca durante el mes de noviembre del año 2004, bajo la dirección del profesor Ricardo Robledo. La versión que presentamos ahora contiene algunas de las sugerencias que salieron a la luz durante las sesiones de trabajo de dicho seminario, entre las cuales es preciso hacer mención especial a las planteadas por los profesores Ricardo Robledo y Juan Carmona, a quienes me gustaría expresar mi agradecimiento desde esta nota introductoria.

1 Según Villares (1982), pp. 50-51, las instituciones eclesiásticas y casas nobiliarias e hidalgas que hemos de considerar rentistas excepcionales en la Galicia del Antiguo Régimen acostumbran a superar los 1000 ferrados o, si se prefiere, los $200 \mathrm{hL}$ de renta anuales. 
lar, los patrimonios de las viejas clases dominantes procedentes del Antiguo Régimen. ${ }^{2}$ Como es bien sabido, la interpretación de dichas transformaciones no se halla exenta en el caso gallego de cierto grado de complejidad, habida cuenta de los resultados que se derivaron de la aplicación de la reforma agraria liberal que pretendía liberalizar el mercado de la tierra, integrando en él los patrimonios rústicos incorporados a sus vínculos y mayorazgos, y que se manifiestan desde el momento mismo en que cristaliza la crisis del Antiguo Régimen. ${ }^{3}$

La pervivencia de los patrimonios de esta elite regional en la Galicia decimonónica se halla estrechamente relacionada con el sistema de propiedad más extendido y todavía predominante, esto es, el foro, ${ }^{4}$ que había permitido la consolidación de un marco relacional singular entre los colonos que usufructúan el dominio útil de la tierra y la compleja red de foristas que detentan su dominio eminente. De hecho, esta particular tipología de propiedad enfitéutica, que, tengámoslo presente, hunde sus raíces en los siglos centrales de la Edad Media, ${ }^{5}$ se había convertido en uno de los pilares de la sociedad tradicional gallega en torno al cual se habían articulado sus principales estructuras socioeconómicas y de poder durante el Antiguo Régimen, tal como demostraron en su día conjuntamente Pegerto Saavedra y Ramón Villares. ${ }^{6}$

Una parte considerable de las investigaciones históricas elaboradas por los especialistas que se han aproximado a la evolución de los patrimonios nobiliarios e hidalgos galaicos en la larga duración, publicadas desde comienzos de la década de los años noventa del pasado siglo XX, ${ }^{7}$ han podido confirmar, a través del estudio de importantes casas rentistas, la tesis villariana de la exitosa adaptación que experimentó este heterogéneo grupo social, consolidado entre los siglos XVI y XVIII, al nuevo orden de cosas pro-

2 Cf. para el caso gallego Villares (1982), pp. 141 y ss., y Barreiro Fernández (1991), pp. 252-255, y para el contexto peninsular, García Sanz y Garrabou (eds.) (1985), Saavedra Fernández y Villares (eds.) (1991), vol. 1; y Carmona y Simpson (2003), pp. 53 y ss.

3 Villares (1999), pp. 48-50.

4 Artiaga Rego (1984); Baz Vicente (1996b).

5 Pastor et ál. (1999), pp. 224-230.

6 Saavedra Fernández y Villares (1985), pp. 465-482.

7 Todas ellas deudoras, en mayor o menor medida, de la interpretación acertada y pionera de Villares (1982). 
piciado por la legislación liberal decimonónica. ${ }^{8}$ El sólido entramado relacional que había generado el foro como fórmula de cesión dominial preferida por los grandes rentistas, ya puesto de manifiesto por una serie de autores en la década de los años setenta, poco antes de la publicación de la obra referencial de Ramón Villares, ${ }^{9}$ habría de resultar decisivo para que se pudiese consumar finalmente con éxito dicha adaptación, aun a pesar de que hubo algunas casas hidalgas que se decantaron por otras vías de cesión dominial que permitían un control más efectivo del dominio útil que la enfiteusis, cuando no por la explotación directa de ciertos lotes patrimoniales. ${ }^{10}$

No menos crucial resultó, en este mismo sentido, la capacidad del antiguo estamento nobiliario para cerrar filas en torno a sí mismo a partir del mercado matrimonial, tal como hemos tenido ocasión de demostrar más recientemente al estudiar su modelo de reproducción social. ${ }^{11}$ Las alianzas familiares ayudaron a mitigar considerablemente los efectos de la desmembración patrimonial que pretendía provocar la aplicación de las leyes de desvinculación, y muy especialmente la de 1841. En ocasiones, estos pactos matrimoniales posibilitaron un trasvase patrimonial en el seno de dicha elite al permitir que algunos vínculos fuesen a parar de unas casas hidalgas a otras; ${ }^{12} \mathrm{o}$ también, en otras ocasiones, a familias no necesariamente de procedencia nobiliaria, con una

8 Siguiendo un orden cronológico, es preciso hacer mención a la memoria de licenciatura de Leirós de la Peña (1986) sobre la casa de Fontefiz, a la tesis doctoral de Domínguez Castro (1992a), en la que estudia la evolución del patrimonio de la casa de Casaldereito, a la de Baz Vicente (1996a) sobre el patrimonio de la casa de Alba en Galicia, que había conseguido incorporar los condados de Andrade, Lemos y Monterrey, a la de Migués Rodríguez (2002a) sobre las casas hidalgas incorporadas al marquesado de San Martín de Hombreiro, a la de Presedo Garazo (2001), en la que se ha abordado el estudio de una veintena de patrimonios nobiliarios e hidalgos procedentes principalmente de la Galicia interior, y también — más recientemente- a la memoria de licenciatura de Iglesias Blanco (2004), en la que se analizan las exhaustivas contabilidades de la casa de Xunqueiras en los siglos XVIII y XIX.

9 Entre dicho grupo de autores se hallan Eiras Roel (1972), pp. 10-12; García Lombardero (1973), pp. 93-110; Barreiro Mallón (1978), pp. 470 y ss.; y Pérez García (1979), pp. 299 y ss.

10 Un caso representativo de explotación agrícola directa por parte de la hidalguía gallega es el de las granjas vitícolas de la hidalguía orensana. Cf. Domínguez Castro (1992b) y (1996), pp. 131-134.

11 Tema al que hemos dedicado una parte sustancial de los contenidos desarrollados en nuestro último libro. Cf. Presedo Garazo (2005a).

12 Domínguez Castro (1992a), pp. 37-38; Presedo Garazo (1995), pp. 87-90; Erias Martínez (1996), pp. 147-148; García Tato (2001), pp. 32-37; y Rubia Alejos (2004), pp. 213 y ss. 
riqueza considerable. Así que las ventas de bienes amayorazgados y vinculares, previamente repartidos entre los distintos herederos según el nuevo marco legal estipulado en la legislación desvinculadora, no se produjeron de manera sistemática cuando menos hasta la década de 1861-1870.13

Hubo además un tercer factor que facilitó esta adaptación nobiliaria al nuevo contexto decimonónico liberal y que habría de resultar decisivo en dicha pervivencia patrimonial. Nos referimos al modelo administrativo y de gestión de los ingresos que generan las propiedades incorporadas a los vínculos y mayorazgos, ya extendido entre dicha elite a comienzos del siglo XVIII ${ }^{14}$ coincidiendo con el momento en que se ha alcanzado, o está a punto de hacerlo, el techo de su expansión dominical. Éste se halla supeditado a una racionalidad administrativa, originariamente piramidal, que pretende supervisar el cobro de los heterogéneos ingresos de la casa, la comercialización de parte o la totalidad de dicho producto y el reintegro al rentista del beneficio obtenido anualmente en las distintas circunscripciones que integran su patrimonio, mayoritariamente rústico pese a su gran dispersión y heterogeneidad. ${ }^{15}$ En él, la figura del administrador o mayordomo general va a desempeñar un protagonismo cada vez más relevante. La dinámica expansionista de estas poderosas casas hidalgas a las que nos vamos a referir en las páginas siguientes, que cuentan con unos ingresos superiores a los 500 hectolitros anuales en el periodo 1750-1850, pudiendo llegar incluso a superar en ocasiones la barrera de los 1000 hectolitros, ${ }^{16}$ les había obligado a disponer de una administración propia y debidamente jerarquizada para poder controlar con cierta eficacia los abundantes ingresos que debían generar sus dispersos patrimonios, según consta en los memoriales de renta teórica y recuentos patrimoniales elaborados en dicho periodo, en los cuales fue asentado el canon que debían abonar regularmente todos y cada uno de sus colonos. ${ }^{17}$

13 Presedo Garazo (2001), pp. 590-591. Cf. Migués Rodríguez (2002a), pp. 480 482, en relación con el reparto efectuado en 1850 de los vínculos incorporados al marquesado de San Martín de Hombreiro; y también Baz Vicente (1996a), pp. 272-280, para los mayorazgos integrados en los condados de Andrade, Lemos y Monterrey, realizado incluso más tardíamente, en 1904.

14 Cf. Villares (1982), pp. 56-67, para la casa de Lagariños.

15 Migués Rodríguez (2002a), pp. 228 y ss.

16 Cf. Presedo Garazo (2004b), para la elite hidalga de la ciudad de Santiago de Compostela a mediados del siglo XIX.

17 Presedo Garazo (2001), pp. 403-408. 
Durante la primera mitad del siglo XIX, cuando estos rentistas seculares excepcionales comiencen a diseñar las estrategias políticas que les van a permitir integrarse con habilidad en el nuevo ordenamiento jurídicopolítico establecido por el liberalismo, ${ }^{18}$ sus patrimonios todavía presentan una robustez palpable que les va a permitir esquivar coyunturalmente los efectos de la reforma agraria liberal. En buena medida, este logro no hubiese sido posible sin una administración hacendística eficaz y con posibilidades de hacer frente a los nuevos retos que se le plantean, que incluso ahora es capaz de mejorar algunos de sus aspectos básicos.

\section{Los patrimonios de la élite hidalga a las puertas de la crisis del Antiguo Régimen, 1750-1808}

A mediados del siglo XVIII, las casas hidalgas gallegas que forman parte de la reducida elite regional que representa la hidalguía acomodada ya han consolidado sus extensos, dispersos y heterogéneos patrimonios. A diferencia de lo que sucede con el grueso de la hidalguía regional, cuyos miembros acostumbran a presentar generalmente un nivel de riqueza próximo al del campesinado medio, y que todavía tendrán ocasión de protagonizar una destacada actividad fundacional en dicha centuria, ${ }^{19}$ estos hidalgos acomodados ya disponen de unos dominios considerables a la altura de $1700 .{ }^{20}$ Buena parte de ellos ya han decidido dar el paso de urbanizar sus costumbres y hábitos, al trasladar su residencia principal a los núcleos urbanos, ${ }^{21}$ y es precisamente en dicho ámbito donde podemos calibrar mejor su presencia en relación con el total de individuos que forman parte del estamento noble gallego en torno a 1750 .

Los vecinos hidalgos representan entonces el 3,2\% del vecindario gallego, constatándose una mayor presencia en las provincias orientales - esto es, en Lugo y Orense- a la vez que en los núcleos urbanos. ${ }^{22}$ En dos ciuda-

18 Cf. las aportaciones de Veiga Alonso (1999) y Viveiro Mogo (2004) sobre la integración de la hidalguía gallega en la vida política decimonónica.

19 Cf. Domínguez Castro (1996), en relación con la hidalguía orensana.

20 Villares (1982), pp. 77-78.

21 Saavedra Fernández (1997), pp. 139-140.

22 Rey Castelao (1998), p. 243. 
des capitales de provincia de la Galicia occidental para las cuales disponemos de datos contrastados, como lo son Santiago de Compostela y Betanzos, la elite hidalga tan sólo engloba al 33-35\% de dicho sector nobiliario. $^{23}$ La hidalguía acomodada apenas supone, por tanto, un tercio de la población hidalga en aquellos núcleos urbanos en los que es posible constatar su presencia. Eso sí, quienes se hallan integrados en sus filas disponen de unos ingresos en renta considerables, sin los cuales difícilmente habrían podido dar el paso de incorporarse a dicha elite. Así, por ejemplo, entre los hidalgos elitistas de la ciudad de Santiago de Compostela podríamos citar al conde de Ximonde, cuyos ingresos ascienden a 700 hectolitros en $1784,{ }^{24}$ o a la familia Porras de la Casa-Torre de Raíndo, con 810 hectolitros en $1759 .^{25}$

Estos datos nos animan a plantearnos tres cuestiones relacionadas con la temática que nos ocupa, a las que ya se ha dado respuesta por parte de la investigación histórica gallega: ¿quiénes eran realmente estos hidalgos que aparecen al frente de estas poderosas casas rentistas a mediados del siglo XVIII?, ¿cuál era su origen social? y ¿¿de qué mecanismos económicos se habían valido para consolidar sus patrimonios?

A la primera de ellas ya hemos dado respuesta en parte. Se trata de un grupo reducido y selecto dentro de la propia hidalguía regional, con un perfil marcadamente elitista, cuyos miembros disponen de unos ingresos anuales excepcionales debido a una exitosa reproducción social secular y a su capacidad para sacar beneficio del frágil equilibrio al que se halla sometida la economía de subsistencia campesina, aun a pesar de la progresiva diversificación que ésta ha experimentado. ${ }^{26}$ Por dicho motivo disponen de una capacidad adquisitiva notable que les ha permitido refinar su estilo de vida, tras invertir una parte considerable de sus ingresos ordinarios

23 Es preciso aclarar, eso sí, que el criterio seguido por Eiras Roel (1984), pp. 119124, y Vaquero Lastres (1986), p. 55, a la hora de identificar a la élite social de las ciudades de Santiago de Compostela y Betanzos, respectivamente, se basa en la posesión de un servicio doméstico superior a tres individuos, y no en parámetros de riqueza. El porcentaje correspondiente a Santiago de Compostela lo hemos calculado a partir de los datos que aporta Eiras Roel (1984), p. 123.

24 Estimación propia a partir de los datos que ofrece Barreiro Mallón (1978), p. 478.

25 Barreiro Mallón (1990), p. 29.

26 Véanse, en relación con la evolución que experimentan las actividades complementarias a la explotación campesina, los interesantes resultados obtenidos por Sobrado Correa (2001), pp. 299-309, para el interior de la provincia de Lugo. 
en el mantenimiento de un tren de vida ostentoso acorde con su estatus privilegiado y el ethos aristocrático. ${ }^{27}$ Es de sus filas de donde ha salido la mayoría de los 310 súbditos gallegos que consiguieron un hábito de una orden militar, y también los 105 individuos que fueron distinguidos con un título nobiliario por parte de la Monarquía entre 1500 y $1850 .{ }^{28}$

En lo que se refiere a su origen social, pese a que la hidalguía gallega se caracteriza por su evidente composición heterogénea, fruto de exitosos procesos de ascenso social por parte de plebeyos con vocación por ennoblecer su sangre (principalmente comerciantes enriquecidos, hombres de leyes y campesinos acomodados), ${ }^{29}$ por el contrario esta elite nobiliaria se ha vuelto más hermética y menos permeable a medida que avanzamos en el tiempo. El origen histórico de sus casas acostumbra a hundir sus raíces en los últimos siglos medievales, puesto que sus antepasados remotos, o bien habían estado emparentados con alguna de las familias troncales que arrancan de los poderosos linajes nobiliarios bajomedievales, ya subdivididos en diferentes ramas con la llegada del siglo XVI a consecuencia de las nuevas exigencias de la política de reproducción social, o bien habían estado al servicio de éstas, desempeñando diversas tareas gubernamentales y administrativas. ${ }^{30} \mathrm{Sin}$ ir más lejos, a esta segunda casuística responde el origen de la casa de Lagariños estudiada por Ramón Villares, que todavía a día de hoy sigue siendo el modelo paradigmático para comprender cómo se articuló la consolidación dominical de estas casas grandes hidalgas durante la Época Moderna. ${ }^{31}$

La casa de Noceda, cuyo solar se asienta en la Galicia oriental, también reproduce perfectamente el modelo villariano. Sus orígenes histórico-genealógicos se remontan a la última centuria medieval; exactamente, se hallan en una rama segundogénita de la casa de Torés, cuyos jefes habían estado al servicio, en un primer momento, de la casa de Andrade, y luego de la de Ulloa. A partir de 1527, los jefes de casa muestran su intención de mantener el patrimonio familiar unido en manos de una única línea sucesoria, por lo que será incrementado con sucesivas fundaciones y agregaciones vinculares a lo

27 Cf. Presedo Garazo (1999), en relación con la ya citada Casa-Torre de Raíndo.

28 Migués Rodríguez (2002a), pp. 394-402; Acuña Rubio (2000).

29 Presedo Garazo (2003a), pp. 919, 937 y 949-957.

30 Presedo Garazo (2004a), pp. 128-129.

31 De hecho, el antecesor de Lopo da Somoza, quien comenzó la expansión patrimonial de dicha casa a mediados del siglo XVI, fue Lopo Conde, que había servido en calidad de escudero al conde de Ribadavia, tal como señala Villares (1982), p. 77. 
largo del siglo XVII y un mayorazgo con licencia real en 1704. El reforzamiento definitivo de su haber vincular fue posible, finalmente, gracias a la adopción de un modelo de reproducción social no igualitario que tan sólo permitía el acceso al mercado matrimonial de aquellos vástagos cuyo enlace pudiese reportar beneficios económicos sustanciales; junto al poder económico de que dispusieron los Ulloa Ribadeneira y Miranda para intervenir en el mercado de la tierra en el ámbito local. ${ }^{32}$ Este último aspecto señalado nos sirve, además, para dar respuesta a la tercera cuestión que nos hemos planteado, esto es: ¿¿de qué mecanismos económicos se había valido la hidalguía gallega acomodada a la hora de consolidar sus patrimonios?

Entre 1595 y 1769, los señores de la casa de Noceda invirtieron 152047 reales en 408 operaciones de compraventa de diferentes bienes rústicos, entre los cuales hemos de mencionar edificios, legítimas, lugares, tierras y rentas de diversa índole. Además, fijaron nuevas rentas agrarias, sobre todo forales, entre 1537 y 1790 . El principal impulso de su expansión dominical acontece entre 1630 y mediados del siglo XVIII. Es justo entonces cuando se acomete el $75 \%$ de las adquisiciones y se fija el 64,28\% de las nuevas rentas forales que habrán de abonar los nuevos colonos enfiteutas (tablas 1 y 2). Este impulso patrimonial basado en el establecimiento de nuevas rentas territoriales ofrece un saldo sorprendente: si en 1623 Noceda ingresaba regularmente 270 hectolitros anuales en concepto de renta, ciento cincuenta años después, en 1777, ya había superado los 1000 hectolitros. Es decir, a las puertas de la crisis del Antiguo Régimen, esta casa hidalga había conseguido triplicar el nivel de ingresos que presentaba a comienzos del siglo XVII gracias al mercado de la tierra y al mercado matrimonial.

Este conjunto de nuevos bienes rústicos adquiridos y nuevas rentas forales fijadas se halla emplazado en un área de dispersión de 20 kilómetros concéntricos al propio pazo de Noceda. Los bienes aportados en las dotes de los cónyuges femeninos que accedieron a la jefatura se encuentran incluso a mayor distancia. Es evidente que dicha dispersión territorial del patrimonio incorporado a los vínculos, más palpable en las dotes, va a influir notablemente en el modelo de administración hacendística por el que se decantaron los señores de Noceda.

32 Estos datos referidos a la casa de Noceda proceden de Presedo Garazo (2003b), pp. 77 y ss., y (2004c). 
TABLA 1

ADQUISICIONES REALIZADAS POR LA CASA DE NOCEDA EN 1595-1770

\begin{tabular}{|c|c|c|c|c|c|}
\hline Quinquenio & $\begin{array}{c}\text { Adquisiciones } \\
\left(n .{ }^{\circ}\right)\end{array}$ & Indices & $\begin{array}{c}\text { Capital invertido } \\
(r s .)\end{array}$ & Indices & $\begin{array}{c}\text { Rs./ } \\
\text { adquisición }\end{array}$ \\
\hline $1595-1600$ & 15 & 24 & 1595,00 & 18 & 106,33 \\
\hline $1601-1605$ & 3 & 5 & 129,00 & 1 & 43,00 \\
\hline $1606-1610$ & 6 & 9 & 483,50 & 6 & 80,59 \\
\hline $1611-1615$ & 5 & 8 & 468,50 & 5 & 93,70 \\
\hline $1616-1620$ & 5 & 8 & 340,50 & 4 & 68,10 \\
\hline $1621-1625$ & 3 & 5 & 365,00 & 4 & 121,16 \\
\hline $1626-1630$ & 5 & 8 & 726,00 & 8 & 145,30 \\
\hline $1631-1635$ & 47 & 74 & 6303,25 & 72 & 134,11 \\
\hline $1636-1640$ & 23 & 36 & 2468,50 & 28 & 107,32 \\
\hline 1641-1645 & 121 & 190 & 17506,50 & 200 & 144,68 \\
\hline $1646-1650$ & 3 & 5 & 376,00 & 4 & 125,33 \\
\hline $1651-1655$ & 1 & 2 & 132,00 & 1 & 132,00 \\
\hline $1656-1660$ & 12 & 19 & 2091,50 & 24 & 174,29 \\
\hline $1661-1665$ & 8 & 13 & 1595,00 & 18 & 199,37 \\
\hline $1666-1670$ & 1 & 2 & 121,00 & 1 & 121,00 \\
\hline $1671-1675$ & 9 & 14 & 1886,00 & 22 & 209,55 \\
\hline $1676-1680$ & 3 & 5 & 1793,00 & 20 & 597,66 \\
\hline $1681-1685$ & 19 & 30 & 5479,00 & 63 & 288,36 \\
\hline $1686-1690$ & 8 & 13 & 3553,00 & 41 & 444,12 \\
\hline $1691-1695$ & 22 & 35 & 4331,00 & 49 & 196,86 \\
\hline $1696-1700$ & 18 & 28 & 6357,00 & 73 & 353,16 \\
\hline $1701-1705$ & 6 & 9 & 2299,00 & 26 & 383,16 \\
\hline $1706-1710$ & 9 & 14 & 1231,00 & 14 & 136,77 \\
\hline $1711-1715$ & 7 & 11 & 1179,00 & 13 & 168,42 \\
\hline $1716-1720$ & 1 & 2 & 88,00 & 1 & 88,00 \\
\hline $1721-1725$ & - & - & - & - & - \\
\hline $1726-1730$ & 1 & 2 & 198,00 & 2 & 198,00 \\
\hline $1731-1735$ & - & - & - & - & - \\
\hline $1736-1740$ & - & - & - & - & - \\
\hline $1741-1745$ & - & - & - & - & - \\
\hline $1746-1750$ & & & & & \\
\hline $1751-1755$ & 25 & 39 & 18851,63 & 215 & 754,65 \\
\hline $1756-1760$ & 14 & 22 & 58327,23 & 666 & 4166,23 \\
\hline $1761-1765$ & 11 & 17 & 14105,29 & 161 & 1282,29 \\
\hline $1766-1770$ & 1 & 2 & 330,00 & 4 & 330,00 \\
\hline
\end{tabular}

FUENTE: Elaboración propia a partir de Archivo Histórico Provincial de Orense [en adelante, AHPO], Casas Particulares [en adelante, CP], Casa de Castro, Noceda, Hacienda, cajas 7 a 12 y 19 a 25.

NOTA: Base 100: 1631-1645. 
TABLA 2

FOROS OTORGADOS POR LA CASA DE NOCEDA EN 1536-1815

\begin{tabular}{|c|c|c|c|c|c|}
\hline Quinquenio & Foros & Indices & Quinquenio & Foros & Indices \\
\hline $1536-1540$ & 1 & 8 & $1676-1680$ & 3 & 23 \\
\hline $1541-1545$ & _ & _ & $1681-1685$ & 9 & 67 \\
\hline $1546-1550$ & _- & _- & $1686-1690$ & 16 & 120 \\
\hline $1551-1555$ & 1 & 8 & $1691-1695$ & 4 & 30 \\
\hline $1556-1560$ & - & - & $1696-1700$ & 2 & 15 \\
\hline $1561-1565$ & _ & _ & $1701-1705$ & 3 & 23 \\
\hline $1566-1570$ & - & - & $1706-1710$ & 36 & 270 \\
\hline $1571-1575$ & - & - & $1711-1715$ & 6 & 45 \\
\hline $1576-1580$ & - & - & $1716-1720$ & 5 & 38 \\
\hline $1581-1585$ & 1 & 8 & $1721-1725$ & 3 & 23 \\
\hline $1586-1590$ & _ & _ & $1726-1730$ & _ & - \\
\hline $1591-1595$ & - & - & $1731-1735$ & 3 & 23 \\
\hline $1596-1600$ & 1 & 8 & $1736-1740$ & 2 & 15 \\
\hline $1601-1605$ & 3 & 23 & $1741-1745$ & - & - \\
\hline $1606-1610$ & 3 & 23 & $1746-1750$ & - & - \\
\hline $1611-1615$ & _ & _ & $1751-1755$ & 2 & 15 \\
\hline $1616-1620$ & 2 & 15 & $1756-1760$ & 1 & 8 \\
\hline $1621-1625$ & 3 & 23 & $1761-1765$ & - & - \\
\hline $1626-1630$ & 1 & 8 & $1766-1770$ & 1 & 8 \\
\hline $1631-1635$ & 4 & 30 & $1771-1775$ & 2 & 15 \\
\hline $1636-1640$ & 22 & 165 & $1776-1780$ & 1 & 8 \\
\hline $1641-1645$ & 14 & 105 & $1781-1785$ & - & - \\
\hline $1646-1650$ & 3 & 23 & $1786-1790$ & 2 & 15 \\
\hline $1651-1655$ & _ & - & $1791-1795$ & - & - \\
\hline $1656-1660$ & 1 & 8 & $1796-1800$ & - & - \\
\hline $1661-1665$ & 3 & 23 & $1801-1805$ & _ & _ \\
\hline $1666-1670$ & 4 & 30 & $1806-1810$ & - & - \\
\hline $1671-1675$ & 5 & 38 & $1811-1815$ & 2 & $1 \overline{5}$ \\
\hline
\end{tabular}

FUENTE: Elaboración propia a partir de AHPO, CP, Casa de Castro, Noceda, Hacienda, cajas 9 a 12 y 20 a 25.

NOTA: Base 100: 1631-1645.

Otras poderosas casas hidalgas, para las cuales disponemos de información, ofrecen un aspecto similar al de Lagariños y Noceda en el periodo 1750-1808. El patrimonio del marquesado de Mos, ${ }^{33}$ el de las casas que acabarán por integrarse en el marquesado de San Martín de Hom-

33 AHPO, CP, Casa de Castro, Noceda, caja 2. 
breiro, ${ }^{34}$ e incluso el del condado de Ximonde y el de la Casa-Torre de Raíndo, a las que ya hemos hecho mención, confirman esta tendencia: siempre nos hallamos ante patrimonios geográficamente muy dispersos que generan unos ingresos considerables y diversificados, entre los cuales destacan sobre todo aquellos que proceden de contratos de foro y subforo.

Para llevar a cabo la administración y gestión de dichos patrimonios, estos rentistas seculares se decantaron por un modelo hacendístico piramidal cuya base está constituida por los colectores de los diversos productos en especie y en metálico, que asimismo eran supervisados —en un segundo nivelpor un administrador en todas y cada una de las circunscripciones o partidos cobratorios, y éstos, a su vez, por un mayordomo o administrador general, quien debía remitirle en última instancia al hidalgo rentista el balance de sus ingresos y gastos o, si se prefiere, el alcance final de las ganancias que habían generado sus dominios. Habitualmente, estos subalternos que desempeñan la mayordomía acostumbran a ser reclutados entre la clerecía e incluso la misma hidalguía rural, y disponen de cierta solvencia económica. ${ }^{35}$

Sin ir más lejos, la mayordomía general de Noceda recayó en don Pedro Ocampo en 1797 y en don Alejo García en $1823^{36}$ y, cuando menos a tenor de los datos del libro de administración que fue confeccionado en 1777, los individuos que ocupasen este cargo debían supervisar las tareas encomendadas a los 31 colectores de rentas agrícolas que estaban al servicio de la casa, de los cuales 9 también tenían que responder ante él por otros tantos partidos cobratorios. También estaban sometidas a su supervisión las cuentas que debían entregarle los administradores que se hallaban al frente de las dos herrerías que pertenecían a la casa, y cuya explotación había sido cedida en arriendo a herreros especializados (tabla 3). A fin de cuentas, tal como nos informa dicho

34 Migués Rodríguez (2002a), p. 236.

35 Saavedra Fernández (1998), p. 392. Como ejemplo, podemos citar la administración y gestión de las rentas de Pazo de Veiga, que recayó en el presbítero don Juan Varela entre 1777 y 1788, a su vez procedente de la casa de Goldeiros (Archivo de la Casa de Mirapeixe, Pardo Montenegro, leg. 14, s.n.); la del marquesado de Viance, primero en el apoderado general don Francisco García de Anca a la altura de 1766, y luego en don José de Ulloa en 1782 (Archivo de la Casa de Vilarxóan, cajas 3 y 4); y también la de la ya citada Casa-Torre de Raíndo, de la cual fue administrador don Ramón Couceiro Mariño en 1798-1800 (Archivo Histórico Universitario de Santiago [AHUS], Protocolos Notariales [PN], Arzúa, leg. 3791, f. 28r y ss.).

36 AHPO, CP, Casa de Castro, Noceda, Cuentas, caja 18, n. ${ }^{\circ} 4$ y 12. 
documento, que ofrece una información de gran valor para la cuestión que nos ocupa, sobre el mayordomo general de Noceda recaía la principal responsabilidad administrativa del patrimonio de la casa, puesto que se halla a cargo del "govierno político y económico de dicha casa y por conseqüencia la obligación de sostener y conservar sus derechos, usos, costumbres y servidumbres», y además «Debe así mismo celar que los demás colectores cumplan exactamente con sus respectivos encargos y dar cuenta al Amo del que no lo haga».37

TABLA 3

COMPETENCIAS Y EXTRACCIÓN SOCIAL DE LOS ADMINISTRADORES

$Y$ GESTORES DE RENTA DE LA HACIENDA DE LA CASA DE NOCEDA EN 1777

\begin{tabular}{|l|l|l|l|}
\hline Partido & $\begin{array}{l}\text { Personal } \\
\text { administrativo }\end{array}$ & Gestores de renta & Extracción social \\
\hline Noceda y Herrería de Bois & $\begin{array}{l}1 \text { mayordomo } \\
\text { general }\end{array}$ & $\begin{array}{l}2 \text { colectores mixtos } \\
1 \text { íd. de lechones } \\
1 \text { íd. de carneros } \\
1 \text { íd. de gallinas } \\
13 \text { íd. de grano } \\
2 \text { íd. de la sincura } \\
1 \text { coadjutor para la } \\
\text { herrería }\end{array}$ & $\begin{array}{l}18 \text { plebeyos } \\
\text { mayordósticos }\end{array}$ \\
\hline Sta. María do Cebreiro-Hospi- \\
tal da Condesa & & 3 colectores mixtos & $\begin{array}{l}2 \text { plebeyos } \\
1 \text { al que se designa } \\
\text { con «Don» }\end{array}$ \\
\hline Cervantes-Cancelada-Vilapún & & 1 colector general & se designa con «Don» \\
\hline Sto. Andrés y Sta. María das & & 1 colector general & se designa con «Don» \\
\hline Nogais-Viladicente-Morcelle & & 1 colector general & se designa con «Don» \\
\hline Triacastela & & 1 colector general & magistrado \\
\hline Lugo & & 1 colector general & se designa con «Don» \\
\hline Atán-Mosińos & & $\begin{array}{l}1 \text { colector general } \\
1 \text { administrador } \\
\text { interino de la herrería }\end{array}$ & se designa con «Don» \\
\hline Valcarce & & 1 colector general & $\begin{array}{c}\text { mayordomo de otra } \\
\text { casa hidalga }\end{array}$ \\
\hline Lailaxilde & & $\begin{array}{c}\text { mayordomo de otra } \\
\text { casa hidalga }\end{array}$ \\
\hline
\end{tabular}

FUENTE: Presedo Garazo (2004c), p. 726.

37 AHPO, CP, Casa de Castro, Noceda, Documentos generales, caja 7, n. ${ }^{\circ} 20$. 
El jefe de la casa no se había desprendido del todo del gobierno económico de su patrimonio. Otro buen ejemplo de ello lo tenemos en el marquesado de Viance, tal como se deduce de las «obligaciones del mayordomo» que el propio titular don Tomás Suárez de Deza redactó a mediados del siglo XVIII para que las siguiese el individuo encargado de desempeñar la mayordomía de su casa de Outarelo. ${ }^{38}$ De hecho, era frecuente la presencia del «amo» en el pazo rural coincidiendo con la época en que se recaudaban las rentas. Dicho inmueble operaba en la práctica como la capital económico-administrativa de sus dispersos dominios, y en él ya había fijado su residencia habitual el mayordomo general.

Estos mayordomos generales perfeccionaron notablemente los sistemas de contabilidad y registro de ingresos respecto a etapas anteriores, lo cual les permitió reforzar la estructura cobratoria de la casa y mejorar su gestión hacendística. Al contabilizar simultáneamente en los libros cobratorios la renta teórica que debían abonar todos y cada uno de los colonos, la que efectivamente pagaban una vez vencido el año agrícola y la que se comprometían a pagar, expresada en atrasos que automáticamente se convertían en débitos, pusieron en funcionamiento un método contable muy rudimentario, pero a la vez visiblemente eficaz para llevar a cabo un control más exhaustivo tanto de los ingresos teóricos como de los ingresos reales que debía percibir la casa. La administración de estas haciendas hidalgas se vio fortalecida, además, gracias al progresivo empleo de la comunicación epistolar entre los señores y sus subalternos, cuestión ésta todavía no abordada con suficiente profundidad, aun a pesar de la gran proliferación de esta tipología documental en los archivos hidalgos gallegos a medida que nos acercamos al tramo final del siglo XVIII. Asimismo, estos poderosos rentistas, en ocasiones con la ayuda de personal especializado e incluso con la de los propios mayordomos generales, pusieron gran empeño en centralizar sus archivos familiares privados en sus pazos rurales, en los cuales se hallan depositados los títulos de propiedad y de los heterogéneos derechos pertenecientes a sus casas. ${ }^{39}$

38 Véase una edición de dichas instrucciones, de gran interés para la temática abordada en el presente trabajo, en García Tato (1999), pp. 830-839.

39 Presedo Garazo (2001), pp. 47-49. 
Estos tres instrumentos administrativos (una contabilidad más exhaustiva, una comunicación epistolar más fluida con los subalternos y la preocupación por los archivos familiares privados) habrían de resultar decisivos para la pervivencia — durante buena parte del siglo XIX - de los patrimonios de esta vieja elite consolidada en el transcurso del Antiguo Régimen, aun a pesar de los intentos de transformación que propició la reforma agraria liberal.

\section{Retos que se plantean a los patrimonios de la élite hidalga durante el siglo XIX}

Para comprender hasta qué punto influyó el perfeccionamiento de estos instrumentos administrativos en la pervivencia de los patrimonios de la elite hidalga durante el siglo XIX, todavía conviene tener en cuenta dos cuestiones que propiciaron una mayor preocupación por parte de dicho sector nobiliario hacia sus dominios. Una de ellas es el alcance real de la nueva legislación liberal, toda vez que ésta no parece haberles afectado seriamente en el transcurso de la primera mitad de la centuria. La otra, en cambio, sí se manifestó negativamente en los registros de ingresos de estas casas: la influencia negativa de las crisis de subsistencia que se suceden en Galicia intermitentemente entre 1790 y 1855.

\subsection{Repercusión de la legislación liberal sobre los patrimonios de la hidalguía acomodada, 1811-1873 ${ }^{40}$}

En lo que respecta a la primera de ambas cuestiones, fue Ramón Villares el primero en poner de manifiesto que la abolición de los señoríos de 1811, ratificada luego en 1823 y 1837, no llegó a suponer un desgaste económico sustancial para la elite hidalga. ${ }^{41}$ Bien sea porque en su estructura de ingresos predominan aquellos que tienen su origen en la renta territorial, y dentro de ésta preferiblemente en la que procede de contratos enfi-

40 En fechas recientes hemos tenido ocasión de analizar más extensamente este aspecto decisivo para la pervivencia de los patrimonios de la elite hidalga en el nuevo contexto liberal decimonónico, en Presedo Garazo (2005b).

41 Villares (1982), pp. 146-150. 
téuticos, y no del ejercicio jurisdiccional ni de rentas reales enajenadas, o bien porque algunos señores se habían anticipado a integrar en el canon foral algunas antiguas cargas vasalláticas, la supresión de los señoríos no se tradujo en ningún momento en una merma sustancial de sus ingresos. Al contrario, incluso está documentado el caso de alguno de estos hidalgos grandes rentistas, que también habían ejercido en la práctica como señores de vasallos, que supieron sacar provecho de dicha coyuntura al reconvertir parte de sus ingresos jurisdiccionales en nuevas cargas forales. ${ }^{42}$

La ley de desvinculación definitiva del 19 de agosto de 1841 tampoco les afectó drásticamente en un principio. El hecho de que no haya sido hasta mediados del siglo XIX cuando se aprobó un texto legislativo concluyente que obligaba a los poseedores de vínculos y mayorazgos a dividirlos finalmente entre todos y cada uno de sus herederos legítimos, todavía les permitió disfrutar de sus patrimonios indivisos hasta el tercer cuarto de la centuria. Es más, algún proyecto anterior de desvinculación, como de hecho lo fue la ley de 1820 promulgada durante el Trienio Constitucional, ${ }^{43}$ les había prevenido de los cambios que se avecinaban, permitiéndoles tomar conciencia — con cierta perspectiva — de la necesidad de redefinir las estrategias de reproducción social que más les convendrían en caso de verse obligados a mitigar, con el mejor éxito posible, los resultados que se podrían derivar de la división inevitable de sus bienes amayorazgados. ${ }^{44}$ Lejos de suponer un handicap insalvable, esta elite rentista demostró unas cualidades asombrosas a la hora de sacar partido del mercado matrimonial en el transcurso de la centuria, y propició el reforzamiento de las solidaridades internas dentro del ámbito doméstico de la casa hacia aquellos parientes que, a pesar de que podían disponer libremente de sus herencias, optaron por permanecer supeditados a ésta, como en tiempos pasados, para beneficiar al pariente que había recibido la mitad reservable - generalmente el hijo varón de mayor edad del último usufructuario del mayorazgo - o a algún otro que había emparentado con otra casa con un nivel de riqueza similar.

42 Villares (1982), p. 147.

43 Baz Vicente (1996a), p. 273.

44 Cf. Migués Rodríguez (2002a), pp. 480-482, en relación con el marquesado de San Martín de Hombreiro. 
Las leyes de redención de foros, que previsiblemente sí podrían haber afectado con más seriedad a estos patrimonios si tenemos en cuenta que el grueso de los ingresos que generaban tiene su origen en contratos enfitéuticos, tampoco tuvieron una incidencia sustancial durante el siglo XIX. El debate sobre la cuestión foral ${ }^{45}$ no dio sus primeros resultados objetivos hasta que se aprobó la ley de 1873, que habría de permitir a algunos colonos enfiteutas redimir sus antiguas cargas forales, ${ }^{46}$ pero las redenciones generalizadas todavía se aplazarán hasta el primer cuarto del siglo XX. ${ }^{47}$

Así que ni la abolición de los señoríos ni de los mayorazgos, ni tampoco la redención foral, propiciaron cambios significativos en la estructura de ingresos de estas poderosas casas hidalgas a corto o a medio plazo, cuando menos hasta las tres últimas décadas de la centuria. A lo sumo, la ley de desvinculación definitiva de 1841 provocó cierta redistribución patrimonial dentro del propio grupo, pero nunca antes de mediados de siglo.

\subsection{Los efectos de los desequilibrios estructurales acontecidos en} 1790-1855 sobre los patrimonios de la hidalguía acomodada

A diferencia de la repercusión tardía de la legislación liberal sobre los patrimonios de la elite hidalga, los desequilibrios estructurales provocados por las pérdidas de cosechas y las crisis de mortandad que se suceden en Galicia entre 1790 y $1855,{ }^{48}$ sí llegaron a dejar su impronta en la evolución de los ingresos de estos poderosos rentistas seculares. Incluso ya antes, a mediados del siglo XVIII, la capacidad de los rentistas para presionar al campesinado parece haber experimentado una mutación respecto a etapas anteriores. ${ }^{49}$ Las crisis coyunturales que se suceden entre 1760 y 1812 no sólo traen de la mano la acumulación de

45 Villares (1982), pp. 251 y ss.; Veiga Alonso (1999), pp. 105 y ss.

46 Villares (1982), pp. 283-296; López Rodríguez (1985); y Domínguez Castro (1992a), pp. 80-85.

47 Presedo Garazo et ál. (1999), p. 149.

48 Sobrado Correa (2001), pp. 299-309, ofrece una secuencia detallada de ellas para la provincia de Lugo.

49 Villares (1982), p. 134. 
impagos por parte de los colonos con apuros para realizar los pagos puntualmente, sino que además van a propiciar que éstos se acostumbren a pagar en función de sus propias posibilidades, aferrándose al dominio útil del terrazgo. Para ilustrar mejor este aspecto, podemos fijarnos, una vez más, en lo que acontece en la casa de Noceda: en 1769 quedó sin cobrarse el 8,18\% de la renta en especie líquida que debía ingresarse en el partido de Noceda; $5^{50}$ en 1790 las deudas generadas por el partido de Cancelo llegaron a situarse cerca de los 1000 reales; ${ }^{51}$ y en 1811 sus dueños se vieron obligados a rebajar hasta un cuarto de la renta correspondiente al año agrícola de 1810, así como a eximir de la totalidad de la de 1809, a todos los caseros de Noceda cuyos inmuebles habían sido arrasados por los franceses, lo cual supuso 3608 reales más de pérdida. ${ }^{52}$

Esta relajación en el pago de la renta por parte de los colonos, que se dejó sentir sobre todo en periodos de caída de la producción agrícola, ${ }^{53}$ obligó al estamento noble gallego en su conjunto a reconvertir dichos impagos en deuda activa a su favor. Ante el temor de que se pudiesen oscurecer sus ingresos, la mayoría de las casas hidalgas que percibían rentas territoriales, y muy especialmente la elite, procedió a apear y prorratear aquellas explotaciones en las que existían indicios suficientes de que esto pudiese llegar a acontecer. ${ }^{54}$ Con ello, al garantizar los derechos que percibían en calidad de propietarios del dominio directo, también reforzaron su logística administrativa. Pero no deja de ser ciertamente paradójico el hecho de que el saneamiento de sus haciendas dependiese cada vez más, y no precisamente en poca medida, de la capacidad que pudiesen mostrar sus colonos para seguir abonando con la regularidad deseable unas rentas fijadas desde mucho tiempo atrás.

Esta situación se afianzó a lo largo de la primera mitad del siglo XIX. Lo podemos observar con más claridad tomando como referencia la evolución que presenta la renta foral que ingresó la casa de Mundín en el

50 AHPO, CP, Casa de Castro, Noceda, Documentos generales, caja 7, n. ${ }^{\circ} 18$ bis.

51 AHPO, CP, Casa de Castro, Noceda, Hacienda-Torés, caja 21, n. 9.

52 AHPO, CP, Casa de Castro, Noceda, Documentos generales, caja 8, n. ${ }^{\circ} 30$.

53 Domínguez Castro (1992b), pp. 101-102; Leirós de la Peña (1993), p. 211.

54 Presedo Garazo (2001), pp. 375-376. 
periodo $1836-1856 .{ }^{55}$ Durante las dos décadas que comprende el memorial cobrador, ${ }^{56}$ los ingresos brutos describen un movimiento parejo al de la renta teórica, aunque sin alcanzar - y menos superar- los valores de ésta, a excepción de los años 1840, 1842-1843 y 1850, por lo que el alcance de los impagos tiende a acumularse a medida que avanzamos en el tiempo (gráfico 1). El hecho de que no se alcance regularmente el listón de la renta teórica nos está indicando que los colonos no son capaces de abonar regularmente el canon que les corresponde y que, además, se han acostumbrado a no pagar. A los impagos de un año agrícola suceden los del siguiente, y así sucesivamente, y los enfiteutas sólo consiguen abonar sus deudas si el mercado se lo permite. Por tanto, éstos saldan las deudas atrasadas en función de sus propias posibilidades, generalmente después de una buena cosecha o tras haber obtenido ingresos adicionales fuera de la explotación agrícola familiar.

Podemos constatar mejor esta tendencia al comparar el movimiento que describen los índices de los pagos regulares de renta en centeno con los correspondientes al abono de impagos (gráfico 2). Aunque en valores absolutos los primeros siempre superan a los segundos, ${ }^{57}$ describiendo un movimiento análogo al que presenta el precio del centeno, los índices de los impagos se incrementan coyunturalmente en 1840-1841, justo después de la crisis de mortandad de 1837-1839, en 1843-1845 después de la hambruna de 1843, en 1847-1848 también después de otra hambruna, la de 1847, en 1851, un año antes de la peste de 1852, y en 1854 a continuación de la pérdida de las cosechas de $1853 .{ }^{58}$

Lejos de tratarse de una excepción, esta acumulación de impagos también la vemos reflejada en otras poderosas casas rentistas gallegas, como

55 En dicho periodo, los ingresos medios anuales de la casa de Mundín, procedentes del cobro de la renta foral abonada en centeno, ascienden a 104922,31 rs.

56 Archivo de la Casa de Souto de Rei, caja 7, s.n.

57 Ya que, a lo largo de los 20 años comprendidos entre 1836 y 1856, los pagos regulares ascienden a 2203368,60 rs., equivaliendo al 95,97\% de los ingresos en dicho periodo, mientras que el abono de impagos se sitúa en 92496,93 rs., esto es, un 4,02\% sobre el total ingresado.

58 La repercusión de estas crisis agrarias de mediados del siglo XIX sobre el tejido agrario gallego ya han sido analizadas por Rodríguez Galdo y Dopico (1981). Cf. además Sobrado Correa (2001), pp. 299-309. 


\section{GRÁFICO 1}

\section{EVOLUCIÓN COMPARADA DE LA RENTA TEÓRICA Y LA RENTA EFECTIVA}

DE CENTENO QUE INGRESA LA CASA DE MUNDÍN EN 1836-1856

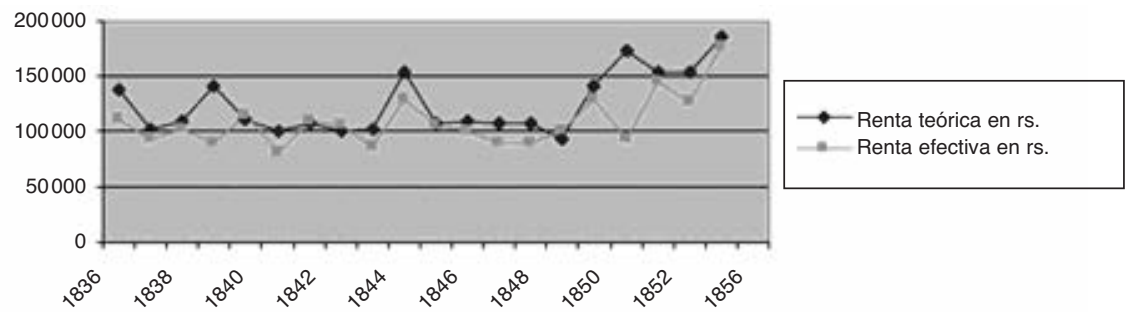

FUENTE: Elaboración propia a partir de Archivo de la Casa de Souto de Rei, caja 7, s.n.

\section{GRÁFICO 2}

EVOLUCIÓN COMPARADA DE LOS PAGOS REGULARES DE RENTA EN CENTENO, EL PRECIO DE DICHO CEREAL Y EL ABONO DE IMPAGOS A FAVOR DE LA CASA DE MUNDÍN EN 1836-1856 (en índices)
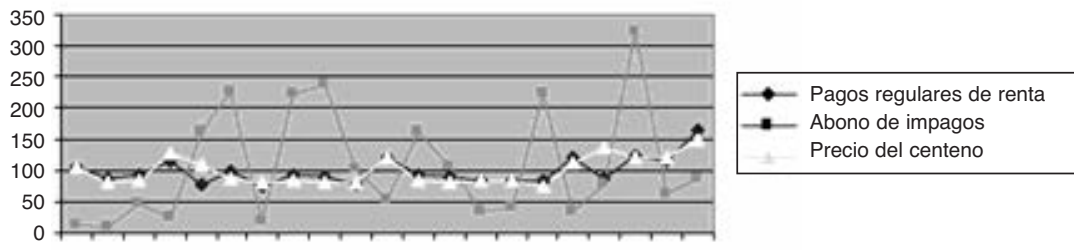

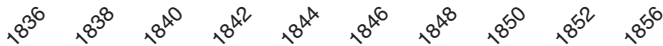

FUENTE: Elaboración propia a partir de Archivo de la Casa de Souto de Rei, caja 7, s.n. NOTA: $100=1836-1856$.

por ejemplo la casa de Láncara (gráfico 3), puesto que también vio como se incrementaron los impagos de renta foral a su favor entre 1839 y $1847,{ }^{59}$ coincidiendo con la serie de crisis cíclicas que dejaron su impronta en el balance anual de ingresos de Mundín. ${ }^{60}$

59 AHUS, PN, Santiago, leg. 8548, f. 77r y ss.

60 Cf. Iglesias Blanco (2004), pp. 139 y ss., en relación con la acumulación de impagos en la casa de Xunqueiras en el periodo 1818-1850, que en algunos años llega a superar el $20 \%$ de los ingresos teóricos. 
GRÁFICO 3

IMPAGOS DE RENTA DE QUE ES ACREEDORA

LA CASA DE LÁNCARA EN 1833-1847

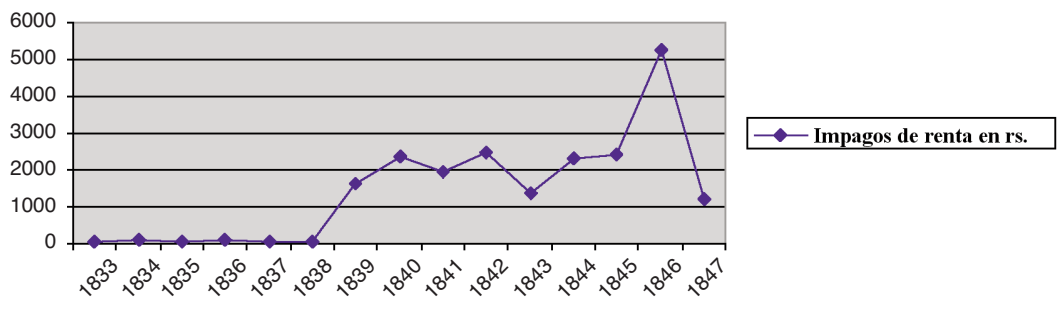

FUENTE: Elaboración propia a partir de AHUS, PN, Santiago, leg. 8548, f. 77r y ss.

En definitiva, los efectos negativos de las reiteradas malas cosechas y de los accidentes demográficos se tradujeron en una acumulación progresiva de deuda activa a favor de los rentistas, que enseguida cayeron en la cuenta de que era preciso controlarla para evitar que sus casas llegasen a perder parte de la capacidad adquisitiva de que habían disfrutado hasta el momento. ${ }^{61}$ Para ello, la elite hidalga reforzó, y lo que es aun más importante, perfeccionó, los mecanismos administrativos de que ya disponían sus haciendas privadas desde comienzos del siglo XVIII. Este perfeccionamiento administrativo, que todavía no ha suscitado un interés palpable entre los especialistas, ${ }^{62}$ resultó fundamental, a nuestro entender, para que sus patrimonios todavía pudiesen resultar enormemente rentables en la Galicia decimonónica.

61 Saavedra Fernández (2003), pp. 298-315, ha tenido ocasión de estudiar recientemente la importancia del gasto suntuoso como expresión de poderío socioeconómico entre la elite hidalga a través del ejemplo del pazo de Oca. En este mismo sentido, cf. además Presedo Garazo (1999) para la Casa-Torre de Raíndo, y Migués Rodríguez (2002a), pp. 372-388, en relación con la casa de San Fiz.

62 Entre los investigadores que han incluido más recientemente esta temática como objeto de estudio, es preciso hacer mención a las exhaustivas aportaciones de Iglesias Blanco (2004), pp. 50-65, sobre la casa de Xunqueiras. 


\section{Mejoras en la estructura hacendística de los patrimonios de la hidalguía acomodada en 1811-1868}

Entre los elementos del antiguo modelo administrativo que había sido puesto en funcionamiento para asegurar la gestión de las haciendas privadas de la elite hidalga, y que experimentan un notable perfeccionamiento a lo largo de la primera mitad del siglo XIX, debemos destacar, en primer lugar, el interés que muestran estos rentistas hacia sus archivos familiares privados. En la medida en que en ellos se hallan depositados los títulos acreditativos de la propiedad de las tierras y rentas incorporadas a los vínculos y mayorazgos de sus casas, ${ }^{63}$ su conservación y catalogación van a convertirse en dos objetivos esenciales a la hora de garantizar la pervivencia de sus patrimonios y, por ende, en uno de los pilares de su administración privada.

Como era de esperar, ya nos encontramos a algunos de estos poderosos rentistas seculares preocupándose por la catalogación y conservación de sus archivos privados principalmente a finales del siglo XVIII. ${ }^{64}$ A fin de cuentas, tal como hemos señalado, es a mediados de esta centuria cuando comienzan a sucederse las crisis de subsistencia que obligarán a los colonos enfiteutas a abonar las rentas en función de sus propias posibilidades. Entre ellos, el conde de Ximonde, don Juan Antonio Cisneros y Castro, gastó 15000 reales en ordenar y recatalogar al completo el archivo condal que había heredado de su tío. Sus propias palabras, procedentes del testamento que otorgó en 1798, son por sí solas lo suficientemente ilustrativas de la idea que pretendemos transmitir:

63 Vaamonde Gamo (1995), p. 77; Vázquez Bertomeu (2004), pp. 896-902.

64 E incluso se puede percibir un interés evidente por parte de ciertos miembros de la elite hidalga hacia sus archivos privados ya a comienzos de dicha centuria. De hecho, la casa de Noceda ya disponía de un importante archivo en el primer cuarto del siglo XVIII. Tal como se desprende del inventario post mórtem de don Pedro de Ulloa Ribadeneira, realizado en 1724, había en dicho inmueble un «quartto donde se halla el Archibo de los papeles y escriptorio de que tiene las llaves [el juez del propio coto de Noceda], y con una de ellas habrió dicho Archivo, y en el halló diez cajones de papeles y otros cinco güecos de otros cinco caxones sin ellos». AHPO, CP, Casa de Castro, Noceda, Documentos generales, caja 7, n. ${ }^{\circ} 19$. 
Luego de la muerte de dicho señor mi tío, viendo que los papeles de mi archivo estaban muy traspapelados, sin horden ni consierto, me puse a su reconosimiento con sus pautas, maseándolos, valiéndome de personas ábiles que me leiesen // la letra antigua, y oficiales para el copio de las pautas, pues de no aber echo esto mal podía io trabajar como lo he echo en el reconosimiento de mis bienes, y perderse muchos de ellos por no saberse las pertenençias, poniéndose en los dichos masos con arreglo a los papeles, trasladando la sustancia en las pautas para más brebe en barios casos que urjen saberse lo conbeniente para las acciones o siguimientos de pleitos, cuia orden boi siguiendo y poniendo en el maso que sigue, esperando de mi susesor no ponga esto en olvido, como también custodiar la llabe del archibo, que en ella consiste el seguro de nuestras aciendas. ${ }^{65}$

La catalogación del archivo de la casa de Bergondo, incorporada al marquesado de Mos, también se acomete por entonces, exactamente en 1787, bajo la supervisión de la marquesa doña Joaquina Josefa de Oca, y de ella se desprenden 28 cajones de documentación para los cuales fue preciso elaborar otros tantos inventarios. ${ }^{66}$

Sin embargo, es durante la primera mitad del siglo XIX cuando nos encontramos con más evidencias de este interés que muestra la elite hidalga hacia sus archivos privados. En 1848, el archivo de la casa de Láncara ya estaba compuesto por 17 cajones ordenados por partidos cobratorios, y cada uno de ellos contiene los «documentos de pertenencia [...] en legajos separados, con la inscripción del nombre de la parroquia, cajón, legajo y número de su referencia al libro tumbo a donde están anotados».67 No menos voluminoso resultaba el archivo de la casa de Rubiáns en 1850: constaba de 14 cajones, 30 legajos y 2 mazos y, según el recuento acometido por el perito, dichos documentos «legitiman la pertenencia y propiedad de los bienes raízes de la Casa y señorío de Rubianes y demás anecsas a la misma». ${ }^{68}$

No en vano, el erudito brigantino Froilán Troche y Zúñiga ya se había anticipado a reconocer en 1828 , en una obra que trata precisamente sobre el método más acertado que se debía seguir a la hora de recatalogar dichos fondos hidalgos, que

65 AHUS, PN, Santiago, leg. 6259, f. 273r-273v.

66 El cuadernillo n. ${ }^{\circ}$ 1, donde se halla la "Noticia para el manejo de los Papeles», es la pieza clave del catálogo. AHPO, CP, Casa de Castro, Noceda, cajas 1 (inventarios núms. 1-22), 3 (núms. 1-7 y 13) y 4 (núms. 14-25 y 28).

67 AHUS, PN, Santiago, leg. 8548, f. 148v.

68 AHUS, PN, Santiago, leg. 8550, f. 191r. 
Al tiempo de arreglarse un archivo, se puede ir preparando un trabajo muy interesante para describir las rentas, bienes y derechos que la casa tiene perdidos: esto es mas facil cuando el que lo arregla es el dueño de ella, ú otro que tenga conocimiento de lo que posee la casa. ${ }^{69}$

Algunas de estas poderosas casas hidalgas incluso seguirán manifestando un interés evidente por el estado de conservación de sus fondos documentales y su catalogación a lo largo de la segunda mitad del siglo XIX y comienzos del XX. Sin ir más lejos, y siguiendo con el ejemplo de la casa de Noceda reiteradamente citado en nuestra reflexión, sus dueños encargaron una nueva recatalogación completa y minuciosa de su archivo familiar privado, que se efectuó entre 1895 y $1908 .^{70}$

En estos archivos privados, que ahora suscitan un mayor interés entre sus dueños, va a destacar muy especialmente la documentación administrativa, esto es, aquella cuya finalidad consiste en dejar constancia de las diversas tareas encomendadas al personal encargado de gestionar los ingresos de la casa, lo cual nos sitúa sobre todo ante el cobro de rentas territoriales, que, como ya se ha dicho, debía ser supervisado por el mayordomo general. La proliferación de esta tipología documental en los archivos de la hidalguía gallega, y no exclusivamente entre los de la elite, nos está revelando que, a partir de un momento dado, este sector nobiliario en su con-

69 F. Troche y Zúñiga (1835), El archivo cronológico topográfico. Arte de archiveros. Metodo fácil, sencillo y poco costoso para el arreglo de los Archivos particulares, útil a los Hacendados y poseedores de bienes que tienen documentos para conservar sus intereses. Arreglo interior y economico de las casas, dirección y manejo de los intereses de ellas, La Coruña (ed. literal de 1830 [ed. orig., 1828]), p. 145. Cf. además Migués Rodríguez (2002b), pp. 26-38.

70 Inicialmente se realiza un "proyecto de inventario» que se finaliza en 1895, del que va a resultar el «Ymbentario de los papeles pertenecientes a los mayorazgos de las casas de Noceda, Villamar, Regueras, Lagunas de la Somoza, Pontevedra y sus unidas y agregadas para separarlos según sus respectivas fundaciones». Se trata de 37 cuadernillos referidos a 16 mazos, de los cuales del 1 al 12 ya se habían inventariado previamente en el siglo XVIII. En el año 1900, los archiveros encargados de catalogar esta sección del archivo ya depositado en la Casa do Castro, en El Barco de Valdeorras, revisan los protocolos de los escribanos por cuyas escribanías habían pasado los señores de Noceda a poner por escrito sus asuntos durante el Antiguo Régimen, para comprobar cuáles están depositados en dicho archivo privado. Entre otros, fueron consultados los fondos pertenecientes a los escribanos Domingo de Bernedo y Domingo de Bernedo y Quiroga. Y finalmente, entre 1903 y 1908 se procede al reordenamiento definitivo de los fondos documentales según los criterios inicialmente establecidos. AHPO, CP, Casa de Castro, Noceda, cajas 46, 124 (cuadernos núms. 29 y 31-34) y 125 (cuadernos núms. 37-56). 
junto sintió la necesidad de disponer de guías administrativas — eso sí, de mayor o menor complejidad, dependiendo del alcance del patrimonio en que nos fijemos - que les permitiesen controlar con más rigor el cobro de sus heterogéneos ingresos agrícolas. ${ }^{71}$

En todos estos cuadernillos y libros administrativos que se redactan ahora, los hidalgos manifiestan claramente su intención de poner por escrito aquellos elementos más singulares de la organización hacendística de sus patrimonios; de ahí que echen mano de la documentación albergada en el propio archivo familiar, o que incluso soliciten copias de documentación depositada en determinadas instituciones.

Los métodos contables de que dispone el personal que desempeña las tareas de gestión y administración al servicio de estas casas también experimentan ahora cierta especialización, si los comparamos con la documentación administrativa procedente de etapas históricas anteriores. La estructura de estos libros cobratorios elaborados durante la primera mitad del siglo XIX acostumbra a incorporar tres apartados básicos: $10^{\circ}$ ) un índice, o índices, por productos que debe percibir la casa, junto con los caseros o colonos que deben efectuar los pagos, alfabéticamente ordenados; 2. $\left.{ }^{\circ}\right)$ una relación detallada de los precios de los distintos productos cobrables, que facilite el abono de los impagos de renta, bien en valores o bien en especie; y $3 .^{\circ}$ ) un listado pormenorizado de los pagos e impagos procedentes de cada colono, año a año.

La pieza clave que va a permitir que este engranaje administrativo perfeccionado resulte operativo es el antiguo mayordomo o administrador general, que ya nos podemos encontrar difundido a comienzos del siglo XVIII. Eso sí, su figura se ve enormemente revalorizada ahora, en un nuevo contexto en el cual los grandes rentistas, a estas alturas absentistas en su mayoría, ${ }^{72}$ pretenden ejercer un control más firme de la estructura cobratoria de sus patrimonios con el objeto de evitar que se oscurezcan algunas de sus rentas tras la reiterada, y coyuntural, acumulación de impagos por parte de algunos de sus colonos. En la medida en que éste supervisa que

71 Presedo Garazo (2001), pp. 50-52.

72 Cf., en relación con los patrimonios de la élite hidalga compostelana a mediados del siglo XIX, nuestra reciente aportación en Presedo Garazo (2004b), pp. 671-679. 
los operarios al servicio de la casa encargados de contabilizar y gestionar las rentas que se ingresan cada año en los diversos partidos cobratorios cumplan debidamente con su cometido, en la práctica actúa como si se tratase de una verdadera prolongación del propio «amo», máxime si tenemos en cuenta que aquél acostumbra a residir en un núcleo urbano situado a veces a bastante distancia del centro administrativo de su extenso patrimonio, que, recordemos, acostumbra a localizarse en el pazo rural principal de la casa con el que ésta se ha identificado simbólicamente.

Si el patrimonio de estas poderosas casas rentistas seguía resultando rentable era debido, en buena medida, a los esfuerzos de sus apoderados generales, cuyos «amos» habían delegado en ellos su salvaguarda. De hecho, Froilán Troche y Zúñiga ya había destacado en 1828 el sumo cuidado que debía poner esta elite a la hora de contratar a los operarios que habrían de desempeñar la mayordomía de la casa. ${ }^{73}$ Ellos eran, en definitiva, los principales responsables de que todos y cada uno de los colonos abonasen la renta que les correspondía, bien según el plazo estipulado en los contratos de cesión dominial o bien con algo de demora si es que ésta se traducía en impagos. Así que estos mayordomos o administradores generales fueron adquiriendo más poder a medida que se consolidaba y divulgaba este particular modelo administrativo conforme fue avanzando la centuria.

Este perfeccionamiento del modelo administrativo que regía sus haciendas, por el cual apostó decididamente la elite hidalga gallega durante el siglo XIX antes de que comenzasen a producirse las primeras redenciones de foros a partir de 1873, no hubiese sido posible sin una mejora en el principal medio de comunicación que permitía la circulación regular de información entre el "amo» y su mayordomo general. Esto es, la correspondencia privada. Todavía no estamos en condiciones de dar respuestas definitivas en este sentido, habida cuenta de la falta de estudios especializados sobre esta cuestión, pero tanto la correspondencia privada procedente de la casa de Goián como la que se conserva en la casa de Taboi para el tramo central de la centuria nos indican que la comunicación epistolar fluida y regular entre el hidalgo acomodado y el personal administrativo al servicio de su casa era ya un hecho consumado.

73 Troche y Zúñiga, op. cit., pp. 171 y ss. 



\title{
4. LA LEGISLACIÓN DESVINCULADORA: UNA OPORTUNIDAD PARA RACIONALIZAR LA GESTIÓN DE LOS PATRIMONIOS NOBILIARIOS MALLORQUINES Y RETRASAR SU DESMEMBRACIÓN*
}

\author{
Antònia Morey Tous \\ (Universitat de les Illes Balears)
}

\section{Introducción}

En Mallorca, como sucede en la práctica totalidad del territorio español, la pervivencia de los patrimonios nobiliarios más allá de las reformas liberales está fuera de duda. Las investigaciones recientes han puesto de manifiesto que la correlación entre legislación desvinculadora y extinción de la propiedad nobiliaria no fue automática. La trascendencia de dichas medidas no radica tanto, sobre todo en una primera etapa, en que obligaran a poner un número considerable de tierras en

* Este trabajo se inserta, a la vez, dentro de dos proyectos de investigación subvencionados desde el Ministerio de Ciencia y Tecnología en los que estoy trabajando de forma simultánea: uno, coordinado por la Universitat de Girona (A. López Estudillo) y dirigido por Ramón Garrabou, sobre la evolución histórica de los paisajes agrarios (SEC 200308449-C04-02) y otro, dirigido desde la Universitat de les Illes Balears por Carles Manera (SEJ 2004-06649/ECON), sobre la historia económica del turismo de masas. 
circulación, ${ }^{1}$ como en permitir que los titulares de los patrimonios antes vinculados se sirvieran de las citadas leyes para reestructurar, racionalizar y sanear sus haciendas. A mi entender, el modo de proceder de los grandes terratenientes mallorquines ilustra la necesidad de valorar las consecuencias de dichas medidas no sólo por la cantidad de tierras que a su amparo se pusieron en circulación, sino por sus posibles repercusiones en muchos otros aspectos: la modificación de la tradicional estructura de ingresos de las casas nobiliarias, las formas de gestión de los nuevos patrimonios surgidos de la desvinculación, la racionalización de los sistemas de contabilidad, la intensificación e introducción de nuevos cultivos en los latifundios antes explotados de forma extensiva, etc.

Estas hipótesis se fundamentan, de hecho, en los resultados obtenidos a partir de una investigación sobre los traspasos de propiedad nobiliaria registrados en los libros de las antiguas contadurías de hipotecas (17681862). Una investigación que evidenció que en Mallorca el alcance de la legislación desvinculadora sobre el mercado de la propiedad nobiliaria fue limitado (Morey, 1999a). En prácticamente un siglo, desde el inicio de la reforma ilustrada de la propiedad vinculada hasta pasados veinte años de la abolición "definitiva» de los vínculos y fideicomisos, el número de hectáreas traspasadas por la nobleza mallorquina no llegó a 20000 , lo que significa que sólo perdió alrededor de un $5 \%$ respecto a la extensión que controlaba a mediados del siglo XVIII. No fue hasta después de la publicación de la ley de 1841 cuando el mercado de la tierra se activó de forma clara. En veinte años, desde 1841 hasta 1862, los miembros del grupo nobiliario traspasan cerca del $73 \%$ de la extensión total segregada a lo largo de casi un siglo. Con anterioridad, y sobre todo dadas la escasa vigencia que había tenido la ley de 11 de octubre de 1821 y la contundencia de la real cédula de 11 de marzo de 1824 que obligaba a restituir los bienes traspasados durante el Trienio y a devolver las cantidades pagadas por ellos, fueron pocos los que a pesar de su falta de liquidez quisieron aventurarse a

1 Parte de esta comunicación, principalmente la introducción, incorpora las conclusiones de varios trabajos anteriores en los que, a partir del vaciado de los registros de hipotecas y de fuentes catastrales de distintas épocas, se analizó el alcance de la reforma agraria liberal sobre el mercado de la propiedad nobiliaria. Fundamentalmente los siguientes: Moll, Albertí y Morey (1993), Morey (1998), (1999a), (1999b) y (1999c) y Jover y Morey (2003). 
vender. Otra constatación que se deduce de la documentación trabajada es que incluso con posterioridad a la publicación de la ley de 1841 la participación de la nobleza mallorquina en el proceso desvinculador fue muy desigual. El cuadro número 1 no deja lugar a dudas: el $70 \%$ de las hectáreas traspasadas durante el periodo de máxima activación del mercado de la tierra fueron realizadas por sólo diez miembros del grupo nobiliario.

En definitiva, lo que evidencia la sistematización del registro de hipotecas es la necesidad de realizar un tipo de valoración cualitativa del alcance del proceso desvinculador. Un tipo de análisis para el que Mallorca se

\section{CUADRO 1}

PARTICIPACIÓN DESIGUAL DE LOS TITULARES DE LOS PATRIMONIOS NOBILIARIOS MALLORQUINES EN EL PROCESO DESVINCULADOR (1841-1862)

\begin{tabular}{|l|c|c|}
\hline Titular & Hectáreas segregadas & \% sobre el total \\
\hline Fuster de Puigdorfila & 343 & $2,79 \%$ \\
Zaforteza (Quint) & 348 & $2,83 \%$ \\
Ramis d'Ayreflor & 422 & $3,43 \%$ \\
Zaforteza (Burgues) & 462 & $3,76 \%$ \\
Lante della Rovere & 711 & $5,78 \%$ \\
Montaner & 732 & $5,95 \%$ \\
Ferrer de Sant Jordi & 962 & $7,82 \%$ \\
Orlandis & 1078 & $8,76 \%$ \\
Caro & 1276 & $10,37 \%$ \\
Morey de Santmartí & 2626 & $21,35 \%$ \\
Resto (59 casas) & 3340 & $27,16 \%$ \\
Total & 12300 & 100 \\
\hline
\end{tabular}

2 Este cuadro ha sido elaborado a partir de la sistematización de los registros de hipotecas después de la publicación de la ley de $1841 \mathrm{y}$, aunque ya ha sido utilizado en anteriores trabajos, por lo bien que ilustra la desigual participación de la nobleza mallorquina en los traspasos de propiedad he considerado oportuno incorporarlo también en la parte introductoria de este capítulo. Morey (1999b), p. 94. 
presenta como un marco de estudio privilegiado. Tanto por su reducida extensión (3640 km² o $364000 \mathrm{ha}$ ) como por el tamaño relativamente moderado de la gran propiedad (muy pocos latifundios superaban las 1000 ha y la mayoría oscilaban entre 50 y 300 ha). Y, asimismo, por el hecho de que en la etapa final del Antiguo Régimen los principales poseedores de bienes vinculados pertenecían a un grupo integrado por no más de un centenar de familias que controlaban cerca del $80 \%$ de la gran propiedad, lo que ha facilitado la localización de las actas de traspaso de propiedad en los protocolos notariales. Por otra parte, el elevado grado de endogamia mantenido por estas familias y el uso y abuso que hicieron de las instituciones vinculares hasta el momento de su abolición, se convierten también en una ventaja cuando se trata de investigar en los archivos privados. A pesar de que todavía no son muchos los que se encuentran a disposición de los investigadores, las prácticas hereditarias y matrimoniales mantenidas por la nobleza terrateniente desde los siglos XVI y XVII posibilitaron que tanto los bienes como los documentos de los linajes que se iban extinguiendo fueran incorporados por un grupo muy reducido, de familias, en las que, a diferencia de lo que solía ser habitual, nunca faltó la descendencia masculina. Un colectivo ciertamente reducido, a gran parte de cuya documentación, por fortuna, hemos tenido acceso, y cuya exploración ha posibilitado conocer el modo de proceder de una muestra suficientemente representativa de patrimonios. Dicha muestra ha permitido, incluso, tipificar las principales estrategias seguidas por aquellos titulares que la ley denominó «actuales poseedores» y tuvieron por primera vez la posibilidad, previa reserva de la mitad de los bienes vinculados para el «inmediato sucesor», de disponer libremente de unos patrimonios que hasta entonces sólo usufructuaban. Gracias a la legislación liberal adquirieron, finalmente, la condición de propietarios que la mayoría venían reclamando desde mediados del siglo XVIII, y ello les permitió decidir y proceder de la forma más conveniente y afín a sus intereses y necesidades. Esta comunicación pretende, precisamente, poner de manifiesto las principales estrategias que a partir de entonces adoptaron los titulares de los antiguos patrimonios vinculados y, asimismo, incidir en algunas de sus principales implicaciones sobre la estructura agraria mallorquina:

- La erosión progresiva de los límites territoriales de los antiguos latifundios y el surgimiento de una nueva tipología de gran explotación que ha convivido hasta mediados del siglo XX con múltiples 
parcelas de extensiones reducidas situadas en la periferia de las grandes explotaciones.

- El cambio de titularidad de un número reducido de grandes explotaciones sin que éstas vieran prácticamente modificados sus límites, lo que en algunos casos pudo ser un aliciente para que sus adquirientes (en general miembros de la burguesía agraria, industrial y comercial) iniciaran un tipo de gestión más racional y pusieran en práctica un sistema de cultivo más intensivo.

- El desmantelamiento de aquellos patrimonios cuyos titulares no residían habitualmente en la isla y a los cuales la ley de desvinculación les otorgó la oportunidad de deshacerse de sus propiedades mallorquinas (la mayoría incorporadas por herencia a lo largo del siglo XVIII) y comprar, si lo preferían o el estado de sus economías se lo permitía, tierras más próximas a sus lugares de residencia o más afines a sus intereses.

- La aniquilación definitiva de un número restringido de patrimonios cuyos últimos poseedores no tenían generalmente descendencia directa, razón por la cual a su muerte, y a diferencia de lo que venía sucediendo desde hacía siglos, no pasaron íntegros al siguiente llamado en la línea sucesoria, sino que fueron repartidos en dos o más mitades según las circunstancias de cada caso concreto.

1. La segregación de tierras marginales y la erosión progresiva de los límites de los antiguos latifundios

Ésta es, sin duda, una de las repercusiones de mayor alcance de la nueva legislación. Hasta el punto que dicho proceso da lugar, con el tiempo, al surgimiento de una nueva tipología de gran explotación: ${ }^{3}$ una unidad compacta, regida por unas casas destinadas a la vez a servir de apoyo para la explotación y el cultivo de las tierras y a ser el lugar de residencia habitual del personal que trabaja en la explotación. Pero, sobre todo, una unidad compacta que al amparo de la nueva situación experi-

3 Sobre los orígenes y la evolución de los latifundios mallorquines resultan de especial interés los trabajos de Jover (1996), (1999) y (2002). 
menta una reducción considerable de las tierras antes ocupadas por bosque y monte bajo. ${ }^{4}$ Y ello debido a que, de entrada, la estrategia elegida por la mayoría de vinculistas mallorquines para solucionar su falta de liquidez consistió en valorar primero qué fincas de entre todas las de sus respectivos patrimonios eran las que les proporcionaban menores rentas (generalmente las cerealícolas situadas en el Llano y el Migjorn de la isla) para proceder, a continuación, a alienar de estas fincas aquellas tierras de inferior calidad. El análisis de la extensión más frecuente de las parcelas segregadas ha corroborado que no solían superar las dos hectáreas y que se trataba, sobre todo, de segregaciones inferiores a una quarterada $(0,71 \mathrm{ha})$. Ello, unido a la baja calidad de dichas parcelas — básicamente yermos, bosques, selvas, antiguas tierras de novales y tierras de labor sin árboles-, hace comprensible que no permitiesen la autosuficiencia de sus compradores (Tello, 1983). Y, al mismo tiempo, explica la continuidad del sistema latifundista, ya que para sobrevivir los nuevos compradores no tenían generalmente más remedio que continuar yendo a jornal a las tierras remanentes de la misma finca o a otros predios que todavía no habían sido parcelados. ${ }^{5}$

La decisión de establecer parcialmente una finca no implicó, en principio, modificaciones sustanciales en el sistema de gestión. La mayoría se continuaron explotando en régimen de arrendamiento y en muchas ocasiones no se produjo siquiera un cambio de arrendatario. Por lo general, sólo una nueva negociación en torno a la renta que, en función de la superficie que se reducía, el arrendatario quedaba obligado a pagar y, a su vez, la introducción de un conjunto de cláusulas sobre las obligaciones de ambas partes en caso de que el propietario decidiera continuar, en el futu-

4 A partir de entonces, el término possessió (equivalente en castellano a predio, gran explotación) se utilizaba, siguiendo las observaciones de autores coetáneos, para designar aquellas propiedades rústicas que, por su extensión, requerían al menos un par de mulas para su labranza. Habsburg-Lorena (1982-1983), vol. 5, pp. 40-45.

5 Es también innegable que con el tiempo la parcelación fomentó cambios importantes en la distribución general de cultivos. Hasta el punto que algunos autores coetáneos, entre otros Canut (1865) y Satorras (1878), no dudaron en relacionar la expansión de determinados cultivos arbóreos —almendros, higueras, algarrobos, etc. - con la parcelación de la gran propiedad. Una correlación que incluso antes de la promulgación de las leyes de desvinculación establecían algunos de sus partidarios, y de la que más recientemente diversos estudiosos, principalmente Bisson (1977), pp. 220-223, Cela Conde (1979), pp. 55-62, Manera (1995), pp. 66-99, y (1999), pp. 373-379, y Jover (1996), pp. 454-460, han ofrecido cifras contundentes. 
ro, con el goteo de establecimientos. Estas cláusulas ya empiezan a aparecer en algunos contratos inmediatamente después de la publicación de la ley de 11 de octubre de 1820 y reaparecen, cada vez con más fuerza, a partir de 1836-1841. Hacen referencia, normalmente, a aspectos como el ya mencionado del montante de la renta, a la posibilidad de que tanto el propietario como el arrendatario nombren peritos de su confianza para valorar las tierras por segregar y a las nuevas obligaciones que tendrán que asumir muchos arrendatarios cuando empiece la parcelación. ${ }^{6}$ Entre las más frecuentes, cobrar a cuenta del propietario las pensiones y otros derechos que anualmente quedaban obligados a pagar los adquirientes de las parceladas segregadas. Un tipo de derechos relacionados con el hecho de que la modalidad elegida por la mayoría de terratenientes a la hora de alienar sus tierras fuese el "establecimiento enfitéutico», y no el contrato de compraventa propiamente dicho. Es decir, un contrato que implicaba sólo la cesión del dominio útil y, en muchas ocasiones, la obligatoriedad de continuar pagando al propietario del dominio directo toda una serie de derechos de carácter más propiamente feudal: ${ }^{7}$ alodios, laudemios, etc.

En la práctica, el modo como se iba erosionando la gran propiedad (establecimientos enfitéuticos que obligaban al pago de una entrada, una pensión anual y distintos derechos de carácter feudal en posteriores traspasos) vino a complicar el sistema de recaudación de rentas de la nobleza terrateniente. En parte, porque con el tiempo muchos de estos derechos se pusieron en entredicho y los pleitos sobre si se trataba de enfiteusis común o de enfiteusis feudal empezaron a multiplicarse y, a la vez, porque los nue-

6 Sirva como ejemplo la cláusula del contrato de la possessió del Rafalet firmado por Francisco Villalonga y Escalada el mes de septiembre de 1826 ante el notario J. Oliver: "Sempre que mon principal vulga establir o vendrer algunas terras de la mateixa Posesio, pugue executarlo librement [...] deureu [...] seguir en lo arrendament, y respecte que no valdria tant de annua merce se nombrará per cadaun de nosaltres un perito a fi de que los dos acordin la rebaixe corresponent [...] y no podent acordarla estos tendran facultat de elegir un tercer á dit efecte y nosaltres deurem entrar y pasar per lo que hauran acordat los dits peritos o tercers en cas de discordia" (Archivo Villalonga-Escalada, Carpeta de arrendamientos, sin signatura).

7 Una constatación que confirma, también en el caso de Mallorca, que el tema de la división de dominios fue la asignatura pendiente de la reforma agraria liberal (García Sanz, 1985). Ni siquiera después de la instauración definitiva del Estado liberal el porcentaje de ventas superó al de establecimientos, y todavía hoy algunos de aquellos derechos (como el laudemio o el retracto) siguen vigentes. 
vos adquirientes intentaron muchas veces evadir los pagos de censos y otros derechos. Estrategia esta última que fue perseguida por los propietarios directos (los establecedores de fincas anteriormente vinculadas) nombrando personas de su confianza, pagadas normalmente en función de la proporción de censos y derechos atrasados que conseguían cobrar, para que se desplazaran a los respectivos municipios donde residían los adquirientes $y$, "talonario en mano», persiguieran a los morosos bajo pena de arrebatarles las parcelas de tierra que con tanto esfuerzo habían conseguido adquirir y poner en explotación. En este ámbito los ejemplos son numerosos ${ }^{8}$ y llama la atención la progresiva importancia que, a medida que los establecimientos de tierras proliferan, van adquiriendo los «perceptores de censos». Dicho colectivo resulta fácilmente identificable en las fuentes fiscales de la época. Por ejemplo, en los sucesivos registros de "Contribución industrial y de comercio de Palma» elaborados a partir de 1852, cuya sistematización ha permitido comprobar que desde mediados del siglo XIX (cuando empieza a activarse el proceso de parcelación) hasta la década de 1920-1930 (cuando los índices de traspasos de propiedad adquieren cuotas más elevadas) el número de profesionales que se dedican a esta actividad va en aumento. ${ }^{9}$ Asimismo, el entrecruzamiento de estas fuentes fiscales con otros datos relativos a la formación de los individuos que a menudo ejercían esta profesión ha puesto de manifiesto que la mayoría poseían conocimientos jurídicos y ejercían la abogacía o el notariado. Una prueba más, al fin y al cabo, del temor que tenían los titulares de los patrimonios nobiliarios de que, a raíz de la reforma agraria

8 En este sentido, resultan ilustrativos varios pleitos promovidos durante los primeros años del siglo XX por el marqués de Vivot contra varios establecedores, en los que se discute sobre si trata de derechos fundamentados en una enfiteusis común o en una enfiteusis señorial. En el transcurso de estos autos se hacen asimismo continuas referencias a la figura del perceptor de censos, a los vicios en los que éste generalmente incurría con el fin de enriquecerse y a distintos individuos que desde finales del siglo XIX habían ejercido esta actividad a cuenta del marqués: Gabriel Bibiloni, Jorge Perelló y Bartolomé Singala, quien con el tiempo pasó de simple cobrador de censos a administrador general de la casa (Archivo Vivot, Series Nuevas, 1).

9 Debo esta información a la sistematización de los registros de la matrícula industrial y de comercio de Mallorca realizada durante los años 2002-2003 por A. Albertí durante el disfrute de una beca auspiciada por la Fundación Jaume Ignasi Villalonga sobre Los orígenes de la burguesía mallorquina y su implicación en las transformaciones económicas de los siglos XIX y XX. 
liberal, determinados derechos pudieran ponerse en entredicho y ello repercutiera, a corto plazo, en una disminución de sus ingresos. Fue precisamente para intentar evitarlo para lo que contrataron los servicios de estos "perceptores de censos profesionales», quienes, además de vigilar el cobro de las pensiones y otros derechos, les asesoraban en temas jurídicos y los defendían cuando las desavenencias con los establecedores llegaban a los tribunales.

En este contexto, interesa subrayar también que, a la hora de tomar la decisión de establecer total o parcialmente una finca, los terratenientes mallorquines actuaban sobre todo guiados (en muchos casos asesorados por ingenieros, peritos, agrimensores e incluso relojeros) por criterios de rentabilidad económica. Y, de hecho, en el transcurso de una investigación destinada a relacionar el ritmo de los traspasos contabilizados entre 1768 y 1862 con algunos indicadores económicos básicos ${ }^{10}$ — fundamentalmente el movimiento del precio de los cereales y del aceite y la evolución de la renta de la tierra-, se pudo comprobar que antes de segregar valoraban, fundamentalmente, la evolución de la renta de las distintas fincas que integraban sus patrimonios. Éstos solían incluir explotaciones de dos tipologías principales: cerealícolas, ubicadas sobre todo en el Llano de Mallorca (Pla) y oleícolas, localizadas principalmente en la Sierra Norte (Tramuntana) y en el Levante. Ambos tipos de explotaciones atravesaban, en el momento en que se aprobó la legislación desvinculadora, una coyuntura económica distinta. Mientras que la renta de las fincas cerealícolas se encontraba estancada e incluso devaluada, tanto el valor como la renta de las explotaciones oleícolas iban en aumento. Y ello es, al fin y al cabo, lo que no puede perderse de vista para entender que lo que en un primer momento estimula la nueva legislación es una segregación selectiva de la propiedad.

En un estudio destinado a valorar la extensión segregada por la nobleza en las distintas comarcas de la isla entre 1768 y 1965, es decir, durante prácticamente dos siglos, se comprobó (Jover y Morey, 2003, pp. 230233) que en una primera etapa los antiguos titulares de bienes vinculados

10 Este aspecto ocupó igualmente un capítulo de mi tesis doctoral —Morey (1999a), pp. 313-344-, que utilicé en un artículo destinado a demostrar la relación entre el ritmo de los traspasos de propiedad y las variables económicas (Morey, 1998). 
parcelaron únicamente aquellas fincas más alejadas de Palma (su lugar de residencia habitual). Generalmente las de cultivo cerealícola, que solían encontrarse desprovistas de árboles; lo que significa que, siempre que el estado de sus economías se lo permitió, se reservaron, bien para explotar en régimen de arrendamiento e incluso para gestionar de forma directa, las fincas oleícolas de la Sierra Norte. ${ }^{11}$ En realidad, no fue hasta la década de 1870-1880 cuando la parcelación empezó a hacerse extensiva a todo tipo de explotaciones; coincidiendo con la progresiva interrupción de la fase expansiva que inició la agricultura española en el segundo tercio del siglo, y más en concreto a partir de finales del siglo XIX, cuando, debido a la coyuntura finisecular, empezaron a caer los precios de los productos agrícolas en general y, en particular, el del aceite de oliva. Entonces, a los terratenientes mallorquines les empezó a resultar difícil encontrar arrendatarios dispuestos a cultivar sus propiedades incluso bajando la renta, y la mayoría no tuvieron más opción que empezar a segregar también aquellas fincas que hasta el momento habían constituido una especie de reserva para sus economías y les habían permitido, en definitiva, mantener su condición de grupo terrateniente hegemónico. ${ }^{12}$

Con todo, a pesar de que inicialmente la legislación desvinculadora fomentara sólo una segregación selectiva, parece que fue trascendental para que los titulares de los patrimonios nobiliarios tomaran conciencia de que la nueva situación no les permitiría continuar acumulando deudas sin responder de ellas. Es decir, sin que, como había sucedido hasta entonces, se vieran en la necesidad de responder forzosamente con los bienes de sus respectivos patrimonios. Ello explica el esfuerzo de muchos titulares por desarrollar distintas estrategias para incrementar sus ingresos. Desde el nombramiento, como veíamos, de personas con el encargo especial de cobrar censos y pensiones que en algunos casos los nuevos adquisidores se negaban a pagar, pasando por el cambio de las formas de gestión de aque-

11 Como lo demuestra el hecho de que entre 1768 y 1862 el porcentaje de propiedad territorial controlado por la nobleza en esta zona se redujera sólo un 1,44\% (Jover y Morey, 2003), p. 230.

12 El estudio citado - Jover y Morey (2003), p. 230 - pone de manifiesto que en 1965 la propiedad nobiliaria se había reducido un $20 \%$ y el porcentaje de traspasos relativos a propiedades ubicadas en la Sierra Norte (un 22,33\%) se encontraba ya prácticamente igualado al de los traspasos del Llano procedentes de fincas cerealícolas (23,03\%). 
llas fincas que presentaban una renta más devaluada (sustitución del arrendamiento por la gestión directa a través de un «mayoral»), hasta el nombramiento de administradores profesionales encargados, entre otras posibles funciones, ${ }^{13}$ de poner las cuentas al día y confeccionar estados de cargo y data que permitieran conocer tanto el montante de los ingresos anuales como los gastos y las deudas acumuladas.

Los administradores ajenos al ámbito estrictamente familiar empiezan a ser habituales en los grandes patrimonios nobiliarios mallorquines ${ }^{14}$ a partir de mediados del siglo XIX. Reemplazan progresivamente a las figuras del "pariente-administrador» (en muchas ocasiones clérigo) y del "mayoral de mayorales», que hasta entonces se habían encargado de pasar periódicamente por las distintas fincas del patrimonio y de revisar las cuentas de los arrendatarios y mayorales sin poseer, la mayoría de veces, conocimientos jurídicos ni de contabilidad. Hecho, este último, que al menos teóricamente los diferenciaba de los denominados «administradores profesionales», los cuales solían poseer formación contable suficiente para llevar las cuentas siguiendo las pautas recomendadas por los tratadistas del momento. Y, además, gozaban del prestigio y la buena reputación «suficiente» para ganarse la confianza de las casas para las que iban a trabajar.

13 Sobre la evolución de las funciones de los administradores, resultan especialmente clarificadores algunos trabajos recientes. Entre los principales, Carmona (2001), Garrabou, Planas y Saguer (2001a) y (2001b), Serrano García (2002), Lana (2003) y López y Robledo (2004).

14 Los grandes patrimonios mallorquines estaban formados por fincas de extensión considerable y de tipología distinta, ubicadas en las diferentes comarcas de la isla, lo que dificultaba su explotación en régimen de gestión directa y la vigilancia de los trabajadores por parte de sus propietarios. La mayoría pertenecían a la nobleza ciudadana, que sólo iba a algunas de sus fincas a pasar determinadas temporadas o fiestas y, como hacían en general los titulares de los antiguos patrimonios - López y Robledo (2004) —, se servían de distintos agentes para explotar las tierras y asegurarse la percepción de las rentas. La cadena de agentes era larga y variaba en función de las distintas coyunturas, pero en la cúspide se encontraba siempre una figura muy similar a la del administrador propiamente dicho: un «mayoral de mayorales», un administrador-contable, un administrador-procurador, etc. En cambio, los patrimonios de menores dimensiones, que por lo general eran propiedad de casas nobiliarias de segunda fila o de terratenientes de origen campesino que habitualmente vivían en las localidades donde tenían la mayor parte de sus tierras, presentaban unas formas de gestión y una cadena de agentes mucho más simple. En la cúspide solía situarse, todavía a mediados del siglo XIX, algún miembro de la familia, normalmente el titular o el heredero o algún pariente con formación eclesiástica o jurídica (Pascual, 1997). 
Sobre estos aspectos falta concluir todavía algunas exploraciones en archivos particulares, pero disponemos ya de algunos ejemplos que resultan ilustrativos de la rapidez con que a raíz de la reforma liberal tuvieron que actuar algunas casas para no perder la mayor parte de sus patrimonios. Eran conscientes de que la nueva legislación no les permitiría arrastrar las deudas que habían ido acumulando y de que sus acreedores, en un momento en que era posible cobrar con bienes inmuebles, ya no estarían dispuestos a relegar el cobro de los intereses y los capitales prestados. De ahí la urgencia de hacer balances y estados de cuentas y de encontrar el modo de saldar las deudas atrasadas a costa de desmembrar la menor parte posible de los antiguos bienes vinculados. Una tarea para la que se sirvieron en muchos casos de los servicios de los administradores antes mencionados, ${ }^{15}$ cuya actuación, e incluso el provecho que algunos de ellos intentaron sacar de la mala situación por la que atravesaban los patrimonios que administraron, pone al descubierto el análisis de no pocas contabilidades de la época. Entre otras la del marqués de Ariany, elegida como ejemplo para ilustrar como un patrimonio con propiedades de distinta tipología ${ }^{16}$ y con capacidad para negociar sus rentas a partir de la coyuntura económica de diversos productos, se ve obligado por las numerosas deudas contraídas a contratar los servicios de varios profesionales y a segregar total o parcialmente diversas propiedades.

Inicialmente se segregarán, siguiendo la práctica habitual, las fincas menos productivas y las que por lo general sólo eran aptas para el cultivo cerealícola, lo que dará lugar a partir del 19 de septiembre de 1852 al esta-

15 Una tarea, la de intervenir en las ventas de las fincas, que fue bastante común entre los administradores a partir de la reforma agraria liberal y en la que, puesto que cobraban a comisión, se supone que debieron de ser los primeros interesados en que las ventas se realizaran al máximo precio (López y Robledo, 2004), pp. 111-112. Asimismo, parece evidente que los administradores se aprovecharon personalmente de la mala situación económica que atravesaban los titulares de los patrimonios que administraban y adquirieron porciones importantes de aquellas tierras cuyas ventas gestionaban personalmente. Una práctica, por otra parte, de la que ha quedado constancia en algunas obras de la literatura popular mallorquina, donde los «administradores profesionales» son presentados como usureros sin escrúpulos que persiguen sobre todo ascender socialmente (Peñarrubia, 2001), p. 199.

16 Tal y como se desprende de la sistematización de los Apeos de Garay de 1818, los titulares de este patrimonio poseían propiedades de distinta tipología ubicadas en varios municipios: Cas Fosser i Can Coves en Palma; fincas oleícolas en Bañalbufar (la Baronia), Esporles (la Font Seca) y Escorca (Mortitx), y fincas cerealícolas en Manacor (els Promets, Rafalet, Son Negre y la Vall de la Nou) y Sineu (Son Pere Creixell). Morey (1999a), p. 294. 
blecimiento parcial de la primera finca: Son Negre. Un predio en el que, con una renta prácticamente estancada, se habían mantenido entre 1778 y 1830 diferentes miembros de una misma familia de arrendatarios, ${ }^{17}$ lo que ocasionó que las ganancias del propietario disminuyeran de forma progresiva y, a la vez, que en el contrato de 1822, es decir, en el primero que se firmó justo después de haberse aprobado la primera ley de desvinculación, se introdujera una cláusula que contemplaba la posibilidad de parcelar la finca (Morey, 1998, p. 108). Una cláusula, no obstante, de la que no se hizo uso hasta mucho tiempo después. En parte porque la real cédula de 11 de marzo de 1824 anuló la ley del Trienio, pero sobre todo porque a partir del contrato de 1832 la situación se invirtió: los precios de los cereales continuaron bajando, pero el propietario consiguió una espectacular subida de la renta, lo que hasta 1852 significó un incremento de sus ganancias de entre un 80 y un $90 \%$ y, por el contrario, una drástica reducción de los beneficios del arrendatario, que a partir del mes de septiembre de 1852 ya no estuvo dispuesto a renovar el contrato. Entonces el propietario no encontró a ningún arrendatario para cultivar aquellas tierras por la misma renta, y no tuvo más remedio que proceder a su establecimiento. En principio parcial, ya que el núcleo principal de la finca continuó explotándose a través de un mayoral en régimen de gestión directa, pero a partir de 1854 , bien porque aquel sistema no reportaba tantos beneficios como los que se habían obtenido a través del arrendamiento o bien porque la mala situación económica de la familia lo hacía necesario, se tomó la decisión de parcelar totalmente el predio. ${ }^{18}$

Paralelamente, el marqués de Ariany había contratado los servicios de un administrador profesional con el objetivo de poner orden en su contabilidad y obtener unos estados de cargo (entradas) y data (salidas) que le permitieran hacer un diagnóstico de la situación y encontrar una salida lo más airosa posible. De dichos estados se han conservado solamente los

17 Los datos relativos al montante total de la renta de este predio se han tomado de Suau $(1991 a)$ y fueron ya utilizados en el transcurso de mi tesis doctoral para ilustrar la correlación entre parcelación y evolución de la renta de la tierra (Morey, 1999a).

18 Entre 1852 y 1862 segregaron concretamente unas 172 ha de tierra en 112 parcelas, la mayoría a través de contratos enfitéuticos y con la obligación por parte de los nuevos propietarios de pagar un censo anual y distintos derechos de origen feudal (Archivo Municipal de Palma [en adelante, AMP], Fondo Cotoner, regs. 419, 1294 y 1299). 
CUADRO 2

EVOLUCIÓN DE LA RENTA DE LA FINCA SON NEGRE, PROPIEDAD DEL MARQUÉS DE ARIANY (1778-1852)

\begin{tabular}{|l|c|c|c|c|}
\hline Años & Renta (en sueldos) & Indice precios & Renta deflactada & Indice R. D. \\
\hline $1778-1787$ & 9655,85 & 100 & 9655,85 & 100 \\
$1787-1793$ & 10548,85 & 111,92 & 9425,35 & 97,61 \\
$1801-1806$ & 13759,90 & 154,97 & 8879,07 & 91,95 \\
$1813-1818$ & 15931,80 & 183,80 & 8868,00 & 91,84 \\
$1822-1830$ & 11593,88 & 124,34 & 9324,34 & 96,57 \\
$1832-1836$ & 21489,60 & 124,83 & 17215,09 & 178,29 \\
$1836-1840$ & 20379,20 & 121,31 & 16799,27 & 173,98 \\
$1840-1844$ & 17050,70 & 101,51 & 16797,06 & 173,96 \\
$1844-1848$ & 18155,85 & 109,38 & 16598,87 & 171,90 \\
$1848-1852$ & 17698,00 & 100,83 & 17552,32 & 181,78 \\
\hline
\end{tabular}

relativos al cargo desde el mes de febrero de 1861 hasta el mes de septiembre de 1864 (cuadro 3). No obstante, resultan de gran interés para conocer, por un lado, la tipología de las principales entradas de los patrimonios nobiliarios mallorquines una vez concluida la reforma agraria liberal $^{19} \mathrm{y}$, por otro, para adelantar una serie de hipótesis que con el tiempo deberán contrastarse con el estudio de otros casos:

- La enorme dependencia de los propietarios de antiguos bienes vinculados de los capitales prestados por particulares para hacer frente a su falta de liquidez. Como se pone de manifiesto en el cuadro 3, sólo en 1863 el porcentaje de entradas procedentes de préstamos es irrelevante, lo que se compensa este año concreto por los ingresos procedentes de un pleito por herencia. Una partida, la de los pleitos, que tanto antes como después de la legislación liberal estará presente en las contabilidades nobiliarias.

- La continuidad, como de hecho había sucedido en la mayoría de casas nobiliarias mallorquinas desde los siglos XVII y XVIII, de las entradas procedentes de la renta de la tierra; tanto de los arrendamientos como de la venta de los productos procedentes de las fincas que se llevan en explotación directa.

19 Hasta ahora, todos los trabajos que se han ocupado de esta problemática se han referido únicamente a las etapas anteriores a la reforma agraria liberal: Jover (1996), (1998) y (1999), Suau (1988) y Morey (1999a). 
CUADRO 3

DISTRIBUCIÓN EN LIBRAS MALLORQUINAS DEL ESTADO DE CARGO (ENTRADAS) DE LA CASA DEL MARQUÉS DE ARIANY ENTRE 1861 Y 186420

\begin{tabular}{|c|c|c|c|c|c|c|c|c|c|c|}
\hline Partidas & 1861 & $\%$ & 1862 & $\%$ & 1863 & $\%$ & 1864 & $\%$ & Totales & $\begin{array}{c}\text { Media } \\
\%\end{array}$ \\
\hline 1. Capitales préstamos & 9801 & 28,02 & 24389 & 54,29 & 3514 & 4,62 & 22000 & 65,57 & 59773 & 25,61 \\
\hline 2. Depósito Hacienda & 8951 & 25,59 & 9714 & 21,62 & 6613 & 8,70 & - & 0,00 & 25322 & 10,85 \\
\hline 3. Arrendamientos & 4893 & 13,99 & 4327 & 9,63 & 5563 & 7,32 & 4099 & 12,22 & 18906 & 8,10 \\
\hline $\begin{array}{l}\text { 4. Venta productos } \\
\text { agrícolas }\end{array}$ & 9445 & 27,00 & 5097 & 11,35 & 4925 & 6,48 & 5257 & 15,67 & 24758 & 10,61 \\
\hline $\begin{array}{l}\text { 5. Arrend. + venta } \\
\text { productos agrícolas } \\
\text { (Renta de la tierra) }\end{array}$ & 14338 & 40,98 & 9424 & 20,98 & 10488 & 13,80 & 9356 & 27,88 & 43665 & 18,71 \\
\hline $\begin{array}{l}\text { 6. Traspasos de } \\
\text { propiedades }\end{array}$ & 1028 & 2,94 & 949 & 2,11 & 1014 & 1,33 & - & 0,00 & 2996 & 1,28 \\
\hline 7. Herencias & - & 0,00 & - & 0,00 & 53521 & 70,43 & - & 0,00 & 53583 & 22,96 \\
\hline 8. Otros & 866 & 2,48 & 451 & 1,00 & 842 & 1,11 & 2197 & 6,55 & 4360 & 1,87 \\
\hline 9. Totales anuales & 34984 & - & 44927 & - & 75992 & - & 33553 & - & 233362 & - \\
\hline
\end{tabular}

- La novedad que supone, a partir de la aprobación de la legislación desvinculadora, la aparición, en los estados de cargo, de ingresos procedentes de la venta o el establecimiento de fincas que anteriormente se encontraban exentas del mercado. Una partida que en el momento que comentamos tenía todavía una presencia testimonial, pero que en poco tiempo irá arrinconando los ingresos procedentes de otras partidas.

La dependencia del marqués de los acreedores externos y la urgencia de restituir los capitales prestados, le llevó entre 1865 y 1868 a contratar los servicios de un nuevo administrador: Miguel Pons y Burrutia. ${ }^{21}$ Teóri-

20 AMP, Fondo Cotoner, reg. 540.

21 Según los listados del reparto de la contribución de Palma de 1852 sistematizados por A. Albertí (2002), p. 23, M. Pons y Burrutia ocupaba la posición número veinte en el escalafón de máximos contribuyentes, con un total de 1962,12 reales de vellón repartidos del siguiente modo: prestador sobre joyas (1614), administrador de fincas rústicas y urbanas $(323,02)$ y propietario de un carro de transporte $(32,10)$. 
camente, un «administrador profesional» con experiencia y formación suficiente (poseía conocimientos contables y era además abogado de profesión) para sacar a flote su maltrecha economía. No obstante, el balance de estos cuatro años fue negativo y, al final, la decisión del marqués se mostró totalmente equivocada, ya que el nuevo administrador actuó en beneficio propio y hundió todavía más la economía que administraba. ${ }^{22}$ Por una parte, porque, en lugar de vender todas las tierras necesarias para saldar deudas antiguas, procedió a tomar nuevas cantidades en préstamo, procurándose incluso un poder notarial nuevo y engañando al marqués, lo que supuso un incremento considerable tanto de las deudas como de los intereses. Asimismo, porque el maltrato, las mentiras e insultos que profirió a los acreedores antiguos hicieron que muchos lo denunciaran y exigieran la devolución de los capitales prestados. Y, por si fuera poco, intentó falsear las cuentas y estafó, como mínimo, unas 68000 libras. Todo ello sin olvidar que a voluntad propia dejó las cuentas y los papeles tan embrollados que resultó prácticamente imposible conocer a ciencia cierta lo que había supuesto su administración. Hecho que, por otra parte, no resulta extraño si tenemos en cuenta, como apuntó su sucesor en el cargo, que esto era lo que habitualmente hacían muchos administradores con el deseo expreso de dificultar la revisión de sus cuentas: "sabido es que el administrador que defrauda no da sus cuentas corrientes, ni las rinde cuando se las piden, que se niega a rendirlas con efugios y falsedades». ${ }^{23}$

El saneamiento del patrimonio vino, finalmente, de la mano de otro reputado profesional mallorquín, Antonio María Sbert, ${ }^{24}$ que, por los

22 AMP, Fondo Cotoner, «Reparos a la administración llevada por M. Pons y Burrutia entre 1865-68» (reg. 927).

23 AMP, Fondo Cotoner, reg. 927.

24 Según se desprende de los estudios realizados por I. Peñarrubia (2001), p. 326, Sbert gozaba en la segunda mitad del siglo XIX de muy buena reputación. Además de ser administrador del marqués de Ariany, sobresalió por ejercer la abogacía y el notariado y por ocupar diferentes cargos: la presidencia y la vicepresidencia del primer Ateneo Balear desde 1863, la vicepresidencia en 1875 de la Asociación de Propietarios de Mallorca, la presidencia de la Academia de Derecho y Notariado y la presidencia, entre 1882 y 1894, de la Caja de Baleares («Sa Nostra»), entre otros. 
lazos de amistad que lo unían al marqués, accedió a su encargo de elaborar los correspondientes estados de cargo y data y de recomendar la venta de los bienes necesarios para evitar que la enorme masa de acreedores consiguiera aniquilar la práctica totalidad del patrimonio de su principal. La administración de Sbert transcurrió entre los años 1868-1871, y esta vez sí que se consiguieron los objetivos propuestos. Las partidas de cargo (cuadro 4) demuestran que por fin habían cesado los créditos y los pagos de intereses, mientras que las de data ponen de manifiesto que entre ambas fechas se destinaron cerca de 212000 libras a saldar antiguas deudas y a pagar intereses a particulares. Una cantidad sin duda más que respetable, que se había obtenido prácticamente en su totalidad de la venta de propiedades (190523) y, en menor medida, de los ingresos procedentes de la renta de las tierras remanentes (16986). En conjunto, la valoración de la administración de A. M. Sbert es diametralmente opuesta a la de M. Pons y Burrutia. Se llevaron las cuentas claras y se consiguieron, como apuntaba el mismo Sbert al final de los balances que remitía al marqués, los fines propuestos. $^{25}$

25 En su informe final decía textualmente: «Las ejecuciones se cobraron; se pagaron los acreedores que devengaban alto interes y que ejercieron constante presión amenazadora; puse mi nombre y mi reputación en garantía de los nobles propósitos y deseos del Sr. Marqués de pagar a todos los acreedores, vendiendo lo necesario de su rico patrimonio. La gran masa de acreedores fió en mi palabra y en mis actos y me ha permitido ir pagando los intereses con todo el atraso que el estado de los fondos ha hecho necesario y sin gravar para ello con un céntimo al Sr. Marqués, y devolver los capitales que han permitido las ventas realizadas y los precios cobrados; y cuando a fines de Diciembre último por repetida solicitud mía tuvo Su Señoría la bondad de dispensarme de continuar en dicho cargo [...] eran ya muchos los acreedores que habían rogado que no se les devolviese el capital ó á lo menos que sean de los últimos». Asimismo, puesto que inicialmente nada se había estipulado de sus honorarios, Sbert apuntaba que trató de indagar cuál era la costumbre entre los simples administradores: «y tomando informes de personas ilustradas" se convino en que cobraban un porcentaje sobre las cantidades recaudadas, que variaba en función de la tipología de dichas cantidades. Razón por la cual se convino que cobraría según lo dispuesto en la ley de enjuiciamiento para los administradores de testamentarías y abintestatos. A saber: el $1 \%$ sobre el producto líquido de los bienes inmuebles y el $5 \%$ sobre los demás ingresos de la administración (AMP, Fondo Cotoner, reg. 66). Un sistema de remuneración, en definitiva, muy similar al que ha sido documentado para los procuradores y administradores de los grandes patrimonios catalanes — Garrabou, Planas y Saguer (2001a), pp. 60-62 - y castellanos —López y Robledo (2004). 


\section{CUADRO 4}

DISTRIBUCIÓN EN LIBRAS MALLORQUINAS DE LOS ESTADOS DE CARGO Y DATA DE LA CASA DEL MARQUÉS DE ARIANY ENTRE 1868 Y $1871^{26}$

\begin{tabular}{|c|c|c|c|c|c|c|c|c|c|c|c|}
\hline Partidas de cargo & 1868 & $\%$ & 1869 & $\%$ & 1870 & $\%$ & 1871 & $\%$ & Totales & $\%$ & Media \\
\hline $\begin{array}{l}\text { 1. Depósitos } \\
\text { de capital }\end{array}$ & - & 0,00 & - & 0,00 & - & 0,00 & 4738 & 11,33 & 4738 & 2,02 & 4738 \\
\hline 2. Arrendamientos & 3848 & 12,47 & 2879 & 4,95 & 2683 & 2,60 & 7576 & 18,11 & 16986 & 7,26 & 4247 \\
\hline $\begin{array}{l}\text { 3. Traspasos } \\
\text { propiedades }\end{array}$ & 21746 & 70,45 & 49311 & 84,73 & 91088 & 88,33 & 28373 & 67,84 & 190523 & 81,42 & 47630 \\
\hline 4. Herencias & - & 0,00 & - & 0,00 & - & 0,00 & 1033 & 2,47 & 1033 & 0,44 & 1033 \\
\hline 5. Sin especificar & 5272 & 17,08 & 6008 & 10,32 & 9347 & 9,06 & 106 & 0,25 & 20733 & 8,86 & 5183 \\
\hline 6. Totales anuales & 30866 & 100,00 & 58198 & 100,00 & 103118 & 100,00 & 41826 & 100,00 & 234013 & 100,00 & 58502 \\
\hline Partidas de data & 1868 & $\%$ & 1869 & $\%$ & 1870 & $\%$ & 1871 & $\%$ & Totales & $\%$ & Media \\
\hline $\begin{array}{r}\text { 1.Préstamos a } \\
\text { particulares }\end{array}$ & 9224 & 84,41 & 62836 & 95,27 & 93373 & 93,12 & 36069 & 81,27 & 201572 & 91,37 & 50376 \\
\hline $\begin{array}{l}\text { 2. Intereses } \\
\text { a bancos }\end{array}$ & 300 & 2,75 & 677 & 1,03 & 4544 & 4,53 & 4675 & 10,53 & 10196 & 4,62 & 2549 \\
\hline 3. Censos al Estado & 294 & 2,69 & 556 & 0,84 & 271 & 0,27 & 358 & 0,81 & 1479 & 0,67 & 370 \\
\hline $\begin{array}{l}\text { 4. Censos a } \\
\text { particulares }\end{array}$ & 716 & 6,55 & 1069 & 1,62 & 636 & 0,63 & 1231 & 2,77 & 3652 & 1,66 & 913 \\
\hline 5. Contribuciones & 386 & 3,53 & 313 & 0,47 & 475 & 0,47 & 946 & 2,13 & 2120 & 0,96 & 530 \\
\hline 6. Honorarios varios & 7 & 0,06 & 507 & 0,77 & 972 & 0,97 & 1105 & 2,49 & 1591 & 0,72 & 648 \\
\hline 7. Totales anuales & 10927 & 100,00 & 65958 & 100,00 & 100271 & 100,00 & 44384 & 100,00 & 220610 & 100,00 & 55385 \\
\hline
\end{tabular}

A partir de 1872, su sucesor en el cargo (el administrador R. Bauzá) continuó con las prácticas contables iniciadas por Sbert. Elaboró minuciosos balances y dedicó igualmente, como se demuestra en el cuadro 5 , grandes esfuerzos a pagar los créditos y a restituir los intereses a particulares y entidades bancarias. Fundamentalmente, para evitar que los acreedores se apropiaran de los bienes que el marqués había puesto como fianza para conseguir sus créditos.

26 AMP, Fondo Cotoner, reg. 66. 
CUADRO 5

DISTRIBUCIÓN EN LIBRAS MALLORQUINAS DE LAS DISTINTAS PARTIDAS DE LOS ESTADOS DE DATA DE LA CASA DEL MARQUÉS DE ARIANY (1872-1888)

\begin{tabular}{|l|c|c|}
\hline Estados de data & Totales periodo & \% sobre el total del periodo \\
\hline 1. Capitales devueltos a particulares & 161678 & 33,97 \\
\hline 2. Pagos de intereses & 171380 & 36,01 \\
\hline 3. Capitales devueltos a bancos & 53889 & 11,32 \\
\hline 4. Censos al Estado & 5556 & 1,17 \\
\hline 5. Censos a particulares & 12877 & 2,71 \\
\hline 6. Pleitos & 1977 & 0,42 \\
\hline 7. Contribuciones & 25671 & 5,39 \\
\hline 8. Obras y mejoras & 13296 & 2,79 \\
\hline 9. Pagos al marqués & 5084 & 1,07 \\
\hline 10. Varios & 24483 & 5,14 \\
\hline 11. Totales & 475891 & 100,00 \\
\hline
\end{tabular}

De este modo, es decir, segregando las tierras con cuentagotas y en función sobre todo de sus necesidades crediticias, la nobleza mallorquina consiguió mantenerse como grupo terrateniente hegemónico hasta finales del siglo XIX. Hasta el momento, como veíamos, en que la situación económica general la obligó también a iniciar la segregación de las explotaciones oleícolas, que se habían mantenido prácticamente intactas. De ahí la idea, también ya reiterada, de que en una primera etapa la legislación desvinculadora afectó sólo parcialmente a la remodelación de un número restringido de patrimonios nobiliarios. En general, a aquellos cuya falta de liquidez era más acuciante y no tuvieron más remedio que segregar lo necesario para ir saldando sus deudas, ya fuera con antiguos acreedores o con miembros de su propia familia que, al amparo de la nueva legislación, empezaron a exigir sus derechos hereditarios en metálico o en bienes inmuebles.

27 AMP, Fondo Cotoner, reg. 679. Interesa advertir, no obstante, que la serie no está completa: faltan los años 1874 y 1875 , razón por la cual no se han podido incluir en el cuadro. 


\section{La aprobación de la legislación liberal no se traduce en el desmantelamiento generalizado de los antiguos patrimonios vinculados}

En realidad son pocas las grandes explotaciones que cambian de propietario sin ser antes parceladas, pero esta posibilidad tiene igualmente importantes repercusiones sobre la estructura de la propiedad isleña. Tanto para la remodelación y reestructuración de los antiguos patrimonios, vinculados como para la formación de nuevos patrimonios, cuyos titulares, a diferencia de lo que había ocurrido hasta entonces, pertenecen a una nueva clase social que pasa a formar parte del codiciado grupo de los «mayores contribuyentes» a partir, precisamente, de la reforma agraria liberal. Las principales razones que explican el traspaso de grandes extensiones de tierra sin una parcelación previa son fundamentalmente tres:

a) La mala situación económica, prácticamente de quiebra, en la que se encontraban algunos herederos, y su dependencia de los adelantos monetarios de ciertos arrendatarios y algunos comerciantes de Palma, lo que facilitó que sus antiguos acreedores se hicieran con algunas de sus propiedades. Bien porque a la nobleza le fue imposible afrontar el pago de los intereses de los capitales prestados, o bien porque antes de que esto ocurriera decidieron vender sus tierras y pagar lo que debían. Las razones que están en la base de la mala situación económica que atraviesan desde el segundo tercio del siglo XIX numerosos titulares de bienes anteriormente vinculados son múltiples. Van desde la deflación de los precios de los productos cerealícolas hasta la falta de previsión general, la obligación de tener que afrontar las deudas contraídas por sus antecesores y el pago de derechos legitimarios. Una situación que sus arrendatarios conocían y de la que en múltiples ocasiones se aprovecharon. Como ilustra, por citar sólo uno de entre los numerosos ejemplos, lo sucedido entre Miguel Ramis d'Ayreflor y Marcel, heredero de un patrimonio más que respetable, y el arrendatario Antonio Rosselló y Pizá, quien gracias a las leyes desvinculadoras se convirtió en poco tiempo en terrateniente (Morey, 1999a, pp. 297-298).

Antonio Rosselló descendía de una prestigiosa familia de grandes arrendatarios del pueblo de Alaró y desde los últimos años del siglo XVIII (primero junto a su padre y después en solitario o con la ayuda 
de sus hermanos) explotó algunas fincas que finalmente consiguió comprar: Son Pere Antoni (1795-1816) y Son Fortesa (1829-1858), donde se mantuvo durante décadas con una renta prácticamente estancada. El mes de septiembre de 1842 arrienda, además, una finca fuera del término municipal de Alaró (Son Marró de Sineu) y entra por primera vez en contacto con la familia Ramis d'Ayreflor, que por entonces, a pesar de haber heredado un rico patrimonio, se encontraba fuertemente endeudada. Por esta razón, en el contrato inicial, establecido para un periodo de seis años (1842-1848), Ramis exige a Rosselló, por vía de préstamo y sin intereses, la cantidad de 3000 libras mallorquinas que se comprometía a devolverle una vez finalizado el contrato. Como garantía del cumplimiento de esta cláusula, ambas partes hipotecan sus respectivos bienes y, una vez terminado el plazo estipulado, dado que el capital no ha sido restituido, el arrendatario se queda con Son Marró: ${ }^{28}$ una finca cerealícola de unas 200 hectáreas de extensión, provista de casas y otras dependencias para servir de apoyo a la explotación y al cultivo de las tierras.

Este ejemplo, aunque extremo, sirve para ilustrar el provecho que supieron sacar muchos de los antiguos prestamistas de la nobleza terrateniente de su mala situación económica. En el caso concreto de los Rosselló, no sólo de los Ramis, sino en general de todas aquellas familias nobiliarias con las que tuvieron relación. Como lo demuestra el hecho de que, además de adquirir numerosos bienes urbanos en Alaró, varias parcelas de tierra procedentes de establecimientos diversos y el ya citado predio de Son Marró, compraran en 1842 una porción de unas 60 hectáreas procedente del predio Son Pere Antoni y, en 1858, la mayor parte del predio (unas 150 ha) de Son Fortesa de Alaró, propiedad de los marqueses de la Romana y en el que también se habían mantenido durante más de treinta años como simples arrendatarios. ${ }^{29}$

28 Esta obligación se estipula el 28 de abril de 1849 ante el notario J. V. Castell (Biblioteca Pública de Mallorca, fondos del arrendatario Antonio Rosselló, sin signatura).

29 Las primeras hipótesis sobre la forma como los Rosselló pasaron a gestionar estas tierras después de haberlas adquirido provienen de una investigación realizada juntamente con A. Pascual y auspiciada por la firma Camper durante los años 1999-2001. Sus resultados se plasmaron en un trabajo, todavía inédito, titulado Empresa rural $i$ canvi agrari a Mallorca: el cas de Son Fortesa d'Alaro (segles XVI-XX), 122 pp. 
b) En cualquier caso, más que insistir en la enumeración de otros ejemplos, lo que interesa es subrayar que la situación de endeudamiento de los antiguos propietarios de bienes vinculados no fue el único motivo por el que, a partir de la publicación de la ley de 19 de agosto 1841, se produjo el cambio de titularidad de un número respetable de grandes explotaciones e incluso la desaparición de entre las listas de mayores contribuyentes de la isla de un conjunto de familias nobiliarias que desde el siglo XVIII venían ocupando un lugar preeminente. Pues no hay que olvidar que la ley les otorgó el derecho de poder disponer libremente, como mínimo, de la mitad de los bienes que poseían. En definitiva, la facultad de poderlos transmitir libremente y venderlos sin necesidad de justificar ante ninguna institución (a diferencia de lo que ocurría anteriormente con la Cámara de Castilla o las Cortes) el motivo del traspaso. Una posibilidad de la que se aprovecharon distintas familias; fundamentalmente aquellas que a través de la institución fideicomisaria habían heredado bienes procedentes de otros linajes extinguidos y que a mediados del siglo XIX ya no residían habitualmente en la isla: Pasqual de Riquelme, Lante della Rovere, Andreu de Nápoles, Bustamante, Sentmenat y Caro (marqueses de la Romana), entre otros (Morey, 1999b). Ejemplo, este último, que sirve para ilustrar que la desvinculación no ha de asociarse exclusivamente con endeudamiento y desmembración patrimonial, sino también con la posibilidad de reinvertir el dinero obtenido con los traspasos en la compra de otras tierras, o incluso con la adquisición de bienes más afines a los nuevos tiempos: acciones en empresas y sociedades, fincas urbanas, etc. En este sentido, resulta interesante constatar que los marqueses de la Romana, que a mediados del siglo XIX figuraban en las listas de máximos contribuyentes de Mallorca en quinto lugar y poseían cerca de 4000 hectáreas de tierra procedentes de distintos fideicomisos, a partir de 1858 (tres años después del fallecimiento del último poseedor, Pedro Caro y Salas) se van deshaciendo progresivamente de las distintas fincas y casas que poseían en la isla. Sin embargo, como contrapartida, configuran un nuevo patrimonio con una extensión tres veces superior a su anterior patrimonio mallorquín y cuyos bienes proceden, por lo general, de fincas anteriormente vinculadas (la mayoría, del duque de Frías) a las que antes de la desvinculación difícilmente hubieran podido acceder ni los marqueses de la Romana ni otros compradores potenciales. 
CUADRO 6

COMPRAS REALIZADAS POR LOS MARQUESES

DE LA ROMANA ENTRE 1877 Y $1884^{30}$

\begin{tabular}{|c|c|c|}
\hline Inmueble & Ext. aprox. & Procedencia \\
\hline $\begin{array}{l}\text { Diversas dehesas y cuartos en el término de } \\
\text { Calera (Toledo) }\end{array}$ & 2290 ha & $\begin{array}{l}\text { Compra al duque de Frías } \\
(18 / \mathrm{XI} / 1877)\end{array}$ \\
\hline $\begin{array}{l}\text { La dehesa del Torrejón en los términos de Talave- } \\
\text { ra de la Reina y Calera (Toledo) }\end{array}$ & 652 ha & $\begin{array}{l}\text { Compra al duque de } \\
\text { Frías }(20 / \mathrm{XII} / 1877)\end{array}$ \\
\hline $\begin{array}{l}\text { Administración de Sta. Olalla (Toledo): } \\
\text { - Dehesa La Moraleja } \\
\text { - Dehesa Nueva del Torcón } \\
\text { - Dehesa del Retamar } \\
\text { - Dehesa de Carrascosa } \\
\text { - Dehesa de Los Parditos } \\
\text { - Dehesa de Madrigal } \\
\text { - Dehesa de San Antonio } \\
\text { - Dehesa de Cantos Blancos y } \\
\text { otras tierras en los términos de Navalmoral y } \\
\text { Montanar }\end{array}$ & $\begin{array}{l}500 \text { ha } \\
535 \text { ha } \\
155 \text { ha } \\
560 \text { ha } \\
286 \text { ha } \\
3760 \text { ha } \\
493 \text { ha }\end{array}$ & $\begin{array}{l}\text { Compra duque Frías; } 1877 \\
\text { Compra duque Frías; } 1877 \\
\text { Compra duque Frías; } 1877 \\
\text { Compra duque Frías; } 1877 \\
\text { Compra duque Frías; } 1877 \\
\text { Compra duque Frías; } 1877 \\
\text { Compra a Pascual Eusta- } \\
\text { quio Arroyo (23/XII/1884) } \\
\text { Compra a Pascual Eusta- } \\
\text { quio Arroyo (23/XII/1884) }\end{array}$ \\
\hline $\begin{array}{l}\text { Administración de Almaraz (Cáceres): } \\
\text { - Dehesa Suertes de la Iglesia } \\
\text { - Dehesa Las Doscientas } \\
\text { - Dehesa Puertas alta y baja } \\
\text { - Coto de Baezuela } \\
\text { - Pieza de tierra en el término de Mojente }\end{array}$ & $\begin{array}{l}56 \text { ha } \\
184 \text { ha } \\
928 \text { ha } \\
710 \text { ha } \\
700 \mathrm{~m}^{2}\end{array}$ & $\begin{array}{l}\text { Compra duque Frías; } 1879 \\
\text { Compra duque Frías; } 1879 \\
\text { Compra duque Frías; } 1879 \\
\text { Compra a las hermanas Carra- } \\
\text { fa }(19 / \mathrm{VI} / 1879) \\
\text { Compra a los hermanos Díaz } \\
\text { de Mendoza }(8 / \mathrm{I} / 1879)\end{array}$ \\
\hline $\begin{array}{l}\text { Administración de Los Vélez: } \\
\text { - Diversas participaciones proindivisas con los } \\
\text { herederos de Carlos Caro sobre diversas piezas } \\
\text { de tierra, molinos, bancales, graneros y tabernas. }\end{array}$ & & $\begin{array}{l}\text { Por herencia de su madre } \\
\text { María Tomasa Álvarez de } \\
\text { Toledo y Palafox } \\
\text { (27/VII/1882) }\end{array}$ \\
\hline $\begin{array}{l}\text { Una casa con jardín en la calle de Segovia de } \\
\text { Madrid }\end{array}$ & [ca. 23 áreas] & $\begin{array}{l}\text { Compra a Pedro Téllez } \\
\text { Girón, marqués de Santi- } \\
\text { llán }(13 / \text { IV/1872) }\end{array}$ \\
\hline $\begin{array}{l}\text { Una finca de recreo con casa y jardín en Biarritz } \\
\text { llamada villa Romana y otro terreno agregado }\end{array}$ & & $\begin{array}{l}\text { Compra a Alfredo Lacour y a } \\
\text { Francisco Mossempés } \\
(29 / \mathrm{X} / 1882)\end{array}$ \\
\hline TOTAL & $11774 \mathrm{ha}$ & \\
\hline
\end{tabular}

30 Los datos de este cuadro proceden del Inventario y avalúo de los bienes relíctos por fallecimiento de Don Pedro Maza de Lizana, antes Caro y Alvarez de Toledo..., levantado en 1893 ante el notario Bruno Pascual Ruilópez y conservado en el Archivo Histórico de Protocolos de Madrid. Morey (1999a), p. 305. 
c) Otro factor a considerar para entender el traspaso de algunas fincas sin ser previamente parceladas o, a lo sumo, divididas sólo en dos mitades, es la casuística propia de la nueva legislación sobre la transmisión hereditaria de los antiguos patrimonios vinculados. La primera normativa por la que se ven afectados es la citada ley de 11 de octubre de 1820, promulgada durante el Trienio Liberal. Dicha ley otorga la categoría de libres, no sujetos a la obligación de disponer, a los bienes antes vinculados y arbitra, para evitar la posible oposición de los sucesores inmediatos, un repartimiento igualitario de los patrimonios vinculados: una mitad para los poseedores actuales y otra para los inmediatos sucesores. Sin embargo, como se ha dicho, su primer periodo de vigencia es muy breve: con la reacción absolutista de 1823 se vuelve a la situación anterior a 1820, y con la famosa real cédula de 11 de marzo de 1824 se dispone la restitución de los bienes antes traspasados y el reintegro de las cantidades pagadas. La ley del Trienio no vuelve a entrar en vigor hasta 1836 y no es en rigor hasta la publicación de la ley de 19 de agosto de 1841 cuando quedan reglamentadas las reparticiones de bienes y las compras hechas durante la primera etapa constitucional. Entonces, los miembros del grupo nobiliario y en general todos los poseedores de vínculos pudieron ser sistemáticamente obligados a liquidar sus heredades respetando las dos mitades establecidas por el nuevo orden jurídico. Quedaron facultados, en teoría, para transmitir los bienes desvinculados a su libre voluntad y para no respetar el orden de sucesión establecido en las fundaciones fideicomisarias de sus antecesores. En la práctica ello significaba que, si el último poseedor no tenía hijos, cabía averiguar primero si el heredero reunía la condición de ser el siguiente llamado y decidir, en consecuencia, si se habían de distinguir los bienes vinculados de los libres. Mientras que si tenía hijos se podía proceder, ya de entrada, a distinguir los dos tipos de bienes mencionados: los vinculados, que serían posteriormente divididos en dos mitades - una para el hijo mayor y la otra para todos los hijos, incluido nuevamente el primogénito-, y los libres, que debían repartirse otra vez entre todos. 


\section{CUADRO 7}

ESQUEMA DE LIQUIDACIÓN DE UN ANTIGUO PATRIMONIO VINCULADO

REALIZADO A PARTIR DEL REPARTO DEL CÚMULO HEREDITARIO

DEL IV MARQUÉS DE LA ROMANA (M. 1855)

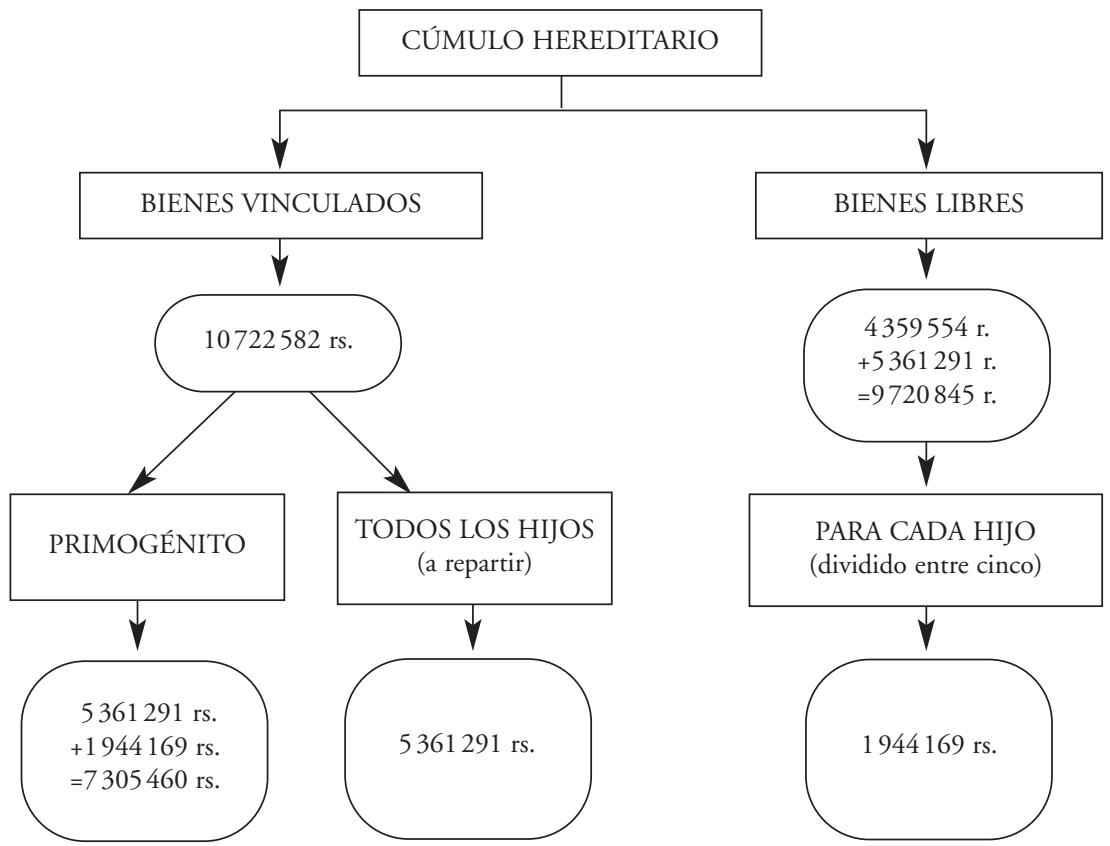

Esta forma de liquidar, aunque más igualitaria, significaba nuevamente una mayor participación de los primogénitos y, en realidad, obligaba muchas veces, sobre todo a la hora de adjudicar las partes, a estipular algún pacto concreto para compensar las posibles diferencias. Los acuerdos podían ser múltiples y contemplar, por ejemplo, que algunos herederos cobraran total o parcialmente el valor de sus respectivos cúmulos hereditarios en metálico, en lugar de en bienes inmuebles, o, incluso, que algunas de las antiguas propiedades vinculadas se dividieran literalmente en dos mitades: una para

31 Este esquema ha sido realizado a partir de la información contenida en el inventario y liquidación de la herencia de Pedro Caro y Salas (Archivo del Reino de Mallorca, protocolo 6.150). 
el poseedor actual y otra para el inmediato sucesor. Esto ayuda a entender que algunas propiedades antes vinculadas salieran al mercado divididas $^{32}$ o, simplemente, que en lugar de salir al mercado fueran simplemente intercambiadas entre parientes que poseían propiedades próximas a ellas (Morey, 1999a, p. 335).

En cualquier caso, no es generalmente la nobleza tradicional el colectivo que se beneficia de la salida al mercado de propiedades de grandes dimensiones, sino los miembros de la burguesía agraria y comercial. Los antiguos arrendatarios, los comerciantes y navieros, los profesionales liberales y algunos indianos, conscientes de que la tierra, además de ser una inversión segura, ${ }^{33}$ era un distintivo de poder y de riqueza. Como apuntábamos, una condición indispensable para formar parte del grupo de los «mayores contribuyentes» y sacar provecho de todas las prerrogativas que de ello se derivaban: ser elector, poder ejercer determinados cargos públicos, formar parte de las juntas periciales encargadas de valorar las tierras para el repartimiento de la contribución territorial, etc. (Salas, 1997). Asimismo, interesa no perder de vista que el acceso a la gran propiedad por parte de un colectivo que, a diferencia de lo que había sucedido tradicionalmente con la nobleza, no tenía problemas de liquidez y era además propietario en sentido pleno, no mero usufructuario, pudo significar un aliciente para introducir cambios en las formas de gestión y explotación de unas propiedades que tradicionalmente habían sido cultivadas de forma extensiva y gestionadas en régimen de arrendamiento. Un aspecto sin duda de gran importancia, pero sobre el cual no estamos todavía en con-

32 Una forma de proceder de la que ha quedado también constancia en la toponimia, con la abundancia de calificativos del tipo Son Verí Vell y Son Verí Nou, El Rafal d'Amunt i el Rafal d'Avall, etc. Rosselló Verger (1981).

33 Así lo ponía de manifiesto, entre otros autores coetáneos, G. Creus: «La desmembración de las propiedades rústicas que de un tiempo a esta parte viene observándose en esta isla, ha tenido notable incremento en los últimos meses [...] Como la demanda aumenta cada día, los precios se mantienen firmes, más bien con tendencia al alza [...] No abona seguramente esta preferencia el mayor rendimiento del capital invertido en esta clase de inmuebles, ya que, como sabe todo el mundo, por regla general no suelen alcanzar el 3 por ciento. Tiene sin embargo, una explicación lógica y es el mayor grado de seguridad que comúnmente se les concede en relación á las demás especulaciones [...] Los capitales acumulados a fuerza de trabajo suelen ser muy recelosos [...] y como la mayor parte de los que afluyen a esta isla tienen este carácter, no es extraño que prefieran una colocación segura, aunque poco lucrativa, á otras de mayor rendimiento sujetas á vaivenes» (Creus, 1911), pp. 210-211. 
diciones de ofrecer datos concluyentes, pues lo que se deduce de una primera exploración en algunos de los archivos particulares de estos nuevos terratenientes es que su forma de proceder no fue homogénea. Mientras en algunos casos el cambio de titularidad en la propiedad no significó siquiera la interrupción del contrato de arrendamiento en curso, en otros implicó el paso hacia la gestión directa y una explotación más intensiva de la tierra. Desde transformaciones en el sistema de rotación de cultivos, pasando por la progresiva introducción de abonos de tipo inorgánico, hasta la implantación de cultivos que tradicionalmente habían tenido una escasa representación en las grandes explotaciones: ${ }^{34}$ almendros, algarrobos y cultivos arbóreos en general. Cambios, de todos modos, que de momento sólo han podido documentarse en un número restringido de grandes explotaciones y que requieren ser tomados con cautela, pues lo que se deduce del estado general de la investigación es que los verdaderos protagonistas del cambio agrario documentado en la isla desde mediados del siglo XIX fueron los pequeños propietarios que, al amparo de la parcelación estimulada por la reforma agraria liberal, adquirieron parcelas de extensiones reducidas que progresivamente fueron poblando de árboles:

El campesino que adquiere esas parcelas paga por ellas un capital ó renta superior al que realmente les corresponde y gasta sin tasa su esfuerzo muscular en mejorarlas y cultivarlas, en cantidad desproporcionada con el valor de los frutos. Pero aun siendo así, hay que considerar como muy conveniente la división territorial agrícola en esta forma. Sin la división parcelaria que nos ocupa, seguramente no se hubieran sembrado y criado en Mallorca almendros, cuyos frutos alcanzan un valor anual superior á 15.000 .000 de pesetas (G. Creus, 1911), p. 213.

\section{Epílogo}

Para terminar, interesa recapitular sobre las principales razones que, a pesar de los reajustes que a raíz de la legislación liberal tuvieron que ir introduciendo los titulares de antiguos bienes vinculados, explican la pervivencia de sus patrimonios más allá de la legislación desvinculadora:

34 En este ámbito, un caso paradigmático es el ya citado del arrendatario Antonio Rosselló y Pizà, quien a partir de la compra de Son Fortesa al marqués de la Romana pasa a explotarla de forma directa con la ayuda de sus hijos. 
- En primer lugar, la continuidad de las prácticas de transmisión tradicionales: herencia indivisa, sucesión por línea masculina, fundación de fideicomisos de carácter temporal, etc. Asimismo, el hecho de que la forma de liquidar los antiguos patrimonios vinculados volviera a beneficiar a los primogénitos, quienes desplegaron a su vez estrategias variadas para conseguir la práctica totalidad de los patrimonios liquidados. Y, por otro lado, que después de unos años de incertidumbre fuera legalmente aceptada la continuidad de los fideicomisos temporales, ${ }^{35}$ es decir, la posibilidad de hacer sustituciones que no sobrepasasen un número determinado de generaciones. Estos factores son desde luego suficientes para comprender la práctica integridad de los latifundios mallorquines después de la década de los sesenta, pero hay además otros supuestos que posibilitan retardar todavía más las particiones. Por ejemplo, que muchos patrimonios no se llegasen a dividir porque el primogénito reunía a la vez la condición de heredero y de inmediato sucesor, razón por la cual conseguía incluso llegar a alguna especie de pacto con sus hermanos. Otras veces se trataba de cuestiones de carácter demográfico, básicamente porque los últimos poseedores legales de algunos patrimonios no murieron hasta muchos años después de la ley de abolición y por ello sus heredades no se repartieron hasta entonces. No hemos de olvidar tampoco los numerosos pleitos suscitados al amparo de la nueva legislación y las múltiples interpretaciones a las que generalmente dio lugar la ley de 19 de agosto de 1841. Supuestos, todos ellos, que

35 La institución fideicomisaria fue, de hecho, la forma de vinculación más extendida en los antiguos territorios de la corona de Aragón y, en sus orígenes, a diferencia del mayorazgo castellano, la mayoría de fideicomisos fueron de carácter temporal (limitados a cuatro generaciones). Con el tiempo, muchos de sus titulares consiguieron, no obstante, convertirlos en perpetuos y evitaron hacer las distintas detracciones que, a diferencia también de lo que ocurría con los mayorazgos, estaban permitidas en los fideicomisos temporales: pagos de dotes y legítimas del difunto, deudas, cuarta trebeliánica, etc. Dicha práctica ayuda a entender que la legislación liberal asimilara los fideicomisos perpetuos a los mayorazgos y aboliera, finalmente, ambas instituciones. Lo que no ocurrió, sin embargo, con los fideicomisos temporales, que después de unos años de incertidumbre fueron aceptados por una sentencia publicada el mes de abril de 1865. Maluquer de Motes (1983), pp. 192-193. Es más, en el caso de Baleares, el fideicomiso sobrevivió, aunque reducido a dos generaciones, al Código Civil de 1889. 
obligan una vez más a retardar hasta finales del siglo XIX, o incluso hasta comienzos del XX, la división de los latifundios mallorquines.

- Respecto a la escasa influencia que en una primera etapa tuvo la nueva legislación sobre el mercado de la tierra, interesa recordar las principales estrategias desplegadas por algunas casas nobiliarias desde mediados del siglo XIX: parcelación selectiva, cambios en los sistemas de gestión de determinadas fincas, introducción de nuevas cláusulas en los contratos de arrendamiento, que dejaban abierta la posibilidad de parcelar con cuentagotas, sustitución de los «parientes-administradores» por la figura del «administrador profesional» y contratación de personal específico (perceptores de censos) con el objetivo de maximizar las entradas procedentes de las ventas a censo. Asimismo, interesa no perder de vista que la abolición definitiva de los vínculos y fideicomisos se produce en unos momentos en que la coyuntura económica es favorable al grupo terrateniente. No es realmente hasta las décadas finales del siglo XIX, cuando la situación económica empeora, cuando se inicia la fragmentación masiva de la gran propiedad isleña; tímidamente a partir de los años noventa, y de forma más intensa a partir de 1911. 



\section{ESTRATEGIAS DE GESTIÓN PATRIMONIAL ANTE LOS CAMBIOS INSTITUCIONALES EN EL PIRINEO CATALÁN (SIGLOS XIX-XX) Jacinto Bonales \\ (Universitat de Lleida)}

En el presente artículo reflexionamos sobre los condicionantes institucionales que inciden sobre la gran propiedad del Pirineo catalán en su formación y, principalmente, en las estrategias seguidas ante las reformas liberales del siglo XIX. ${ }^{1}$ Para ello tomaremos como ejemplos diversos patrimonios del Prepirineo leridano (Conca de Tremp) y del Alto Pirineo andorrano, lo que nos proporcionará elementos de reflexión sobre las dinámicas propias del sistema socioeconómico pirenaico y las incidencias del liberalismo. Por otro lado, nos centraremos en los patrimonios cuya fase de expansión se inicia en el siglo XVII y se alarga hasta el XIX-XX, dejando de lado aquellos patrimonios de origen anterior o que se descomponen antes del XIX, así como aquellos que se forman en este siglo. ${ }^{2}$

1 El material documental con que se trabaja procede tanto de nuestra tesis doctoral, Comunidad rural y economía de mercado en la Conca de Tremp (siglos XVIII-XIX). Cambio económico y éxodo rural (Bonales, 2003), como de la investigación inédita La construcció dels limits parroquials a Andorra. El cas d'Ordino-La Massana (Bonales, 2004b).

2 Sí que nos pararemos a observar algún ejemplo de aquellos patrimonios que se forman en manos de administradores gracias a la disgregación de los patrimonios señoriales anteriores. 
Dos problemas centrarán el discurso, al afectar directamente a las estrategias patrimoniales y de gestión de la gran propiedad: la negociación continuada del propietario con la comunidad rural durante los procesos de formación y consolidación del gran patrimonio, así como durante el cambio institucional liberal, es decir, los costes de transacción en un determinado sistema de relaciones sociales y de propiedad en transformación; y la incidencia de los mecanismos de reproducción social en dichas estrategias.

El estudio se divide en tres partes: planteamos las características de formación y consolidación de la gran propiedad de Antiguo Régimen y su relación con la comunidad rural; seguidamente mostramos las tres alternativas seguidas por la gran propiedad ante el cambio institucional liberal; y finalmente, siguiendo las líneas planteadas por los directores del congreso, hacemos un balance sobre la figura del administrador y su relación con el propietario, destacando que en dicha relación de agencia no sólo juegan los conocimientos de gestión y de mercados, debiéndose mantener e incrementar las redes sociales y las negociaciones políticas, con un claro beneficio directo del agente.

\section{Universitat y gran propiedad}

Hablar de gran propiedad en los Pirineos puede resultar anecdótico si la comparamos con las diferentes estructuras agrarias peninsulares. En los Pirineos catalanes predominan la pequeña explotación agropecuaria y los bienes públicos: en el Alto Pirineo la superficie pública, según el catastro de la década de 1950, abarcaba el 72,3\% de la superficie catastral, con diferencias comarcales que iban del 91,4\% del Valle de Arán al 45,2\% del Alto Urgel, mientras que en el Prepirineo ascendía al 49,3\%, con diferencias que pasaban del 65,6\% de la Terreta al $40,6 \%$ de la Conca de Baix. ${ }^{3}$ Así, eran relativamente escasos los patrimonios de más de 100 hectáreas, constituyendo en el Pirineo el 0,56\% de propietarios que poseían el 19,4\% de la superficie privada (con un promedio de $307 \mathrm{ha}$ ), y en el Prepirineo el 0,15\% de propietarios que poseían el 33,1\% de la superficie privada (con un promedio de $317 \mathrm{ha}$ ).

3 Datos aportados por Suñol i Molina (1989). 
Cifras que sitúan al Pirineo en sintonía con la gran propiedad de la Cataluña decimonónica. ${ }^{4}$

Esta gran propiedad se caracterizaba, en los siglos XVIII y XIX, por su fragmentación espacial: compuesta por varias "casas» (unidades de explotación constituidas por edificios y parcelas dispersas) en diferentes poblaciones, así como parcelas dispersas por diferentes pueblos de la comarca, que eran periféricas a los núcleos principales de la explotación. ${ }^{5}$ En todos los casos, el gran propietario poseía el dominio directo de los bienes, y en la mayoría de ellos también el dominio útil de las "casas» principales del patrimonio familiar. ${ }^{6}$

La gran propiedad y la comunidad rural organizaban un sistema socioeconómico en nada arcaico, sino funcional y en continua renovación, bajo premisas de individualismo agrícola y titularidad y establecimiento colectivo de normas. La universitat pirenaica (comunidad rural) del Antiguo Régimen ha de observarse como una institución con personalidad jurídica, propietaria de derecho (franc alou o plena propiedad reconocida por los señores) o de hecho (a falta de títulos en contra, y gracias al omnes causa o posesión inmemorial no interrumpida) de los bienes no privados (propios de las casas), con capacidad de arrendar aprovechamientos, pero también de comprar, vender, permutar e hipotecar bienes raíces; y que estaba compuesta por un número limitado de titulares (vecinos, frente a los residentes sin derecho de vecindad) que poseían la participación en la propiedad proindiviso, sin cuotas de participación (lo que los juristas denominarían comunidad de bienes de tipo germánico, pero con la posibilidad de alienación). Organizados en asamblea o consell general, los cotitulares de los bienes establecían las reglas del juego económico a través de las normas de explotación (o aprovechamiento), no estancadas, sino renovadas mediante negociación año tras año, adaptándose a las realidades sociales y económicas de tipo local, comarcal y regional. ${ }^{7}$ En resumen, la

4 Al respecto, Garrabou, Planas y Saguer (2001a).

5 Sobre el acceso a la tierra y la incidencia de las instituciones comunitarias en las formas de contratación, ver, para el siglo XVIII, Bonales (2000). Para los siglos XVIII y XIX, Bonales (2003).

6 Sobre los diferentes tipos de propiedad y estructuras agrarias en Cataluña, ver Ferrer i Alós (1995) y Tello (1997).

7 Sobre estas comunidades rurales y la generación de normas, ver Bonales (2003), Bringué (1995) y Sanllehy (1996). 
universitat era la titular de la mayor parte de los bienes y quien establecía las normas básicas de explotación que llevaban a cabo los cotitulares de forma individual y, si se quiere, bajo motivaciones oportunistas y maximizadoras, pero con límites institucionales y autolimitaciones estructurales (capacidad de explotación, disponibilidad de mano de obra, disposición de capital, ciclo vital de los componentes de la familia, etc.). Estas normas prevalecían sobre la ley, aunque se acudiera a la ley frente a la norma en situaciones puntuales pero reversibles, acto facilitado por la reproducción de la relación contractual entre principal y agente en el ámbito jurídico y político a nivel comarcal. ${ }^{8}$ La universitat era, pues, un conjunto de individuos que a la vez eran principales y agentes, propietarios y vigilantes, explotadores oportunistas y celadores perpetuos en una negociación continua y una extensa red de contratos formales e informales.

La gran propiedad negociaba con contratos formales e informales, que iban más allá de lo económico, con estas instituciones comunitarias (por ejemplo, consiguiendo la restricción de formas de arriendo de ganado para obtener casi el monopolio de los pastos a cambio de una mayor flexibilidad en el acceso al cultivo del comunal por parte de los no ganaderos) y, al mismo tiempo, con los individuos que las componían, pero siempre estando sometidas todas las partes al control formal e informal del colectivo.

Para entender la validez de la negociación entre gran propiedad y universitat, hay que observar, a largo plazo, el sistema social pirenaico. Desde la crisis demográfica del siglo XIV se configura un sistema socioeconómico basado en la baja densidad demográfica y en la flexibilidad de los recursos disponibles; sistema que aparece consolidado en el siglo XVI y que resiste a las diferentes embestidas señoriales. ${ }^{9}$ Organizados como universitat, los vecinos controlan los cambios demográficos a través del sistema de suce-

8 Las élites comarcales, surgidas del seno de las comunidades rurales, ejercen de hecho el poder económico y político a nivel comarcal, ya sea en su papel de asesores jurisdiccionales (jueces al fin y al cabo), como asesores del corregidor (que desconoce la ley e incluso la lengua local) y como administradores de rentas y créditos señoriales, participando activamente en el mercado regional.

9 Un ejemplo de larga duración cronológica del sistema socioeconómico, en Bonales $(2004 a)$. Para la época moderna en la vertiente norte de los Pirineos, algunos matices que apuntan a la formulación de este modelo, en Zink (1997). 
sión (herencia universal indivisa) y recolocación social de los miembros no herederos fuera de la comunidad. A esto se suma el control efectivo de las nuevas residencias a través de diversos mecanismos basados en la condición de vecindad (participación en los derechos colectivos). El control llega a su máximo exponente mediante los mecanismos de recuperación, por parte de la universitat, de los bienes raíces. ${ }^{10}$ Así se constituye un bloque más o menos estable en el tiempo de bienes patrimoniales de cada casa, ${ }^{11}$ y otro bloque de comunales susceptibles de explotación (bajo las normas establecidas por el colectivo).

La gran propiedad nace dentro de estas universitats mediante el enriquecimiento de una de las casas «antiguas» (capmassers, prohoms) a través de la convergencia de diversas estrategias: producción agropecuaria, crédito, comercio y, en ocasiones, explotación siderúrgica (fundamentalmente en el Alto Pirineo). Estas casas, que se caracterizan por un alto riesgo e incertidumbre de las actividades, ${ }^{12}$ mantendrán las estrategias de acumulación de capital con fluctuaciones según condicionantes diversos (combinación de las coyunturas con el ciclo vital familiar, condiciones del mercado, etc.), aprovechándose especialmente de las fases de crisis demo-económica regional para enriquecerse mediante el crédito. Estas actividades se combinarán con una activa política matrimonial (buscando la fusión de casas con descendiente directo único) que llevará a constituir un respetable conjunto patrimonial difícil de explotar directamente por su extensión y dispersión. El siguiente paso pasaba por el incremento del control del comercio y del crédito (dada la imposibilidad de controlar totalmente el factor tierra) y la participación en las rentas señoriales (sin olvidarnos de su papel de agentes como asesores jurídicos o administradores

10 Con diferentes figuras jurídicas, como la renovación anual de la concesión de bö̈gas (cultivos sobre comunal) en las comunidades con poca superficie cultivable, la reserva de prelación (fadiga) por parte de la comunidad en las ventas de bienes raíces a foráneos, o la posesión indiscutida del derecho a poseer la comunidad los bienes mostrencos y la capacidad de venderlos, donarlos (conlloc) o retornarlos al comunal, etc.

11 La mayor parte de estos bienes procede del periodo anterior a la consolidación del modelo de baja densidad y de los mecanismos comunitarios de control de la tierra y de la justicia civil y rústica.

12 Características propias de las áreas de montaña pirenaicas y alpinas; al respecto, ver Fontaine (1990) y (1994). 
de grandes patrimonios), ${ }^{13}$ hasta hacerse, vía matrimonial o vía compra, con señoríos jurisdiccionales (basados en el diezmo, pagos por la jurisdicción como la quistia, en algunos casos monopolios, así como el escaso patrimonio del titular jurisdiccional consistente en una unidad de explotación — casa-)..$^{14}$ Pero el ascenso social (y formación de la gran propiedad) tenía su contrapartida: la herencia universal indivisa permitía el mantenimiento de la mayor parte del patrimonio a través del tiempo sucediéndose los herederos en su dirección, pero no dejaba al resto de hijos sin herencia, buscándose diferentes mecanismos de reubicación social de éstos con unos altos costes para el patrimonio, ya fuera para la dotación de las hijas, ya para dar oficio o beneficio a los hijos. Por ello, la mayor parte de la actividad prestamista de los grandes patrimonios era destinada a colocar a los no herederos, llegando a erosionar paulatinamente el patrimonio familiar, en especial a partir de la reducción del tipo de interés en 1750, generándose unos considerables costes de reproducción generacional y social. ${ }^{15}$

El método de gestión generalizado consistía en la explotación directa (con mozos y jornaleros) del patrimonio principal, el arriendo de la segunda y siguientes unidades de explotación (casas), el establecimiento enfitéutico de las parcelas periféricas y el arriendo mediante subasta de las rentas señoriales y pagos fijos (censos, diezmos, quístias, etc.). A este nivel patrimonial (la fase de consolidación de la gran propiedad) no se usa de la

13 Un ejemplo claro al respecto es el papel que juega Jacinto Orteu, de la Pobla de Segur, administrador del marqués de Sentmenat en la Valvasoría de Toralla, que a mediados del siglo XVIII acaba comprando a dicho marqués la mayor parte de sus jurisdicciones y sus escasos bienes raíces patrimoniales en ese señorío.

14 Facilitado por el gran dinamismo del mercado de señoríos jurisdiccionales en el marco pirenaico. La adquisición de señoríos proporcionaba nuevas rentas, pero también diferentes franquicias en muchos casos anheladas por las grandes casas locales. A corte de ejemplo, en 1783 Francisco de Sangenís y Pocurull, señor de Blancafort, vendió el señorío jurisdiccional del término de Escarlà a Josep Castells y a Miquel Capdevila, payeses de Mur y Claret, respectivamente. En 1791 Miquel Capdevila reconoció que no había satisfecho ninguna cantidad en dicha operación, renunciando a todas las rentas y señalando que su actuación «solamente se entendiese á favor mio en quanto al goce de la jurisdiccion de dicho lugar [...] para gozar assí la exempcion, y demas prerrogativas concedidas á tales señores jurisdiccionales» (Archivo Notarial de Tremp, libro 578, f. 49v, libro 580, f. 43v, y libro 661, f. 130).

15 Al respecto, Bonales (2003) y Mirabet (1989). 
figura del administrador, sino que el propietario lo gestiona directamente u opta por el uso de procuradores para el arriendo en subasta de los derechos señoriales y censos fijos: en este modelo los costes de información sobre precios son ínfimos, ya que controlan gran parte de la producción y del dinero y, a través de su capacidad de negociación con la universitat, también, en parte, los precios de los factores. En lo que se refiere al arriendo de las explotaciones secundarias, el coste de información y negociación es mínimo, ya que se hereda el primero y se mantiene estable el segundo durante diversas generaciones: ${ }^{16}$ la información procede de los ascendientes (negociación heredada) y los aparceros se suceden en la explotación durante diversas generaciones en un pacto de mutua confianza en el que, sin duda alguna, el agente merma rentas, pero donde se anulan los costes de información y negociación por parte del principal para cambiar de agente. Finalmente, en el arriendo de rentas señoriales y censos, el principal negocia en subasta las rentas según las condiciones del mercado, y se asegura el mantenimiento del statu quo de éstas (prohibiendo cualquier innovación). A cambio, el agente se obliga a soportar los costes de negociación y vigilancia frente a la universitat, habitualmente mediante el subarriendo a un agente local. Este sistema provoca una merma de derechos de propiedad que quedará patente con las reformas liberales al dividirse, en cuanto a los censos se refiere, el censo pagado respecto al bien sometido a censo, especialmente allí donde la universitat ha conseguido con el tiempo el privilegio de que sea el batlle (doble agente del señor y de la comunidad rural) el que recaude las rentas locales y las entregue al agente del principal (colector) o arrendatario.

La última fase de la gran propiedad pirenaica moderna constituye un nuevo nivel de ascenso social con emigración a los centros de decisión regional o el encuadramiento en el aparato administrativo (político o judicial) estatal. En un primer momento se mantiene la estructura de relaciones anterior mediante la contratación de un administrador-procurador (a menudo también asesor jurisdiccional) elegido de entre los principales comerciantes comarcales. Éste gestiona el gran patrimonio siguiendo las líneas generales

16 Especialmente en las zonas más alejadas de la explotación principal, donde se usa esta práctica o la enfiteusis. En caso de escasa demanda de tierras a censo o en aparcería, los costes de información del principal se elevan, igual que el riesgo asumido por éste, pero es un mal menor, comparado con la posibilidad de dejar el patrimonio sin explotar. 
anteriores, sin producir cambios en los métodos de explotación y cesión de los bienes, y satisfaciendo las rentas al principal. Pero pronto el principal varía su política patrimonial y se inicia un doble proceso de establecimiento de bienes a censo (reduciendo por lo tanto los costes de información y negociación, y limitando la función del administrador a la mera percepción de las rentas) y de venta paulatina del patrimonio. ${ }^{17} \mathrm{En}$ ambos procesos el agente participa como intermediario, siendo fundamental su actuación en cuanto posee la información necesaria. Sin duda el agente actuará más en su propio favor (no son empleados únicos de los propietarios, sino comerciantes y propietarios), y de este grupo surgirán los nuevos grandes propietarios de los siglos XIX y XX, tanto por su participación en la propiedad como a través del crédito y el control del mercado de productos. ${ }^{18}$

\section{Gran propiedad y reformas liberales}

Las diferentes reformas liberales suponían un grave cambio institucional que, en el Pirineo, significaba una ruptura radical de las normas formales e informales y de sus mecanismos de imposición. Por eso mismo, dichas reformas no se ejecutaron sistemáticamente, sino de forma paulatina, adaptándose a las realidades sociales y económicas locales (lo que denominaríamos cointegración de instituciones).

La universitat era sin duda alguna la peor parada de la aplicación sistemática de la reforma liberal: perdía su capacidad jurídica, la propiedad de sus bienes (que pasaban a ser públicos, protegidos o desamortizables), la capacidad de crear normas y, sobre todo, de imponerlas. La ley, además,

$17 \mathrm{Al}$ respecto existen muchos ejemplos en los protocolos notariales; así, en $1788 \mathrm{D}$. Ignasi de Castells y de Casanovas, natural de Tremp y residente en Barcelona, establece diversas parcelas "por lo poch cuidado y mala cultura dels arrendataris que ha cultivat la avall nomenada pessa de terra á parts de fruÿts de alguns anÿs á esta part, está y se troba en molt mal estát, y mitg herma, de modo que casi no reditúa fruÿts alguns, y que en vista de estas circunstancias, algunas personas noticiosas de ellas, é intelligents en estas cosas, han aconsellát á dit noble Señor mon Principal, serli molt mes util y convenient per si, y per sos successors, lo vendre, ó establir dita Pessa de Terra, ó per enter, ó dividida en diferents pedazos, ó porcions ab imposició de alguns censos irredimibles en fruyts, ó diner» (Archivo Notarial de Tremp, libro 659, folio 62).

18 Un ejemplo podría ser el del agente Miquel Utrillo, que expondremos enseguida. 
favorecía la conversión del proindiviso de tipo germánico en un proindiviso de cuotas de participación (de tipo romano), y por lo tanto divisible y susceptible de reparto entre los titulares en las sociedades vecinales formadas para mantener los bienes. ${ }^{19}$ Todo ello abría las puertas a una dinamización del individualismo patrimonial en el nuevo marco institucional. Evidentemente, la propiedad individual tendrá ahora un reconocimiento jurídico a través del asentamiento en el registro de la propiedad, con lo que se pierde definitivamente el antiguo carácter comunal de la mayor parte de las parcelas, pero no se genera un asalto a los comunales con explotación no individualizada, tanto por los altos costes de negociación con todos los antiguos principales-agentes, como por los altísimos costes políticos en una zona claramente violenta durante todo el XIX. Así, de nuevo primará la norma sobre la ley, manteniéndose las negociaciones que facilitan la adaptación de todos los ámbitos al nuevo marco institucional, incluidos los mecanismos de imposición, y que toma forma con el mantenimiento de hecho de los comunales, el control de la gestión de éstos y la capacidad de generación de normas con nuevos mecanismos de imposición básicos a nivel municipal. ${ }^{20}$

Centrándonos en las grandes propiedades, éstas se vieron también fuertemente afectadas por las reformas liberales. La pérdida de los derechos jurisdiccionales y de la participación en los diezmos pudo ser indemnizada, pero estos señores no pudieron invertir en tierras en la zona dado el escaso (en la mayoría de los lugares, nulo) peso patrimonial de la Iglesia y la fortaleza de las universitats, lo que supuso un incremento de la participación señorial en inversiones en bienes raíces fuera del Pirineo. ${ }^{21}$ En lo

19 Sobre la formación, características y funcionamiento de las asociaciones vecinales, ver Bonales (1999), especialmente pp. 121-129.

20 Bonales (2003).

21 Un ejemplo al respecto es la venta de los bienes de los herederos del barón de Claret. Sus apoderados señalan en 1844 «Que en atención á ser de absoluta necesidad y suma conveniencia á sus señores Principales el reunir la cantidad de seis mil Duros para cubrir algunas deudas y acudir á obligaciones muy precisas y urgentes que pesan sobre su patrimonio, y serles de otra parte muy ventajoso el imbertir una cantidad de dinero en compra de papel moneda para la adquisicion en Navarra (donde tienen su residencia) de bienes Nacionales que les redituarán mas de un cuadruplo de lo que importan los Patrimoniales en igual cantidad, y no teniendo dinero ni siéndoles posible por trastornos, perdidas y desgracias considerables que sufrió el señor Marques de Valle Santoro y Baron de Claret difunto y su señora viuda é hijo [...]», y venden todo el patrimonio sito en el Prepirineo leridano (Archivo Notarial de Tremp, libro 907, f. 170 y ss.). 
que se refiere al mantenimiento de la propiedad, ésta se consolidó con bajos costes de transacción (con excepciones allí donde la negociación entre universitat y gran propiedad se encontraba fuertemente polarizada), ${ }^{22}$ pero se perdió el monopolio de los bienes de transformación, debiendo mantener unos altos costes de negociación (económica y política) ante unas universitats ilegales, pero efectivas a través de las nuevas formas jurídicas de sociedades vecinales o del control de los colectivos sobre los ayuntamientos. En todo caso, los grandes propietarios no llevaron a cabo una gran privatización (por individualización) de comunales que fuera más allá de la posesión de bienes anterior.

Finalmente, los mecanismos de reproducción generacional (biológica, bajo aspectos de recolocación social de los componentes de la familia) sufrieron una trascendental modificación en tanto que desaparecieron o se modificaron sustancialmente las instituciones y organizaciones anteriores: la Iglesia perdió peso social efectivo, y sobre todo económico (con la nacionalización de los créditos que subvencionaban a los beneficios eclesiásticos, que fueron redimidos en su mayor parte a partir de 1855), difícil de reconstruir dado el cambio de la figura del censal por otras formas de crédito, con la consecuente pérdida del control del mercado de capitales local y comarcal.

Todas estas transformaciones hacían que la gran propiedad pirenaica reaccionara de forma diferenciada según cada caso, pero con unos problemas idénticos que se centraban en la reproducción social familiar. Tres soluciones de continuidad se dan en las estrategias patrimoniales y de gestión: la modernización y diversificación de los ingresos, el mantenimiento del carácter agrícola y la consolidación o ampliación de la propiedad bajo premisas de Antiguo Régimen, y finalmente el absentismo por reubicación social y económica en los centros de decisión regional.

\subsection{Modernización y diversificación de los ingresos}

Algunos propietarios optaron por vías de crecimiento económico o simple incremento de rentas a través de cambios profundos en la estructura o gestión patrimonial. En todos los casos se da una actuación directa

22 Como veremos más abajo en el ejemplo de los barones de Abella. 
del propietario en la negociación, configuración, dirección y control del proceso de renovación. El papel del administrador es reducido (al menos en el núcleo principal del patrimonio), ya que los propietarios se implican directamente en la contratación y negociación al intentar aplicar su pensamiento económico de desarrollo. Tres aspectos marcan el final de esta iniciativa: la reacción de las universitats, que hacen duras las negociaciones y que logran moderar la actuación de los grandes propietarios (tanto en España como en Andorra); el alto precio político de esta actuación (en un ambiente procarlista); y los problemas seculares de reproducción biológica (carencia de sucesión, división del patrimonio, etc.). Destacan dentro de este modelo el barón de Abella, el barón de Senaller (Areny-Plandolit) y la casa Rossell de Ordino (Andorra).

El ejemplo más claro de las difíciles relaciones entre gran propiedad y comunidad rural nos lo ofrece la evolución de la familia del barón de Abella. ${ }^{23}$ Originaria del Valle de Arán, donde formó una pequeña fortuna gracias al comercio y al crédito facilitados por el ejercicio del cargo público de gobernador, ${ }^{24}$ a principios del siglo XVIII consolidó su ascenso social a través de la compra de baronías. Una rama familiar adquirió a la Corona la baronía de Altrón y Vall d’Àssua, en el Alto Pirineo, ${ }^{25}$ mientras que la rama principal compró la baronía de Abella, compuesta por la jurisdicción, la participación en el diezmo y el monopolio del molino harinero de la villa de Abella y una explotación agropecuaria en Sant Romà d'Abella que será explotada directamente mediante trabajo asalariado. ${ }^{26}$

23 Una exposición más detallada, en Bonales (2003); la base documental se encuentra en diversos archivos: Archivo Notarial de Tremp, protocolos diversos; Archivo Histórico Provincial de Huesca, fondo Archivos Familiares, Bardají; Arxiu Històric Comarcal de Manresa, protocolos diversos; Archivo de la Corona de Aragón, Real Audiencia y Real Patrimonio, causas diversas; así como en el libro de Abad de Subirà (1842).

24 Sobre los orígenes de los barones de Abella y su pasado turbio en el Valle de Arán, donde se les acusó de numerosos delitos y faltas mediante las cuales formarían su fortuna, ver Poujade (1998).

25 Venta de la Corona a principios del siglo XVIII a Josep de Subirà y de Julià. En 1706 toma posesión y, siguiendo con el protocolo del país, jura los privilegios, costumbres y franquicias escritos y no escritos de los individuos y universidades del valle.

26 La compra se da en 1695 y es carta de gracia (es decir, con pacto de retroventa), y finalmente como venta perpetua en 1700, a Isabel Meca de Cardona, Guimerà y Abella, sumando toda la venta el precio de 44700 libras catalanas (Archivo de la Corona de Aragón, Real Audiencia, Procesos Civiles, 6979). 
La lucha entre la comunidad y los barones no tardaría en mostrarse en los tribunales, ya fuera por la reclamación señorial sobre el diezmo primero, ya por el control y propiedad de los molinos y hornos y su carácter de monopolio con privativa. El punto culminante del conflicto se registró en el último tercio del siglo XVIII, cuando el barón consiguió sentencia favorable en la Real Audiencia de Cataluña, que le reconocía como propietario único del despoblado de Carreu, de algo más de 8000 hectáreas. ${ }^{27}$ Los vecinos perdieron el uso comunal de dicho despoblado y se vieron obligados a pagar individualmente los «daños» por cultivo en dicho término en los últimos 20 años, lo que provocó un fuerte endeudamiento y la pérdida a favor del barón del dominio directo de diversos patrimonios, sin olvidar el pago que la universitat de la baronía (los pueblos de Sant Romà d'Abella, Abella de la Conca y Bóixols) debieron satisfacer por los costes procesales. Pero el triunfo de los barones no dejó desarmadas a las comunidades, ya que supuso el impulso definitivo para la formación de una mancomunidad o agermanament, con instituciones político-administrativas propias que regulaban los recursos colectivos ahora comunes a todos los pueblos e iniciaron un proceso en los tribunales para la reincorporación de la baronía a la Corona, que no llegó a finalizar. ${ }^{28}$

A finales del siglo XVIII, la situación de hecho cambia considerablemente. Dentro de las líneas generales del gran patrimonio pirenaico, los barones de Abella siguen una política matrimonial de anexión que les llevará a trasladarse a Graus, dejando por lo tanto la administración directa de la baronía para gestionarla a través de procuradores, con una evolución de la renta relativamente positiva en los últimos años del siglo XVIII y principios del XIX gracias a la explotación maderera y de pastos del despobla-

27 Archivo de la Corona de Aragón, Real Audiencia, Procesos Civiles, 6979. La superficie, según el propio propietario en 1892 (Archivo Notarial de Tremp, libro 192, f. 207).

28 Hermanamiento de defensa colectiva en 1760 (Archivo Notarial de Tremp, libro 63, f. 92); convenio de imposición de bando entre los pueblos de la baronía en 1767 (ibídem, libro 77, f. 69); convenio o concordia para el uso de los comunales de forma indivisa entre todos los pueblos de la baronía y establecimiento de normas de aprovechamiento colectivas en 1774 (ibídem, libro 77, f. 144v). El pleito de reincorporación a la Corona, en Archivo de la Corona de Aragón, Real Patrimonio, Bailía, Procesos Modernos, 1819-9-B (RP.1207). 
do de Carreu. ${ }^{29}$ En este periodo los vecinos parecen conquistar de hecho lo que de derecho perdieron en el periodo anterior a través del uso común sobre Carreu (ahora fraudulento), fundamentalmente de los pastos.

La primera mitad del siglo XIX, la que más nos interesa, presenta un clima totalmente diferente, beneficioso en este caso para las comunidades rurales. A principios de siglo, la muerte del barón en Graus sin descendencia lleva a que la viuda se instale en Sant Romà d'Abella y dirija directamente la explotación, pero se vio envuelta en un conjunto de litigios por la sucesión, ya del hermano del difunto, ya de los herederos de los antiguos señores del siglo XVII, que reclamaban la vinculación por fideicomiso testamentario. Ganada la baronía por el hermano del difunto, residente en Cardona (Barcelona), el absentismo del titular y el continuado conflicto bélico en el Pirineo llevó a la conquista definitiva, de hecho, de los pastos del despoblado de Carreu por parte de los vecinos. Todo ello cambió cuando la heredera de los barones de Abella se casó con José Calasanz de Abad, destacado liberal, miembro de la Sociedad Económica de Amigos del País de Reus y fundador y presidente de las de Tremp y la Pobla de Segur. Cuando éste tomó las riendas de la administración de la baronía, inició un ambicioso proyecto de desarrollo económico que se basaba en la colonización de Carreu mediante establecimientos enfitéuticos con un control rígido de los sistemas de cultivo y de la interrelación entre agricultura y ganado; la industrialización de productos forestales a través de la explotación racional con replantación del bosque de Carreu, la instalación y participación en sociedades de serrerías y tornerías para la elaboración de manufacturas en madera; la creación de un embalse en Abella de la Conca que pusiera en regadío gran parte de la tierra de la Conca Dellà, bajo pago de un canon del 10\% de la producción que sustituiría al diezmo señorial perdido, regadío que impulsaría diversas industrias textiles que se instalarían en Abella de la Conca; y finalmente el establecimiento de diversas tiendas que ofrecerían innovaciones tecnológicas, simientes y otros productos para abastecer a la comarca. Todo ello estaría gestionado por un administrador y un grupo de

29 A diferencia de lo que ocurre en otros señoríos, la baronía de Abella no acusa una grave caída de la renta, como muestra el valor en libras catalanas de los arriendos del periodo: 1780-1785: 3215 libras; 1786-1788: 3200 libras; 1789-1794: 3400 libras; 1797-1802: 5250 libras; 1802-1804: 4700 libras (de 1804 a 1812, administración directa); 18131814: 1300 libras (posteriormente sin datos); y 1824-1827: 3600 libras (Archivo Notarial de Tremp, Protocolos, libros diversos). 
celadores, y supervisado por el propietario, que residiría largas temporadas cada año en Sant Romà d'Abella. Este plan de desarrollo necesitó de una dura negociación del barón de Abella con los vecinos, que vieron perder de nuevo los usos sobre Carreu al hacerse efectiva la colonización en 1829, y finalmente se vio truncado: la industria de manufacturas madereras no tendrá la solvencia esperada, debiendo el propietario empeñar las rentas de esta especie en 1848; en 1843 los barones se vieron obligados a renegociar el colonato de Carreu, ya que los colonos se unieron en universitat y consiguieron la libertad de cultivos y usos y el cambio del sistema de pago de rentas por un censo colectivo anual fijo en moneda. Finalmente, la construcción del embalse, la puesta en regadío, la instalación de fábricas textiles y las tiendas de novedades agropecuarias no llegaron a hacerse realidad por la muerte del barón, en 1849, fusilado a manos de una partida carlista.

La muerte del barón supone la muerte del proyecto; los nuevos titulares no introducirán novedades en la explotación, arrendando de nuevo las rentas mediante procurador, limitándose la explotación forestal a la extracción maderera con destino a Barcelona mediante contratas de larga duración, y abandonándose paulatinamente la explotación agropecuaria en Carreu. Por el contrario, la Revolución liberal dará alas a las comunidades rurales, que se harán de nuevo de hecho con el uso del monte hasta el punto de reclamar la propiedad, negando a los barones la posibilidad de inscribir el monte en el amillaramiento y yendo de nuevo a juicio por la titularidad. Fragmentado el patrimonio familiar y enajenada parte de él, finalmente en 1881 los tribunales confirmarán la propiedad de Carreu a favor del nuevo titular.

La modernización de la explotación bajo premisas de desarrollo económico local no implica que el titular del patrimonio destaque por su pensamiento liberal. Ejemplo de ello es la propuesta de la familia Areny-Plandolit de Andorra, ${ }^{30}$ al combinar un proyecto de terciarización del principado sobre la base del ocio con una postura claramente partidista en pro del carlismo. ${ }^{31}$

30 Los documentos con que trabajamos proceden del Arxiu Històric Nacional d'Andorra, fondo Casa Areny-Plandolit y fondo Xavier d'Areny-Plandolit, así como de las obras de Albert i Corp (1987) y López, Peruga y Tudel (1988).

31 Josep d'Areny fue partidario de la insurrección carlista de 1833, motivo por el cual sus bienes en España fueron confiscados hasta 1843; postura también defendida por sus hermanos Benet, Llorenç y Pere, que participaron activamente. Por otra parte, Guillem d'ArenyPlandolit destacó en la política pirenaica española, presentándose como candidato carlista por la circunscripción de la Seo de Urgel (López, Peruga y Tudel, 1988), pp. 336-344. 
Casa Guillemareny de Ordino (Andorra) experimentó un importante proceso de concentración patrimonial ya en el siglo XVII, con base en los beneficios de la producción siderúrgica, el comercio transpirenaico y fundamentalmente el crédito en el seno de los valles de Andorra, llegando a convertirse en el principal patrimonio territorial andorrano. Dicho proceso se mantuvo en el siglo XVIII y la primera mitad del siglo XIX, llegando a consolidar unidades de explotación agropecuaria en Andorra, en la provincia de Lérida (Noves de Segre, Mas d'en Gras de Pujol), en la de Barcelona (Mas de Targarona, Torelló) y en la Cerdaña francesa (Mas Blanc de Bourg-Madame), además de diferentes parcelas y edificios en la Seo de Urgel y las pertenecientes a la baronía de Senaller (en la Vall Fosca de Lérida), ${ }^{32}$ sin olvidarnos de las fraguas de Ordino, de la participación asociada en la de Moles (Farga de Moles) y la propiedad de los molinos de Espui y Mont-rós.

Este patrimonio era gestionado de forma mixta entre el control directo por parte del propietario (las heredades de Andorra, Bourg-Madame y durante una temporada la de Noves de Segre, articulando el crédito y el comercio transpirenaico), el uso de procuras que recaían en familiares (los bienes y censos enfitéuticos de la baronía de Senaller y Gramanet) y el uso de un administrador para la lejana heredad del Mas de Targarona. En ambos casos, procurador y administrador también se ocupaban de ceder capital en forma de créditos en nombre del principal. Posteriormente instaló también un administrador en Noves de Segre, siendo controlada su actuación y la de los jornaleros mediante una intensa relación con la comunidad eclesiástica de dicha población, que periódicamente emitía informes al propietario (ver cuadro 1). ${ }^{33}$

En la persona de Guillem d'Areny-Plandolit el patrimonio de la casa Guillemareny (en el siglo XIX, ya casa de Dom Guillem) llega a su máximo esplendor. En el marco andorrano alcanzó la plenitud del poder político con el cargo de sindic general d'Andorra, desde el cual intentó, asociado con capital francés, instalar en Andorra casinos y balnearios, si bien finalmente

32 Con parcelas en Pobleta de Bellveí, Paüls, Mont-rós, Gramanet, Moviera, Molins, Espui, Pobellà y Torre de Cabdella.

33 A través de la correspondencia sabemos de la emisión de informes por parte de un eclesiástico con el que posiblemente la familia tiene una relación de patronato, aunque hasta el momento no hemos podido contrastarla. 


\section{CUADRO 1}

\section{ESTRUCTURA DE LA ADMINISTRACIÓN DEL PATRIMONIO DE CASA ARENY-PLANDOLIT}

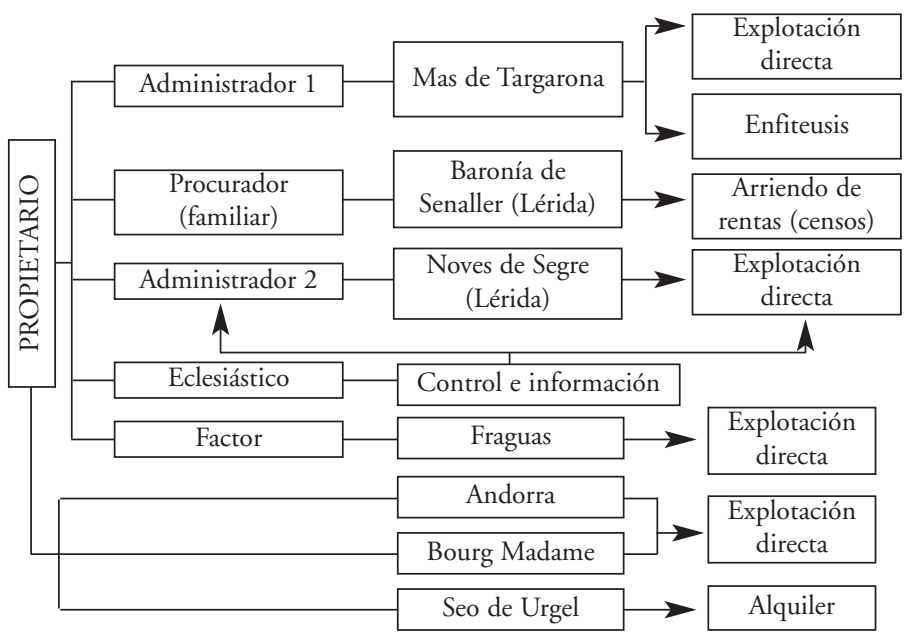

FUENTES: Arxiu Històric Nacional d'Andorra, fondos Casa Areny-Plandolit y Xavier d'Areny-Plandolit. Elaboración propia.

se vio derrotado por los sectores comunitarios más conservadores del principado, viéndose finalmente apartado del juego político. ${ }^{34}$ Su muerte supuso la desmembración del patrimonio familiar, al disponer en su testamento el reparto de los bienes familiares a partes iguales entre sus hijos. ${ }^{35}$

34 La cuestión de las concesiones de juego centró el panorama político andorrano en la segunda mitad del siglo XIX; al respecto, ver López, Peruga y Tudel (1988).

35 Tras diversas vicisitudes patrimoniales provocadas por las dotes y legítimas de los miembros de la familia, que a mediados de siglo llevaron a litigios y convenios (1842, 1846, 1848, 1849 y 1868), el testamento de Guillem d'Areny-Plandolit, datado en 1875, provocó la desmembración del patrimonio. Casado dos veces, dejó a los 9 hijos de su segundo matrimonio, a partes iguales, los bienes y rentas del Mas de Targarona, en Torelló, así como la heredad de la Seo de Urgel; a su viuda, diversas propiedades en Ordino (Andorra); y el resto de bienes los divide a partes iguales entre todos los hijos del primer y segundo matrimonios (13 hijos vivos en total), excepto una hija. La herencia será discutida por todos y llevada a juicio. El resultado final será el de la venta total del patrimonio, si bien uno de los hijos intentó unificarlo sin éxito, llegando a vender él mismo las propiedades recuperadas. 


\subsection{Mantenimiento del carácter agrícola y consolidación o ampliación de la propiedad bajo premisas de Antiguo Régimen}

Es la vía de solución menos utilizada; en ella se da un control directo del patrimonio por parte del propietario mediante la combinación de contratos económicos y el control político local y comarcal. Usan puntualmente de apoderados, pero gestionan directamente el patrimonio mediante la explotación directa de parte de él, manteniendo la enfiteusis (y el cobro de censos y laudemios) y arrendando parte del patrimonio bajo contratos basados en la confianza (sucesión de los aparceros durante varias generaciones). Tienden a la erosión del patrimonio por ventas y al fin biológico de los propietarios (la línea directa de sucesión).

Ejemplo claro de este grupo es casa Sullà de Tremp, barones de Sapeira y señores de El Meüll. Su origen como «grandes» propietarios ha de buscarse en el siglo XVI, e irán incrementando su patrimonio hasta finales del siglo XVIII. El patrimonio se caracteriza por el control directo de toda la heredad, excepto del Mas de Querol, situado en Gerona; ${ }^{36}$ un control factible por la cercanía de las diferentes unidades de explotación entre sí: así, se dio una explotación directa de la heredad de Tremp y Talarn y de la heredad de El Meüll hasta 1820, el arriendo en aparcería de la masía de la Vall de Llimiana (y la de Tremp desde 1820) y el establecimiento en enfiteusis de las parcelas de Suterranya, El Meüll, algunas de Tremp y Talarn y de la heredad de Sapeira, aunque con problemas en esta última para mantener a los colonos. ${ }^{37}$ A lo largo del siglo XIX quedan patentes los problemas con que se debate este patrimonio: por un lado, los costes para la consolidación de la propiedad (y, en algunos casos, la conquista sin derecho) ante unas

36 El Mas de Querol, sito en Dosquers, estaba gestionado a través de un beneficio eclesiástico: la familia Sullà arrendaba en aparcería bajo el pago de un tercio de los frutos, y éstos se satisfacían al beneficio eclesiástico de San Agustín y del Santo Sepulcro de la colegiata de Sant Feliu de Gerona, beneficio del que dicha familia era patrona y que concedían siempre a uno de los hijos no herederos. Asimismo, parte de los frutos iban destinados a una beca en el colegio de «Sobre Portas» de Gerona. Al respecto, Archivo Notarial de Tremp, libro 713, f. 114, libro 992, f. 39v, y libro 1008, f. 169.

37 Incluso cuando se dan establecimientos sobre el conjunto de la heredad de Sapeira (tierras, edificios y molino harinero), se producen abandonos bajo la declaración de «inútiles y dañosos»: por ejemplo, Archivo Notarial de Tremp, libro 999, f. 81. 
comunidades rurales que controlan el poder municipal; 38 y, por otro lado, los problemas financieros que provoca desde 1856 la progresiva venta de parcelas y de toda la heredad de El Meüll. La actitud de los propietarios, fundamentalmente en la segunda mitad del siglo, sigue las líneas anteriores en cuanto al patrimonio y su gestión, al tiempo que políticamente consiguen obtener una gran cuota de control político comarcal. ${ }^{39}$ La familia tendrá su fin biológico (en cuanto a línea directa) durante la Segunda República, siendo partido el patrimonio entre diversos herederos.

\subsection{Absentismo por reubicación social y económica}

Constituye una mezcla entre la emigración tradicional y las nuevas estrategias de disposición de la inversión, en las que el cambio generacional de la titularidad tiene una gran trascendencia. Las vías de actuación siguen dos líneas generales: la venta paulatina o en bloque de todo el patrimonio situado en los Pirineos (por ejemplo, el barón de Claret) o la contratación de un administrador para la gestión del patrimonio (cedido a terceros), tan sólo ocupándose el propietario de obtener las rentas (por ejemplo, el barón de Eroles). En este último caso, la labor del gestor tiene un papel diferenciado en dos periodos. En un primer momento, su papel es básico en la consolidación de la propiedad, intentando recuperar dominios directos y conquistar (con mayor o menor éxito) nuevas propiedades al pretender identificar el pago de la quistia jurisdiccional con el censo enfitéutico. En la segunda fase, los agentes basan su actuación en el cobro de las rentas (en moneda o participando en el mercado con las rentas en especie) y, funda-

$38 \mathrm{Al}$ respecto, la familia Sullà pudo consolidar la propiedad de la heredad principal de Sapeira (pero no el pretendido dominio directo de todo el término), el dominio directo de parcelas en Suterranya y la propiedad plena en Tremp y Talarn. Para El Meüll, la conquista de la propiedad, arrancando de gran parte de los habitantes el reconocimiento de su carácter de enfiteutas, provocó un efecto adverso, al acelerar de forma significativa el proceso de emigración rural: diversas explotaciones no pudieron hacer frente al pago de los censos atrasados y abandonaron la explotación y el pueblo. Cuando la situación llegó a niveles importantes de despoblación, la familia Sullà vendió el patrimonio. Sobre este aspecto, ver Bonales (2003), pp. 419-424.

39 A nivel político, queda claro el papel predominante de la familia Sullà en la comarca, como cabezas del carlismo y posteriormente del integrismo, especialmente tras el matrimonio de la heredera de Sullà con Luis de Cuenca y Pessino, cabeza del integrismo catalán. Diputados a Cortes (1871), diputados provinciales y, entre otros, fundadores del Sindicato Agrícola de la Conca de Tremp. 
mentalmente, buscando la colocación óptima de los bienes del propietario en el mercado, donde sin duda el agente maximiza sus intereses personales (económicos y sociales) frente a los intereses del principal.

Tras la Guerra de la Independencia, en que el titular destacó como capitán general del Ejército del Principado de Cataluña, y tras los primeros escarceos como realista acérrimo, la familia del barón de Eroles se instaló en Madrid al tiempo que obtuvo el título de marqués de la Cañada. ${ }^{40}$ Desde su nueva residencia gestionó su patrimonio ${ }^{41}$ mediante la contratación de administradores con diferentes funciones según el periodo en el que se ocupasen. Así, el primer administrador del que tenemos noticia es Miquel Utrillo, agente de negocios y procurador natural de Azanuy (Huesca) y residente en Tremp, que ejerció entre 1833 y aproximadamente 1850. Su función, al margen de cobrar las rentas (arriendos y censos), se basó en la consolidación de la propiedad a través de la realización de inventarios y la investigación en el archivo familiar y en las notarías comarcales. ${ }^{42}$ En torno a 1850 tomó el relevo en la administración Francisco Laboria, vecino natural de Tremp (hacendado, comerciante y prestamista), con el que se inicia un continuado problema por el control no tanto de la propiedad, sino de la propia gestión; así, en 1857 el administrador debe dimitir de sus funciones, traspasando al principal algunos créditos hipotecarios a su favor, para saldar las cuentas y terminar con las reclamaciones de éste. ${ }^{43}$ Entre 1860 y 1887 administra el patrimonio José Antonio Mir, natural y habitante de Tremp (abogado y prestamista, hijo de Bonifacio Mir, que había estado asociado con Miquel Utrillo). En este periodo destaca la pérdida de parte de la propiedad (por la prescripción de censos enfi-

40 Información básica extraída del Archivo Notarial de Tremp, protocolos diversos, y Arxiu Nacional de Catalunya, Fondo Familia Seix, código 96.

41 La baronía de Eroles consistía en derechos jurisdiccionales en Alsamora, Eroles y Sant Adrià, la propiedad del término despoblado de Montllobar, el dominio directo de la masía llamada La Vileta, el dominio útil del molino harinero de Aramunt y una explotación agropecuaria situada en Talarn, donde tenían su residencia antes de trasladarse a Madrid.

42 Listados que se encuentran en Arxiu Nacional de Catalunya, Fondo Familia Seix, código 96, caja 1. Destaca en ellos la asimilación de las quístias jurisdiccionales a los censos enfiéuticos, pagos que no se pudieron recuperar por no haberse cobrado desde 1808 como mínimo.

43 Archivo Notarial de Tremp, libro 825, f. 151. 
téuticos) y la gestión de la explotación directa de la heredad principal de Talarn. Este cambio de actitud, pasando del arriendo a la explotación directa, no supuso un cambio en los problemas administrativos, ya que la administración acabó con un juicio por las cuentas de la explotación directa y el cambio de administrador. ${ }^{44}$ Tomando la administración Ignacio Seix Cerqueda, abogado natural de Vilamitjana y vecino de Tremp, entre 1888 y 1906, se acaban los problemas de administración (o bien el principal no reclama en ningún momento sobre las cuentas), que se mantiene en la explotación directa y el comercio de productos, siguiendo siempre el administrador las órdenes directas de compra o venta de productos agropecuarios que por correo le enviaba el principal. ${ }^{45}$ Finalmente, entre 1906 y 1921 administra la heredad Francisco Ferrer, de Tremp, que sigue las líneas básicas de su antecesor y recibe el encargo del principal de buscar el mejor negocio posible en la venta del patrimonio.

\section{La relación de agencia y la venta de los patrimonios}

De todas las anteriores consideraciones y ejemplos se puede desprender que la gran propiedad absentista pirenaica, con administradores, no era especialmente deseada. Durante el periodo de control directo (gestión y explotación) por parte del principal (aunque poseyera agentes ya para la explotación directa, ya como intermediarios puntuales), el principal poseía una amplia información tanto de los precios (por participación directa en los diferentes mercados) como del funcionamiento de las instituciones, articulándolos todos ellos a través de la negociación económica, política y social en su propio beneficio dentro del marco institucional dado (y del que forma parte activa en su configuración). La emigración o reubicación social, en un proceso de ascenso social, debía dar las riendas del patrimonio a un agente administrador que debía negociar continuadamente con las universitats, hacer de puente entre ley y norma y mantener las redes de contactos políticos, sociales y económicos: en resumen, gestionar el patrimonio y mantener las redes con participación activa. Para ello debía poseer la información adecuada (en todos los aspectos), pero la posesión de

44 Arxiu Nacional de Catalunya, Fondo Familia Seix, código 96, cajas 2 y 3.

45 Ibídem, caja 3. 
información no es aleatoria, sino que se da por la participación (con ciertos grados de control), mediante redes de contactos y crédito, en el mercado de productos y factores. Así, los agentes podían ser meros administradores (contratados para mantener los mecanismos de extracción de renta) o miembros activos de la red (no sólo "contratados», sino propietarios, comerciantes, etc.) que proporcionarían información aprovechando e incrementando las redes. En ambos casos el agente saldrá beneficiado de su función de administrador más allá del salario, pero en el primer caso (mero administrador) el agente no posee información a priori, sino que la percibe del principal, siendo negativo para el interés de éste en cuanto a la articulación de redes (conllevaría estancamiento y pérdida de control efectivo a nivel comarcal), por lo que se tendería al segundo (administrador miembro activo a priori en el mercado), que a su vez aprovechará la función de agente para explotar al máximo sus oportunidades.

Todo ello desembocaría en la tendencia a la venta o cesión del patrimonio por parte del principal y la reinversión en áreas donde no se daba un control comunitario sobre los factores y donde había más oferta de mano de obra. No en vano, al igual que este gran patrimonio en sus orígenes se aprovechó de su papel de gestión y administración de los patrimonios de los siglos XIV-XVI, los agentes de los grandes patrimonios del siglo XIX formarán a su vez grandes propiedades en la segunda mitad de ese siglo y principios del XX.

Un ejemplo claro del uso de la información en beneficio propio del agente nos la muestra el ejercicio de la administración por Miquel Utrillo. Originario de Azanuy (Huesca), se trasladó a Tremp para llevar las riendas del patrimonio de los barones de Eroles. La elección de este personaje como administrador no debió de ser en ningún caso gratuita, dados los mismos orígenes de parte de la familia de los barones. ${ }^{46}$ Asimismo, los estrechos lazos comerciales entre la zona y el Pirineo por el comercio del aceite, y la información que al respecto debía de tener el agente, debieron de contribuir a su elección.

46 A finales del siglo XVIII, José de Ibáñez y de Borrell, barón de Eroles, estaba casado con María Ana Valonga Tarín, natural de Azanuy. Desconocemos si los barones tenían bienes raíces en la zona, pero es posible que así sea, ya que posteriormente se documentan (de forma indirecta) propiedades en Monzón. 
En ningún momento los principales debieron de tener problemas con el administrador, que realizó un completo inventario de los bienes y derechos de la familia dentro y fuera de la baronía durante algunos siglos, consiguiendo incluso identificar pagos jurisdiccionales de quistias con censos enfitéuticos, si bien ya imposibles de cobrar tras más de treinta años de impagos. Al margen de la simple gestión patrimonial, la diferente documentación sobre este personaje deja claro que jugó en su interés propio, ya que, además de como administrador, ejerció como procurador y agente de negocios, llegando a ser el principal prestamista comarcal en el periodo 1840-1860, haciéndose con un patrimonio relativamente importante a través de las ejecuciones de créditos y la acumulación de dominios directos. ${ }^{47}$

El máximo exponente de su política de aprovechamiento de redes sociales y económicas y de su papel de administrador queda patente en la formación de una sociedad de alcance comarcal destinada a la compra de baronías, es decir, de los derechos señoriales no abolidos que se pusieron a la venta por los señores absentistas en las décadas de 1840 y $1850 .{ }^{48}$

$\mathrm{Al}$ igual que otros patrimonios de origen comercial y crediticio del siglo XIX, el patrimonio de Miquel Utrillo no tuvo continuidad en el

47 Miquel Utrillo se convirtió en el principal prestamista de Tremp en el periodo comprendido entre 1820 y 1867; según el vaciado sistemático de protocolos notariales, concedió un mínimo de 159 préstamos, que ascendían a un mínimo de 63664,3 libras catalanas, préstamos que se destinaban tanto a pequeños propietarios como a grandes patrimonios; así, por ejemplo, por las deudas contraídas el barón de Abella cedió en 1848 a Miquel Utrillo las rentas generadas por la explotación forestal de Carreu y por la heredad de Sant Romà d'Abella (Archivo Notarial de Tremp, libro 908, f. 81v). Algunos créditos, además, desembocaron en ejecuciones que tomaron forma con la cesión del dominio directo por parte del propietario a favor de Miquel Utrillo, convirtiéndose los primeros en enfiteutas. Esta actividad le facilitó además participar en el mercado de tierras, documentándose un mínimo de 52 compras por valor de 20 122,3 libras en forma de ventas perpetuas, y de 17 con pacto de retroventa, que ascendían a 6787,7 libras.

48 Ya entre 1844 y 1845 se asociaron Miquel Utrillo, Bonifacio Mir, abogado de Tremp, y Miquel Mir, comerciante de Tremp, para comprar todos los bienes, censos y réditos de los barones de Claret en la comarca y en el resto del Pirineo de Lérida (Archivo Notarial de Tremp, libro 907, f. 170 y ss., y libro 911, f. 410 y ss.). Posteriormente, en 1862 formó sociedad con Domingo Gallart, propietario de Tremp, para la compra de bienes, censos y réditos de los duques de Híjar en el prebostato de Mur, baronía de Orcau y baronía de Estac (Archivo Notarial de Tremp, libro 918, f. 35 y ss., y f. 165 y ss.). Finalmente se asoció con Antonio Feu y Juan Orrit, propietarios de Tremp y Vilamitjana, para la compra de los bienes del fideicomiso de Rosa de Macià en Vilamitjana (Archivo Notarial de Tremp, libro 924, f. 707 y ss.). 
tiempo, ya que el hijo heredero, Miquel, después de viajar por Europa, se instaló en Barcelona y vendió todo el patrimonio pirenaico heredado de su padre. ${ }^{49}$

En el caso andorrano hemos de hablar de excepción en la fuga de capitales, si bien en los siglos XIX y XX también hay inversiones en el exterior. Esta excepción es debida a que la gran propiedad (la surgida en los siglos XVII-XIX o la propia del XX) mantiene la negociación con la universitat $\mathrm{y}$, mediante el control de ésta, consigue una construcción del Estado a su medida, es decir, partiendo del poder de las comunidades rurales hacia el Estado, con lo que obtiene beneficios y franquicias directas (por ejemplo, la carencia de fiscalidad directa sobre los tres pilares básicos en que se asienta el gran patrimonio: propiedad, comercio y crédito). En este caso, la gran propiedad moderna (siglos XVIII-XIX) en gran parte morirá de éxito (ejemplo claro es la casa Rossell de Ordino, cuyos bienes pasaron por defunción al Consell General al desconocerse algún heredero), facilitando nuevos procesos de concentración patrimonial en el siglo XX.

La comparación de los ejemplos de Andorra y Lérida, en cuanto a la evolución de la gran propiedad, nos proporciona nuevos elementos de valoración respecto al binomio derechos de propiedad-Estado o, si se prefiere, a la intervención del Estado en la organización de la agricultura y en los mercados de factores y productos y sus efectos en la gran propiedad y su gestión. Las reformas liberales españolas pudieron tender a una mayor especialización productiva y a la construcción de unos mercados más eficientes que posibilitaran un crecimiento de la productividad, pero los efectos de las políticas estatales sobre el territorio (es decir, el impacto de éstas sobre los diferentes sistemas agrarios) fueron claramente diversos. Así, mientras que en Andorra — que quedó al margen de las políticas españolas, excepto en cuestiones arancelarias - la gran propiedad construyó un Estado a su medida facilitando su permanencia y reproducción, en el resto del Pirineo leridano se produjo una doble periferización: por un lado, res-

49 Con una clara orientación cultural y artística, Miquel Utrillo hijo, antes de instalarse en Barcelona, estuvo residiendo en París, desde donde enviaba artículos culturales al periódico El País de Lérida (por ejemplo, el número 3365 del 22 de mayo de 1890, sección «Revista de París»). Una vez instalado en Barcelona, vendió los bienes heredados en los Pirineos, siendo escriturados algunos de ellos en la notaría de Tremp. 
pecto al centro de decisión política, ante la necesidad de los propietarios de adaptar su realidad económica, social y política a unas transformaciones dadas por un Estado lejano que a menudo imponía normas contrarias a las necesidades y realidades locales; un Estado del que, además, perdió en gran parte el control de su articulación espacial a nivel comarcal y regional (perdiendo los propietarios pirenaicos, por lo tanto, capacidad de negociación). Y, por otro lado, la periferización respecto a Barcelona y su área industrial y comercial, que haría converger la tradicional atracción social y de capitales con la nueva inversión en unos sectores más lucrativos y con menores incertidumbres y costes de transacción.

\section{Conclusión}

En el análisis de las transformaciones de las formas de gestión de la gran propiedad pirenaica y de sus costes de transacción y negociación político-económica en el tránsito del Antiguo Régimen al liberalismo, la teoría de los costes de agencia debe relativizarse. Es cierto que permite comprender mejor los procesos que afectan a la microeconomía, pero no debe obviarse el sistema agrario en que se enmarca la explotación. Así, en el Pirineo catalán debemos situar las relaciones de agencia dentro de un sistema agrario en el que las reglas del juego económico son continuamente negociadas por los diferentes componentes de la sociedad, pero también del juego político y del rol social; de dichas negociaciones sociales dependía el óptimo - por eficaz - funcionamiento de la gestión de los patrimonios, pero también — como hemos podido ver - la propia integridad física de unos propietarios que se movieron entre la innovación y modernización de las explotaciones, el mantenimiento de los sistemas tradicionales, la emigración a los centros de decisión económica y política y la venta de la herencia familiar.

\section{Fuentes}

Archivo de la Corona de Aragón, Fondo Real Audiencia, Pleitos civiles, diversos procesos. Fondo Real Patrimonio, Batllia, procesos modernos, diversos procesos.

Archivo Histórico Provincial de Huesca, Fondo Archivos Familiares, Bardají. 
Arxiu Històric Comarcal de Manresa, Fondo Protocolos Notariales. Fondo Contaduría de Hipotecas.

Arxiu Històric Comarcal de Tremp, Fondo Protocolos Notariales del Arxiu Notarial de Tremp. Libros diversos.

Arxiu Històric Nacional d'Andorra, Fondo Casa Areny-Plandolit, Fondo Xavier d'Areny-Plandolit, Fondo Rosell.

Arxiu Nacional de Catalunya, Fondo Familia Seix, código 96, cajas 1 a 3. 



\section{ADMINISTRACIÓN Y RENTAS DEL PATRIMONIO RÚSTICO DEL ESTADO DE BORNOS, 1814-1924*

\author{
Javier Moreno Lázaro \\ (Universidad de Valladolid)
}

\section{Introducción}

A fecha de hoy, las condiciones de explotación de los bienes raíces de la nobleza española y la propia evolución de su patrimonio rústico a lo largo de las dos últimas centurias constituyen un enigma historiográfico. Es sabido que la reforma liberal mantuvo y perfeccionó sus propiedades; pero ignoramos lo que hicieron con ellas desde 1836 en adelante. Tan sólo diversos trabajos han arrojado alguna luz sobre lo sucedido a comienzos del siglo XX, mientras que lo acaecido en la segunda mitad del XIX nos es por completo desconocido, con las únicas excepciones de las casas de Osuna y Alcañices. ${ }^{1}$

* Este trabajo ha sido realizado en mi condición de integrante del proyecto de investigación "Gestión de grandes patrimonios y reforma agraria en España», dirigido por Ricardo Robledo y financiado por la DGICYT. Al propio Ricardo Robledo y a Emilio Pérez Romero debo agudas observaciones que enriquecieron este texto. Quiero manifestar mi profunda gratitud al personal de la sección «Nobleza» del Archivo Histórico Nacional, con sede en Toledo (en adelante, AHNN), por las facilidades y ayudas prestadas en la documentación de este trabajo, y muy especialmente a David López.

1 Atienza y Mata (1986), en el caso del duque de Osuna, y Carmona (1995) y (2001), en el del marqués de Alcañices. 
Este trabajo aspira a arrojar alguna luz sobre el particular. A tal efecto, he considerado los bienes que conformaban el estado de Bornos. En la persona de su titular en 1834, Manuel Ramírez de Haro, tres veces grande de España, convergieron varios de los linajes de prosapia de la nobleza española, de la que era uno de los miembros más acaudalados y reputados por su olfato mercantil.

La extensión de su estado justifica plenamente su elección en este capítulo. Pero hay otras singularidades de la familia que acrecientan su interés. La primera de ellas es la propia trayectoria vital de sus miembros, más truculenta que las historias por entregas publicadas por la prensa madrileña de la época. La segunda descansa en la particular relación con la propiedad de la tierra de los miembros de la saga. Y finalmente, llama la atención el mayor contacto con el mercado que a esta familia le proporcionó el beneficio de su cabaña trashumante, materializado en unas condiciones de gestión de sus bienes raíces, a priori, poco habituales en la nobleza hispana.

Pero mi interés no se limita al análisis de la explotación de ese patrimonio y a la reconstrucción de sus agregados contables. Pretendo ir más allá y obtener alguna información que permita medir los cambios en la distribución del ingreso y en la retribución de los factores en la España rural.

En otras palabras, propongo en estas páginas un recorrido por la historia agraria de España a lo largo del siglo XIX y el primer cuarto del XX desde la perspectiva de una casa nobiliaria cuyas propiedades se extendían por toda la Península.

He de precisar, no obstante, que me limito a examinar y evaluar la gestión y resultados del patrimonio rústico familiar. Obvia este trabajo el peso en los ingresos totales de sus negocios pastoriles, del arrendamiento de sus inmuebles y de la gestión de sus fábricas.

En la confección de este relato me he servido de los fondos del estado de Bornos, custodiado en la sección "Nobleza» del Archivo Histórico Nacional, con sede en Toledo, y de la documentación impresa generada por los pleitos sucesorios a que tuvo que enfrentarse la familia.

Desde 1915, entre estos fondos apenas se encuentra un puñado de expedientes relativos a las últimas fincas no enajenadas, por lo que mis referencias sobre lo sucedido entre ese año y el de 1924 son forzosamente escuetas y poco concluyentes. 


\section{Los instrumentos de análisis}

No resulta fácil calcular la extensión del patrimonio rústico del esta$d o$, algo que ni siquiera los propios condes fueron capaces de hacer. Con todo, se puede cifrar, en estimación moderada, en 1854 en 22000 hectáreas, distribuidas, en su mayor parte, en las provincias de la antigua corona de Castilla (mapa 1). ${ }^{2}$ Las tierras de pan llevar en Castilla y León y las dehesas en las provincias de Toledo y Ciudad Real, donde pastaban sus merinas, sumaban dos tercios de sus bienes raíces. El resto lo conformaban, grosso modo, sus viñedos en Valladolid y La Rioja y los olivares de Navarra y Andalucía. Como tendré ocasión de relatar en estas páginas, este patrimonio no sólo no mermó desde entonces, sino que los titulares

\section{MAPA 1}

DISTRIBUCIÓN DE LAS PROPIEDADES RÚSTICAS DEL ESTADO DE BORNOS, MURILLO, VILLARIEZO Y VILLANUEVA DE DUERO

(en porcentaje de su valor tasado en 1854)
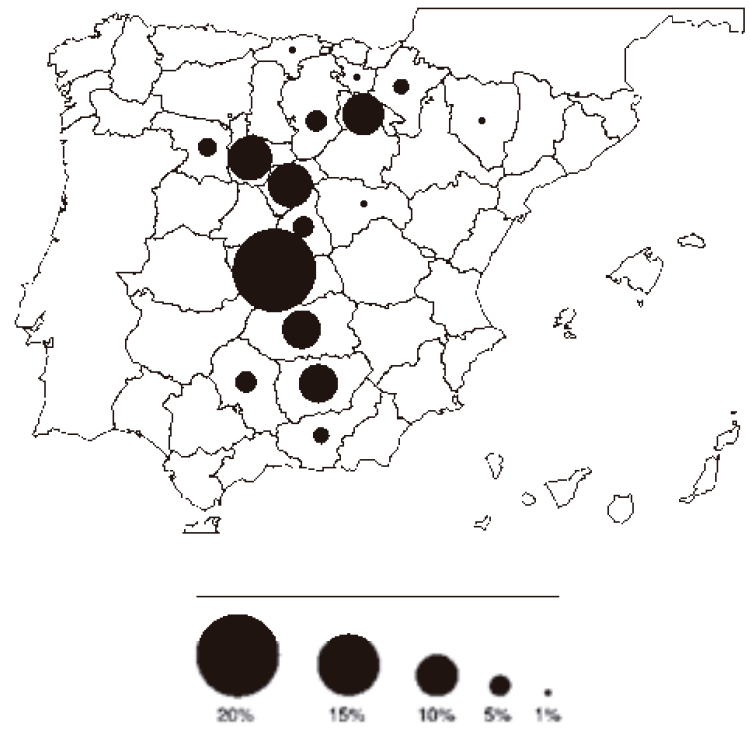

2 He realizado este cálculo atendiendo a la superficie y valor de las fincas legadas a su mujer por el XI conde de Bornos en 1854, que sí fueron medidas. 
del estado incrementaron sus propiedades hasta 1915, en que se procedió a su liquidación.

Todavía más compleja resulta la reconstrucción de agregados estimativos de la renta de la tierra y de los resultados de explotación del patrimonio rústico, debido a la pérdida de los informes de algunos administradores durante los procesos judiciales ocasionados por el reparto de los legados de los condes y los criterios, muy singulares y mutables, empleados en la contabilización de los ingresos y gastos del estado. En la práctica, no dispongo de información completa y continua para ninguna de las administraciones a lo largo del periodo de estudio.

Ello me ha obligado a construir tres índices indicativos de la trayectoria de los negocios del estado, que, en mi criterio, constituyen la mayor aportación cuantitativa de este trabajo.

El primero de ellos es el índice de beneficios líquidos (gráfico 1). En la confección de este estadístico he empleado la contabilidad de una selec-

\section{GRÁFICO 1}

ÍNDICE DE BENEFICIOS LÍQUIDOS EN TÉRMINOS REALES

DE LA ADMINISTRACIÓN DE LOS ESTADOS DE BORNOS, 1800-1914

(números índices media 1900-1909 = 100 y medias móviles quinquenales)

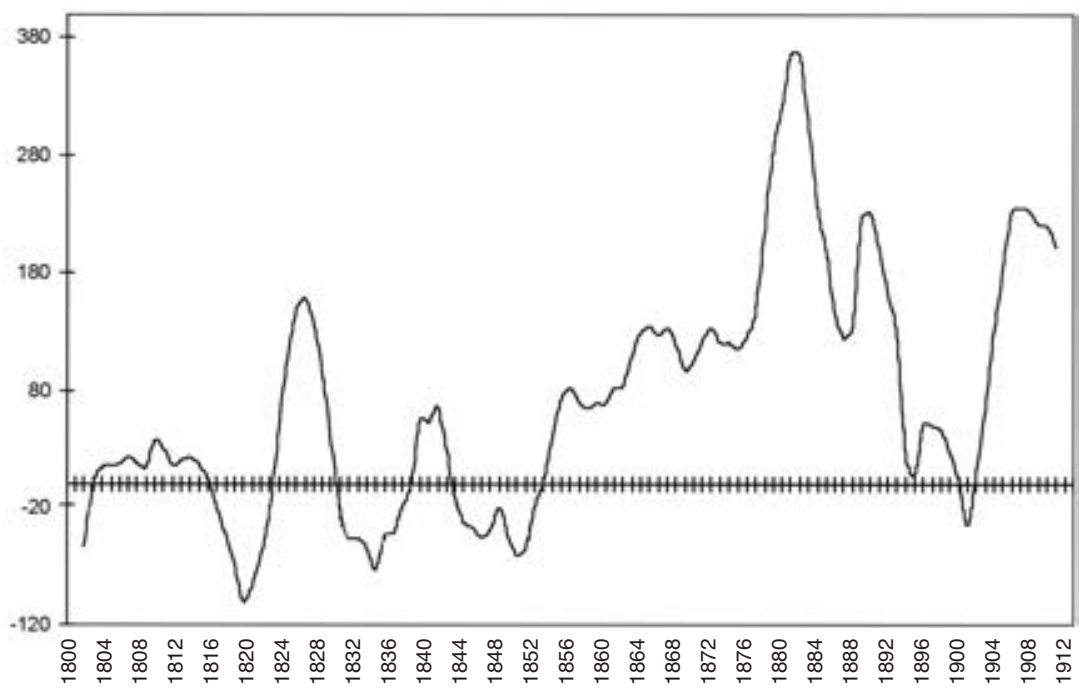

FUENTE: AHNN, Bornos, Cuentas de los administradores. 
ción de administraciones compuesta por las de Medina del Campo, Tordesillas, Villanueva de Duero y Torrelobatón (Valladolid); Tomilloso y Talavera (Toledo), Segovia, Guadalajara, Cintruénigo (Navarra), Jaén, Burgos y Zamora. Los beneficios de cada una de estas administraciones han sido ponderados con arreglo al valor de los bienes raíces atribuido en 1854. La serie ha sido deflactada con el índice de Moreno (2006), a falta de un deflactor implícito de PIB que cubriese todo el periodo. ${ }^{3}$

En un segundo término, he elaborado un índice de la renta percibida (no la escriturada) por las tierras de pan llevar en Castilla y León (gráfico 2). En su valoración he empleado los precios del trigo y de la cebada en Palencia a fin de facilitar las comparaciones con otros índices calculados para esta ciudad.

\section{GRÁFICO 2}

RENTA REAL DE LA TIERRA PERCIBIDA POR LOS CONDES

DE BORNOS EN CASTILLA Y LEÓN, 1800-1924

(índices media 1900-1909 = 100 y medias móviles quinquenales)

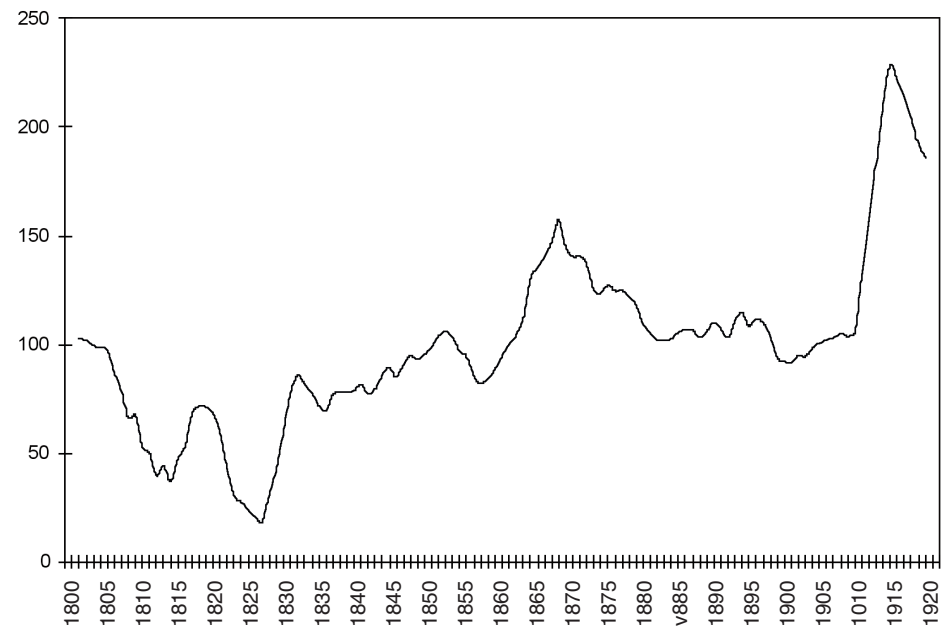

FUENTE: AHNN, Bornos, Cuentas de las administraciones de Burgos, Zamora, Torrelobatón, Medina del Campo, Tordesillas, Tudela de Duero, Villanueva de Duero y Segovia, y Moreno (2006).

3 Los resultados son bastante congruentes con los obtenidos por Lana (2002) en un estudio muy similar al que aquí presento para un pequeño patrimonio nobiliario de Navarra. 
GRÁFICO 3

RENTABILIDAD DE LAS VENTAS DE LAS EXPLOTACIONES RÚSTICAS EN CASTILLA Y LEÓN, 1800-1924

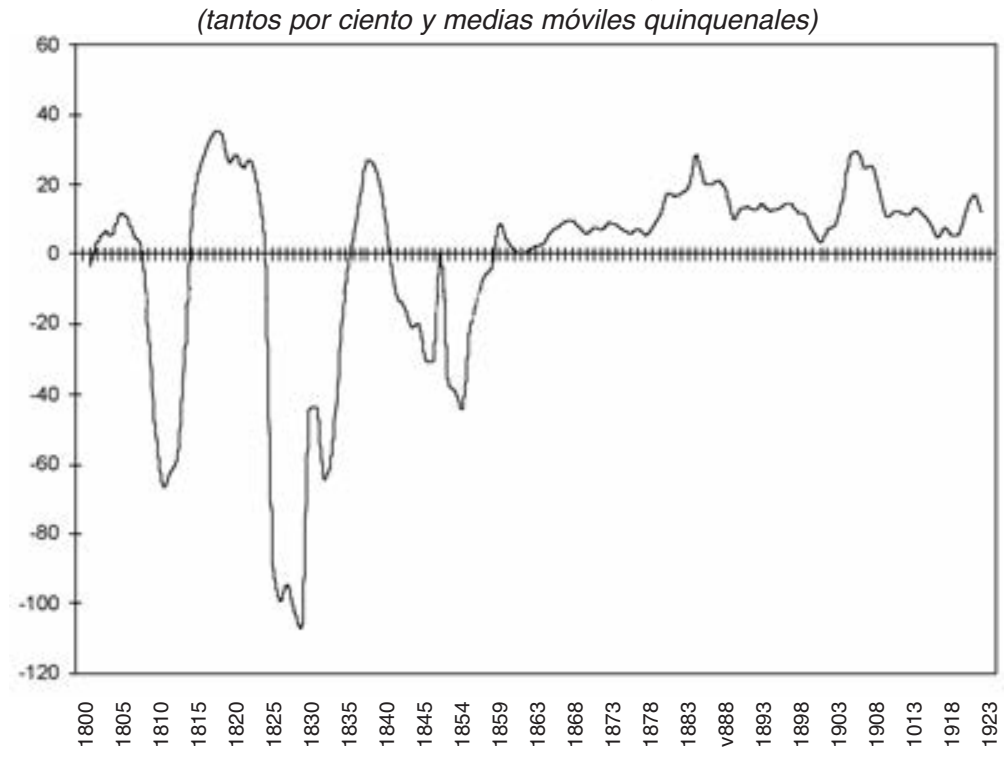

FUENTE: AHNN, Bornos, Cuentas de las administraciones de Castilla y León.

Los datos deben ser considerados con extraordinaria cautela a partir de 1915, en tanto que sólo computan los resultados de las fincas de Burgos. Pero entiendo que, por su cobertura geográfica y la naturaleza de las fuentes empleadas, el índice tiene un valor singular. No en balde, se trata del primero de estas características elaborado para la cuenca del Duero en este periodo.

Para reforzar este indicador propongo un último estadístico, también circunscrito a las propiedades condales en el territorio castellano y leonés. Se trata de la rentabilidad de las ventas, esto es, la razón porcentual entre los beneficios y los ingresos brutos de explotación (gráfico 3).

\section{Los apuros de comienzos de siglo (1814-1825)}

En 1814 José Ramírez de Haro, X conde de Bornos y de Murillo, título concedido en 1644 por Felipe IV a Diego Ramírez de Haro, heredero del secretario de Isabel la Católica, casó con Asunción de Belvis y Monca- 
da, hija única de los marqueses de Duero y condes de Villariezo, Montenuevo, Villaverde y Peñas Rubias. ${ }^{4}$

La marquesa viuda de Villanueva de Duero cedió las responsabilidades de gestión de su patrimonio a su yerno. Al conde competió desde entonces explotar una cabaña de merinas compuesta por las 46000 cabezas que sumaban la de Rojas y Contreras (fundada en 1763), propia del marquesado de Villanueva de Duero, y la de Bornos. ${ }^{5}$ Ambas familias disponían de un vasto patrimonio inmobiliario en Madrid. A cargo de José Ramírez de Haro quedó también la explotación de un ingenio azucarero en Granada y de unas salinas en Córdoba.

En el momento del enlace matrimonial, las finanzas de ambos estados, el de Bornos y el de Duero, padecían un total abatimiento. La caída de las rentas inmediata a la crisis de subsistencias de 1803-1804 había mermado considerablemente el alcance obtenido por el beneficio de sus predios rústicos (gráficos 1 y 2). Los ingresos brutos declarados en las administraciones del marquesado de Duero evidencian la intensidad del declive (cuadro 1).

Las minutas e informes enviados por los administradores castellanos, azotada la región por la carestía y el hambre, eran desoladores. Durante esos años, muchas de las fincas de Valladolid y otras provincias de la Meseta permanecieron incultas. ${ }^{6}$ Los ingresos obtenidos en Zamora en términos nominales se dividieron por 15 . El panorama en Andalucía era todavía más sombrío, a juzgar por los noticias que recibía el conde desde Jaén.

La situación se agravó durante los años de la ocupación francesa (gráfico 3), por culpa de las incautaciones practicadas por las tropas invasoras, el descenso de la renta y, al menos hasta 1812, el encarecimiento de los salarios (gráfico 4).

La mejoría de los ingresos inmediata al fin del conflicto, acompañada de una moderación de los jornales agrícolas, resultó pasajera (gráfico 4). El conde no pudo restablecer las comunicaciones con sus representantes, que obraban sin dirección alguna. De algunos de ellos se carecía de noticias desde hacía ocho años (cuadro 2). Y lo que era peor, el abatimiento de los precios del grano mermó extraordinariamente los ingresos de la casa.

4 Las referencias biográficas que siguen han sido obtenidas, salvo otra indicación, de AHNN, Bornos, cajas 505/5, 121 y 399, y Bugallal (1917).

5 Noticias (1878).

6 AHNN, Bornos, 189/3. 
CUADRO 1

INGRESOS BRUTOS PERCIBIDOS EN LAS ADMINISTRACIONES DEL MARQUESADO DE VILLANUEVA DE DUERO 1795-1826 (en reales de vellón corrientes)

\begin{tabular}{|l|r|r|r|}
\hline Administración & 1795 & 1807 & 1826 \\
\hline Burgos & 34000 & 30000 & 20000 \\
Ávila & 31000 & 24000 & 16000 \\
Arévalo & 49655 & 30000 & 20000 \\
Olmedo & 15000 & 33000 & 16000 \\
Sepúlveda & n.d. & n.d. & 2000 \\
Jaén & 13324 & n.d. & 13000 \\
Tordesillas & 10000 & n.d. & 3000 \\
Guadalajara, & & & 2000 \\
Zamora y Aranda & 3000 & 2000 & \\
\hline
\end{tabular}

FUENTE: AHNN, Bornos, 292. NOTA: n.d.= no hay datos.

CUADRO 2

ALCANCE OBTENIDO EN LOS ESTADOS DE VILLANUEVA DE DUERO $Y$ VILLARIEZO EN CADA UNA DE LAS ADMINISTRACIONES, 1815

(en reales de vellón)

\begin{tabular}{|l|r|r|}
\hline Administración & Año $\left(^{*}\right)$ & Alcance \\
\hline Burgos & 1815 & -13244 \\
Toledo & 1814 & 6389 \\
Talavera & 1815 & 20039 \\
Ávila & 1815 & 6902 \\
Zamora & 1815 & 536 \\
Olmedo & 1815 & 2580 \\
Arévalo & 1809 & -35763 \\
Sepúlveda & 1815 & 200 \\
Aranda & 1816 & -86 \\
Marchamalo & 1813 & -83 \\
Miajadas & 1809 & 1207 \\
Madrid (casas) & 1815 & 14679 \\
Segovia & 1814 & 1152 \\
Jaén & 1814 & 2711 \\
Loja & 1814 & 501 \\
Guadalajara & 1815 & 0 \\
Tordesillas & 1815 & 1261 \\
Pueblanueva & 1815 & 10089 \\
Talavera & 1815 & 2081 \\
\hline
\end{tabular}

FUENTE: AHNN, Bornos, 121/1, y elaboración propia. 
GRÁFICO 4

RENTA DE LA TIERRA EN CASTILLA Y LEÓN

Y JORNALES AGRÍCOLES EN PALENCIA, 1800-1858

(en términos reales y números índices media 1840-1944 =100)

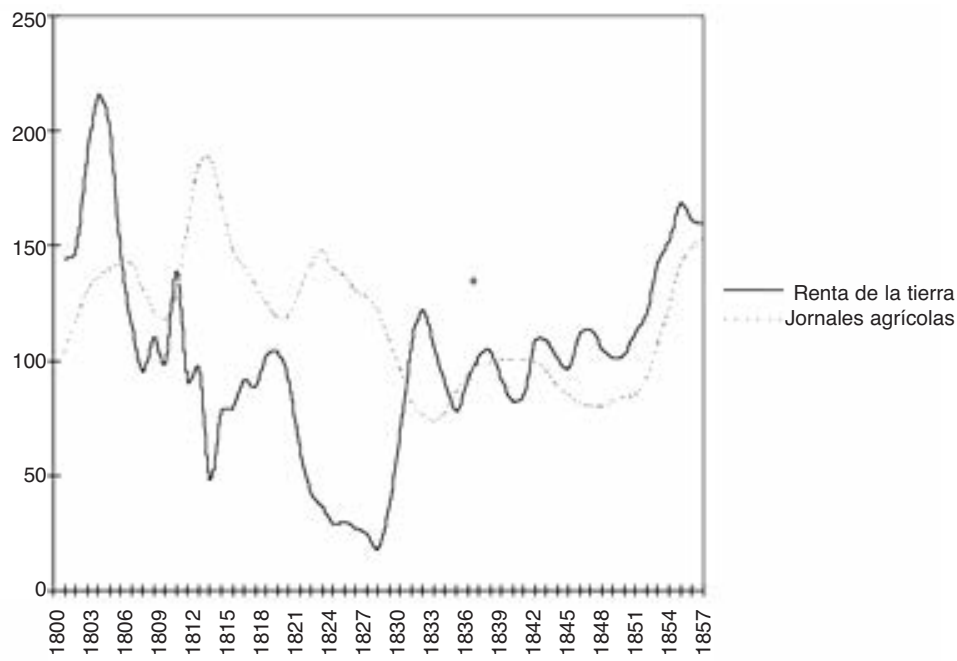

FUENTE: Las mismas del gráfico 2 y Moreno (2006).

En 1821 Ramírez de Haro dispuso un incremento de la renta de todas sus fincas, persuadido por la prohibición de la entrada de trigos foráneos decretada un año antes. ${ }^{7}$ Pero tanto esta disposición como el incremento de los derechos arancelarios devengados por la introducción de harinas extranjeras en la isla de Cuba en 1824 no tuvieron en el corto plazo el impacto esperado en el comercio exterior de granos, por lo que el valor en renta de la tierra se desplomó (gráfico 2). Para colmo de males, los costes laborales se mostraron mucho más inflexibles a la baja (gráfico 4).

La situación era también alarmante en los negocios pastoriles. Desde 1821 en adelante, la lana se depreció y en 1826 se acumulaban ya unas pérdidas en la administración de las cabañas de 687062 reales de vellón. ${ }^{8}$ En palabras de la marquesa de Villanueva de Duero,

7 AHNN, Bornos, 121/2.

8 AHNN, Bornos, 292. Sobre los apuros en esos años de otros nobles propietarios de cabañas, véase García Sanz (1978) y (1983), pp. 269-279. 
Cuando después de la Guerra de la Independencia se vio las quiebras de las rentas por los motivos que son tan notorios, no fue tan sensible la minoración de sus productos porque felizmente la casa tenía otros con que atender y cubrir sus obligaciones. Esto es, las lanas y carnes de sus cabañas finas y leonesas lograban precios y estimación; pero diferentes accidentes reunidos hicieron desaparecer desde 1821 estas ventajas que proporcionaban la venta de dichos artículos, particularmente la lana. ${ }^{9}$

Así las cosas, en 1825 la amenaza de la ruina se cernía sobre los Bornos (gráfico 1).

\section{Los primeros paliativos, 1826-1846}

El conde habría podido, como hicieron otros nobles, desprenderse de parte de su patrimonio y evitar males mayores..$^{10}$ Pero debido a una anacrónica concepción de la propiedad de la tierra, que consideraba indisociable de su linaje y títulos, y a su propio rechazo a la normativa liberal, el $\mathrm{X}$ conde de Bornos evitó vender una sola finca por ruinosa que fuese su explotación y apuradas que estuviesen sus finanzas.

En 1826 el conde desoyó los consejos de sus administradores y asesores, que le conminaban a vender para salvar la ruina de la familia con estos argumentos:

[...] yo no trato de vender [...] Sólo quiero sacar de las fincas el producto de que sean susceptibles. Y usted, en esa y las demás administraciones, procure con los medios justos sacar el mayor partido, haciendo nuevos arriendos cuando cumplan los pendientes con alguna ventaja en aquellos. ${ }^{11}$

Descartadas las ventas, Ramírez de Haro no tuvo más alternativa que racionalizar la explotación de su estado. En marzo de 1826 redactó personalmente un nuevo "régimen de administración» y un «reglamento de economías»

debido al actual estado de abatimiento en que, por desgracia, se hallan constituidas nuestras casas por la considerable minoración y decadencia de las rentas de muchos años a esta parte, emanada de las vicisitudes de los tiempos más fatales. ${ }^{12}$

9 AHNN, Bornos, 121/2.

10 AHNN, Bornos, 141/2.

11 AHNN, Bornos, 833/8.

12 AHNN, Bornos, 121/3. 
El conde nombró a un administrador general, a cuyo cargo estaban sendos responsables de "pagaduría», "mayordomía», "secretaría», "cabañas» y «lavadero» (véase el organigrama que acompaña a estas notas). Los agentes de negocios, procuradores y notarios de la casa, así como los responsables de la casa en Londres y París, despachaban directamente con el administrador o el conde. El responsable de secretaría era el encargado de las comunicaciones con los apoderados en provincias, el recaudador de alquileres en Madrid y el director del Hospital de la Latina. El conde nombró también un administrador general en Valladolid, encargado de supervisar y fiscalizar el trabajo de los representantes en esa provincia, Zamora, Burgos, Logroño, Santander y Segovia. En el resto de las regiones, donde el patrimonio era menos extenso, no existió tal figura. ${ }^{13}$

Los cambios introducidos por el conde se toparon con la resistencia inicial de los administradores, acostumbrados a una enorme discrecionalidad en el ejercicio de sus tareas. El retraso de dos años en la confección de los estadillos que había ordenado elaborar al de Tordesillas, so pretexto de una enfermedad inexistente, enfureció al conde. Tras este incidente, en octubre de 1829 envió a todos ellos una circular de este tenor:

Antes de que este administrador trate de hacer arriendos de fincas, bien sea porque están por cumplirse los que se hallan pendientes o porque se considere que deben hacerse por cuenta de la casa, me lo comunicarán y no procederán a ello sin mi expreso consentimiento. Y obtenido podrán llevarlos a efecto bajo las bases y condiciones que tenga a bien ordenarle, cuidando de remitirme copias simples de las escrituras para gobierno de la contaduría.

Tengo ordenado a todos mis administradores que en los primeros meses de cada año me remitan las cuentas de esas rentas que tengo puestas a su cuidado, lo que servirá a este gobierno para su cumplimiento, sin perjuicio de que todos los meses deben hacer un estado de todas sus existencias de frutos y demás que obran en su poder, con expresión de los precios a que corran aquellos y si presentan aspecto de mejora o viceversa.

La correspondencia respectiva a negocios de dichas administraciones la seguirán conmigo directamente y cuando haya que remesar caudales, lo harán por medio de letras a mi orden, así como los libramientos y abonos que se les expidan serán autorizados con mi firma. ${ }^{14}$

Desde entonces, cada administrador debía mandar dos informes semanales al responsable de secretaría. El subarriendo estaba expresamente

13 AHNN, Bornos, 121/1.

14 AHNN, Bornos, 167/1. 


\section{ORGANIGRAMA DE GESTIÓN \\ DEL ESTADO DE BORNOS. MURILLO, VILLARIEZO \\ $Y$ VILLANUEVA DE DUERO (1826-1854)}

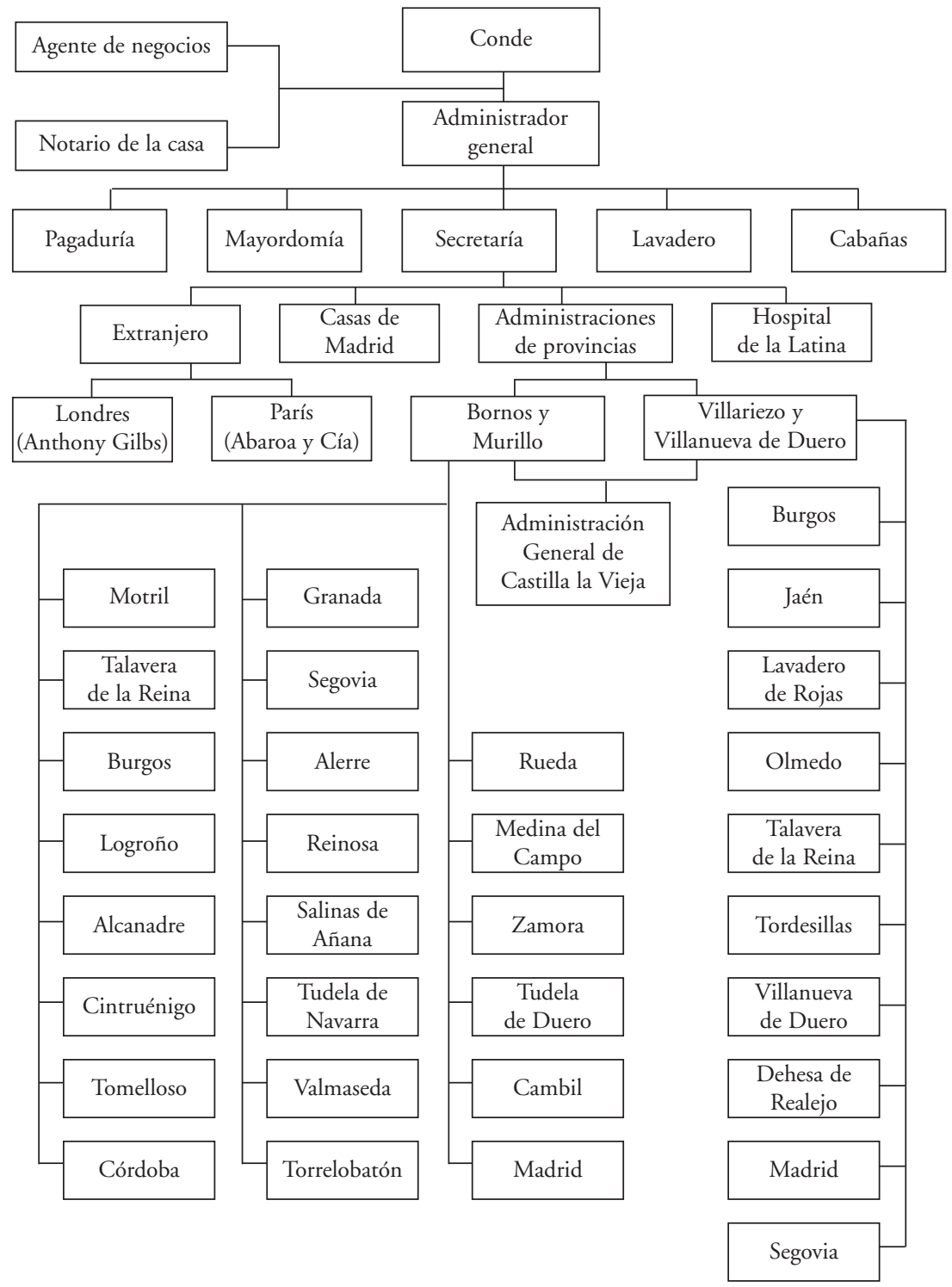


prohibido, para evitar la pérdida de control sobre sus posesiones. Tampoco podía disponer moratorias en el cobro sin la autorización de Madrid. El conde gestionaba personalmente las comunicaciones con alcaldes y autoridades. El administrador debía responder con su patrimonio de los alcances negativos de un ejercicio en tanto no se recaudasen las rentas del próximo. Para garantizar su máxima implicación en el negocio, al margen de sus ingresos era retribuido con un $10 \%$ de los beneficios netos obtenidos.

El conde trató también de incrementar los ingresos percibidos por la venta de los granos recaudados. Todas las rentas de las fincas (salvo de los viñedos) eran percibidas en especie (los olivares eran explotados directamente por la casa). Los granos debían ser recolectados por el administrador en agosto y custodiados en las paneras del conde, hasta que éste, con arreglo a la información recibida semanalmente sobre el precio del trigo y las conducciones, ordenase su venta. Para Ramírez de Haro, muy familiarizado con las transacciones de lana a gran escala, esta mayor participación en el mercado triguero debió de resultarle bastante familiar.

A priori, estas condiciones de gestión, por su complejidad, especialización y delegación de responsabilidades, serían más propias de una empresa que de un estado nobiliario. Pero la realidad era muy otra.

La gestión, inspirada en la administración de la intendencia militar, no se distinguía por su eficacia y racionalidad. Cada una de las cinco dependencias en que estaba dividida trabajaba autónomamente. Ni el conde ni el administrador general tuvieron nunca la noción de dirigir una masa patrimonial común y uniforme, ni se vieron en la necesidad de calcular un estado global de ingresos y gastos. Quiere ello decir que el conde ignoraba las rentas netas que le proporcionaban sus posesiones. Ni siquiera tenía un conocimiento veraz de los beneficios de las cabañas, debido a un sistema contable muy intrincado que no distinguía los gastos de lavadero y pastoreo. Por extraño que parezca, rara vez fueron computados expresamente los ingresos obtenidos por la venta de la lana en Sabadell y Londres.

Con todo, y a corto plazo, el nuevo régimen de administración consiguió resultados muy encomiables (gráfico 1), no tanto por el incremento de los ingresos, cuanto por la reducción del gasto, mediante la eliminación de dispendios suntuarios y de prerrogativas de los mayorales. Mas el conde los dilapidó en costear las campañas de Fernando VII en Cataluña. 
Estos dispendios pasaron factura en el corto plazo. Tras un repunte fugaz y engañoso, las rentas de su estado se desmoronaron desde comienzos de la década de 1830 (gráfico 2 y cuadro 3). ${ }^{15}$ A lo largo de 1832 no se recaudó una sola fanega en Medina del Campo. La cosecha de 1833 se perdió por culpa de la langosta en La Mancha. Un año más tarde, el administrador de Tomilloso (Ciudad Real) informaba al conde:

No puede figurarse V.E. el cuadro tan triste y miserable que hoy presenta este partido y, con él, la mayor parte de la provincia.

Los problemas durante estos años obedecieron al que fue durante el siglo XIX el mayor determinante, desde la perspectiva del mercado de bienes, de la renta de la tierra en la Meseta: las exportaciones de harina (gráfico 6). El intendente de la isla de Cuba, presionado por el empresariado habanero, se negó a aplicar el incremento arancelario a la importación de harinas procedentes de Estados Unidos dispuesto en 1830, lo que ocasionó un descenso de las exportaciones peninsulares y la caída del valor en arrendamiento de la tierra de la que antes daba cuenta. ${ }^{16}$

En circunstancias tan adversas para la casa, en febrero de 1834 falleció el x conde de Bornos. Transcurridos dos años murió su suegra, la marquesa viuda de Duero.

A Asunción Belvis de Moncada competió, por tanto, la unión efectiva de ambos estados, de los que se hizo cargo. En 1836, una vez practicadas las cuentas de testamentaría de su marido y de su madre y concluida la obra legislativa liberal en lo que concernía a la propiedad nobiliaria y a los mayorazgos, la condesa viuda ordenó a los administradores efectuar nuevos apeos y registrar sus fincas. La tarea resultó tan complicada como costosa, debido a la multitud de peritaciones que hubieron de practicarse, a los pleitos con municipios y particulares y a las exigencias burocráticas de unos registros todavía atendidos por la antigua Contaduría de Hipotecas.

Conseguido el objetivo de "perfeccionar» la propiedad de sus posesiones, la condesa abordó el saneamiento de las finanzas de la casa. En abril de 1838 dictó nuevas reformas en su administración, si bien no efectuó

15 Sobre la caída de la renta de la tierra a comienzos de la década de 1830, véase García Sanz (1995).

16 Moreno (1995). 
CUADRO 3

RESULTADOS DE EXPLOTACIÓN DE LAS FINCAS ADSCRITAS

A LA ADMINISTRACIÓN DE TORDESILLAS (EN MEDIAS ANUALES,

REALES DE VELLÓN CORRIENTES Y TANTOS POR CIENTO)

\begin{tabular}{|c|r|r|r|r|}
\hline Periodo & Ingresos & Gastos & Beneficios & $\begin{array}{c}\text { Rentabilidad } \\
\text { de las ventas } \\
(*)\end{array}$ \\
\hline $1800-1809$ & 12281,0 & 7303,0 & 4978,0 & 40,5 \\
$1810-1814$ & 5600,3 & 9085,9 & $-3485,6$ & $-62,2$ \\
$1815-1819$ & 7392,8 & 6429,0 & 963,8 & 13,0 \\
$1820-1824$ & 7336,8 & 5353,4 & 1983,4 & 27,0 \\
$1825-1829$ & 6775,7 & 10104,6 & $-3328,9$ & $-49,1$ \\
$1830-1834$ & 6852,0 & 8439,8 & $-1587,8$ & $-23,2$ \\
$1835-1839$ & 6693,2 & 7076,6 & $-383,4$ & $-5,7$ \\
$1840-1844$ & 7733,2 & 5807,0 & 1926,2 & 24,9 \\
$1845-1849$ & 10366,8 & 10433,6 & $-66,8$ & $-0,6$ \\
$1850-1854$ & 5006,5 & 6977,9 & $-1971,4$ & $-39,4$ \\
$1855-1859$ & 8602,0 & 9278,6 & $-676,6$ & $-7,9$ \\
$1860-1864$ & 10010,8 & 9512,4 & 498,4 & 5,0 \\
$1865-1869$ & 14805,2 & 13276,5 & 1528,7 & 10,3 \\
$1870-1874$ & 12274,6 & 9637,0 & 2637,6 & 21,5 \\
$1875-1879$ & 11294,4 & 9895,4 & 1399,0 & 12,4 \\
$1880-1884$ & 18209,6 & 16213,4 & 1996,2 & 11,0 \\
$1885-1887$ & 15339,7 & 13513,0 & 1826,7 & 11,9 \\
\hline
\end{tabular}

${ }^{*}$ : : Beneficios expresados como porcentaje de los ingresos.

FUENTE: AHNN, Bornos, Cuentas de la administración de Tordesillas.

cambios substanciales en el reglamento de economías y en el organigrama de gestión diseñado por su padre. Estas nuevas providencias no tuvieron en el corto plazo los resultados esperados (gráficos 1 y 2), por culpa de la inflexibilidad a la baja de los gastos.

Concluida la Guerra Carlista en 1841, las finanzas de los Bornos mejoraron sensiblemente (gráfico 1). Pero la situación de holgura no se prolongó por mucho tiempo (gráfico 2). En esta ocasión, los problemas no obedecieron a razones exclusivamente económicas, sino también a conflictos políticos. En 1844 las fincas e inmuebles de los Bornos (incluido su palacio de Villanueva de Duero) en algunos pueblos de Castilla fueron ocupados por jornaleros, azuzados por las nuevas autoridades liberales. ${ }^{17}$

17 AHNN, Bornos, 270. 


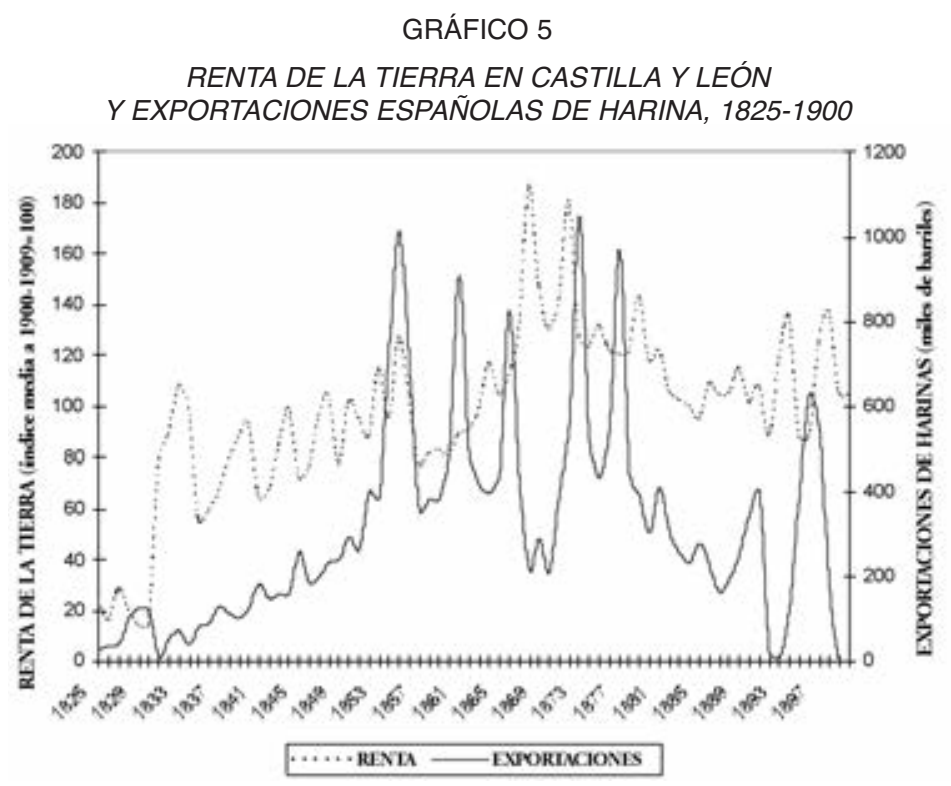

FUENTE: Las mismas del gráfico 2 y Moreno (1998).

\section{Los años dorados, 1847-1879}

En 1847 falleció la condesa viuda de Bornos. Su primogénito, Manuel Jesús Ramírez de Haro, asumió a sus 25 años la gestión del estado. El XI conde había recibido una severa educación a cargo del jesuita Domingo Oloscoaga y una instrucción mercantil no menos metódica en el Lavadero de Rojas, una finca extramuros de Toledo que acabó por convertirse en la residencia permanente de la familia.

Pasado el año de luto, Manuel Jesús Ramírez de Haro casó con Francisca Caracciolo Crespí de Valldaura, hija de los condes de Orgaz y Castrillo. La familia de Francisca, exiliada en Turín entre 1837 y 1846, donde permaneció bajo la protección del conde de Solaro della Margherita y el rey Carlos Alberto, carecía de todo bien, en tanto que sus propiedades fueron incautadas en 1836. Pero la condesa viuda de Bornos simpatizó con ella por la filiación carlista de sus padres, que compartía, aunque de manera menos militante. Los principios religiosos inculcados por el jesuita francés Guibert en Génova disiparon las aficiones mundanas de la nueva con- 
desa, bien conocidas en los salones de baile de Turín. ${ }^{18}$ Pudo así acomodarse a la vida ascética que le esperaba en Toledo, donde nació en febrero de 1850 la única hija de los condes, María de la Asunción.

Una vez a cargo del estado, y como hizo su padre en circunstancias similares, Manuel Jesús Ramírez de Haro acometió una nueva reforma gerencial. ${ }^{19}$ El conde encomendó en 1847 el trabajo, en su condición de administrador general, al joven Hilario Zapata, persuadido por los elevados ingresos obtenidos por las fincas de Medina del Campo, en medio del marasmo del resto de las administraciones, de las que se había ocupado hasta entonces.

Zapata, un hombre extremadamente puntilloso, eficaz y enérgico, emprendió con entusiasmo su nueva tarea. A las pocas semanas de establecerse en el palacio de los Bornos en la calle del Pez de Madrid, ordenó que todos los administradores le remitiesen

una relación circunstanciada de todas las finas rústicas y urbanas que componen sus administraciones, sus sitios y cabidas, sujetos que las labran y ocupan, nombres que tengan aquellas sus calles, sus productos anuales, censos y foros en pro y en contra. ${ }^{20}$

Estos informes desvelaron las pésimas condiciones de explotación del patrimonio rústico de la casa. Zapata tuvo ocasión de constatar que muchas de sus propiedades en Castilla eran aprovechadas como plantíos y prados, en plena expansión del precio del grano. Desde entonces, él debía aprobar (y, en su caso, imponer) el tipo de aprovechamiento de los predios del conde. ${ }^{21}$

Zapata trató también de atajar de inmediato la dejadez aparente de los administradores, que, estaba convencido, enmascaraba un enriquecimiento ilícito. Zapata estudiaba partida por partida las cuentas enviadas por los mandatarios de la casa, quienes debían responder de inmediato a

18 Mir (1898).

19 Le inquietaba especialmente el lamentable estado de las finanzas, que él atribuía, en gran parte, a la elevada morosidad de sus arrendatarios y a la mala administración de su patrimonio inmobiliario en Madrid, un aspecto descuidado en el reglamento de 1826.

20 AHNN, Bornos, 121/1.

21 AHNN, caja 833/8. 
sus «reparos». Su celo en este particular llegó a ser obsesivo. A uno de ellos le sancionó severamente por una pérdida de dos reales que no fue capaz de acreditar. $^{22}$

Finalmente, el nuevo administrador trató de sacar mayor provecho de las posibilidades de lucro que proporcionaban las exportaciones de harinas. Zapata exigió información semanal del precio al que cotizaba este producto en La Habana y del de las conducciones de granos desde los diferentes puntos de Castilla al puerto de Santander. Los administradores castellanos debían negociar a lo largo del año y en las mejores condiciones la venta de partidas de grano con los fabricantes del entorno. ${ }^{23}$

El empeño de Zapata sorprendió a los administradores, acostumbrados a la desidia y a la complicidad de los empleados del conde en Madrid. Así respondió Zapata en 1849 a una carta del administrador de Tordesillas, en la que reclamaba su comprensión:

Los demás extremos de su oficio me han incomodado sobremanera. Y, por última vez, le prevengo de que, si en lo sucesivo no despliega más energía en el desempeño de sus obligaciones, me veré obligado a la precisión de comunicárselo a Su Excelencia. ${ }^{24}$

Las gestiones de Zapata no se materializaron en el corto plazo en una mejora tangible, por culpa de la situación coyuntural por la que atravesaba la economía española. La liberalización de las importaciones de trigo y harinas dictada en 1847 para conjurar la crisis de subsistencia que asoló el país en ese año, ocasionó un retraimiento de la renta de la tierra, aunque se mostró más firme que la de los inmuebles (gráfico 6). Los problemas financieros del estado, a pesar de los desvelos del conde y de su nuevo administrador, parecían no tocar fondo (gráficos 1 y 3 ).

El estallido en 1853 de la Guerra de Crimea supuso un respiro para la casa. El conflicto abrió de par en par las puertas del mercado europeo a las harinas españolas, lo que redundó en un apreciable incremento de la renta de la tierra en la España interior, de la que supo sacar provecho Ramírez de Haro (gráfico 5).

22 AHNN, 166/1.

23 Véase, a este respecto, la correspondencia con el administrador de Segovia.

24 AHNN, 365/14 


\section{GRÁFICO 6}

VALOR EN RENTA DE LOS BIENES RAÍCES EN CASTILLA Y LEÓN, 1800-1924 (en medidas móviles quinquenales y números índices media 1900-1909 = 100)

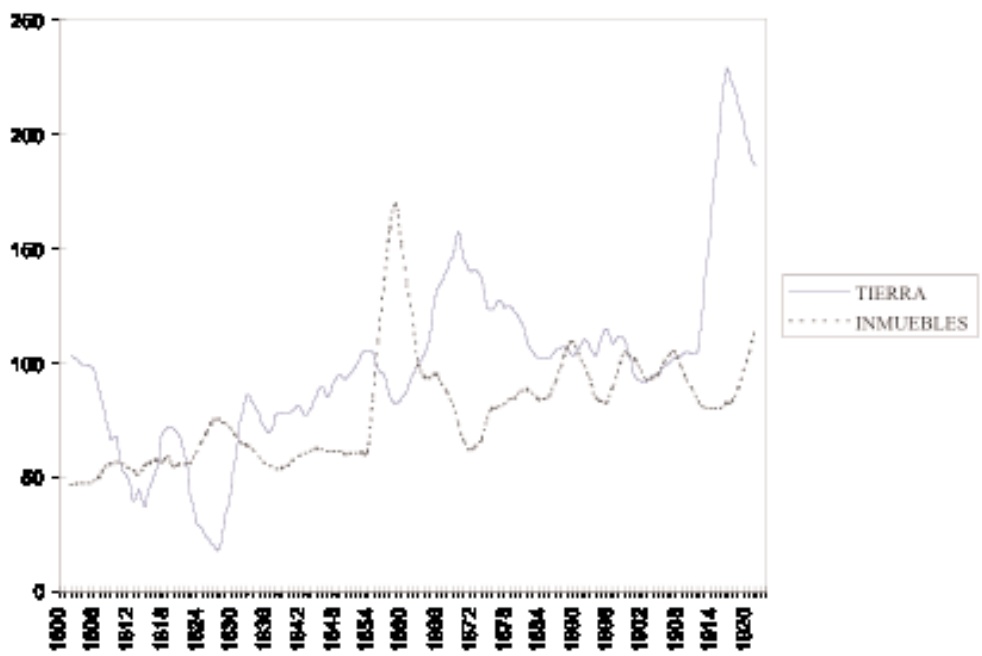

FUENTE: Las mismas del gráfico 2 y Moreno (2006).

El 26 de mayo de 1854 falleció el XI conde de Bornos, con tan sólo 31 años, dejando el legado que detallo en el cuadro 4. Su viuda, como reconocieron sus propios hagiógrafos, una mujer de carácter arisco y demente, se entregó por completo a la interpretación de las señales divinas y milagros que creía ver a diario. ${ }^{25} \mathrm{Su}$ llegada a la misa mayor en la catedral, transitando por las calles toledanas descalza y rodeada de lacayos y mendigos, se convirtió en todo un ritual diario en la anodina capital castellana. ${ }^{26}$

La condesa viuda renovó en su cargo a Zapata, quien atendió conjuntamente su legado (un quinto del total de los bienes) y el de su hija. Una vez más, las desgracias familiares coincidieron en el tiempo con un momento depresivo para los ingresos de la casa. Los motines populares generalizados en toda España en 1856, materializados en los incendios de grandes propie-

25 Mir (1898).

26 Mir (1898). 
CUADRO 4

COMPOSICIÓN DEL PATRIMONIO DEL XI CONDE DE BORNOS EN 1854

(en reales corrientes y porcentaje sobre el total)

\begin{tabular}{|l|r|r|}
\hline Partida & Valor & \% total \\
\hline Alhajas y cuadros & 536913 & 1,7 \\
Mobiliario doméstico & 151390 & 0,5 \\
Efectos públicos & 134734 & 0,4 \\
Metálico & 3738745 & 12,1 \\
Existencias & 370688 & 1,2 \\
Acciones & 66000 & 0,2 \\
Clientes & 755752 & 2,5 \\
Incobrables & 492196 & 1,6 \\
Juros y efectos & 446497 & 1,4 \\
Bienes raíces & 22802276 & 74,0 \\
Ganado lanar y caballar & 775631 & 2,5 \\
Lavaderos & 519343 & 1,7 \\
Ingenio azucarero & 31733 & 0,1 \\
Total & 30821898 & 100,0 \\
\hline
\end{tabular}

FUENTE: AHNN, Bornos, Escritura de liquidación del legado del XI conde de Bornos.

dades, que afectaron también a los predios de los Bornos, la liberalización de las importaciones de trigo, vigente entre julio de 1856 y diciembre de 1858, y el descenso de las exportaciones a Cuba, provocaron una nueva caída de la renta y un deterioro de la situación financiera del estado (gráficos 1, 3 y 5).

En tales circunstancias, Zapata acometió una nueva racionalización de la gestión. El perspicaz gestor redujo a la mitad el número de apoderados y unificó la administración de las propiedades adscritas al condado de Bornos y al marquesado de Villanueva de Duero. En 1856 ordenó la confección de un estadillo quinquenal de las rentas y gastos de la casa, primer ejercicio contable de esta naturaleza jamás realizado en ese estado.

Zapata quiso también poner fin a la ocupación de fincas, teóricamente incultas, aprovechando la información de las cuentas de testamentaría del conde difunto. Muchas propiedades de Castilla y Andalucía figuraban en sus apeos desde 1830, en que se generalizó el abandono de cultivos, como marjales y zonas pantanosas, cuando, en muchos casos, eran explotadas por vecinos de esas localidades. Zapata ordenó a sus administradores que recorriesen a caballo una vez por semana las fincas a su cargo para cerciorase in situ de que ningún colono las cultivaba sin pagar renta. Ante la sospecha de que muchas ocupaciones fraudulentas se reali- 
Administración y rentas del patrimonio rústico...

205

zaron con la complicidad de los representantes de la casa, Zapata facultó al administrador de Medina del Campo para que visitase por sorpresa las administraciones de Castilla y León y reclamase en su nombre las cuentas y relación de arrendatarios.

En esta ocasión la coyuntura sí dio recompensa a su celo. Merced a la guerra de Italia y a la de Secesión estadounidense, las exportaciones de harinas al resto de Europa y al Caribe se multiplicaron y, con ellas, el precio del grano y del valor de la renta de la tierra (gráficos 5 y 7).

Entre tanto, los salarios se moderaron. No dispongo de datos de calidad contrastada sobre la retribución de los jornaleros del campo en Castilla, por lo que he de emplear la de los albañiles, que no difirieron, en su trayectoria, de los anteriores. Los datos glosados en el gráfico 8 evidencian la magnitud de los cambios en la distribución de la renta en beneficio de los propietarios de la tierra, experimentados en estos años en que adquirió cuerpo como modelo de crecimiento el denominado "capitalismo agrario». Incluso los ingresos de los propietarios de la tierra crecieron por encima de los de inmuebles (gráfico 6), a pesar de la presión de la demanda

GRÁFICO 7

RENTA PERCIBIDA EN TRIGO EN LA PROVINCIA DE ZAMORA, 1824-1887 (en fanegas)

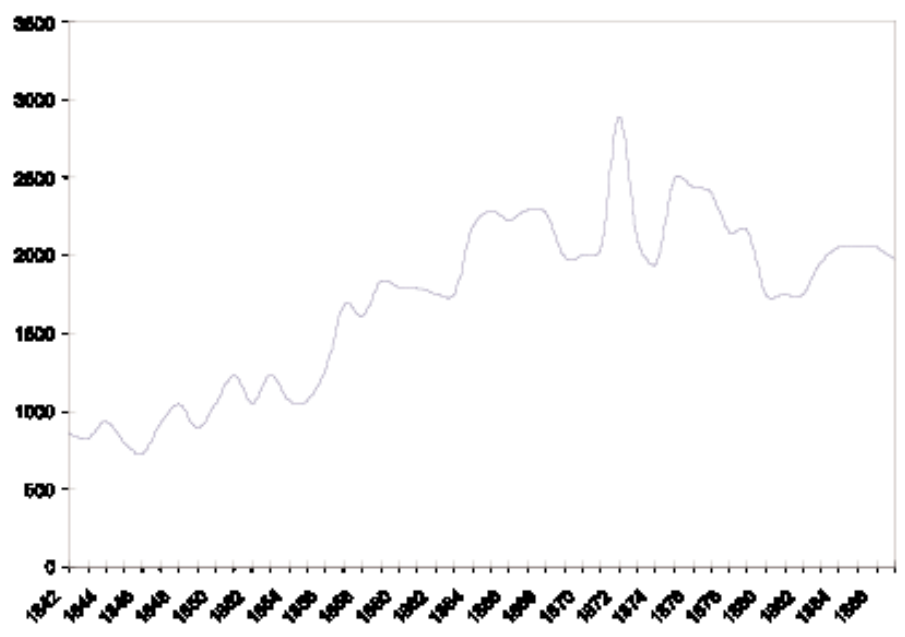

FUENTE: AHNN, Bornos, cuentas de los administradores de Zamora. 


\section{GRÁFICO 8}

RENTA REAL DE LA TIERRA EN CASTILLA Y LEÓN Y SALARIOS REALES

DE LOS ALBAÑILES PALENTINOS, 1800-1924

(en números índices media 1900-1909 = 100 y medias móviles quinquenales)

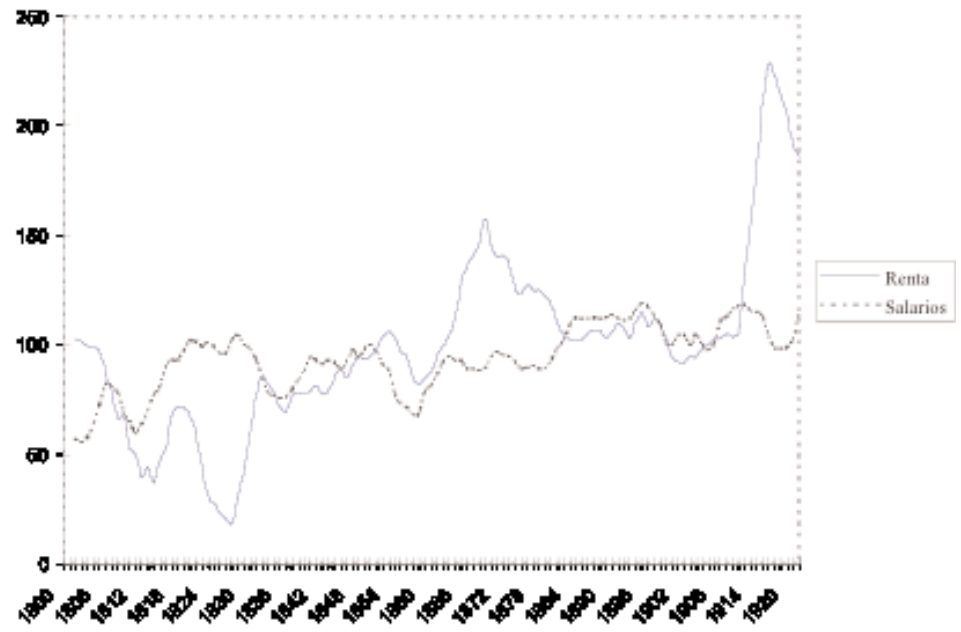

FUENTE: Las mismas del gráfico 2 y Moreno (2006).

urbana de vivienda ocasionada por el crecimiento demográfico y de las distorsiones provocadas en el corto plazo en este mercado por la aprobación de la Ley General de Desamortización de 1855.

Gracias a esta situación tan favorable en el mercado de bienes y de factores, así como a las economías introducidas por Zapata en la gestión, cesaron los financieros en lo que al patrimonio rústico concierne. Las cosas también fueron razonablemente bien para la casa en los negocios lanares a lo largo de la década de 1850. Incluso el número de cabezas (32943 en 1848) se había incrementado, tras la adquisición de 2200 merinas pertenecientes a la cabaña real en $1854 .{ }^{27}$

Pero no sólo la condesa pudo sacar provecho de esta excepcional coyuntura. También lo hicieron los administradores. Por razones de seguridad, el metálico obtenido en la venta de los granos recaudados no era

27 Noticias (1878). 
enviado a Madrid, sino que el administrador giraba una letra con un vencimiento a dos o tres meses que, por lo común, Zapata negociaba tan pronto como era recibida. Los representantes del estado en la casa emplearon este líquido en la compraventa de grano, en no pocas ocasiones, cosechado en las propias fincas a su cargo.

La crisis de subsistencias de 1868 puso fin a casi un decenio durante el cual la casa registró resultados excepcionales. Incluso algunos titulares de predios rústicos castellanos, como la viuda de Pombo, tuvieron que condonar la deuda de sus arrendatarios, por temor a la reproducción de los motines de $1856 .^{28}$ Desde entonces, el descenso de las exportaciones de harinas a Cuba, ocasionado por la introducción desde 1865 de las primeras medidas liberalizadoras de este tráfico, forzaron el de la renta de la tierra (gráfico 5).

El cambio de régimen arancelario en lo que a la importación de trigo y de harinas concierne, diseñado por Figueroa, tuvo efectos letales en los ingresos que proporcionaban los predios castellanos (gráfico 9). Incluso la condesa sufrió durante la Tercera Guerra Carlista la incautación de sus bienes en algunas provincias castellanas (particularmente en Zamora). ${ }^{29}$

Los resultados de los negocios lanares tampoco fueron muy halagüeños. La reducción de las exportaciones y el hundimiento del precio de la lana provocaron cuantiosas pérdidas, que entre 1867 y 1871 ascendieron, en promedio anual, a 109000 reales de vellón. ${ }^{30}$ Según confesión propia en 1878, la condesa mantuvo la explotación de sus merinas por razones de mero prestigio. ${ }^{31}$

Como en ocasiones anteriores, Zapata respondió a los reveses coyunturales intensificando los mecanismos de control, en el convencimiento (veraz) de que, durante las situaciones de carestía y escasez, se daba una mayor complicidad entre arrendatarios y administradores, quienes pactaban bajo cuerda rebajas y demoras en la renta en beneficio mutuo y en detrimento de los ingresos del condado.

\footnotetext{
28 Moreno (1994).

29 AHNN, Bornos, 303/6.

30 ANNN, Bornos 303. Sobre la evolución de los negocios trashumantes en la segunda mitad del XIX, véase García Sanz (1999).

31 Noticias (1878).
} 
En 1870 confeccionó un formulario que debían cumplimentar los administradores y encargó la elaboración de nuevos apeos. ${ }^{32}$ Un año más tarde ordenó la elaboración de nuevos estadillos de la situación financiera de cada una de las administraciones, a cuyos responsables trajo, literalmente, de cabeza.

En realidad, la situación económica era más saneada de lo que Zapata creía (insisto en que el estado carecía de instrumentos contables para una verificación inmediata), debido a que la caída de la renta no vino acompañada de un incremento significativo de los costes laborales (gráfico 8). Por otra parte, el substancial incremento de los ingresos obtenidos en las administraciones andaluzas, estimulado por el de las exportaciones de aceite, enjugó, en parte, las pérdidas contabilizadas en Castilla (gráfico 10).

\section{GRÁFICO 9}

BENEFICIOS LÍQUIDOS OBTENIDOS EN LAS ADMINISTRACIONES

DE ZAMORA Y TORRELOBATÓN, 1842-1887

(reales de vellón corrientes y medias móviles trienales)

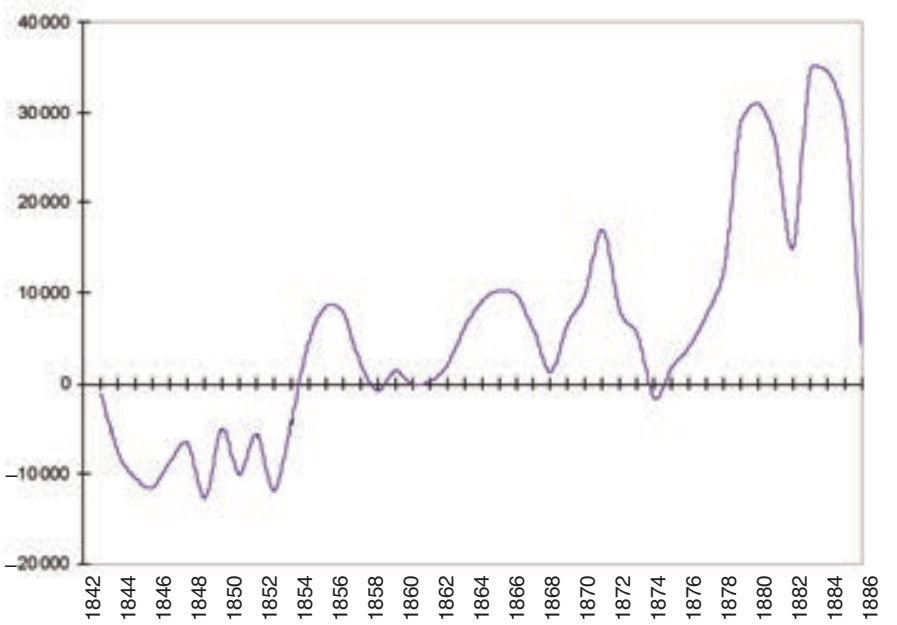

FUENTE: AHNN, Bornos, Cuentas de los administradores de Zamora y Torrelobatón.

32 AHNN, caja 166/1. 
GRÁFICO 10

RENTABILIDAD DE LAS VENTAS OBTENIDAS

EN LA ADMINISTRACIÓN DE JAÉN, 1861-1909

(en tantos por ciento y medias móviles trienales)

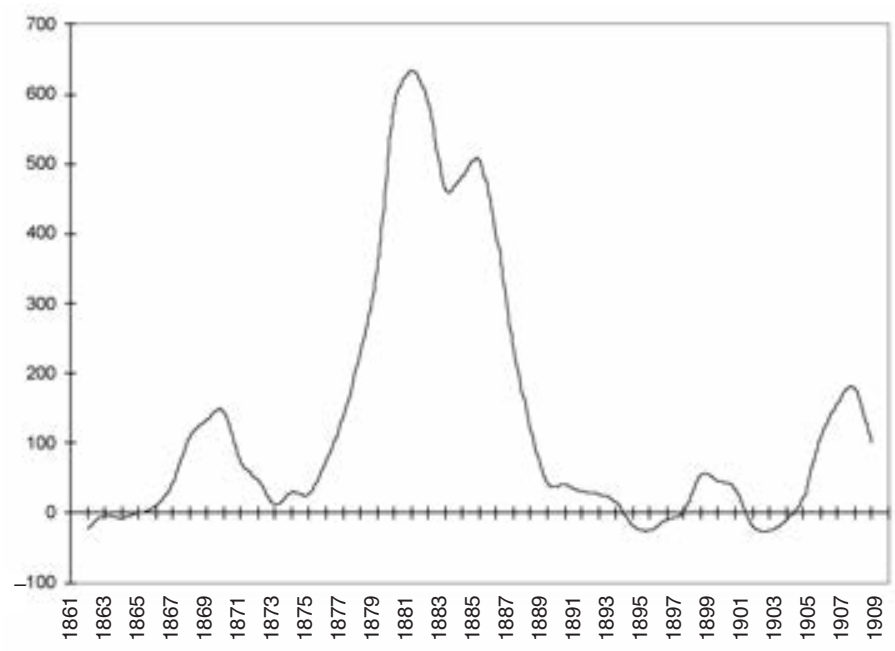

FUENTE: AHNN, Bornos, Cuentas de los administradores de Jaén.

El estado de Bornos recuperó el sosiego financiero tras la eliminación por Cánovas de la dichosa base quinta del arancel en 1875. Cierto es que la medida sólo atenuó la caída de la renta (gráfico 2). Pero, unida al aumento muy notable de los beneficios obtenidos de las explotaciones de los olivares andaluces (gráfico 10), bastó para aliviar los apuros de la condesa.

Aun así, Zapata no bajó la guardia en la vigilancia de los administradores, cuyas mañas conocía tan bien. Por primera vez desde hacía décadas, en 1878 un apoderado de la casa, el de Rueda (Valladolid), Pedro Pablo Ruiz Capillas, fue condenado por fraude. ${ }^{33}$

La condesa tenía sobradas razones para sentirse satisfecha con la gestión del vallisoletano. Sus arcas estaban llenas y, lo que era para ella más importante, su patrimonio rústico no sufrió merma alguna en estos años, salvo algunas fincas de menor importancia cedidas a compañías ferrovia-

33 AHNN, Bornos, 71/2. 
rias. Es más, sus propiedades crecieron considerablemente (cuadro 5) gracias a la compra de dehesas para servicio de sus merinas a otros nobles que no tuvieron tanta fortuna: el marqués de Esmérelo, el duque de Osuna (a quien adquirió la dehesa de Bodegón, en La Puebla de Alcocer, en 1872) y el marqués de Villafuente (una finca de 394 hectáreas en Talavera de la Reina en 1879). ${ }^{34}$

\section{El declive y las angustias familiares, 1880-1997}

El 12 de enero de 1880 falleció la condesa viuda de Bornos. La heredera, Asunción Ramírez de Haro, era, como ella, una completa desequilibrada, a causa de un desengaño amoroso que le atormentó durante toda su vida.

En 1874 la condesa había dispuesto los esponsales de su hija con el conde de Guevara, un apuesto teniente carlista. Sin embargo, concluida la guerra, Asunción de Belvis suspendió el enlace, temerosa de enemistarse con Alfonso XII y convencida de que Guevara, carente de todo ingreso, no era tan buen partido para su hija, a quien contrarió sobremanera la decisión. Roto el compromiso de boda, y a pesar de las protestas de su madre, decidió mantenerse célibe.

CUADRO 5

DEHESAS ADQUIRIDAS POR LOS BORNOS EN LAS PROVINCIAS

DE TOLEDO Y CIUDAD REAL, 1850-1909 (en hectáreas)

\begin{tabular}{|l|c|}
\hline Periodo & Extensión \\
\hline $1850-1859$ & 94,4 \\
$1860-1869$ & 0 \\
$1870-1879$ & 431,72 \\
$1880-1889$ & 129,52 \\
$1890-1899$ & 29,57 \\
$1900-1909$ & 122,16 \\
Total & 807,37 \\
\hline
\end{tabular}

FUENTE: AHNN, Bornos, Escrituras.

34 Otro tanto hicieron nobles como el marqués de Alcañices, animados por el aumento de la renta de la tierra. Véase Carmona (1995), p. 75. 
Asunción abandonó Madrid y se retiró al Lavadero de Rojas, donde trató de conjurar las cuitas amorosas entregándose por entero a las obras benéficas. En palabras del arzobispo de Toledo,

le gustaba la vida metódica y ordenada más que el bullicio y la algaraza; y por eso mismo hacía muchos años que no paraba en Madrid, enamorada de la vida del campo, de sus merinas y de su lavadero. ${ }^{35}$

La gestión de la casa quedó a cargo, en la práctica, de su sobrino Fernando Ramírez de Haro y Patiño, a quien llamó a su lado para ahuyentar la soledad y adiestrarle en la gestión de fincas, como futuro titular del condado.

La desidia de la condesa, poco preocupada por las cuestiones terrenales, no tuvo inicialmente mayor repercusión en los ingresos de la casa. Incluso, en los primeros años de disfrute de este patrimonio las cosas fueron muy bien (gráfico 2). Prueba de ello es la adquisición en 1881 al duque de Osuna de una nueva dehesa en La Puebla de Alcocer. Los ingresos, multiplicados por el arrendamiento de fincas, permitieron compensar las pérdidas por la explotación de las cabañas.

En 1882 se hicieron sentir las primeras señales de una crisis en ciernes con la caída de los beneficios ocasionados por las malas expectativas para los negocios harineros que deparó la firma del tratado comercial con Estados Unidos (gráfico 10). Pero la recuperación de este agregado en el muy corto plazo debió de hacer creer a los responsables de la casa que no había razones para la alarma.

Sin embargo, esta mejora tan súbita resultó un espejismo. Desde mediados de la década de 1880 la caída del precio del grano, el desplome de la renta de la tierra ocasionado por el incremento de las importaciones de trigo, el descenso de las exportaciones de harina, los problemas en el mercado del aceite y el encarecimiento en términos relativos de los costes laborales, forzaron el hundimiento de las ingresos netos del estado (gráfi$\cos 1,2,3,5,6$ y 10$){ }^{36}$

35 AHNN, Bornos, 833/8.

36 Sobre la evolución de la renta de la tierra en los años finiseculares, véase Robledo (1984) y (1988). 
CUADRO 6

RESULTADOS DE EXPLOTACIÓN DE LAS FINCAS EN LA PROVINCIA DE JAÉN, 1861-1909 (en medias anuales y reales de vellón corrientes)

\begin{tabular}{|l|r|r|r|}
\hline Periodo & Ingresos & Gastos & Beneficios \\
\hline $1861-1865$ & 3198,4 & 3642,4 & $-444,0$ \\
$1866-1870$ & 9349,0 & 5158,1 & 4191,0 \\
$1871-1875$ & 8029,7 & 6281,7 & 1748,0 \\
$1876-1880$ & 13689,6 & 4328,8 & 9360,8 \\
$1881-1885$ & 31750,6 & 5234,3 & 26516,3 \\
$1886-1890$ & 31150,1 & 17253,6 & 13896,5 \\
$1891-1895$ & 12421,2 & 12052,4 & 368,8 \\
$1896-1900$ & 12807,6 & 11255,4 & 1552,2 \\
$1901-1905$ & 8178,0 & 8464,4 & $-286,4$ \\
$1906-1909$ & 17766,7 & 6678,2 & 11088,5 \\
\hline
\end{tabular}

FUENTE: AHNN, Cuentas de los administradores de Jaén.

La condesa no mostró mayor inquietud por esta situación, preocupada por cuestiones nada crematísticas. Asunción abrigaba todavía la esperanza de casarse con Guevara, desaparecido desde hacía años. Pero en 1883 llegaron a sus oídos noticias de su muerte. En medio de la estupefacción y el escarnio de la ciudad, Asunción escenificó el drama de viuda desconsolada en los funerales que ordenó celebrar en la catedral de Toledo. Presa de una profunda depresión, la condesa desheredó entonces a Fernando Ramírez de Haro y nombró nuevos legatarios a su confesor, el vallisoletano Juan Camarero y Pachón, y a Matías Alvarado, el hijo de uno de sus criados, de cuya educación se había ocupado.

Asunción ordenó la vuelta a Madrid de su sobrino, con la excusa de que la sordera que padecía le sacaba de quicio. Jubilado Zapata y defenestrado Ramírez de Haro, el desgobierno más absoluto se adueñó del estado, de nuevo al albur de una condesa atrabiliaria sumida en el misticismo religioso.

Sus asesores le conminaban a que vendiese parte del patrimonio para evitar la ruina. Mas Asunción, a quien sus padres habían inculcado su veneración por la propiedad, se negó a desprenderse de sus tierras y merinas. De hecho, siguió haciendo uso de los remanentes de tesorería en la compra en 1887 de bienes raíces (una casa en Zamora y nuevas fincas en Tordesillas), sin atender a la imperiosa necesidad de sanear el estado.

Desechada la venta, la única respuesta que supieron arbitrar los gestores de Madrid consistió en una reducción de los niveles de morosidad de 
los arrendatarios, bajo amenaza de desahucio, ejecutado en tierras de Castilla con más resolución y frecuencia que nunca (gráfico 11). La medida, que no tuvo mayor reflejo en los ingresos de la casa, obligó a muchos de los renteros a emprender la senda de la emigración.

Otros tuvieron más suerte, aprovechando que, privados de la minuciosa vigilancia de Zapata, los administradores hicieron literalmente de su capa un sayo. Muchos de ellos compensaron la caída de los ingresos obtenidos por la comisión del $10 \%$ que facilitaba la condesa conjurándose con los colonos para falsear la cuantía de la renta y conceder moratorias en su pago a cambio de alguna compensación.

Incluso algunos administradores, abogados y notarios en su mayor parte, cuando no registradores de la propiedad, llegaron a apropiarse de terrenos, sobre todo pequeñas fincas en Castilla incluidas en los apeos con lindes imprecisas o aprovechamientos erróneos. ${ }^{37}$ La condesa, absorta en sus mortificaciones, miraba para otro lado.

GRÁFICO 11

ÍNDICE DE MOROSIDAD DE LOS ARRENDATARIOS

DE MEDINA DEL CAMPO, 1874-1897

(en tantos por ciento y medias móviles trienales)

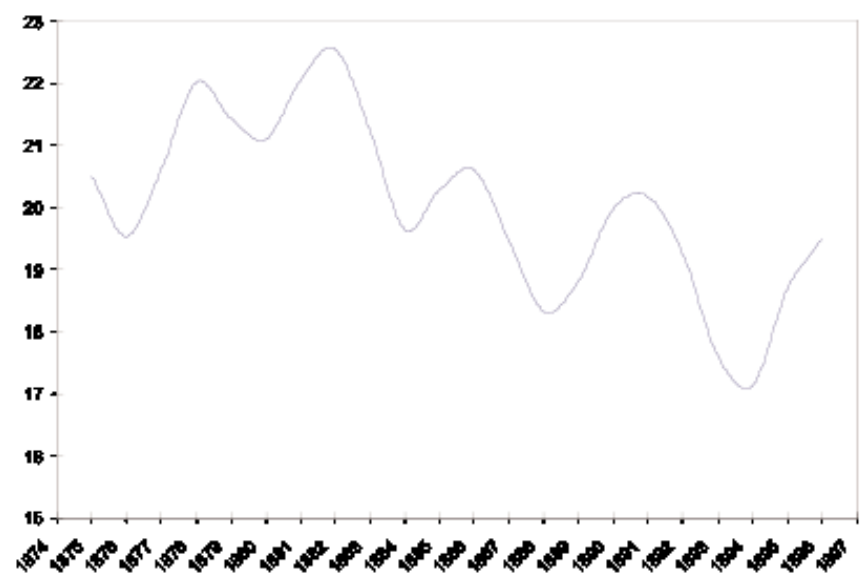

FUENTE: AHNN, Bornos, Cuentas de los administradores de Medina del Campo.

37 Sobre el perfil profesional del apoderado, véase Garrabou, Planas y Saguer (2002). 
La caída de la renta se atenuó en 1890 por efecto de la aprobación del arancel proteccionista de Cánovas. El giro en materia de política comercial tuvo también efectos inmediatos en los resultados del estado (gráficos 1, 2 y 3). Esta situación de momentánea holgura permitió a los responsables de la casa ser algo más tolerantes con los arrendatarios deudores (gráfico 11).

Sin embargo, la bonanza fue muy fugaz. En 1894 se perdió la cosecha en Castilla a causa del pedrisco. En medio del marasmo, los administradores camparon por sus fueros. La ocultación alcanzó, en algún caso, proporciones escandalosas. Las existencias declaradas en 1896 por el responsable del estado en Tordesillas (100 fanegas) fueron cinco veces inferiores a las reales. ${ }^{38}$

El nuevo administrador general, el palentino de Villada Tomás Borge Palomino, trató de poner orden en un caos financiero que a la condesa le traía completamente al pairo. En 1894, cuando la quiebra de la casa parecía ineludible, contrató con agrimensores la realización de valoraciones y planos de todas las propiedades y restableció la obligatoriedad de que los administradores visitasen semanalmente las fincas para cerciorarse de que los colonos respetasen los apeos, tarea que habían eludido desde hacía lustros. ${ }^{39}$ Gracias a su gestión, más vigorosa y profesional, y al aumento de las exportaciones de harinas provocado por el inicio de la Guerra de Cuba en 1895 , los ingresos de la casa sufrieron una pequeño incremento. ${ }^{40} \mathrm{Sin}$ embargo, esta leve mejoría no tuvo continuidad (gráfico 1).

\section{Los problemas de agencia y la recuperación, 1898-1914}

Las cuitas amorosas que durante años habían atormentado a la condesa de Bornos carecían de todo fundamento. Resultó que Guevara había fingido su muerte, en espera de que el tiempo atemperase a sus acreedores y se sobreseyesen las causas abiertas por la justicia. El momento llegó en

38 AHNN, Bornos, 602/11.

39 AHNN, Bornos, 71/3.

40 Idéntica situación sufrieron otros nobles con propiedades en Castilla. Véase Robledo (1999). 
1898. Guevara, acompañado de su mujer y de sus dos hijos, reapareció en una fiesta a la que acudió la condesa de Bornos en uno de sus contados viajes a Madrid.

El inopinado encuentro acabó por perturbar del todo el ánimo inestable de la condesa de Bornos. Guevara, con el pleno consentimiento de su esposa, aceptó su oferta de establecerse en Toledo para asesorarle en la gestión de su estado, del que en 1905 fue nombrado administrador general. El escándalo que ello causó en la mojigata sociedad madrileña fue mayúsculo.

Mas resultó que el personaje era un excelente gestor. Su principal inquietud fue poner coto a la impunidad con la que obraban los administradores y la expulsión de los «propietarios bastardos» que habían ocupado sus fincas. A tal efecto, en 1901 dispuso la confección de nuevos apeos e informes sobre las condiciones de explotación de los predios a expertos locales.

La memoria más jugosa fue la redactada por el decano de la Facultad de Ciencias de Granada, Juan Antonio Tejedor, en colaboración con el administrador de Cambil. Tejedor denunció la escasa formación en Agronomía de los representantes de la casa y, lo que era peor, su conducta delictiva:

De modestos campesinos — escribió- que eran estos señores y sus familias, se convirtieron en ricos hacendados, lo cual da motivo a sospechar si el capital lo hicieron con las tierras de S.E. o por otras medidas, según parecen indicar las propiedades que tienen enclavadas entre las de la casa. ${ }^{41}$

Los colonos enriquecidos con la complicidad de los administradores tampoco se libraron de sus denuncias:

El enemigo más temible para mi es el colono de corbata, el sacado entre los más humildes trabajadores con el producto de las tierras de V.E. en los años en que alcanzaron altos precios. ${ }^{42}$

Guevara exigió en 1905 un minucioso informe a todos y cada uno de los administradores, en el que habían de detallar con toda precisión el

42 AHNN, Bornos, 482/12. 
estado de los ingresos y gastos, la cuantía de las rentas pendientes y el número e identidad de los arrendatarios. En 1909 reclamó la confección de un nuevo estado económico de las administraciones desde $1903 .{ }^{43}$

En 1913 fue todavía más lejos y encargó a vecinos de honradez constatada en cada localidad un informe secreto sobre la moralidad de los administradores, con estos argumentos:

Así como no puede separar lo moral de lo material en lo humano, tampoco puede separarse lo particular de lo oficial en el individuo que, ostentando una representación o un cargo cualquiera, se sirve de la autoridad o poder para satisfacer sus afectos o sus caprichos, sus apetitos o sus odios; en fin, sus pasiones o fines particulares, en perjuicio de los intereses que le están encomendados. ${ }^{44}$

Uno de estos informes puso al tanto a Guevara de la desordenada vida del administrador de Motril, un "borracho, un mujeriego y un soberbio» que se paseaba en calesa por las fincas a su cargo «haciendo el oso [sic]». Una segunda memoria confidencial, de contenido más profesional, reveló que el disipado administrador "hinchaba» la partida de gastos en un $40 \%$, alojaba sin su permiso y de balde a sus sobrinos y amantes en los inmuebles de la condesa y llevaba la administración con métodos «casi socialistas [sic]». ${ }^{45}$ También resultó de enorme utilidad la delación de vecinos o de otros administradores sobre la escasa pulcritud de algunos apoderados en Castilla.

El control sobre los administradores fue más expeditivo que nunca. Guevara debía aprobar personalmente la ejecución de obras de cuantía superior a 50 pesetas, para evitar la distracción de dinero en estas inversiones, de la que tenía constancia cierta. Incluso pasó a ocuparse personalmente de la venta de trigo, de manera que los administradores tenían orden de enviárselo a Toledo por tren inmediatamente después de recaudado. ${ }^{46}$

Los resultados de estos cambios en la gestión, unidos a la apreciación del trigo estimulada por el arancel de 1906, fueron más que notables (gráficos 1,2 y 3). Guevara prosiguió con la política de incremento del patri-

\footnotetext{
43 AHNN, Bornos, 553/4.

44 AHNN, Bornos, 481/9.

45 AHNN, Bornos, 482/18.

46 AHNN, Bornos, 833/5.
} 
monio rústico de la casa. Gracias a la adquisición en 1907 de varias fincas a la duquesa de Luna, pudo subsanar el problema que representó desde antiguo la falta de pastos en propiedad en León. Ya en 1909 compró una última dehesa, la de Cerro-Dávila, en las proximidades de Talavera de la Reina.

Guevara se consagró a la gestión del estado no sólo guiado por motivaciones económicas o por fidelidad a la condesa. Guevara empleó las propiedades de cuya administración se ocupaba en beneficio de sus aspiraciones políticas y para mejorar una imagen pública muy deteriorada tras su misteriosa desaparición. Desde 1905 los administradores tuvieron orden de movilizar y presionar a los arrendatarios para sacar adelante las candidaturas conservadoras. Así, en 1914 el de Zamora informó que

los colonos de su excelencia, a los cuales visitó mi hijo, dieron espontáneamente una muy lúcida votación al señor Osorio Gallardo.

\section{La liquidación del estado, 1915-1924}

En marzo de 1915 falleció la condesa de Bornos. La lectura del testamento dejó estupefacta a la familia. Asunción Ramírez de Haro había revocado el escriturado en 1883 (del que tampoco su sobrino tenía noticia) y nombrado heredero universal de todos sus bienes a Guevara, quien falleció pocas semanas más tarde de la apertura del controvertido documento.

Ramírez de Haro impugnó el testamento, alegando la influencia de Guevara en la voluntad de su tía y que no había enviado al notario un codicilo firmado en 1906 en el que le restituía en sus derechos, tal y como le ordenó en su condición de administrador. Juristas de la talla de García Prieto, Alcalá Zamora y Bugallal se involucraron en la espinosa resolución del conflicto. El asunto llegó incluso al Parlamento. La prensa encontró un auténtico filón en esta historia cortesana.

Finalmente, los tribunales fallaron a favor de los herederos de Guevara, de manera que Fernando Fernández Ramírez de Haro sólo pudo recuperar los títulos. Pocos días después de dictarse sentencia firme, la familia comenzó a desprenderse de sus propiedades menos lucrativas y de las cabañas. 
Las cuentas, bastante menos fiables, insisto, que en periodos precedentes, desvelan que la coyuntura bélica resultó bastante favorable para los intereses de los nuevos propietarios (gráfico 2). La combinación de la protección arancelaria y la política de precios mínimos arbitrada desde la aprobación de la ley de subsistencias de 1915 provocó cambios muy profundos en la distribución de la renta, en favor de los propietarios de la tierra, como delatan las cuentas de los Guevara (gráficos 6 y 8). Y ello a pesar de las importaciones de trigo practicadas ocasionalmente durante la guerra.

La intervención del mercado triguero, a través de instrumentos arancelarios y de la fijación administrativa de los precios, se intensificó tras la conclusión del conflicto. Con ello el Ejecutivo evitó que la crisis de sobreproducción postbélica provocase un desplome de la renta de la tierra (gráfico 2) y un deterioro de los ingresos de explotación de las empresas agrarias, lo que habría tenido efectos no deseados en otras macromagnitudes. Con la prohibición de la importación de trigo aprobada por Antonio Maura y su ministro de Hacienda Francesc Cambó, se consiguió la impermeabilización total del mercado triguero y, con ella, el sostenimiento, mediante procedimientos administrativos, de la renta agraria.

A pesar de ello, los herederos de Guevara, poco interesados en mantener el negocio, se deshicieron inmediatamente después de la guerra de las propiedades que aún conservaban del viejo estado, salvo de las fincas de El Escorial, los inmuebles de Madrid y alguna dehesa, de las que se desprendieron en 1932, tan pronto como comenzaron las discusiones parlamentarias de la Ley de Reforma Agraria.

\section{Conclusiones}

Con toda probabilidad, la estabilidad en el patrimonio del estado de los Bornos no fue la norma en la nobleza española. Pero esta aproximación a las condiciones de gestión suscita algunas valoraciones que difuminan las diferencias entre lo que entendemos como gestión patrimonial y empresarial.

La del estado de Bornos persiguió no tanto la maximización del beneficio, cuanto la conservación del patrimonio. De ahí que empleasen métodos contables tan rudimentarios que ni siquiera eran capaces de esclarecer la cuantía de los ingresos líquidos, o que mantuviesen una administración muy costosa y poco operativa. 
Sin embargo, los Bornos supieron incorporar algunos cambios en la administración de la casa que, como poco, sugieren la mayor semejanza a una gestión empresarial, por más que el «beneficio» no tuviese encaje en sus motivaciones.

Llama la atención, en este sentido, su grado de implicación en la administración de la casa (al menos hasta 1880), que contradice la extendida visión de la nobleza española, entregada a una vida mundana y ajena al día a día de la llevanza de sus rentas. Aun cuando no tuvieron mayor inquietud por fomentar el cambio técnico, también debe ser señalada la imposición desde 1847 del tipo de cultivo a sus arrendatarios, como una muestra añadida de la asunción de actitudes y estrategias estrictamente empresariales. Otro tanto puede decirse de sus intentos, en mayor o menor medida, de poner coto a los problemas de agencia, sobre todo desde 1894. Al menos, los Bornos fueron conscientes de que su negligencia alimentaba la rapacidad de los administradores.

Pero, sobre todo, quiero llamar la atención sobre un aspecto al que no siempre se le ha atribuido la importancia debida: la condición de especuladores de granos de los miembros de la nobleza. En tanto que grandes propietarios, en sus manos recayó la comercialización de buena parte del excedente triguero castellano. Y la consideración de los Bornos revela que lo hicieron guiados por estímulos de mercado. En otras palabras, los Bornos tuvieron que robar algún tiempo a la tarea de «repintar sus blasones», para ocuparse del cambio en los aranceles, la disponibilidad de carreteros, la oferta de algún harinero o la probidad de los administradores. Su comportamiento, visto desde esta perspectiva, no sería muy distinto al de la burguesía agraria, recientemente rehabilitada por la historiografía española.

En este sentido, y atendiendo a la reconstrucción de sus ingresos líquidos, se puede sostener que la legislación arancelaria en materia de importación de trigo en las colonias y en la metrópoli garantizó desde 1853 y durante dos décadas la continuidad de los grandes patrimonios nobiliarios, que escaparon al marasmo de la crisis del Antiguo Régimen y cuyos responsables, como los Bornos, supieron adoptar algunos instrumentos de gestión empresarial empleados por los nuevos grandes propietarios de origen plebeyo.

El estudio revela, por otra parte, las dificultades que tuvo la nobleza para solventar los problemas de agencia. Paradójicamente, la mejora de los 
medios de comunicación sirvió para integrar el mercado interno, pero no parece que el ferrocarril y el telégrafo bastasen para que los titulares de patrimonios rústicos repartidos en diferentes puntos del país tuviesen mayor control sobre sus propiedades.

Pero, al cabo, la falta de honradez de algunos administradores de los Bornos (o, por mejor decir, casi todos) tuvo su funcionalidad económica. Las ocupaciones y deslindes de fincas y los cambios en los cultivos redundaron en unas mejores condiciones de explotación y en unos mayores ingresos, aunque este dinero fuese a parar a sus bolsillos y no a los de los Bornos.

Quiero llamar, por último, la atención sobre la evolución de la renta de la tierra, esclarecida en este trabajo con un índice, por más que provisional y con una cobertura geográfica limitada. El indicador sugiere que, desde mediados del ochocientos, salvo en los últimos años de siglo, la política arancelaria y, desde 1915, la fijación de precios mínimos, beneficiaron a los propietarios de la tierra, en detrimento de los intereses de los pequeños arrendatarios y de los jornaleros.

Esta desigual distribución del ingreso inducida por los poderes públicos fue a más en los años de la dictadura de Primo, lo que no hizo otra cosa que generalizar la condena social a la gran propiedad. 


\section{ANEXO}

RENTA DE LA TIERRA PERCIBIDA POR LOS CONDES DE BORNOS EN CASTILLA Y LEÓN, 1800-1924 (en números índices media 1900-1909 = 100)

\begin{tabular}{|c|c|c|c|c|c|c|c|c|}
\hline & $\begin{array}{r}\text { Renta } \\
\text { nominal }\end{array}$ & $\begin{array}{r}\text { Renta } \\
\text { real }\end{array}$ & & $\begin{array}{r}\text { Renta } \\
\text { nominal }\end{array}$ & $\begin{array}{r}\text { Renta } \\
\text { real } \\
\end{array}$ & & $\begin{array}{r}\text { Renta } \\
\text { nominal }\end{array}$ & $\begin{array}{r}\text { Renta } \\
\text { real }\end{array}$ \\
\hline 1800 & 106,7 & 130,6 & 1842 & 52,9 & 66,7 & 1884 & 86,6 & 99,8 \\
\hline 1801 & 101,3 & 106,7 & 1843 & 66,3 & 84,2 & 1885 & 83,0 & 95,0 \\
\hline 1802 & 68,4 & 83,0 & 1844 & 88,3 & 99,1 & 1886 & 97,8 & 108,8 \\
\hline 1803 & 113,6 & 83,7 & 1845 & 53,7 & 72,2 & 1887 & 96,5 & 104,5 \\
\hline 1804 & 176,1 & 110,9 & 1846 & 53,0 & 76,2 & 1888 & 98,2 & 104,9 \\
\hline 1805 & 124,2 & 124,2 & 1847 & 79,5 & 96,1 & 1889 & 100,8 & 114,7 \\
\hline 1806 & 87,5 & 95,7 & 1848 & 80,7 & 104,4 & 1890 & 91,5 & 101,2 \\
\hline 1807 & 69,1 & 81,0 & 1849 & 57,3 & 77,4 & 1891 & 105,1 & 108,2 \\
\hline 1808 & 64,6 & 75,4 & 1850 & 64,1 & 101,7 & 1892 & 85,8 & 88,0 \\
\hline 1809 & 50,5 & 60,1 & 1851 & 73,5 & 95,0 & 1893 & 109,8 & 118,4 \\
\hline 1810 & 96,1 & 80,4 & 1852 & 60,4 & 87,9 & 1894 & 121,2 & 135,2 \\
\hline 1811 & 44,4 & 35,9 & 1853 & 81,5 & 114,8 & 1895 & 76,8 & 87,8 \\
\hline 1812 & 125,6 & 85,1 & 1854 & 89,8 & 95,5 & 1896 & 76,8 & 87,7 \\
\hline 1813 & 5,3 & 4,4 & 1855 & 101,9 & 127,3 & 1897 & 88,7 & 125,5 \\
\hline 1814 & 56,1 & 44,2 & 1856 & 100,9 & 103,9 & 1898 & 103,5 & 137,3 \\
\hline 1815 & 32,1 & 29,9 & 1857 & 120,3 & 77,1 & 1899 & 100,6 & 104,5 \\
\hline 1816 & 62,2 & 58,3 & 1858 & 88,6 & 81,2 & 1900 & 90,5 & 104,2 \\
\hline 1817 & 57,9 & 49,2 & 1859 & 96,6 & 82,6 & 1901 & 82,2 & 79,7 \\
\hline 1818 & 56,1 & 54,6 & 1860 & 98,7 & 81,0 & 1902 & 89,6 & 90,4 \\
\hline 1819 & 56,6 & 73,0 & 1861 & 97,5 & 89,0 & 1903 & 88,3 & 91,1 \\
\hline 1820 & 83,6 & 104,5 & 1862 & 92,6 & 90,5 & 1904 & 98,5 & 96,0 \\
\hline 1821 & 60,0 & 78,2 & 1863 & 99,7 & 98,8 & 1905 & 100,5 & 102,0 \\
\hline 1822 & 32,8 & 45,8 & 1864 & 115,7 & 116,8 & 1906 & 97,0 & 94,8 \\
\hline 1823 & 28,2 & 39,6 & 1865 & 97,3 & 104,5 & 1907 & 93,8 & 89,4 \\
\hline 1824 & 20,4 & 29,5 & 1866 & 109,8 & 111,7 & 1908 & 109,3 & 110,6 \\
\hline 1825 & 21,4 & 23,5 & 1867 & 123,5 & 129,7 & 1909 & 101,6 & 105,7 \\
\hline 1826 & 14,6 & 16,2 & 1868 & 219,4 & 186,7 & 1910 & 109,4 & 111,6 \\
\hline 1827 & 21,5 & 28,4 & 1869 & 138,4 & 146,8 & 1911 & 94,5 & 99,0 \\
\hline 1828 & 16,1 & 20,3 & 1870 & 109,0 & 130,2 & 1912 & 88,7 & 99,1 \\
\hline 1829 & 10,0 & 13,8 & 1871 & 130,4 & 141,9 & 1913 & 99,3 & 104,7 \\
\hline 1830 & 9,4 & 14,3 & 1872 & 148,0 & 180,9 & 1914 & 104,3 & 113,7 \\
\hline 1831 & 51,6 & 78,8 & 1873 & 106,6 & 127,1 & 1915 & 241,9 & 241,3 \\
\hline 1832 & 74,3 & 88,7 & 1874 & 112,3 & 123,0 & 1916 & 239,5 & 228,7 \\
\hline 1833 & 80,1 & 108,1 & 1875 & 125,4 & 131,7 & 1917 & 247,9 & 226,1 \\
\hline 1834 & 79,0 & 99,3 & 1876 & 128,0 & 122,1 & 1918 & 313,0 & 244,2 \\
\hline 1835 & 43,3 & 55,0 & 1877 & 118,2 & 120,3 & 1919 & 321,7 & 202,4 \\
\hline 1836 & 51,3 & 59,2 & 1878 & 121,8 & 121,0 & 1920 & 366,9 & 210,0 \\
\hline 1837 & 56,1 & 66,6 & 1879 & 144,1 & 143,2 & 1921 & 328,9 & 190,4 \\
\hline 1838 & 68,4 & 79,1 & 1880 & 121,1 & 117,6 & 1922 & 295,8 & 176,8 \\
\hline 1839 & 71,3 & 87,4 & 1881 & 117,2 & 122,1 & 1923 & 293,3 & 183,1 \\
\hline 1840 & 60,9 & 93,3 & 1882 & 99,1 & 106,0 & 1924 & 283,1 & 169,3 \\
\hline 1841 & 44,8 & 64,4 & 1883 & 90,3 & 102,4 & & & \\
\hline
\end{tabular}





\section{7. ¿CONDENADO AL ABSENTISMO? LA ADMINISTRACIÓN DEL CONDE DE ZALDÍVAR EN CORTES DE NAVARRA (1859-1935)* \\ José Miguel Gastón Aguas \\ (I. E. S. Ega de San Adrián [Navarra]) \\ José Miguel Lana Berasain \\ (Universidad Pública de Navarra)}

\section{Introducción}

El 23 de marzo de 1934 se inscribían en el Registro de la Propiedad Expropiable a nombre de María Concepción Azlor de Aragón, casada, de 55 años, natural de "Zarauz (Zaragoza) [sic]», 865 hectáreas en Cortes de Navarra y 172 hectáreas en Buñuel, distribuidas en 273 parcelas. Todas ellas se inscribían como afectas al apartado 12 de la base $5 .^{a}$ de la ley de bases para la reforma agraria de 15 de septiembre de 1932, que aludía a «las explotadas sistemáticamente en régimen de arrendamiento a renta fija, en dinero o en especie, durante doce o más años, excepción hecha de las

* Agradecemos a los actuales duques de Miranda el permiso y las facilidades que generosamente nos han brindado para el estudio de la documentación que ha servido de base a este trabajo, que se halla depositada provisionalmente en su finca de Traibuenas (Navarra). 
arrendadas en nombre de menores o incapacitados, los bienes que constituyen la dote inestimada de las mujeres casadas, los poseídos en usufructo, los sujetos a sustitución fideicomisaria o a condición resolutoria y los reservables». ${ }^{1}$

Se trataba, por tanto, de una más de las grandes haciendas aristocráticas diseminadas por el norte de la Península, aparentemente de origen señorial y catalogables en la retórica política como «supervivencias feudales». Cumplía además otro rasgo característico de la gran propiedad hispana: el recurso sistemático al arrendamiento en pequeños lotes como modo de gestión; el denostado ausenteísmo o absentismo. ${ }^{2}$

Podría por tanto tomarse como un ejemplo arquetípico de los males que acarreó a la agricultura, y a la economía española en general, una determinada y arcaica estructura de clases lastrada por una ineficiente distribución de la propiedad de la tierra y por unas mentalidades ancladas en la pasividad y en la rutina.

Sin embargo, un examen más detenido del caso revela matices interesantes que obligan a revisar el cliché. Ni se trata, sin más, de una supervivencia feudal, ni las estrategias de gestión basadas en la renta que aquí hallamos pueden ser calificadas de absentistas si por ello entendemos un desentendimiento de la marcha de la explotación y una despreocupación por las posibilidades de optimizar. Como se comprobará, el análisis del caso apunta en la misma dirección que han señalado diversos trabajos publicados para otras regiones peninsulares, y no es ajeno al contexto general en que se movieron las agriculturas europeas entre 1850 y $1940 .^{3}$

En las páginas que siguen se ofrecerá un relato de las vicisitudes que atravesó la gestión de esta hacienda desde su adquisición por compraventa en 1857 hasta el estallido de la Guerra Civil en 1936. En la primera

1 Archivo I.R.Y.D.A., I.R.A., Registro de la Propiedad Expropiable, Navarra, Partido de Tudela, Cortes, asientos 13 a 285, pp. 230-267.

2 Un análisis de la crítica regeneracionista al absentismo, en Robledo (1993).

3 Para el caso español, vid. Carmona Pidal (2001), Garrabou, Planas y Saguer (2001a), Calatayud, Millán y Romeo (2000), Pérez Picazo (1991), Serrano García (2002) y Lana Berasain (2002) y (2003). El panorama general europeo, en Garrier (1979), Garrabou (ed.) (1988), Koning (1994). 
parte se examinará el despliegue de una ambiciosa estrategia de inversión y administración directa que irá agotándose paulatinamente hasta su liquidación en la década de 1890. En la segunda parte se analizará el viraje hacia un modelo de gestión más conservador apoyado en arrendamientos y aparcerías. Por último, se analizará la coyuntura de reforma agraria de la Segunda República bajo la perspectiva que surge de este recorrido.

\section{El sueño de José Hurtado de Zaldívar: la administración directa de fincas modelo, 1857-1893}

En 1857 se adjudicaba por 1006000 reales de vellón a José Hurtado de Zaldívar y Fernández de Villavicencio (1811-1894), como mejor puja en las subastas celebradas simultáneamente en Madrid y Zaragoza, 808,25 hectáreas de regadío ubicadas en Cortes (Navarra) procedentes de la testamentaría del VI duque de Granada de Ega, fallecido en Bayona en 1848. La casa ducal ponía así remedio al grave quebranto financiero legado por Francisco Javier Idiáquez Carvajal (1778-1848), infelizmente comprometido con el carlismo, y permitía a los herederos del x marqués de Cortes afrontar la partición de la herencia. Por su parte, el comprador lograba una hacienda de jugosas posibilidades, ya que se componía en su práctica totalidad de tierra de cultivo susceptible de ser regada desde los canales Imperial y de Tauste, directamente o previa elevación con bombas de vapor, o desde otros cauces menos seguros, como el río Huecha («aguas de Mallén») o un manantial particular. Y ello en un momento en que se proyectaba el tendido del ferrocarril a lo largo del valle del Ebro y en que las mercancías agrarias obtenían una demanda creciente y unos precios en alza. ${ }^{4}$

Hay que recalcar que José Hurtado de Zaldívar, III conde de Zaldívar desde el 7 de junio de 1847 y senador del reino desde el 30 de diciembre de

4 Según el inventario confeccionado en 1857, la hacienda de los Granada de Ega, en Navarra, se llevaba por ocho administraciones: Traibuenas, Pamplona, Cortes, Javier, Estella, Peralta, Úcar, Salinas de Oro y Tafalla. En ese momento la hacienda estaba valorada en 23616752 reales. Sus deudas, tres años después, rondaban los dos millones de reales (Virto, 2002), pp. 124-137. En 1849, según el resumen catastral de ese año, había en Cortes 179 contribuyentes residentes, incluidos 10 calificados como jornaleros. Sobre el regadío en Navarra y la máquina de vapor instalada en Cortes, Lana Berasain (1999a). 
1848, se hallaba sociológicamente muy lejos tanto de las hermanas Idiáquez como de José Antonio y Marcelino Azlor de Aragón, vástagos de la casa de Villahermosa, con quienes aquéllas estaban desposadas. Zaldívar era, en cierta medida, «un hombre nuevo». En la colonia había dado sus primeros pasos y no parece que fuera ajeno al mundo del gran comercio y de los negocios. Sus redes de relaciones así lo hacen sospechar. De hecho, Zaldívar se insertó en una de las redes familiares más dinámicas del capitalismo decimonónico español, al contraer matrimonio con Isabel Heredia Livermore, hija del conocido empresario malagueño Manuel Agustín Heredia. Dentro de su red de íntimas relaciones se contaba, pues, lo más granado de la burguesía de negocios española: Heredia, Salamanca, Loring, Larios. ${ }^{5}$

De la fortuna de Heredia le habían correspondido bienes por valor de 70000 reales de vellón de renta anual, según documentos que aportaba en 1846 para acceder al rango de senador. De su padre había heredado la hacienda de Cuba en 1841, valorada en 285486 pesos y 2 reales de vellón, con una renta anual de 7110 pesos, aunque debió indemnizar en metálico en 1846 a su hermano Luis el exceso de valor de su partija. Con la vista puesta en su asentamiento en la corte y en sus aspiraciones al rango de senador vitalicio, había comprado en 1847 una casa en Madrid por valor de 620956,59 reales de vellón. ${ }^{6}$

\section{CUADRO 1}

CORTES, 1858. TIERRAS ADQUIRIDAS POR EL CONDE DE ZALDÍVAR SEGÚN EL SERVICIO DE LAS TIERRAS Y LA PROCEDENCIA DEL AGUA DE RIEGO

\begin{tabular}{|c|c|c|c|c|c|c|c|}
\hline & Eras & Cultivos & Pastos & Sotos & Eriales & & Total \\
\hline \multirow[t]{2}{*}{$\begin{array}{l}\text { Hectáreas } \\
\%\end{array}$} & $\begin{array}{l}2,4942 \\
0,31\end{array}$ & $\begin{array}{l}728,7351 \\
90,16\end{array}$ & $\begin{array}{l}44,9043 \\
5,56\end{array}$ & $\begin{array}{l}25,5715 \\
3,16\end{array}$ & $\begin{array}{l}6,5545 \\
0,81\end{array}$ & & $\begin{array}{l}808,2596 \\
100\end{array}$ \\
\hline & $\begin{array}{l}\text { Aguas } \\
\text { de Mallén }\end{array}$ & Fuente & $\begin{array}{l}\text { Máquina } \\
\text { de vapor }\end{array}$ & $\begin{array}{l}\text { Aguas } \\
\text { Altas del } \\
\text { Canal }\end{array}$ & $\begin{array}{l}\text { Canal } \\
\text { Imperial }\end{array}$ & $\begin{array}{l}\text { Canal } \\
\text { de Tauste }\end{array}$ & Total \\
\hline $\begin{array}{l}\text { Hectáreas } \\
\%\end{array}$ & $\begin{array}{l}69,7813 \\
8,63\end{array}$ & $\begin{array}{l}116,6903 \\
14,44\end{array}$ & $\begin{array}{l}195,0054 \\
24,13\end{array}$ & $\begin{array}{l}34,3193 \\
4,24\end{array}$ & $\begin{array}{l}295,7544 \\
36,59\end{array}$ & $\begin{array}{l}96,7089 \\
11,96\end{array}$ & $\begin{array}{l}808,2596 \\
100\end{array}$ \\
\hline
\end{tabular}

FUENTE: Archivo de los duques de Miranda (ADM en adelante), Apeo de noviembre de 1858. Elaboración propia.

5 García Montoro (1978) y Parejo (1990).

6 <http://www.senado.es/historia/senadores/alfanombre.html>. 
La compra del antiguo marquesado de Cortes se completó con la adquisición por 390000 reales de vellón de los bienes en Peralta y Tafalla que fueron adjudicados en el reparto de la herencia a Rosario Idiáquez, ${ }^{7}$ y más tarde con otras 60 hectáreas en el término de Cortes procedentes de varios propietarios, entre ellos la Administración de Bienes Nacionales, y en 1866 con el coto redondo de El Espartal (171,60 hectáreas), en el inmediato término de Buñuel, propiedad hasta entonces de la familia madrileña Sainz de Baranda. Con ello, Zaldívar constituyó un patrimonio rústico compacto, bien avenado por los canales Imperial y de Tauste, y estratégicamente situado tras la construcción de la línea ferroviaria Zaragoza-Tudela-Bilbao. Con esas bases patrimoniales, Zaldívar podía poner en marcha una ambiciosa empresa agraria, arriesgando para ello importantes capitales en inversiones a largo plazo, con el objetivo indiscutible de maximizar el beneficio.

La localidad en la que recalaba Zaldívar era un poblado de 1153 habitantes en 1860, con una jurisdicción sobre 3651 hectáreas, en la cual de modo inevitable los ocupantes del viejo castillo, quienes contro-

CUADRO 2

DISTRIBUCIÓN DE LA PROPIEDAD DE LA TIERRA

EN CORTES DE NAVARRA EN 1890

\begin{tabular}{|c|c|c|c|c|c|c|c|c|}
\hline & \multicolumn{4}{|c|}{ Sin aprovechamientos comunales } & \multicolumn{4}{|c|}{ Con aprovechamientos comunales } \\
\hline & \multicolumn{2}{|c|}{ Propietarios } & \multicolumn{2}{|c|}{ Superficie } & \multicolumn{2}{|c|}{ Propietarios } & \multicolumn{2}{|c|}{ Superficie } \\
\hline & $n .^{o}$ & $\%$ & ha & $\%$ & $n .^{o}$ & $\%$ & ha & $\%$ \\
\hline $0-1$ & 144 & 41,6 & 87,96 & 4,3 & 110 & 26,8 & 63,73 & 2,5 \\
\hline $1-5$ & 162 & 46,8 & 377,34 & 18,7 & 216 & 52,6 & 514,60 & 19,8 \\
\hline $5-10$ & 17 & 4,9 & 112,91 & 5,6 & 50 & 12,2 & 342,63 & 13,2 \\
\hline $10-50$ & 18 & 5,2 & 324,45 & 16,0 & 30 & 7,3 & 529,38 & 20,4 \\
\hline $50-100$ & 4 & 1,1 & 237,83 & 11,8 & 4 & 0,9 & 262,61 & 10,1 \\
\hline$>100$ & 1 & 0,3 & 882,69 & 43,6 & 1 & 0,2 & 882,69 & 34,0 \\
\hline Suma & 346 & 100 & 2023,18 & 100 & 411 & 100 & 2595,64 & 100 \\
\hline
\end{tabular}

FUENTE: J. M. Lana Berasain (1997).

7 La escritura de compraventa de Cortes terminaría por firmarse el 15 de febrero de 1858. En la misma subasta se había vendido también el coto de Silillos (Madrid). Antes, el 3 de agosto de 1857 se había escriturado la compra de los bienes de Peralta, Funes, Tafalla y Pueyo (90 ha). 
laban según el catastro de 1890 la cuarta parte de la superficie municipal y el $44 \%$ de la propiedad particular amillarada, jugaban un protagonismo indiscutible. El grueso de la población lo componían jornaleros sin tierra (65 accedían en 1890 a la tierra gracias a un reciente reparto de 6 robadas por vecino) y propietarios de pequeñas parcelas que dependían para su subsistencia del trabajo asalariado y de la cesión de tierra en arriendo.

La llegada del nuevo propietario debió de suponer una auténtica conmoción en el pueblo. El año 1859 fue el año en que el nuevo dueño asumió el cultivo directo de la mayor parte de las tierras de labor, sembrando 572 hectolitros de trigo y 158 de cebada, junto con maíz, alubias y alfalfa. Esta apuesta por el cultivo directo de cereales a gran escala parece constituir un fenómeno pasajero, ligado tal vez al reordenamiento de las formas de explotación, ya que fue enseguida redimensionada, de modo que entre 1860 y 1867 se sembraron por termino medio anual 21,5 hectolitros de trigo, 4,3 de cebada y 1,25 de maíz. En agosto de 1860 entró en vigor el primer gran grupo de contratos de arrendamiento por seis años, con un condicionado claro, al que se acogerían algo más de 100 colonos, y cuya renta media rondaba los 8,5 hectolitros de trigo. La superficie de la que disfrutaban era desigual, como también lo era su fortuna personal; todos los sectores sociales, también los pudientes, como es el caso de D. Juan José Gaviria, segundo mayor contribuyente residente, disfrutaban de tierras del conde en arriendo. No fue la única fórmula de cesión. Las tierras que se regaban con la máquina de vapor, gestionada por la «Sociedad Unión y Constancia», fueron arrendadas inicialmente por una cantidad fija, pero la fórmula se recondujo enseguida al pago de un séptimo de la cosecha al conde. Dieciocho años después, en 1878, el contrato de arrendamiento mantenía las rentas en los mismos niveles de precio, lo cual no fue óbice para el aumento sustancial de los ingresos en grano, gracias a la inserción en el circuito de arrendamiento de nuevas tierras, al amparo de nuevas coyunturas. De modo que, prácticamente desde el primer momento, el modelo de gestión apostaba también por la cesión de ciertos aprovechamientos mediante contratos de arrendamiento, ya fuera a cultivadores (parcelas y quiñones), ganaderos (pastos) o inquilinos (fincas urbanas), con el fin de obtener una renta en metálico o en especie, susceptible esta última de ser valo- 
rizada en el mercado, no sin una atenta vigilancia y cierto grado de incertidumbre. ${ }^{8}$

Pero, a tenor de la correspondencia que se cruzaban el administrador y el conde, los objetivos de la operación de compra eran mucho más ambiciosos y se dirigían a la administración directa y a la producción para el mercado, previo diseño de una estrategia de inversión en varias fincas acotadas. Las Mejanas de Santa Isabel, un soto o coto redondo ubicado al otro lado del río Ebro, acogieron la apuesta más compleja, con la puesta en marcha de una explotación polivalente, dedicada al cultivo de hortalizas y cereales, a la cría de ganado y a la explotación maderera. Se trataba de una finca de 90,17 hectáreas con usos diversos (18 hectáreas de arbolado, 9 de soto y labor, 56 de cultivo herbáceo, 4 de yermo y 3 de cascajar, según el catastro de 1890), cuyo inconveniente principal radicaba en la distancia y el difícil acceso desde Cortes (la barca de Novillas estaba algunos kilómetros aguas abajo). Las expectativas del conde parecían amplias: en 1863 se sembraron hasta "cinco clases de trigo a hoya [...] y tanto la siembra, siega y trilla es bastante costosa pues es necesario que no se mezclen unos con otros»; se sembró cebada "de la Australia» y maíz; en la huerta había todo tipo de verduras, patatas y esparragueras; se plantaron frutales «de los más desconocidos en este País [...] manzanas de varias clases, perales, pavíos y melocotoneros»; olmos, chopos y fresnos jalonaban la finca y también había espacio para los viveros donde se colocaban «las estaquillas y baretas», así como los barbados para las viñas. Sin embargo, esas expectativas bien pronto se vieron truncadas y, ya en marzo de 1863, el administrador advertía que «los productos de las Mejanas no llegan a cubrir los gastos», lo cual, a su juicio, no debía extrañarle, porque «si la memoria no me es infiel creo haber hecho presente a V. E. que las tierras de labor administradas por cuenta de la casa no darían el producto que arrendadas». Buscando razones para tal hecho, encontraba en las obras ejecutadas el año anterior en el río y en el arreglo de caminos alguna explicación. También el acceso era un obstáculo, ya que había que dar «un gran rodeo cuando

8 El 1 de febrero de 1865 el administrador se quejaba de no haber vendido antes el trigo, ya que «Por el Eco de Aragón habrá observado V. E. la baja del trigo ocasionada a mi parecer por el buen estado de los campos, el mucho trigo y harinas que bajan de Castilla por el ferrocarril de Bilbao y por el temor general de un trastorno político que nadie prevé hasta donde puede llegar». 
viene crecido el río». Las soluciones que el conde planteaba pasaban por una reducción de gastos y por un control exhaustivo por parte de los empleados, comenzando por el propio administrador, de las labores que se desarrollaban. Fueron muchas las prevenciones que desde la administración general de Madrid llegaron para que «no se hicieran más gastos que los de absoluta necesidad». Se intentó contener los salarios tanto de peones como de yuntas, aunque no fue sencillo, pues, entre otras cosas, los trabajos del ferrocarril presionaron al alza los jornales, además de que el proyecto en sí mismo era lo suficientemente amplio como para necesitar una voluminosa inyección de capital. ${ }^{9}$ Tampoco resultaba sencillo conjugar el abaratamiento de costes con la vigilancia y control de la fuerza de trabajo. ${ }^{10} \mathrm{El}$ administrador optaba por fórmulas como ajustar la siega «a un tanto alzado o destajo», con "macheteros», aun siendo consciente de que «nunca lo hacen tan bien como a jornal». Cuando no era posible, Zaragoza proporcionaba «jornaleros murcianos» que lo hacían a jornal, en caso de no haberlos en el entorno más próximo. Y, aunque más caro, se mostraba satisfecho "porque eran muy trabajadores y recogerían bien la mies». Un difícil equilibrio al que se veía sometido el administrador, ${ }^{11}$ que finalmente no pudo sostenerse, por lo que a la altura de 1867 ya se planteó el conde la conveniencia de arrendar las tierras de labor a varios labradores; eso sí, pocos y de los que más garantías ofrecían. En 1869 se ingresaban 168 hectolitros de trigo por los arriendos de Las Mejanas.

La otra gran apuesta inversora se dirigió hacia la producción de uva y de vino, al abrigo del primer boom exportador a Francia. «Veintidós hombres y sin oírles una palabra» explanaban, en diciembre de 1860, un terre-

9 En febrero de 1861 señala el administrador que «la razón de haber habido tantos gastos en este mes es por haber empleado en las últimas semanas sesenta y cuatro yuntas en arar en Las Mejanas y en los peones que aumenté para la cava de las viñas que van sobre cincuenta diarios, además de los que se emplearon en Las Mejanas que no bajarán de veinte, plantando frutales y viveros y contorneando el estiércol».

10 El administrador dice el 16 de marzo de 1861 que «he vigilado y vigilo a los dependientes de esta administración para que a los trabajadores que van a sus órdenes les obliguen a cumplir con su deber».

11 Pese a todo, en julio de 1865 aseguraba: «a mi parecer he conseguido una notable economía y dado a las fincas las labores precisas para que no decaigan a cuyo fin además de que a los guardas les apuraba para que se adelantase en los trabajos todo lo posible y conveniente yo mismo iba de una a otra empujando a la peonía para terminarla en el menos tiempo posible». 
no para, luego, hoyarlo y plantar barbados de Málaga en la Viña de Nuestra Señora del Carmen. Los barbados se trajeron también de Jerez, así como de las más próximas Tudela y Fréscano. Al mismo tiempo, se hoyaban y plantaban las fincas denominadas Viña de San José y Olivar de Santa Isabel. Entre las tres fincas, significativamente acogidas a advocaciones religiosas como para granjearse de ese modo para la empresa el favor del cielo, podrían sumar 53,4 hectáreas. Sin tiempo para obtener las primeras cosechas, Zaldívar se encaprichó del término de Camponuevo: 44,56 hectáreas de terreno que también se fueron explanando con la idea de hacer un "campo redondo» dedicado al cultivo de la vid, con su propio caserío, desde el que el guarda vigilaría la finca. Durante el invierno de 1863, los destajistas de Novillas comenzaron a hoyar la finca, no sin quejas por el escaso jornal para el «mucho trabajo que supone la hoya con las medidas que hoy tienen». ${ }^{12}$ Una vez acabado este proceso, los barbados fueron cubriendo la superficie de tierra hoyada. Proceso laborioso al que se dedicó todo tipo de atenciones, igual que a la poda, tarea para la que se buscó a personas «inteligentes», como el «Maestro Podador de Borja», cuyo jornal triplicaba el de los braceros. Los resultados comenzaron a ser visibles desde 1863, en que la producción de vino tinto dejó atrás el umbral de 350 hectolitros (en 1867 se rebasaron los mil y en 1881 se logró el máximo de 3395), y en que las soleras se fueron llenando con vino jerez (en diciembre de 1869 se inventariaban 417 hectolitros y en 1880 se anotaban 820$)$.

Encauzado el proceso de obtención de la materia prima a partir del otoño de 1861, todos los esfuerzos del conde y de su administrador irían encaminados hacia el proceso de elaboración de caldos, para lo cual no reparó en gastos. En junio de ese año, el administrador reconocía que «en este País se han hecho pocos adelantos en la fabricación del vino pues se elabora lo mismo hoy que hace 50 años y por esta razón sería conveniente como V. E. ya manifestó el traer una persona inteligente que se encargara en el primer año de la dirección en la elaboración de este líquido y que nos instruyera para en lo sucesivo». Se encontró en Francia, donde el

12 Dice el administrador que habría que hacerlas «con 34 centímetros de anchura, 50 de profundidad y otros 50 o 55 de largo en una para cada planta, en lugar de 1 metro y 67 que llevan ahora para dos». Plantea reducir la largura y abaratar costos. 
conde pasaba sus descansos estivales, lejos de los rigores de la Península. Se contrató a monsieur Renè, quien se desplazaba a Cortes, donde pasaba largas temporadas. Pese a su presencia, el administrador, celoso de su trabajo, no desaprovechaba ocasión alguna para ir adquiriendo conocimientos adicionales. Sus viajes a Zaragoza, Borja, Cariñena o Puente la Reina de Navarra le permitieron intercambiar opiniones y recibir sugerencias sobre cómo clarificar el vino con clara de huevo, cómo construir lagares para la cocción del vino o sobre la necesidad de comprar, entre otras herramientas, una bomba para trasegar el vino. En septiembre de 1865 sugería al conde que, si se desplazaba a París o Burdeos, comprase «un instrumento que sirve de guía para la elaboración del vino llamado Gleucoenómetro [sic] y aunque no conozco su aplicación la aprenderé en el viaje que tengo proyectado este año a Puente la Reina a la bodega del conde de Guenduláin». El proyecto de la bodega fue redactado por Francisco Nuria a finales de 1862, con un presupuesto inicial que superaba los 160000 reales. Los tres años siguientes fueron frenéticos en la finca; desmontes, nivelaciones, arrastre de materiales y, por fin, un edificio «de muy buen efecto sobre todo mirado desde la parte del camino de yerro» que se erguía en el horizonte. La construcción de la bodega permitió desarrollar al conde, en los años que siguieron hasta su muerte en 1894, una explotación directa de parte de su patrimonio, al amparo de una coyuntura alcista, controlando, en este caso, el proceso de obtención de materias primas, la elaboración de caldos y su inserción en los circuitos mercantiles, gracias a la presencia del ferrocarril.

A diferencia de la estructura del ingreso, mucho más expuesta a factores exógenos y circunstancias fortuitas o de mercado, la estructura del gasto es un buen indicador de las estrategias de gestión desplegadas y sostenidas deliberadamente. A través de la composición del gasto podemos comprobar tanto las dimensiones de esta apuesta inversora como las dificultades con que tropezaron a la hora de reajustar las partidas del debe. Si prescindimos de las remesas giradas al propietario, presentes tan sólo en las décadas de 1880 y 1890 , una parte sustancial del gasto, entre un tercio y la mitad de él, correspondía a la contratación de fuerza de trabajo para la explotación directa. Entre el sexenio 1862-1867 y 1868-1873 observamos una sustancial reducción de esta partida, prácticamente a la mitad, que es el resultado de algunas de las decisiones comentadas anteriormente: el abandono del cultivo directo de cereales en Las Mejanas y los recortes de 


\section{CUADRO 3}

PARTIDAS DE GASTO DE LA ADMINISTRACIÓN

DEL CONDE DE ZALDÍVAR EN CORTES-BUÑUEL, 1862-1893.

PROMEDIOS ANUALES EN PESETAS CORRIENTES

\begin{tabular}{|c|c|c|c|c|c|c|c|c|}
\hline \multirow{2}{*}{$\begin{array}{l}\text { Concepto } \\
\text { de gasto }\end{array}$} & \multicolumn{2}{|c|}{$1862-1867$} & \multicolumn{2}{|c|}{$1868-1873$} & \multicolumn{2}{|c|}{$1884-1887$} & \multicolumn{2}{|c|}{$1891-1893$} \\
\hline & ptas. & $\%$ & ptas. & $\%$ & ptas. & $\%$ & ptas. & $\%$ \\
\hline Salarios & 22950 & 35,3 & 12699 & 34,9 & 22467 & 49,1 & 11681 & 34,4 \\
\hline Materiales & 6408 & 9,9 & 5832 & 16,0 & 5633 & 12,3 & 5607 & 16,5 \\
\hline Administración & 3604 & 5,5 & 3761 & 10,3 & 3350 & 7,3 & 3385 & 10,0 \\
\hline Otros gastos & 1181 & 1,8 & 1688 & 4,6 & 977 & 2,1 & 856 & 2,5 \\
\hline Mantenimiento & 4162 & 6,4 & 3766 & 10,4 & 3639 & 7,9 & 3252 & 9,6 \\
\hline Inversiones & 24695 & 38,0 & 4927 & 13,6 & 3855 & 8,4 & 0 & 0 \\
\hline Contribuciones & 1987 & 3,1 & 3673 & 10,1 & 5869 & 12,8 & 9158 & 27,0 \\
\hline Remesas & 0 & - & 0 & - & 25963 & - & 25447 & - \\
\hline Suma sin remesas & 64987 & 100 & 36346 & 100 & 45790 & 100 & 33939 & 100 \\
\hline Sin inversiones & 40292 & & 31419 & & 41935 & & 33939 & \\
\hline Índices & 100 & & 78 & & 104 & & 84 & \\
\hline
\end{tabular}

FUENTE: ADM, Cuentas anuales y Cuaderno de frutos. Elaboración propia

gasto en otras tareas. En 1884-1887 esta partida vuelve a los niveles anteriores debido a la inclusión de los gastos de personal de la bodega, a un cultivo más esmerado de las viñas en el contexto del segundo boom exportador a Francia y a un retorno pasajero al cultivo de cereales. Para 18911893, el gasto en salarios se situaba de nuevo en el umbral de las 12000 pesetas anuales.

Otra de las partidas estrechamente asociadas al cultivo directo, la referida a materiales o inputs (barbados, semillas, fertilizantes, piensos, agua de riego, herramientas,...), se movió en un margen entre el 10 y el 16\% del gasto, con una cuantía estable en torno a las 6000 pesetas anuales. Igualmente estables se muestran los gastos de administración, superando muy poco el sueldo del administrador (3000 ptas. anuales). Importantes resultaban también los gastos de mantenimiento, con una estabilidad tendente a la baja como consecuencia probablemente de ese empeño por economizar. Se trata de gastos relacionados con la conservación en buen estado y la custodia del patrimonio: reparaciones de edificios, mobiliario y utensilios, arreglos de fincas y caminos, limpieza de acequias y fuentes, salarios de guardas y facturas y dietas de artesanos. En la partida de otros gastos se incluyen partidas diversas, como indemnizaciones, misas y limosnas, portes, pensiones, servicio del palacio y estancias del propietario; de 
ahí que fluctúe sin un sentido preciso. Mención especial merece el capítulo de contribuciones (fundamentalmente integrada por la denominada contribución foral y la de culto y clero), que presenta una clara y sostenida tendencia al alza, llegando a multiplicarse por 4,6 entre 1862-1867 y 1891-1893. En ello hay que ver no solamente un reflejo del aumento de rentabilidad del patrimonio, sino también una creciente eficacia en el control catastral de la riqueza inmobiliaria y una presión fiscal en ascenso. Por último, debemos destacar la cuantía de las inversiones realizadas en los primeros años (casi 25000 pesetas de promedio anual hasta 1867), así como la continuidad del pulso inversor, bien que a la baja, hasta la década de 1880. En 1891-1893, en un contexto difícil debido a la crisis vinícola, las inversiones han desaparecido.

\section{El repliegue conservador de Francisco Javier Azlor de Aragón (1894-1923)}

La agonía de la ambiciosa apuesta corrió paralela a la propia agonía de Zaldívar. Desde finales de la década de 1880 fueron acumulándose los síntomas de sobreproducción en los mercados del vino, y en la década siguiente aún se agravarían más. En noviembre de 1893 el precio del vino no alcanzaba las cinco pesetas por alquez, pero ni el estado del producto, tendiendo a "picarse», ni el mercado, «en vista de cómo se ha puesto el negocio", ofrecían muchas expectativas. Las dificultades se plasmaban asimismo en la acumulación de débitos a favor de la administración por razón de rentas y alquileres. En la relación de cargo de 1891-1893 los débitos a favor de la casa superaban los 75000 reales de vellón, suponiendo casi el $25 \%$ de los ingresos previstos, mientras que la partida de venta de vino caía hasta ser imperceptible, representando apenas un $0,20 \%$ de los ingresos de la administración.

José Hurtado de Zaldívar moría en Madrid el 3 de marzo de 1894. «Terminada la testamentaría», le fueron adjudicados los bienes de Cortes, Buñuel y Peralta a su hija Isabel Hurtado de Zaldívar y Heredia (18531923), desposada en 1871 con Francisco Javier Azlor de Aragón e Idiáquez (1842-1919), VI duque de Granada de Ega y XVI duque de Villahermosa. El patrimonio regresaba así al tronco del que había salido en 1857 . El cambio de titulares coincidía con la liquidación del modelo de gestión 
tenazmente sostenido por Zaldívar y con la búsqueda de un diseño más seguro y rentable.

En 1896, año en que se declaró oficialmente la filoxera en Navarra tras ser detectada en Puente la Reina, tanto la bodega como los viñedos eran arrendados a la Sociedad Vinícola Mercantil Las Campanas por 4000 pesetas anuales y plazo de diez años. Por esas mismas fechas se llevaba a cabo también una completa reordenación de los arriendos, sustituyendo los arrendamientos por seis años vigentes hasta entonces por alquileres anuales de 15 de agosto a 15 de agosto, renovables tácitamente. De este modo se aprovechaban las oportunidades de maximización de la renta que ofrecía un vecindario en crecimiento ávido de tierra (los 1153 habitantes de Cortes en 1860 eran 1410 en 1900 y llegarían a 2346 en 1930; en Buñuel, las cifras eran respectivamente 1302, 1589 y 2779).

El retorno a una estrategia rentista coincidió por tanto con el regreso al tronco patrimonial de la casa de Granada de Ega. Esta circunstancia puede llevar a dudar de si el cambio en el modelo de gestión es el resultado de una evaluación económica del comportamiento de los mercados y de las expectativas de negocio, o bien si responde a factores psicológicos o de mentalidad. Al fin y al cabo, el viejo linaje señorial de los Navarra, el patrimonio aristocrático más extenso de Navarra y de Guipúzcoa al inicio del siglo XIX, había mantenido una estricta política de cobro de rentas y tributos en sus estados hasta la muerte del último Idiáquez. En el caso de Cortes, se llegó a firmar un contrato de arrendamiento por diez años que finalizaba en 1856, por el que, a cambio de 34000 reales de vellón al año, se cedía la finca en bloque a la sociedad anónima La Unión y Constancia. ${ }^{13}$

13 La referencia al arrendamiento, en Virto (2002), p. 129. La compañía de Monlet, constituida en Zaragoza "con el objetivo de proporcionar el beneficio del riego a cuantos terrenos fuesen susceptibles de recibirlo», concertaba en enero de 1844 unas bases con el Ayuntamiento y mayores propietarios para transformar el regadío de Cortes a cambio de una quinta parte de todos los frutos (Archivo General de Navarra, Protocolos, Cortes, J. Ruiz, 1844, 15). Reciclada luego en La Unión y Constancia, sociedad con un capital fundacional de dos millones de reales, se decidió a emplear el vapor como fuente de energía para elevar las aguas desde el canal, importando en 1845 de Inglaterra una bomba impelente aspirante de $30 \mathrm{CV}$ y peso de $603 \mathrm{q}$ con todos sus aparejos (Madoz, 1986), pp. 89-90. 
Lo cierto es que ese retorno al rentismo no refleja propiamente una opción absentista. La transformación de los contratos de arrendamiento de parcelas en contratos anuales y la atomización de éstos hacía su gestión más complicada y requería una vigilancia más atenta que si se hubiese optado, por ejemplo, por un arrendamiento en bloque y por plazos más largos. El número de arrendatarios, que había crecido con suavidad durante el último tercio del siglo XIX (un 34,5\%), aumentó en un 38,8\% entre 1900 y 1903, y entre esa última fecha y 1923 lo hizo en un 42,8\%, hasta alcanzar el número de 372 en 1933. El resultado fue una atomización del arrendamiento medio, cuya cuantía en grano bajó de 11,35 hectolitros en 1869 a 7,60 en 1903. La cuantía de la renta, entretanto, se había incrementado en una cuarta parte, y en los veinte años que median hasta 1923 aún creció en un $76,8 \%$.

Un elemento que puede servir para calibrar la mentalidad subyacente a este cambio en el modelo de gestión es la actitud mostrada ante la nueva oportunidad de negocio difundida en el valle del Ebro tras la independencia de Cuba. Al fin y al cabo, la irrupción del negocio remolachero en lo que se denominó el «Triángulo del Azúcar», entre Aragón, Navarra y La Rioja, tomó el testigo de lo que había supuesto en el medio siglo anterior la especialización vitivinícola, aunque esta vez orientada hacia el mercado interior. A finales de 1899 se construyeron en Navarra dos azucareras, una en Marcilla y otra en Tudela, que vendrían a sumarse a las que

\section{CUADRO 4}

ESTRUCTURA DE LOS ARRENDAMIENTOS EN GRANO DE TIERRAS

EN CORTES, 1869-1923 (ordenados según la cuantía del canon en hectolitros de trigo. Datos en \%)

\begin{tabular}{|c|c|c|c|c|c|c|c|c|}
\hline \multirow[b]{2}{*}{ Cuantía del canon } & \multicolumn{2}{|c|}{1869} & \multicolumn{2}{|c|}{1900} & \multicolumn{2}{|c|}{1903} & \multicolumn{2}{|c|}{1923} \\
\hline & $n .^{o}$ & $h L$ & $n .^{o}$ & $h L$ & $n .^{o}$ & $h L$ & $n .^{o}$ & $h L$ \\
\hline$<5 \mathrm{hL}$ & 57,1 & 11,6 & 62,5 & 14,6 & 67,6 & 20,2 & 35,3 & 11,8 \\
\hline $5-20 \mathrm{hL}$ & 28,6 & 27,0 & 25,0 & 25,2 & 24,3 & 28,1 & 56,8 & 53,0 \\
\hline $20-50 \mathrm{hL}$ & 10,1 & 25,0 & 9,4 & 31,8 & 6,3 & 26,6 & 6,0 & 17,0 \\
\hline $50-100 \mathrm{hL}$ & 2,5 & 16,0 & 2,5 & 20,0 & 1,3 & 13,4 & 1,3 & 10,6 \\
\hline$>100 \mathrm{hL}$ & 1,7 & 20,4 & 0,6 & 8,4 & 0,5 & 11,7 & 0,6 & 7,6 \\
\hline Suma & 100 & 100 & 100 & 100 & 100 & 100 & 100 & 100 \\
\hline Totales (n. ${ }^{\circ}$ y hL) & 119 & 1350,86 & 160 & 1566,68 & 222 & 1687,80 & 317 & 2983,72 \\
\hline Renta media (hL) & & 11,35 & & 9,79 & & 7,60 & & 9,41 \\
\hline
\end{tabular}


se instalaron por entonces en Aragón, lo que permitió dedicar al cultivo de la remolacha una cada vez mayor superficie de tierra. ${ }^{14}$ En teoría, los precios, más remuneradores que los del trigo, la firma de contratos de cultivo, la disponibilidad de semilla barata, los anticipos de abonos y de dinero, así como el continuo asesoramiento y control que las fábricas ofrecieron a los cultivadores parecían irradiar un atractivo irresistible para éstos. ${ }^{15}$ Además, la planta se adaptaba bien a los rigores climáticos de la zona, se recogía en una época en la que, tradicionalmente, no había ocupación y permitía a un buen número de pequeños cultivadores compaginar su trabajo en su explotación con una dedicación temporal en la propia fábrica, en procesos de transformación. ${ }^{16}$

Las expectativas que abría un cultivo como el de la remolacha no pasaron desapercibidas para el duque, quien, con el cambio de siglo, siguió con interés las gestiones que su administrador hizo para encontrar argumentos que le embarcasen en esa nueva experiencia agrícola. A mediados de diciembre de 1899, fue el barón de Areyzaga quien, desde Zaragoza, le escribía dándole noticias del resultado que había obtenido él con la remolacha azucarera. A su juicio, su cultivo resultaba muy conveniente, «siempre que se gaste en él lo necesario para que la tierra no quede esquilmada en pocos años», controlando que "los colonos, engolosinados por la mayor ganancia que al pronto obtienen, sin más que plantar en tierras que hasta ahora se han cultivado de cereales y de año y vez», abonen la tierra "como la práctica y ciencia aconsejan» y den las labores de forma correcta. El barón le sugiere que se regule correctamente el cultivo de la remolacha a los colonos y, para ello, propone dos fórmulas. En la primera, plantea que

14 Gracia Guillén (2001), pp. 382, 312 y 273. El 26 de septiembre de 1899 se firmó la escritura de constitución de la "Azucarera Navarra», en Marcilla, y el 10 de noviembre de ese mismo año la de "La Azucarera de Tudela», en Tudela. Añade que en ese año se crearon 14 fábricas de remolacha. Gastón (1997), p. 66, señala que para 1911 había en la comarca de Marcilla más de 2400 cultivadores de remolacha, con una superficie cultivada de 1106 hectáreas.

15 Gracia Guillén (2001), p. 109. Este autor señala que en la campaña de 1907-1908 los beneficios podían llegar a ser de 300 pesetas por hectárea. En Gastón (1997), p. 68, aparece un estudio realizado por el Ayuntamiento de Villafranca, según el cual los beneficios en 1932 eran menores, en torno a 218 pesetas por hectárea.

16 Gracia Guillén (2001), p. 193, apunta que en Cortes pudieron ocuparse hasta 600 obreros en las fábricas, cifra similar a la que Gastón (1997) establece para Marcilla, en su época de máxima actividad. 
«no se permita que el colono plante una misma tierra más que cada tres años». A pesar de la restricción, la producción de remolacha le permitiría al colono, una vez cubiertos los gastos de yuntas y jornales y de la renta, «obtener un beneficio mínimo de 30 pesetas por robada». ${ }^{17}$ Dicho beneficio, aplicado en última instancia al propietario, significaría, según Areyzaga, la posibilidad de aumentar la renta percibida por esas tierras hasta 10 pesetas por robada (111 ptas./ha).

La segunda fórmula pasaba por hacer un contrato de mediería con los colonos. El propietario se haría cargo de las labores de preparación, de los abonos - estiércol, superfosfato y nitrato de sosa - y del semillero; el colono, por su parte, «de los jornales empleados en el semillero, de los riegos, de la escarda, del arranque y de la preparación de la remolacha» para ser entregada a la fábrica. El producto que el propietario podía obtener por esta vía se aproximaba, según él, a las 22 pesetas por robada (245 ptas./ha). El único problema, en este caso, era que «la administración se hacía más complicada y que el administrador ha de ser persona activa y que lo vigile todo personalmente con conocimiento de agricultura». Pintadas así las cosas, parecía no caber lugar para la duda. Sin embargo, y de ello también se hizo eco el propio barón, las cosas no iban a ser tan sencillas, ya que «la gente de Cortes, Mallén y Novillas, mal aconsejados sin duda, han tomado una actitud de resistencia al cultivo de la remolacha, mientras no se acceda a pretensiones exageradas unas y absurdas otras, a las que la fábrica de Gallur está decidida a no acceder». Por ello, pese a que al duque podría convenirle dicho cultivo, probablemente no podría concretarlo con sus viejos colonos, por lo que le planteaba que arrendase a la fábrica de Gallur las tierras de El Espartal y Las Mejanas o que las cultivase directamente.

El administrador quiso tener otros puntos de vista y, por ese motivo, le envió la carta del barón a su homólogo en la hacienda que el duque de Granada tenía en Traibuenas. Jesús Arilla de Ciraco no se mostró tan eufórico. Para él, el cultivo de la remolacha no era para esta zona, por sus condiciones de clima y suelo, y sí para el centro y norte de Europa, «donde se cultiva en terreno de secano frecuentemente regado por la lluvia». «Aquí

17 Equivalente a 334 pesetas por hectárea. El barón estipula una producción media de 2,5 toneladas por robada $(27,82 \mathrm{t} / \mathrm{ha})$, que, al precio de 38 pesetas por tonelada, suponía 95 pesetas por robada (1057 ptas./ha). 
- dice- haciendo con esta planta industrial un cultivo de regadío invertimos por completo el proceso y con cuidados y gastos que aumentan en mucho el coste del producto se ha conseguido una planta que sí es beneficiosa, pero no es lo que dicen los ingenieros de propaganda pagados por las fábricas». Pese a todo, él no quería ser «obstruccionista» y apostaba por su cultivo; eso sí, con los pies en el suelo, porque, aunque era consciente de que el boom constructor de fábricas abriría una "competencia favorable a los intereses agrícolas», y pagarían más y más la remolacha, había que ser realistas y analizar con ensayos el rendimiento de dicho cultivo. Era partidario de reglamentarlo, pero no tanto al colono viejo, quien "considera la tierra como suya» y no la quiere esquilmar, como a las fábricas de azúcar. Y también aporta su particular estudio de rentabilidad, que, teniendo en cuenta la producción, daría unos beneficios de 14,75 pesetas por robada (164,17 ptas./ha), muy lejos de lo aventurado por Areyzaga. ${ }^{18}$

\section{CUADRO 5}

ESTIMACIÓN DEL COSTE DEL CULTIVO DE REMOLACHA EN 1899

(realizada por Jesús Arilla de Ciraco, administrador en Traibuenas)

\begin{tabular}{|l|c|c|c|}
\hline Conceptos & Ptas./robada & Ptas./ha & $\%$ \\
\hline Preparación: Por tres labores en el suelo & 9 & 100,17 & 11,2 \\
Plantación: Jornal de 2 obreros & 5 & 55,65 & 6,2 \\
Hedrar: Gastos de 2 hedraduras & 5 & 55,65 & 6,2 \\
Arranque: Gasto de 2 obreros & 4 & 44,52 & 5,0 \\
Limpia: Gasto de limpia de raíces & 4,25 & 47,30 & 5,3 \\
Total de Labores & 27,25 & 303,29 & 33,9 \\
Estiércol imprescindible (3000 kilos) & 21 & 233,73 & 26,2 \\
Superfosfato de 16\% & 4 & 44,52 & 5,0 \\
Nitrato Sódico & 5 & 55,65 & 6,2 \\
Total de Abonos & 30 & 333,90 & 37,4 \\
Semillero: Gasto mínimo de 94 m² & 3 & 33,39 & 3,7 \\
Riegos: Gasto de 5 ó 6 riegos & 3 & 33,39 & 3,7 \\
Transporte a la estación & 12 & 133,56 & 15,0 \\
Renta & 5 & 55,65 & 6,2 \\
TOTAL & 80,25 & 893,18 & 100 \\
\hline
\end{tabular}

FUENTE: ADM, Administración de Traibuenas de Navarra, 1899.

18 ADM, Administración de Traibuenas de Navarra, 1899. 
En fin, lo más importante era encontrar un buen mediero, "pues su inteligencia, actividad, posición agrícola y honradez han de traducirse en el resultado». Si no se encontraban medieros, siempre quedaba el recurso de arrendar a fábricas. Y así se intentó. En primer lugar, se limitó a los cotos redondos de Las Mejanas y El Espartal la posibilidad de cultivar remolacha; en total, unas 200 hectáreas, tierras que no todas eran aptas para el cultivo, por ser arcillosas, según un ingeniero de la Granja Modelo de Zaragoza. A las posibles carencias orgánicas de la tierra había que añadir otro inconveniente. Su situación, en la otra margen del Ebro, «sin medios fáciles de comunicación con la vía férrea, ni con el Canal Imperial, por el cual se transportará la remolacha a Gallur», encarecería el transporte, agravando el ya de por sí más elevado coste de explotación por estar situado lejos de pueblos y ser necesaria mano de obra abundante. Pese a todo, «aprovechando el furor que hoy se ha desarrollado en esta comarca para que cada fábrica tenga asegurada la producción de la remolacha que ha de consumir", en febrero de 1900 el duque presentó un condicionado de arriendo de esas tierras. ${ }^{19}$ Dichas bases fueron remitidas al consejo de la Azucarera de Gallur, en julio de ese mismo año, y la respuesta fue negativa. En su argumentación, el gerente de la Azucarera insistió en que «corre la voz de que el arrendatario de esas fincas ha de luchar con una cuestión social», propagada por los labradores de los pueblos limítrofes que cultivaban El Espartal y Las Mejanas, "pues — dicen — saldrán perjudicados al quitarles las tierras que llevan en arriendo». Las gestiones para conseguir el arriendo continuaron. Se habló con la Azucarera de Casetas y con La Ibérica, de Zaragoza, pero su respuesta no fue inmediata; también lo hicieron con la Azucarera de Tudela, en este caso a instancias de la propia fábrica. Su consejo de administración, una vez examinadas las tierras por el «director de cultivos» y analizado el precio del arrendamiento, desestimó, en octubre de 1900, el arriendo. El fracaso de las negociaciones condujo al duque a renunciar al cultivo de la remolacha. El 6 de enero de 1901 escribía: «enterado del resultado poco halagüeño de la producción de remola-

19 Se planteaba un arriendo por 10 años, desde primero de octubre de 1902, con una renta anual de 15000 pesetas por las 200 hectáreas que contemplaba. Se dividía la tierra en tres hojas y cada año sólo se podía cultivar una de remolacha; las otras dos, de cereales. Las tierras debían fertilizarse con al menos «dos carretadas de a par de mulas de estiércol», además de los abonos químicos necesarios. La contribución y el agua del Canal de Tauste quedarían por cuenta del duque. 
CUADRO 6

PARTIDAS DE GASTO DE LA ADMINISTRACIÓN DE LOS DUQUES

DE GRANADA DE EGA EN CORTES-BUÑUEL, 1900-1935

(promedios anuales en pesetas corrientes)

\begin{tabular}{|c|c|c|c|c|c|c|c|c|}
\hline \multirow{2}{*}{$\begin{array}{l}\text { Concepto } \\
\text { de gasto }\end{array}$} & \multicolumn{2}{|c|}{$1900-1906$} & \multicolumn{2}{|c|}{$1911-1919$} & \multicolumn{2}{|c|}{$1924-1926$} & \multicolumn{2}{|c|}{ 1931-1935 } \\
\hline & ptas. & $\%$ & ptas. & $\%$ & ptas. & $\%$ & ptas. & $\%$ \\
\hline Salarios & 350 & 1,5 & 802 & 3,2 & 2953 & 3,3 & 6496 & 9,0 \\
\hline Materiales & 5029 & 22,1 & 6739 & 27,1 & 10041 & 11,2 & 21648 & 30,0 \\
\hline Administración & 1626 & 7,1 & 235 & 0,9 & 7042 & 7,9 & 5907 & 8,2 \\
\hline Otros gastos & 120 & 0,5 & 621 & 2,5 & 11315 & 12,7 & 623 & 0,8 \\
\hline Mantenimiento & 5843 & 25,7 & 5231 & 21,0 & 7658 & 8,6 & 11202 & 15,5 \\
\hline Inversiones & 1343 & 5,9 & 3039 & 12,2 & 37001 & 41,4 & 3739 & 5,2 \\
\hline Contribuciones & 8455 & 37,1 & 8194 & 33,0 & 13319 & 14,9 & 22571 & 31,3 \\
\hline Remesas & 23917 & - & 2889 & - & 83223 & - & 91951 & - \\
\hline Suma sin remesas & 22766 & 100 & 24861 & 100 & 89328 & 100 & 72187 & 100 \\
\hline Sin inversiones & 22766 & & 21822 & & 52328 & & 68447 & \\
\hline Índices & 100 & & 96 & & 230 & & 301 & \\
\hline
\end{tabular}

FUENTE: ADM, Cuentas anuales y Cuaderno de frutos. Elaboración propia.

cha, parece más natural desistir de esa labor y volver al anterior sistema». En los siguientes años no habrá noticias sobre cultivo de remolacha en la correspondencia de la administración de Cortes; es decir, parece que desistió, lo cual no fue óbice para que los colonos, a título particular, se dedicasen a ese cultivo. ${ }^{20}$

La composición del gasto en la administración de Cortes refleja este repliegue conservador. El gasto salarial se reduce a un mínimo $(1,5 \%$ del gasto total), al tiempo que las inversiones se limitan a la luición de un censo. El grueso del gasto se concentra así en la adquisición de inputs (básicamente en el pago del canon de agua de riego a los canales de Tauste e Imperial de Aragón), en mantenimiento (reparaciones de edificios, especialmente del castillo, seguro de incendios y sueldos de guardas) y en contribuciones. En conjunto, la cuantía del gasto anual para el primer sexenio del nuevo siglo se había reducido en un $33 \%$ respecto a 1891 1893, y hasta en un 50\% respecto a 1884-1887. Merece destacarse de

20 En 1901-1902 fueron 16 cultivadores, que abonaban un recargo en la renta por cultivar remolacha; en total, 18,28 hectolitros. En 1902-1903, 23 cultivadores que abonaban 23,35 hectolitros. Al año siguiente, 24 que pagaban 24,75 hL. 
CUADRO 7

INGRESOS DE LA ADMINISTRACIÓN DEL CONDE DE ZALDÍVAR EN CORTES-BUÑUEL, 1862-1919 (promedios anuales en pesetas corrientes)

\begin{tabular}{|l|r|r|r|r|r|r|r|r|}
\hline Concepto & $1862-67$ & $1868-73$ & $1884-87$ & $1891-93$ & $1900-06$ & $1911-19$ & $1924-26$ & $1931-35$ \\
\hline Trigo (I) & 30860 & 34533 & 24794 & - & - & - & - & - \\
Trigo (II) & 1439 & 1000 & 8162 & 25447 & 34622 & 0 & 89737 & 86854 \\
Granos & 1515 & 333 & 0 & 1837 & 0 & 0 & 0 & 3099 \\
Vino & 2879 & 9865 & 21837 & 611 & 0 & 0 & 0 & 0 \\
Remolacha & 0 & 0 & 0 & 0 & 0 & 0 & 0 & 11871 \\
Alfalfa & 0 & 0 & 0 & 0 & 0 & 0 & 0 & 2750 \\
Pecuarios & 593 & 1883 & 1158 & 640 & 0 & 0 & 0 & 0 \\
Maderas y otros & 576 & 1213 & 1809 & 685 & 0 & 2195 & 5756 & 2709 \\
Venta trigo & 30860 & 34533 & 24794 & 25447 & 34622 & $? ?$ & 89737 & 86854 \\
Ventas productos & 5563 & 13293 & 24804 & 3773 & 0 & 2195 & 5756 & 20429 \\
Alquileres & 4597 & 4902 & 5056 & 4693 & 9064 & 11289 & 32225 & 20607 \\
Otros ingresos & 173 & 83 & 281 & 174 & 557 & 1465 & 43 & 2354 \\
Ventas patrimonio & 0 & 156 & 0 & 0 & 0 & 33 & 15029 & 5281 \\
Remesas & 52385 & 15787 & 33416 & 24804 & 0 & 12756 & 29608 & 21597 \\
Suma sin remesas & 41 193 & 52967 & 54935 & 34087 & 44244 & 14982 & 142790 & 135525 \\
\hline Trigo (I) recoge el importe de las ventas de trigo según las anotaciones del cuaderno de frutos \\
(1859-1888). Trigo (II) recoge los ingresos por venta de trigo según aparece en las cuentas genera- \\
les presentadas por el administrador. Estas últimas no recogen al parecer una parte sustancial del \\
importe abonado por las casas de comercio de Zaragoza con las que se contrató la venta del trigo, \\
ya que debía ser girado directamente al conde en Madrid. En 1911-1919 el trigo de rentas era reme- \\
sado a la administración de Traibuenas para su venta.
\end{tabular}

FUENTE: ADM, Cuentas anuales y Cuaderno de frutos. Elaboración propia.

igual modo el drástico recorte en los gastos de administración, plenamente perceptible en el periodo 1911-1919, y que es debido a la supresión del empleo de administrador en Cortes. Durante esas primeras dos décadas del novecientos la administración de la hacienda sería responsabilidad del administrador de Traibuenas, el citado Arilla de Ciraco. ${ }^{21}$

Advertimos, por tanto, un relativo abandono de la antaño mimada administración de Cortes, convertida ahora en una pieza más de un conglomerado patrimonial mucho más amplio. Se desecha sin contemplaciones la posibilidad de retornar al cultivo directo en nuevas líneas de especialización e incluso se renuncia a contar con un agente sobre el terreno capaz

21 Jesús Arilla de Ciraco era él mismo un importante terrateniente de la comarca del Bajo Aragón, llegando a declarar 595,46 hectáreas en 1933 en el Registro de la Propiedad Expropiable. 
de sostener una estrategia fundada en aparcerías. La gestión se reduce al cobro de rentas en trigo y en metálico, así como a la venta de maderas y leñas de Las Mejanas. Hacia 1911-1919 los desembolsos en salarios se habían elevado algo, debido a la participación en un "medial» sobre unas 40 hectáreas, que llegó a reportar en 1913 unos 373 hectolitros de trigo. La adquisición de inputs aumentaba su cuantía por la compra de fertilizantes y semillas; se sostenía el gasto en reparaciones de inmuebles, arreglos de caminos y fincas, limpieza de acequias, etc.; y hasta aparecían desembolsos de cierta importancia relativos a obras de defensa en las márgenes del río o a mejoras (nivelaciones, cercamientos) en algunas fincas. Abandono de la administración directa no equivale, al parecer, a descuido de la hacienda.

Lamentablemente, no podemos conocer con exactitud lo que esa gestión de tono bajo pudo reportar a sus propietarios. El trigo cobrado de rentas era probablemente remesado a Traibuenas, donde el administrador se encargaba de su comercialización, y no ha dejado por ello huella en la contabilidad que hemos manejado. Lo que se deduce de la observación de la estructura del ingreso es que para la década de 1910 se habían incrementado sustancialmente las entradas por arrendamientos, tanto por la elevación del precio de los pastos (desde 2550 ptas. en 1884-1887 hasta 5521 en 1917-1919) como por la subida más moderada de los alquileres de las viviendas, y por la aparición de una práctica cada vez más extendi$\mathrm{da}$, la de entregar el importe de las rentas en grano en un equivalente pactado en metálico. Las características de la gestión, tanto desde el punto de vista del ingreso como del gasto, iban no obstante a registrar algunas ligeras alteraciones en la década de 1920, tras un nuevo cambio de titular.

\section{Concepción Azlor de Aragón y Hurtado de Zaldívar, bajo el signo de la reforma agraria (1923-1936)}

En abril de 1919 moría el vi duque de Granada de Ega y tres años más tarde, el mismo mes, lo hacía su esposa. El 12 de julio de 1923 se resolvía la testamentaría adjudicando las haciendas de Cortes y Peralta a María Concepción Azlor Hurtado de Zaldívar (1878-1969), XIII condesa de Sinarcas y XXI vizcondesa de Villanova, casada desde 1904 con Luis de Silva y Carvajal, 
duque de Miranda y IV conde de La Unión. ${ }^{22}$ Desgajado así de la «Administración General de la Casa de los Villahermosa, Granada de Ega y Luna», se hizo indispensable volver a contratar un administrador con sede en Cortes, que entró a servir con el mismo sueldo (3000 pesetas) que cuarenta años atrás.

Pocos cambios más se perciben en esos primeros años con los nuevos titulares: el incremento de la cuantía del gasto en salarios y en inputs (cuyo $93 \%$ siguen siendo cánones de agua de riego) parece tener más que ver con la fuerte inflación de los años anteriores que con una mayor implicación en el cultivo. Crecieron, claro, los gastos de administración, tanto por la presencia del nuevo empleado como por los desembolsos derivados de notarías y agrimensura. Por su parte, el capítulo de otros gastos acusa una prolongada estancia de los propietarios en 1926. Únicamente el crecimiento del capítulo de inversiones supone una nota distintiva respecto a años anteriores. La cifra refleja la compra de varios edificios, los gastos en la traída de aguas, la instalación de una motobomba en la huerta y la construcción de una barca de sirga para vadear el Ebro hasta la finca de Las Mejanas. ${ }^{23}$

Para entonces el panorama de la industria azucarera había cambiado. La derogación de la Ley Osma había permitido la instalación en 1917 de dos fábricas azucareras en el pueblo de Cortes, la una dependiente de la Sociedad Azucarera del Ebro y la otra de la Sociedad General Azucarera de España. La competencia entre ambas pudo favorecer los intereses de los cultivadores, aunque bien pronto se hicieron notar los problemas de sobreproducción. En cualquier caso, no será hasta 1928 cuando volvamos a encontrar noticias referidas a la remolacha en la documentación de la hacienda. Ese año fueron 312 los colonos del duque, con una superficie arrendada de 846,80 hectáreas. El resto, 65,14 hectáreas, las dedicaría al cultivo de la remolacha, trigo, maíz y alfalfa en «mediaría». ${ }^{24}$

22 <http://users.swing.be/sw.239020/sangre/nindex.htm>.

23 No podemos responder de momento al interrogante que surge de inmediato al conocer este dato: ¿por qué no se acometió antes esa inversión que hubiese resuelto los problemas de distancia y acceso a la finca de Las Mejanas de Santa Isabel?

24 El 27 de febrero de 1929, la Azucarera del Ebro le envió el contrato para la siguiente campaña de remolacha. En total, 54 hectáreas; 45 del duque, y el resto del propio administrador de la hacienda del duque. A los tres meses recibiría $5000 \mathrm{~kg}$ de nitrato de sosa y $600 \mathrm{~kg}$ de semilla. La mediería de trigo supuso, en 1930, un total de 189 hectolitros. De las dos fábricas instaladas en 1917, La Raperie cerró sus puertas en 1922, mientras que La Regional terminó por hacerlo en 1933. 
La estructura del gasto en el quinquenio 1931-1935 refleja ese mayor empeño de los propietarios, con un incremento en términos absolutos y relativos del gasto en inputs $(30 \%)$ y en salarios $(9 \%)$. El gasto en administración revela el aumento del salario del gestor hasta 5000 pesetas, junto a nuevas partidas como el teléfono. Por su parte, el gasto en mantenimiento se resuelve en reparaciones de edificios, arreglos de la barca y los caminos, seguro de incendios y accidentes y sueldos y "retiro obrero» de los guardas. Por último, apenas hay inversiones productivas, ya que el grueso del gasto extraordinario se destina a obras en el palacio. Por el lado del ingreso, aparecen las ventas de remolacha y alfalfa junto a las de otros productos con mayor tradición (trigo, maíz, maderas), aunque estos nuevos productos resultantes de los contratos de aparcería no llegan a superar el $10 \%$ del ingreso total.

En definitiva, aunque advertimos tras el cambio de propietarios una vigilancia más atenta y una mayor implicación en el cultivo a través del recurso a la aparcería, al tiempo que la recuperación de cierto pulso inversor, la administración de Cortes continuó descansando sobre el esfuerzo productivo de los agricultores, grandes y pequeños, que asumían los arriendos y los mediales. Éstos eran escogidos entre una población que no había dejado de crecer a buen ritmo a lo largo de los últimos cuarenta o cincuenta años. La tasa de crecimiento demográfico acumulativo de la localidad entre 1887 y 1940 se situó en un 1,25\% anual, alcanzando en la década de 1910 la proporción del 2,3\% al año. Qué duda cabe de que, en parte, este crecimiento respondió a las nuevas oportunidades de empleo tanto en la industria agroalimentaria como en las obras públicas (canal de Lodosa), pero también a la intensificación del cultivo en el regadío y a la roturación del secano. Las estructuras de propiedad de la tierra no presentan, sin embargo, un panorama excesivamente halagüeño para ese enjambre de campesinos si no fuese por la ampliación del reparto de parcelas de comunal. Si en 1890 eran 572 hectáreas y en 1912 se mantenían en 586, para 1940 ya llegaban a 1363, de las que 954 eran de regadío. Los aprovechamientos agrícolas del comunal servían tanto para disminuir la presión de la miseria como para robustecer la capacidad productiva de algunos grandes labradores. Pero por lo que se refiere estrictamente a la propiedad privada, el lapso 1890-1912 contempló tanto una reducción del número de propietarios como un debilitamiento patrimonial de los menos afortunados. Entre 1912 y 1940 el número de propietarios volvió 
a crecer, pero la tendencia que observamos se puede sintetizar en una multiplicación de los ínfimos propietarios y en un fortalecimiento de los tramos intermedios situados entre 5 y 50 hectáreas. El catastro revela además una suave aunque continuada erosión del patrimonio ducal, que pierde 50 hectáreas entre 1890 y 1940.

Es en ese escenario en el que se produce la proclamación de la Segunda República, que viene a aflorar las tensiones subyacentes en estas localidades, y que los propietarios vivieron con incertidumbre y preocupación. "Mucho me acuerdo de usted en estos días y espero que no le haya ocurrido nada desagradable; por aquí ha habido mucha animación y ya parece que se ha entrado en la normalidad», escribía, desde Madrid, el administrador del duque nada más instalarse el nuevo régimen político. Normalidad que bien puede referirse a una relativa mitigación de la animación callejera; no tanto, con el futuro inmediato, ya que, además de verse despojados temporalmente de sus títulos, la situación política y la conflictividad social les iría pasando factura. ${ }^{25}$ Confiados sus ingresos a la percepción de las rentas y a su posterior inserción en el mercado, la irregular evolución de aquel proceso y los vaivenes de éste, en función de cambiantes coyunturas políticas, les hicieron muy vulnerables.

CUADRO 8

DISTRIBUCIÓN DE LA PROPIEDAD PRIVADA DE LA TIERRA EN CORTES, 1890-1940

\begin{tabular}{|c|c|c|c|c|c|c|c|c|c|}
\hline & \multicolumn{3}{|c|}{ Propietarios $\left(n .0^{\circ}\right)$} & \multicolumn{2}{|c|}{ Superficie (ha) } & \multirow[b]{2}{*}{1912} & \multirow[b]{2}{*}{$\%$} & \multirow[b]{2}{*}{ c. 1940} & \multirow[b]{2}{*}{$\%$} \\
\hline & 1890 & 1912 & c. 1940 & 1890 & $\%$ & & & & \\
\hline $0-1$ & 144 & 129 & 174 & 87,96 & 4,3 & 60,92 & 3,3 & 77,86 & 4,2 \\
\hline $1-5$ & 162 & 115 & 139 & 377,34 & 18,7 & 247,13 & 13,6 & 335,19 & 18,0 \\
\hline $5-10$ & 17 & 19 & 27 & 112,91 & 5,6 & 124,33 & 6,8 & 196,69 & 10,6 \\
\hline $10-50$ & 18 & 17 & 23 & 324,45 & 16,0 & 360,04 & 19,7 & 415,26 & 22,3 \\
\hline $50-100$ & 4 & 3 & 0 & 237,83 & 11,8 & 171,93 & 9,4 & 0 & 0 \\
\hline$>100$ & 1 & 1 & 1 & 882,69 & 43,6 & 859,21 & 47,1 & 833,22 & 44,8 \\
\hline Suma & 346 & 284 & 364 & 2023,18 & 100 & 1823,56 & 100 & 1858,22 & 100 \\
\hline Comunal cultivado & $(+65)$ & $(+27)$ & $(+?)$ & 572,48 & & 585,62 & & 1363,42 & \\
\hline Habitantes & 1.291 & 1.577 & 2.505 & & & & & & \\
\hline
\end{tabular}

FUENTE: J. M. Lana Berasain (1997).

25 La conflictividad social durante la Segunda República en Navarra, en Majuelo (1989) y, ceñido al partido de Tudela, Majuelo (1986). 
Desde el mismo año 1931, la correspondencia de la administración se tiñe de tonos negros, alarmados por la "pendiente» que les conducía a la «ruina» y que provocaba el "disgusto» que embargaba a la duquesa cada vez que recibía los estados contables de Cortes. La causa primera de ese "déficit enorme de la administración, que si en tiempos normales es para asustar, en estos mucho más», tenía que ver fundamentalmente con los débitos en las rentas de la tierra y casas. Cansado de recordar «a los deudores la obligación que tenían de pagar sus atrasos», y de escuchar "cosas que no se pueden oír», el administrador parecía resignado, pues "están así las cosas y hay que tener conformación». La respuesta desde la matriz, localizada esos años en Zarauz, proponía tres medidas. Por un lado, presionar a los morosos con amenazas de desahucio; por otro, reducir drásticamente los gastos; y, por último, vender tierras o casas para enjugar el déficit. Cuestiones, de cualquier forma, no sencillas de aplicar. De hecho, pese a que sobre la mesa del administrador se encontraban las disposiciones que regulaban los desahucios desde comienzos de 1932, hasta después de las elecciones de noviembre del 33 no se va a plantear aplicarlo, "pues no me parece prudente hacerlo». Bien por las amenazas, bien por la nueva coyuntura política a partir de ese momento, o bien porque la cosecha fue mejor, el caso fue que al año siguiente el cobro de las rentas parece que se regularizó. No por mucho tiempo; en los días previos a las elecciones del 36 se ralentizó de nuevo, obedeciendo, según decía el administrador, «a la situación política, pues en todos estos pueblos hay un ambiente comunista que les parece que va a ser todo para repartírselo y debido a eso ya no pagan a nadie». Ante ello, y si no era posible normalizar los ingresos, había que ir pensando en limitar los gastos. Porque «ya es bastante con darles la tierra gratis, puesto que no pagan, [como] para regalarles también agua, guarderío, etc. De modo que, si los tiempos están malos para ellos, también lo son para los señores y no tienen fortuna para hacer regalos. Una finca tan importante va resultando una carga y lo mejor sería venderla, pero como esto, hoy por hoy, no puede hacerse en condiciones es preciso aminorar las cargas, suprimiendo los gastos superfluos».

La evolución del mercado de trigo tampoco ayudó a paliar las carencias financieras provocadas por la lenta percepción de las rentas. Desde la lonja de Zaragoza, el comisionado de cereales Enrique Viamonte fue dando puntual información de cómo se movía el mercado y de los contactos que iba estableciendo para colocar el grano. Siempre se vendía, pero 
da la sensación de que no sin dificultades y después de numerosas negociaciones. Viamonte se mostraba, además, muy crítico con la actitud del Gobierno. A su juicio, según relataba en enero de 1936, «este mercado de trigos lo hemos tenido dos meses tan sumamente paralizado que apenas se han hecho operaciones y de todo ello ha sido la causa la intervención del gobierno con su política pues está demostrado que tan sólo hacen estropear todos los negocios». El precio del trigo cayó en la primavera de 1936; se estaba vendiendo a 35 pesetas los 100 kilos, cuando en septiembre de 1931 se había fijado un precio de 46,65 pesetas. No sabía si proceder o no a la venta de toda la partida; mientras tanto, había que colocar algo en el mercado, para evitar apremios por impago de contribuciones o, en su defecto, solicitar un crédito a cuenta del trigo «en la misma forma que lo hacen los ayuntamientos a base de tasación, cobrando el $75 \%$ y pagando al $6 \frac{1}{2}$ de interés».

Por si no fuera suficiente, hubo una sensación de riesgo añadido: el generado por la posible afección de la legislación republicana. Desde el mismo verano del 31, las noticias sobre petición de tierras para arrendar iban a ser frecuentes tanto en Cortes como en Buñuel. El 11 de agosto de ese año, el secretario de la UGT de este último pueblo solicitaba al administrador del duque, tras una reunión de la unión local del sindicato, que los terrenos de El Espartal fuesen arrendados a vecinos de Buñuel y no a forasteros. Su petición se basaba en una peculiar interpretación del decreto del Ministerio de Trabajo de 28 de abril. «No puede permitirse — decían - ni legal ni humanamente que mientras los jornaleros de Buñuel no pueden encontrar quien les facilite jornales, haya individuos ajenos a la localidad que tengan terrenos en arriendo del Sr. Duque». Pese a lo que dijeran los demandantes, la Ley de Términos Municipales no consideraba ilegal el cultivo de las tierras con medieros forasteros, por lo que, tras una respuesta inicial favorable, el administrador respondía que el decreto invocado no amparaba el despido de los actuales colonos y no concedía preferencia para el arrendamiento a los vecinos de la localidad. Tan sólo ofrecía mediar ante aquéllos para que hicieran las operaciones agrícolas con vecinos de ese pueblo. Limitado horizonte que no satisfizo a los jornaleros, quienes solicitaron a la autoridad municipal que intercediese ante los propietarios. Se celebró una reunión entre éstos y la junta directiva de la UGT el 23 de octubre de 1931. En ella se pusieron sobre la mesa las aspiraciones de la central sindical, la cual pretendía que «a cada uno de sus afilia- 
dos que carecen en absoluto de tierra en arriendo se les proporcione de 6 a 8 robadas». En total, de 36 a 54 hectáreas. Dos semanas después, la comisión de propietarios presentaba a la «agrupación de obreros» un condicionado que, tras alguna modificación por parte de estos últimos, parecía definitivo. Se repartirían seis robadas a cada «socio» que no poseyera tierra, pagando la renta que fijasen el jurado mixto o el propietario de acuerdo con la directiva de la UGT; el contrato sería por cinco años, periodo durante el que el propietario proporcionaría al obrero abono suficiente; la garantía de pago sería "la solvencia moral de cada uno", aunque en realidad la propia organización ugetista se encargaba de recoger las rentas y abonarlas a los propietarios, respondiendo, «solidaria y mancomunadamente», de su pago. Las reuniones continuaron en los meses siguientes, participando, incluso, el propio gobernador civil. Finalmente, el 24 de enero de 1932 se firmarían las bases para la cesión de tierras en arriendo.

La experiencia de Buñuel acabaría calando, también, en Cortes, donde a lo largo del verano se produjeron sucesivas reuniones entre propietarios y obreros agrícolas para tratar el tema del arriendo de tierras. El administrador del duque, haciéndose eco de los deseos de éste, no mostró inconveniente alguno en acceder a las peticiones de arrendamiento de tierras, pero respetando siempre a los colonos anteriores. Su compromiso, en este caso, pasaba por invitar a éstos a que cediesen tierra de la que tenían arrendada del duque para repartirla entre los vecinos de Cortes que no poseyeran, y evitar así «la crisis de trabajo» existente. Pero, bien por los recelos que esa medida suscitaba en el administrador, bien por las reticencias de los colonos a cederlas, el caso fue que, todavía en octubre, el administrador seguía haciendo caso omiso de los requerimientos para que fuera a las reuniones o, en su defecto, para que presentara la lista de los colonos que habían aceptado la propuesta de cesión, lo cual no ayudaba a «resolver el conflicto». ${ }^{26}$

El paso de los meses no amainó la petición de tierras en arriendo, sino todo lo contrario, manteniéndose su fuerza reivindicativa y sumándose a otras peticiones. La primavera del 33 fue especialmente intensa. El 25 de

26 Majuelo (1989), p. 169, da cuenta de una invasión de fincas en el Estado de Mora de Cortes por parte de 60 ó 70 vecinos, a mediados de noviembre de 1932. Antes, en abril, fueron talados 85 árboles frutales del duque de Miranda. 
marzo, tras el segundo congreso de la UGT, se desarrollaron por numerosos pueblos de la geografía ribereña una serie de manifestaciones exigiendo el rescate de las corralizas y de los comunales, así como la aplicación de la reforma agraria. También en Cortes, donde es probable que se añadieran a ésas otras reivindicaciones, relacionadas en este caso con las tierras de señorío. En todos los pueblos afectados por su presencia, «había que lograr el cese de los viejos administradores, que una comisión del IRA recogiera las aspiraciones de los colonos y que se otorgase a dichos pueblos como patrimonio comunal las tierras expropiadas». ${ }^{27}$ Con el tiempo, "los tres centros" de Cortes redoblaron sus peticiones de tierras, amenazando con una huelga si no se las concedían. El 13 de mayo se reunieron más de cien vecinos en Cortes, entre propietarios, obreros y colonos, para intentar llegar a un acuerdo. No fue posible, ya que «unos quieren dejar tierras y otros no». El administrador, en tierra de nadie, seguía insistiendo en mostrarse proclive a los repartos, siempre que los colonos lo quisieran; la responsabilidad, para éstos y para el resto de propietarios. Finalmente, el 11 de junio de 1933 se concretó la huelga anunciada, «algo seria pues vinieron unas cuantas parejas de la guardia civil», aunque "no ha ocurrido nada que lamentar [salvo] unos cuantos días de paro general». Fueron tres días de huelga y en ella participaron la UGT, la CNT y el Sindicato Agrícola San Juan Bautista, quienes se posicionaron, entre otras cuestiones, por una reducción de los diez años de vecindad que se exigían para tener derecho al reparto de parcelas.

El segundo momento coincidió con las protestas de junio del 34. En Buñuel tuvo una gran repercusión, participando los más de 300 afiliados que la UGT tenía en ese pueblo. Distribuidos en pequeños grupos, fueron consiguiendo que las labores del campo se paralizasen, no siempre de forma pacífica, por lo que las coacciones darían lugar a unas cuantas denuncias. ${ }^{28} \mathrm{El}$ comité de huelga de Buñuel acabaría presentando una propuesta; su aceptación era la condición para volver al trabajo. Decían: «Que todas esas grandes cantidades de tierra que de otros mayores propietarios tienen en su poder algunos señores especuladores por los sistemas de mediales y a la tercera, sean arrendadas de un modo global a la UGT, para

27 Majuelo (1989), pp. 192-193.

28 Majuelo (1989), p. 236. También hubo paros en Cortes. 
ellos repartirlos del modo más justo entre todos los obreros del pueblo con arreglo a las necesidades de cada familia». ${ }^{29}$

Las peticiones de tierra continuaron, de cualquier forma, tras los sucesos de octubre de $1934 .{ }^{30}$ La comisión nombrada en Buñuel para resolver esa cuestión todavía solicitaba, en noviembre de ese año, datos para realizar el «estudio del reparto de tierra en arrendamiento con todo detalle y pueda dar las normas a seguir en dicho reparto dentro de los más elementales principios de equidad y justicia».

El reparto de tierras en arrendamiento no afectaba, teóricamente, a la percepción de las rentas, «garantizadas» por la agrupación socialista. Tampoco, pese a todo, a las posibles reclamaciones de rentas fruto de la aplicación de la legislación republicana. A Peralta llegó un sujeto de Calahorra, «alentando a los arrendatarios a pedir la revisión de las rentas». Fueron en ese pueblo más de 800 las reclamaciones que esas «aves negras» o «abogados y redentores del pobre» lograron; de ellas, tan sólo 24 al duque, debido a que, «seguramente, la de los Sres. Duques [será] la hoja de rentas que menos alteraciones ha sufrido y la casa que más tolerancia usa para con los arrendatarios, los cuales son considerados como dueños».

Nada, sin embargo, comparado con los efectos que la aplicación de la Ley de Reforma Agraria podía tener sobre la hacienda de Cortes. ${ }^{31}$ En Navarra fue la UGT, en su primer Congreso Obrero Agrario, celebrado a comienzos de octubre de 1931, quien solicitó que los señoríos fueran expropiados para ser incorporados al disfrute del comunal. La reforma agraria en Navarra, como señala Majuelo, era «sustancialmente el proble-

29 El «ex-duque de Miranda» debía ceder unas 27 hectáreas. El cinco de enero de 1934 escribía el administrador a la duquesa en estos términos: «El día primero aquí mandaron los socialistas, con todo género de insultos para las derechas, pero por fin se terminó el día sin daños mayores y anoche hubo un mitin pidiendo las tierras para el que la trabaja».

30 Desde Cortes dicen que el 6 de octubre estuvieron «expuestos a una catástrofe, pues salieron de madrugada con armas y cortaron todas las comunicaciones, dirigiéndose primero al ayuntamiento dando vivas al comunismo libertario con propósito de apoderarse, lo que no consiguieron por tener noticias de que venía fuerza de Tudela, que al pasar por Mallén mataron a un cabo e hirieron a dos guardias más». Ese día ardió un pajar de un propietario.

31 Sobre la reforma agraria republicana y sus circunstancias, vid. Malefakis (1970), Robledo (1996). 
ma corralicero», sin olvidar los señoríos, el disfrute equitativo de los comunales o los arrendamientos, entre otros asuntos más. No obstante, tras el pronunciamiento de Sanjurjo, en agosto de 1932, cobraron especial protagonismo los señoríos, acelerándose el proceso de recopilación de datos. El riesgo de perderlo todo parecía real, por lo que la orden ministerial publicada en la Gaceta de Madrid, el 6 de abril de 1933, excluyendo a algunos títulos nobiliarios de la relación de octubre de 1932, entre ellos el duque de Miranda, "Mayordomo Mayor Sumiller de Corps de S. M.», debió de dar un respiro a la casa ducal. La aplicación definitiva de la Ley de Reforma Agraria daría cobertura a una nueva recopilación de datos, creándose, dentro del Instituto de Reforma Agraria, el Registro de la Propiedad Expropiable. ${ }^{32}$

El invierno del 36, con el horizonte electoral de febrero, fue de nuevo intenso en Cortes. Paralizado el mercado de trabajo, quien tenía trigo o maíz lo tuvo que vender a cualquier precio para poder subsistir; quien no lo tenía, como tampoco había jornales, fue radicalizando, en una dirección u otra, su postura, «mezclando en este terreno la política». En ese sentido, frente a consignas como "que todo es vuestro», lanzadas por los propagandistas de izquierdas, había, según el administrador, que proteger a «los de derecha», quienes, «llegado el caso pueden defender algo». Por ese motivo, «no es bastante con mítines derechistas [sino que] necesitan trabajo y comer». ${ }^{33}$ En un ambiente donde parecía que «estamos volviendo a los tiempos de atrás y se están poniendo las cosas imposibles», no resulta extraño que las rentas, como decíamos antes, se volviesen a cobrar lentamente. Como tampoco lo debían ser los miedos que embargaban a la

32 Virto (2002), p. 323, señala que el duque acompañó al monarca al exilio. El 25 de abril de 1934, desde Zarauz, se comunicó que había esperanza de que podría volver pronto el duque, pues «ahora no hay la dificultad de la entrada en España» (ADM, Correspondencia). Preso de una dolencia de riñón, moriría el 6 de marzo de 1935. Conforme a la relación definitiva remitida por la Diputación de Navarra al IRA el 16-II-1933, los bienes de la grandeza de España en la provincia ocupaban 18483 hectáreas. De ellas, 8805 hectáreas (el 47,6\%) en la órbita de los Granada de Ega: 5642, del conde del Real y marqués de Narros en Traibuenas y Mélida; 1329, del duque de Granada de Ega en Javier y Lónguida; 1096, del duque de Miranda en Cortes y Buñuel; y otras 738 más, del marqués de Narros en Zolina (Lana, 1999b), p. 172. El Registro de la Propiedad Expropiable inscribió más de cien mil hectáreas en la provincia (ibíd.), p. 174.

33 La duquesa acabaría donando 1000 pesetas a los obreros de Acción Popular, para "premiar de ese modo su conducta». 
duquesa, quien temía tanto por el trigo que dormitaba en sus graneros como por el rumbo de las elecciones. La primera cuestión resultaba sencilla de resolver, asegurándolo "contra incendio ocasionado por motín o tumulto popular incluido el robo, deterioro y saqueo»; la segunda cuestión, pese a la implicación de la familia con las candidaturas de derechas, se escapaba de sus competencias, y «sus consecuencias en lo que atañe a Cortes son sabidas si perdemos». Con el paso de los meses, «la cuestión social — decía el administrador - era cada vez peor, se está implantando la bolsa de trabajo, que es una torre de Babel»; el mercado del trigo, animado en junio en Zaragoza, decaería en julio en la plaza de Barcelona, auténtico «mercado regulador» para la zona.

El 18 de julio de 1936 llegarían los ecos del golpe militar. El administrador de la duquesa fue encarcelado por «los rojos», aunque sólo por tres horas, ya que entonces se impusieron en Cortes «las derechas». La duquesa no tuvo tanta suerte, aunque "después de una horrorosa temporada pudo salir de Madrid y llegar a Portugal», desde donde se trasladó a la plaza fuerte de Salamanca. Sus dos hijos, mientras tanto, «luchando por el bien de España».

\section{Como conclusión}

En esta comunicación se ha trazado un recorrido por las formas de gestión de un gran patrimonio del valle medio del Ebro desde su adquisición por compraventa en 1859 hasta el estallido de la Guerra Civil.

Durante la segunda mitad del siglo XIX asistimos al despliegue de una ambiciosa apuesta por la inversión y el cultivo directo. La administración de la hacienda se consolidó en la década de 1860 como una gestión mixta con explotación directa de viñedos, olivar, huerta, cereal, alameda y bodega, junto con un pequeño hato de ganado, y cesión en arrendamiento de tierras de labor, casas y pastos. Pero esta apuesta fue paulatinamente abandonada a lo largo del último tercio del siglo: en 1867 fue el cultivo directo de cereales en Las Mejanas el que quedó orillado; en 1896 lo fueron los viñedos y la bodega; por entonces también se renunciaba a la cría de ganado.

Con el cambio de siglo y de titular, la gestión de la hacienda experimentó una transformación radical. El gasto se redujo a lo imprescindible 
y se optó masivamente por la cesión de toda la tierra en arrendamiento, y ocasionalmente en aparcería. Las nuevas alternativas que emergieron en esos años, como por ejemplo la remolacha azucarera, no merecieron, tras una atenta consideración, una renovada apuesta por el cultivo directo. Se había impuesto con rotundidad la opción rentista.

Creemos que, más allá de avatares personales o generacionales, de contingencias sociológicas o psicológicas, el episodio tiene una proyección más general. Revela de modo nítido las posibilidades y los límites del capitalismo agrario en las condiciones que encontramos en la Europa de 18501930. Un proyecto tan ambicioso como el definido por Zaldívar en la próspera coyuntura de 1850, a pesar de contar con buenas condiciones, como eran riego seguro, buenas comunicaciones y disposición de capital, no pudo impulsar un aumento suficiente de la productividad y pereció víctima de las contradicciones planteadas por el manejo de la fuerza de trabajo y las fluctuaciones de los mercados agrarios.

El contraste entre los ingresos y los gastos de la explotación en términos de moneda constante (cuadro 9) permite comprobar la racionalidad, desde el punto de vista estrictamente empresarial, de este viraje. En los años en que se mantuvo la explotación directa, el ingreso neto de la casa se nos ofrece como irregular y de menor cuantía y proporción que el que

\section{CUADRO 9}

ESTIMACIÓN DE LA RENTA DE LA ADMINISTRACIÓN DEL CONDE DE ZALDÍVAR EN CORTES-BUÑUEL, 1862-1919 (promedios anuales en pesetas de 1913)

\begin{tabular}{|l|r|r|r|r|r|r|r|r|}
\hline Concepto & $1862-67$ & $1868-73$ & $1884-87$ & $1891-93$ & $1900-06$ & $1911-19$ & $1924-26$ & $1931-35$ \\
\hline Ingresos sin remesas & 36591 & 52060 & 43988 & 31696 & 36437 & 12006 & 66862 & 64015 \\
Gastos sin remesas & 65819 & 35699 & 41484 & 31331 & 18605 & 20113 & 41512 & 34340 \\
Renta & -29227 & +16360 & +2504 & +365 & +17832 & -8107 & +25350 & +29675 \\
Ingresos ordinarios & 36591 & 52060 & 43988 & 31696 & 36437 & 11983 & 59842 & 61495 \\
Gastos ordinarios & 40829 & 30894 & 37969 & 31285 & 18605 & 17269 & 35264 & 32600 \\
Renta & -4238 & +21166 & +6019 & +411 & +17832 & -5286 & +24578 & +28895 \\
Renta en \% de ingreso & $-11,6$ & 40,7 & 13,7 & 1,3 & 48,9 & - & 41,1 & 47,0 \\
\hline
\end{tabular}

FUENTE: Cuadros 3,6 y 7 . Los datos se han deflactado utilizando el índice de precios de Navarra (Lana, 2007). 
obtuvieron durante el primer tercio del siglo XX con un modelo de gestión fundamentado en la renta. ${ }^{34}$ En definitiva, ese cambio en el modelo de gestión no podemos por menos que atribuirlo a un cálculo racional efectuado en un contexto histórico, el de la crisis agraria finisecular, en que, parafraseando a Koning, el capitalismo agrario certificaba su fracaso.

Pero el triunfo del rentista en ese contexto no dejaba de tener contrapartidas a medio y largo plazo. Por un lado, al hacer descansar los ingresos sobre el cobro de las rentas y alquileres, abría un flanco vulnerable, al ligar la regularidad del ingreso con la voluntad o capacidad de pago de los inquilinos, obligando a gastos crecientes para hacer frente a la morosidad. Por otra parte, al consolidar una imagen parasitaria del propietario en un contexto de creciente movilización política de las masas, contribuía a deslegitimar la propiedad y a legitimar los argumentos a favor de una reforma agraria que hiciese realidad el lema "La tierra para quien la trabaja».

El patrimonio Zaldívar-Granada de Ega llegaría así a 1932 como un ejemplo de comportamiento absentista que justificaba plenamente la aplicación de la ley de bases para la reforma agraria, en un contexto local de agitación y movilización campesina.

34 Es, en efecto, durante el primer tercio del siglo Xx, bajo el modelo de gestión basado en la renta, cuando la proporción del ingreso neto se acerca mínimamente a los niveles que podemos encontrar en otras regiones con economías más dinámicas, como es el caso de los grandes patrimonios ingleses estudiados por Perren (1970), p. 39, en los cuales la proporción oscilaba entre el 42,6\% del duque de Bedford en 1890-1892 y el 86,5\% de un gran patrimonio de Suffolk en 1872-1874, con un promedio del $62 \%$. 



\section{EL DECLIVE DE UNA CASA ARISTOCRÁTICA EN CASTILLA LA VIEJA Y LEÓN: LAS ADMINISTRACIONES DE LOS ALBURQUERQUE EN LA PRIMERA MITAD DEL SIGLO XX Rafael Serrano García \\ (Instituto Universitario de Historia «Simancas»)}

El estudio que aquí se presenta está referido al patrimonio, ya extremadamente mermado y en buena medida reducido a elementos simbólicos, como castillos o grandes casonas, que la casa nobiliaria de AlcañicesAlburquerque aún conservaba en Castilla la Vieja y León en la primera mitad del siglo Xx. Debe advertirse, con todo, que la documentación disponible, pese a su riqueza y a que ha permitido la realización de importantes investigaciones, ${ }^{1}$ flaquea un poco por lo que se refiere a los fondos del siglo XX, ya que no existe continuidad en cuanto a la correspondencia mantenida con las distintas administraciones ni, tampoco, por lo que se refiere a la conservación de las cuentas anuales. Así, la etapa que se perfila mejor de cara a su estudio es la que va de los años finales de la dictadura de Primo de Rivera al primer franquismo, por lo que nuestro análisis irá referido básicamente a esos años $\mathrm{y}$, con especialidad, al interesante quinquenio 1931-1936, cuando la gestión y la continuidad misma del patri-

1 Carmona Pidal (1991) y (2001). 
monio se verá interferida por la legislación republicana y por una contestación social susceptible de diferentes lecturas según los casos contemplados. Creemos que es justamente esta conflictividad la que otorga un mayor interés al estudio de cómo se administró este patrimonio, ya en neto declive, pero en que aún funcionaban en el imaginario colectivo y en la mentalidad de los administradores poderosos simbolismos ligados al antiguo poder señorial. Deseamos advertir, por último, que, como contrapartida a esa escasa documentación, hemos podido conectar con la familia que llevó la administración local de Cuéllar y, luego, la general en Madrid desde finales de los años 1940, que nos ha proporcionado información de primera mano y un libro copiador de correspondencia. ${ }^{2}$

1. La casa nobiliaria en cuestión mantuvo un muy considerable patrimonio en Castilla la Vieja y León hasta aproximadamente la década de 1870, en que dicha masa de bienes inició una sensible merma no tanto por una mala gestión, como ocurrió con Osuna, sino por los gastos derivados de la implicación del duque de Sesto, luego marqués de Alcañices, en la restauración alfonsina, asumiendo importantes compromisos. ${ }^{3}$ Pero todavía en 1868 , en que se hizo un detalladísimo y veraz inventario ${ }^{4}$ —en vísperas, pues, de dicha implicación-, la casa contaba con 25 administraciones, ${ }^{5}$ de las que nada menos que 16 se ubicaban en el territorio castellano y leonés, entre ellas algunas de las más importantes por su extensión o por el volumen de sus rentas, como Salamanca, la primera en ambos conceptos, o Toro. Ello indicaba que, como en otras viejas casas nobiliarias, la base del primitivo poder señorial castellano se había originado en los antiguos reinos de León y de Castilla.

Es verdad que al lado de esos potentes estados de Salamanca o Toro había otras administraciones que eran ya poco menos que simbólicas,

2 Nos referimos a D. Segundo Velasco, hijo del último administrador de la casa, a quien agradecemos sus informaciones.

3 En el archivo citado de la casa ducal de Alburquerque, en Cuéllar (en adelante, ACDA), existe una abundante correspondencia (legs. 631-638) del marqués de Alcañices, que podría ser interesante estudiar desde la perspectiva citada.

4 Carmona Pidal (2001), pp. 118-122.

5 Carmona Pidal (2001), cuadro de pp. 132-133. En otro lugar del texto, sin embargo (p. 119), el autor habla de la existencia de 34 administraciones. 
como Mombeltrán, resto de un antiguo estado señorial que, aparte del castillo, sólo reunía dieciséis hectáreas o, más aún, Ayóo, que en la fecha referida no llegaba ni siquiera a una hectárea. Otras, como Grajal o Alcañices, no llegaban al centenar, pero aquí los ingresos nobiliarios provenían de otra fuente, la percepción de foros y censos.

A partir del Sexenio hubo un drástico recorte, desmantelamiento incluso, del patrimonio total de los marqueses de Alcañices, y más especialmente del ubicado en el territorio castellano y leonés. De hecho, en 1909 , en que se realizó nuevo inventario a la muerte de José Osorio, las tierras en poder de la casa habían disminuido en dos terceras partes, pasando de 35400 a 12300 hectáreas, en cifras aproximadas, aun cuando el valor de lo subsistente se hubiera incrementado. Esa merma afectó brutalmente a los estados ubicados en Castilla y León, de tal modo que de los dieciséis que aún existían en 1868 sólo quedaban tres en la última fecha, los de Mombeltrán, Cuéllar y Alcañices, que son los que van a subsistir en la etapa estudiada aquí. Es verdad que en todo este proceso de desmantelamiento hubo margen para algunas adquisiciones, siendo en Alcañices donde la casa amplió más sus posesiones, comprando diversos montes de poco valor, pero que totalizaban aproximadamente 1200 hectáreas en 1909. Cuellár, donde la masa patrimonial consistía todavía en dos extensos pinares, también incrementó levemente su superficie entre los dos inventarios referidos, situándose cerca de las 2000 hectáreas. Todo lo demás se vendió, de forma vertiginosa en algún caso, como el estado de Toro, que fue enajenado en bloque al financiero y comerciante cántabro Jerónimo Ruiz de la Parra, o el de Salamanca, cuyas doce mil hectáreas se enajenaron en apenas seis años, entre 1872 y 1877 . Cabría afirmar, por las fechas de estas operaciones, que lo vendido en esta provincia y en Toro hubo de coadyuvar en no pequeña medida a la financiación de la causa alfonsina.

Con todas estas ventas, los estados que quedaban en poder de los Alcañices en 1909 eran sólo ocho, siendo las piezas más importantes por su extensión superficial los de Cadreíta, en Navarra, Noez, en Toledo, Lebrija, Cuéllar y Alcañices, y eso que Cuéllar pronto sería reducido a un papel simbólico más que otra cosa, ya que los ricos pinares de Losáñez y La Serreta fueron vendidos a la Unión Resinera Española. Por tanto, las administraciones en Castilla y León, con excepción de la de Alcañices, que aún conservaba una cierta importancia económica, y donde aparte de 
foros y censos se contaba con una considerable extensión de montes, habían quedado reducidas a la mínima expresión, subsistiendo aquellas que, como la de Cuéllar, se vinculaban más directamente a las tradiciones de la casa nobiliaria y mantenían viva la memoria de pasados más gloriosos y prósperos. ${ }^{6}$ Para la larga subsistencia de la de Mombeltrán, en cambio, no tenemos por el momento explicación, dada su inconsistencia económica, que venía de muy atrás. Quizás lo que le interesaba a la casa era el castillo que recordaba la jurisdicción que Beltrán de la Cueva, el fundador de la estirpe de los Alburquerque, había ejercido sobre el lugar. O, tal vez, no se había recibido una oferta remuneradora por los dispersos bienes que formaban aquel estado: de hecho, durante la Segunda República se intentó llevar a cabo dicha venta. Es cierto, con todo, que Mombeltrán, pese a su carácter poco menos que irrelevante, aportaba generalmente ingresos, más que gastos, a la administración central.

2. Veamos, en efecto, en qué consistían dichas administraciones, qué bienes conservaban y qué problemas acarreaban en cuanto a su gestión. Alcañices, la más importante, era el estado y título que daba nombre a la casa (al menos hasta 1909, en que su nuevo titular optó por el título de duque de Alburquerque), pese a que, en puridad, había otros linajes más antiguos. Dicho estado radica en la parte más occidental de la provincia de Zamora, lindando con Portugal, y se situaba, junto a otros pertenecientes a diversas casas de la nobleza española, en una comarca intensamente feudalizada y marcada de forma duradera por las jurisdicciones nobiliarias del Antiguo Régimen, ya que allí habían subsistido, pese a la reforma agraria liberal, todo un conjunto de prestaciones, como foros, bodos y noveno, que sus respectivos titulares percibían en Alcañices, sin duda el estado más extenso, pues comprendía cincuenta y tres pueblos, y en los de Tábara y Alba. ${ }^{7}$

El de Alcañices reunía todavía, en el primer tercio del siglo XX, varios montes escasamente productivos, situados en localidades como Vivinera,

6 En 1903, todavía subsistían, además de las citadas, administraciones como las de Benavente (titular: José Jalón), Fuensaldaña (íd.: Ignacio M. ${ }^{a}$ Pizarro), Grajal de Campos (íd.: Antonio Sánchez Guaza) o Ledesma (ACDA, leg. 691, 1903, correspondencia con distintos administradores). En Ledesma aún se cobraba el derecho de pontazgo, que había dado pie a un largo litigio que subsistió hasta su venta al Ayuntamiento en 1909 (Torijano Pérez, 2000), pp. 135 y ss.

7 Un estudio específico, en Moreno Sebastián (1993). 
Pobladura, Tolilla o Trabazos, varias huertas y toda una serie de pensiones forales en proceso de desaparición a través de acuerdos de redención que se aceleraron en las primeras décadas del siglo, ya que, si en 1909, en el inventario ya mencionado, aún se consignan como propiedad de la casa 53 foros en otros tantos pueblos, en 1928, según el estado de cuentas que remite el administrador, sólo quedaban 16, y ello respondía a una voluntad compartida de liquidar un tipo de rentas que se habían tornado muy problemáticas desde la Revolución liberal, elevando los costes de transacción y contaminando probablemente, por ese componente tardofeudal, la percepción de otras rentas más seguras y el disfrute tranquilo de los bienes del marquesado. ${ }^{8}$ Creemos, en efecto, que la renacida conflictividad que se vivió en la comarca de Alcañices en la etapa de nuestro estudio se debió a ese problema irresuelto, por lo que no debe extrañar que el administrador de Zamora lamentara, en tiempos ya de la Segunda República, que esos dieciséis pueblos no hubieran optado por la vía de la redención. ${ }^{9}$

Debe puntualizarse que dichas pensiones forales no eran exactamente las que la casa percibía en el Antiguo Régimen, ya que, tras la Concordia de 1845 con que las partes pusieron fin a un largo litigio y al impago de aquéllas, que databa del sexenio absolutista (1814-1820), desaparecían los foros particulares y a cada pueblo se le asignaba una cantidad fija, a pagar en especie y en dinero, que recaudarían los ayuntamientos. ${ }^{10}$ Con ello, además, la responsabilidad del pago de la suma correspondiente se trasladaba al conjunto del vecindario, dando pie a una movilización de mayores dimensiones en caso de nuevo conflicto, como iba a ocurrir en la Segunda República. Debe precisarse que dichas pensiones subsistentes aún aportaban el grueso de la recaudación en el estado, cerca de 5500 pesetas sobre un cargo total de 7730, siempre en 1928. Y la casa conservaba aún el derecho de presentación de ecónomos en los curatos del marquesado y creemos que percibía una cantidad por su ejercicio, si bien dicho extremo no lo hemos

8 Resulta expresivo el que en 1868 la renta en metálico aportada por foros, censos, concordias y cargas de justicia supusiera 620174 rs., en tanto que en 1910 hubiera descendido a 67446 (Carmona Pidal, 1991), p. 126.

9 ACDA, leg. 620 n.$^{\circ}$ 4, Correspondencia de Alfonso Pérez Pólope con diversos administradores, Carta de Francisco Calvo, 16-I-1933.

10 Sobre dicha concordia, Carmona Pidal (2001), p. 90. Una referencia detallada, en Moreno Sebastián (1993), pp. 89-92. 
visto consignado en las cuentas. ${ }^{11}$ En todo caso, más allá del posible lucro que derivara de esa prerrogativa, es claro el apego que los marqueses tuvieron a ese derecho de presentación, que les garantizaba el control del clero en los pueblos del antiguo marquesado y, por esa vía, de los feligreses rurales.

Finalmente, debe relacionarse la posesión de varios inmuebles, como un palacio ruinoso en Alcañices, dos paneras y dos edificios que antaño habían tenido un objeto asistencial — hospital y alhóndiga-, cuyo patronato había recaído antiguamente en los marqueses, pero del que, de creer a su administrador, se consideraban completamente desvinculados en las fechas referidas, un desentendimiento, sin embargo, que sería objetado en la etapa que estamos estudiando.

Este conjunto de bienes, rentas y obligaciones pretéritas sería fuertemente cuestionado por los pueblos durante la Segunda República, reduciéndose drásticamente los ingresos por el impago de los foros y ocurriendo intrusiones en algunos de los montes, y además acarreó serios quebraderos de cabeza por lo que respecta al antiguo patronato sobre la alhóndiga y el hospital. Por todo ello, el titular de la administración, el médico Francisco Calvo, hubo de promover diversos litigios judiciales, lo que situó las cuentas anuales en un imparable déficit.

La administración abulense de Mombeltrán era meramente residual: consistía en un castillo también ruinoso en el pueblo que daba nombre al estado, una casa en Lanzahíta y varios olivares, huertas y tierras de muy reducida extensión. El cargo anual en vísperas de la República no llegaba a las dos mil pesetas, pero ello no fue óbice para que en esta administración se generaran fuertes tensiones en torno al pago de las rentas o a la disputa por las escasas propiedades que aún les quedaban a los duques de Alburquerque. Unas tensiones que se vieron aumentadas por la actitud implacable con los colonos del propio administrador, Victoriano López, que en ocasiones parece ampararse en su cargo y en la defensa de los exiguos bienes señoriales como punta de lanza de una ansiada ofensiva de los elementos de orden frente a unos colonos y obreros levantiscos en unos pueblos en que se registró una intensa movilización campesina.

11 Existe abundante documentación en el archivo ducal, que en un buen número de casos llega hasta bien entrado el siglo XX (ACDA, legs. 464-493). 
Cuéllar era, todavía en 1909, una administración importante en el cuadro de rentas de la casa: los pinares ya mencionados de Losáñez y La Serreta hacían que el antiguo estado cuellarano proporcionara una renta neta anual de más de 45000 pesetas, la segunda en cuantía después de Cadreíta. Se trataba, además, de una administración con relativamente pocos gastos. Sin embargo, dichos bienes, que eran gestionados de forma autónoma, se vendieron muy pronto, con motivo de la testamentaría del antiguo duque de Sesto. De esa manera, lo que restaba en el periodo aquí estudiado se cifraba en el castillo, una iglesia en ruinas, una gran panera, que era al mismo tiempo residencia del administrador, una huerta y algunas heredades de escasa dimensión y que rentaban muy poco. La casa, además, mantenía el patronato sobre el convento de Santa Clara, una fundación religiosa por la que los Alcañices habían mostrado una particular afección, por lo que la renta impuesta a las monjas era meramente simbólica. Llegaron a acariciar, incluso, la idea de hacerse allí un panteón familiar. ${ }^{12}$ En todo caso, esta administración era netamente deficitaria, debiendo girarse anualmente fondos desde Madrid, sobre todo para atender gastos derivados del convento citado o para la conservación del castillo.

A la vista de los datos anteriores, cabe pensar que en la etapa considerada pesaban más en la continuidad en su trabajo, por parte de los agentes de la casa en Alcañices, Mombeltrán o Cuéllar, los incentivos inmateriales, la autoridad y el rango que dentro de la comunidad les deparaba el estar asociados a una gran casa de la nobleza española, aunque ya venida a menos, que los meramente pecuniarios o clientelares, pues en los convulsos años de la Segunda República los duques difícilmente pudieron brindar su protección o sus influencias a sus agentes, dado que fijaron su residencia fuera de España tras el golpe de Sanjurjo. ${ }^{13}$ Por supuesto que en dicha continuidad hubo de funcionar también la común hostilidad a la República y la identificación explícita con la Monarquía - como observamos en el caso del administrador de Mombeltrán- ${ }^{14}$ o con las opciones políticas que buscaban trastocar el proyecto republicano, como sucede con el administrador de Cuéllar.

12 Carmona Pidal (2001), p. 217. El duque figuraba como propietario del convento y pagaba contribución.

13 Carmona y Simpson (2003), p. 197.

14 ACDA, leg. 620, n. ${ }^{\circ}$, Carta sin fecha de V. López a A. Pérez Pólope, en que expresa su añoranza por la Monarquía. 
3. La documentación más sugerente que hemos llegado a consultar se refiere no tanto a las cuentas anuales que rendían estos administradores, que son muy fragmentarias y que, dados el estado prácticamente residual de estas administraciones y las dificultades por las que atravesó la percepción de las rentas en estos años tan convulsos, no revisten un interés excesivo (pese a lo cual, las comentaremos), sino a la correspondencia que, centrada sobre todo en los años de la Segunda República, intercambiaron sus responsables con el apoderado general, Alfonso Pérez Pólope, en Madrid. Se trata, como digo, de una documentación de interés por cuanto arroja luz sobre las directrices de la casa en un tiempo tan complicado, sobre la actitud de rebeldía de los colonos, especialmente en Alcañices y Mombeltrán, y sobre el hondo simbolismo que para el vecindario de estos pueblos aún debía de revestir el viejo poder señorial y la manera como, en ocasiones, sus administradores se asociaban a dicho simbolismo y se amparaban en él en las luchas políticas de estos años, como se comprueba en el caso de Cuéllar, respecto del cual hemos podido completar nuestra información gracias al copiador de correspondencia ya citado.

3.1. Veamos, en efecto, algunas incidencias de esta última administración, que, insistimos, era ya completamente residual. Llama la atención, de entrada, que la casa, carente ya de bienes, confiara sus intereses a un titulado superior, el abogado Román Velasco, es cierto que hijo de un antiguo administrador, ${ }^{15}$ al que reemplazó en 1931, tres semanas antes de que tuviera lugar el cambio de régimen, pero que luego sería promovido, ya en los años cuarenta, al puesto de administrador general en Madrid. Funcionaba aquí, seguramente, una inercia derivada del hecho de que Cuéllar había sido, hasta iniciada la década de 1910, uno de los grandes estados de la casa y donde era habitual nombrar para el cargo a un abogado o a un procurador, por la complejidad jurídica que iba implícita al cobro de algunas rentas. ${ }^{16}$ En todo caso, es claro que los Alburquerque seguían estimando conveniente confiar su representación a una persona técnicamente

15 Se trataba del procurador Segundo Velasco, que había sido nombrado administrador en 1894, tras la muerte del anterior titular, Mariano de Cillanueva. Véase Marqués de Alcañices. Copiador de correspondencia [estado de Cuéllar], 1894-1936, n. ${ }^{\circ} 1$, 28-III-1894, sin paginar.

16 Carmona Pidal (2001), p. 234. El recurso a abogados, por otra parte, era bastante habitual en las administraciones nobiliarias (López y Robledo, 2004). 
bien preparada y, además, provista de peso específico en las relaciones de poder local, como veremos pronto, lo que no impide reconocer, a estas alturas, la existencia de un desfase neto entre la capacitación técnica o el relieve social del administrador elegido y el carácter ya irrelevante, desde un punto de vista rentístico, de los bienes allí radicados. Es cierto, con todo, que la casa mostró un fuerte apego a la posesión del castillo (aunque ello no le impidió ceder su usufructo en 1938 al naciente Estado franquista para que fuera utilizado como prisión) ${ }^{17} \mathrm{o}$ a la fundación religiosa antes mencionada: es decir, que se trataba de bienes que importaban mucho a los titulares de la casa, aunque no generaran rentas sino cargas.

Las cuestiones que aparecen en la correspondencia con Pérez Pólope se refieren en buena medida - como ocurre, por otro lado, con los otros dos casos que estudiamos - a los trabajos de inscripción de las pocas fincas subsistentes en el Registro de la Propiedad ${ }^{18}$ y, también, a la tramitación de un recurso de reforma ante el Instituto de Reforma Agraria en una coyuntura en que se estaba produciendo el viraje de la opinión hacia el centro-derecha, como era el otoño de 1933 (las elecciones que dieron el triunfo a la CEDA y al Partido Radical se produjeron en noviembre de ese año). ${ }^{19}$ Como la casa tenía ya poco que arrendar, apenas si hay referencias a estas cuestiones, aunque sí a las obligaciones que como contribuyente conservaba el duque en el municipio cuellarano: así, el adminis-

17 ACDA, leg. 687, n. ${ }^{\circ}$ 2, Documentación sobre los castillos de Mombeltrán (197072), Fuensaldaña (1969-72), Grajal de Campos (1968-72) y Cuéllar (1938-72). Según esta información, el duque hizo cesión gratuita en 1938 al Estado del usufructo del castillo, reservándose la nuda propiedad. En 1971 se produjo la desafección del castillo y su paso de la Dirección General de Prisiones del Ministerio de Justicia a Bellas Artes.

18 Suponemos que expropiable, aunque no se precisa este dato en la correspondencia.

19 La confiscación de las tierras de la grandeza sin indemnización fue posible merced a una enmienda presentada por Azaña el 8 de septiembre de 1932 (Malefakis, 1970), p. 264. No obstante, comoquiera que se contemplaban diversas excepciones, relativas a aquellos grandes que no hubieran hecho uso de las prerrogativas honoríficas propias de su rango o que hubieran prestado, ellos o sus familias, eminentes servicios a la nación, el consejo del IRA hubo de emplear buena parte de su primer año de existencia en resolver los recursos presentados por los nobles sobre la base de dichas excepciones. Como explica R. Robledo, cada noble debía recurrir contra la inclusión de las fincas en cada uno de los registros de la propiedad donde tuviera fincas inventariadas, y después se seguía el expediente sobre inclusión o exclusión de cada finca en el inventario, lo que explica la actividad de cada uno de los administradores en este plano concreto (Robledo, 1996), pp. 265-269. 
trador será convocado a una reunión de contribuyentes para aliviar la crisis de trabajo que en el invierno de 1933 estaba padeciendo la localidad. Es significativo que Pérez Pólope, siguiendo instrucciones del duque que rompían la tradición paternalista de la casa en materia social, diera instrucciones para que Velasco no aportara nada a la suscripción abierta, «en vista de que la situación en que la colocan recientes disposiciones del Gobierno, no es la más a propósito para acudir a remediar necesidades ajenas». ${ }^{20}$

Pero lo más sustancioso de esta correspondencia es un conflicto aparentemente irrelevante que opone a la casa, pero muy en primer término a su administrador, con un sujeto poderoso en el plano local, el fabricante Leocadio Suárez, a propósito de un asunto nimio como es la petición de este último de que se le permita colocar tres palomillas en la fachada de la antigua panera, una gran casona que servía de vivienda a Román Velasco. ${ }^{21}$ El objeto era instalar una red de energía eléctrica. Debe precisarse que Suárez llevaba en arriendo desde hacía tiempo un terreno en la villa perteneciente a los Alburquerque, que ya había tenido un serio conflicto con el administrador en 1926, también en relación con el paso de una línea de fluido eléctrico por la huerta ducal, y respecto del cual la casa, por motivos que no conocemos, se había mostrado hasta entonces muy deferente, ${ }^{22}$ lo que le permitía —o así lo interpretaban los Velasco-, hacer caso omiso de los requerimientos de su administrador.

Pues bien, la denegación de esta solicitud por parte de la administración general - a instancias de la de Cuéllar-, iba a dar lugar a un duro pulso entre Velasco y Suárez, con acusaciones de este último de estar el primero engañando a su principal y de utilizar su cargo para satisfacer sus venganzas, y con amenazas de acudir personalmente a entrevistarse con el duque en Madrid y prevenirle contra la gestión presuntamente parcial de

20 ACDA, leg. 620, n. ${ }^{\circ}$ 2, Carta de Román Velasco a Pérez Pólope, 8-V-1933.

21 Leocadio Suárez llevaba en arrendamiento un terreno titulado "Las cocheras", perteneciente a la casa ducal, y a su finalización, en diciembre de 1926, R. Velasco propuso renovarlo por cuatro años prorrogables por otros cuatro (Marqués de Alcañices. Copiador de correspondencia [estado de Cuéllar], 1894-1936, 1-VII y 3-IX-1925).

22 R. Velasco reconocía que en el pasado «el sr. Suárez tuvo un buen comportamiento con la familia de V. E.» y que por ello se le habían "guardado favores y beneficios con que le han recompensado tal comportamiento hasta con creces», (Marqués de Alcañices. Copiador de correspondencia [estado de Cuéllar], 1894-1936, n. ${ }^{\circ}$ 15, 2-VII-1926). 
su administrador de Cuéllar. Este pulso afectaba directamente al honor y autoridad moral de Velasco ante sus convecinos, por lo que puso todo su interés en que el duque le amparase y mantuviera la denegación del permiso, un amparo en absoluto irrelevante, por lo que se ve, dada la autoridad que aún le deparaba al titular de la casa el haber ostentado en tiempos ya pasados el señorío de la villa y, posteriormente, altos cargos cortesanos. ${ }^{23}$ Pero ello resulta también revelador de como en un estado en un notorio declive, como era ya el de Cuéllar, la casa aún contaba con poderosos incentivos de carácter inmaterial que le valían para controlar la actividad de sus agentes y mantener su fidelidad.

Pero es que, además, este pulso entre ambos personajes está trufado no sólo de rencillas personales que, por lo que sabemos, vienen de muy atrás, sino también de una marcada rivalidad política en que lo que se disputa es el liderazgo de la gente de orden, de la derecha, en el territorio cuellarano. Según la detallada carta que envía Velasco el 13 de agosto de 1933, Suárez, al llegar la República, ingresó con sus amigos en el Partido Radical de Lerroux y, luego, en el de Miguel Maura, en tanto que él mismo ostentaba la presidencia del partido Acción Popular y, como tal, hubo de ocuparse muy directamente de la campaña electoral en los comicios de noviembre. ${ }^{24}$ Resulta significativo de su ubicación política el que a finales de octubre de 1931 Román Velasco hubiera autorizado la realización de un mitin de Acción Nacional en el patio del castillo o que en 1935 procediera a alquilar las paneras de la casa-administración, donde él mismo vivía, a la Federación Católico-Agraria de Segovia. Sospechamos, por tanto, que obtener el apoyo del duque o que éste desautorizara a su administrador en la villa, como pretendía Suárez, podía también tener sus efectos en la reorganización y liderazgo de las fuerzas de la derecha de esta localidad segoviana. ${ }^{25} \mathrm{Y}$ todo ello a cuenta del permiso para instalar tres palomillas para el tendido eléctrico.

23 El conflicto se detalla en la correspondencia mantenida entre el 26 de julio y el 13 de agosto de 1933, e incluye varias cartas de Leocadio Suárez.

24 ACDA, leg. 620, n. ${ }^{\circ}$ 2, Carta de 23-XII-1933, en la que Velasco justifica su retraso en enviar los estados mensuales de cuentas por los afanes de la reciente campaña electoral, ya que sobre él habría recaído la mayor parte de los trabajos de dicha formación política en el partido judicial.

25 Para el estudio de las fuerzas políticas en el espacio castellano y leonés durante los años treinta, Marcos del Olmo (1995). 
3.2. Veamos lo que nos dice la correspondencia mantenida entre Victoriano López Dégamo, administrador de Mombeltrán hasta aproximadamente 1935, en que es sustituido por Ángela de la Cruz, y Pérez Pólope. Ante todo, hay que observar que el perfil de dicho sujeto, en tanto que administrador, es bien diferente: se trata de un propietario, sin que le conozcamos otra cualificación, muy beligerante respecto de los derechos de la casa, pero también de los de su grupo social, frente a colonos y obreros; muy inculto, comete graves faltas de ortografía y no se abstiene de incluir gruesos epítetos despreciativos o comentarios maliciosos respecto de todos aquellos — colonos, obreros, cargos municipales—, con los que tiene tratos en su condición de administrador. Ya desde la llegada del nuevo régimen pretende transmitir en su prolija correspondencia la impresión de hallarse inmersos los pueblos de la comarca y el conjunto del país en una auténtica guerra social que opondría a propietarios y trabajadores, atribuyendo a la República la causa de todos los males. «Ladrona, maldita república", la califica en una carta de noviembre de 1931. Por lo que dice en una de ellas, sus fincas fueron las primeras en ser reconocidas para comprobar que estaban bien labradas, y a continuación las del duque. ${ }^{26}$

En el caso de esta administración, la política que sigue Victoriano, contando sin duda con el aval de la casa, es de una implacable dureza con los colonos que incumplen sus plazos y obligaciones. Bien es cierto que el caso que mejor se documenta viene en realidad de la dictadura de Primo de Rivera, en que, de resultas de la insolvencia del arrendatario de un olivar en Lanzahíta, el administrador le desahució y procedió de forma persecutoria contra sus fiadores, obligándoles a pagar, pese a sus súplicas. ${ }^{27}$ No sabemos si en esa posición de dureza no interviene, además de sus obligaciones respecto de los intereses del duque, el deseo de hacer una demostración de fuerza que apuntale los derechos de los propietarios y, por tanto, de los suyos también, en un clima social muy problemático, pues, a poco de llegar el nuevo régimen se constituyó en Mombeltrán una sección local de la Federación de Trabajadores de la Tierra, con más de 400 afiliados (el dato es de Victoriano), cuya presión determinó una fuerte subida de los

26 ACDA, leg. 620, n. ${ }^{\circ}$ 1, Carta de 23-IX-1932.

27 Una práctica que era poco frecuente, salvo que la casa abrigara el propósito de vender la finca, cosa posible dado el enrarecido ambiente que se respiraba en la comarca (Carmona y Simpson, 2003), p. 130. 
costes salariales y una caída de las expectativas de beneficio para el labrador, ${ }^{28}$ como efectivamente se comprueba en las cuentas anuales, ya que el salario del jornalero habría pasado de 2,50 pesetas en 1928 a 5 en 1932 (también las mujeres que recogían la aceituna aumentaron sus exiguos jornales, al menos de 1,25 a 2 pesetas). ${ }^{29}$ En esas condiciones resultaba difícil arrendar o mantener en vigor los contratos por las fincas de la casa ducal, ya que los eventuales colonos se mostraban descorazonados ante las crecidas exigencias salariales, lo que explica que el administrador general diera órdenes de transigir con el monto de la renta en la negociación iniciada para arrendar de nuevo el terreno de Lanzahíta. ${ }^{30}$ Tampoco resultaba rentable, siempre según el administrador, efectuar labores como las huebras de arado, el prensado de la aceituna o la limpieza de los árboles. Con todo, las cuentas anuales arrojan resultados positivos para la casa en los años 1932 a 1934.

Esta movilización obrera, jalonada por huelgas e incidentes con la Guardia Civil, como ocurrió en el mismo Mombeltrán, tuvo bastante importancia en la provincia de Ávila, ${ }^{31}$ y en este caso concreto debió de verse favorecida por la proximidad de la comarca a Extremadura y a Toledo, donde la FTT era muy fuerte. ${ }^{32}$ Uno de sus efectos iba a consistir en

28 Toda esta parte del sur de la provincia de Ávila fue de las pocas, en Castilla y León, que permanecieron en manos de la República en los primeros meses de la Guerra (Aróstegui y Blanco, 1995), p. 475.

29 Una buena explicación, referida en este caso a Andalucía, de cómo la legislación agraria del Primer Bienio y el ascenso de la FNTT en muchas localidades favorecieron las subidas salariales y redujeron el poder tradicional de los terratenientes, en Cobo Romero (1999), pp. 177-208.

30 No merecería la pena, a juicio de Pérez Pólope, meterse en un nuevo litigio, aparte de que el colono estaba al tanto del derecho que le asistía a una rebaja del $20 \%$ en el precio del arriendo según la nueva legislación republicana (ACDA, leg. 620, n. ${ }^{\circ} 1$, Carta de 16-I-1932).

31 Carreño Díaz (2004), p. 181. En 1932, con motivo de la celebración del II Congreso de la FNTT, Ávila, con 8113 afiliados, se situaba en el segundo lugar de Castilla la Vieja y León. Sobre los conflictos en la provincia de Ávila en 1932-1933, Hermida Revillas (1988), pp. 241-243.

32 Extremadura, en efecto, fue una de las regiones donde el sindicato tuvo un mayor desarrollo. De la federación provincial de Toledo, "por aquel entonces probablemente, la sección más amplia y belicosa de la FNTT", partió la idea de la huelga campesina, que se llevaría a cabo con desigual éxito, en el mes de junio de 1934 (Malefakis, 1970), pp. 338 y 387. No debe olvidarse, por otro lado, que en coyunturas anteriores de gran movilización social, como la del Sexenio Democrático, esta comarca abulense había registrado también una elevada conflictividad, aunque de un sesgo más tradicional (Serrano García, 1992). 
que algunas propiedades de la casa fueran cuestionadas, y así en Lanzahíta, donde existía un fuerte malestar contra Victoriano como administrador de aquélla, hasta el punto de recibir amenazas de muerte por la dureza demostrada con el anterior colono, la sociedad obrera habría resuelto construir la nueva escuela en un olivar del duque, cercano a la iglesia, amenazando incluso con congregarse allí los obreros y descuajar los olivos. Quizás por ello la administración central, ante el cariz que tomaban las cosas, prefirió presentar una cara paternalista y conceder el olivar al Ayuntamiento para el fin referido, no sin cierta reserva por parte de su administrador, que veía intereses particulares de algunos miembros de la corporación municipal en el control de dicho terreno. También en Mombeltrán la movilización de la sociedad obrera va a poner en riesgo la propiedad ducal situada junto al castillo y se formará una gran manifestación, muy hostil al Ayuntamiento, uno de cuyos objetivos sería el de intrusarse de dicha propiedad, descuajar los olivos y colocar allí en trabajos de siembra a los veinte afiliados más viejos. ${ }^{33}$

Cabe pensar que gravitase, en estos proyectos de ocupación, el recuerdo de la vieja opresión señorial, que posiciones intransigentes como las del propio Victoriano y otros propietarios seguramente no hicieron sino reavivar, así como la posición de debilidad en que familias como los Alburquerque se encontraban situados por su condición de grandes de España, tras la intentona frustrada de Sanjurjo: ${ }^{34}$ de ello los obreros estaban muy al corriente gracias al periódico socialista la Voz, que era leído con fruición. En esas condiciones no es extraño tampoco que determinados vecinos con recursos - incluido el propio alcalde de uno de los pue-

33 El relato, muy sabroso, de la manifestación obrera, en la carta de Victoriano de 22IV-1932. Dicha manifestación había tenido lugar el 16 de marzo y se saldó con veinticuatro detenidos y varios miembros de la Benemérita heridos (El Socialista, 17-III-1932, y Diario de Avila, 18-III-1932). El teniente de la Guardia Civil, que prefirió disparar al aire para no herir a los niños que andaban por la calle, fue trasladado y suspendido de empleo y sueldo, ya que, como expresaba el administrador de los Alburquerque, «hubiera estado muy bien haber dejado una siembra de muertos».

34 Cuenta Victoriano que, poco tiempo después de dicha intentona y de la aprobación por las Cortes de la Ley de Reforma Agraria, se presentaron en el pueblo unos señores de Madrid que le mandaron llamar para preguntarle que a quién pertenecía el castillo. Él contestó que al duque de Alburquerque, a lo que le replicaron que estaba deportado por cómplice en lo de Sanjurjo y que sus bienes serían incautados (ACDA, leg. 620, n. ${ }^{\circ} 1$, Carta de 23-IX-1932). 
blos- pretendan aprovechar la oportunidad y hacerse con las fincas a un precio muy ventajoso, dada la sombra de la expropiación que pesaba sobre ellas, y que la administración esté interesada en venderlas, máxime cuando, como reitera Victoriano en marzo de 1933, resulta muy difícil en las actuales circunstancias encontrar colonos solventes que quieran hacerse cargo de las fincas, dado el elevado precio de la mano de obra, con lo que el grado de riesgo moral y la eventualidad de incurrir en gastos judiciales derivados del incumplimiento de los contratos se potenciaban considerablemente.

La administración no se desmembró, sin embargo, ya que subsistía en la década de 1940, aunque con un nuevo titular, una mujer, Ángela de la Cruz, seguramente la viuda de Victoriano, que ya firmaba las cuentas de $1935^{35}$ y que iba a ser ayudada en su cometido por una hija, Filomena López. La correspondencia mantenida por la nueva titular es muy escasa y las cuentas extremadamente sucintas, pero sí hay algunos datos interesantes, como el momentáneo frenazo de la escalada de salarios y labores después del control de la comarca por los insurrectos, ya que el jornal del peón baja a 4 pesetas en 1937, respecto de las 5 que se pagaron aún en 1936, la no revisión de las rentas por las fincas y pastos arrendados respecto de las pagadas en la Segunda República y, en fin, el reinicio de las subidas salariales y del coste de las labores, hasta el punto de duplicar en pocos años, efecto, suponemos, que de la inflación, los niveles de los años 1930: el jornal masculino, por ejemplo, después de recuperar la cota perdida de 5 pesetas, en 1945 se situaba en 10 pesetas; por su parte, la peonada de las mujeres que recogían la aceituna, se estabilizó en 4 pesetas, a partir de 1941, mientras que el coste de las huebras de arado subió de 12 pesetas por una en 1937 a 50 en 1944. Por ello, y aunque los resultados de la casa fueron generalmente positivos por la venta de aceite, el coste de salarios y fiscalidad parecía comprometer la viabilidad de esta administración, siempre por supuesto que las cuentas rendidas por Á. de la Cruz fueran completamente veraces, particularmente por lo que respecta al precio de la mano de obra, ya que desde la administración central se le reprochaba el que no enviara recibos de los gastos efectuados. ${ }^{36}$

35 ACDA, leg. 575, n. ${ }^{\circ} 9$.

36 ACDA, leg. 575, n. ${ }^{\circ} 11$. 
3.3. Respecto de Alcañices, aunque existe también un notable clima de crispación y de movilización (si bien diferente al de Mombeltrán: responde a un modelo más tradicional de protesta campesina), el administrador, que tiene un perfil más parecido al de Cuéllar, no se implica tanto en el relato de los acontecimientos y no proporciona una descripción tan vívida y pasional, aun cuando, igual que vimos con R. Velasco en Cuéllar, también convierte en cosa de amor propio el resolver en un sentido favorable a la casa el pulso que los colonos y foreros le echan al llegar la República. Se trata de un médico, Francisco Calvo Casado, que no reside en Alcañices, sino en Zamora, y que también debe afrontar una situación muy compleja al llegar el nuevo régimen, en tanto que gestor de los intereses de la casa. Más compleja, si cabe, que en Mombeltrán, ya que aquí, amén de la inscripción de las fincas en el Registro de la Propiedad, alegando las causas por las que estimaba no debían ser expropiadas, Calvo debe hacer frente al sempiterno problema de los foros, de su impago generalizado, que obtuvo un respaldo legal al resultar abolidos por la base 22. ${ }^{a}$ de la Ley de Reforma Agraria. Un impago que es el núcleo de la contestación que los arrendatarios y los pueblos del antiguo marquesado hacen al viejo poder señorial, en una coyuntura que tiene también un claro matiz antinobiliario. No parece existir, en cambio, ese componente obrero y anticapitalista de Mombeltrán y Lanzahita. Así, en enero de 1933 el administrador se lamenta de que todo el mundo sigue sin pagar ni foros ni rentas de fincas, y que no lo harán sin llevarles al juzgado. Aquí, dice, «aunque [...] las gentes son ignorantes, lo que afecta a no pagar, lo han aprendido muy bien».

Una contestación que, en el caso del pueblo de Alcañices, parece que involucra a todo el vecindario, que ya en noviembre de 1931 quiso adueñarse por la fuerza del monte «El Marqués», sobre el que existía antes de la llegada del régimen republicano la costumbre, pese a que el administrador la consideraba sin fundamento legal, de que los vecinos utilizaban el suelo, mientras que la casa se reservaba el vuelo. Posteriormente, el Ayuntamiento, que según Calvo «está empeñadísimo», procedió a descotar el monte, permitiendo la entrada de toda clase de ganados, incluido el cabrío, pese a que éste no había entrado nunca allí, ni siquiera en las épocas de mayor tolerancia. Así, la dirección de esa contestación popular no la llevan las sociedades obreras, como era el caso de Mombeltrán, sino el Ayuntamiento de la villa, y particularmente el alcalde y el secretario, abogado y procurador respectivamente, que es a quienes Calvo responsabili- 
za, acusándoles de perturbadores y de deseosos de pleitos, pues según él se encontraban en la ruina. Por la correspondencia sabemos que el alcalde había defendido a los pueblos en asuntos de foros y que, incluso, debía algún dinero al propio Calvo, todo lo cual permite comprender mejor la inquina que aquél siente hacia el alcalde y el Ayuntamiento, y que considere asunto personal el hacer prevalecer los intereses de la casa. Un pulso, no obstante, en el que el administrador cuenta con aliados, como el juez municipal de Alcañices, que es sobrino suyo, o el registrador de la propiedad, también amigo.

Este contencioso entre la casa y el Ayuntamiento se complica aún más por la cuestión del hospital y la alhóndiga de Alcañices, una cuestión que la documentación consultada no nos permite aclarar del todo, pero que es una de las que más quebraderos de cabeza proporciona a Calvo, ya que da origen a una denuncia que tramita la Junta de Beneficencia de Zamora, abriendo un expediente, llegando incluso el diputado zamorano José María Cid a interesarse en el Congreso por el asunto, asumiendo una posición contraria a los intereses de la casa. ${ }^{37}$ El administrador previene a Pólope de que la Junta de Beneficencia está controlada por radicales-socialistas que no se olvidan de ello. ${ }^{38}$ El litigio, que viene de atrás, ${ }^{39}$ parece envolver, por un lado, la pretensión del Ayuntamiento de hacerse con el edificio del viejo hospital para dedicarlo a escuelas, pero también la reclamación de los fondos que la casa ducal habría consignado para esta obra asistencial y de las fanegas de grano que supuestamente debería custodiar la alhóndiga y de las que la casa, en tanto titular del patronato, debería res-

37 El agrario José María Cid Ruiz Zorrilla mantuvo en la Segunda República una activa red clientelar, especialmente densa en los partidos de Benavente y de Alcañices (Mateos Rodríguez, 1988), vol. I, p. 257.

38 Leído este dato en clave política provincial, esto equivale a hablar de galarcismo, esto es, de la red caciquil nucleada en torno a Ángel Galarza Gago, cofundador del Partido Radical-Socialista, que fue quien lo constituyó en Zamora. Sus leales en el partido de Alcañices eran Manuel del Río y Antonio Calvo, el cual había estado vinculado al marqués de Alcañices (Mateos Rodríguez, 1988), vol. I, p. 267.

39 Ya en 1920, con motivo de las elecciones a Cortes en las que se presentó por el distrito de Alcañices precisamente el duque de Alburquerque, los liberales zamoranos le presentaron como una «sanguijuela que aún cobra foros feudales, mientras ha abandonado sus obligaciones con el pueblo de Alcañices, permitiendo la destrucción del hospital y la alhóndiga, en otro tiempo sostenidos por su casa marquesado" (Carasa, dir., 1977), vol. I, p. 434. 
ponder. El administrador niega que en el tiempo que lleva el actual duque en el ejercicio de su título dicho patronato haya estado en vigor, aunque, por lo que sabemos, todavía en 1908 la Dirección General de Beneficencia asignaba funciones asistenciales a ambas entidades. ${ }^{40}$

Esta correspondencia permite además que conozcamos la relativa inversión de la situación, a favor de la casa, que tiene lugar tras el triunfo del centro-derecha en noviembre de 1933. Así, una carta de finales de 1935 relata como los arrendatarios del duque en Trabazos pagan ya sus rentas, aunque ello exigió un fallo favorable de la Audiencia Provincial de Zamora. Dado, sin embargo, que las pensiones forales no fueron repuestas, la administración arrojaba un cuantioso déficit, incrementado por los gastos judiciales, de registro, etc. Fue el administrador quien adelantó el dinero para afrontar dichos gastos, procurando coadyuvar «al sostenimiento de los derechos de Su Excelencia», una anticipación que debió de mantener en los difíciles años de la guerra y la postguerra, ya que en la cuenta de 1941, además del déficit anual, suplido por él, que en algunos años de la década llegó a ser muy voluminoso, existía un saldo a su favor de más de 23000 pesetas por gastos judiciales y donativos patrióticos. Quizás por ello, y porque la situación política había cambiado sustancialmente en beneficio de los propietarios, Calvo propuso en febrero de 1942 intentar cobrar lo que se pudiese en concepto de foros, ofreciendo hacerse cargo él del coste del proceso a cambio de quedarse con el $40 \%$ de los ingresos, en el caso de que dicho proceso diera un resultado favorable. Sabemos, por el estudio de Atilana Moreno, que los tribunales dieron la razón en 1943 a la casa ducal, sentenciando que los pueblos debían pagar las pensiones forales que adeudaban desde 1932, es decir, once años. En 1947, de los dieciséis pueblos que aún pagaban foros al llegar la República, quedaban cinco ${ }^{41}$ que no habían pagado los atrasos ni redimido el foro, si bien a estas alturas el dueño de los foros no era ya la casa, sino Francis-

40 En la estadística de beneficencia, publicada en 1908 en el Boletín Oficial de la Provincia, se mencionaba al duque de Alburquerque como propietario de la alhóndiga «Enrique de Almansa», con la finalidad de "prestar dinero a los pobres». También se incluía en ella el hospital para socorro de enfermos «Doña Juana de Aragón», mujer del tercer marqués de Alcañices (Moreno Sebastián, 1993), p. 95.

41 Esos cinco pueblos eran Gallegos del Río, Vivinera, Puercas, San Martín del Pedroso y Trabazos. 
co Calvo, al que se le traspasaron en abril de 1945. No creemos sin embargo que llegara a cobrar, al menos de forma rápida, ya que el Tribunal de Foros del partido de Alcañices declaró de señorío el foro que gravaba a los cinco pueblos que se resistían al pago, y lo declaró «extinguido a todos los efectos legales e incluso registrales que pudieran derivarse». ${ }^{42}$

Las cuentas, por otro lado, correspondientes a los años 1940 arrojan unos déficits anuales muy considerables en perjuicio de la casa central, motivados por la escasez de rentas (la finca más rentable, el monte «El Bostal», no pudo ser arrendada hasta 1944), por el aumento de los sueldos de los dos guardas, que se duplican, y sobre todo por una mayor presión fiscal, que resultaba aún más gravosa cuando alguna de las fincas del marquesado, como el monte «El Marqués», no producía renta en tanto debía satisfacer una cantidad importante por contribución. El déficit, en fin, hubo de incrementarse aún más — si bien esto hubo de reflejarse en las cuentas de años posteriores a los consultados, que no se conservan en el archivo- por los gastos registrales derivados de la nueva testamentaría en que se vio inmersa la casa en dichos años. Debe tenerse en cuenta, además, que la no percepción de foros en especie hubo de privar a la casa de un producto muy negociable y cotizado en esta etapa de escasez y autarquía.

En definitiva, lo visto hasta aquí, aunque referido a un patrimonio en buena medida testimonial, creemos que puede arrojar una luz interesante sobre el declive de una vieja casa de la alta nobleza española, que en este caso no parece se viera del todo invertido con la victoria de los militares sublevados en la Guerra Civil, como muestra sobre todo el caso - es verdad que ya muy excepcional y anacrónico- de Alcañices. Por otro lado, el comportamiento de sus administradores también resulta de interés, pues parecen moverse por incentivos inmateriales o por mantener, haciendo valer su condición de representantes del antiguo poder señorial, una posición de fuerza o de predominio, incluso, dentro de la esfera política local, ya frente a otros poderes caciquiles que cabe presumir se vieron fortalecidos por su alineamiento con la Segunda República, ya frente a la irrupción en dicha escena de un nuevo y temible actor colectivo, como eran las sociedades de la FNTT.

42 Moreno Sebastián (1993), pp. 154-161. 


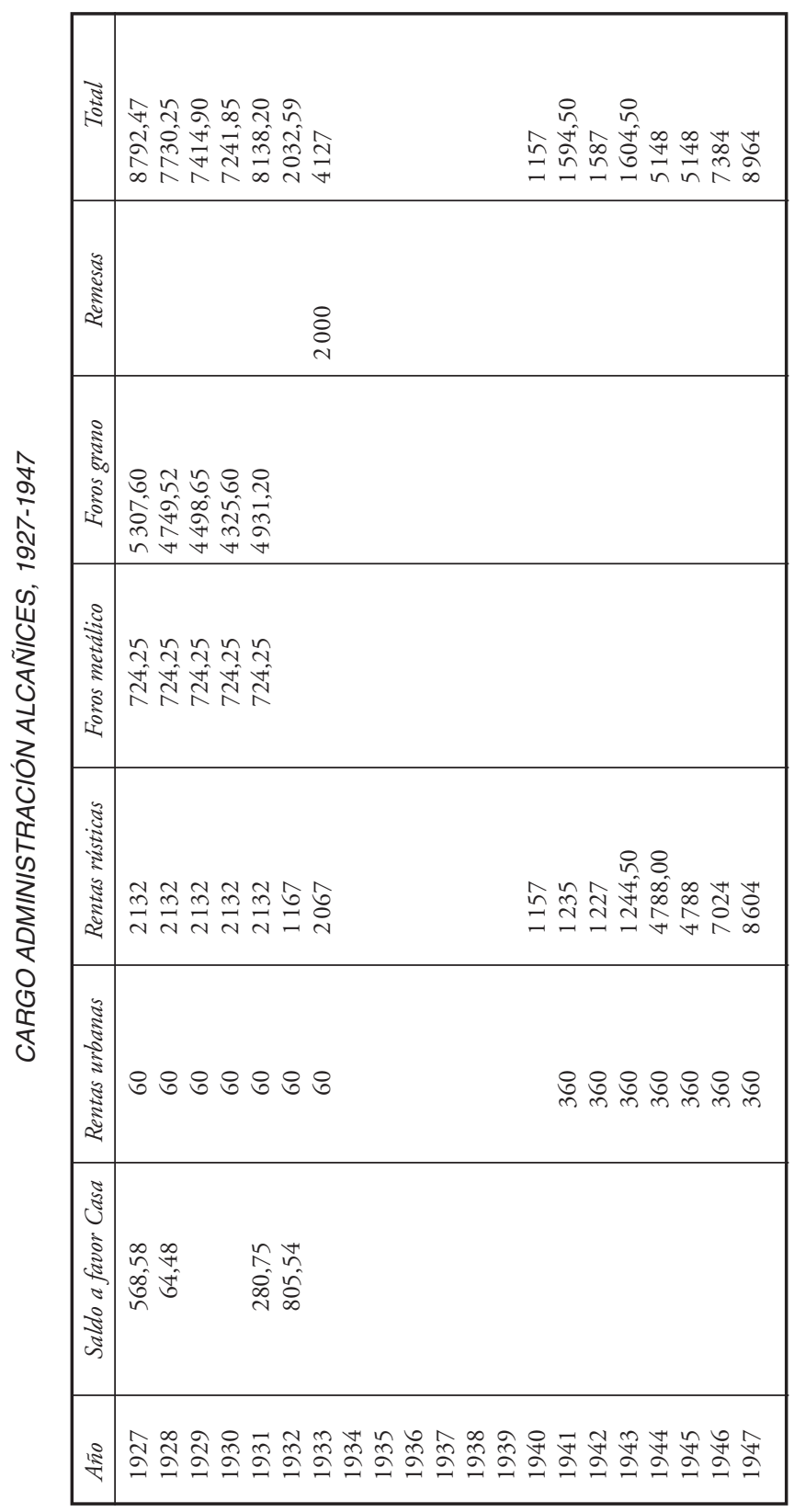




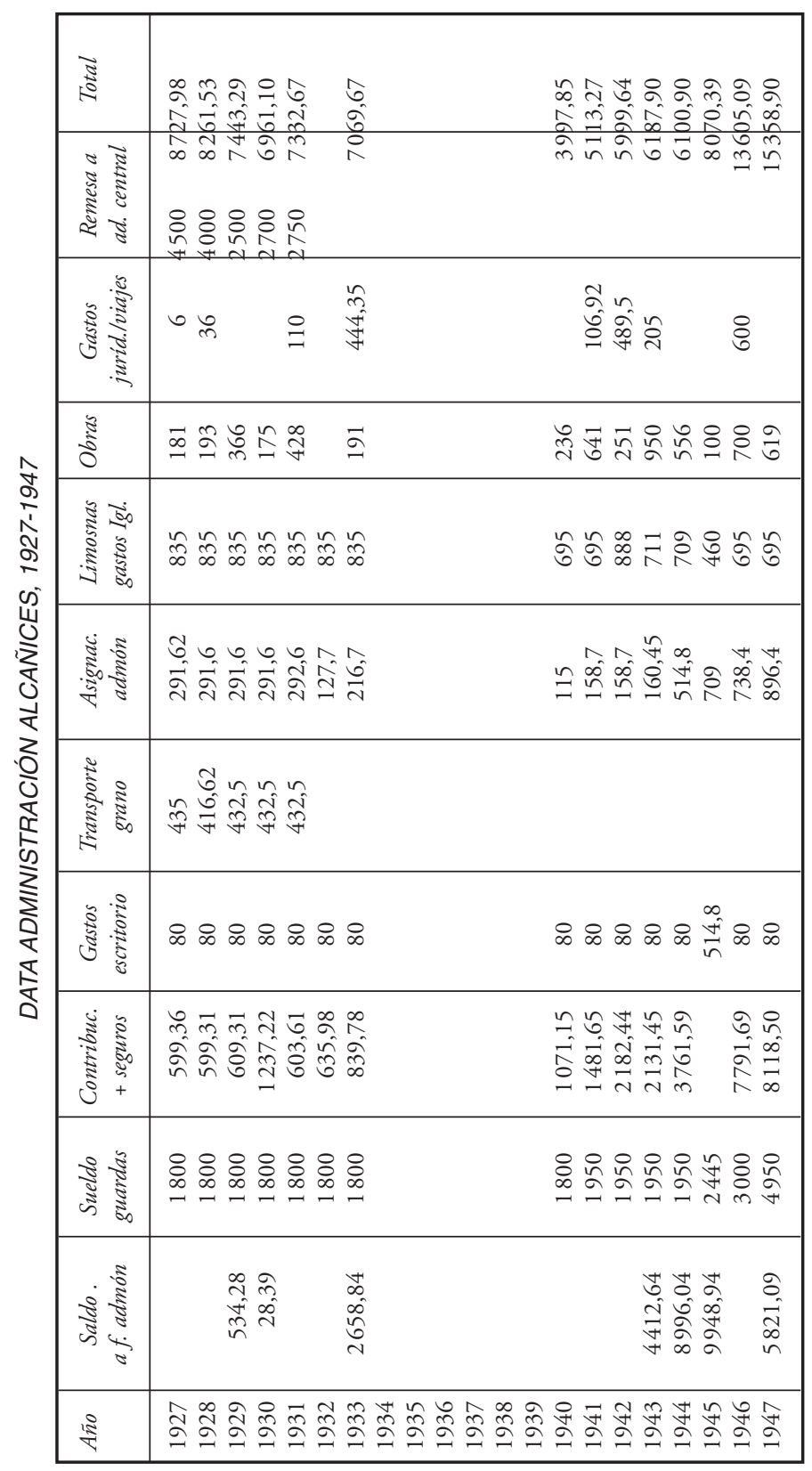




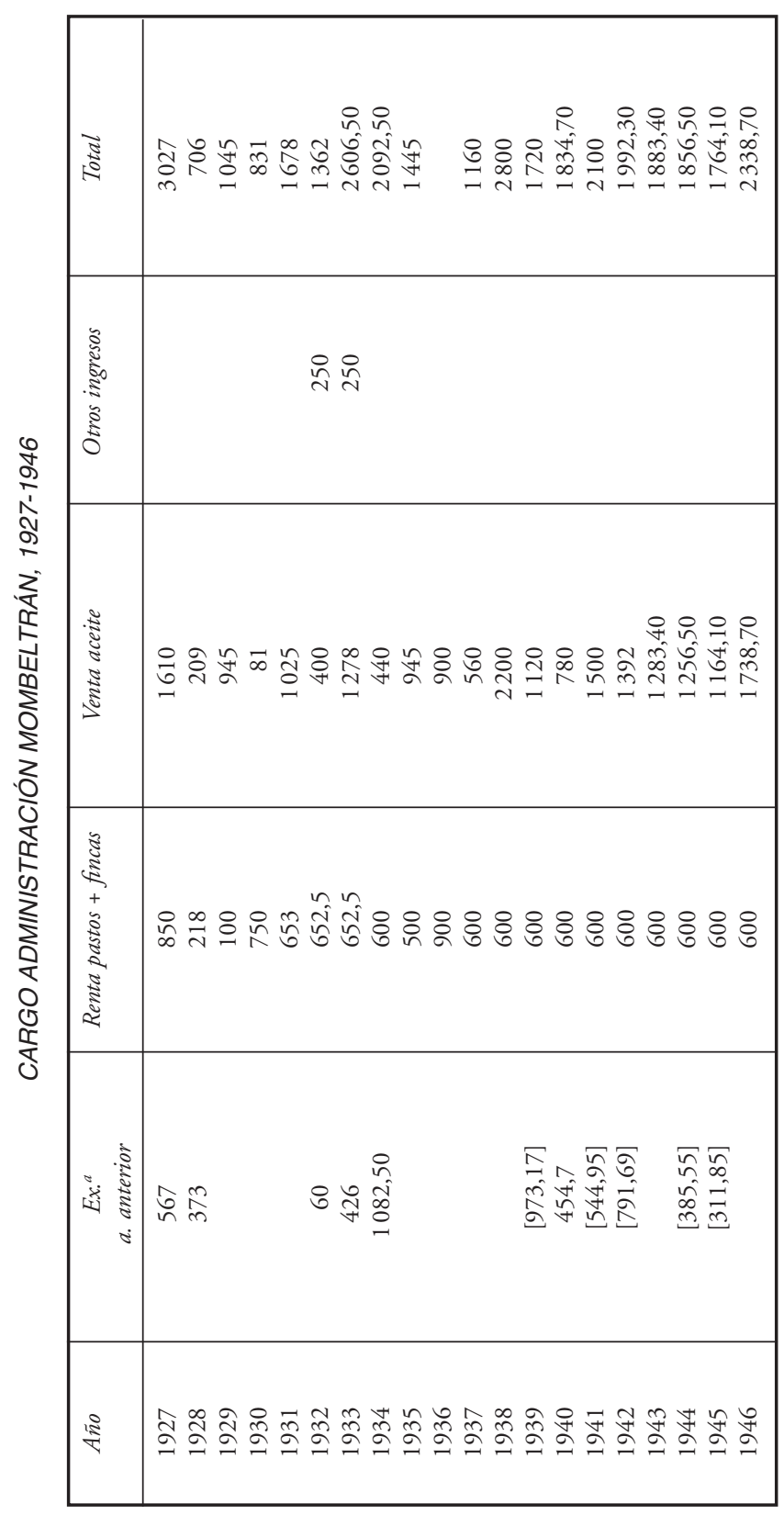




\begin{tabular}{|c|c|}
\hline 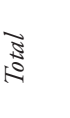 & 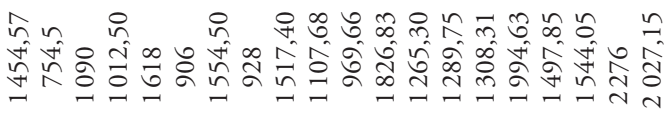 \\
\hline$\stackrel{0}{\vdots}$ & 유 \\
\hline$\frac{\sqrt{2}}{3}$ & $\stackrel{\varrho}{ }$ \\
\hline$\overbrace{}^{2}$ & 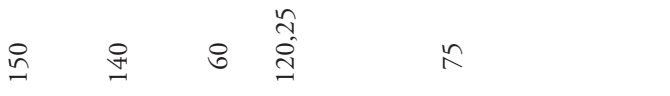 \\
\hline 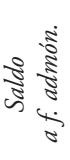 & 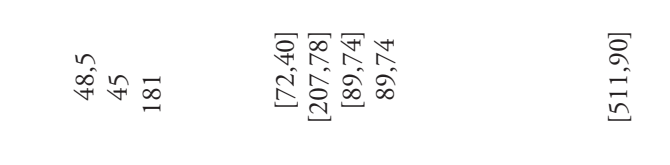 \\
\hline 通 & 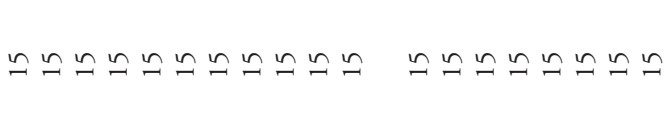 \\
\hline 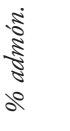 & 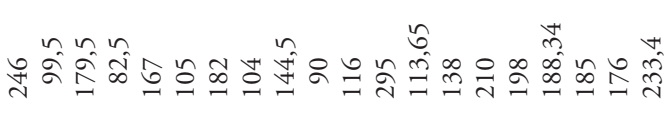 \\
\hline 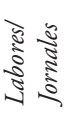 & 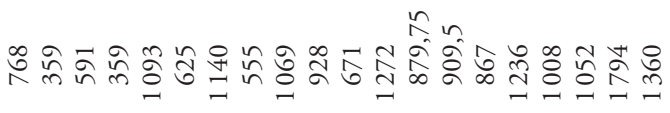 \\
\hline 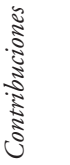 & 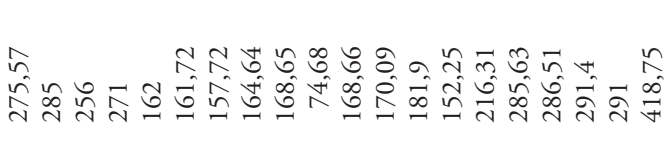 \\
\hline$\stackrel{8}{\mathbb{Z}}$ & 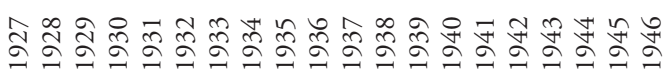 \\
\hline
\end{tabular}





\title{
9. LA ACCIÓN SOCIAL EN CASA. GESTIÓN PATRIMONIAL DE UN DIRIGENTE SINDICAL (PELAYO NEGRE Y PASTELL, 1924-1936)*
}

\author{
Enric Saguer \\ (Universitat de Girona)
}

La agricultura catalana registró un notable dinamismo transformador durante los últimos años del siglo XIX y las tres primeras décadas del siglo XX. Fue en dicho periodo cuando se desarrollaron algunas tendencias apuntadas con anterioridad —expansión de la ganadería de renta, supresión del barbecho, nuevas rotaciones de cultivos, difusión de nuevos instrumentos aratorios, incremento del uso de fertilizantes inorgánicos, expansión del regadío...-, al tiempo que se consolidaba y redefinía un mapa agrícola caracterizado por una mayor especialización comarcal y una notable reducción de la viticultura postfiloxérica, la cual tendió a concentrarse especialmente en algunas áreas de las provincias de Barcelona y Tarragona. ${ }^{1}$ Los resultados de dicho proceso de transformación quizás no fueran espectaculares, pero hubo un aumento de los rendimientos agrícolas y también de la productividad del trabajo, aunque ello tuviera poca repercusión en el nivel de ingreso de los distintos agentes que participaban en el proceso de producción agraria. ${ }^{2}$

* Este trabajo se ha realizado en el marco del proyecto de investigación BHA200203051 financiado por la DGICYT.

1 Pujol (1988), (1998a), (1998b) y (1998c).

2 Garrabou, Pascual, Pujol y Saguer (1995) y Pascual (2000), vol. II, pp. 96-112. 
Si bien disponemos de bastante información sobre las tendencias básicas de transformación del sector, los datos y trabajos disponibles aún no permiten responder de forma completa y satisfactoria a la pregunta de quién protagonizó dicho proceso y en qué grado o de qué forma. Ciertamente, entre los grupos o agentes sociales implicados cabe tener presente el papel jugado por los propietarios rentistas, quienes, forzados por las circunstancias económicas y por las presiones sociales, desplegaron iniciativas tanto privadas como colectivas que tenían como objetivo mantener la viabilidad económica de sus explotaciones y, al mismo tiempo, conservar la estabilidad social y su propia autoridad. Los trabajos de Jordi Planas han puesto de relieve la vitalidad del asociacionismo agrario patronal durante el periodo posterior a la crisis agraria finisecular — hasta el estallido de la guerra-, y han destacado como la voluntad de atraer y organizar a los grupos subalternos dio lugar al desarrollo de un amplio abanico de servicios dirigidos a los agricultores —desde la adquisición colectiva de abonos hasta el asesoramiento técnico- cuyo impacto sobre el proceso de transformación agraria no debe magnificarse pero tampoco menospreciarse. ${ }^{3}$ Sin embargo, queda por evaluar con solidez la acción de los propietarios agrarios de puertas adentro, sobre su propio patrimonio.

Algunos trabajos realizados hasta el momento han puesto en evidencia la inviabilidad de la explotación directa durante el primer tercio del novecientos excepto bajo condiciones singulares, como fue el caso de Can Codorníu, cuya baja rentabilidad quedaba neutralizada por su integración en una empresa agroindustrial productora de cava. ${ }^{4}$ También se ha apuntado la existencia de una presión a la baja sobre la renta de la tierra obtenida mediante arriendos y aparcerías, cuya evolución pudo forzar a los propietarios a adoptar medidas atenuantes de signo diverso. La cuestión principal es hasta qué punto se adoptaron y, desechado el cultivo directo, cuáles fueron las opciones escogidas. Cabe indicar, en este sentido, que el predominio de la aparcería como forma de cesión y explotación de los masos dotaba a los propietarios de una notable capacidad de intervención sobre la dirección de

3 Planas Maresma (2003), (2004a), (2004b) y (2006).

4 Sobre Can Codorníu, véase Pujol Andreu (1999). Un ensayo de explotación directa fracasado, en Planas Maresma (1994a). Ver también Garrabou, Planas y Saguer (2001a). 
las explotaciones. ${ }^{5}$ Bajo coyunturas expansivas, como se demostró durante las décadas anteriores a la crisis finisecular, la posición ausente y rentista de muchos propietarios no impidió que respondiesen a las oportunidades brindadas por el mercado, que realizaran inversiones sustanciales, ni que reorientaran el sistema de cultivo de sus fincas. Pero cuando la coyuntura invertía su signo, era frecuente que los mismos propietarios reajustaran los gastos e inversiones a la baja, minimizando los costes de explotación. En el caso de los Torelló, Pere Pascual ha observado que la contención en el gasto monetario - y especialmente en la inversión - fue clave para el mantenimiento del nivel de renta del propietario en términos reales durante el periodo 1900-1930. ${ }^{6}$ En dicho caso, la estrategia adoptada estaba relacionada con un proceso de especialización cerealícola de carácter extensivo que permitió sortear la realización de grandes inversiones y transferir a los aparceros los costes de producción, crecientes aunque fuera en términos de oportunidad. Sin embargo, allí donde el proceso de especialización apuntaba hacia cultivos más intensivos, hacia nuevos cultivos arbóreos o hacia la ganadería de renta, la contención inversora podía tener efectos contraproducentes e, iniciado el proceso de despoblación rural, en algunas áreas incluso podía reducir la posibilidad de encontrar aparceros para las fincas. ${ }^{7}$

En el presente estudio queremos ahondar en las respuestas de los propietarios a los desafíos económicos y sociales que afectaron a sus patrimonios durante las décadas de 1920 y 1930. Concretamente examinaremos un caso singular, el de Pelayo Negre y Pastell (1895-1984), en el que convergen, además de la disponibilidad documental, ${ }^{8}$ varias

5 Garrabou, Planas y Saguer (2001b).

6 Pascual (2000), p. 202.

7 Sobre el proceso de despoblación rural y su cronología, veáse Vidal Bendito (1979) y, aunque referido sólo a las comarcas de montaña, también puede consultarse Collantes (2005). Un ejemplo local que pone de relieve la importancia del abandono de masos durante el primer tercio del siglo XX en una zona con un fuerte componente forestal, se encuentra en Parés Ganyet (2001), pp. 141-157.

8 El fondo documental se encuentra depositado en el Arxiu Històric Municipal de Girona. Está constituido por 74 cajas, correspondientes básicamente a los siglos XIX y XX, una notable colección de pergaminos y un considerable fondo hemerográfico y bibliográfico. Aunque la documentación fue cedida hace unos veinte años, aún está por catalogar y sólo se dispone de un inventario de cajas realizado en el momento de ingresar el fondo. Para la elaboración de este trabajo se ha utilizado documentación de las siguientes cajas: 5 , $6,7,13,17,18,19,20,62$ у 63 . 
facetas que lo convierten en especialmente atractivo. Por una parte, poseyó uno de los grandes patrimonios rústicos gerundenses del siglo XX; por otra, destacó como dirigente del sindicalismo católico local y participó activamente en la vida política desde las filas del catalanismo conservador; y, finalmente, lo más interesante es que también desarrolló una notable actividad intelectual como analista y propagandista agrario. En calidad de lo último, abanderó una batería de propuestas reformistas de signo católico, inspiradas en la doctrina social emanada de la encíclica Rerum Novarum y que él mismo agrupaba bajo la etiqueta — nada original- de Acción Social Agraria para contraponerla a los proyectos de reforma agraria de carácter menos conservador. ${ }^{9}$ La posibilidad de contrastar, en una misma persona, discurso público y gestión privada constituye un ejercicio de notable interés. ${ }^{10}$ En las páginas que siguen, pues, vamos a indagar hasta qué punto existía una coherencia entre lo que realmente se practicaba en materia de gestión patrimonial y lo que se defendía públicamente. El ejemplo de Pelayo Negre nos permitirá preguntarnos si los terratenientes que, en las convulsas décadas de 1920 y 1930, defendieron un modelo conservador de transformación de las estructuras agrarias —en contraposición y respuesta a las propuestas de reforma agraria que, con mayor o menor intensidad, podían lesionar los derechos de propiedad que habían adquirido- desarrollaron modelos de explotación y gestión privada coherentes con su discurso. Ciertamente, el análisis de un caso es insuficiente para establecer conclusiones referentes a pautas de acción colectivas; sin embargo, constituye una buena vía para enriquecer y matizar los perfiles demasiado simples que con frecuencia se han utilizado para describir la acción de los terratenientes en tanto que agentes económicos.

9 Cabe recordar que el concepto de acción social tuvo, en la misma época, significados distintos y que es, por tanto, un concepto equívoco. Un ejemplo de esta ambigüedad lo constituye la aparición, en la década de 1930, de una organización sindical con el nombre de Acció Social Agraria de les Terres Gironines, que dirigió el proceso de revisión de contratos de cultivo abierto por la Generalitat (decreto de 29 de abril de 1931) y que estuvo en la órbita del Bloc Obrer $i$ Camperol, un partido de orientación marxista. Ver Pujol (1977) y Pujol y Clara (1978).

10 En esta línea pueden consultarse los trabajos de Jordi Planas (1994a), (1994b) y (1996) sobre Jaume Maspons i Camarasa y el reciente libro de Rosa María Almansa (2005) sobre el conde de Torres Cabrera. 


\section{El patrimonio: formación y consolidación}

Según las rectificaciones de los amillaramientos realizadas durante las décadas de 1940 y 1950, el patrimonio de Pelayo Negre ascendía a 431 hectáreas, distribuidas en tres comarcas y un total de trece municipios. Aunque no se encontraba entre los 49 propietarios que poseían más de 500 hectáreas dentro de los límites de la provincia de Gerona, ${ }^{11}$ es muy probable que la renta generada por sus fincas, dada su composición, superara con creces a muchos que le aventajaban en extensión. Efectivamente, si comparamos el peso de las tierras de cultivo en los grandes patrimonios (donde raramente alcanzaba el 25\% y cuyo promedio era del $11 \%$ ) con la estructura de usos del suelo del patrimonio Negre y Pastell, observamos una presencia baja de bosque (26\%) y yermo $(15 \%)$ y un porcentaje comparativamente alto de suelo agrícola (59\%). Buena parte de éste, además, se hallaba ubicado en las zonas llanas y fértiles del Ampurdán y de la comarca de Gerona. Sin duda se trataba de uno de los patrimonios agrarios más importantes de la provincia. No en vano su bisabuelo - Salvador Negre y Vancells — fue el contribuyente por rústica número 25 de la provincia de Gerona, con una cuota de 2256 pesetas, ${ }^{12}$ en un momento en que el patrimonio aún no había incorporado sucesivas agregaciones que acrecentaron de forma significativa el volumen de inmuebles.

El patrimonio heredado por Pelayo Negre tenía unos orígenes relativamente recientes. Sus raíces remotas las hallamos, básicamente, en dos familias de Castelló d'Empúries que ejercieron oficios liberales (boticarios y, después, licenciados en farmacia, los Negre; notarios y doctores en leyes, los Pastell) y que, durante los siglos XVII y XVIII, protagonizaron sendos procesos de acumulación de tierras a través del mercado inmobiliario local. No fue propiamente hasta el siglo XIX cuando se constituyó como un único gran patrimonio, especialmente como consecuencia de una cadena de uniones matrimoniales que implicaron agregaciones patrimoniales. ${ }^{13}$ Dichas agregaciones no fueron tanto el resultado de una estrategia matrimonial prediseñada y consciente como producto del azar biológico. Sólo

11 Estalella (1984).

12 Congost (1983).

13 Saguer (2001). 
TABLA 1

LOCALIZACIÓN Y EXTENSIÓN DEL PATRIMONIO NEGRE Y PASTELL, 1959

\begin{tabular}{|l|c|l|}
\hline Municipio & Extensión (ha) & Patrimonio de origen \\
\hline Aiguaviva & 2,2 & Goy \\
Fornells de la Selva & 52,2 & Goy \\
Quart & 13,9 & Vidal - Goy \\
Garriguella & 6,0 & Rimbau \\
Castelló d'Empúries & 176,3 & Pastell + Negre \\
Fortià & 3,5 & Pastell \\
Mollet de Perelada & 60,2 & Pastell \\
Perelada & 3,8 & Pastell \\
Vilanova de la Muga & 27,8 & Pastell \\
Sant Climent Sescebes & 47,8 & Teixidor de Vilartolí \\
Espolla & 7,0 & \\
Gualta & 14,8 & Negre - Pla \\
Torroella de Montgrí & 16,3 & Negre - Pla \\
\hline Total & 431,8 & \\
\hline
\end{tabular}

FUENTE: Estalella (1984).

el matrimonio de los padres de Pelayo Negre, celebrado en 1894, concuerda con la idea de una estrategia premeditada de acumulación, puesto que ambos contrayentes, que eran parientes muy cercanos y tuvieron que tramitar la pertinente dispensa papal, se sabían de antemano herederos del patrimonio de sus respectivas familias.

Uno de los patrimonios agregados durante el siglo XIX fue el patrimonio Goy, procedente de un tronco familiar de payeses de remensa que habían evolucionado hasta convertirse en pequeños hacendados rentistas. Poseían tres masos en dos municipios colindantes y situados a pocos kilómetros de la ciudad de Gerona: el mas Goy y el mas Casas, en Fornells de la Selva; el mas Vidal, en Quart. Conjuntamente, según los amillaramientos de 1879-1880, abarcaban una superficie de 72 hectáreas, de las cuales se cultivaban unas 50 (69\%). Eran explotaciones ubicadas en un llano fértil e irrigado por un afluente del Ter (Oñar) y por diversos afluentes menores. Como era habitual entre los grandes propietarios, cuando se reunían dos patrimonios se mantenían como entidades de gestión autónoma, con sus propias administraciones y contabilidades separadas. A falta de libros que registren los resultados del conjunto del patrimonio, nuestro trabajo se ha centrado en el análisis de esta unidad patrimonial, porque en las catas realizadas fue la serie que mostró una documentación más rica y continua. 


\section{Una propuesta de Acción Social}

Pelayo Negre (1895-1984) fue un rico propietario que — a diferencia de otros terratenientes - ${ }^{14}$ participó activamente en la vertebración del sindicalismo agrario de signo católico tanto en su localidad de residencia como en el ámbito provincial. Presidió el Centre Agrícola i Social de Castelló d'Empúries y fue durante mucho tiempo secretario de la Federació Sindical Agrària, la entidad que agrupaba al sindicalismo católico en la provincia de Gerona. También estuvo presente en diversas entidades locales, fue miembro del consejo directivo del Instituto Agrícola Catalán de San Isidro - núcleo de la patronal agraria catalana- - y militó en la Lliga, partido por el que se presentó a elecciones en dos ocasiones (noviembre de 1932 y noviembre de 1933). ${ }^{15}$

Destacó como propagandista, divulgador e historiador del derecho y de las instituciones agrarias. Tuvo una formación superior en derecho y se doctoró con una tesis sobre la evolución de la propiedad de la tierra en la diócesis de Gerona, publicada en $1921{ }^{16}$ Sus intereses intelectuales siempre estuvieron ligados a estos orígenes y sus publicaciones en la prensa sindical, agronómica y local durante las décadas de 1920 y 1930 giraron insistentemente en torno a la cuestión del derecho de propiedad, los proyectos de reforma agraria, los conflictos sociales, la política social agraria y cuestiones similares. Hemos localizado un total de setenta artículos publicados entre 1923 y 1935 en distintos órganos de prensa, cuyo contenido básicamente se circunscribe a dichas cuestiones. Muchos aparecieron en el órgano de prensa del sindicalismo católico provincial (Butlletí de la Federació Sindical Agrària) o en boletines de las asociaciones patronales (Butlletí Oficial de la Cámara Agrícola de l'Empordà), pero también —especialmente durante la década de 1930 - en la prensa agronómica española y catalana (Agricultura. Revista agropecuaria; Agricultura i ramaderia).

El discurso político de Pelayo Negre tuvo como eje vertebrador la reacción contra cualquier propuesta de reforma agraria y la defensa de la inviolabilidad del derecho de la propiedad privada ante el Estado. Su

14 Sobre la baja participación de los terratenientes en la acción sindical, véase Garrido (2003).

15 Saguer y Tébar (1991).

16 Negre y Pastell (1921). 
argumentación tiene un carácter marcadamente local: insiste en la bondad del régimen de distribución y acceso a la propiedad de Gerona y, por extensión, de Cataluña, comparándolo con las regiones españolas latifundistas y minifundistas; y minimiza los conflictos existentes, atribuyéndoles un carácter local y la posibilidad de resolverlos sin mediar medidas legislativas. Sus propuestas en materia de política social se centraban en la difusión de la propiedad entre los pequeños campesinos: «La propietat és un bé: augmentem doncs el número de propietaris» (1927). A esta tarea, la Federación Sindical Agraria dedicó cierta prioridad, aunque finalmente con resultados escasamente relevantes en términos redistributivos. Los textos de Pelayo Negre, sin embargo, tendían a magnificar y sobrevalorar la acción de los terratenientes en la resolución de los problemas económicos y sociales del campo, aspecto claramente visible en una cuestión central como la transformación de los tratos de masovería. En definitiva, la Acción Social que defendía Pelayo Negre pasaba por fomentar la acción colectiva a través de organizaciones sindicales, por facilitar el acceso de los pequeños campesinos a la propiedad mediante el mercado y por modernizar el sistema contractual dominante para facilitar la adaptación de las explotaciones a las condiciones del mercado. Todo ello con el fin de evitar la intervención del Estado a través de medidas legislativas de reforma agraria.

Es relevante, más allá de la biografía personal, que tuviera formación universitaria y que ésta fuera en el ámbito del Derecho. Durante el siglo XIX estudiar - realizar estudios superiores - fue cosa de segundones (fadristerns), a quienes les convenía tener una profesión con que ganarse la vida, dado el régimen hereditario vigente. Con frecuencia el pago de los estudios se financiaba a cargo de la legítima, a la cual los segundones tenían derecho. Por contra, pocos hereus cursaban estudios universitarios. No lo necesitaban, e incluso podía alejarlos de sus funciones sociales y de la gestión del patrimonio. Un estudio sobre 35 historias de vida de grandes propietarios gerundenses, realizado mediante entrevistas orales, nos ha permitido observar que fue básicamente la generación que se formó antes de la Guerra Civil la que empezó a acudir de forma significativa a la universidad. ${ }^{17}$ Sin embargo, no parece que entre ellos hubiera demasiada predilección por los estudios técnicos de agronomía, veterinaria o

17 Saguer (2005), pp. 109-119. 
silvicultura. La carrera de Derecho, que había sido uno de los estudios tradicionales para los segundones de las familias propietarias, lo continuó siendo cuando los primogénitos o hereus acudieron a la Universidad. No fue hasta después de la guerra cuando el número de hereus con formación técnica empezó a ser significativo. ${ }^{18} \mathrm{Al}$ margen de casos concretos, con una formación agronómica autodidacta, la escasa capacitación técnica de muchos propietarios pudo limitar seriamente su papel en el proceso de transformación que la agricultura estaba experimentando desde fines del siglo XIX.

\section{Una gestión muy conservadora}

Sería apresurado establecer una relación causal demasiado estrecha entre el tipo de formación universitaria de los hereus y el modelo de gestión patrimonial aplicado. Sin embargo, no deja de llamar la atención que un propietario como Pelayo Negre, muy activo en el ámbito sindical y firme partidario de la realización de cambios en el ámbito privado para evitar la intervención del Estado en la resolución de los conflictos agrarios, se caracterizara por una gestión patrimonial muy conservadora. En términos globales su actuación sobre el patrimonio parece gobernada por la inercia, puesto que se perciben pocos cambios en relación con las pautas seguidas por sus antecesores.

\subsection{Estructura de cultivos y de la renta}

Analicemos, en primer lugar, la estructura de cultivos de sus fincas. La documentación nos permite combinar dos puntos de observación: el número de treznales (cavallons) obtenidos antes de trillar y repartir el grano, y las cantidades de renta en especie recaudadas por el propietario.

Las relaciones de treznales sólo contemplan lo que en la zona se conocía como granos de arista (trigo, tranquillón, avena, cebada y centeno), mientras que las relaciones de renta son más completas e incluyen todos los cultivos que rentaban. De ambos cuadros se deduce que los cambios en

18 La tardía orientación hacia los estudios agronómicos entre los propietarios catalanes también fue detectada por Camps i Arboix (1965), p. 21. 
TABLA 2

NÚMERO DE TREZNALES COSECHADOS EN EL PATRIMONIO GOY (media anual)

\begin{tabular}{|l|c|c|c|c|c|}
\hline & Trigo & Tranquillón & Avena & Centeno y cebada & Suma \\
\hline $1886-1895$ & 493 & 76 & $i$ & 0 & 569 \\
$1896-1905$ & 467 & 88 & 31 & 0 & 564 \\
$1927-1935$ & 550 & 21 & 37 & 24 & 623 \\
\hline
\end{tabular}

FUENTE Y NOTA: Arxiu Municipal de Girona, Fondo Pelayo Negre. Un treznal (cavalló) estaba compuesto por diez gavillas (garbes).

TABLA 3

RENTA EN ESPECIE PROCEDENTE DEL PATRIMONIO GOY (media anual en cuarteras)

\begin{tabular}{|c|c|c|c|c|c|c|c|c|c|}
\hline & Trigo & Tranquillón & Avena & Cebada y centeno & Maiz & Habas & Mijo & Judias & Suma \\
\hline $1886-1895$ & 115 & 20 & 2 & 0 & 23 & 1 & 0 & 8 & 169 \\
$1896-1805$ & 113 & 27 & 6 & 0 & 22 & 2 & 0 & 4 & 173 \\
$1927-1935$ & 107 & 4 & 10 & 4 & 16 & 1 & 1 & 2 & 145 \\
\hline
\end{tabular}

FUENTE Y NOTA: Arxiu Municipal de Girona, Fondo Pelayo Negre. Una cuartera equivale a 72,32 litros.

la esfera de la producción fueron escasos. Es posible que la producción experimentara un cierto aumento, dado que la cantidad de treznales creció. Sin embargo, el incremento fue ligero, del orden de un $10 \%$, y lo que los datos dejan patente es que no repercutió sobre la renta del propietario. Al contrario, ésta se mantuvo estancada e incluso, en el trigo, parece que tendió a la baja cuando la producción bruta (en número de treznales) ascendió de forma significativa (cerca del $18 \%$ sobre el promedio 18861905). ¿Es reflejo de un cambio en los tratos de masovería? Las cifras parecen sugerirlo, aunque, como veremos, las informaciones sobre el sistema contractual no lo corroboran.

En cualquier caso, tanto producción como renta no experimentaron aumentos significativos entre fines del siglo XIX y el periodo en que Pelayo Negre empezó a gestionar el patrimonio Goy. Se aprecian algunos cambios en la estructura de la producción, pero en ningún caso implican una reorientación a fondo de las explotaciones, y menos en el sentido hacia el cual estaba avanzando la comarca, donde se estaba desarrollando un modelo centrado en la ganadería de engorde y la producción de forraje en 
alternancia con los cereales. ${ }^{19}$ El retroceso del tranquillón (mezcla de trigo y centeno) es fruto de un proceso general de rechazo de las calidades inferiores de pan por parte de la población, perceptible desde fines del siglo $\mathrm{XIX} ;{ }^{20}$ mientras que el aumento de la avena o la aparición de la cebada y el centeno pueden considerarse como cultivos sustitutivos del tranquillón. El trigo no sólo continuó siendo el cultivo dominante, sino que aumentó su participación en la estructura productiva del patrimonio, pasando del $66 \%$ al $74 \%$ de la renta del propietario en términos de volumen. Un cultivo como el maíz, generalmente vinculado al engorde de ganado, tenía una presencia importante, más si se tiene en cuenta que rentaba en menor proporción que los granos de arista. Sin embargo, los datos muestran que su cultivo se mantuvo sin alteración en la proporción ya existente a fines del siglo XIX. Finalmente, también es muy relevante que no aparezcan aquellos cultivos que estaban asociados con los nuevos modelos de rotación que se estaban expandiendo por la región, particularmente la alfalfa, la esparceta y las raíces forrajeras. Si algún cambio ocurrió, éste debió de producirse en el espacio de cultivos francos que los tratos contemplaban.

Si la producción agrícola parece no seguir el ritmo de los cambios que se estaban imponiendo en los ámbitos regional o comarcal, lo que sucedió con la producción pecuaria es aún más significativo. Durante la primera mitad del siglo XIX la zona próxima a la capital (Gerona) experimentó un crecimiento importante de la ganadería de recría para carne, especialmente bovina y porcina. ${ }^{21}$ La participación de Pelayo Negre en este negocio ganadero fue, sin embargo, absolutamente nula. Como otros propietarios sobre los cuales tenemos conocimiento, rechazó participar en el desarrollo de esta línea de producción comparativamente más remuneradora que los cultivos tradicionales. Ni estableció tratos de aparcería pecuaria con sus masoveros, ni permitió modificar la estructura de cultivos para facilitar una mayor integración de las producciones agrícolas y pecuarias. Ello no impidió a sus masoveros apostar con mayor o menor intensidad por dicha actividad. E incluso, como veremos más adelante, Pelayo Negre apoyó en cierto sentido la reorientación ganadera de sus fincas. Pero mantuvo siempre una posición distanciada, más propia de un rentista.

19 Cortada Reus (1950), pp. 97-99.

20 Garrabou y Cussó (2004).

21 Cortada Reus (1950), pp. 205 y 218. 
El análisis de la correspondencia emitida por el administrador parece corroborar las conclusiones anteriores, en la medida en que permite observar cuáles son las cuestiones consideradas relevantes en la relación con el administrador. Hasta el momento hemos localizado 79 cartas correspondientes al periodo 1905-1936, de las cuales 50 fueron dirigidas a Pelayo Negre y las otras a su padre, Enric Negre. Aunque su distribución en el tiempo es irregular, el contenido de la muestra es bastante indicativo. ¿Cuáles son las cuestiones que centran la correspondencia? Buena parte de las cartas informan al propietario sobre el estado de la cosecha en términos genéricos (si el año es bueno o malo, seco o lluvioso), sobre el proceso de recolección y sobre el cobro de las rentas. Otro aspecto central en esta serie de correspondencia se refiere a la comercialización de la producción (precios del mercado, tratos con mayoristas, tratos con fábricas de harina...), dado que ésta la llevaba a cabo el administrador con el consentimiento o siguiendo órdenes del propietario, según el caso. La gestión de un silo excavado dentro de uno de los masos y la venta del grano contenido en él son otro centro de atención, así como el control y pago de las distintas obras realizadas en las fincas. La intervención del administrador en la resolución de conflictos con propietarios vecinos (por razón de caminos o captación de aguas) y con (o entre) los masoveros también era motivo de información por escrito, así como la actuación en la búsqueda y selección de nuevos aparceros. Finalmente, también existen otros aspectos menores recogidos por la correspondencia: plantación de árboles, vigilancia del bosque, mantenimiento de una casa de los Negre en la ciudad de Gerona..., pero lo más relevante es que no se destinase espacio alguno a tratar sobre cuestiones relativas al sistema de cultivo (qué se debía plantar, qué superficie dedicar a cada cultivo, qué dosis de abonado debía aplicarse, qué variedades cabía experimentar...), y mucho menos al ganado. Ni una sola línea. Ciertamente, la correspondencia emitida por el administrador no refleja plenamente la intervención del propietario, pero da bastantes indicios sobre los aspectos que se trataban y sobre los que no eran motivo de preocupación, puesto que ni tan sólo se recababa información sobre ellos.

El contrato de aparcería que regulaba la explotación de los masos era una fórmula flexible que permitía una intervención activa del propietario en los procesos de toma de decisiones sobre el sistema productivo de las fincas, no sólo en términos genéricos, sino también en su concreción diaria. A diferencia de un arrendatario, el aparcero podía ser considerado en 
cierto sentido como un trabajador al servicio del propietario, y su trabajo, dirigido de cerca o de lejos por éste. No parece, sin embargo, que esta facultad fuera ejercida por Pelayo Negre. Y si lo hizo probablemente fue para evitar o limitar cambios en el uso del suelo de sus fincas.

\subsection{Régimen de explotación y tenencia}

El régimen de explotación y tenencia de las fincas es otro aspecto que, por los datos disponibles, también permaneció bastante anclado hasta que el conflicto abierto durante la Segunda República forzó un proceso de revisión de la renta. El primer elemento a destacar sobre esta cuestión es el elevado grado de fraccionamiento de las explotaciones. Se trata de un aspecto heredado, que Pelayo Negre mantuvo al menos hasta la Guerra Civil. Durante la década de 1920 los tres masos del patrimonio estuvieron repartidos entre doce aparceros. A fines del siglo XIX habían sido trece. En algún momento anterior a mediados del siglo XIX, las masías fueron ampliadas $\mathrm{y}$, al tiempo, fragmentadas. Varias familias aparceras compartían el espacio que anteriormente había sido de un solo mas, aunque cinco de ellas no residían propiamente en los masos, sino en casas situadas dentro del pueblo de Fornells de la Selva. El total de tierra destinada al cultivo era de 50 hectáreas, las cuales se distribuían de forma desigual entre los aparceros. Algunos disponían de una explotación de reducidas dimensiones, aunque probablemente capaz de garantizar un nivel mínimo de reproducción. Concretamente se trata de los tres masoveros que tenían asignadas 8,75 hectáreas (40 vessanes). Pero los demás disponían de lotes de dimensión bastante más reducida: a cuatro les correspondían 4,4 hectáreas (20 vessanes) y los otros se situaban por debajo de dicho nivel. A pesar de dicho diferencial, no parece que los tratos difirieran de forma sustantiva entre unos y otros excepto en dos casos: un horno de ladrillos adjunto al mas Casas, que contaba con poco más de una hectárea, y la casa y 20 vessanes ( 4,4 hectáreas) de tierra cedidas a la familia Vilà, quienes ejercieron como administradores del patrimonio a lo largo de tres generaciones.

Aunque los antiguos masos integraban un territorio bastante compacto - lo cual, en algunas zonas, era menos frecuente de lo que se supone$y$, por tanto, era posible reunir las fincas en explotaciones mayores, lo cierto es que sólo se detecta un pequeño movimiento de concentración parcelaria que afectó a una de las explotaciones más pequeñas. No faltaron las 
TABLA 4

MASOVEROS DEL PATRIMONIO GOY, 1931

\begin{tabular}{|ll|c|c|}
\hline & & $\begin{array}{c}\text { Extensión } \\
\text { (vessanes) }\end{array}$ & $\begin{array}{c}\text { Estimación renta } \\
\text { (en ptas.) }\end{array}$ \\
\hline Miguel Ribes & mas Goy & 40 & 1238,23 \\
Jaume Torrent & mas Goy & 40 & 1474,16 \\
Joan Badia & mas Goy & 20 & 728,15 \\
Baldiri Vilà & mas Vidal & 40 & 1138,71 \\
Josep Coloma & mas Cases & 20 & 843,48 \\
Josep Francisco & mas Cases & 20 & 587,09 \\
Josep Quintana & horno ladrillos & 5 & 650,00 \\
Jaume Ventura & casa pueblo & 6 & 318,19 \\
Sebastià Peralta & casa pueblo & 10 & 436,78 \\
Miquel Pla & casa pueblo & 5,5 & 280,50 \\
Vda Lluis Darna & casa pueblo & 2,5 & 180,00 \\
Miquel Vilà & casa pueblo & 20 & 333,17 \\
\hline Total & & 229 & 8208,46 \\
\hline
\end{tabular}

NOTA: Una vesana equivale a 0,2187 hectáreas.

oportunidades para ello, sino la voluntad. Si se observa la nómina de aparceros que figuran en los estados de cosecha, se observa que cuatro de las nueve explotaciones experimentaron un cambio de aparcero entre 1923 y 1935. Excepto en un caso, se trata de casos de desahucio asociados a viudedad. Sea cual fuere el motivo, hubiera podido dar pie a reunir fincas para constituir explotaciones mayores, pero se renunció a ello. Tiempo después, en 1954, el patrimonio aún continuaba cultivado por diez aparceros. Los avances en materia de concentración parcelaria habían sido mínimos

Otro aspecto destacable del sistema de explotación y tenencia se refiere a la persistencia de la aparcería como fórmula de cesión. Pelayo Negre fue siempre un firme defensor de los tratos de aparcería, a pesar de las peticiones de arriendo monetario que le plantearon algunos candidatos a fincas vacantes, a las que se negó, y a pesar de existir una tendencia general en sentido contrario. Cabe señalar a continuación de lo dicho que, realmente, los tratos eran sólo parcialmente de aparcería, puesto que se percibía una cantidad importante en metálico en concepto de alquiler de la casa y edificios anexos. Entre 1927 y 1931 los pagos en metálico por alquiler y por compensación de contribuciones ascendieron al 37\% del ingreso bruto del propietario. Y esta proporción es probable que creciera en los años siguientes, porque el ingreso por venta de granos descendió de forma 
significativa. La existencia de estas rentas correspondientes al alquiler de edificios puede explicar que no llegara a plantearse la posibilidad de reunir fincas contiguas. Dado que los edificios, especialmente los integrados dentro de los masos, no tenían valor sin tierras, reagrupar éstas significaba perder unas rentas en nada despreciables.

Donde parece que Pelayo Negre estuvo relativamente dispuesto a transigir fue en la renta en especie. Desconocemos si alguno de los aparceros llegó a presentar una demanda de revisión del contrato. Es probable que no lo hicieran, ${ }^{22}$ aunque tenían motivos sobrados para ello. La renta que se les exigía era considerable. Desde mediados del siglo XIX, con independencia de los pagos en metálico, debían entregar un tercio de la cosecha de granos de arista y un cuarto de los demás granos (o una compensación monetaria), además del diezmo, que una vez abolido continuó siendo exigido por los sucesivos propietarios. A fines del ochocientos, la abuela de Pelayo Negre convirtió el doble pago en especie (por diezmo y por renta) en un concepto único por el cual debían entregarse las $2 / 5$ partes de la cosecha de granos de arista y $1 / 3$ de los demás. La mayoría, además, debía pagar una cantidad adicional en metálico en compensación por las contribuciones (adjutori). Estas onerosas condiciones de cesión fueron las que heredó Pelayo Negre, y éste las mantuvo sin práctica alteración durante la década de 1920, aunque en el contexto de la Segunda República se vio forzado a aceptar su revisión. La presión de los aparceros, detectable a través de la correspondencia desde fines de los años veinte, estalló en julio de 1933, momento en que algunos de ellos mostraron claramente su disconformidad con las reglas de distribución del producto. Los datos disponibles hasta el momento sugieren que no se tomaron represalias contra ningún masovero, y que en la cosecha siguiente (1934) se aplicó una rebaja sustancial de la renta en especie (1/3 para el grano de arista y $1 / 4$ para los demás), aunque no podemos valorar correctamente su efecto en términos de renta.

Finalmente, un último aspecto relativo al sistema de cesión y tenencia se refiere a la participación del propietario en los costes de explotación. Podría esperarse que una renta tan elevada diese lugar a una participación

22 No consta que en el pueblo de Fornells se presentara ninguna demanda de revisión a la Comisión Arbitral del partido de Gerona. Ver Matas Balaguer (1991), p. 34. 
del propietario en ciertos costes de producción, como era habitual en las medierías. Sin embargo no era así. A pesar de lo que el propio Pelayo Negre propugnaba desde la prensa sindical y agronómica sobre este aspecto del sistema contractual, ${ }^{23}$ no existe ningún indicio de que lo aplicara con anterioridad a la Guerra Civil. Posteriormente, en el marco del proceso de revisión contractual llevado a cabo a principios de los años cuarenta, sí que asumió de forma sistemática el coste de la simiente, los fertilizantes y, en algunos casos, la trilla en la misma proporción que la renta obtenida. Pero no antes.

\subsection{Régimen de administración}

El conservadurismo también caracterizó a la esfera de la administración patrimonial. Pelayo Negre heredó un régimen de administración gestado durante la primera mitad del siglo XIX y lo mantuvo sin alterar sus líneas básicas. Dicho régimen administrativo se basaba en la figura de un masovero que, al mismo tiempo, actuaba como administrador y encargado. No era una figura extraña en el campo catalán. Victorino Santamaría ya recogió algunos ejemplos relacionados con terratenientes nobles como el marqués de Castellvell o el marqués de Alfarrás. ${ }^{24}$ Tenía asignadas funciones bastante amplias que iban desde la colecta de rentas hasta la comercialización de granos, pasando por la supervisión de las fincas y el pago de servicios prestados por terceros. También actuaba como intermediario entre los demás aparceros y el propietario (excepto en el caso del ladrillero, quien, al parecer, tenía el privilegio de tratar directamente con el propietario), mediaba en los conflictos entre masoveros y tenia un papel activo en el proceso de selección de nuevos aparceros. La doble condición de administrador y masovero tenía dos ventajas para el propietario: por una parte, la condición de masovero le facilitaba una mayor subordinación del administrador; por otra, le permitía establecer un sistema de remuneración basado en la compensación por las tareas realizadas con rebajas en la renta y ciertas franquicias. Es muy probable que dicha forma de remuneración significara un ahorro notable en los costes de administración, que usualmente se elevaban al $10 \%$ del ingreso bruto ordinario. Comparando

23 Por ejemplo, Negre y Pastell (1925).

24 Santamaría y Tous (1902). 
la renta obtenida de aquellos aparceros que trabajaban fincas de la misma extensión que el masovero-administrador con la efectivamente pagada por éste, se deduce que el coste del administrador durante el periodo 19271931 estaba entre las 200 y 250 pesetas anuales, o sea, entre el 2,5\% y el $3 \%$ de la renta bruta total.

La eficacia y la funcionalidad de este régimen administrativo parece corroborada por su larga pervivencia no sólo en términos generales, sino también en su concreción en el ámbito individual o, mejor dicho, familiar. Efectivamente, desde la década de 1840 hasta, al menos, la de 1960 la administración del patrimonio Goy corrió a cargo de una misma familia masovera, los Vilà, que se sucedieron en esta tarea de la misma forma que algunos masoveros de confianza podían transmitir la masovería de padres a hijos. No es habitual encontrar administradores que hayan perdurado tanto tiempo al servicio de un gran patrimonio agrario. Cuando Pelayo Negre accedió al patrimonio, ejercía como administrador Miquel Vilà y él lo confirmó y lo mantuvo con los mismos tratos que su padre.

\section{Evolución de la renta}

Una actuación tan aparentemente gobernada por la inercia tuvo su repercusión sobre la renta. No cabía esperar otra cosa. Aunque la documentación no nos permite reconstruir con detalle la evolución de la renta líquida, ni tan sólo de la renta bruta total, los indicios sobre su caída parecen claros.

Por lo que se refiere a las rentas en especie, como se ha visto, éstas se mantuvieron prácticamente estancadas en un contexto de depreciación relativa de los precios agrarios y, especialmente, de las especies cerealícolas sobre las cuales se percibían partes de cosecha. Sólo al final del periodo, fruto de la renegociación de la renta en el contexto de la Segunda República, las cantidades colectadas parece que sufrieron una merma significativa. En cualquier caso, no se aprecia ningún aumento significativo y perdurable de las cantidades rentadas en especie en comparación con las últimas décadas del siglo XIX.

En términos de ingreso, aunque, obviamente, el importe nominal por venta de granos aumentó de forma sensible, este aumento fue menor que 
TABLA 5

VALORACIÓN DE LA RENTA BRUTA DEL PATRIMONIO GOY, EN PESETAS CONSTANTES DE 1913

\begin{tabular}{|l|c|c|c|c|c|c|}
\hline Periodo & $\begin{array}{c}\text { Renta } \\
\text { en especie }\end{array}$ & $\begin{array}{c}\text { Alquiler } \\
\text { casa }\end{array}$ & $\begin{array}{c}\text { Hornadas } \\
\text { ladrillos }\end{array}$ & Adjutori & Bosque & Suma \\
\hline $1884-1893$ & 3302 & 2467 & 254 & [casa] & 142 & 6165 \\
$1893-1900$ & 3228 & 2501 & [casa] & [casa] & 129 & 5857 \\
$1927-1931$ & 3021 & 1257 & [casa] & 486 & [no computada] & 4764 \\
\hline
\end{tabular}

NOTA: Lo percibido en concepto de hornadas de ladrillos y adjutori, cuando no se explicita en la columna correspondiente, es porque está agregado a la partida de alquiler de la casa.

la evolución general de los precios y, por tanto, se aprecia una baja en el ingreso real, especialmente intensa, aunque los datos son fragmentarios, durante los años de la Segunda República.

Caso aparte lo constituyen los componentes monetarios de la renta, atribuidos al alquiler de las casas o masías y a pagos compensatorios por la contribución (adjutoris). Como se ha observado en otros patrimonios (por ejemplo, en el patrimonio Bru), los componentes monetarios de las aparcerías parece que se mantuvieron bastante fosilizados desde las últimas décadas del siglo XIX, a pesar de los procesos inflacionarios que devaluaron fuertemente dichas rentas. ${ }^{25}$ Es bastante sorprendente observar la incapacidad de los propietarios para forzar una renegociación de estos componentes, a pesar de los cambios de masoveros (y por ende el establecimiento de nuevos tratos) y a pesar de que el propietario consiguiera imponer cambios en algunos productos (mijo, sorgo, panizo) que rentaban en moneda y pasaron a partes de fruto, concretamente al cuarto. En términos generales, la renta monetaria real — deflactada- disminuyó un 36\% entre 1884-1893 y 1927-1931, aunque en términos nominales registrara un crecimiento del $50 \%$. Este aumento del ingreso nominal se debió a dos procesos complementarios: a) una mayor exigencia de pagos compensatorios por la contribución de inmuebles y b) la repercusión sobre la renta de las inversiones y mejoras realizadas en los edificios (a razón de un 5\% del capital invertido).

25 Saguer (1998). 
En cualquier caso, caben pocas dudas de que la renta experimentó un proceso de erosión que, probablemente, se acentuó durante la década de 1930, aunque las cifras de que disponemos para estos últimos años sean fragmentarias. La evolución del patrimonio Goy confirma, pues, la hipótesis de una caída en la renta de la tierra durante el primer tercio del siglo XX y una disminución, por tanto, del ingreso obtenido por los grandes propietarios a través de sus fincas agrícolas. A diferencia de lo observado en otros casos (por ejemplo, en el patrimonio Maspons), dicha disminución no fue paliada con la venta de productos forestales. Como se ha expuesto anteriormente, la superficie forestal del conjunto de los patrimonios de los Negre y Pastell era excepcionalmente baja en relación con la estructura típica de la gran propiedad. En las fincas del patrimonio Goy, lo que se detecta durante estos años, más que talas paliativas, es un creciente interés por mejorar los recursos forestales mediante la plantación de árboles de ribera, aprovechando la proximidad al río Oñar. Sólo se anotó una operación importante de venta de árboles en 1927 (683 pinos y algunos olmos y fresnos), por un valor nominal de 3800 pesetas, y otra operación de venta a gran escala inmediatamente después de la Guerra Civil.

\section{El contrapunto: las pautas de inversión}

A pesar de lo expuesto hasta el momento, no se puede calificar a Pelayo Negre de propietario absentista. Quizás su gestión fuera en muchos aspectos conservadora, quizás se inhibió en la toma de decisiones sobre aspectos productivos, quizás rechazó un papel más activo, pero en ningún caso su actitud respecto al patrimonio fue de desinterés. Al contrario, seguía la gestión de su administrador con gran minuciosidad. Los estados de cuentas que éste le entregaba eran revisados y sistemáticamente corregidos, generalmente por minucias, hasta un punto que aún no hemos encontrado en ningún otro propietario de la región. Realizó pequeños estudios sobre la evolución de la producción y del ingreso de sus fincas durante las décadas de 1920 y 1930 con la finalidad de evaluar las demandas de sus aparceros. También visitó las fincas con cierta periodicidad, aunque probablemente menor de la que reclamaba su administrador. En fin, de los documentos contenidos en su archivo se deduce claramente que su actuación no puede tildarse simplemente de absentista. 
La caracterización que hemos realizado de la gestión de Pelayo Negre, calificándola de altamente conservadora y casi inercial, tampoco encaja con las pautas de gasto e inversión del propietario. Éstas constituyen un contrapunto clave en la comprensión de la acción de Pelayo Negre como gestor patrimonial. Cabe señalar, en primer lugar, que una pauta común que emerge de los trabajos sobre distintos patrimonios catalanes durante el primer tercio del siglo XX fue la contracción del flujo inversor, que antes de la crisis agraria de fines del siglo XIX había adquirido cierta dimensión. A diferencia de otros casos conocidos, Pelayo Negre mantuvo un flujo inversor notable durante las décadas de 1920 y 1930.

Éste se aplicó básicamente a obras y mejoras en los edificios del patrimonio, además de la realización de obras de regadío en algunas parcelas. Según la estimación que hemos podido realizar, entre 1925 y 1934 gastó un promedio de 3000 pesetas anuales en obras, cuando la renta bruta media ascendía a unas 8200 pesetas anuales (promedio 1927-1931). Que el grueso de la inversión se destinara a los edificios no sorprende. La misma pauta inversora se ha detectado, por ejemplo, en el patrimonio Maspons. Lo singular es que, a diferencia de Jaume Maspons, la inversión no se dirigió a mejorar y embellecer la residencia del propietario — ninguna de las casas del patrimonio Goy tenía asignada dicha función-, sino a mejorar los edificios habitados por los masoveros. Ahí sí que se encuentra, a nuestro parecer, un comportamiento original, anómalo. Dicho gasto tuvo como objetivos la mejora de la confortabilidad de las viviendas de los aparceros y la construcción y reparación de establos y cuadras.

Aunque sólo conocemos el destino de poco más del $40 \%$ de las cantidades empleadas en obras de reforma o de nueva construcción, ésta revela

TABLA 6

DESTINO DEL GASTO EN OBRAS, 1925-1931

\begin{tabular}{|l|r|r|}
\hline & Pesetas & $\%$ \\
\hline Regadío & 3366,55 & 12,5 \\
Cocinas & 3071,92 & 11,4 \\
Establos & 2990,29 & 11,1 \\
Horno ladrillos & 286,97 & 1,1 \\
Tejados & 1663,62 & 6,2 \\
Varios & 15618,36 & 57,9 \\
\hline Suma & 26997,71 & 100,0 \\
\hline
\end{tabular}


que se empleó básicamente en obras de regadío o de extracción de agua (pozos, bombas, depósitos de agua para riego...), en obras relacionadas con cuadras y establos (además de las reparaciones constantes en las instalaciones existentes, sabemos que se construyeron nuevas, destinadas concretamente a vacas, cerdos y yeguas) y, lo que nos parece más significativo, en la mejora de la habitabilidad de las casas. Muchas de dichas mejoras (cambio de ventanas, embaldosado de suelos, etc.) están incluidas en el capítulo de varios de la tabla 6 por la dificultad de discriminarlas con claridad. En cambio se pueden identificar mejor los gastos realizados en las cocinas de las casas, aunque con seguridad fueron superiores a la cantidad señalada en la tabla. Como puede observarse, se invirtió una suma considerable en mejorar las cocinas (el 11,4\% del gasto en obras y el $27 \%$ de los gastos identificados). Además de reparar la estructura, se colocaron fregaderos, armarios, escurreplatos, azulejos... y se arreglaron las despensas y las ventanas.

En conclusión, el propietario sacrificó una parte significativa de su renta para atender ciertas mejoras en las condiciones de vida de sus masoveros, al tiempo que se mostró dispuesto a apoyar financieramente la dedicación de éstos a la ganadería de engorde. Cabe preguntarse a qué se debió tal estrategia. Por los datos que hemos manejado, no parece que las condiciones de habitabilidad de las viviendas limitaran las posibilidades de encontrar aparceros en el mercado de trabajo agrícola. A pesar de existir una cierta movilidad entre los masoveros, en ningún momento quedaron fincas vacantes, sin cultivador. Al contrario, de la correspondencia emitida por el administrador se deduce que existía una oferta amplia de aparceros potenciales, que permitía rechazar a algunos candidatos y seleccionar a los que se consideraba idóneos. La crisis de la masovería - entendida en términos de falta de aparceros - había empezado a afectar a algunas zonas marginales de la montaña, pero los llanos agrícolas de la región aún no habían experimentado tal situación de escasez en la oferta de trabajo. No les alcanzó propiamente hasta las décadas de 1950 y 1960.

Tampoco creemos que el propietario buscara aumentar la renta mediante la repercusión del importe de las obras sobre aquélla. Aunque puntualmente la realización de ciertas obras implicó un aumento de la renta monetaria equivalente al 5\% del capital invertido (en concepto de interés), lo cierto es que ello sólo se aplicó sobre algunas obras y actuó más como forma de compensar la depreciación sufrida por los componentes 
monetarios de la renta. Otra posibilidad que, a modo de hipótesis, creemos que podría arrojar luz sobre el comportamiento inversor de Pelayo Negre tiene relación con su propio discurso. Aunque no debe buscarse una coherencia estrecha entre las palabras y los hechos de los agentes sociales, tanto en el ámbito individual como colectivo, es probable que algunas decisiones singulares puedan explicarse en términos ideológicos. Quizás la forma en que Pelayo Negre entendió que debía aplicar la Acción Social en su propio patrimonio fuera la mejora en ciertas condiciones de vida de sus subordinados. Con ello apostaba por el tipo de relaciones paternalistas que reforzaban la cohesión social, al tiempo que se mantenían inalterados los derechos consuetudinarios del propietario. Es probable que este comportamiento, al tiempo conservador y transigente con ciertas demandas sociales, no pueda entenderse fuera del marco ideológico donde se ubicaba Pelayo Negre, que no era otro que el del catolicismo social.

\section{Conclusión}

Empezábamos este trabajo preguntándonos por los protagonistas del proceso de transformación de la agricultura catalana después de la crisis agraria de fines del siglo XIX y, más concretamente, por la actuación de los mayores terratenientes en dicho proceso, especialmente de aquel sector más implicado en las redes del asociacionismo agrario y más dispuesto a aceptar ciertas modificaciones estructurales, al margen, claro está, de cualquier intervención reformista del Estado. La contribución de Pelayo Negre a la transformación y modernización de sus fincas fue bastante minúscula y, probablemente, como respuesta a una creciente presión social. Ciertamente, su gestión no puede considerarse en modo alguno absentista y despreocupada, puesto que la documentación pone de relieve un alto nivel de control y seguimiento de sus fincas y un comportamiento inversor notable por lo que se refiere a la porción del ingreso bruto reinvertido. Por otra parte, sus publicaciones en la prensa local y agronómica ponen de relieve una preocupación por los problemas sociales del campo y una apuesta para que éste los resolviera por sí mismo. Sin embargo, ello apenas repercutió en las estrategias productivas de sus fincas, que conservaron una estructura de cultivos muy tradicional, un alto nivel de fragmentación y una gestión que hemos calificado de inercial. Las inversiones se utilizaron, en buena medida, para mejorar las condiciones de habitabilidad de las vivien- 
das — un objetivo socialmente deseable- y también para proporcionar a los masoveros mejores infraestructuras productivas, particularmente establos y pequeñas huertas de regadío. La repercusión de dichas inversiones sobre la renta del propietario, sin embargo, fue poco importante. Ésta continuó menguando, y no sólo a consecuencia de la importante rebaja negociada en 1934. La actuación de Pelayo Negre tiene un aspecto paradójico que quizás pueda resolverse, como se ha apuntado, alegando motivos de carácter ideológico. Al margen de ello, sin embargo, los cambios que observamos en el patrimonio analizado concuerdan con una idea que va tomando cuerpo a medida que se van analizando casos particulares: el protagonismo de los masoveros y aparceros en el proceso de transformación del sector. 



\section{II \\ REFORMAS AGRARIAS}





\section{ESTRUCTURA SOCIAL DEL CAMPO ESPAÑOL: EL CENSO DE CAMPESINOS (1932-1936). PRIMEROS RESULTADOS (I)*}

Luis E. Espinoza, Ricardo Robledo, M. a Pilar Brel y Julio Villar (Universidad de Salamanca)

\section{Introducción}

El objetivo de este capítulo consiste en explorar los límites y posibilidades de una fuente de alcance estatal que interesa a los estudiosos de la historia social y económica de los años 30 , particularmente si se dedican a la historia agraria. Al igual que ocurrió con la magna encuesta del catastro de Ensenada, el planteamiento y ejecución de la reforma agraria republicana generó una documentación de una amplitud que sobrepasó con mucho el ámbito de su aplicación. Esto ocurre no sólo con los cientos de legajos que guarda el archivo del antiguo Instituto de Reforma Agraria (IRA) y que se han explorado en una mínima parte, ${ }^{1}$ sino con el Inventa-

* Departamento de Economía e Historia Económica, salvo J. Villar (depto. de Geografía). Investigación financiada por el proyecto del Ministerio de Ciencia y Tecnología BEC 2002-03704 y Junta de Castilla y León SA 041A06. Agradecemos las orientaciones de Vicente Pérez Moreda, Domingo Gallego y Antonio López Estudillo. Parte de esta investigación fue presentada en la Universidad de Córdoba, en el Seminario Fuentes y Métodos para la historia rural, en noviembre de 2000.

1 Martín (dir.) (1997); queremos dejar constancia aquí de la generosidad del recientemente fallecido José Luis Martín, que permitió a tantos investigadores la consulta del catálogo antes de la edición por la UNED. 
rio de Fincas Expropiables y con el Censo de Campesinos. Ambas fuentes se refieren a la casi totalidad de las provincias españolas, pero, así como el inventario ha sido muy utilizado para investigar la estructura de la propiedad, no ocurre lo mismo con el censo. Pocos se han acercado a la documentación primaria que guardan los archivos municipales y, por lo general, se ha seguido sin muchas comprobaciones la información que proporcionan el Boletín del Instituto de Reforma Agraria (BIRA) u otras fuentes (el resumen utilizado por Malefakis, por ejemplo). Ésta es la primera vez, en todo caso, que se ofrecen datos con un nivel de agregación, y de detalle a la vez, que cubre buena parte de la geografía española; los datos figuran en el anexo (pp. 335-342).

$\mathrm{Al}$ presentar esta información relativa a los partidos judiciales, las restricciones de espacio no nos permiten más que exponer las características de la fuente y la metodología empleada para comprobar su fiabilidad y poder representar adecuadamente la escala de partido judicial. Junto a un breve estado de la cuestión, completa este texto la presentación de varios mapas que muestran la distribución de los jornaleros y del resto de categorías que conformaban lo que se entendía por campesinos.

\section{Reforma agraria: asentamientos y Censo de Campesinos}

La investigación sobre la reforma agraria de la Segunda República no suscita la preocupación de los historiadores como ocurría hace dos o tres décadas, ni es un tema que figure de forma destacada en las explicaciones del crecimiento regional o en las revisiones de la historia agraria. Por otra parte, bien desde los criterios de la eficiencia y de la productividad, o bien de los que critican el productivismo, la reforma es enjuiciada severamente, de modo que hoy es raro hallar defensores de unas medidas que en nuestra opinión eran respuestas coherentes a unas necesidades estructurales y coyunturales. A la postre, el asunto de la reforma agraria republicana aparece casi como un episodio de los que hay que poner entre paréntesis. Estas observaciones no tienen la intención de incitar a la polémica; sirven para comprender los limitados avances de la investigación después de la obra de Malefakis, pese a que una abundante documentación, que conserva el IRA (depositada inicialmente en lo que fue el Instituto de Reforma y Desarrollo Agrario, IRYDA), permanece aún inexplorada. Parte de 
esa documentación que merece la pena dar a conocer es la del Censo de Campesinos.

Una vez que se abandonó la idea de los asentamientos propuesta por la comisión técnica en 1931, la reforma republicana, en lo que a asentamiento de comunidades se refiere (pues hay otros aspectos en los que la reforma se ejecutó inmediatamente), entró en un sendero más lento de lo debido, si se tienen en cuenta las necesidades de la sociedad rural y las expectativas que levantó el régimen republicano. Para el primer presidente del consejo del IRA, Vázquez Humasqué, «no se permitía tocar una sola hectárea» que no estuviera en el inventario y sin que hubiera dado tiempo a establecer los recursos oportunos; este criterio obligó a superar una serie de trámites de los que da cuenta el cuadro que figura más adelante. En él se advierte bien el lugar ocupado por el Censo de Campesinos como una de las primeras actuaciones de las juntas provinciales agrarias. Estas juntas se constituyeron con la participación de propietarios y obreros, además de representantes de la Administración, y se les encomendó la laboriosa tarea de elaborar el Censo de Campesinos, en colaboración con las juntas agrarias locales, para determinar la relación de posibles asentados.

Entre los numerosos engranajes que componían la maquinaria de la reforma agraria republicana no era el menos importante el censo de los potenciales beneficiarios que iban a formar parte de las comunidades campesinas; una selección inadecuada, como acusaban los ingenieros, ocasionaba numerosos retrasos en los asentamientos o disensiones en las asambleas (Ladrón de Guevara, 1993, p. 363).

Que tengamos datos de casi todas las provincias españolas ${ }^{2}$ obedece a la forma en que se aprobó la territorialidad de la ley: "Los efectos de esta Ley se extienden a todo el territorio de la República», precisaba la base 2 . En cuanto a los asentamientos, la ley se limitaba, como es sabido, a Andalucía, Extremadura, Ciudad Real, Toledo, Albacete y Salamanca, pero no cerraba la puerta a que mediante una ley votada en Cortes hubiera asentamientos en las 36 provincias restantes.

2 Carecemos de datos de Álava, Barcelona, Murcia, Santa Cruz de Tenerife, Valladolid y Vizcaya (en blanco, en los mapas de p. 324 y ss.). 


\title{
ESQUEMA DEL PROCESO EXPROPIATORIO Y DE ASENTAMIENTO \\ DE COMUNIDADES DE CAMPESINOS SEGÚN LA LEY \\ DE REFORMA AGRARIA DE 1932 (ROBLEDO Y ESPINOZA, 1999)
}

\begin{abstract}
ELABORACIÓN DEL INVENTARIO DE FINCAS EXPROPIABLES. Registradores de la propiedad e Instituto de Reforma Agraria (IRA).

RESOLUCIÓN DE RECURSOS CONTRA LA INCLUSIÓN EN INVENTARIO. Consejo ejecutivo del IRA, previo informe del servicio provincial.

CONSTITUCIÓN DE JUNTAS PROVINCIALES AGRARIAS. ELABORACIÓN DEL CENSO CAMPESINO. Junta provincial agraria.

MEMORIAS AGRONÓMICAS Y PLANES DE APLICACIÓN AGRÍCOLA Y PECUARIA. PROPUESTA SOCIAL (composición de comunidad de campesinos). Fijación del crédito, del canon de asentamiento y cálculo del «rédito neto». Servicio provincial del IRA.

ACUERDO DE OCUPACIÓN. Consejo ejecutivo del IRA.

VALORACIÓN DE LABORES, COSECHAS Y CAPITAL MOBILIARIO. Servicio provincial. ACTA DE POSESIÓN Y ENTREGA A LAS COMUNIDADES. Junta provincial.

TUTELA DE LAS COMUNIDADES. Servicio provincial.
\end{abstract}

\section{El Censo de Campesinos. Principales estudios}

Como consta en la base 11 de la Ley de Reforma Agraria de septiembre de 1932, los campesinos que se podían asentar en las fincas ocupadas debían salir de una relación nominal integrada por los siguientes grupos: a) obreros agrícolas y obreros ganaderos, sin posesión alguna de tierra, b) «sociedades obreras de campesinos legalmente constituidas», con al menos dos años de existencia, c) pequeños propietarios — menos de 50 pesetas de contribución por explotación directa o menos de 25 por tierras cedidas en arrendamiento- $-\mathrm{y} \mathrm{d}$ ) pequeños arrendatarios o aparceros —-menos de diez hectáreas de secano o una de regadío.

Frente a la ambigüedad de algunas definiciones del campesinado, por ejemplo la acuñada hace años por Eric Wolf, «la población que, para su existencia, se ocupa en el cultivo y toma decisiones autónomas para su realización» (Wolf, 1976, p. 10), queremos llamar la atención sobre la mayor precisión que recoge la anterior clasificación, al aportar unos criterios fis- 
cales o de propiedad que, no obstante, pueden discutirse en cuanto tales o según regiones. ${ }^{3}$

A partir de la relación nominal que debían formar las juntas provinciales para cada pueblo expresando situación familiar y diversas características socioeconómicas de los posibles beneficiarios, el IRA realizó un resumen recogiendo el número de los integrantes en cada una de las cuatro categorías reseñadas. De dicho resumen mimeografiado dio cuenta Malefakis (1982, pp. 87 y 140-142) elaborando un somero cuadro por regiones y dos mapas por provincias, no siempre de fácil interpretación y sin referencias de las sociedades obreras; de hecho, sólo pudo disponer de un resumen de una página que recogía resultados incompletos sobre 44 provincias. Gracias al catálogo de los fondos del IRA realizado por J. L. Martín (ed., 1997), hemos localizado en distintas secciones del archivo del IRA los resúmenes provinciales que contienen información para cada pueblo y partido judicial.

El Censo de Campesinos tuvo en su origen, más que una motivación estadística, un objetivo político y social, pues de su inclusión o exclusión dependía acceder o no a los asentamientos; la misma composición del organismo encargado de elaborar el censo, las juntas provinciales, donde estaban representados obreros campesinos y propietarios, tuvo que provocar diversos sesgos entre los partidarios de extender la reforma agraria y los de reducir su influencia. De hecho, en diciembre de 1934 hubo que proceder a la revisión de los primeros censos, efectuados con el apremio y precipitación que había impuesto el poner en marcha una reforma que, dos años después de la llegada de la República, aún no había iniciado ningún asentamiento.

3 Un propietario de una minúscula parcela de secano con cereal y leguminosas en los ruedos de Córdoba no tendría hacia 1930 derecho a entrar en el Censo de Campesinos, aunque él y sus familiares debiesen trabajar muchos días como jornaleros. Por el contrario, en otras áreas sí podría entrar en el Censo de Campesinos quien cultivase en arrendamiento hasta 10 ha si no pagaba 25 ptas. de cuota fiscal por ello, aunque obtuviese ingresos netos muy superiores y en lugar de ir a jornal emplease a otros. Allí donde el líquido imponible fuese más reducido en relación con la renta neta de la finca, puede que la renta de la tierra casi completase todo el líquido imponible imputado a la finca, y por ello se diese el caso de que quien cultivase 10 ha de secano (como arrendatario) no alcanzara una cuota fiscal de 25 ptas. Agradecemos esta observación a A. López Estudillo. 
Pese a las deficiencias iniciales de la fuente, no se dispone de mucha información de la estructura social referida al ámbito municipal (amillaramientos, resúmenes de cuotas por contribución rústica, padrones), pero además no es posible contar con estos datos para la mayoría de pueblos de España, que es lo que proporcionan los resúmenes del IRA. Los estudiosos de la reforma agraria republicana han utilizado esta fuente de forma desigual, y siempre con menor intensidad que el Inventario de Fincas Expropiables.

Cuando se desciende al análisis local de la fuente, la explotación de la información ofrece amplias posibilidades para conocer al menos los siguientes aspectos: la estructura familiar, la diversidad de la población activa agraria, el nivel tecnológico del trabajo agrícola, la organización obrera rural y los sistemas de tenencia de la tierra (Corrionero, 1986, p. 201). López Ontiveros y Mata Olmo (1993, p. 90), acudiendo a la explotación de la fuente original, han podido no sólo precisar los rasgos principales del mercado de trabajo en las distintas comarcas, sino valorar las posibilidades y el alcance de la reforma al relacionar el número de jornaleros con las tierras expropiables. Además de servir para caracterizar las formas de tenencia del pequeño campesinado y las estructuras de propiedad y explotación, la fuente local permite contrastar estos datos con la renta de la tierra, como ha efectuado Lana (1997); en algún caso la documentación no se limitó a quienes cumplían con situarse por debajo de los umbrales marcados en la Ley de Bases de la Reforma Agraria, sino que también se anotó a los que rebasaban ese umbral, con lo cual se obtenía un magnifico retrato de las estructuras de propiedad y explotación en ese caso (Lana, 1997, pp. 235-249).

Aparte de estas investigaciones, la de Ladrón de Guevara (1993) citada antes — quien utilizó la información del archivo municipal de Daimiel — y alguna más, ${ }^{4}$ el resto de estudios se ha basado en los acuerdos de las juntas que publicó el $B I R A$ o en los resúmenes que conserva el archivo del IRA. Esta documentación sólo da cuenta de las cuatro magnitudes que exigía la base 11: obreros agrícolas, pequeños propietarios, pequeños arrendatarios y sociedades obreras, y por tanto prescinde de la rica infor-

4 López Martínez (1995), pp. 35-37, utilizó la fuente original para la provincia de Granada, y de nuevo en López Martínez y Gil Bracero (1997), pp. 31-32 y 95-96. 
mación que se incluía en los formularios municipales y que podía llegar hasta a precisar el grado de tecnología agrícola de cada familia. ${ }^{5}$ En compensación, los resúmenes sobre las cuatro categorías posibilitan con cierta facilidad un nivel de agregación provincial o superior. Gracias a un brevísimo resumen del Censo de Campesinos, Malefakis hizo una aproximación a la estructura social de la España del sur en los años 30 en comparación con otras regiones. El recurso al Censo de Campesinos, comparado con otros datos demográficos o de tenencia de la tierra, permite comprender mejor el paro estructural (Maurice, 1990, pp. 70-71 y 86-91).

Otros autores que han utilizado la fuente en estudios provinciales son Pérez Yruela (1979, p. 86), quien tomó los datos de Córdoba del BIRA. Garrido (1990, pp. 84-89 y 474-481) contó con datos similares sobre Jaén en 1933 y 1934 y realizó una comparación con la población activa masculina según el censo de población de 1930. En su opinión, aunque pudo darse el caso de doble inscripción de pequeños propietarios que fuesen al tiempo aparceros o arrendatarios, y admitió como posible que el número de éstos estuviese inflado por las expectativas creadas en estos sectores, consideró que las cifras de jornaleros se hallaban más bien infravaloradas por falta de inscripción voluntaria motivada por la desconfianza en la reforma, y aportó algunos ejemplos en este sentido. Cabo Villaverde (1995), por su parte, advirtió sobre la inconsistencia de los datos del censo para Galicia. Robledo y Espinoza (1999) comprobaron el alcance de la reforma según el número de potenciales beneficiarios que proporcionaba el Censo de Campesinos. Saguer (2000) utilizó la información incompleta de Gerona, por partidos judiciales, localizada en el archivo del IRYDA, para sostener el carácter "pluriactivo" del trabajo campesino. Florencio Puntas (2001) manejó los datos parciales disponibles de los censos de cam-

5 La plantilla de algún censo municipal precisa para el apartado de pequeños propietarios las siguientes variables: Apellidos / Nombre / Sexo / Edad / Estado civil / Número de individuos que componen la familia (varones y hembras) / Número de individuos de la familia aptos para la labor mayores de 14 años (varones y hembras) / Elementos de trabajo de que dispone (yuntas — número, clase- aperos) / Número de ganado de renta que poseen (vacuno, lanar, cabrío, cerda) / Tierras de su propiedad que trabaja directamente (superficie, término municipal) / Tierras que trabaja en arrendamiento (término, nombre del propietario, superficie) / Tierras que llevan en aparcería (término, nombre del propietario, superficie, modalidad de la aparcería) / Contribución anual (urbana-industrial) / Observaciones. Archivo Municipal de San Felices (Salamanca). 
pesinos elaborados en 1933 y 1935 en las provincias andaluzas de Cádiz, Córdoba, Granada, Jaén y Sevilla para determinar el grado de «proletarización", destacando que la proporción de jornaleros en relación con el conjunto de campesinos asentables se incrementaba según se avanzaba hacia el oeste. Cobo Romero (2003) ha utilizado los datos del censo publicados en el BIRA de varias provincias andaluzas y, con más detalle, de Jaén. Por último, Riesco, en su tesis doctoral sobre la reforma agraria en Cáceres, además de dar cuenta del grado de cumplimiento en la elaboración del censo, se basa en los resúmenes municipales del archivo del IRA para medir el impacto del paro en el colectivo de campesinos y la fuerte representación de los yunteros (grupo D) en varios partidos (Riesco, 2005, pp. 216-217). ${ }^{6}$

La importancia del censo no se reduce a que proporcione información sobre la estructura social, en este caso sobre el proletariado rural en los años 30. Las amplias posibilidades que ofrece la explotación de la fuente original, los censos locales, ofrecen elementos para comprender la pluriactividad dentro de la amplia categoría de "campesinado" (Domínguez Martín, 1993); el análisis de los resúmenes de esos censos en los distintos niveles debe servir para reducir alguna de las incertidumbres que rodean la evaluación de la población activa agraria (Erdozaín y Mikelarena, 1999) y para completar investigaciones sobre la evolución de las explotaciones campesinas o la estacionalidad del trabajo agrario (Garrabou, coord., 1992).

\section{El proceso de formación del Censo de Campesinos}

Transcribimos a continuación algunos textos básicos que permiten fijar el proceso de formación del censo (en realidad, de distintos censos campesinos) entre 1932 y 1936 :

La base 11 de la Ley de Bases de la Reforma Agraria (Gaceta de 21 y 23 de septiembre de 1932) dice textualmente:

6 Sus datos coinciden con los que se presentan en el anexo, salvo en algunos partidos, debido, entre otras cosas, a que este autor no incluye algún municipio y a los problemas de adscripción de pueblos a partidos, tal como se comenta más adelante. 
Constituidas las Juntas Provinciales, procederán inmediatamente a la formación del Censo de campesinos que puedan ser asentados en cada término municipal, con relación nominal y circunstanciada, en la que se expresen nombres y apellidos, edad, estado y situación familiar de los relacionados. Este Censo estará dividido en los cuatro grupos siguientes:

a) Obreros agrícolas y obreros ganaderos propiamente dichos, o sea campesinos que no labren ni posean porción alguna de tierras.

b) Sociedades obreras de campesinos, legalmente constituidas, siempre que lleven de dos años en adelante de existencia.

c) Propietarios que satisfagan menos de 50 pesetas de contribución anual por tierras cultivadas directamente o que paguen menos de 25 por tierras cedidas en arrendamiento.

d) Arrendatarios o aparceros que explotan menos de diez hectáreas de secano o una de regadío.

Los que pertenezcan a los dos últimos grupos se colocarán en el que sea más apropiado, a juicio de la Junta provincial.

Formado el Censo y llegado el momento del asentamiento, se procederá, una vez fijado el cupo correspondiente al término municipal, a la determinación de los campesinos que han de ser asentados, siguiendo el orden de esta Base, así como las Sociedades u organizaciones obreras que, habiéndolo solicitado, han de proceder a la ocupación colectiva de los terrenos asignados a este objeto.

Dentro de cada grupo se dará preferencia a los cultivadores bajo cuya responsabilidad esté constituida una familia, y dentro de esta categoría, tendrán derecho de prelación las familias que cuenten con mayor número de brazos útiles para la labor.

Por lo que se refiere a los secanos, la preferencia se dará siempre a las organizaciones obreras que lo hubieran solicitado para los fines de la explotación colectiva.

El 1 de agosto de 1933 el director general de Reforma Agraria, Dionisio Terrer, dictó unas Instrucciones para la formación del Censo de campesinos que en su disposición $3 .^{a}$ decían:

3. ${ }^{a}$ Para que las Juntas Provinciales y el Instituto de Reforma Agraria puedan conocer en todo momento no sólo las familias campesinas de cada localidad, sino también los de tal condición que no sean cabeza de familia, y los obreros rurales accidentalmente agrícolas o ganaderos, se incorporarán al grupo a) los siguientes complementos:

Complemento primero: obreros agrícolas y obreros ganaderos propiamente dichos, o sea campesinos que no posean porción alguna de tierra y no sean cabezas de familia.

Complemento segundo: obreros, cabeza de familia, accidentalmente agrícolas o ganaderos; o sea, obreros rurales de distintas profesiones que necesitan vivir durante una cuarta parte del año por lo menos empleando su trabajo por cuenta ajena, en faenas del campo.

Complemento tercero: obreros de análoga condición a la registrada en el complemento anterior, pero que no sean cabeza de familia. 
Estas instrucciones obligaron a rehacer los censos ya elaborados, tal como se refleja en los acuerdos de las juntas provinciales de reforma agraria. Así, en el BIRA n. ${ }^{\circ} 16$, de octubre de 1933, se recoge el acuerdo de la de Salamanca, donde se decía:

Cuando la Junta había recibido los Censos de toda la provincia y procedía a revisarlos, fueron dictadas las Instrucciones de la Dirección General, y en sesión de 1 de septiembre se acordó proceder de nuevo a la formación del censo con arreglo a dichas instrucciones, publicándose el oportuno anuncio en el Boletín Oficial de la Provincia de 16 de septiembre.

La Gaceta de 15 de diciembre de 1934 publicó el decreto del Ministerio de Agricultura de 13 de diciembre de 1934 referido al Censo de Campesinos, en el que se señalaba que

modificadas las circunstancias sociales y pasados los apremios que presidieron su confección, es conveniente revisar, no ya superficialmente para las altas y bajas normales motivadas por defunciones o cambios de vecindad, sino más profundamente para dejar sin efecto inclusiones que se hicieron indebidamente, dando lugar a que figurasen en el Censo obreros ajenos a las actividades agrícolas, y para efectuar inclusiones que también sin justa causa dejaron de hacerse.

\section{El artículo 3 especificaba que}

Se entiende por obrero agrícola o ganadero, a los efectos de su inclusión en el grupo a) del Censo de campesinos, al que habitualmente se dedica a trabajos del campo por cuenta ajena y mediante salario. Se considerará habitual el trabajo cuando constituya la principal actividad económica del trabajador. En ningún caso se comprenderá entre los obreros agrícolas o ganaderos sin tierra a los que paguen contribución industrial.

De la lectura de estas disposiciones se desprende la intención de revisar a la baja los primeros censos, donde se habrían incluido habitantes de los pueblos con dedicación a la agricultura de forma muy parcial. Estamos pensando en artesanos, herreros, panaderos... con una vinculación indirecta con la explotación agraria. Este fenómeno venía de lejos. En los orígenes del reformismo agrario a fines del siglo XVIII, tal como ha investigado Robledo (1991), cuando empezó el reparto de baldíos o la política de repoblación en Salamanca se escucharon quejas por la inclusión de este colectivo rural, cuya dependencia de la agricultura siempre podía discutirse. 
De acuerdo con el decreto, la formación del censo competía a las juntas provinciales, auxiliadas por las juntas municipales, que se constituirían con el alcalde, que las presidiría, y cuatro vocales, uno por cada uno de los grupos A, C y D y otro propietario de fincas rústicas. El nombramiento lo efectuaría el juez municipal, debiendo recaer el de propietario en uno de los tres mayores contribuyentes (artículos $7 .^{\circ}$ y $8 .^{\circ}$ ). El artículo 16 disponía que en los pueblos donde el censo hubiese sido formado con arreglo a las instrucciones de 1 de agosto de 1933 se procedería a su rectificación, y donde se hallase sin formar se procedería a su confección inmediata. La rectificación del censo se verificaría anualmente en el mes de enero, tratándose de una «verdadera revisión del Censo" para determinar si persistían las circunstancias personales de inclusión o, si se modifican, proceder a la exclusión (artículo 23).

El 5 de enero de 1935 se dictaron unas instrucciones de la Dirección General aclaratorias del decreto de 13 de diciembre, que se referían a los modelos de impresos. En la instrucción sexta se decía: "Cuando en los impresos correspondientes a los Grupos A, C y D se inscriba un campesino que no sea cabeza de familia, deberá hacerse constar en la casilla de observaciones, el número que en el Censo corresponde a su respectivo cabeza de familia».

El decreto mencionado y una orden posterior de 18 de diciembre de 1934 preveían la máxima celeridad en la elaboración del censo, iniciando los trabajos de revisión o formación en el mes de enero. Sin embargo, en el caso de Salamanca, si bien algunos se aprobaron por la junta provincial en mayo de 1935, el consejo ejecutivo del IRA, en sesión celebrada el 17 de octubre de 1935, acordó imponer sanciones de 50 pesetas a cada uno de los alcaldes y secretarios de 119 municipios salmantinos "por incumplimiento de las órdenes transmitidas por la Junta Provincial respecto a la confección de los Censos de campesinos» (BIRA, n. ${ }^{\circ} 40$, octubre de 1935). Éste no fue un caso excepcional, tal como se puede constatar a través del $B I R A$, que entre 1933 y 1936 publicó los acuerdos de las juntas provinciales de reforma agraria (que hemos procedido a sistematizar y que podremos ofrecer próximamente a los investigadores), en cuyas sesiones se fueron aprobando y rectificando los distintos censos campesinos municipales, al tiempo que se detectaban retrasos e incumplimientos de las juntas locales en su formación, lo cual conllevaba amonestaciones y sanciones que pueden dar indicios (previo contraste con otras fuentes) de una "geografía 
de la resistencia» a la elaboración de este instrumento, indispensable, como queda dicho, para avanzar en los asentamientos. ${ }^{7}$

La Ley de Reforma Agraria de 9 de noviembre de 1935 (Gaceta de 19 y 20 de noviembre de 1935), conocida habitualmente como contrarreforma agraria, no varió la estructura de los censos de campesinos en cuanto a su obligatoriedad y composición, aunque se suprimió la referencia a las sociedades obreras como beneficiarias de asentamientos. Los resultados que presentamos pertenecen al periodo de 1935 e inicios de 1936, en el que - como señalaba el decreto de 13 de diciembre de 1934 citado antesse habían visto «modificadas las circunstancias sociales y pasados los apremios que presidieron [la] confección [del censo de campesinos]». Esto podría avalar la idea de que la coyuntura política derivada de las elecciones de noviembre de 1933 influyera en rebajar la importancia del problema social agrario, revisando a la baja los censos anteriores. De hecho, los datos que presentamos en esta investigación son inferiores, con algunos matices, a los que ofrecen para Andalucía otros historiadores a partir de los datos del $B I R A .^{8}$

\section{CUADRO 1}

CENSO DE CAMPESINOS (JORNALEROS, PEQUEÑOS PROPIETARIOS, ARRENDATARIOS) ${ }^{9}$

\begin{tabular}{|l|c|c|c|}
\hline & $1933-1934$ & $1933-1934$ & $1935-1936$ \\
\hline Cádiz & 23929 & 23960 & 13190 \\
Córdoba & 42084 & 39422 & 50817 \\
Jaén & 82562 & 86448 & 64421 \\
Sevilla & 60789 & 61106 & 62970 \\
Total & 209364 & 210936 & 191398 \\
\hline
\end{tabular}

7 Hay ausencias andaluzas que habría que investigar si guardan relación o no con la influencia del anarquismo, como apuntó hace tiempo Pérez Yruela. En Cádiz, los pueblos de los partidos de Jerez y San Fernando no enviaron datos al primer Censo de Campesinos, ni al de 1935-1936, donde tampoco enviaron datos los de los partidos de Algeciras y Chiclana (si bien en todos los casos el número de ayuntamientos no es muy grande). Garrido (1990), p. 88, establece la correlación con el anarquismo en núcleos como Úbeda y Cazorla. Este último Ayuntamiento no cumplimentó el censo de 1933-1934; sin embargo, en 1935-1936 sí lo hizo, según nuestros datos.

8 Garrido ofrece para Jaén 86436 (años 1933-1934), pero tanto en este caso como en el de Maurice, hay algunos municipios o partidos cuyos datos están por debajo de los nuestros.

9 La primera columna se basa en los datos de Maurice, la segunda en los de Florencio Puntas y la de 1935-1936 procede de la fuente en la que nos hemos basado nosotros. 
Ahora bien, si prescindimos del caso de la provincia de Cádiz (de hecho, nosotros ya hemos limitado su representación en los datos de partidos judiciales), la desviación de nuestros datos de los que pertenecen a 1933-1934 no llega al 5\%, siempre que se nos permita compensar las "ganancias» de Córdoba y Sevilla con las «pérdidas» de Jaén. Cabe hablar, pues, de una ligera infravaloración, bien motivada por cuestiones de índole sociopolítica o bien por un mayor rigor en la ejecución del censo.

\section{El Resumen del Censo de Campesinos por municipios, partidos judiciales y provincias localizado en el archivo del IRA}

El Resumen, que se encuentra disperso en varias decenas de carpetas o legajos, ${ }^{10}$ está formado por los datos sobre sociedades obreras, jornaleros, arrendatarios y pequeños propietarios de 5239 municipios pertenecientes a 44 provincias (de un total de 8399 municipios, disponemos información de los $2 / 3$ de ellos), desigualmente representadas. No está fechado, pero creemos que es de 1936, formado a partir de los censos aprobados por las juntas provinciales a lo largo del año anterior. Hemos podido datarlo gracias a la consulta en diversos archivos municipales de Salamanca, donde se han podido cotejar ejemplares de censos de 1933, 1934, 1935 y 1936 con el resumen provincial del que disponemos, y se puede confirmar que éste es posterior a 1935. Se han recogido también censos municipales hallados por investigadores en otras provincias con el mismo fin de cotejo. Hasta fines de 1934, en los censos municipales se puede encontrar un grupo A formado por individuos solteros y casados. $\mathrm{O}$ también un grupo A sólo de cabezas de familia y unas hojas de complemento con los solteros.

A la vista de las instrucciones mencionadas, queda claro que en 1935 era posible inscribir a los no cabezas de familia en cualquiera de los tres grupos A (obreros agrícolas), C (pequeños propietarios) y D (pequeños arrendatarios), siempre que se especificara en el apartado de observaciones quién era su cabeza de familia (y en qué grupo aparecía éste).

10 IRA, Archivo Colonias, caja 1; Archivo Reforma, Censos y Foros, cajas 16 y 16d. 
En los censos de campesinos que tenemos de Salamanca hay algún caso donde en el grupo A sólo aparecen casados, pero predominan los casos donde aparecen también solteros, indicando en las observaciones quién es el cabeza de familia.

Encontramos viudas en el grupo C e incluso en un caso en el grupo A. Cuando repasamos los asentados en comunidades de campesinos (listados que aparecen en la documentación del IRA referida a las fincas ocupadas), también encontramos varias viudas como cabezas de familia.

Advertimos diferencias en los impresos utilizados por las distintas juntas provinciales de reforma agraria para confeccionar los censos; por ejemplo, en el caso de Gerona los impresos que cumplimentan las juntas municipales especifican claramente, en el caso del grupo A, si se trata de cabezas de familia o no, en el resumen final de cada hoja. Esto no existe en Salamanca.

\section{La fuente del Censo de Campesinos. Problemas de interpretación}

Como ya se apuntó más arriba, el Censo de Campesinos puede ser una fuente útil para la investigación más allá de la obvia referencia a la reforma agraria republicana. Para ello conviene, en primer lugar, tener en cuenta su alcance y limitaciones, debidos al origen y finalidad del censo, que condicionaron sus circunstancias de elaboración, algo que puede resultar distinto en cada municipio o provincia y que corresponderá valorar a cada investigador en función de la escala de su trabajo. Lo que no tiene sentido es descartar la fuente del todo porque se hayan detectado incongruencias en algunos municipios.

Los problemas como fuente del Censo de Campesinos son de diversa índole, algunos de los cuales son comunes al intento de encasillar profesiones que en el campo tienen una frontera muy difusa, como se podía ya comprobar en el primer y único censo de población, el de 1860, que empleó este tipo de clasificaciones. De hecho, la mezcla entre pequeño propietario y arrendatario la daba la propia Ley de Reforma Agraria al aceptar como potencial beneficiario al propietario 
que pagara una pequeña contribución anual por tierras cultivadas, directamente compatible con el pago de una pequeña contribución por tierras cedidas en arrendamiento. No parece muy oportuno emplear tiempo en discriminar entre pequeños propietarios y pequeños arrendatarios; distinta es la situación de los jornaleros, que, si bien podían coincidir con los anteriores, tenían elementos propios para distinguirlos algo más de las otras categorías afines. Seguramente en cada región se podría perfilar el grado de separación que conviene establecer entre las diversas clasificaciones.

Un segundo problema es el de la representación de la fuente; posiblemente hay sesgos al alza de los que querían acogerse a los beneficios de la reforma, pero también, como se ha aludido antes, puede haber fenómenos de infravaloración, y no sabemos en qué grado se pueden compensar o no. Lo que está fuera de duda es que la elaboración del censo llevó aparejada una supervisión con cierto rigor por parte de las juntas respectivas. ${ }^{11}$

Otros son los problemas para convertir el Censo de Campesinos en una fuente útil donde el historiador de hoy pueda acercarse a la estructura social de los años 30 del siglo pasado. Si queremos aprovechar los sistemas de representación gráfica que utilizan los códigos municipales actuales del INE, hay que recorrer el tedioso camino de homologar la división municipal de 1930, que es la que rige en el Censo de Campesinos, con la de 2001, y se deben corregir las diferencias debidas a desaparición de municipios, segregaciones y otras circunstancias. Este esfuerzo, realmente importante al trabajar con 44 provincias, afecta a quien quiera beneficiarse de los sistemas de representación de la actual clasificación municipal

11 Sirvan a título de ejemplo tres casos de provincias no afectadas por la Ley de Asentamientos: se acuerda devolver el censo de Guntín por estar mal confeccionado y se acuerda oficiar a los alcaldes de Baleira y Mondoñedo (Lugo) para investigar si los jueces municipales se encargaron de nombrar a los miembros de sus respectivas juntas $\left(B I R A, \mathrm{n} .{ }^{\circ} 37\right.$, 19 de junio de 1935). Son devueltos los censos de Ponferrada, Zotes del Páramo y Villamil (León), este último para que sean incluidos dos reclamantes. Se acuerda publicar una circular para recordar a las juntas la urgencia de confeccionar el censo; si no, se impondrán sanciones (BIRA, n. ${ }^{\circ} 39,31$ de julio de 1935). Se acuerda devolver por segunda vez el censo de Balaguer y quedan sobre la mesa los de Barbens, Mongay y Torres de Segre (Lérida) (BIRA, n. ${ }^{\circ} 42,26$ de noviembre de 1935). 
(INE) o necesite identificar la evolución de un municipio afectado por las distintas alteraciones administrativas. ${ }^{12}$

Otra importancia tiene el conseguir cierto nivel de agregación a partir de los datos municipales; nosotros hemos optado por el nivel de los partidos judiciales, con lo que «se podrá matizar la homogeneidad, a menudo arbitraria y engañosa, que presentan los datos agregados por provincias o por regiones históricas» y acercarse a la realidad comarcal de España. ${ }^{13}$ Cuando Malefakis presentó los datos del Censo de Campesinos a partir de un resumen por provincias (1982, pp. 139-143), los resultados eran más que discutibles, al juntarse los defectos de representatividad con la escala inadecuada; por ejemplo, las provincias de Granada, Cádiz ${ }^{14}$ o Badajoz aparecían, junto a Gerona, como las que tenían el máximo de arrendatarios y aparceros entre "agricultores empobrecidos», clasificación que no dejaba de crear cierta confusión por tautológica.

El problema reside en adoptar para la década de 1930 la escala de análisis de partido judicial, de cuya población, como tal división, no informó el censo de población, pues el censo de 1887 fue el único que incluyó este aspecto. Hemos calculado nosotros la población absoluta de cada uno de los partidos judiciales que corresponde a la suma de la población de hecho de todos los pueblos del partido. Si no se dispone de este dato agregado, carecemos de un indicador básico para medir el grado de representatividad del Censo de Campesinos, pues hubo bastantes municipios que no enviaron datos, y de seis provincias se carece de cualquier información. Para complicar las cosas, se produjeron cambios en la adscripción de los partidos: con posterioridad al censo de población de 1930 se restablecieron partidos judiciales suprimidos en dicho censo que volvieron a restablecerse antes de 1936, es decir, cuando

12 Muchos municipios de 1930 ya no existen —al menos como municipios - en la actualidad. A veces se han unido varios antiguos municipios y se ha formado uno nuevo con su suma (el nombre no corresponde a ninguno de los anteriores). Otras veces se añaden pequeños municipios a otro más grande y el nombre del grande prevalece. El problema es que en 1930 formaban varios ayuntamientos y tenemos datos de todos ellos —o de algunos-, y en 2001 ya es uno solo y solamente podemos poner un dato.

13 Reher, Pombo y Nogueras (1993), p. 34.

14 Granada y Cádiz, como figura en el mapa 1, carecen de información para buen número de pueblos, lo que nos ha obligado en la presentación de los datos por partidos judiciales a prescindir de la primera y a tomar con cautela los datos de algunos partidos de Cádiz. 
se estaba elaborando el Censo de Campesinos. ${ }^{15}$ Puesto que cuando se efectuó el Censo de Campesinos ya estaba en vigor el restablecimiento de los antiguos partidos, seguimos la última adscripción, aunque hay varios casos de municipios con discrepancias de adscripción entre el censo de 1930 y el que figuraba en el Censo de Campesinos; en esos casos hemos dado prioridad a la información censal, porque nos parece más fiable.

\section{Presentación de los primeros resultados}

El mapa 1 nos ofrece el grado de representación que permite el Censo de Campesinos, una muestra amplia, pues están repartidos por todas las provincias con la excepción de las seis citadas antes. En conjunto se dispone de datos de 5239 municipios, de un total de 8399 (62,4\% ) en estas 44 provincias, con una representación desigual. Los vacíos tienden a aumentar a medida que nos alejamos de las provincias que fueron afectadas por los asentamientos de la Ley de Reforma Agraria, si bien algunas provincias andaluzas, como Granada o Cádiz, no gozan de buena representación en esta fecha (1935-1936).

Nuestra intención es comparar estos datos con la información disponible, aunque sea indirecta, de la población activa agraria que ofrece el censo de población de 1930. Este mapa mide el peso de los jornaleros en el total del Censo de Campesinos (jornaleros, pequeños propietarios, arrendatarios), algo así como la proletarización de la sociedad rural.

Hemos creído oportuno presentar este mapa junto con el del crecimiento real de la población municipal en el periodo de 1900-1930 (mapa 2); aunque sea de forma intuitiva, puede apreciarse el fenómeno sobre el que han insistido diversos historiadores: en general, las provincias latifundistas, que serían afectadas más directamente por la reforma agraria republicana, siguen creciendo demográficamente, mientras que las zonas de propiedad más repartida, donde los jornaleros no son mayoritarios, pierden población o crecen lentamente. ${ }^{16}$

15 Por ejemplo, en Cáceres se restableció el partido de Alcántara, en Cantabria el de Cabuérniga o en Pontevedra el de Puente-Caldelas.

16 Entre otros, Gallego (1993), pp. 251-253, quien establece también la divisoria en dos mitades con menor emigración en la mitad sur, salvo en su franja mediterránea. 


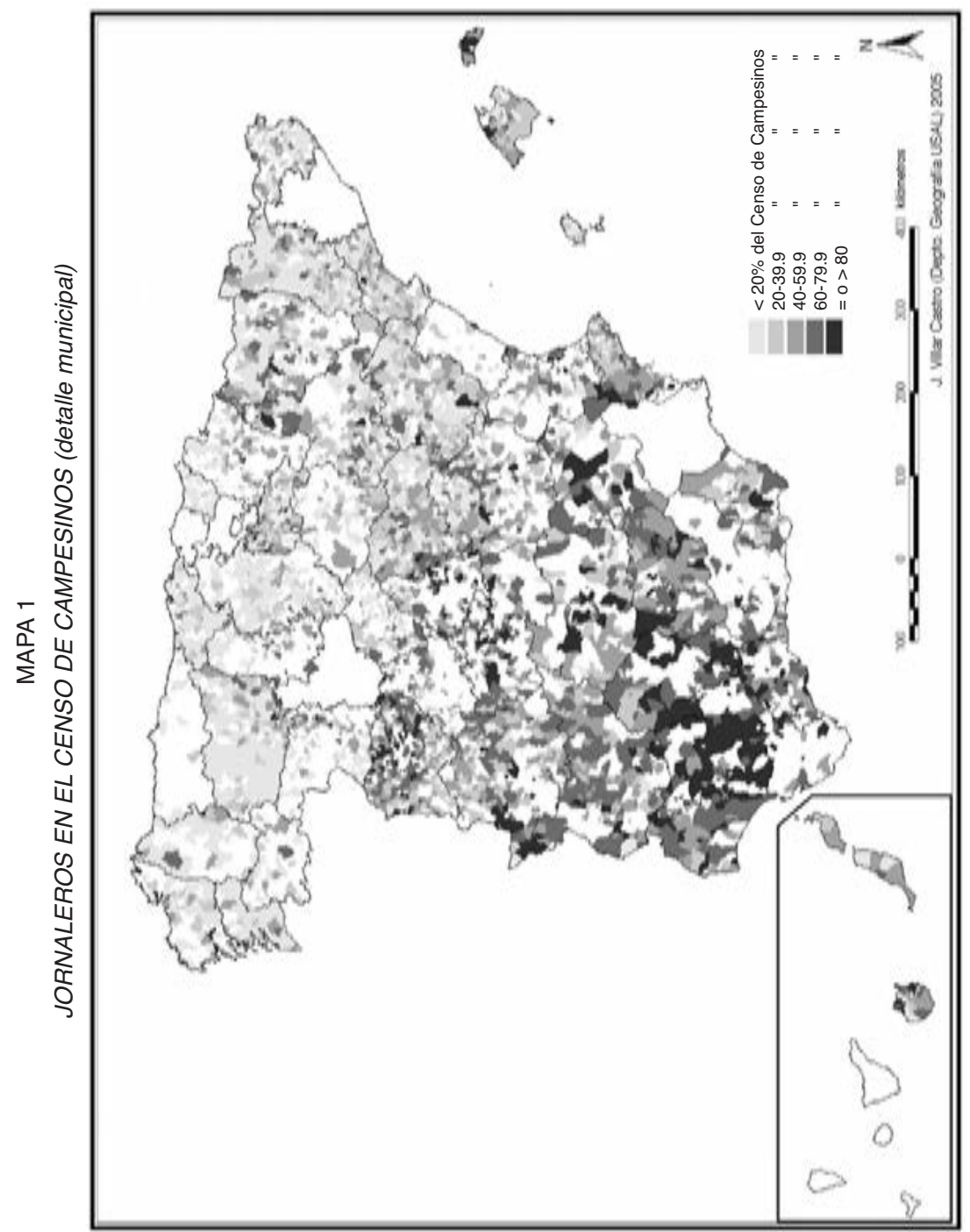




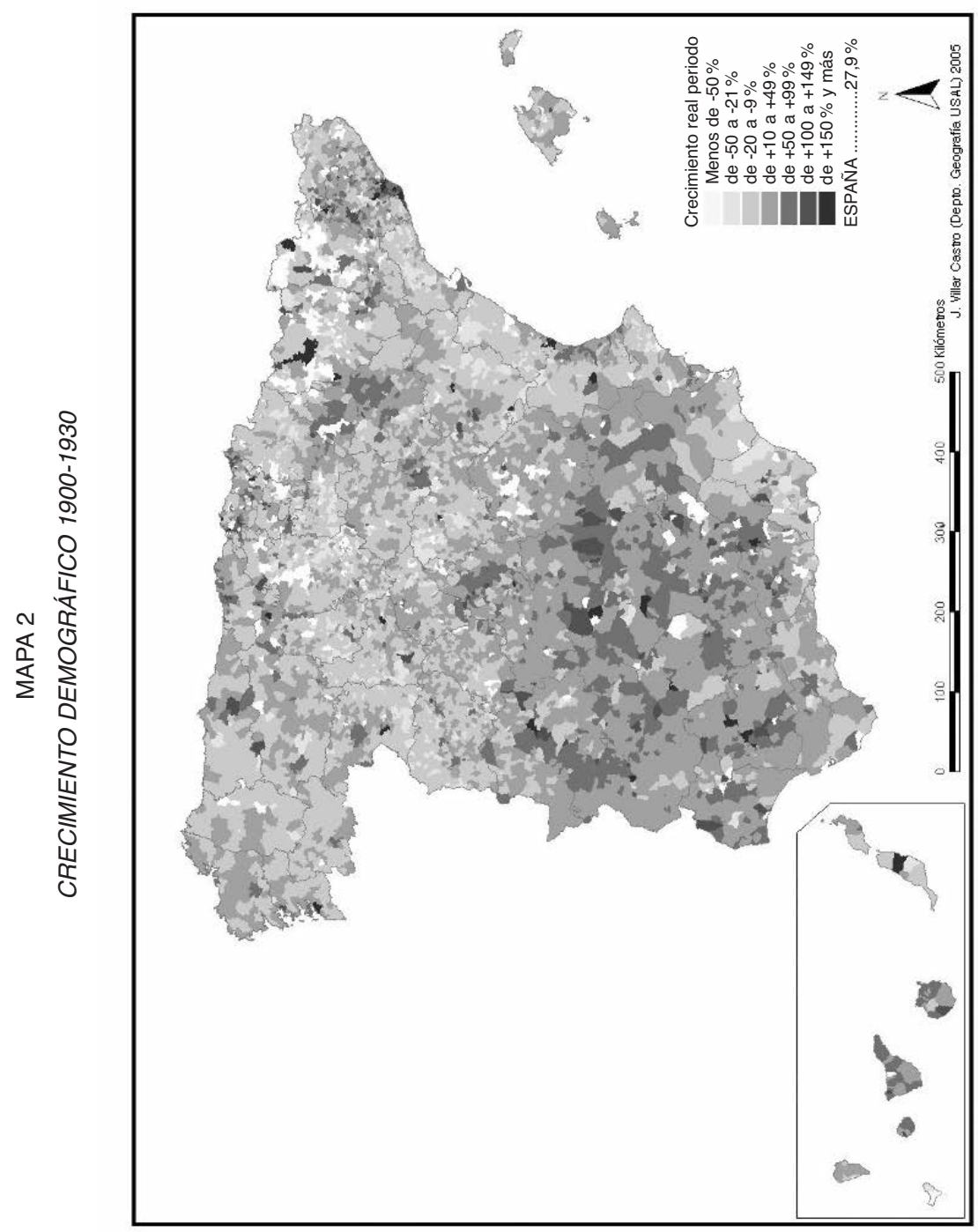


Creemos que una de las principales aportaciones de este texto está en la presentación del amplio cuadro que figura en el anexo, con la información de 260 partidos judiciales y que esperamos que pueda valer tanto como ha costado su elaboración; para empezar, hay que fijarse en los datos de la columna 3, la población de hecho de los partidos judiciales. El Censo de Campesinos nos ofrece datos de municipios pertenecientes a 421 partidos judiciales, pero hemos preferido centrarnos en el $62 \%$ de ellos donde el grado de representación es razonablemente fiable; nueve de cada diez partidos tienen representada más de la mitad de la población del censo de 1930 en el Censo de Campesinos (columna 8 del anexo). ${ }^{17}$

Esto es lo que nos ha permitido extender a todo el partido la información de la muestra del Censo de Campesinos. La única manipulación efectuada en la columna 3 es la de descontar la población de la capital siempre que se carezca de datos de ella en el Censo de Campesinos, cosa que ocurre en ocho casos que oportunamente se señalan. Si ampliáramos este criterio en atención a determinados núcleos urbanos mal o nada representados en el Censo de Campesinos, la muestra ganaría aún más en representación, pero de momento no se ha efectuado ningún ajuste más. Con la información del anexo se han elaborado los cuatro mapas que vienen a continuación. Los mapas 3 y 4 informan del peso de los jornaleros a partir de los datos del Censo de Campesinos, mientras que el mapa 5 relaciona datos del Censo de Campesinos con la población de 1930 y el mapa 6 representa la importancia de los pequeños propietarios.

El mapa 3 reproduce la misma información que el mapa 1, con la diferencia de que ahora la escala es la de los partidos judiciales. De los 260 partidos en que nos hemos basado, 153 están por debajo del $50 \%$ de peso de los jornaleros en el total de los grupos representados en el Censo de Campesinos (jornaleros, pequeños propietarios y arrendatarios); los partidos de la cornisa cantábrica, de Galicia y de León concentran, con excepciones significativas, los núcleos con menos de $1 / 5$ de jornaleros.

17 En los pocos casos en que más nos alejamos de esa representatividad superior al $50 \%$ — provincia de Cádiz, partidos de Cuevas de Almanzora (Almería), Alfaro y Zaragoza, donde la muestra de población representada no llega al $33 \%$ de la población censal de 1930 - , se ha optado por incorporarlos en atención a la representación de la muestra del numero de municipios (columnas 8 y 9 del cuadro del anexo). 


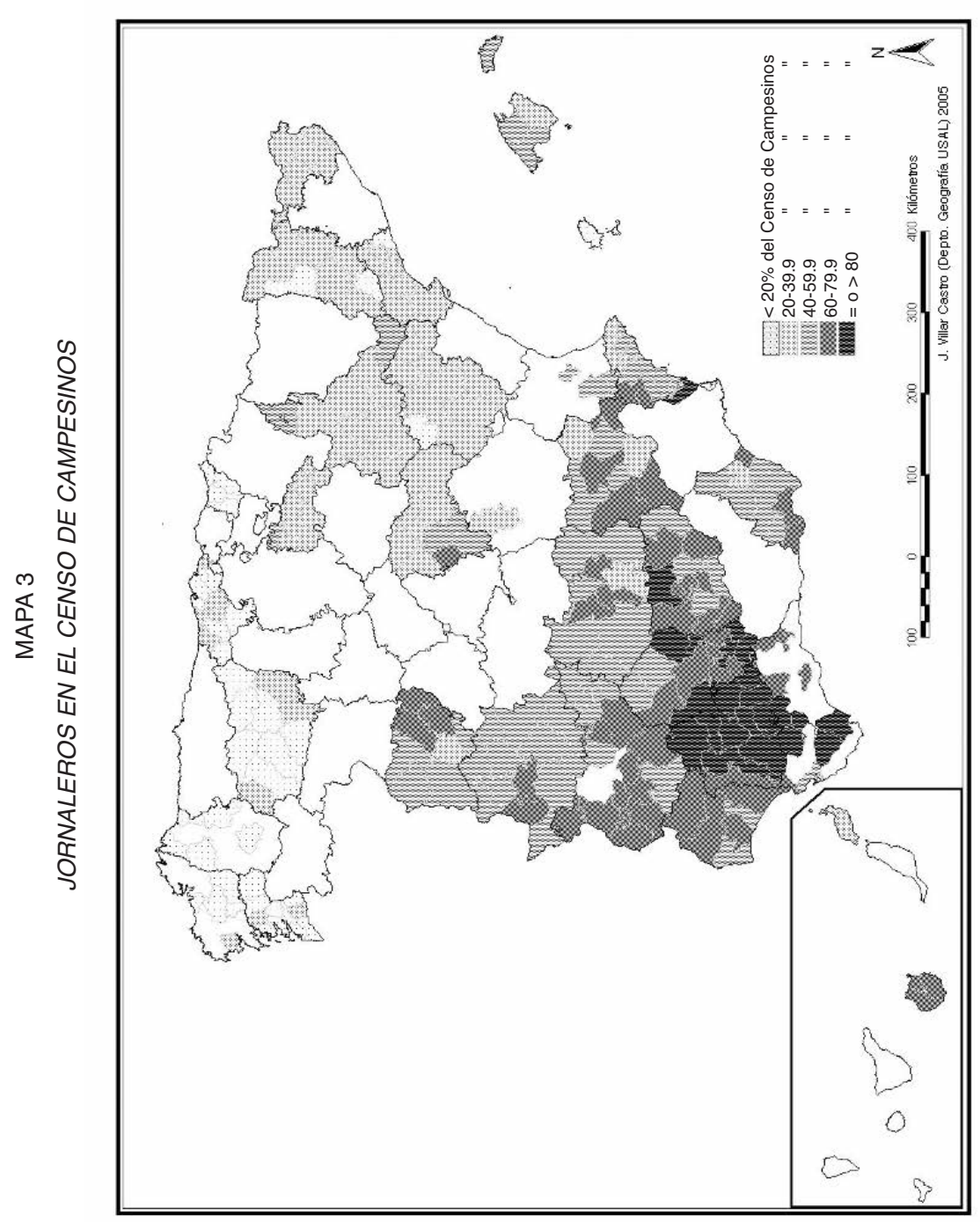




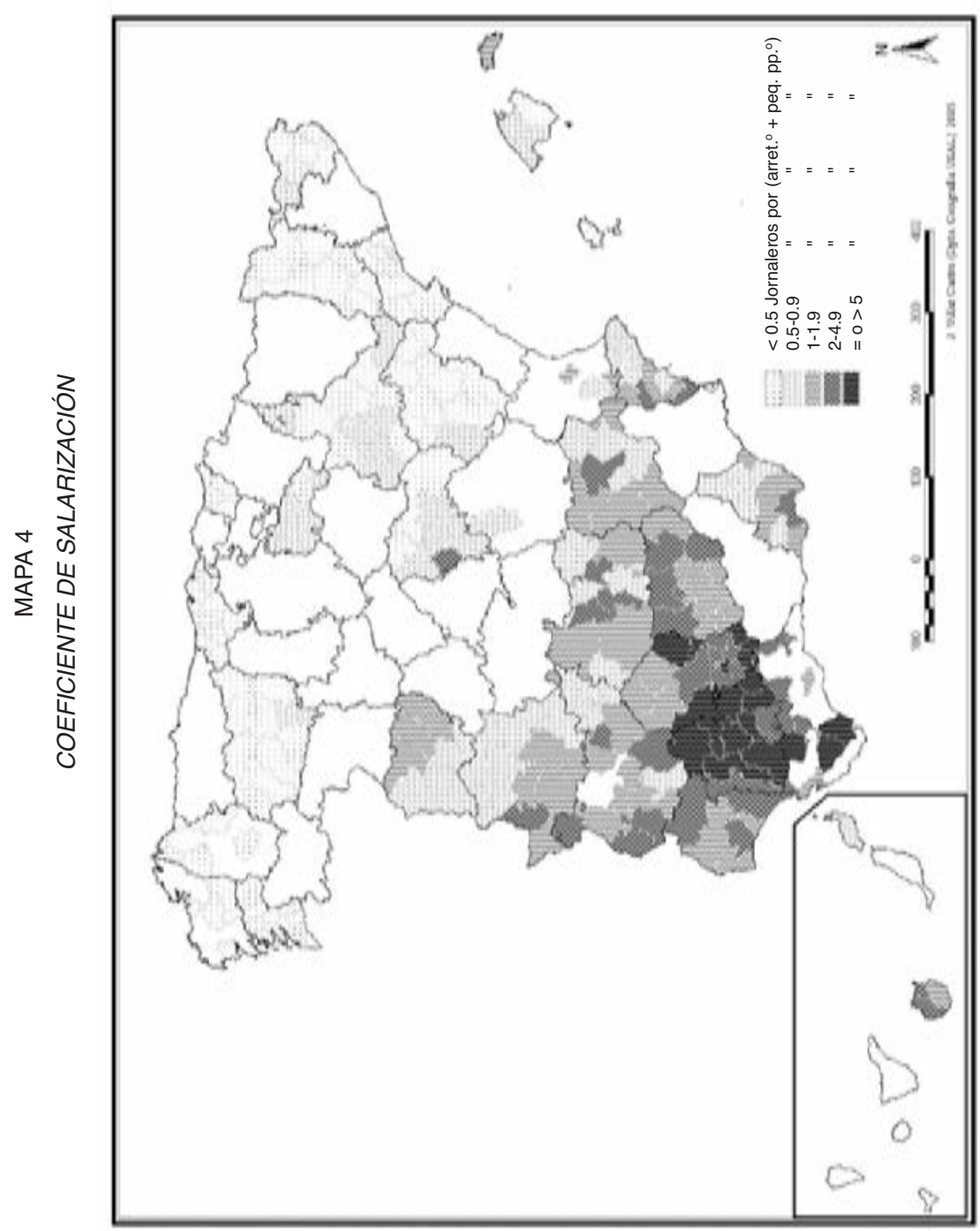


Guadalajara, La Rioja, Aragón y Cataluña parecen conformar una amplia región intermedia con porcentajes superiores al del noroeste peninsular, pero inferiores a los del suroeste. Sobresale el manchón de la Bética, donde más se acusa el fenómeno, y a medida que nos alejamos va cayendo en intensidad.

Si el mapa 3 medía el peso de los jornaleros en el conjunto de las categorías que recoge el Censo de Campesinos (jornaleros, pequeños propietarios y arrendatarios), el mapa 4 simplifica los términos y sirve para contestar a la pregunta: ¿cuántos jornaleros había por cada campesino (entendiendo aquí campesino por pequeño propietario más pequeño arrendatario)? La contestación es lo que hemos llamado coeficiente de salarización (columna 11 del anexo). Los límites de partidos judiciales, e incluso de las provincias, se desdibujan... casi un 60 por ciento de los partidos judiciales no llegan a un jornalero por campesino. Ahora bien, si precisamos un poco más y fijamos la divisoria en 0,5 jornaleros, es decir, un jornalero por dos campesinos, entonces veremos que los mínimos, los que no llegan a esa relación, se sitúan en el cuadrante noroccidental, mientras que a partir de 0,5 hasta 1 se diluyen por el cuadrante nororiental (Santo Domingo de la Calzada, Sos, Caspe, Calatayud, La Almunia, oeste de Guadalajara) y varios partidos del Levante y zonas de latifundio.

Los dos últimos mapas nos alejan del problema tópico de la reforma agraria y los jornaleros. El mapa 5 lo hace de nuevo al relacionar el conjunto de jornaleros, pequeños propietarios y arrendatarios con la población de 1930; lo correcto sería hacerlo con la población activa, pero este dato no lo tenemos disponible para los partidos judiciales. De momento, el aspecto del "problema agrario" cambia bastante, en parte porque los partidos que acogen la capital de provincia o los municipios más populosos del sur rebajan la importancia numérica de los incluidos en el Censo de Campesinos. Si aceptamos provisionalmente como población activa del partido la correspondiente a la provincia sin capitales (sólo varones), tendríamos, por ejemplo, que en cerca de 100 partidos judiciales (38\% de la muestra) el porcentaje de población activa imputable al conjunto de jornaleros, pequeños propietarios y arrendatarios se movía entre el 20 y el $50 \%$, con unos máximos que se agrupan en la parte occidental de la provincia de Cáceres. Tanto en este caso como en los mapas anteriores, tendremos que dejar para otro momento los comentarios sobre la diversa 


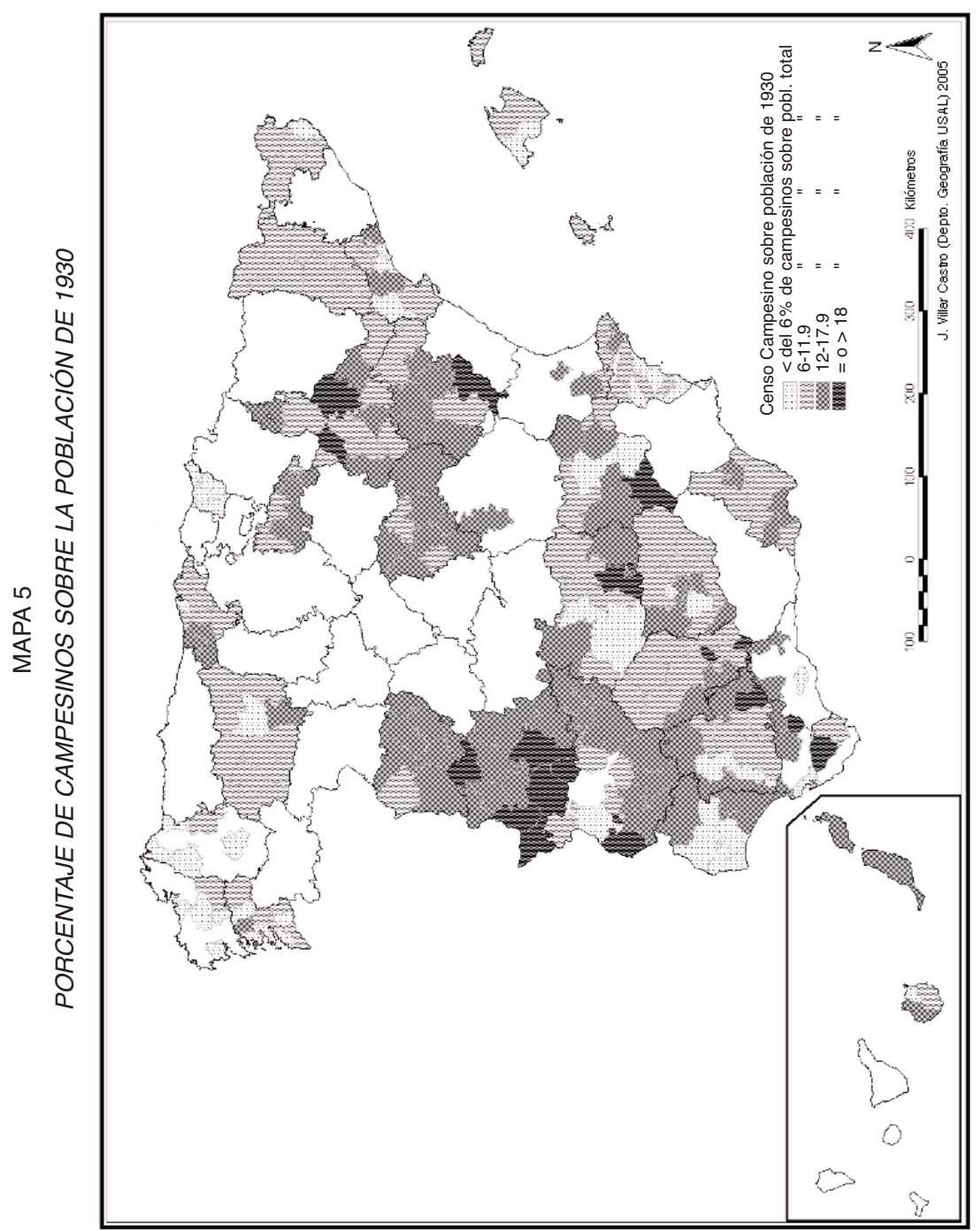




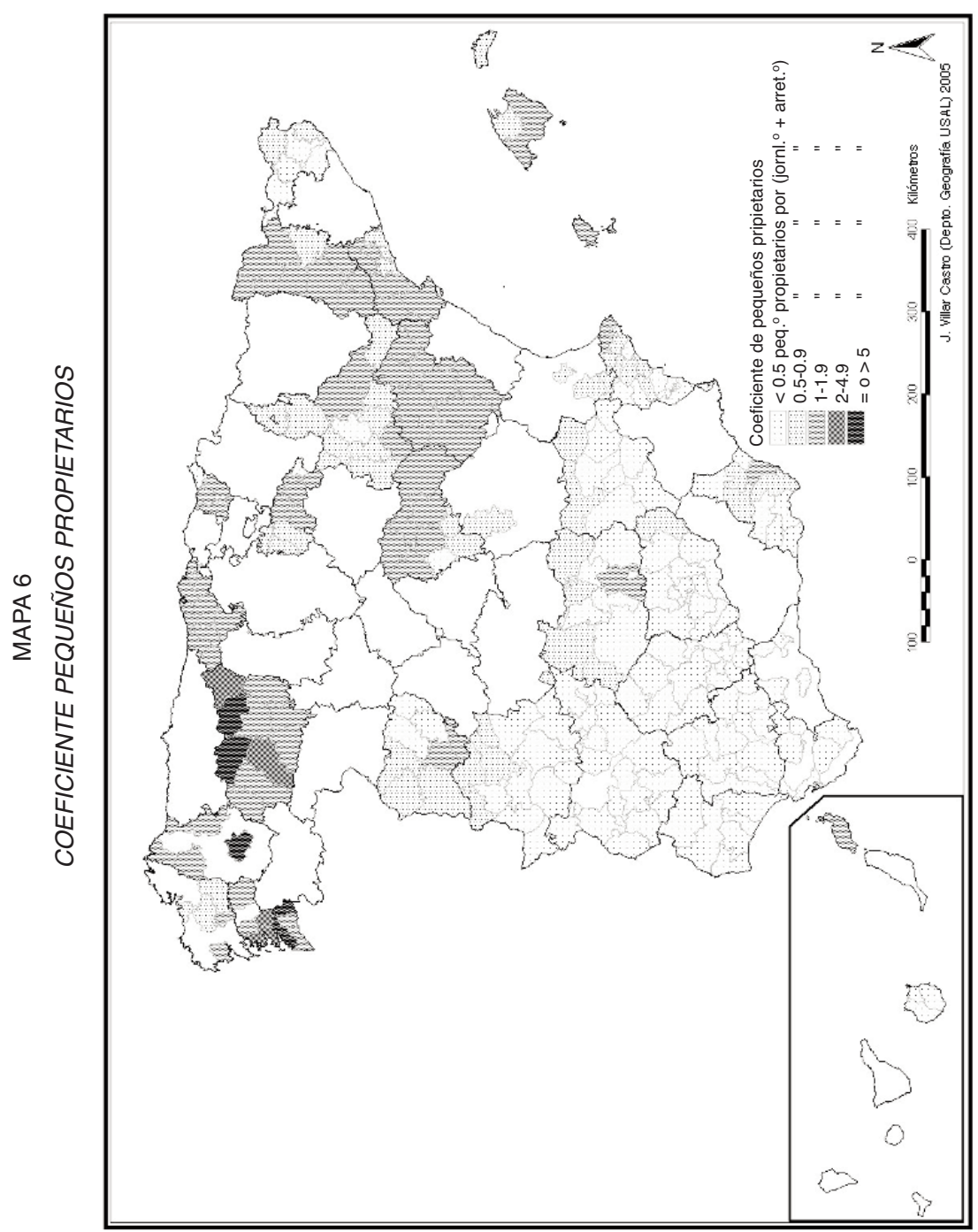


casuística que ofrecen los datos en relación con las distintas variables de una agricultura peninsular muy poco uniforme.

Por último, el mapa 6 nos muestra la otra cara del mapa 3 y presenta un coeficiente que mide la importancia de los pequeños propietarios en relación con los otros grupos (número de pequeños propietarios por jornalero + arrendatario). Un tercio de los partidos superan el coeficiente 1, y prácticamente todos (con la excepción salmantino-cacereña y de algunos otros núcleos) están situados por encima de una línea imaginaria que cruzara la Península de Pontevedra a Alicante. Son las comarcas donde el problema de los precios se superpone al de la desigualdad de la propiedad, espacios propicios por otra parte para la captación de mensajes conservadores; ${ }^{18}$ el problema triguero constituiría uno de los aspectos más conocidos, pero no el único.

\section{Observaciones finales}

No hizo falta la elaboración del Censo de Campesinos para justificar la necesidad de la reforma agraria; los datos catastrales de los que se disponía para varias provincias y la propia conflictividad social se encargaban de empujar hacia la puesta en marcha de la reforma republicana, que consistió en algo más que en repartir tierras, es decir, en asentar campesinos en las catorce provincias afectadas por la ley de septiembre de 1932. Pocas veces un fenómeno social como éste se resiste a ser analizado desde un solo ángulo de vista y haciendo abstracción de la coyuntura económica y política de los años 30. Pero no es el lugar para entablar polémicas.

El Censo de Campesinos contabilizó un total de 1101013 personas, repartidas casi por igual entre jornaleros por una parte $(48,4 \%)$ y pequeños propietarios y arrendatarios (o aparceros) por otra. Son datos de las 44 provincias de las que se dispone de información, con un grado de representa-

18 Véase por ejemplo El Campesino, «órgano oficioso de La Liga Nacional de Campesinos», en mayo de 1931, n. ${ }^{\circ} 86$ : «Hacia la solución del principal problema del labrador: el aumento de los ingresos de sus casa»; y en noviembre de 1933, n. ${ }^{\circ}$ 116: "iA votar por la salvación de España, [católica y libre] ¡", acusando al socialismo español de la situación de «500 000 pequeños y medianos labradores arruinados». 
ción muy desigual, lo que obliga a ser cautelosos en el manejo agregado de estas cifras. Del poco más de medio millón de jornaleros, dos tercios justos (352396) se concentraban en las catorce provincias donde se establecieron varias comunidades de campesinos de acuerdo con la ley de 1932. Se trata de una cifra que, aun recogiendo de modo incompleto el número de obreros agrícolas, superaba con creces el número de campesinos asentados hasta febrero de 1936 (unos 10-12000); ahora bien, hubo otras medidas, como la aplicación de decretos de intensificación de cultivos (donde participaba una mano de obra experimentada, como la de los yunteros), que deben tenerse en cuenta para no quedarse en una aplicación restrictiva de la ley de 1932.

Los primeros resultados permiten aproximarnos a una visión de conjunto de la base social agraria en los años treinta en nuestro país, visión que no desentona con los estudios ya realizados, pero que permite diferenciar mejor distintas áreas según la preeminencia del latifundismo, el pequeño campesinado o la mezcla de ambos. Además de las aproximaciones que permiten conocer mejor la población activa, la estructura agraria y las formas de tenencia, el peso del proletariado rural, etc., también el Censo de Campesinos puede contribuir a identificar áreas potenciales de conflictividad, gracias al dato del asociacionismo, cuya adscripción ideológica nos es desconocida (el grupo B). Véase la columna 7 del anexo.

La significación del censo que hemos presentado no es la misma que la de un censo de población que hace recuento decenal del número de habitantes. Jornaleros, pequeños propietarios y arrendatarios-aparceros de buena parte de los pueblos españoles (además de sociedades obreras) tuvieron que apuntarse una o más veces en menos de tres años. Detrás de este hecho, como es comprensible, había algo más que rellenar la cédula de un censo demográfico. Llevaba implícita la esperanza o la frustración por la aplicación de la reforma, casi siempre postergada. Y después de 1936-1939 el Censo de Campesinos se convierte en un indicador razonablemente fiable para comprender o descubrir las bolsas de represión de que fue objeto la sociedad rural. Al abarcar casi todas las provincias, esperamos que permita fundamentar la dinámica de los movimientos sociales, por ejemplo en La Rioja, Aragón, Cantabria..., zonas alejadas de la conflictividad tópica del latifundio.

En definitiva, la presentación del censo, con la elaboración efectuada a escala de partidos judiciales, pretende ofrecer una fuente complementaria que enriquezca nuestra comprensión del sector agrario en los años 
treinta, completando investigaciones de otros autores o proporcionando pistas para aproximarse a situaciones de tensión social que han podido pasar desapercibidas.

Que el Censo de Campesinos sea una fuente utilizable para el mejor conocimiento del mundo rural español de los años 30 del siglo pasado no debe hacernos pensar que sea del todo inútil en ámbitos urbanos, entendiendo por tales los que superaban los 10000 habitantes. Los datos presentados en otra ocasión ${ }^{19}$ informan sobre situaciones que debían de ser potencialmente muy conflictivas; por poner algunos ejemplos que no son de Andalucía o Extremadura, Carcagente en Valencia, Arucas en Las Palmas o Yeste en la provincia de Albacete. En este último caso, prácticamente 1 de cada 5 habitantes figuraba como jornalero según el Censo de Campesinos. Al comprobar este dato, resulta más comprensible lo ocurrido en el Yeste de 1936, según rescató hace años J. Goytisolo en Señas de identidad: dos mil familias se encontraban sin trabajo, sobresaliendo pineros, carboneros, leñadores y campesinos, que invadieron en mayo de 1936 los montes del cacique y empezaron a talar los árboles o a roturar los del Estado; en la refriega con la Guardia Civil, un guardia resultó muerto a hachazos, muriendo además diecinueve campesinos. ${ }^{20}$

19 Simposio celebrado en Salamanca en noviembre de 2004.

20 Brey y Forgues (1976), Requena Gallego (1982) y Sepúlveda Losa (2003). 


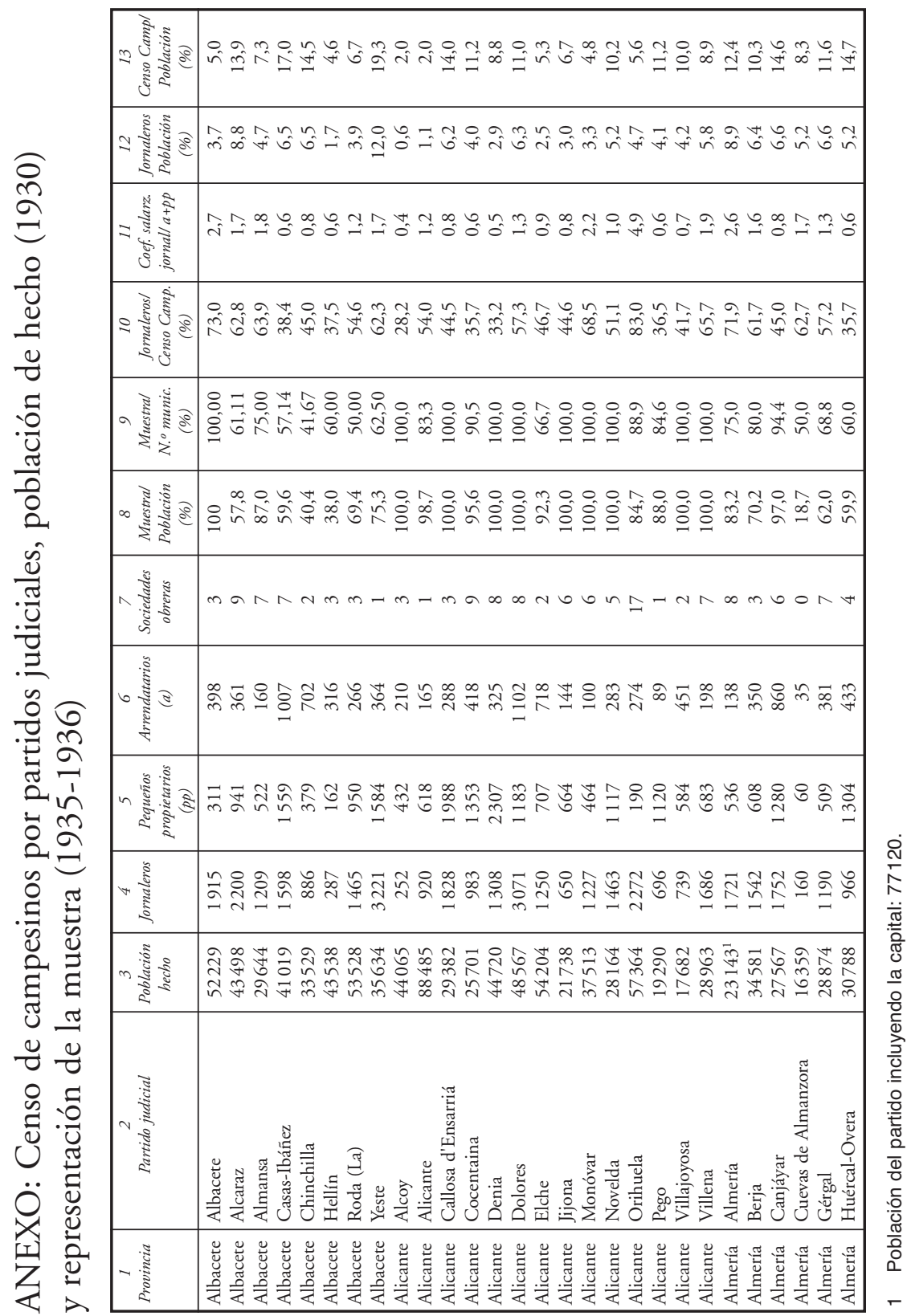




\begin{tabular}{|c|c|}
\hline 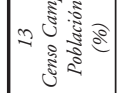 & 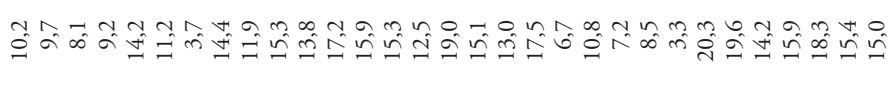 \\
\hline 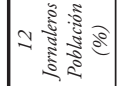 & 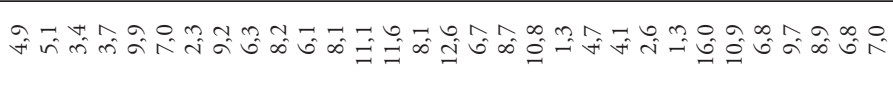 \\
\hline & 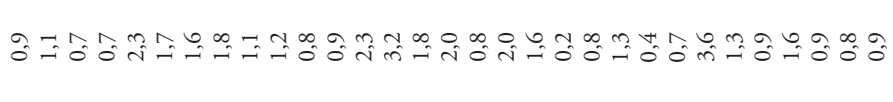 \\
\hline 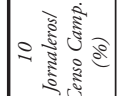 & 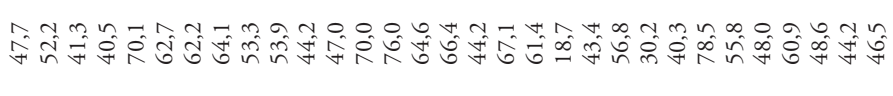 \\
\hline$a \frac{\sqrt{3}}{3}$ & 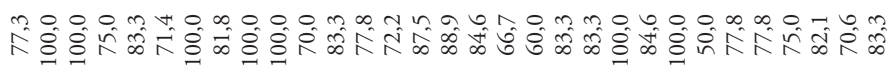 \\
\hline 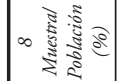 & 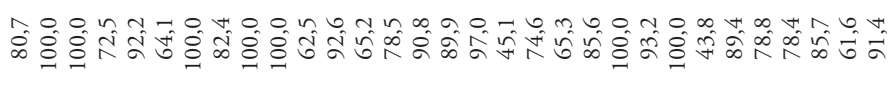 \\
\hline 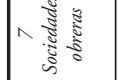 & 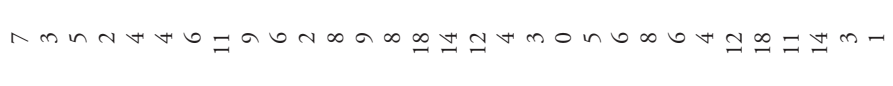 \\
\hline 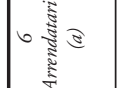 & 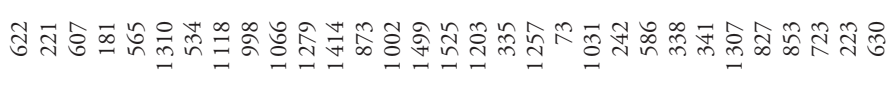 \\
\hline 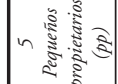 & 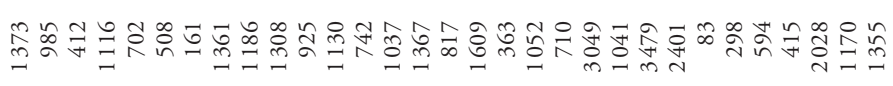 \\
\hline W & 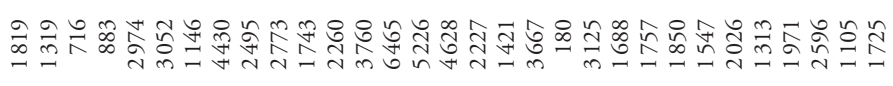 \\
\hline 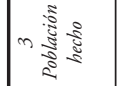 & 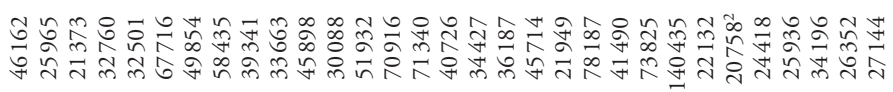 \\
\hline 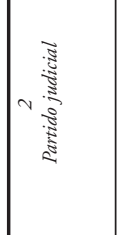 & 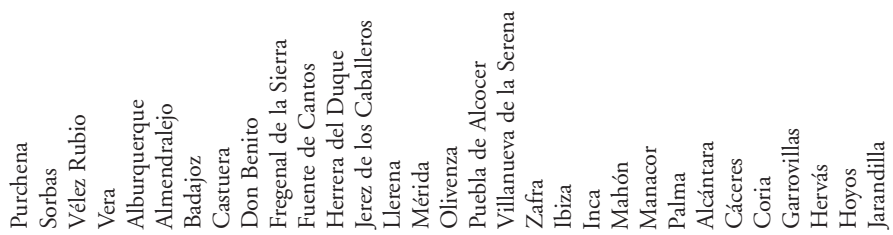 \\
\hline$-\sqrt{2}$ & 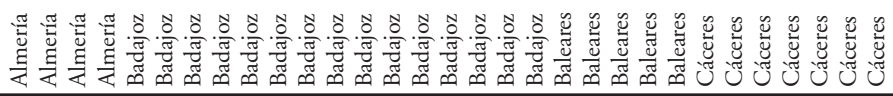 \\
\hline
\end{tabular}




\begin{tabular}{|c|c|}
\hline 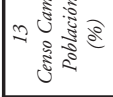 & 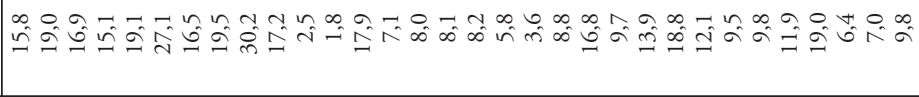 \\
\hline$\approx$ a & 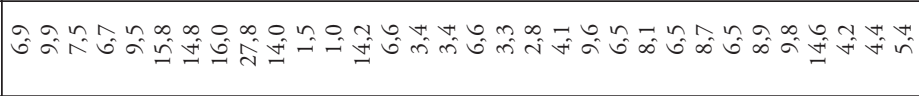 \\
\hline & 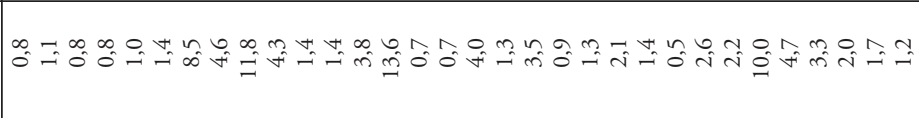 \\
\hline a & 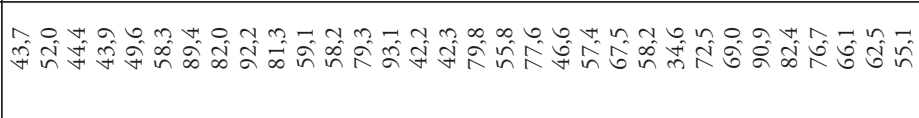 \\
\hline 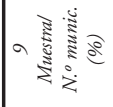 & 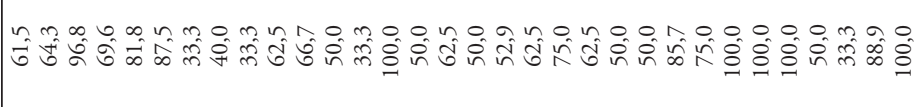 \\
\hline$\infty \frac{3}{3}$ & 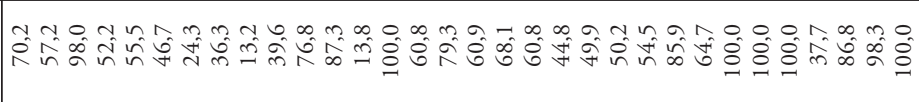 \\
\hline కูँ & 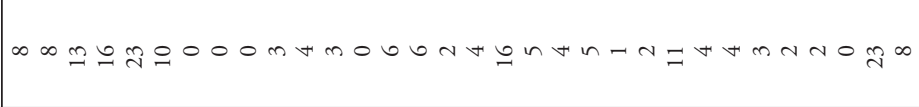 \\
\hline 0 跑 & 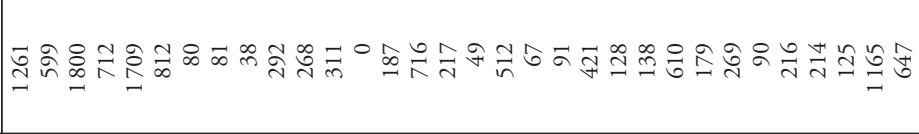 \\
\hline 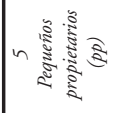 & 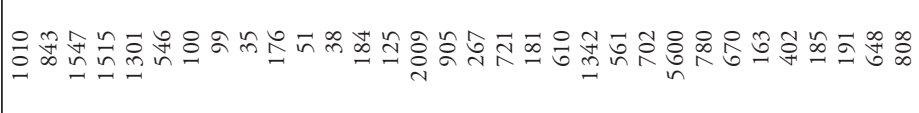 \\
\hline$+\frac{5}{5}$ & 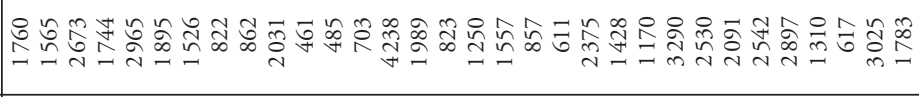 \\
\hline$m \frac{2}{2}$ & 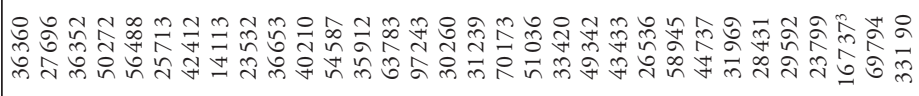 \\
\hline 语 & 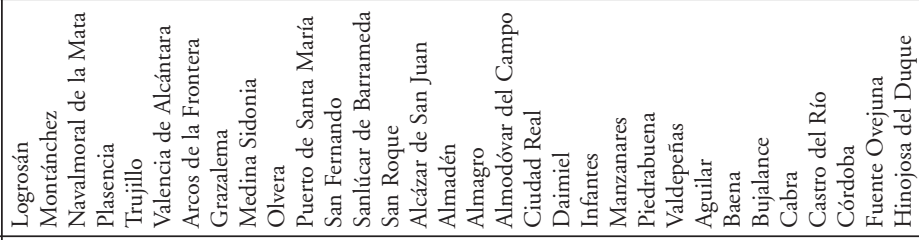 \\
\hline$-\sqrt{-2}$ & 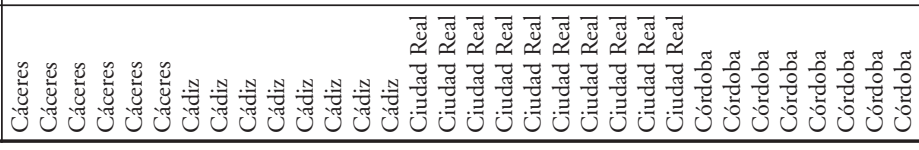 \\
\hline
\end{tabular}




\begin{tabular}{|c|c|}
\hline 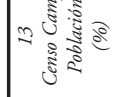 & 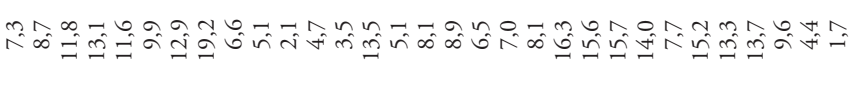 \\
\hline$\therefore \frac{2}{2}$ & 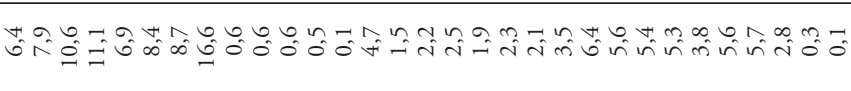 \\
\hline & 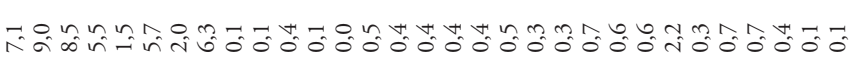 \\
\hline 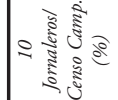 & 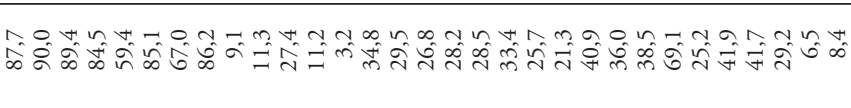 \\
\hline 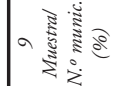 & 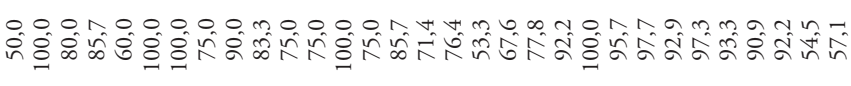 \\
\hline 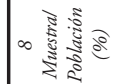 & 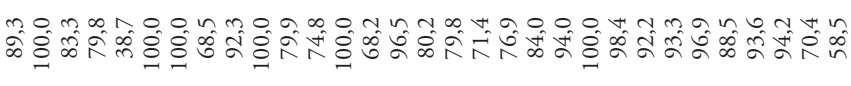 \\
\hline$\wedge$ हूँ & 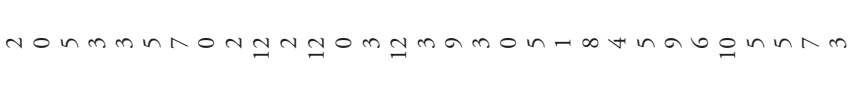 \\
\hline ๑) & 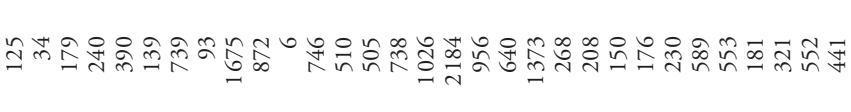 \\
\hline n & 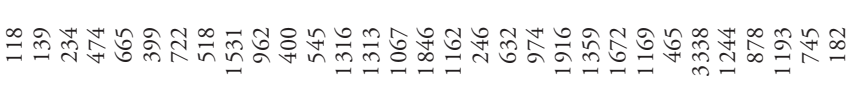 \\
\hline$+\frac{2}{5}$ & 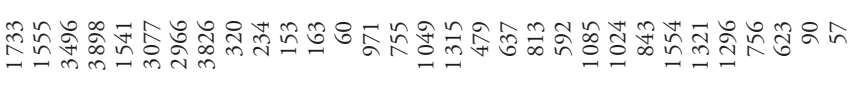 \\
\hline$m \frac{3}{8}$ & 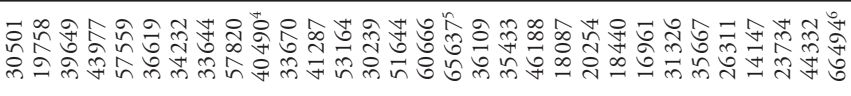 \\
\hline$\sqrt{\frac{\sqrt{2}}{8}}$ & 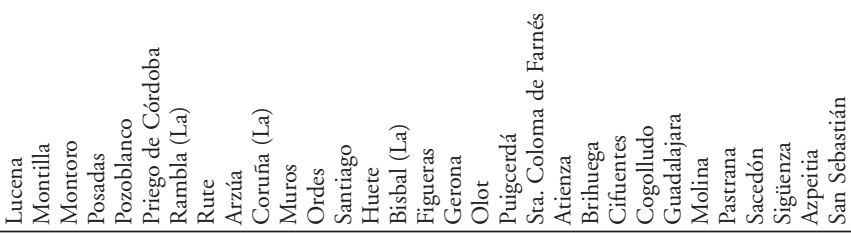 \\
\hline$-\sqrt{2}$ & 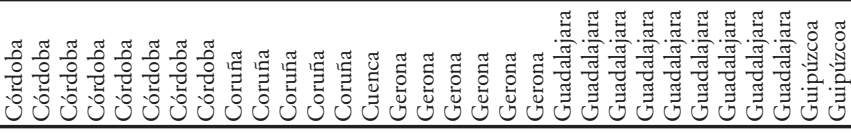 \\
\hline
\end{tabular}




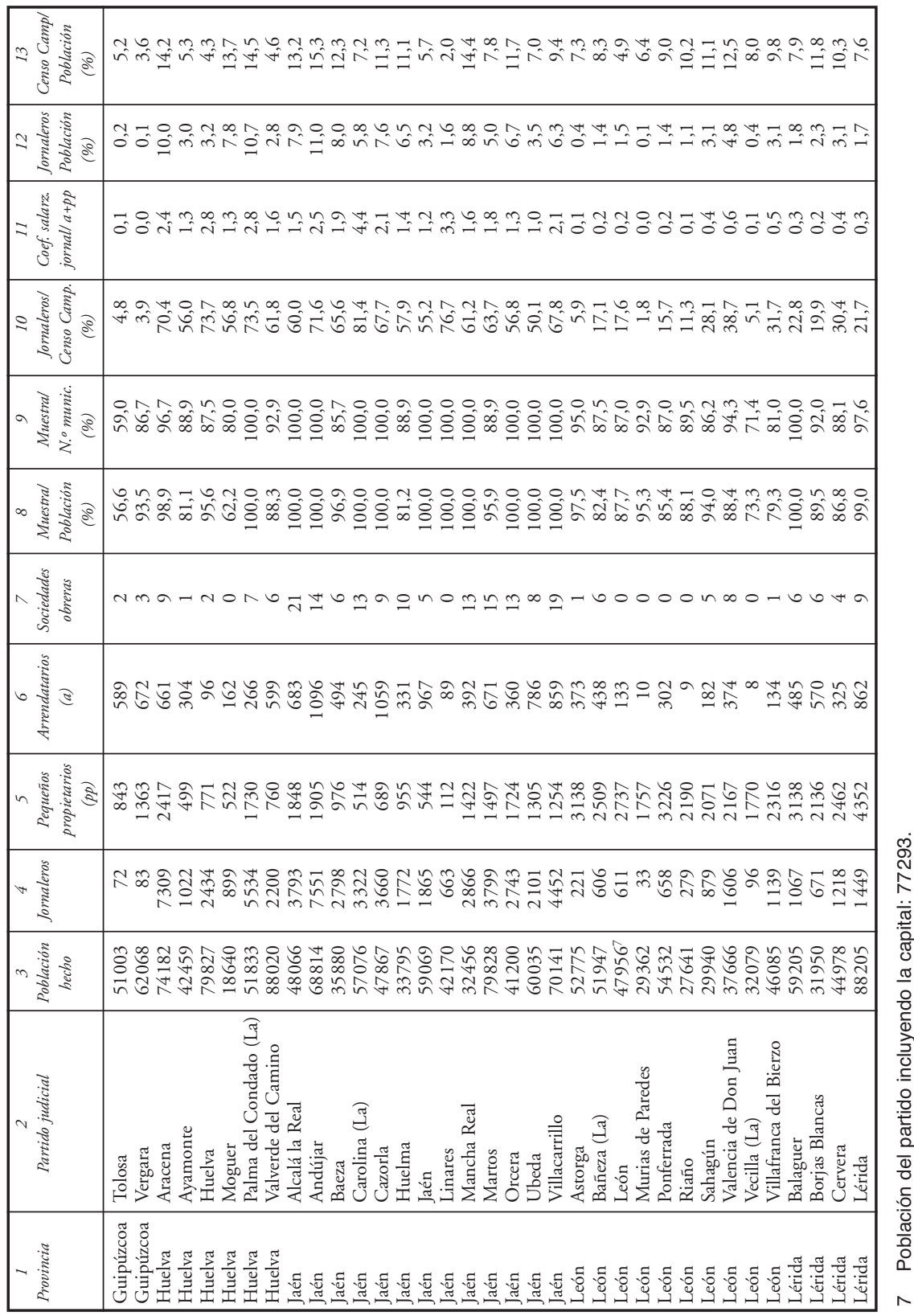




\begin{tabular}{|c|c|}
\hline 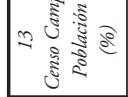 & 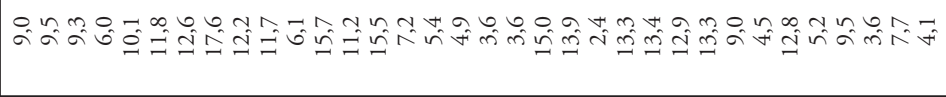 \\
\hline 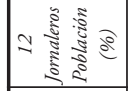 & 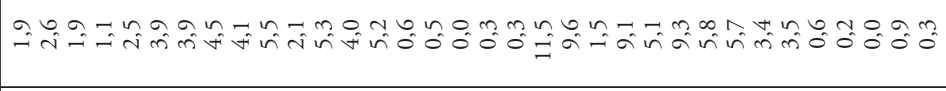 \\
\hline$=\sqrt{3}$ & 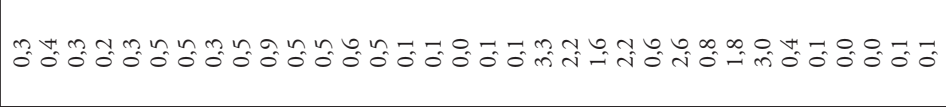 \\
\hline உ & 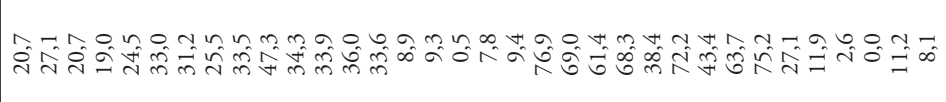 \\
\hline 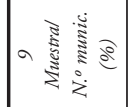 & 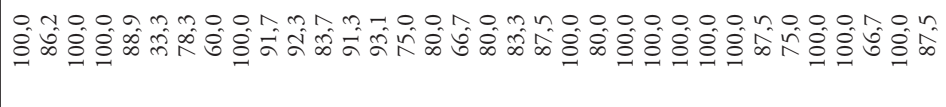 \\
\hline$\infty \frac{\sqrt{3}}{\sqrt[3]{3}}$ & 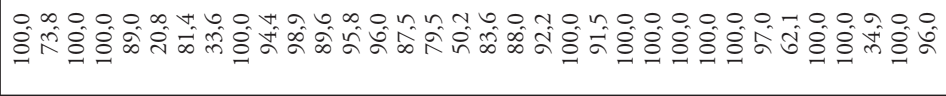 \\
\hline 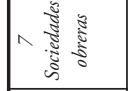 & 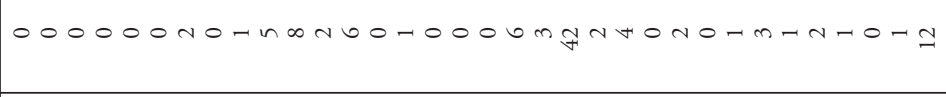 \\
\hline 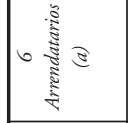 & 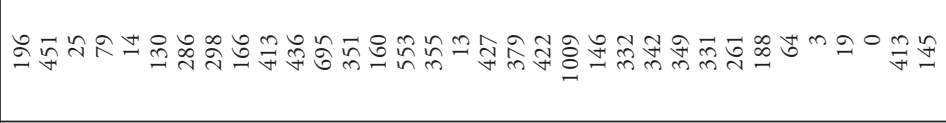 \\
\hline 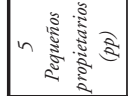 & 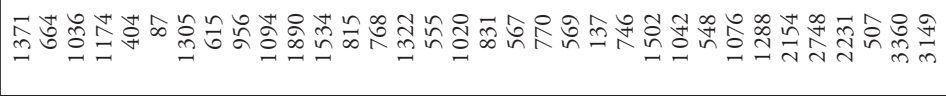 \\
\hline W & 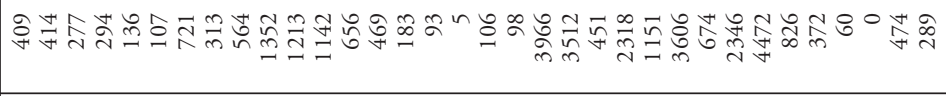 \\
\hline$m \frac{3}{3}$ & 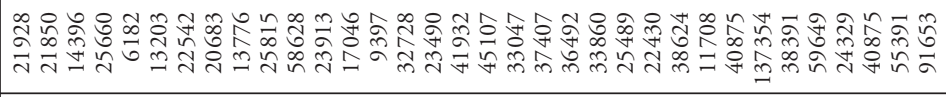 \\
\hline$\sqrt{\frac{\sqrt{2}}{2}}$ & 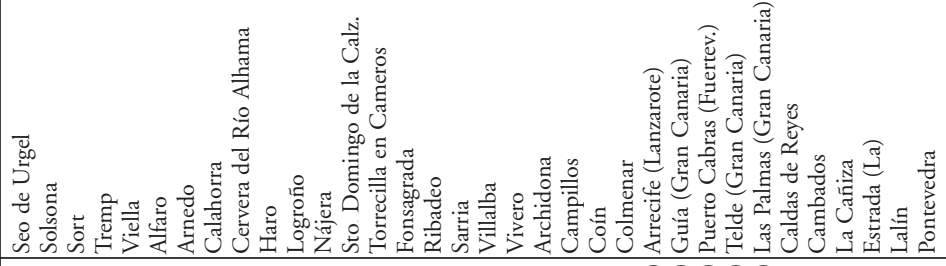 \\
\hline- 营 & 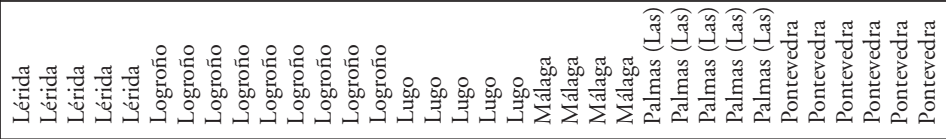 \\
\hline
\end{tabular}




\begin{tabular}{|c|c|}
\hline 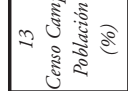 & 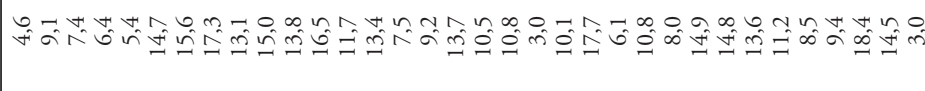 \\
\hline 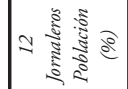 & 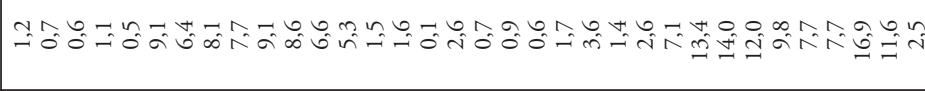 \\
\hline 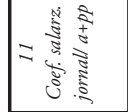 & 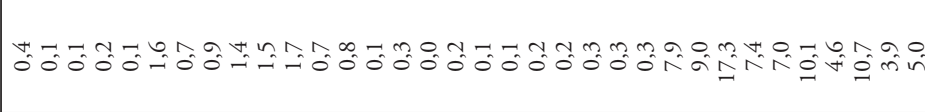 \\
\hline 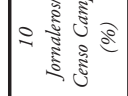 & 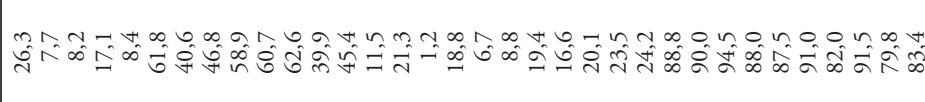 \\
\hline ๙ & 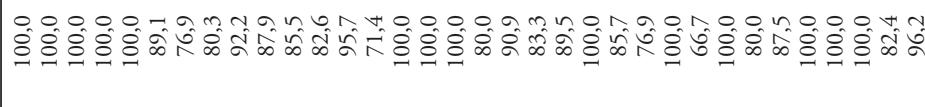 \\
\hline$\infty$ 密 & 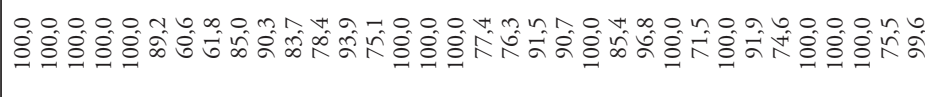 \\
\hline 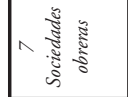 & 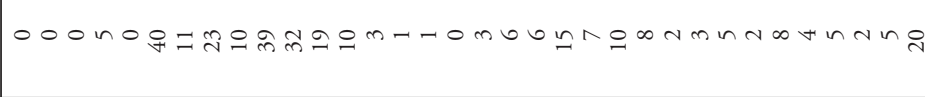 \\
\hline 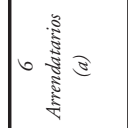 & 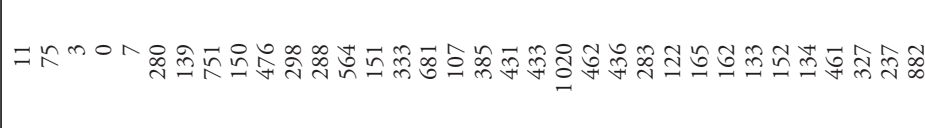 \\
\hline 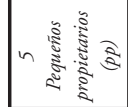 & 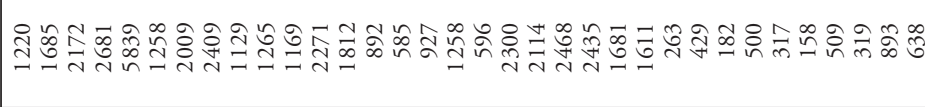 \\
\hline$\forall$ हैँ & 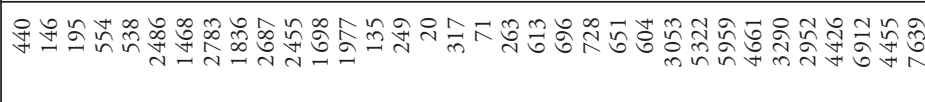 \\
\hline$m \frac{\sqrt{3}}{3}$ & 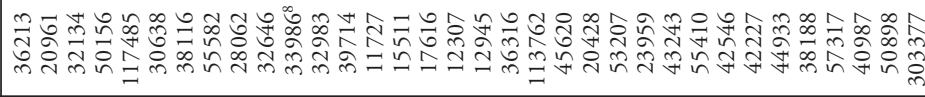 \\
\hline 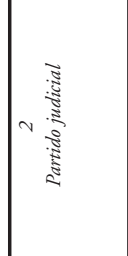 & 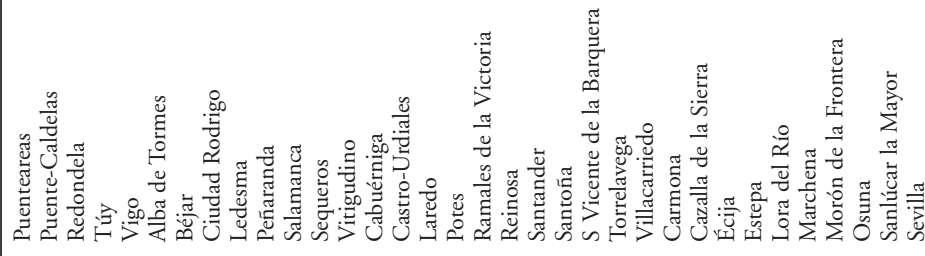 \\
\hline$-\sqrt{2}$ & 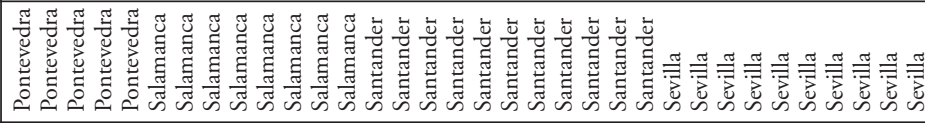 \\
\hline
\end{tabular}




\begin{tabular}{|c|c|}
\hline 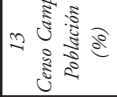 & 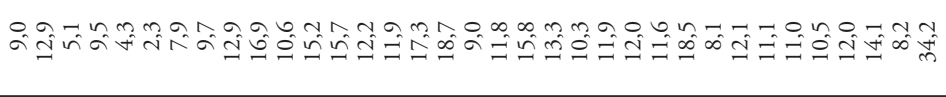 \\
\hline 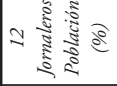 & 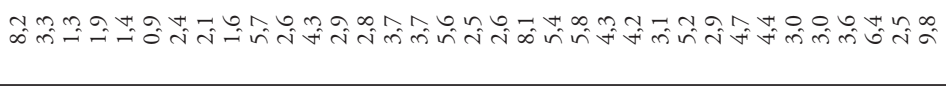 \\
\hline 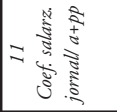 & 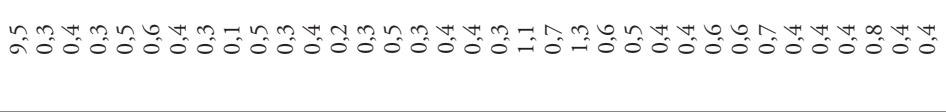 \\
\hline 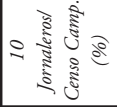 & 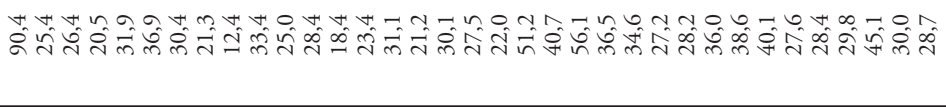 \\
\hline 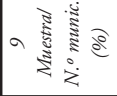 & 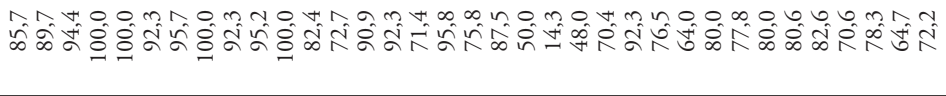 \\
\hline$\infty \frac{a^{2}}{3}$ & 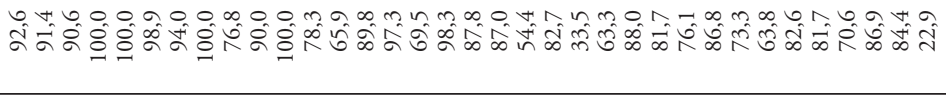 \\
\hline 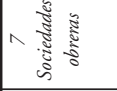 & 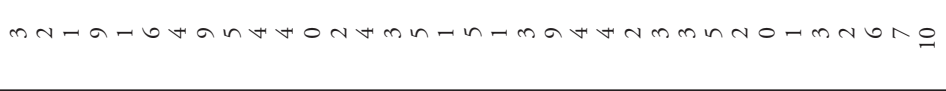 \\
\hline ( ) & 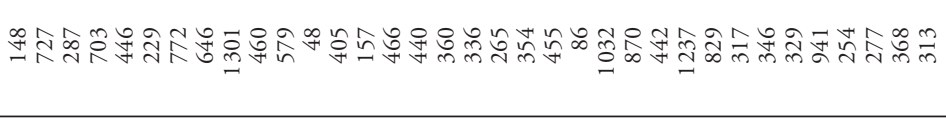 \\
\hline 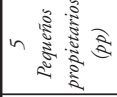 & 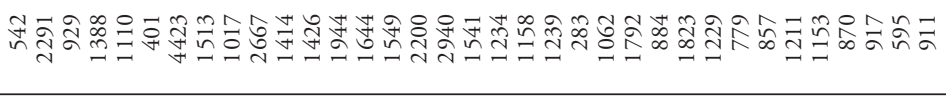 \\
\hline 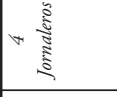 & 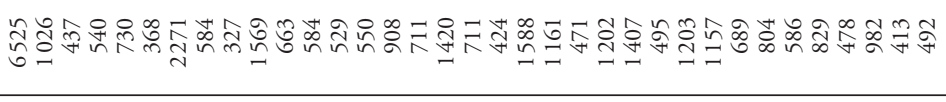 \\
\hline$m \frac{\pi}{3}$ & 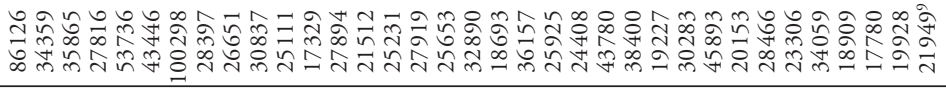 \\
\hline 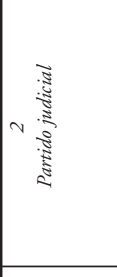 & 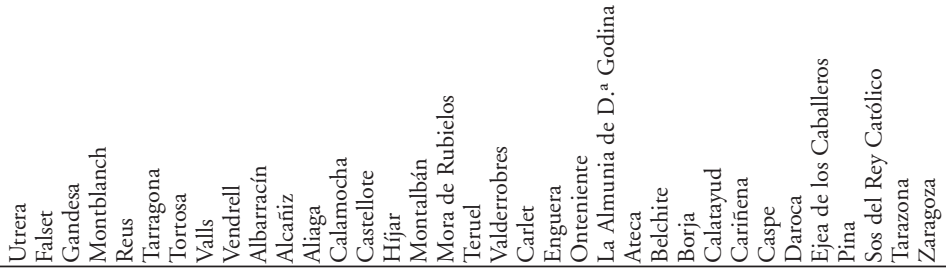 \\
\hline$-\sqrt{3}$ & 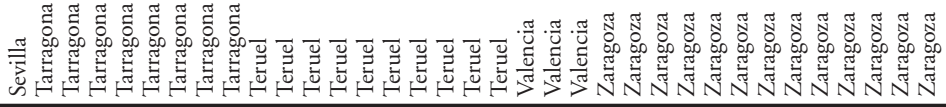 \\
\hline
\end{tabular}




\section{ECONOMÍAS DE ESCALA, ORGANIZACIÓN DE PATRIMONIOS Y OBSTÁCULOS A UNA REFORMA AGRARIA. ANDALUCÍA, 1880-1936* \\ Juan Carmona y James Simpson \\ (Universidad Carlos III de Madrid)}

Aunque la productividad total de los factores puede ser similar en las grandes como en las pequeñas explotaciones, utilizan los factores de producción en proporciones muy diferentes. Las pequeñas explotaciones pueden alcanzar altos niveles de productividad trabajando la tierra intensamente utilizando la abundante mano de obra familiar, pero con aportaciones modestas de capital. En cambio, las grandes explotaciones tienden a utilizar extensamente la mano de obra y la tierra, mientras que la producción es más intensiva en capital (y en tecnología, a veces). El resultado es, en este último caso, que los rendimientos por hectárea a veces disminuyen a medida que aumenta la superficie de la explotación, que en las grandes fincas las rotaciones son más largas y que los propietarios tien-

* Agradecemos los comentarios recibidos por los participantes en la sesión «Cambio institucional en la agricultura: modificaciones en la gestión de los grandes patrimonios y reforma agraria, 1800-1939» del VIII Congreso de la Asociación Española de Historia Económica (Santiago, 13-16 de septiembre de 2005), en especial de Ricardo Robledo, Antonio López Estudillo y María Teresa Pérez Picazo. Los autores han contado con la ayuda del proyecto de investigación BEC 2003-06481 y SEJ 2006-08188. 
den a preferir una combinación de productos que ahorre mano de obra, sobre todo si ésta ha de ser supervisada estrechamente. ${ }^{1}$ Los incentivos a los que se enfrentan los grandes y los pequeños colonos difieren así sistemáticamente entre sí. ${ }^{2}$ Dado que la productividad total de los factores no es necesariamente distinta, la mejor justificación de una reforma agraria en los países en desarrollo con un bajo nivel de renta es que las grandes explotaciones ahorran en el factor más abundante y barato (mano de obra), pero utilizan más intensamente un factor escaso (capital).

Una reforma agraria exitosa requiere probablemente una reorientación de los cultivos desde los de menor a los de mayor intensidad y, sobre todo, hacia cultivos más intensivos en un tipo de mano de obra fácil de satisfacer por las familias. En el contexto de Andalucía y Extremadura en la década de 1930, esto implicaba el abandono del cereal, que

\section{CUADRO 1}

INTENSIDAD DE TRABAJO EN DIFERENTES SISTEMAS DE EXPLOTACIÓN DE LA TIERRA

\begin{tabular}{|l|c|c|c|}
\hline $\begin{array}{l}\text { Cultivos y } \\
\text { aprovechamientos }\end{array}$ & $\begin{array}{l}\text { Mano de obra emplea- } \\
\text { da por día (número de } \\
\text { días por hectárea) }\end{array}$ & $\begin{array}{l}\text { Producción por día } \\
\text { de trabajo, en ptas. }\end{array}$ & $\begin{array}{l}\text { Hectáreas necesarias } \\
\text { para obtener un ingreso } \\
\text { bruto de 5000 ptas. }\end{array}$ \\
\hline Rozas & 8,8 & 11,1 & \\
Cuarto & 12,5 & 12,8 & 125,0 \\
Tercio & 17,5 & 12,9 & 66,7 \\
Año y vez & 25,0 & 14,0 & 28,6 \\
Olivo (normal) & 31,2 & 11,2 & 14,3 \\
Viñas (normal) & 43,8 & 11,3 & 10,1 \\
Olivo (intensivo) & 62,5 & 11,2 & 7,1 \\
Viñas (intensivo) & 237,5 & 6,3 & 3,3 \\
Regadío (normal) & 175,0 & 12,0 & 2,4 \\
Regadío (intensivo) & 375,0 & 10,7 & 1,25 \\
\hline
\end{tabular}

La producción por día ha sido calculada dividiendo el «importe de los productos» por hectárea entre el número de días trabajados.

FUENTE: Carrión ([1932] 1975), pp. 324 y 341-342.

1 Aunque la cuestión de la relación inversa entre rendimientos y tamaño de la explotación sigue siendo debatida en la actualidad. Por ejemplo, Dyer (2004).

2 Berry y Cline (1979), pp. 7 y 14, y Griffin, Khan y Ickowitz (2002), p. 286. 
requería relativamente menos cantidad de mano de obra, hacia el cultivo de la vid o del olivo (en el secano) o cultivos de regadío (cuadro 1). Ahora bien, la experiencia de la reforma agraria en muchos países enseña que un simple «reparto" de la tierra nunca ha sido suficiente en sí mismo y que una reforma agraria exitosa también requiere la reorientación de una política gubernamental habitualmente favorable a los terratenientes y a las poblaciones urbanas. Esta reorientación implica el fomento de la investigación (especialmente en biología y tecnología de altos rendimientos), la intervención de precios en los mercados, en el tipo de productos cultivados en las pequeñas explotaciones, la adopción de políticas de extensión agrícola, el desarrollo de sistemas públicos de regadío, la creación de programas de crédito dirigidos específicamente a las pequeñas explotaciones y políticas institucionales que estimulen la organización de los pequeños productores (cooperativas, sindicatos de trabajadores rurales, asociaciones agrarias). ${ }^{3}$ Aunque los terratenientes suelen disfrutar de un poder político excepcional en los países más pobres, éste tiende a disminuir a medida que empieza el desarrollo económico, tal como ocurrió en Gran Bretaña después de 1846. ${ }^{4}$ Sin embargo, en este caso los pequeños productores no sólo sufren una política favorable a los terratenientes, sino una política con marcado sesgo urbano. Los precios de los alimentos básicos se mantienen artificialmente bajos, y la inversión del sector público en infraestructura y capital humano (educación, investigación y salud) se dirige prioritariamente a las áreas urbanas en detrimento de las rurales. Por ello, "una reforma agraria redistributiva exitosa requiere simultáneamente la eliminación tanto del sesgo terrateniente como del urbano». ${ }^{5}$

Edward Malefakis ha resumido con gran nitidez el problema al que se enfrentaban los que deseaban una reforma agraria en España durante la Segunda República. Una reforma lenta, en la que los terratenientes se vieran plenamente compensados, corría el riesgo de enfrentarse a una amplia oposición de los sin tierra. En cambio, una reforma rápida que no tuviera

3 Griffin, Khan y Ickowitz (2002), p. 284. Solberg (1987), en particular el capítulo 7.

4 De hecho existen casos en que los grandes terratenientes han desanimado deliberadamente las inversiones estatales en sus áreas de influencia. Véase, por ejemplo, Alston y Ferrie (1993).

5 Griffin, Khan y Ickowitz (2002), pp. 284-285. 
en cuenta las florituras legales relacionadas con los derechos de propiedad corría el riesgo de enfrentarse a una fuerte oposición de los terratenientes. ${ }^{6}$ Los gobiernos de la Segunda República se arreglaron para alienarse a ambos grupos, y la cantidad de tierra redistribuida fue relativamente pequeña, al menos antes de febrero de 1936. En esta comunicación argumentamos que existía un problema adicional que no ha sido plenamente considerado por los historiadores, es decir, las dificultades asociadas con una rápida conversión de un sistema extensivo, pero eficiente, y que se había ido conformando durante siglos, en otro de explotación intensiva que habría permitido a los trabajadores sin tierra asentarse en explotaciones económicamente viables. ${ }^{7}$

Este artículo comprende tres secciones. En la primera analizamos la naturaleza del latifundio, en particular porque utilizaba poca mano de obra y las explotaciones siguieron siendo grandes, incluso cuando eran arrendadas. La segunda sección contempla las implicaciones de convertir una agricultura muy especializada y dedicada a la producción de cereales (y ganadería) en otra mejor adaptada a la explotación familiar. Finalmente, en la última sección consideramos las dificultades para eliminar el «sesgo urbano» en una sociedad donde el sector agrario se está convirtiendo en un sector cada vez menos importante.

\section{Latifundios y organización de la gran propiedad en Andalucía}

La propiedad de la tierra en Andalucía, al igual que la del ganado, estaba concentrada en las manos de unos pocos propietarios. Si bien quizás cerca de los dos tercios de la tierra se cultivaban directamente hacia finales de la década de 1920, la tierra se había ido arrendando tradicionalmente en forma de grandes explotaciones. ${ }^{8}$ En esta sección vamos a argu-

6 En esta comunicación no consideramos la importante cuestión de la mano de obra y de los mercados de trabajo. Sobre estos aspectos, véase Carmona y Simpson (2003), pp. 97-115, o Robledo (1993) y (1996).

7 Eficiencia en terminos de productividad total de los factores y beneficios privados en vez de sociales.

8 Ministerio de Hacienda (1931). 
mentar que la evolución histórica del latifundio había producido una estructura que habría dificultado significativamente la reforma agraria. Este problema se vio reforzado por el predominio de la producción extensiva de cereales y ganado, un hecho que habría requerido grandes cambios si se hubiese deseado crear empleo suficiente (sección 2). La reforma agraria habría tenido serias dificultades para tener éxito, incluso en un entorno social y político más favorable.

El cuadro 2 ilustra de forma muy general la concentración de la propiedad de la tierra en España. Existían, claro está, variaciones significativas incluso dentro de las regiones de los latifundios. En la Bética (provincias de Córdoba, Sevilla, Huelva, Jaén y Cádiz), por ejemplo, alrededor del $57 \%$ de la superficie agrícola se hallaba concentrada en explotaciones de más de 100 hectáreas, el $46 \%$ en las de más de 250 hectáreas y el $31 \%$ en las superiores a 500 hectáreas. ${ }^{9}$ Sin embargo, y tal como Edward Malefakis ha puesto en evidencia, no sólo estas cifras subestiman el grado de concentración, sino que existía la misma posibilidad de encontrar latifundios en las fértiles llanuras de la Campiña que en los suelos más pobres. Por ejemplo, las fincas de más 250 hectáreas representaban el 63\% de la superficie de municipios como Almodóvar del Río, el $56 \%$ en Écija, o el $73 \%$

CUADRO 2

DISTRIBUCIÓN DE LAS FINCAS EN ESPAÑA EN 1930 Y 1959

\begin{tabular}{|c|c|c|c|c|c|c|c|}
\hline & \multirow{2}{*}{$\begin{array}{l}\text { Tamaño medio } \\
\text { de las fincas }\end{array}$} & \multicolumn{2}{|c|}{$\begin{array}{l}\text { Fincas pequeñas } \\
\text { (menos de } 10 \mathrm{ha} \text { ) }\end{array}$} & \multicolumn{2}{|c|}{$\begin{array}{l}\text { Fincas medianas } \\
(\text { de } 10 \text { a } 100 \mathrm{ha})\end{array}$} & \multicolumn{2}{|c|}{$\begin{array}{l}\text { Fincas grandes } \\
\text { (más de } 100 \mathrm{ha} \text { ) }\end{array}$} \\
\hline & & $\begin{array}{l}\text { Total en } \\
\text { miles de } \\
\text { fincas }\end{array}$ & $\begin{array}{c}\text { Superficie } \\
\text { en miles } \\
\text { de ha }\end{array}$ & $\begin{array}{l}\text { Total en } \\
\text { miles de } \\
\text { fincas }\end{array}$ & $\begin{array}{c}\text { Superficie } \\
\text { en miles } \\
\text { de ha }\end{array}$ & $\begin{array}{l}\text { Total en } \\
\text { miles de } \\
\text { fincas }\end{array}$ & $\begin{array}{c}\text { Superficie } \\
\text { en miles } \\
\text { de ha }\end{array}$ \\
\hline España & 0,65 hectáreas & 53548 & 11954 & 439 & 10675 & 49 & 12277 \\
\hline Norte & 0,43 hectáreas & 26982 & 7217 & 104 & 2581 & 8 & 1764 \\
\hline Centro & 1,10 hectáreas & 6240 & 3691 & 58 & 1544 & 6 & 1687 \\
\hline Sur & 3,97 hectáreas & 3776 & 4323 & 111 & 3067 & 22 & 8120 \\
\hline
\end{tabular}

Calculado a partir de Malefakis (1970), apéndice III.

9 Carrión ([1932] 1975), pp. 54-55. 
en Jerez, todos ellos situados en la Campiña. ${ }^{10}$ En Andalucía occidental, menos del $1 \%$ de las explotaciones suponían el $57 \%$ del área y el $43 \%$ de la contribución territorial en 1930. Los mayores propietarios españoles contaban con un porcentaje extremadamente elevado de sus propiedades en el sur de España, como muestra el hecho de que a mediados del siglo XIX el $41 \%$ de los impuestos sobre la propiedad pagados por los 55 mayores contribuyentes lo eran en concepto de sus propiedades situadas en la Bética, el $51 \%$ si se incluye Extremadura. ${ }^{11} \mathrm{La}$ totalidad de la gran aristocracia terrateniente absentista poseía extensas propiedades en el sur y, aunque su importancia se redujo mucho con el tiempo, era una opinión general que el hecho de que fueran en su mayoría absentistas y arrendaran sus tierras explicaba de forma determinante la escasa intensidad del cultivo. ${ }^{12}$

Pero la propiedad del ganado se hallaba también muy concentrada. En 1865, aunque Andalucía albergara sólo el 11,2\% de la cabaña vacuna, contaba con el $61 \%$ de todos los animales en cabañas de más de 30 cabezas, una cifra que aumenta hasta el $85 \%$ cuando se utilizan los datos del

\section{CUADRO 3}

CONCENTRACIÓN DE LA PROPIEDAD GANADERA EN EL SUR DE ESPAÑA, 1865 (número de cabezas de vacuno por rebaño)

\begin{tabular}{|l|r|r|r|r|r|r|}
\hline & $30-50$ & \multicolumn{1}{|c|}{$\%$} & $50-100$ & \multicolumn{1}{c|}{$\%$} & $>100$ & \multicolumn{1}{c|}{$\%$} \\
\hline Cádiz & 266 & 12,7 & 175 & 12,4 & 202 & 27,1 \\
Córdoba & 244 & 11,7 & 277 & 19,7 & 88 & 11,8 \\
Huelva & 75 & 3,6 & 46 & 3,3 & 38 & 5,1 \\
Sevilla & 284 & 13,6 & 270 & 19,2 & 175 & 23,5 \\
Bética & 869 & 41,5 & 768 & 54,6 & 503 & 67,5 \\
Badajoz & 143 & 6,8 & 153 & 10,9 & 66 & 8,9 \\
Cáceres & 160 & 7,6 & 96 & 6,8 & 21 & 2,8 \\
Extremadura & 303 & 14,5 & 249 & 17,7 & 87 & 11,7 \\
Total & 1172 & 56,0 & 1017 & 72,3 & 590 & 79,2 \\
España & 2092 & 100,0 & 1407 & 100,0 & 745 & 100,0 \\
\hline
\end{tabular}

FUENTE: Junta General de Estadística (1868), p. 205.

10 No todas estas grandes fincas eran explotadas de forma unitaria. Como veremos más adelante, un cierto número eran parceladas, pero no parece que ésta fuera la forma generalizada de explotación. Para la subestimación de la concentración, véase Malefakis (1970), capítulo 1.

11 Congost (1983), pp. 289 y ss.

12 Rodrigáñez (1886) y Robledo (1993), p. 103. 
sur de España, como lo entiende Edward Malefakis (cuadro 3). Más de la mitad de las cabañas vacunas de más de 100 cabezas se repartían entre las provincias de Cádiz y Sevilla. Muchos de los grandes ganaderos eran a la vez los arrendatarios de los grandes cortijos. Aunque la ganadería de renta estaba muy desarrollada en las zonas pobres del norte de la región o en los ricos pastos de la provincia de Cádiz, una parte sustancial de estas grandes ganaderías servían para cultivar los cortijos de la campiña. El 60\% del vacuno cordobés estaba destinado a los trabajos agrícolas en 1891, y de este porcentaje el $90 \%$ trabajaba en la Campiña, donde dominaba el latifundio. ${ }^{13}$ Una muestra de grandes arrendatarios que residían en el municipio de Córdoba, uno de los más extensos del país, cultivaba en 1860 una media de 430 hectáreas con la ayuda de 68 cabezas de vacuno (cuadro 4). ${ }^{14}$ De hecho, muchos de estos arrendatarios cultivaban más de un cortijo cada uno, lo que muestra que las dimensiones reales de las explotaciones eran aún mayores de lo que indican las estadísticas. ${ }^{15}$ No hay estadísticas sobre la composición de las cabañas ganaderas, pero datos aislados sugieren que, además del ganado de tiro, incluía un cierto porcentaje de vacas para la cría, yeguas para la trilla (un quinto del vacuno de labor), cerdos, ovinos y burros. ${ }^{16}$

CUADRO 4

DIMENSIONES DE GANADERÍAS VACUNAS Y EXPLOTACIONES EN EL MUNICIPIO DE CÓRDOBA, 1860

\begin{tabular}{|l|c|c|c|}
\hline & Hectáreas & $\begin{array}{c}\text { Cabezas } \\
\text { de ganado vacuno }\end{array}$ & $\begin{array}{c}\text { Hectáreas por cabeza } \\
\text { de ganado vacuno }\end{array}$ \\
\hline Total 39 arrendatarios & 17157 & 2644 & 6,5 \\
Media por arrendatario & 439,9 & 67,8 & 1,8 \\
Desviación estándar & 203,9 & 33,3 & \\
\hline
\end{tabular}

FUENTE: Mata (1987), vol. 2, pp. 92-93.

13 López Ontiveros (1974), p. 313.

14 La superficie media, en López Ontiveros (1974), p. 399.

15 Las grandes dimensiones de la explotación era ya algo habitual antes del siglo XIX: el duque de Osuna arrendaba en 1730, por ejemplo, los 260 cortijos que poseía en la villa de Osuna a sólo 75 arrendatarios, estando la media entre 3 y 6 fincas por colono. En Artola et ál. (1978), pp. 75-82. También Gamero, Mata y Muñoz (1997), p. 411.

16 López Ontiveros (1974), pp. 309-310. 
Los bueyes eran los animales de tiro utilizados habitualmente en las grandes explotaciones agrarias de la Bética, y lo seguían siendo incluso en la década de 1930, siendo sustituidos directamente por los tractores. ${ }^{17} \mathrm{La}$ explicación más habitual a la persistencia del ganado vacuno hasta mediados del siglo XX, la atribuye a las características de la tierra, que exigían aradas profundas con pesados arados de vertedera conducidos habitualmente por un mínimo de dos parejas de bueyes. A esto se suma otro factor, y es el hecho de que fuera fácil de alimentar con los rastrojos y los pastos naturales, con lo que se minimizaba su coste. ${ }^{18}$ En contraste, los mulos, el ganado de tiro más utilizado en el resto de la España de secano, sólo eran empleados por pequeños colonos en las inmediaciones de los pueblos o bien en las explotaciones de olivar, que solían plantarse en suelos menos profundos. ${ }^{19} \mathrm{La}$ extensión del cultivo (y la consiguiente disminución de los pastos naturales) y, en particular, la plantación de olivares estimularon la expansión del ganado mular, de tal forma que si suponía sólo un tercio del ganado de tiro en 1865 y en 1891, esta cifra había aumentado hasta los dos tercios en $1933 .{ }^{20}$

Con respecto a la explotación de la tierra, en términos generales los grandes propietarios pueden utilizar cualquier tipo de contrato que maximice su renta. Pero donde existen significativas economías de escala, dominará la gran explotación con mano de obra asalariada, ya que ésta proporciona ventajas de varios tipos: los colonos son más solventes y además cuentan con más capital para invertir en la tierra (o mejores garantías) y aportan un mayor volumen de ganado. Además, también cuentan con ventajas a la hora de comercializar sus productos y, en concreto, están en condiciones de obtener precios más remuneradores. En cambio, los pequeños colonos son más competitivos cuando se dan problemas significativos de riesgo moral y cuando la supervisión del trabajo asalariado a gran escala supone una importante dificultad. En palabras de un contemporáneo, esto se da en los cultivos que requieren la necesidad de mano de

17 Mata Olmo (1987) y Florencio (1994), pp. 149-150.

18 Drain (1977), pp. 142-143. Dirección General de Agricultura, Industria y Comercio (1892), vol. 3, pp. 318-323.

19 López Ontiveros (1974), p. 313, y López Martínez (2003).

20 Simpson (1987), p. 282. Los datos hacen referencia a Córdoba y Sevilla (Zapata, 1986). 
obra «de una calidad especial y de naturaleza individual». ${ }^{21}$ Como veremos, esto implica que es más probable el arriendo en pequeñas parcelas cuando se trata de cultivos que requieren más cuidados, tales como la vid, los cultivos hortícolas o cierto tipo de ganadería intensiva, en particular la relacionada con la producción de leche. Cuando las tareas son más mecánicas, como arar, sembrar o la cosecha de cereales, el agricultor tiene menos dificultades para supervisar la mano de obra y puede llevar por tanto explotaciones de mayores dimensiones. Además, en el periodo que estudiamos, algunas de estas actividades empezaban a mecanizarse, lo que permitía a los grandes colonos beneficiarse no sólo de un mejor acceso al capital, sino de economías de escala suficiente para que la mecanización fuera rentable. ${ }^{22}$

La preferencia por los grandes colonos en el sur de España se debía originariamente a los menores costes de transacción que brindaba el arrendamiento de los extensos patrimonios de las grandes fortunas agrarias españolas a grandes en vez de a pequeños colonos. Antonio Miguel Bernal menciona así el ejemplo del duque de Osuna, con 677 latifundios en la Andalucía bética y distribuidos en 14 municipios a mediados del siglo XIX. ${ }^{23}$ Los propietarios absentistas debían ser capaces de crear sistemas administrativos eficaces con vistas a gestionar el arrendamiento de sus numerosas explotaciones, y eran, de hecho, mucho más sensibles que otros propietarios a los costes de transacción que pudiera suponer tener que lidiar con un excesivo número de colonos. ${ }^{24} \mathrm{El}$ fenómeno no era muy distinto al que encontramos en el Reino Unido, donde los grandes propietarios también arrendaban esencialmente en grandes unidades. Pero las dimensiones del capital ganadero y los adelantos necesarios para cultivar estas grandes explotaciones explican también que los colonos necesitaran suficiente capital, y las economías de escala son habitualmente importantes en el acceso al crédito. ${ }^{25}$ En este caso, los propietarios se arriesgaban a

21 Levy (1911), p. 181.

22 La mecanización puede facilitar la supervisión de los trabajadores y permitir escalas aún mayores.

23 Bernal (1988), p. 119.

24 Carmona (2001). Robledo y Casado (2002), sobre todo los capítulos 6, 11 y 12, y López y Robledo (2004).

25 Carmona y Simpson (2003), capítulo 9. 
que los pequeños arrendatarios tuvieran dificultades para pagar la renta, mientras que los grandes arrendatarios ofrecían habitualmente suficientes garantías, en forma de capital ganadero y fincas. ${ }^{26}$ Pero incluso con estas garantías, en momentos especialmente difíciles, como a finales del siglo XVIII o del siglo XIX, hasta los grandes arrendatarios podían tener dificultades para pagar la renta y verse obligados a solicitar condonaciones, lo que permite dudar de la capacidad que hubiesen podido tener los pequeños colonos para enfrentarse a estas dificultades, y los grandes propietarios de gestionarlas. $^{27}$ Uno de los problemas de los grandes propietarios era encontrar grandes labradores solventes, lo que explica el atractivo de reducir los costes de transacción a través de la simple renovación de contratos o la disminución de las rentas. ${ }^{28}$ Pero la persistencia de estas dificultades explica quizás el hecho de que el número de labradores fuera muy inferior al de explotaciones, como ya se indicó más arriba.

Donde las economías de escala no eran tan importantes, o cuando los cultivos exigían una mayor supervisión del trabajo, como en el cultivo del olivo o de la vid, los propietarios parcelaban sus tierras en explotaciones de menor tamaño. Pero la explotación del olivar requería un tipo de suelo ligero, que hacía que buena parte de la depresión del Guadalquivir no fuera el ámbito más adecuado para este cultivo. ${ }^{29}$

Los grandes propietarios mostraron, por tanto, una preferencia continuada por el arrendamiento de sus tierras en grandes unidades, una política que no era necesariamente ineficiente si los cultivos no implicaban altos costes de supervisión. El hecho de que el cultivo de cereal comportara largos periodos de desempleo estacional explica la importancia del acceso de los trabajadores agrícolas a tierras comunales. Por otra parte, la ganadería extensiva, a diferencia de la intensiva, no requería un gran número de trabajadores. Las encuestas de finales del siglo XIX muestran

26 Espejo (1900), p. 42.

27 López Estudillo (2005), p. 35, ofrece datos sobre la progresiva desaparición en los siglos XVIII y XIX de sistemas tales como los contratos de arrendamiento «a esterilidad», que favorecían el reparto del riesgo entre colono y propietarios y coinciden temporalmente con la progresiva desaparición de la aparcería (que cumplía una función similar) en el Alentejo portugués, tal como señala Santos (2004).

28 López Estudillo (2005), p. 35.

29 Mata (1987) y López Ontiveros (1974). 
que 7 hombres y 5 niños eran suficientes para cuidar un centenar de cabezas de vacuno, una yeguada de 30 cabezas, 200 ovejas, una piara de 20 cerdos y una veintena de asnos. ${ }^{30}$ Sin embargo, dejaba de ser un sistema eficiente cuando los mercados de bienes estimulaban un uso más intensivo de la tierra, tal como ocurrió en Inglaterra en la década de 1870 o en Andalucía en la década de 1930. En efecto, si bien es posible sustituir el cultivo a gran escala por pequeñas explotaciones familiares, la gestión de un gran número de pequeños y pobres colonos no es siempre accesible a los muy grandes propietarios. El pequeño colono no cuenta con las mismas garantías y es fácil que tenga problemas para pagar la renta. Naturalmente, siempre es posible prestar o adelantar dinero al colono más pobre, e incluso en las últimas décadas muchos estudiosos de la elección de contratos han empezado a reconsiderar la eficiencia de este tipo de contratos, pero ello exige una elevada supervisión y usar costosos mecanismos de selección de colonos. ${ }^{31}$ El subarriendo es un arreglo alternativo, ya que le permite al propietario reducir los costes de transacción en la gestión de sus arrendamientos y, a la vez, mantener la flexibilidad en la contratación de pequeños colonos (o subarrendadores). ${ }^{32}$ Sin embargo, el subarriendo fue mucho más habitual en las extensas dehesas de Extremadura o León y para el cultivo de cereales, a pesar de que éste podía producirse con ventaja a gran escala. ${ }^{33}$

Pero éste no es el único motivo por el que la gran explotación extensiva de cereales se mantuvo más tiempo que en otras áreas. La estructura de la explotación se fue conformando paulatinamente y durante siglos con este objeto. Por una parte, el proceso de cerramiento, al igual que en Inglaterra, se inició muy pronto, ya en el siglo XVI, y fue configurando, combi-

30 Dirección General de Agricultura, Industria y Comercio (1892), pp. 330-333.

31 Hayami y Otsuka (1993), capítulo 4, ponen de relieve la importancia de los contratos a largo plazo, la reputación y el capital social para reducir los costes de transacción. Para el caso español, Carmona y Simpson (2003), capítulo 2.

32 La gran difusión de los fermiers généraux, un tipo de subarrendadores, en Francia entre los siglos XVIII y XIX, no se habría debido sólo al éxodo urbano de los propietarios, sino sobre todo a la intensificación de la explotación ganadera y agrícola (Carmona, 2006).

33 Dirección General de Agricultura, Industria y Comercio (1892), vol. 3. En el caso andaluz, parece utilizarse sobre todo para el cultivo del maíz (muy intensivo en mano de obra) o como respuesta a la agitación obrera en la década de 1880 o durante el Trienio Bolchevique (Instituto de Reformas Sociales, 1921), pp. 13, 103 y 158. 
nado con la apropiación de tierras comunales y baldíos, el modelo de latifundio de cultivo al tercio. ${ }^{34}$ Los cerramientos son un aspecto esencial del cortijo y de la gran explotación, y explican el papel que juega la ganadería estante en el cultivo al tercio. Este sistema permitía la producción de trigo, la alimentación del ganado de labor durante todo el año (sin tener que recurrir a las dehesas boyales) y el mantenimiento de una importante cabaña ganadera dedicada a la cría y a la venta de carne. ${ }^{35} \mathrm{Si}$ bien los cerramientos se inician pronto, al igual que el cultivo al tercio, alcanzarían su máxima extensión a finales del siglo XIX. ${ }^{36}$

$\mathrm{Al}$ igual que en el sur de Italia y el este de Europa, la existencia de grandes explotaciones cerradas se asocia también a la existencia de grandes núcleos de población rural, contándose muchos de ellos entre los mayores municipios de España. ${ }^{37}$ Los municipios del sur son mucho más grandes que los del resto del país, triplicando la media española $\left(54 \mathrm{~km}^{2}\right)$ y quintuplicando a los de Castilla y León $\left(33 \mathrm{~km}^{2}\right) .{ }^{38}$ Algunos municipios de la Campiña son aún mayores, con más de $1000 \mathrm{~km}^{2}$, en su mayoría cultivados. ${ }^{39}$ Estas dimensiones afectaban a la viabilidad de su cultivo desde el núcleo de población. Por término medio, las explotaciones agrarias podían hallarse, en el caso de un municipio de 100000 hectáreas, a 9 kilómetros del núcleo de población y las fincas más distantes a más de 18 kilómetros, lo que explica la observación de que en ocasiones fuera necesario recorrer 40 ó 50 kilómetros para encontrar alguna localidad habitada. ${ }^{40}$ Por ello el cultivo de los cortijos no se realizaba desde el núcleo de población. Contaban con un asentamiento permanente, lo que permitía el uso de los lentos bueyes, aunque el número de operarios fijos era reducido, ya

34 López Martínez (2001), pp. 17-19.

35 López Ontiveros (1974). La incorporación de la parte de la dehesa en el latifundio para explicar las tres hojas, en López Martínez (2001), p. 21.

36 Ibídem, pp. 18-19.

37 Una característica que comparte con el sur de Italia y el este de Europa, como pone de manifiesto Dovring (1956).

38 El tamaño medio de los municipios de las provincias de Córdoba $\left(183 \mathrm{~km}^{2}\right)$, Cádiz $\left(174 \mathrm{~km}^{2}\right)$, Sevilla $\left(138 \mathrm{~km}^{2}\right)$ o Ciudad Real $\left(205 \mathrm{~km}^{2}\right)$. Carrión ([1932] 1975), pp. 305-307.

39 Carrión ([1932] 1975), p. 312. Un 70\% de la Campiña cordobesa en 1970, por ejemplo (López Ontiveros, 1974), p. 229.

40 Carrión ([1932] 1975), p. 313. 
que estaba adaptado al cultivo extensivo de cereales o la ganadería. Cualquier opción de intensificación de cultivo habría exigido por tanto una reorganización importante y costosa a corto plazo del paisaje agrario.

\section{Latifundios y cultivo de cereal, 1873-1931}

El impacto de los cereales baratos procedentes del Nuevo Mundo en la agricultura europea después de 1870 varió significativamente según los países. En un extremo, la caída de precios conllevó una disminución del $42 \%$ del área dedicada al trigo en Gran Bretaña, desde 1,35 millones de hectáreas en 1866-1875 hasta 0,78 millones en 1938. ${ }^{41}$ La reorientación hacia la ganadería vacuna y avícola vino impulsada por la importación de piensos baratos y por una mayor elasticidad de la demanda de estos productos entre los cada vez más prósperos consumidores urbanos. Dinamarca siguió una senda similar, especializándose para el mercado británico. Al otro extremo, los niveles de protección en España fueron suficientes para provocar un crecimiento del área de los cereales y legumbres de un $20 \%$, esto es, de 1,56 millones de hectáreas entre $1886-1890$ y $1930-1935 .^{42}$ Los altos precios del trigo, los bajos salarios relativos y los bajos niveles de urbanización limitaron, entre todos ellos, la demanda en España de productos ganaderos y otros productos agrícolas con una alta elasticidad de renta. En 1925-1929, España era autosuficiente en un 96,9\% en cereales panificables, mientras que en Francia la cifra era del 86,2\%, en Italia del $74 \%$ y en Gran Bretaña del $21 \% .{ }^{43}$ En 1910, los cereales y legumbres contribuían sólo al $11 \%$ del producto final agrario en el Reino Unido, al $22 \%$ en Francia, pero $31 \%$ en el caso español (cuadro 5).

Los niveles de protección del cereal y, consecuentemente, la importancia relativa de estos productos son de gran relevancia para contestar a la pregunta de si la reforma agraria tenía posibilidades de tener éxito o no. En primer lugar, la necesidad de mano de obra para la producción de cereales era relativamente pequeña (cuadro 1). De ahí que en Andalucía y Extre-

41 Ministry of Agriculture, Fisheries and Food (1968), p. 34, y Simpson (1997).

42 Grupo de Estudios de Historia Rural (1983), p. 318.

43 International Institute of Agriculture (1931). 
CUADRO 5

ESTRUCTURA DE LA PRODUCCIÓN FINAL DE LA AGRICULTURA EN DIFERENTES PAÍSES EUROPEOS HACIA 1910 (PORCENTAJE SOBRE EL TOTAL)

\begin{tabular}{|l|c|c|c|c|c|}
\hline & Francia & Alemania & Italia & España & $\begin{array}{c}\text { Reino } \\
\text { Unido }\end{array}$ \\
\hline Cereales, leguminosas y heno & 23,0 & 18,9 & 22,2 & 34,7 & 15,0 \\
Hortalizas y plantas industriales & 8,2 & 12,8 & 13,0 & 15,2 & 9,6 \\
Fruta, aceite, frutos secos y vino & 24,4 & 2,7 & 36,2 & 19,8 & 2,4 \\
Productos ganaderos & 44,4 & 65,3 & 28,3 & 30,2 & 71,9 \\
Otros & 0,0 & 0,3 & 0,0 & 0,1 & 1,1 \\
Total & 100 & 100 & 99,5 & 100 & 100 \\
\hline
\end{tabular}

FUENTE: O’Brien y Prados de la Escosura (1992), cuadro 3.

COMPOSICIÓN DE LA PRODUCCIÓN FINAL DE LA AGRICULTURA EN ESPAÑA POR REGIONES (PORCENTAJE SOBRE EL TOTAL), 1929-1933

\begin{tabular}{|l|c|c|c|c|c|}
\hline & Cereales & Vides y olivos & $\begin{array}{c}\text { Otros } \\
\text { cultivos }\end{array}$ & Ganadería & $\begin{array}{c}\text { Hectáreas por } \\
\text { trabajador masculind }\end{array}$ \\
\hline Norte & 16,8 & 2,6 & 26,7 & 53,9 & 3,4 \\
Interior & 41,0 & 13,2 & 23,7 & 22,2 & 10,8 \\
Andalucía & 28,4 & 27,5 & 23,6 & 20,5 & 5,7 \\
Mediterráneo & 15,5 & 17,3 & 48,5 & 18,7 & 4,1 \\
España & 28,0 & 14,3 & 31,0 & 26,7 & 7,1 \\
\hline
\end{tabular}

FUENTE: Simpson (1995), cuadro 2.4.

madura el empleo anual en el sector cerealero fuera en la mayor parte de los casos entre 17,5 y 25 días al año (al tercio y año y vez), comparado con 33 ó 44 días en el olivo de secano y el viñedo. ${ }^{44}$ Un segundo factor también relacionado con esto último era que la mecanización y las tecnologías ahorradoras de mano de obra eran fáciles de aplicar a los cereales. Hans Binswanger agrupa las operaciones agrícolas de acuerdo con la relativa intensidad con la que requieren "poder» (o energía) en relación con las funciones de «control» de la mente humana o, como ya hemos mencionado en la primera sección, la «calidad» del trabajo. ${ }^{45}$ Las actividades como arar o moler

44 En todos los casos las pequeñas explotaciones utilizaban más mano de obra que las grandes.

45 Binswanger (1984). 
requieren una considerable cantidad de poder, pero limitado control, y esto hace que sea fácil de mecanizar. La preparación de la tierra, la roturación, requieren también grandes cantidades de energía que pueden cubrirse con el uso de tractores. Hacia la década de 1930, un relativamente alto grado de mecanización era ya posible con los cereales, pero las oportunidades eran mucho menores con otros cultivos. La cosecha de cereales era intensiva en el uso de energía y mano de obra, pero en el caso de la fruta, la horticultura, olivo o vid, la posibilidad de dañar la cosecha era mucho mayor, y era necesario seleccionar la fruta madura individualmente.

La relativa facilidad de mecanización del cultivo de cereales permitió un incremento en la escala de la producción en la segunda mitad del siglo XIX. En los Estados Unidos, con la excepción de California, los cereales se producían predominantemente en explotaciones familiares. ${ }^{46} \mathrm{El}$ alto coste de la mano de obra estimulaba la mecanización y, con ello, el crecimiento de la escala de la explotación. Paul David ha apuntado que la difusión de la cosechadora a partir de la década de 1850 estimuló el crecimiento de las dimensiones de las explotaciones. Los siguientes cambios tecnológicos estimularon aún mayores incrementos. El estado de Kansas, por ejemplo, pasó de ser el sexto productor en 1889 al primero en 1919, aumentando la explotación media de los 155 a los 283 acres entre 1880 y $1930 .{ }^{47}$ Las dimensiones medias de las explotaciones de los mayores exportadores de trigo, tales como Estados Unidos, Canadá, Argentina o Australia, eran de casi 100 hectáreas en vísperas de la Primera Guerra Mundial. ${ }^{48}$ Éstas eran sin duda considerablemente superiores a las que se podían encontrar en Castilla y León, donde José Cascón apuntaba que en esa época el cultivador típico tenía en torno a 30 hectáreas, de las cuales sólo sembraba la mitad cada año. ${ }^{49}$ Es muy probable, en cambio, que en Andalucía una importante proporción de cereal fuera cultivada en explotaciones al menos tan grandes como las que podían encontrarse en los países exportadores.

46 California era el segundo mayor productor en 1889, pero bajó al puesto 23 dos décadas más tarde, a medida que los agricultores fueron reorientando su producción hacia fruta irrigada y verduras.

47 United States Department of Agriculture (1932), pp. 53 y 743.

48 Los datos son 85 hectáreas en los Estados Unidos, 117 en Canada, 102 en Australia y 78 en Argentina (Offer, 1991), cuadro 6.2.

49 El Progreso Agrícola y Pecuario, 7 de enero de 1909, n. ${ }^{\circ} 610$, p. 3. 
La pronta aparición de tecnología ahorradora de mano de obra en Andalucía ha sido extensamente documentada por los historiadores. ${ }^{50} \mathrm{Si}$ los productores de cereal de la región seguían utilizando grandes cantidades de mano de obra manual en los cincuenta años anteriores a la Guerra Civil, era porque la mano de obra era barata. Cuando los salarios empezaron a crecer, o cuando la militancia obrera aumentó los costes de transacción, entonces los agricultores rápidamente se volcaron hacia la mecanización. ${ }^{51}$ El trigo de regadío no era rentable en los mercados internacionales, y los aumentos de la productividad en el medio siglo anterior a la Segunda Guerra Mundial no provinieron de nuevas tecnologías biológicas y de mejoras en los rendimientos, sino del aumento del tamaño de las explotaciones y la mecanización. ${ }^{52}$

El cuadro 6 evalúa de qué manera las decisiones sobre la protección afectan a explotaciones de diferentes dimensiones. Los países que protegieron a los productores de cereales encontraron que tenían pocos incentivos en parcelar las grandes explotaciones (es el caso de Andalucía), mientras que en aquellos que permitieron el libre comercio los productores de cereal se veían obligados a mecanizar para seguir siendo competitivos (lo que a menudo estimulaba explotaciones de mayor tamaño) o a reorientar su producción hacia otros productos, lo que implicaba entonces explotaciones más pequeñas. Cuando el tamaño original de la explotación era ya pequeño, y la producción era suficiente para estimular al agricultor a permanecer en el cereal, entonces el incentivo era aumentar las explotaciones para aprovechar las mayores oportunidades que le ofrecía la mecanización (Castilla y León). ${ }^{53}$ Si no hubiese habido protección (o los niveles de protección no hubiesen sido suficientemente altos para que los pequeños cultivadores fueran competitivos), entonces estos agricultores se habrían visto forzados a abandonar el cereal y producir otros productos, o a abandonar la agricultura. La calidad del suelo y el clima, la localización, el capital humano y los mercados urbanos determinaban si los agricultores podían reorientar su producción o simplemente emigrar a las ciudades.

50 Bernal (1988) y (1985), Cabral Chamorro (2000), Martínez Ruiz (2000) y Simpson (1987) y (1995).

51 Para los cambios en los salarios rurales y la velocidad de la mecanizacion de la cosecha de cereal en España, véase Simpson (1995), capitulo 7.

52 Malenbaum (1953). Véase, sin embargo, el artículo de Olmstead y Rhode (2002) sobre Estados Unidos.

53 Castilla y León vio como la superficie de cereales (y legumbres asociadas) se incrementó en un 22\% entre 1902-1912 y 1930-1935, y la población rural bajó un 35\%. 


\section{CUADRO 6}

IMPACTO DE LA PROTECCIÓN SOBRE LA PRODUCTIVIDAD SEGÚN EL TAMAÑO DE LAS EXPLOTACIONES

\begin{tabular}{|c|c|c|c|}
\hline $\begin{array}{l}\text { Dimensiones } \\
\text { originales } \\
\text { de la explotación }\end{array}$ & $\begin{array}{l}\text { Protección para } \\
\text { los cereales }\end{array}$ & $\begin{array}{l}\text { Incentivos para reducir el tamaño } \\
\text { de la explotación }\end{array}$ & $\begin{array}{l}\text { Posible impacto en } \\
\text { la productividad } \\
\text { del trabajo }\end{array}$ \\
\hline $\begin{array}{c}\text { Grande } \\
" » \\
" \\
\text { Pequeña } \\
"\end{array}$ & $\begin{array}{c}\text { Sí } \\
\text { No (o limitada) } \\
" \\
\text { Sí } \\
\text { No (o limitada) } \\
\text { " }\end{array}$ & $\begin{array}{l}\text { Ninguno } \\
\text { Sí > cultivos intensivos en mano de obra } \\
\text { No > mecanización } \\
\text { No } \\
\text { Sí > cultivos intensivos en mano de obra } \\
\text { No > éxodo rural }\end{array}$ & $\begin{array}{c}\text { Limitado } \\
\text { Significativo } \\
\text { Significativo } \\
\text { Limitado } \\
\text { ? }\end{array}$ \\
\hline
\end{tabular}

No contamos con contabilidades agrarias para este periodo, pero las evidencias sugieren que los cereales eran bastante rentables. Antonio Miguel Bernal ha apuntado que las tarifas se fijaban a un nivel que permitía proteger al pequeño agricultor del interior, y por tanto permitía importantes beneficios en el sur. ${ }^{54} \mathrm{La}$ importancia relativa de los cereales (y legumbres) en las provincias latifundistas cayó entonces sólo ligeramente, desde el $38 \%$ hasta el $33 \%$ en la producción final agraria entre 1910 y 1930, comparado con una caída nacional del 34 al $28 \%$. En términos de empleo, las oportunidades de trabajo en los cereales y legumbres en las provincias de Cádiz, Córdoba, Jaén y Sevilla alcanzaron quizás un máximo de 24,7 millones de días en 1898-1900, pero seguía siendo de 22,7 millones en 1931-1935, o casi el $40 \%$ de la demanda de los cultivos. ${ }^{55}$ Con el aumento de los salarios reales, especialmente en la década de 1930, los beneficios que podían obtener estas grandes explotaciones compactas eran cada vez menos evidentes. El éxito de la reforma agraria en Andalucía requería, por tanto, no sólo una redistribución de la tierra, sino también un cambio en la naturaleza de los cultivos y de la producción ganadera. Sin embargo, las posibilidades de introducir cambios en el uso de la tierra iban a encontrar probablemente importantes dificultades a corto plazo, no sólo por la naturaleza de la dotación de recursos, sino también por la estructura de la explotación. La necesidad de rápidos cambios en la agricultura, tales como intentar adaptarse a la caída de los precios relativos agrarios, al igual que la experimentada por los agricultores británicos después de 1873, pudo generar una situación donde una agricultu-

\footnotetext{
54 Bernal (1985).

55 Simpson (1992).
} 
ra originariamente eficiente podía volverse rápidamente inadecuada. Avner Offer escribe así que

The English farmer was shackled by his previous success, by past cycles of innovation, by enclosure and high farming which had formed his fields and farmsteads, which had raised his rents to their high levels [...] England in the 1880 s was struck with an obsolete agriculture, inherited from a successful past. Landowners (like industrialists who followed the same path later) found it difficult to write off obsolete investments. At the same time, they were unwilling to make new ones. In any case, enterprise was required more than investment, and this was inhibited by the deadweight of land values. ${ }^{56}$

\section{3. ¿Qué se necesita para que una reforma agraria tenga éxito?}

La redistribución de la tierra es, por tanto, sólo el primer paso. Los nuevos agricultores necesitan equipamiento y construcciones agrícolas y, si quieren cultivar con éxito sus tierras, muchos tendrían que dejar sus pueblos y establecer nuevos asentamientos. ${ }^{57}$ Está claro que estos importantes cambios en la política agraria habrían sido necesarios si se hubiese deseado que los trabajadores sin tierra se convirtieran en pequeños agricultores con éxito. Con el fin de realizar el potencial necesario para incrementar la productividad en las pequeñas explotaciones, los agricultores habrían tenido que poner en práctica una serie de decisiones de inversión. Tendrían primero que elegir una combinación de productos adecuada. Esto implicaba tanto elegir los productos mejor adaptados a su tierra (y a los niveles de capital humano y físico) como también una combinación que se adecuara a la estructura de comercialización disponible. A comienzos del siglo XX se asistió al desarrollo de nuevas tecnologías e instituciones que permitieron a los agricultores reducir los costes de producción y comercialización. Nuevas técnicas de drenaje e irrigación cambiaron la calidad de la tierra y, junto con los fertilizantes químicos, proporcionaron a los agricultores nuevas posibilidades de cambiar sus cestas de productos o incrementar sus rendimientos. Los agricultores necesitaban estar alfabetizados, dado que el número de libros y revistas dedicados a temas de agricultura práctica se estaba expandiendo rápidamente. Finalmente, si las economías de escala en

56 Offer (1991), pp. 119-120.

57 A este respecto, la organización comunal de la propiedad tenía quizás más sentido que la propiedad privada. 
las explotaciones eran limitadas y favorecían por tanto, tal como vimos, las explotaciones familiares, existían cada vez más economías de escala fuera de la explotación. Las cooperativas de compras o de ventas no sólo permitían a los pequeños explotantes beneficiarse de estas economías, sino que también les permitían obtener ellos mismos los márgenes que los intermediarios disfrutaban en el pasado.

La reforma agraria en Andalucía se encontró con tres problemas. Primero, y tal como vimos más arriba, la fuerte dependencia de las rotaciones de cereales y la explotación ganadera a gran escala - tanto si la medimos por el área usada, por la demanda de mano de obra o por su contribución al producto agrario final- era un obstáculo importante a una reforma exitosa. En vez de permitir un mayor uso de la mano de obra, la mecanización tendería probablemente a reducir su demanda. Un segundo problema era que muchos de los posibles beneficiarios de la reforma agraria eran jornaleros que no habían sido arrendatarios de tierra antes de su redistribución. En los cinco países donde tras la Segunda Guerra Mundial se iniciaron las redistribuciones de tierra "que fueron quizás las más completas jamás implementadas», esto es, en Japón, Taiwán, Corea del Sur, China y Vietnam, los beneficiarios habían estando cultivando previamente una tierra extremadamente escasa, en pequeñas explotaciones familiares. ${ }^{58}$ En el caso de los tres primeros países, las reformas agrarias proporcionaron a los pequeños colonos la posibilidad de comprar sus tierras a un precio artificial muy bajo. La adaptación de los agricultores generó por tanto pocos problemas, ya que la redistribución no desplazó a los cultivadores y la actividad agrícola siguió en manos de la misma gente. ${ }^{59}$ En el caso de China y Vietnam, las tierras fueron inicialmente trabajadas en granjas colectivas, y sólo una segunda reforma posterior permitió a los campesinos trabajar sus propias tierras. Conviene subrayar el hecho de que estos cinco países ya contaban, previamente a la reforma, con una agricultura intensiva y de explotación familiar, a diferencia de la zona de latifundios andaluces o las grandes explotaciones latinoamericanas. ${ }^{60}$ Incluso en

58 Griffin, Khan y Ickowitz (2002), p. 303.

59 A ello habría que sumar las circunstancias excepcionales, tales como la existencia de un gran volumen de tierras públicas (Taiwán) o pertenecientes a propietarios extranjeros - y enemigos - (Taiwán y Corea); los gobiernos no necesitaron del apoyo de los terratenientes e, incluso, en el caso de Corea y Japón contaron con el apoyo del ejército norteamericano (Griffin, Khan y Ickowitz, 2002), pp. 302-307.

60 Deininger y Feder (2001), pp. 319-321. 
periodos de bajos conflictos, y con un gobierno comprensivo con los pequeños colonos, las dificultades que habría levantado la conversión de los latifundios andaluces en pequeñas explotaciones orientadas hacia el mercado habrían sido inmensas.

El punto final tiene que ver con los gobiernos «comprensivos». En muchos países donde la reforma agraria ha sido considerada necesaria, tal como España a comienzos del siglo XX, los propietarios de los grandes estados ejercían una considerable influencia sobre las políticas gubernamentales. Los desafíos potenciales a esta influencia podrían proceder de los pequeños explotantes, pero también del sector no agrario. En Latinoamérica, muchos de estos intentos de reforma se iniciaron al mismo tiempo que los gobiernos adoptaron políticas industriales de sustitución de importaciones. Lo mismo fue probablemente cierto en España. En el caso del regadío, Carreras y Tafunell han apuntado que

Los intereses de las compañías eléctricas, de los grandes propietarios - temerosos de la asociación de los pequeños cultivadores en comunidades de regantes - y la inclinación de los gobernantes por políticas industrialistas antes que agraristas, confluyeron en la promoción de embalses para producir energía eléctrica. ${ }^{61}$

Ciertamente, tal como han estudiado Antonio Miguel Bernal, Antonio Florencio, Enrique Montañés, Antonio López Ontiveros y Rafael Mata, José María Sumpsi o Ricardo Robledo, entre otros, el debate sobre «la crisis agraria» en Andalucía no era simple. ${ }^{62}$ Se realizó un cierto número de intentos de establecer "colonias», junto con esquemas de regadío y de diversificación de cultivos. Sin embargo, los resultados no fueron, en general, exitosos, precisamente porque la ventaja comparativa de los latifundios residía en la ganadería y cerealicultura extensiva. El advenimiento de la Segunda República en 1931, cuando se produjo un verdadero mercado político de votos, podía haber llevado al Gobierno a apoyar y no penalizar a los productores campesinos. ${ }^{63} \mathrm{El}$ hecho de que los pequeños agricultores se sintieran amenazados por la ley de 1932 ayudó a la derecha a ganar las elecciones al año siguiente.

61 Carreras y Tafunell (2004), p. 241.

62 Bernal (1988), Florencio Puntas (1994) y (2004), Montañés (2000), Sumpsi (1978), Robledo (1996) y López Ontiveros y Mata Olmo (1993).

63 Bates (1997), p. 167. 


\title{
12. LA INTENSIFICACIÓN DE CULTIVOS DURANTE LA REFORMA AGRARIA DE LA SEGUNDA REPÚBLICA: ¿ALTERNATIVA O COMPLEMENTO?
}

\author{
Sergio Riesco \\ (Grupo de Estudios de Historia \\ Contemporánea de Extremadura)
}

El Estado revolucionario del campo no admite las esperas del rigorismo legal.

Luis Peña Novo, gobernador general de Extremadura (1932)

\section{Introducción}

En este artículo tratamos de ponderar el valor de la «vía de los decretos» en la aplicación de la reforma agraria republicana. Consideramos, pues, que no se puede reducir el estudio del reformismo al seguimiento de la Ley de Bases, sino que se hace necesaria una visión de conjunto para poder valorarla en su justa medida.

Dado que su vigencia es aún manifiesta, hay que recordar que, para Malefakis, con el decreto de intensificación de cultivos de 1932 parecía «que el rumbo que había seguido la República podía ser cambiado definitivamente» (Malefakis, 1978). El historiador norteamericano consideraba 
el proyecto de la Comisión Técnica Agraria del verano de 1931 como la opción más plausible para una reforma justa y ágil, que podría haber sido aprobada por decreto en aquel momento político. Criticaba precisamente la lentitud con la que se estaba debatiendo la Ley de Bases. Esta cita no hace sino incidir en el convencimiento de Malefakis de que se podía aplicar la reforma de manera veloz por la vía del decreto con un poco de iniciativa política.

Aquí no vamos a tratar sólo del texto de 1932, sino que también valoraremos su reposición en la primavera de 1936. En otras palabras, lo que la historiografía ha denominado de modo tradicional como «decretos de yunteros» no es sino una nueva intensificación. El posicionamiento conceptual en este caso es claro:

- En primer lugar, se insiste en el concepto integral de reforma agraria tomando como tal todas las iniciativas que trataron de transformar no ya las estructuras de propiedad, sino la de la producción de las dehesas de secano en el mediodía español.

- En segundo término, nos alineamos con la línea de trabajo que recuerda de modo reiterado la influencia de la situación social en el análisis económico: nos obligamos, pues, a valorar «más flexiblemente las consecuencias de reformas distributivas que no pueden medirse únicamente por aumentos de la productividad en el corto plazo» (Robledo, 2004).

Los decretos de intensificación se aplicaron en algunas de las provincias clásicamente latifundistas del centro y sur de la Península. Las provincias extremeñas aparecen en ambos decretos, pero el resto difiere en algún caso. En 1932 se incluyen Toledo, Ciudad Real, Sevilla y Jaén. En 1936 repiten Toledo y Ciudad Real junto a Extremadura, y aparece Córdoba. En este trabajo el espacio geográfico al que nos referiremos es el extremeño, donde se concentran de manera activa los agentes protagonistas de los decretos:

- Los yunteros, con las tensiones cuasi-revolucionarias vividas por este colectivo durante todo el régimen republicano.

- Los propietarios extremeños, muy representados en la Agrupación Nacional de Propietarios de Fincas Rústicas.

- El Estado, a través de su activa intervención gubernamental, con las figuras de Peña Novo en 1932 y del ministro Ruiz Funes en 1936. 
A continuación, trataremos de hacer un balance cualitativo y cuantitativo de los decretos para tratar de contestar a la pregunta con la que iniciamos este trabajo: la vía de la intensificación ¿fue un complemento a la Ley de Bases o una verdadera alternativa a ésta?

\section{La situación de partida}

La huella más palpable de la crisis del 29 en las dehesas de secano fue lo que podemos denominar "repliegue ganadero». En 1930 se labraban en Extremadura un millón de hectáreas, una cifra que no se había alcanzado hasta entonces y que no se volvería a repetir durante el resto del siglo (Llopis y Zapata, 2001). Era la culminación de un largo proceso, que habría comenzado por el adehesamiento de grandes superficies adquiridas o consolidadas durante la reforma agraria liberal. En un segundo momento se dio en las dehesas mayor peso al componente agrícola. Por supuesto, dados los umbrales ecológicos del ecosistema en cuestión, la carga ganadera seguía disfrutando del mayor protagonismo. La diferencia estriba en que las nuevas hojas de las fincas que se habían venido acondicionando desde fines del XIX eran ahora dedicadas antes a labor que a pastos.

Desconocemos hasta qué punto ese millón de hectáreas podían ser el tope operativo de las explotaciones. Podríamos argüir que si esa cifra no se superó durante el resto de la centuria fue porque la productividad marginal de cada hectárea más podría hacer caer en picado la curva ascendente que hasta entonces había seguido. La decisión de los grandes propietarios no se hizo esperar: era el momento de volver a las relativas ventajas com-

RELACIÓN SUPERFICIE AGRÍCOLA TOTAL DE EXTREMADURA CON LA LABRADA ANUALMENTE, 1900-1978 (miles de ha)

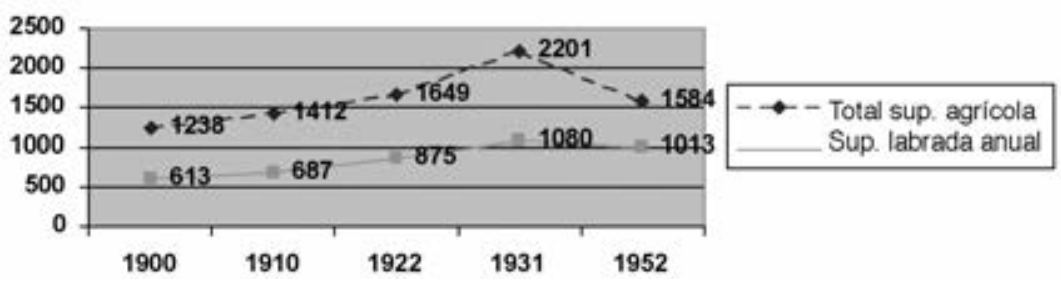

FUENTE: Llopis y Zapata (2001). 
parativas de las dehesas: buena explotación forestal, en especial corchera, $y$, sobre todo, carga ganadera de vacuno y, en particular, ovina.

Esta reacción de los propietarios encuentra la legitimidad de la justificación ecológica (las dehesas sólo sirven para soportar ganado), tal y como ilustraremos más adelante. Sin embargo, se enfrentan dos visiones. Por un lado, contamos con la explicación técnica del ingeniero Alonso Peña, encargado por el IRA de los estudios previos para la implantación de la reforma agraria en Extremadura: «al aumentar los precios de los productos de la tierra como consecuencia de la Gran Guerra se pusieron en cultivo todas aquellas tierras que son susceptible[s] de cultivarse y muchísimas más que no lo son». ${ }^{1}$ Según este informe, la elevación de los costes de producción al comienzo de los años 20 condujo a que la mayor parte de esas tierras regresaran a su condición de pastizales, añadiendo además que "ya sin arbolado». De esta manera, en ese momento (primeros años 20) se debería haber frenado el auge roturador, y sin embargo no fue así. Si el cenit de ese aumento de las tierras labradas dentro de las dehesas se produjo a principios de los años 30, la pregunta que sugiere la presencia de una segunda postura es obvia: ¿por qué se siguió roturando? Aunque la respuesta no sea fácil, parece evidente que los propietarios consideraron que seguía siendo algo más productivo el labrantío que la explotación pecuaria. En términos del precio de la tierra, tomando como índice 100 el año 1905, a la altura de 1930 el precio por hectárea dedicada a cereales, viñedo u olivar en Extremadura se había incrementado hasta alcanzar un valor de 380 (Bringas, 2000).

$\mathrm{El}$ «repliegue ganadero» fue una salida conservadora, una forma de disminuir los costes de transacción, ya que continuar con el máximum agrícola significaría una elevación real tanto de los costes indirectos de producción como de los derivados del funcionamiento del propio sistema económico (Eggertsson, [1990] 1995). Tampoco se puede olvidar que la irrupción del régimen republicano significó sin duda un aumento exponencial de las incertidumbres ante una política agraria que se había articulado a través de todo el repertorio de decretos sancionados durante el verano de 1931 (Ministerio de Trabajo y Previsión Social, 1932). En términos institucionales, la decisión tomada por los propietarios para hacer valer sus derechos de

1 Alonso Peña (1933). 
propiedad fue la inmediata minimización de la hoja de labor de las dehesas, volviendo a una exclusividad pecuaria y forestal mediante el aposto de zonas otrora roturadas. Dicho de otra manera más conocida, numerosas dehesas que hasta entonces habían sido puestas en arrendamiento como de "pasto y labor" pasaban a ser de "puro pasto», en todo caso con «arbolado».

Los costes de producción de la explotación ganadera eran mucho menores y, sobre todo, mucho más controlados por parte de los administradores de las grandes dehesas. Era una mera cuestión de reajuste de los costes:

- En cuanto al factor capital, prescindir de los yunteros, que mayoritariamente trabajaban como aparceros, significaba disminuir la aportación de la parte propietaria. A cambio, se debía invertir en la adquisición del ganado de renta.

- En cuanto al factor tierra, el regreso a majadales de antiguas hazas no requería una inversión tan grande como el acondicionamiento mediante el alzado, binado y terciado de la tierra barbechada para futura sembradura.

- Finalmente, los costes del factor trabajo se reducían sobremanera: no era lo mismo contratar yunteros que pastores, mayorales y zagales.

A cambio, la explotación ganadera era menos remuneradora y la elasticidad de su producto mayor: quizás fuera para justificar la reforma agraria, pero los técnicos del IRA se refieren a los años buenos «en que el exceso de oferta de ovinos en los mataderos de Madrid provoca un derrumbe de precios» (García Romero, 1933). Así pues, la actitud «a la expectativa» de los propietarios se plasmó en una vuelta a la ancestral explotación ganadera de baja productividad.

VARIABLES DEMOGRÁFICAS, DE EMPLEO Y DE PIB RELEVANTES (RELACIÓN EXTREMADURA-ESPAÑA 1930-1935)

\begin{tabular}{|l|l|c|c|c|c|c|}
\hline & $\begin{array}{l}\text { A } \\
\text { Porcentaje } \\
\text { de variación } \\
\text { población } \\
1930-1935\end{array}$ & $\begin{array}{c}\text { B } \\
\text { Porcentaje variación } \\
\text { de empleos } \\
1930-1935\end{array}$ & $\begin{array}{c}\text { B1 } \\
\text { Sector } \\
\text { primario }\end{array}$ & $\begin{array}{c}\text { B2 } \\
\text { Industria y } \\
\text { construcción }\end{array}$ & $\begin{array}{c}\text { B3 } \\
\text { Servicios }\end{array}$ & $\begin{array}{c}\text { PIB a precios } \\
\text { de mercado } \\
(1935, \\
\text { España }=100)\end{array}$ \\
\hline Badajoz & $+3,64$ & $-5,33$ & $-5,50$ & $-8,66$ & $-3,06$ & 66,73 \\
Cáceres & $+6,79$ & $-8,86$ & $-12,65$ & $+1,27$ & $+9,00$ & 58,69 \\
España & $+5,56$ & $-1,03$ & $-9,69$ & $+9,10$ & $+6,25$ & $=100,00$ \\
\hline
\end{tabular}

FUENTE: Selección a partir de Alcaide (2003). 
Existe otro factor que se debe tener en cuenta a la hora de repasar la «situación de partida». Nos referimos al paro obrero y a la falta de absorción por otros sectores tanto del crecimiento demográfico como del posible exceso de población agraria.

Hemos seleccionado algunos aspectos de las tablas ofrecidas por Alcaide, ya que pueden ser significativas de la situación vivida. En primer lugar, el valor de disponer de unas estadísticas quinquenales a nivel provincial resulta vital para articular cualquier explicación, a pesar de las dificultades técnicas de este tipo de trabajos. No tomamos la referencia de 1940, ya que la Guerra Civil no permite valorar tendencias. Además, 1930, como año de referencia inmediatamente anterior a la instauración del régimen republicano, es realmente representativo; 1935, por su parte, nos permite poner el contrapunto y ver los efectos de la coyuntura.

La primera cuestión es que la población extremeña crece por encima de la media nacional, más en la provincia de Cáceres que en la de Badajoz. En términos absolutos, casi en 55000 personas. ¿Grandes expectativas? El caso es que el crecimiento demográfico es un hecho objetivo. Vamos ahora a la última columna antes de abordar la cuestión del empleo. El PIB a precios de mercado se mantiene a unos 34 puntos, en la provincia de Badajoz, y de manera más grave a 42 puntos de la media nacional en la de Cáceres. No descubrimos nada afirmando la situación de atraso de Extremadura en este momento, pero es un asunto que está ahí. Abordemos, ahora sí, la cuestión del desempleo. La destrucción de empleo había sido muy superior a la media nacional tanto en la provincia de Badajoz (4,3 puntos más) como sobre todo, en la de Cáceres (casi 8 puntos).

Hemos desagregado por sectores esta cuestión por ver si este asunto afectó sólo a la agricultura o hubo una reabsorción por parte de otros sectores. La tendencia nacional nos indicaría que la industria, la construcción y los servicios fueron capaces de absorber buena parte del paro agrario. En este caso, las provincias de Cáceres y Badajoz muestran una dinámica algo diferente. Badajoz destruyó empleo en todos los sectores, incluso el sector secundario tuvo una dinámica aún más negativa que el primario; Cáceres, por su parte, tuvo una pérdida de empleo agrario superior en tres puntos a la media nacional, pero a cambio creció muy levemente el empleo en el sector secundario y, sobre todo, en los servicios, superando la media española. Esto querría decir que, mientras que en Badajoz hubo una pérdida 
generalizada de empleo en todos los sectores, en Cáceres sólo el sector primario se vio en verdad acuciado por el paro, siendo incluso probable que el resto de sectores absorbieran parte de ese desempleo. ¿Dónde estribaría, pues, el problema? Sería cuestión de volver al principio de estas tablas, es decir, al crecimiento demográfico. Visto en términos absolutos, la población creció en casi 55000 personas entre 1930 y 1935, pero en el mismo periodo de tiempo se destruyeron en la región cerca de 35000 empleos, en su mayor parte procedentes de la agricultura. Sin la válvula de escape de la emigración durante los años 30, estas cifras hablan bien a las claras de una situación muy difícil para el campesinado extremeño.

\section{Los agentes}

La promulgación de los decretos de intensificación tanto en noviembre de 1932 como en marzo de 1936 es el punto de desencuentro de tres colectivos: los enfrentados entre sí, es decir, en este caso los yunteros extremeños y la patronal agraria, y un árbitro que mediante las modificaciones legales oportunas trata de equilibrar la contienda: el Gobierno de la Segunda República.

\subsection{El Gobierno}

Los proyectos de la Comisión Técnica Agraria y la dilación del debate sobre la Ley de Bases son acontecimientos bien conocidos de la intrahistoria de la reforma sobre los que no es necesario insistir aquí. Terminaba la segunda cosecha cerealística del nuevo régimen y no se había hecho nada significativo en el tema agrario. Lo más importante había venido por la vía judicial, mediante los jurados mixtos, no sólo en la revisión de rentas, sino en la fijación de unas bases de trabajo para las tareas. A su vez, la Ley de Términos, demostrada su inviabilidad, se había ido flexibilizando. Pero todas estas actuaciones se habían llevado a cabo gracias a la labor combinada de los ministerios de Trabajo y Justicia. ¿Y en Agricultura?, ¿qué pasaba con Agricultura? Se ha prestado sobre todo atención a la especulación de los productores castellanos sobre cómo había resultado la cosecha de 1932. Pero en materia de reforma, la única medida que había salido del gabinete más competente era el laboreo forzoso. El primer 
documento de estas características se sanciona a la misma velocidad que los de términos municipales, jurados mixtos, colocación obrera y demás. Tan sólo tres semanas después de proclamado el régimen republicano, el 7 de mayo de 1931, ya se disponía de un decreto sobre laboreo forzoso. Se trata de un texto algo ambiguo, cuya idea central iba encaminada a la creación de un programa anual de cultivos en cada provincia que debía ser cumplido por todos los agentes implicados. Se daba al régimen local un notable protagonismo, ya que se debían crear unas comisiones locales de policía rural que debían velar por el veraz cumplimiento de ese programa. La dependencia orgánica del laboreo forzoso era para el Ministerio de Agricultura, cuyas delegaciones locales recibían el nombre de sección agronómica. Estas instituciones son bien conocidas por la historiografía sobre la economía agraria durante la Restauración, ya que a ellas correspondía, entre otras funciones, la concesión de indemnizaciones a los agricultores en caso de plaga de langosta, cosa que solía ser frecuente.

Este decreto queda ahí, sin que se avanzara nada a lo largo de 1931, hasta su conversión en ley el 23 de septiembre de 1931. En el nuevo texto se hablaba de unas zonas de aplicación (Andalucía, Extremadura, Toledo y Ciudad Real). Lo principal era crear las comisiones locales de policía rural que habían de quedar bajo dependencia de una Comisión Técnica Central del ministerio en Madrid, que era la que tendría la última palabra (decreto de 24 de enero de 1932).

Las comisiones locales de policía rural son una pieza clave en el conocimiento de la reforma agraria republicana, pues ofrecen una visión pueblo a pueblo del encono entre propietarios y yunteros, que saben perfectamente en qué fincas se podría labrar más y, sobre todo, mejor. Los obreros del Casar de Cáceres se quejan de los propietarios porque «no hay quien les haga cumplir el decreto del laboreo forzoso porque aquí tenemos una comisión de policía rural y como si no la hubiera porque las fincas que se denuncian no sabemos cuando vendrá la orden de labrarla». ${ }^{2}$ Que la reforma agraria no es sólo la Ley de Bases queda demostrado aquí de manera palmaria. La lentitud burocrática y la dejación de funciones se

2 Sociedad Socialista Obrera del Casar de Cáceres, Carta al ministro de Agricultura y Comercio de 11 de marzo de 1932, Archivo IRYDA, Fondo Señoríos y Comunales, legajo 43 . 
entremezclan bajo la responsabilidad del gobernante, que lo consiente. Es posible que se tramitaran numerosas denuncias de las comisiones locales; éstas pasaban a las secciones agronómicas en las capitales de provincia y es muy dudoso que de aquí pasaran a la Comisión Técnica Central, de la que apenas quedan rastros archivísticos. De ahí ese «no sabemos cuando vendrá la orden de labrarla». De cara a las posteriores invasiones de fincas y a la promulgación de los decretos de intensificación, parece que estamos ante un claro obstruccionismo por parte de los funcionarios del Ministerio de Agricultura. Es una prueba más de que se disponía de una ingente información procedente de los pueblos: por un lado, la recopilada sobre comunales durante el verano de 1931, que ponía en cuestión la legitimidad de buena parte de la propiedad privada; por otro, se trataba de averiguar en cada pueblo cuáles eran las fincas que estaban explotadas deficientemente y de las que se podía obtener un mayor rendimiento.

Como estamos tratando de la intensificación, no queremos abordar otros fracasos gubernamentales, sino éste en concreto: estrictamente desde el Ministerio de Agricultura, el Gobierno provisional no había hecho nada en materia de reforma agraria. Por los boletines oficiales de las provincias y las circulares del ministerio sabemos que la gran obsesión era saber cuánto trigo se estaba almacenando, pues las incertidumbres sobre el peligro de una cosecha excedentaria cuando se había adquirido trigo del exterior acechaban a Marcelino Domingo.

\subsection{Los yunteros}

Aunque merecedores de una conceptualización más detallada que dejamos para otro lugar, se trata de una parte del campesinado extremeño que adquirió un protagonismo inusitado durante la Segunda República como demandante de tierras. Entre sus muchas peculiaridades está la posesión del medio de producción más adecuado para la explotación agrícola de las dehesas, la yunta vacuna, asnal o mular. La labor en las dehesas solía ejecutarse en zonas clareadas, aunque no en absoluto, de arbolado, por lo que la maquinaria era poco rentable. Según los datos manejados por el Grupo de Estudios de Historia Rural, la superficie agraria de Extremadura se había ampliado un $289 \%$ entre 1860 y 1930, cuando la media nacional estaba en un 49\% (Grupo de Estudios de Historia Rural, 1994). Los propietarios habían invertido capital en convertir grandes extensiones de 
monte bajo en dehesas bien apostadas de encinas y alcornoques, con un buen majadal central para el ganado y con algunas hojas de labor llevadas mediante rotaciones largas. Esas innovaciones explican el crecimiento de la producción agrícola y ganadera de Extremadura en un $78 \%$, que la convertía en la tercera región española donde el incremento había sido más acentuado (Gallego, 1993). Fueron los yunteros la mano de obra especializada a la que correspondió este trabajo de adehesamiento. Hemos visto, siguiendo a Llopis y Zapata, que entre 1900 y 1931 esto pudo suponer el paso de 1,2 a 2,2 millones de hectáreas de superficie agraria, de las cuales la mitad se labraban anualmente. Este proceso de crecimiento quedó detenido a raíz de la crisis mundial y de la instauración del régimen republicano. Un proceso que venía a un ritmo tan fuerte se quebró de una manera radical: aun teniendo en cuenta la distorsión de la Guerra Civil, tan sólo veinte años después la superficie agrícola de la región se había reducido en 700000 hectáreas. Visto de otro modo, se volvía a los valores de 1910, momento en el que además la emigración mitigaba, aunque fuera en parte, la presión demográfica.

Así las cosas, los yunteros hicieron frente a lo que ellos consideraron una injusticia flagrante: si había habido tierras que adehesar y labrar hasta entonces, ¿`cómo podían desaparecer de forma tan radical? El régimen republicano generó numerosas expectativas, que no fueron satisfechas al ritmo que los trabajadores del campo habrían deseado, pero es que además se produjo una ruptura demasiado fuerte en el estilo de explotación de las dehesas de secano. De ahí el alto grado de movilización de este colectivo durante la crisis de los años 30. El «laboreo forzoso» era la expresión máxima del desencanto, ya que los yunteros reclamaban esa actividad para fincas que se habían llevado hasta entonces de un modo más halagüeño para ellos.

Ante la falta de respuesta gubernamental, los yunteros deciden ir a arar aquellas fincas en las que bien antes habían labrado, o bien consideraban que eran susceptibles de ser labradas en mayor proporción. Los procesos de invasiones de fincas durante la Segunda República son el verdadero «laboreo forzoso", ahora bien, realizado sin violencia. Algunos documentos sobre esta cuestión se refieren a los "famosos roturadores arbitrarios», dando rango de tradición ancestral a la vieja competencia en Extremadura entre explotación ganadera y agrícola, fruto de tantos pleitos desde finales del siglo XVIII. 
De la ausencia de violencia dan fe numerosos testimonios de la Guardia Civil. Así, por ejemplo, el que se refiere a la «impotente manifestación» que solía suceder a la prohibición de continuar con su faena una vez que los yunteros eran advertidos por los agentes. ${ }^{3}$ Este testimonio está referido a Peraleda de la Mata (Cáceres), donde se había movilizado sólo en un pueblo a cerca de 800 personas, número que coincide con el total de trabajadores agrarios de la localidad según el Censo de Campesinos de 1933. Era frecuente que se volviera a las fincas más veces y que, incluso cuando se presentaban el propietario o el administrador, los yunteros solicitaran el jornal correspondiente con total normalidad. Se trata de una tensión que pasa de estado de latencia a una eclosión total cuando coinciden un cúmulo de circunstancias como las acaecidas durante 1932 y 1936.

\subsection{Los propietarios}

Ya hemos comentado al principio que la patronal agraria no actuó ajena a sus intereses económicos: si la producción de cereales no iba a ser suficientemente rentable, y ante la desconfianza en la política económica del Gobierno provisional por lo que pudiera hacer en materia de reforma agraria, se volvió a la explotación más conservadora y tradicional de las dehesas. La excedentaria cosecha de 1932 y el subsiguiente descenso de los precios hicieron el resto. El trabajo consistía en reducir la hoja de labor, favorecer la producción de pastos espontáneos y mejorar el arbolado. Se reducían algunos costes, sobre todo de explotación, ya que las actividades ganaderas solían ser arrendadas a media o gran escala.

Pero esta explicación, con su contundente carga macro, no lo explica todo. Estamos ante un nudo que se fue apretando de forma progresiva. Se negó primero la contratación a todo aquel trabajador que se hubiera «atrevido» a demandar a su empleador ante los jurados mixtos. A continuación se puso nombre al enemigo: desde las organizaciones patronales se instó a no contratar trabajadores vinculados a los sindicatos de la FNTT. Luego se decidió no barbechar tierras para no dar trabajo a los yunteros. El recurso al

3 Archivo Histórico Provincial de Cáceres, Gobierno Civil, legajo 487, «Sobre el problema agrario de esta localidad", carta del jefe del puesto de la Guardia Civil de Peraleda de la Mata al gobernador civil de Cáceres de 9 de febrero de 1932. 
argumento ecológico como fuente de legitimación fue más que frecuente: así, la Asociación General de Ganaderos del Reino hablaba con frecuencia de que la naturaleza pizarrosa del suelo no permitía más explotación que la pecuaria y que "su destrucción suponía al mismo tiempo la de todas las dehesas" (AHPC, s.c.). En términos parecidos se expresaba Arturo Gamonal, gran terrateniente del norte de Extremadura y directivo de la Agrupación Nacional de Propietarios de Fincas Rústicas. Desde el boletín ${ }^{4}$ de la asociación, recurre a la comparación con otros casos europeos (Rumanía, Letonia y Alemania), donde se había sido muy respetuoso con la riqueza pecuaria y forestal. Se trataba, pues, de convertir las tradicionales dehesas de "pasto y labor con arbolado» en «de puro pasto». Uno de los líderes de los propietarios extremeños, Alfonso Bardají, temía que cualquier intensificación del cultivo en las dehesas significara el aminoramiento «de la ganadería estante y la desaparición de la trashumante al no encontrar invernaderos en Extremadura».5 Como se puede comprobar, no se trata de declaraciones espontáneas, sino de todo un repertorio de estrategias para oponerse a cualquier tipo de intervención del Estado en la gestión de sus explotaciones.

Las presiones de los propietarios durante la barbechera de 1932 tenían como objetivo frenar las invasiones de fincas y las roturaciones arbitrarias. Sus demandas tuvieron eco en una circular del gobernador civil que resulta muy gráfica:

No puede, en efecto, consentirse por más tiempo los escandalosos abusos de la invasión o roturación de fincas, sin otro fin que el de perjudicar de manera criminal los intereses de los propietarios y de modo especial de los respetables ganaderos, tan respetables como cualquier otros [sic] y sin que exista siquiera la disculpa del beneficio del invasor, pues ni con ellas se han de legitimar derechos de asentamiento al poner en vigor la Reforma agraria, ni las cosechas que podrían obtenerse serían inmediatas. No es, pues, más que el daño acusado a sabiendas por el placer de hacerlo. Por ello encargo a los señores alcaldes, guardias civiles y demás agentes a mis órdenes que en toda inva-

4 Boletín de la Agrupación de Propietarios de Fincas Rústicas, n. ${ }^{\circ}$ 10, octubre de 1932, «Editorial».

5 Bardají a De los Ríos, en Bardají (1933): «Que se derogue todo lo relativo a la intensificación de cultivos, por no ser más que un régimen superpuesto al de la Reforma agraria, que contradice a ésta, estorba su aplicación, crea un estado de ánimo propicio a prescindir de toda garantía procesal, base inexcusable de toda transformación de dominio o posesión, y contribuye al desafecto de la población campesina hacia una ley que el Gobierno ha estimado fundamental en la constitución económica del país». 
sión o roturación de fincas que se lleve a cabo ilegalmente, practiquen con toda urgencia y remitan a este gobierno, una información expresando los nombres de los autores y su vecindad a los que desde luego anuncio impondré el máximo de sanción que a estos efectos me autoriza la ley. ${ }^{6}$

Ésta es la situación en la que cada uno llega al verano de 1932. Estamos ante un ciclo que se repetirá de manera parecida — más radicalizado, quizás- en 1936. Primero los propietarios se mantienen a la espera de si merece la pena producir cereal en las dehesas de secano (invierno de 1931); luego, para contrarrestar el creciente poder obrero, regresan a la explotación ganadero-forestal casi en exclusiva (invierno de 1931-primavera de 1932); los colectivos demandantes de tierras presionan tanto a las autoridades (incapaces hasta entonces de poner en marcha la reforma) como a la propia tierra, lanzándose a roturar (primavera de 1932). El tercer agente, es decir, el Estado, tiene que intervenir con un triple objetivo: cumplir su promesa de reforma agraria, mantener la legalidad en el campo dando seguridad jurídica a los propietarios y solucionar un problema social acuciante, como era el paro campesino del momento.

El ciclo se repetirá en 1935: lanzamiento de los yunteros de las fincas por parte de los propietarios, pasando por encima de las medidas de Giménez Fernández; insoportable tensión social por la falta de tierras ante la resistencia patronal en la barbechera de 1935-1936 y cambio de signo con la victoria del Frente Popular: sin embargo, en aquel momento la presión sobre el terrazgo era mayor y los llamados «decretos de yunteros» coincidirían en el tiempo con un proceso masivo de invasiones de fincas.

\section{La intervención gubernamental}

El informe preparatorio para la reforma agraria de la provincia de Cáceres, obra del ingeniero agrónomo Manuel Alonso Peña, se refería a la "generación de un problema social». Retomamos su informe donde lo habíamos dejado, que era precisamente en este punto: el incremento de las roturaciones en los años 20 habría creado «un interés más», el del

6 Joaquín Arnau, "Circular», Boletín Oficial de la Provincia de Cáceres, 26 de marzo de 1932. 
aparcero o yuntero como le llamamos ahora y la necesidad para esta clase es la tierra en que labrar. No obstante ser una clase pobre, porque no puede ser de otra manera dada la pobreza de las tierras que explota, hay aún otra clase, la de los obreros manuales de la tierra de menos independencia y que en el afán de elevarse tiene puestas sus aspiraciones en convertirse en yunteros y esto hace que esta clase sea cada año más numerosa.

Ante la situación creada (resistencia patronal versus invasiones), Azaña tuvo que intervenir de forma directa mediante el nombramiento de un hombre de confianza de Casares Quiroga. Se trata de Peña Novo, gobernador civil de Cáceres entre mayo y agosto de 1932 y gobernador general de Extremadura desde finales de 1932 hasta el verano de 1933. Peña Novo es el autor de un extenso informe que clasifica las causas de la crisis en función de su naturaleza económica, social y burocrática: ${ }^{7}$

- El asunto social está relacionado directamente con el cambio de signo de los ayuntamientos desde la instauración del régimen republicano. La presencia socialista en las corporaciones y la toma de un viejo puesto ansiado por los trabajadores, el de juez local, habían cambiado la vida agraria de cada localidad de Extremadura. Los socialistas se comportaban con cierta moderación, que no era bien entendida por buena parte del campesinado, que fue encontrando mayor entendimiento en la CNT y en el PCE.

- La cuestión burocrática o, para mejor decir, de ineficiencia en la gestión política radicaba en que no se había aplicado el decreto de laboreo forzoso y en que los censos obreros eran muy deficientes. Describía, además, la "guerra civil» (sic) entre pueblos colindantes por la Ley de Términos y la dureza de los alojamientos para con los propietarios residentes en los pueblos.

- Finalmente, en el plano estrictamente económico, Peña Novo relata el temor de numerosos propietarios a la expropiación en cuanto se promulgara la Ley de Reforma Agraria, por no ser cultivadores directos. Debido a ello, se pusieron al trabajo sin disponer de «capital circulante suficiente» y provocando una caída de la productividad que estimaba Peña en un $20 \%$. Falta de línea de crédito ante la crisis mundial y ausencia de absorción del paro obrero en otros sectores, como la construcción, terminaban de completar el panorama.

7 Peña Novo (1932). 
Sólo una medida extraordinaria podía paliar la situación. Peña Novo exhortaba al Gobierno para que "por necesidades políticas que a nadie se ocultan, considero de imprescindible urgencia iniciarse aplicación de la reforma agraria». El 23 de octubre de 1932 se publicaba por fin en la Gaceta el decreto de intensificación de cultivos, corregido el 3 de noviembre con un solo ámbito de aplicación (Badajoz) y ampliándolo tan sólo al día siguiente a las provincias de Málaga, Sevilla, Granada, Cádiz y Cáceres. Se promulgaba para una duración de dos años, es decir, hasta el 30 de septiembre de 1934 .

El decreto se refería estrictamente a que se debía intensificar el cultivo en las fincas rústicas de secano en términos municipales donde se acreditara una grave crisis obrera, de la que debían dar fe unos censos de parados elaborados al efecto que debían ser enviados directamente al Ministerio de Agricultura. A esa documentación se debía unir un "plan de intensificación cultural» que justificara tanto la necesidad de labores como el respeto a los majadales de las dehesas. Sus ejecutores-supervisores habrían de ser los técnicos del recién creado Instituto de Reforma Agraria, quienes dictaminarían sobre el terreno, oída una comisión local compuesta por cinco propietarios, qué, cómo y por cuánto se podría intensificar.

El IRA pagaría una renta equivalente a la catastral a los propietarios que cedieran partes de sus fincas para esta labor. Se daban tres supuestos mediante los cuales se podía intensificar una finca:

- Permitiendo a los propietarios «alojar» a obreros desde una nueva perspectiva, ya que el Estado garantizaba el pago del arrendamiento.

- Los arrendamientos colectivos de fincas enteras o partes de ellas para agrupaciones de obreros constituidas para tales fines y reconocidas por el Ministerio de Agricultura.

- Cultivo directo bajo supervisión de los técnicos del IRA.

El decreto salvaba el escollo de la Ley de Términos declarando una sola unidad intermunicipal cada provincia, a efectos de su aplicación. Además, los técnicos del IRA tenían la responsabilidad de acomodar el ganado en otras partes de las fincas o incluso en otros predios. Esta cuestión del ganado se debía completar con un censo de ganado mayor y menor de las provincias aludidas en el decreto. Insistimos en esta cuestión pecuaria por ser el mayor temor de los propietarios, tal y como hemos venido expo- 
niendo hasta ahora. De las provincias implicadas, era la de Cáceres en la que la explotación ganadera tenía más importancia. Por eso, el 25 de noviembre de 1932 se promulgaba una nueva orden ministerial en función de las "particularidades que ofrece la explotación agropecuaria de la provincia». ${ }^{8}$ La orden se hacía eco de lo difícil que resultaba «fijar las características de las tierras que se han de clasificar y admitir como de puro pasto». Si se promulgaba una orden complementaria, tendría que ser para tomar postura en esta cuestión, a lo que el legislador comentaba que «una explotación ganadera ancestral y abusiva» no podía ser causa de exención de la intensificación.

Otro aspecto muy interesante de esta orden es la atribución que se otorga a los técnicos de «anular los contratos de arrendamiento que hubieran degenerado en subarriendo o hubieran significado el desarraigo de cultivadores, yunteros o medieros». La responsabilidad de mediar entre propietarios y cultivadores en una situación de encono como la que se podía observar convertía a los técnicos en verdaderos delegados gubernativos (Ruiz Castillo-Basala, 1983).

Pero aún hay más. Se necesitaba un brazo político que monopolizara la aplicación del decreto. A mediados de noviembre de 1932, Peña Novo era nombrado gobernador general de Extremadura y desde el primer día se aplicó en hacer cumplir el decreto en la tierra que se había molestado en conocer bien, como testimoniaba su informe del verano.

Sin embargo, la intervención de Peña Novo pueblo a pueblo fue frenada por los propietarios en Madrid tras seis semanas de intensa actividad. A mediados de enero de 1933, Marcelino Domingo declaraba que se ponía fin a esa "vía gubernativa» de aplicación del decreto y que de nuevo serían las comisiones locales de policía rural y los ingenieros del IRA destinados al efecto los que señalarían qué se podía labrar. La presión del lobby propietario cristalizaba en una limitación de las atribuciones de Peña Novo bajo las apocalípticas visiones de destrucción de la ganadería. La valentía política que había acompañado su

8 Insistimos en las fechas por la importancia que la promulgación de textos legales tiene en relación con el calendario agrícola: se trataba de tener todo preparado para que los asentados pudieran barbechar. 
nombramiento dos meses antes se ponía en cuarentena y, con ello, la ejecución de una verdadera reforma agraria como la exigida según las circunstancias.

El efecto de esta paralización, en el que no vamos a entrar extensamente, fue una espectacular oleada de invasiones de fincas. Esto justificaría en buena medida la actividad de Peña Novo y su lacónica aseveración de que el campo no admitiría «las esperas del rigorismo legal». El proceso parece claro: o el Gobierno ponía en marcha la reforma o, redundando en el tópico, los campesinos la harían por su cuenta.

Antes de entrar en una valoración cuantitativa de lo actuado, queremos hacer hincapié en dos datos: tomando como ejemplo la provincia de Cáceres y manejando datos del IRA, lo obrado en materia de intensificaciones había afectado tan sólo a un $1,25 \%$ de la superficie agraria y a un $0,85 \%$ de la superficie de pastos $(B I R A, 1933)$. Queda planteada, pues, una cuestión fundamental: ¿era o no posible intensificar el cultivo en numerosas fincas de Extremadura que estaban explotadas de manera muy deficiente? Peña Novo tenía el convencimiento de que sí, y por una motivación social debía hacerse.

Por otro lado, en cuanto a las garantías de los propietarios, debemos enfatizar que, en cuanto recuperaron el poder perdido tanto a nivel local (imposición de comisiones gestoras) como estatal (Bienio Radical-cedista), lo primero que hicieron fue promulgar una ley (11 de febrero de 1934) que garantizaba algo tan básico como el cobro de rentas procedentes de la intensificación. Ese ciclo se cerraba con la eliminación en 1935 de todos los «residuos» de la intervención del Estado en la propiedad privada rústica, que se personificaba en la destitución de Giménez Fernández como ministro de Agricultura y en el lanzamiento de los yunteros de las fincas durante el verano y el otoño de 1935.

Es por esto por lo que hablamos de ciclo repetitivo durante la Segunda República, ya que en ese momento se está como en el verano de 1932, pero ahora con una mayor incidencia de la crisis social, tal y como ilustrábamos con datos de desempleo y crecimiento demográfico al principio de estas líneas. Más allá, el hecho de que las elecciones no se celebraran hasta el 16 de febrero de 1936 retrasaba mucho más la posibilidad de barbechar fincas. Aquí contamos con la ventaja que nos da el conocimiento 
de lo acaecido, pero debemos ponernos en la situación de colectivos como los yunteros durante el otoño-invierno de 1935: sin tierras que labrar y sin grandes perspectivas de cambio. Ahora, las medidas intensificadoras se convirtieron en decretos durante las primeras semanas de marzo de 1936, pero la demora que se llevaba convirtió el proceso de invasión de fincas en algo mucho más espectacular: en torno a 50000 trabajadores de la tierra en Extremadura pudieron lanzarse a roturar en las fincas. En este caso, el ministro Ruiz Funes, con Vázquez Humasqué como director de Reforma Agraria, no tuvo más remedio que ir legalizando las ocupaciones ex post facto. Además, en ese momento, la intensidad del proceso no garantizaba tanto respeto a las explotaciones pecuarias, existiendo frecuentes quejas por parte de los propietarios de que se araban los majadales que habían sido tradicionalmente intocables.

La reposición de los yunteros extremeños en las fincas que habían sido intensificadas con anterioridad no se sancionó hasta el decreto de 3 de marzo de 1936. De modo más específico, el requerimiento básico para que se les concedieran tierras era que hubieran «actuado como tales durante el año agrícola 1933-34 o en los siguientes y se encuentren en la fecha de promulgación de este decreto sin tierras a la[s] que aplicar sus actividades» (Gaceta de 5 de marzo de 1936). Debido a las "razonadas peticiones de pueblos de las provincias» colindantes, el 14 de marzo de 1936 se hacía extensiva esta nueva intensificación a Córdoba, Toledo y Ciudad Real de forma explícita, y a Salamanca de modo implícito al referirse a las «provincias españolas limítrofes con las de Cáceres y Badajoz» (Gaceta de 15 de marzo de 1936).

Este segundo ciclo acabó de una manera mucho más trágica para el campesinado, que es conocida por todos. Se hace necesario, pues, abordar la magnitud de estas dos intensificaciones y, sobre todo, plantear si fueron alternativa o complemento de la reforma agraria. 


\section{Balance: intervención y resultados en el caso extremeño}

\section{DECRETO DE INTENSIFICACIÓN DE 1932}

\begin{tabular}{|l|r|r|c|}
\hline Zona & Hectáreas & Asentados & $\begin{array}{c}\text { Tamaño medio del lote } \\
\text { (ha por asentado) }\end{array}$ \\
\hline Cáceres Peña Novo & 23395 & 12449 & 1,87 \\
Cáceres Consejo de Ministros & 8295 & 2188 & 3,79 \\
Total Cáceres & 31690 & 14122 & 2,24 \\
Badajoz & 53146 & 18699 & 2,84 \\
Total Extremadura & 84836 & 32821 & 2,58 \\
Resto & 24950 & 7538 & 3,30 \\
Total general & 119786 & 40359 & 2,96 \\
\hline
\end{tabular}

\section{LEGISLACIÓN SOBRE YUNTEROS DE 1936}

\begin{tabular}{|l|c|c|c|}
\hline Zona & Hectáreas & Yunteros & $\begin{array}{c}\text { Tamaño medio del lote } \\
\text { (ha por asentado) }\end{array}$ \\
\hline Cáceres & 113466 & 31388 & 3,61 \\
Badajoz & 125331 & 49809 & 2,51 \\
Extremadura & 238797 & 81297 & 2,93 \\
Córdoba+Toledo+Ciudad Real & 207113 & 21672 & 9,55 \\
Totales & 445910 & 102969 & 4,33 \\
\hline
\end{tabular}

FUENTE: Instituto de Reforma Agraria. Servicio Provincial de Cáceres (1935) y Malefakis (1970).

\section{RELACIÓN DEL NÚMERO DE ASENTADOS Y HECTÁREAS INTENSIFICADAS EXTREMADURA RESTO, 1932-1936}

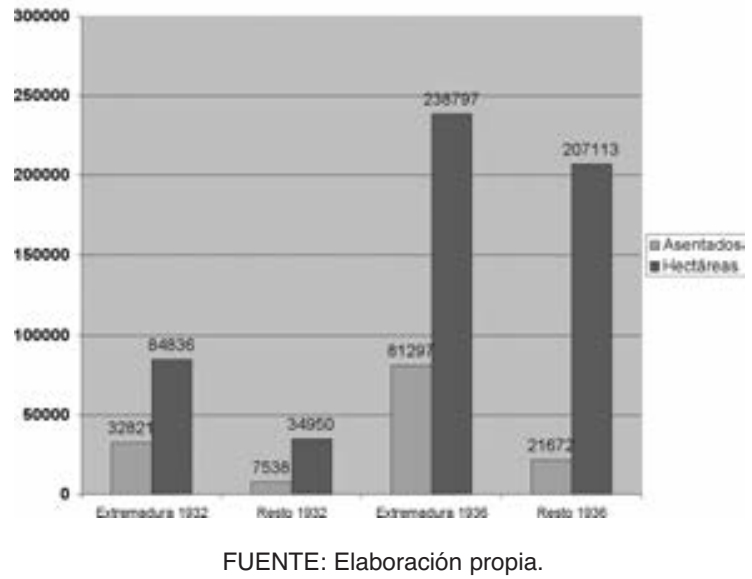


TOTALES DE HECTÁREAS Y ASENTADOS, 1932-1936

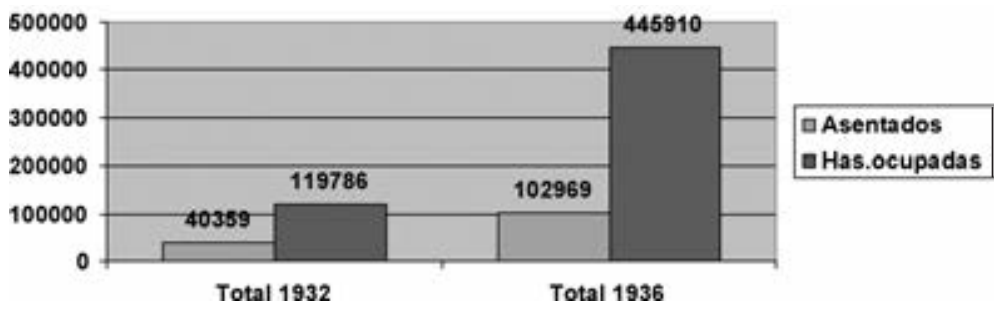

FUENTE: Elaboración propia.

Antes de pasar a la valoración de los datos expuestos, se requieren varias matizaciones. Los datos de Malefakis se basan en los que el Instituto de Reforma Agraria hizo oficiales a través de su boletín. Nosotros hemos contrastado los elaborados con posterioridad por parte de los técnicos para la provincia de Cáceres, siendo necesario un sesgo a la baja tanto del número de asentados como del de hectáreas. La validez de la fuente en este caso procede de que el informe elaborado por los técnicos del IRA en la provincia de Cáceres durante 1935 sirvieron de referencia para pagar las rentas que se fijaron por la ley de 11 de febrero de 1934. En otras palabras, se trata de la legalización absoluta de las intensificaciones realizadas en esa provincia, por lo que no sería de extrañar que el esquema se repitiera para otros casos.

En el caso de las cifras de "yunteros asentados» por los decretos de marzo de 1936, el propio boletín va cambiando de manera progresiva el modo de exponer los datos. En el caso de Cáceres ocurre lo mismo que en 1932, es decir, son un tanto excesivos. Malefakis opta por homogeneizar todos los datos de 1936, que en algunas provincias se refieren tanto al número de asentados mediante los decretos de yunteros como a las ocupaciones temporales efectuadas una vez repuesta la Ley de Bases, y a las declaraciones de utilidad social conforme a la legislación de 1935. La opción de Malefakis es la más lógica, por no disponer de otros datos que sólo monografías provinciales nos podrían aclarar.

Hemos optado, pues, por manejar nuestros datos específicos de la provincia de Cáceres y dar por buenos los de Malefakis para el resto de casos, para no complicar aún más las cosas. Los asuntos que resultan más notables son: 
- Totales de hectáreas: lo más notable del total de hectáreas es su multiplicación casi por cuatro en 1936 respecto de 1932, lo cual refleja de modo fehaciente el agravamiento de la crisis social entre ambos momentos. No se trata en modo alguno de unos totales representativos sobre la superficie agraria útil de las provincias afectadas, sino más bien de la constatación de que se podía forzar el laboreo en un número significativo de fincas de las provincias implicadas.

- Totales de yunteros: el número total de yunteros pasa de los 40000 en 1932 y supera de largo los 100000 en 1936, ejemplo de nuevo de la magnitud del problema y del interés de los gobiernos republicanos por solucionar la grave crisis social, que no había hecho sino empeorar durante el segundo bienio. Resulta bastante notable la fuerza de este colectivo, que disponía de los medios de producción necesarios para aplicarse en las tareas agrícolas.

- Representatividad de Extremadura: al extraer los porcentajes de los totales, queda claro que esta legislación de 1932 y 1936 se hizo pensando en Extremadura, aunque de modo más matizado en el 36. Durante la intensificación de 1932, la región extremeña absorbe el $70,8 \%$ de las tierras ocupadas y el $81,3 \%$ de los obreros asentados. Es decir, más de 2 de cada 3 hectáreas ocupadas y 4 de cada 5 yunteros asentados lo fueron en las provincias de Cáceres y Badajoz. La generalización del problema de los yunteros relativiza un tanto las cifras durante 1936: el 53,5\% de las hectáreas asentadas «reducen» a una de cada dos hectáreas las ocupadas en Extremadura; sin embargo, la «inflación» de yunteros queda constatada con que aún el 78,9\% de los campesinos reasentados en las fincas según los decretos de marzo de 1936 eran extremeños. Se mantiene casi la cifra de 4 de cada 5.

- Excepcionalidad de Cáceres: en el caso de 1932 hemos desagregado los datos de la provincia de Cáceres en dos partes, puesto que ponen de manifiesto dos momentos diferentes:

- Por un lado, el periodo de tiempo (unas seis semanas) en que la aplicación del decreto de intensificación fue prácticamente obra personal de Peña Novo, acudiendo pueblo por pueblo a sancionar legalmente la ocupación de las fincas.

- Por otro, una vez frenado por las presiones de la patronal sobre el Gobierno republicano, el resto de las ocupaciones aprobadas lo fueron por el Consejo de Ministros (enero-febrero de 1933). 
- Tamaño de los lotes: es esta cifra una valoración que no nos agrada demasiado, pero que es la única que permite algo de relativización de los resultados. Una hectárea en una dehesa de pasto y labor con arbolado en Extremadura no puede ser equivalente a una en la llanura palentina, por poner un ejemplo. Quiere decirse que la labor de los yunteros sobre las tierras requiere una labor de preparación que puede permitir con el tiempo una cosecha en rotaciones largas, o incluso una mejora sustancial de las condiciones de la ganadería gracias a cultivos forrajeros. En cualquier caso, es la medida que tenemos y, ya que existen dos momentos distintos para su contraste, tratemos de obtener alguna conclusión. El tamaño del lote resultante según la legislación de 1932 es de 2,96 hectáreas por yuntero, cifra que casi se duplica en 1936, en que asciende a 4,33. Sin embargo, tomando de nuevo como referencia el caso extremeño, podemos colegir que el tamaño del lote casi no varía: de 2,58 en 1932 a 2,93 en 1936, siempre inferior a 3 hectáreas. Aunque no dispongamos de grandes elementos de análisis, resulta impensable que una familia de campesinos pudiera mantenerse todo el año con semejante lote. Pero de nuevo la interpretación cuantitativa nos impediría ver que lo que se priorizó fue conceder tierras al mayor número de yunteros posible, podríamos decir «hasta donde las dehesas soportaron».

Ya que comentamos la cuestión del mantenimiento de las familias yunteras, debemos prestar atención al tema de la financiación de los asentamientos. Una vez "resuelta» la cuestión de los asentamientos, había que tener en cuenta que los yunteros no disponían más que de la yunta, resultando en cierto modo lógico que se subvencionara capital circulante por parte de la Administración para garantizar un mínimo de viabilidad en la obtención de las cosechas. De nuevo se demuestra lo recurrente del ciclo noviembre de 1932-marzo de 1936, ya que hasta octubre de 1933 y abril de 1936, respectivamente, no se dispuso de normativa al respecto.

La lentitud del proceso parece explicarse porque el IRA no tenía consignado este "gasto extraordinario" en su presupuesto. En el caso del año 32, fue necesario recurrir a fondos secretos del Ministerio de la Gobernación, que fueron gestionados por el Servicio Nacional de Crédito Agrario 
(Robledo, 1996). La tensión se pone de nuevo de manifiesto durante los veranos de 1933 y 1934, cuando los yunteros procedieron a retirar las mieses de las eras. Los propietarios, temerosos de que no se les pagara su parte, solicitaron la intervención de la fuerza pública, pero aquí Peña Novo se reservó su derecho a actuar como gobernador general procediendo a que se levantara acta si alguna de las dos partes lo requería. Los propietarios se opusieron también a esta medida, ya que consideraban que cualquier firma en documento oficial suponía la aceptación de una medida extraordinaria que seguían rechazando, tal y como entendían la intensificación. Más bien prefirieron esperar a las elecciones para después ponerse en marcha para cobrar: la ley de 11 de febrero de 1934 es uno de los primeros textos legales del Bienio Radical-cedista, que en pocas palabras obliga al IRA a pagar hasta la última peseta de la renta de las fincas que hubieran sido intensificadas.

En el otoño de 1933 el problema de la financiación se volvía a plantear, pues, si los yunteros no disponían de semillas y abonos, de poco les habrían de servir las tierras. El decreto de 26 de octubre de 1933 fue la solución a este asunto, aunque las cifras oficiales de créditos asignados por el SENCA no parecen un indicador fiable de que existiera gran capital circulante. Más bien los yunteros fiaron todo a que la cosecha a recoger en el verano de 1934 les permitiera cubrir gastos y generar suficiente excedente como para garantizar su subsistencia durante el resto del año.

Como venimos señalando, el problema se reprodujo en 1936, cuando «la situación económica de los yunteros a los que se ha dado por el IRA tierra de barbechera» requirió que fueran "facilitados por el Estado algunos anticipos para que atiendan debidamente sus labores» (Gaceta de 28 de abril de 1936). En este caso se empezaron a conceder antes, con arreglo al decreto de 25 de abril, si bien existe bastante documentación que demuestra que en el mes de junio aún no habían llegado a manos de los yunteros ni los denominados «adelantos para el sostenimiento de la familia campesina» ni los que suponían "una aportación para el cultivo de la finca» (artículo 2. ${ }^{\circ}$ ). De modo que, en el proceso cíclico que abordamos, parece evidente que primero se produjo la ocupación de la finca, luego la sanción legal a través de los decretos y, finalmente, mucho después, la financiación de los asentamientos. 


\section{Conclusiones}

A lo largo de este artículo hemos tratado de ofrecer un panorama de lo que significó, en especial en Extremadura, la aplicación de la reforma agraria a través de los decretos. Desechada la opción de analizarla como el mero resultado numérico de la Ley de Bases, el modelo español de reforma durante los años 30 debía ser la resultante de tres vías:

- Por supuesto, la primera de ellas debería haber partido de una aplicación sistemática de la Ley de Bases una vez que sus principales instrumentos (inventario, censos de campesinos e informes técnicos) hubieran sido elaborados.

- En segundo lugar, la situación de paro casi estructural hacía aún más perentorio el abordar las obras públicas que convirtieran cientos de miles de hectáreas en regadío mediante la aplicación del Plan Nacional de Obras Hidraúlicas vigente desde 1902, y una posterior formación del campesinado en aquellas áreas donde la aparcería (caso de la Vera en Cáceres) podría ofrecer grandes incrementos de la productividad mediante la puesta en riego.

- Tercero y último, esta intensificación o laboreo forzoso venía a demostrar que, con cierta agilidad, podían conocerse aquellas explotaciones de secano tipo dehesa, cuya explotación agrícola podría ser aumentada sin dañar por ello ni a la ganadería (más bien la mejoraría, si se aplicaba una rotación coherente que incluyera los forrajes) ni a unas áreas forestales que debían quedar bien señalizadas y separadas de las hojas de cultivo. Siguiendo con la terminología que hemos utilizado de forma paralela, era posible que las dehesas fueran al mismo tiempo de pasto y labor con arbolado.

Si bien ésa es la reforma agraria que el sencillo contrafactual nos ofrece, el caso que hemos expuesto aquí es si la vía del decreto podía ser una alternativa o un complemento. La respuesta no está cerrada: según el modelo que acabamos de exponer, debería ser, a nivel teórico, no más que un complemento. Es decir, en las explotaciones públicas y privadas tipo dehesa en las que fuera posible aumentar más la producción agrícola sin por ello hundir ni la ganadera ni la riqueza forestal, debería haberse llevado a cabo este incremento con similar dinamismo al experimentado, por ejemplo, en el valle del Guadalquivir. Así, en teoría, es un complemento 
que, de la mano de una reforma agraria eficaz (primer y segundo componente del modelo expuesto), habría podido cambiar la faz de las explotaciones del mediodía español.

Como no es el caso, la práctica demuestra que debemos valorar los decretos de intensificación de 1932 y de yunteros de 1936 como una alternativa muy eficaz a la Ley de Bases. Se demostró que con voluntad política se podía pasar por encima de las trabas de los propietarios. Peña Novo es la constatación de que la iniciativa podía cambiar el estado de cosas sin alterar el modelo productivo. El freno a su gestión, al ser convocado en Madrid por Azaña y Domingo ante la presión de los propietarios, es la muestra del otro lado de la dinámica de la reforma agraria en la España de los años 30: una obstaculización tan dura de la patronal agraria que culminó en una Guerra Civil.

La vía del decreto no fue la elegida en el verano de 1931, cuando la Comisión Técnica Agraria jugaba con la ventaja de que la patronal no estaba suficientemente articulada. Durante todo 1932 se logró empantanar el debate de la Ley de Bases llenándolo de tantas trabas burocráticas que su ritmo de aplicación quedó lastrado durante todo el régimen. Las iniciativas de la intensificación, y también de la «declaración de utilidad social» durante 1936, demostraban que era posible otra reforma agraria: sus resultados son numéricamente más notables que los de la Ley de Bases. Aunque muy limitados por su aplicación en el tiempo y por la escasez de los lotes para los asentados, son dignos de un análisis como el que hemos ofrecido porque se promulgaron en un contexto de tan grave crisis social que superan el modelo de análisis de una reforma agraria que trajera el tan ansiado aumento de la productividad de la agricultura española. 



\section{LA GRAN PROPIEDAD Y SUS TRANSFORMACIONES CON LA REFORMA AGRARIA EN MÉXICO* Alejandro Tortolero (Universidad Autónoma Metropolitana-Iztapalapa)}

El objetivo de este artículo es el de discutir las transformaciones que experimenta la gran propiedad con la reforma agraria llevada a cabo como consecuencia de la Revolución mexicana de 1910-1917. En la primera parte de este trabajo exploro la tesis de la irracionalidad de la gran propiedad. Esta tesis, famosa por ser fruto de una tradición de análisis liberal, se enfrenta a la de los intelectuales conservadores que defienden la gran propiedad. La disputa se salda con la Revolución, que se hace eco de las tesis liberales y se convierten en el fundamento ideológico de los planteamientos reformistas que sanciona la Constitución de 1917. Mi argumentación intenta demostrar que la ineficiencia de la gran propiedad proclamada por los liberales es fruto de una representación de la hacienda mexicana que poco tiene que ver con la realidad agraria a que ellos mismos se refieren. La gran propiedad a que hacen alusión como ineficiente no es tal si tomamos en cuenta su inserción regional y su vinculación con los mercados.

* Este trabajo se benefició de los comentarios realizados por los investigadores que participaron en el Simposio Internacional "Gestión de Patrimonios Agrarios y Reformas Agrarias (1800-1950)» realizado en Salamanca el 15 y 16 de noviembre de 2004. Particularmente agradezco los comentarios y el apoyo recibido por Ricardo Robledo y, como siempre, los errores son exclusiva responsabilidad del autor. Proyecto apoyado por Conacyt H-43960. 
En mi argumentación, esta visión es fruto, más que de un análisis científico, como lo proponía su principal representante, Andrés Molina Enríquez, de una representación ideológica que expresa la posición del autor y busca construir un nacionalismo basado en el viejo sueño liberal de la pequeña y mediana propiedad sobre la tierra. Esto se muestra en la segunda parte de este trabajo, donde exploro el impacto de la reforma agraria sobre algunos grandes patrimonios, para lo cual utilizamos como laboratorio de prueba la región de Chalco, que durante siglos se había caracterizado por ser la cuna de una de las agriculturas mas productivas de todo México. Allí encontramos una élite de grandes propietarios que sufre la destrucción completa de sus patrimonios (la familia Noriega) o bien que tiene que adaptarse a una reforma agraria que transforma sus haciendas en ejidos y pequeñas propiedades.

\section{La gran propiedad en el debate: la ineficiencia de la hacienda}

La historia agraria de México ha sido un objeto de estudio privilegiado, debido fundamentalmente a que violentas revoluciones de origen agrario colorean la historia del país desde principios del XIX hasta por lo menos la segunda década del XX, es decir, de la Revolución de independencia a la Revolución mexicana. Para explicar el origen agrario de estos levantamientos se ha hecho un análisis de las insurrecciones campesinas tratando de mostrar las condiciones en que vivían sus protagonistas. La mayor parte de los trabajos que han emergido de esta corriente de pensamiento han tomado prestada de las ciencias físicas la explicación sobre el origen de estas revoluciones, cuando subrayan que, al agudizarse el sometimiento al campesino, éste se subleva; en otras palabras, a toda acción corresponde una reacción igual, pero de signo contrario. ${ }^{1}$ Si el hacendado oprime, entonces hay protesta rural; si hay intensificación en las relaciones mercantiles, entonces las crisis aparecen creando escenarios de protesta social. Por lo tanto, el programa de investigación ha incorporado el estudio de los niveles de vida del campesino (Van Young, 1992), del comportamiento de los precios (Florescano, 1969), de la intensificación de la economía capitalis-

1 En este sentido, el trabajo de Tutino (1986) es un ejemplo claro. 
ta (Wolf, 1969, Tutino, 1986 y Womack, 1969), de los conflictos por el despojo de tierras y aguas (Crespo et ál., 1992 y Tortolero, 1997), y así sucesivamente.

En la mayoría de los casos se tiende a subrayar la hacienda como responsable del atraso en el campo mexicano y como el elemento negativo que incide en el empobrecimiento de un amplio campesinado, debido a su ambición colonialista de apoderarse de tierras, mercados y capitales (Tannenbaum, 1929). Así, en 1910 los pueblos se levantan enarbolando la bandera de la restitución de tierras arrebatadas por la hacienda y las leyes desamortizadoras de 1856. La variable, entonces, que propició el movimiento revolucionario fue el modo de operar de la hacienda tradicional, que genera reducidas ganancias para una minoría a costa del trabajo de grandes grupos de campesinos sin tierra y con bajos salarios, que casi en su totalidad debían a la tienda de raya. ${ }^{2}$

Esta visión del origen agrario de nuestras revoluciones motivó, entonces, el estudio del campo mexicano y desde el siglo XIX la hacienda se convierte en terreno de disputa entre los intelectuales conservadores y los liberales. ${ }^{3}$ Para los liberales la hacienda no es negocio, es una propiedad de grandes dimensiones pero ociosa, con propietarios absentistas, ajena a la modernidad y a las innovaciones (Molina Enríquez, [1909] 1979, Orozco, 1911, y L. Cabrera, 1913). La comunidad, en cambio, es antes que nada un espacio de relaciones sociales armoniosas, de solidaridad étnica y cohesión, pero también de incapacidad para entender la noción de pro-

2 En vísperas de la Revolución de independencia se señala que la economía presenta los siguientes problemas: la rentabilidad de la producción minera comienza a descender por aumento de costos de producción y caída del valor de la plata en mercados internacionales; una crisis comercial debida a la interrupción del tráfico económico provocada por las guerras europeas; una presión fiscal creciente motivada por el financiamiento de gastos militares de la Corona; una crisis agrícola motivada por la sequía de 1809 y sus secuelas; y un agudo aumento de los precios que, según un informe de la época, explicaba gran parte del descontento popular (Blanco y Romero, 2000), p. 82. El modelo de compresión y revolución se entiende en estos términos. Una presentación general actualizada sobre la historiográfica de la época, aunque con un enfoque distinto, puede verse en Van Young (2001), pp. 1-36.

3 Por ejemplo, E. Florescano (1991, p. 15) afirma que la Revolución de independencia se singularizó de los demás movimientos insurgentes latinoamericanos por la participación masiva de los campesinos y los sectores populares. 
piedad privada; de allí su expoliación por los criollos, ávidos de tierra en el momento de la desamortización de las comunidades. ${ }^{4}$ Los ranchos, por su parte, eran el elemento móvil. Entre la hacienda ociosa y la comunidad comprometida, el rancho representa el desarrollo de la propiedad mediana o pequeña que tanto éxito había originado en la agricultura farmer de los Estados Unidos. El sueño liberal de transformar un país de haciendas en uno de medianos y pequeños propietarios, como los vecinos del norte, se cristalizaba en el ranchero.

Los conservadores, en cambio, hacen una defensa del régimen de hacienda y condenan en cambio a las comunidades, ávidas de apropiarse de las tierras productivas de la hacienda (Bulnes, 1920, y Rabasa, [1920] 1986). E. Rabasa, por ejemplo, se niega a aceptar tres supuestos imperantes en la década de los veinte: el de la miseria agraria, el de la pésima distribución de la propiedad territorial y el del despojo a los menesterosos. Sostiene que el sistema de propiedad comunal se alteró poco y, por tanto, la hacienda no es responsable de la absorción de los terrenos comunales. En cambio, los pueblos sin necesidad de tierras intentan arrebatárselas a la hacienda (Rabasa, [1920] 1986, p. 306). En la matriz del pensamiento conservador está su posición social de hacendado. No es extraño, entonces, observar que hay una continuidad entre los argumentos que ellos emplean y los que distintos hacendados habían utilizado en momentos de conflictos anteriores contra las comunidades.

En efecto, en distintos momentos observamos esta forma de argumentar de los hacendados, por ejemplo en 1847, ante el problema que se genera porque el licenciado Mariano Arizcorreta, gobernador del estado de México, hace una comunicación dirigida a los propietarios para que no paguen los jornales con vales sino en dinero; los hacendados reaccionan como cuerpo y logran hacer dimitir al gobernador. Allí aparece el argu-

4 Para Molina, la comunidad indígena ofrecía a este sector social la posibilidad de vivir en todos los estados de su evolución y, por tanto, era un medio eficaz de ayuda al sector indígena. Al aplicarse la desamortización, el indígena pierde esta independencia y se vuelve un agitador (Molina, [1909] 1979, p. 127). Un análisis sugerente del pensamiento de Molina Enríquez frente a la comunidad es el de Kourí (2002). 
mento de la defensa de la propiedad y de la crítica a los indígenas ávidos de apoderarse de las tierras de la hacienda. ${ }^{5}$

Estamos, entonces, frente a un territorio en disputa que muy pronto, con la Revolución, se convertirá en el triunfo de la representación liberal y la destrucción del régimen de hacienda por los gobiernos posrevolucionarios. En la legitimación de la representación liberal como dominante será decisivo el papel del licenciado Andrés Molina Enríquez, no sólo como principal redactor del artículo 27 de la Constitución, sino también como el ideólogo de la ineficiencia de la gran propiedad. La trilogía del intelectual mexiquense de la hacienda ineficiente, con propietarios absentistas y poco interesados en el cambio, se convierte en dominante y el autor, en una lectura obligada para todos hasta los años cincuenta del siglo $\mathrm{XX}{ }^{6}$

La situación ha cambiado desde entonces, pero a casi un siglo de distancia de la obra de Molina creemos pertinente analizar la construcción de uno de sus grandes problemas nacionales, el de la propiedad, su trascendencia y sus repercusiones, ya que el legado de este autor es imprescindible para entender el México contemporáneo. La construcción del ideario de Molina Enríquez tiene como pilares dos elementos: de un lado, su bagaje teórico y su adhesión a las teorías positivistas en boga durante el porfiriato; de otro, su experiencia práctica como notario en Jilotepec y en Sultepec. Es decir, en la construcción de sus generalizaciones, donde el cientificismo juega un papel crucial, a menudo aparece la observación directa como elemento de prueba. Así, para hablar de las virtudes de la pequeña propiedad y del ranchero, el autor nos remite a la productiva agricultura del poblado de Dos Ríos en Huixquilucan; para hablar de la gran propiedad, nos envía a las haciendas mexiquenses de La Gavia, San Nicolás Peralta, Arroyozarco, La Lechería; para el problema del crédito, men-

5 Los hacendados dicen: «nosotros vemos que en vez de apoyar la propiedad, que es la mejor defensa del gobierno y del orden, con el cual esta identificado su existencia, y en vez de proteger la parte ilustrada de la sociedad, [el gobernador] fomenta la pasión mas fuerte de los indígenas, que es y ha sido siempre la de ocupar y apoderarse, de cualquier modo que sea de las tierras circunvecinas; pasión tan fuerte en ellos que de mansos y pacatos los convierte en fieras inmanejables» (Respuesta, 1849, p. 15).

6 Para Carlos Fuentes, «aun en los años cincuenta, Los grandes problemas nacionales era lectura obligatoria para todos — estudiantes y maestros- en la Facultad de Derecho de la UNAM» (Reforma, 15 de abril de 2002). 
ciona los ejemplos loables del crédito local en los pueblos mexiquenses de Tenango de Arista y en Jilotepec; y así, la arquitectura de su obra es un constante ir y venir entre su observación directa, que en la mayor parte de los casos se remite al estado de México, y la aplicación de su marco teórico para fundamentar la generalización. ${ }^{7}$ Además, el principio metodológico que guía la investigación de Molina Enríquez es el de que para conocer el estado social de un pueblo y los principios de su evolución es necesario estudiar su producción, y particularmente su producción de cereales (Córdova, 1979, p. 30). Para Molina Enríquez la producción era la base fundamental de la existencia de todas las sociedades humanas que se desarrollan y, en esa producción, la de los cereales era la verdaderamente esencial.

En consecuencia, nos pareció importante utilizar el método de Molina Enríquez, sometiendo las generalizaciones a la prueba regional, a la observación a escala microscópica y para ello tomamos como laboratorio de prueba la región de Chalco-Amecameca, que creímos pertinente por tener cuatro condiciones fundamentales. Primero, por estar situada en el estado de México, lugar de observación privilegiado de Molina; segundo, por ubicarse en lo que el autor llama la zona fundamental de los cereales, es decir, el área de estudio central en el pensamiento de Molina Enríquez; tercero, por ser granero de la ciudad de México durante varios siglos, comparable a lo que era el Bajío a escala nacional; y cuarto, por ser una ventana donde se pueden estudiar los grandes problemas nacionales, en particular el problema de la propiedad, que estudia Molina Enríquez en un periodo largo que va desde las reformas borbónicas hasta la Revolución, desde la transición del dominio de los españoles al de los criollos señores y de éstos a los criollos nuevos. Ninguna otra región nos presenta estas condiciones privilegiadas.

Esta zona fundamental de los cereales comprendía, para Molina, el Distrito Federal, los estados de Puebla, Tlaxcala, Hidalgo, México, Querétaro, Guanajuato, Aguascalientes y parte de los estados de San Luis Potosí, Michoacán, Zacatecas y Jalisco. Era, en síntesis, la región de la Mesa

7 Hay que recordar que Molina Enríquez nace en Jilotepec, estudia en Toluca en el Instituto Literario, trabaja en las notarías de Sultepec y Jilotepec y casi nunca se mueve del estado de México y el Distrito Federal —quizá sólo una vez, en 1915, hiciera un viaje a Chihuahua- (Basave, 2001, p. 20). 
Central y parte del Bajío la que había atraído la atención de Molina Enríquez, y es allí donde sus tesis sobre la propiedad se afinan para convertirse en el más importante de los grandes problemas nacionales.

\section{El problema de la propiedad}

Éste es un aspecto crucial en el pensamiento de Molina. Una vez que ha explicado la división étnica y social que existía en el México decimonónico, compuesto en lo esencial por diversos estamentos de criollos, indígenas y mestizos, entonces hace un cuadro de los periodos de dominio territorial y los estados de desarrollo.

En efecto, los criollos señores suceden a los españoles en la propiedad de las minas y las haciendas. Apegados a un catolicismo clásico y a las tradiciones aristocráticas donde la nobleza de sangre y el poder son elementos distintivos, este grupo de hombres de mundo, frívolos, delicados y finos, de pelo rubio y ojos negros, se interesa más en sus haciendas por el gusto de la dominación, de la vinculación y de la renta que por el interés del cultivo y del producto. Los criollos nuevos, en cambio, son laboriosos, sobrios, previsores, instruidos, inteligentes, sociables y prudentes, aunque en sus gustos muestran preferencia por la ostentación. Si los primeros eran de apellido Escandón, Iturbe, Cervantes, Landa, Cortina, Cuevas, De la Torre, Rincón, Pimentel, Rul, Terreros, Moncada, Pérez Gálvez e Icaza, los segundos son los Barron, Robert, Dupont, Duret, Lanz, Henkel, Lancaster y Comonfort.

Los mestizos son vulgares, rudos, desconfiados, inquietos e impetuosos, pero generosos y sufridos. Trabajan como agricultores, empleados, profesionistas y revolucionarios y tienen apellidos como Pérez, Hernández y Flores. Los indígenas, por su parte, debido a su atraso evolutivo, viven en una sumisión servil, en un cristianismo semiidolátrico y trabajan en su mayor parte como jornaleros y propietarios comunales.

Esta división social, hacia 1909, en términos generales nos presentaba una sociedad de 14 millones de personas, compuesta en un 15\% por extranjeros, en un $50 \%$ por mestizos y en un $35 \%$ por indígenas. De ellos sólo los criollos señores, los criollos nuevos y algunos mestizos tenían una propiedad efectiva sobre sus tierras; los demás practican for- 
mas como la propiedad comunal, la posesión comunal, la ocupación común, cuando no son sedentarios movibles y nómadas (Molina, [1909] 1979, p. 152).

La propiedad, entonces, en el pensamiento evolucionista de Molina Enríquez, no conocía su forma más desarrollada y la gran culpable de esta situación lo era la gran propiedad, que, como en España, era una especulación de orgullo y vanidad, no de prudencia y seguridad como en Inglaterra, ni mucho menos de utilidad y ganancia como en la América septentrional (Molina, [1909] 1979, p. 153). Es el acercamiento a la geografía española el que va permeando el análisis del autor, y lo hace explícito cuando menciona como su fuente fundamental a Jovellanos. $\mathrm{Ni}$ siquiera el hecho de que Jovellanos hable de la propiedad vinculada hace que cambie la opinión de Molina sobre su aplicación a México, ya que, si bien esta institución desaparece en las leyes, en cambio en las costumbres sobrevive. La prueba del autor es la hacienda de La Lechería, cerca de doscientos años en poder de la familia Pimentel y Fagoaga, y afirma: «este es el caso general. Los abogados de toda la república saben bien que no hay sucesión que tenga una hacienda entre los bienes mortuorios en que los herederos procuren evitar dos cosas: la división y la venta de esa hacienda» (Molina, [1909] 1979, p. 157).

Así, el autor empieza a presentar su visión de la hacienda emparentada con el pensamiento de Jovellanos, donde las palabras clave son vanidad, orgullo, señorío y renta, en suma un feudalismo rural, concepto que toma prestado de W. L. Orozco. La hacienda se sostiene, entonces, gracias a que lo «tiene todo" por lo vasto de su extensión y a que reduce gastos en el pago de jornales y en el pago al fisco. ${ }^{8}$ Entonces su cuadro se complementa con la descripción de la hacienda improductiva, rutinaria y mal administrada.

Frente a esta gran propiedad ineficiente, el autor propone como modelo de cultivo la ranchería y, en menor medida, la pequeña propiedad

8 En sus palabras, «cada propietario, urgido por el interés de pagar lo menos posible al fisco, por contribución predial, oculta el verdadero valor de la finca [... y ...] el rebajamiento de los salarios no es menos cierto. A el se debe el estado de verdadera esclavitud en que se encuentran los indígenas jornaleros» (Molina, [1909] 1979, p. 169). 
y la propiedad comunal. En realidad el ranchero es el prototipo de verdadero agricultor (Molina, [1909] 1979, p. 165). Por tanto, para facilitar la proliferación de los verdaderos productores agrícolas era necesario dividir la gran propiedad, no a través de la práctica de los arrendamientos o fraccionamientos voluntarios, sino por imposición de leyes. En su análisis, la federación debería crear una institución, la Compañía Bancaria de Obras y Bienes Raíces, para comprar las haciendas que le sean vendidas, fraccionarlas y venderlas. El momento para hacer el fraccionamiento era el de la sucesión, cuando se debería aprovechar la transmisión por herencia para obligar a la división de todas las propiedades que excedieran de una determinada extensión (Molina, [1909] 1979, p. 184).

En los pueblos, tan sumaria y tan imperfectamente repartidos desde la ley de 1856, se deberían hacer varias cosas: los pueblos con posesión comunal, convertirlos a la propiedad comunal con título; los pueblos que sólo tenían ocupadas sus tierras, delimitarlos y darles ocupación legal con títulos; los pueblos nómadas, establecerlos en reservaciones militares. En las rancherías con posesión general debía crearse la propiedad comunal titulada; en las que ya poseyeran propiedad privada individual habría que reconocerlas; y habría que procurar en los terrenos plenamente comunales la formación de posesiones individuales (Molina, [1909] 1979, p. 196).

Éste es en lo esencial el desarrollo que Molina emplea para construir esa imagen de la hacienda ineficiente y de la necesidad de dividirla. En primer lugar hay que señalar que en el momento en que el autor está escribiendo su obra existen en el país mas de ocho mil haciendas, de las cuales casi cuatrocientas se hallan en el estado de México, laboratorio de observación del autor. De éstas, el autor habla explícitamente en este apartado de La Gavia, San Nicolás Peralta, Arroyozarco y La Lechería. La primera, una propiedad inmensa en poder de la familia Riva y Cervantes; la segunda, de la familia De la Torre; la tercera, de Dolores Rosas; y la cuarta, de los Pimentel y Fagoaga.

Se trata, entonces, de cuatro propiedades, ubicada la primera en el distrito de Toluca. Este distrito tenía en la época 61 haciendas y 92 ranchos, de los cuales sólo una hacienda, La Gavia, sobrepasaba las cincuenta mil hectáreas. Una más, Suchitepec, tenía más de diez mil hectáreas (17 136). Ocho unidades eran mayores de dos mil hectáreas, pero menores 
de diez mil, y las 143 explotaciones restantes eran menores de dos mil hectáreas. San Nicolás Peralta se encontraba en el distrito de Lerma, extendiéndose sobre 5418 hectáreas con sus anexas Santa Catarina y Cocoapa. En este distrito existían once haciendas, siete ranchos y ocho rancherías, de las cuales las dos mayores son El Mayorazgo y San Nicolás Peralta. La hacienda de Arroyozarco, por su parte, con sus doce mil hectáreas, era la más grande del distrito de Jilotepec, bien conocido por el notario de ese lugar don Andrés Molina, donde se hallaban 28 haciendas y 35 ranchos. Finalmente, La Lechería era una propiedad de apenas 2408 hectáreas que estaba en el distrito de Cuautitlán, donde encontramos veinte haciendas y seis ranchos (Villada, 1893, pp. 601-803).

Esta información no era un secreto, porque en 1894 el gobernador Jose V. Villada publica su memoria de gobierno del periodo 1889-1893, donde menciona el estado general de la propiedad, su producción y su valor fiscal. Muy probablemente por ella se guía Molina Enríquez para expresar sus cálculos sobre el valor fiscal de las cuatro haciendas y, sin embargo, su generalización en este aspecto es sorprendente. Su mirada se centra, sobre todo, en las mayores propiedades de los distritos respectivos y deja de lado los pequeños ranchos y las haciendas medianas, que dominan la estructura agraria de esos lugares. En efecto, de 569 haciendas y ranchos registrados en la memoria de Villada, 537, que representan el 94,4\% del total, son menores de cinco mil hectáreas y sólo treinta y dos haciendas, el 5,6\% del total de las explotaciones, son mayores de cinco mil. Sobre estas unidades Molina Enríquez clava su mirada, y esto resulta sorprendente por el tratamiento que le da en su obra, donde el lector ve desplegarse un análisis fino y detallado de los grupos sociales al toparse con cuatro tipos de criollos, seis de mestizos y cinco de indígenas; de las formas de propiedad, de las que menciona por lo menos veinte formas distintas; de las diferentes prácticas del crédito; de las variadas formas de distribución del agua; pero en lo que respecta a la hacienda la generalización es desconcertante por su tendencia a la simplificación. Es allí donde la arquitectura de su obra se desmorona y, sin embargo, es allí también donde su legado se vuelve trascendente. ¿Por qué sucede esto?

En efecto, si se han señalado algunas tesis de Molina que trascienden $\mathrm{y}$ se convierten en puntos medulares de la historia mexicana del siglo XX, 
como su nacionalismo mestizo o su apuesta por el poder presidencialista, en realidad no hay una representación que adquiera más fuerza que la de la ineficiencia de la hacienda. ${ }^{9}$ Es ahí donde su representación del campo se convierte en hito, en algo verdadero; pero es también ahí donde su demostración es de lo más endeble en su discurso. ¿Cómo explicar esta contradicción?

Veamos primero cómo se convierte en una representación dominante para explicar en seguida la fuerza que adquiere un argumento científicamente débil. Para explicar el primer punto, creemos que es útil hacer una periodización de los estudios agraristas en México. En la primera etapa encontraríamos a los antecesores de Molina Enríquez, los autores de los cuales se sirve el sociólogo mexiquense para construir su imagen del campo. Aquí está esencialmente Gaspar Melchor de Jovellanos, porque de otros escritos, como el de M. Abad y Queipo, el autor no hace mención. ${ }^{10}$ Jovellanos, en su Ley Agraria, publicada en Madrid en 1795, proponía una serie de medidas para mejorar el estado de la agricultura española y allí hace una critica contra el latifundio, contra la propiedad amortizada y la vinculada por mayorazgos. ${ }^{11}$ Su propuesta en este aspecto es dividir la gran propiedad y éste se convertirá en el argumento fundamental de Molina Enríquez (Jovellanos, 1986, pp. 95 y 114). ${ }^{12}$

En segundo lugar, sus contemporáneos de la tradición liberal W. L. Orozco (1911), L. Cabrera (1913) y R. Escobar (1915). Luis Cabrera, por ejemplo, en una demoledora cita menciona como la hacienda se había

9 Para el nacionalismo, véase Basave (2001); para el presidencialismo, Córdova (1979). Véase también Shadle (1994).

10 Abad y Queipo, el primer gran economista que hubo en México, como lo llama T. Esquivel, señalaba los defectos de la gran propiedad en Nueva España en 1805 en estos términos: «La indivisibilidad de las haciendas, dificultad de su manejo y falta de propiedad en el pueblo, produjeron y aun producen efectos muy funestos a la agricultura misma, a la población y al Estado en general» (Abad y Queipo, 1986, p. 150).

11 En sus palabras, «ya en tiempo de Vespasiano se quejaba Plinio el Viejo de que la gran cultura, después de haber arruinado la agricultura de Italia iba acabando con las regiones sujetas al Imperio: latifundia deci perdidere Italiam jam rero et provintias (los latifundios perdieron a Italia y también a las otras provincias)» (Jovellanos, 1986, p. 46).

12 Un análisis sugerente sobre Abad y Queipo y sobre Jovellanos es el de Luna (2002) y (2006). 
apropiado del territorio de los pueblos. ${ }^{13}$ Luego, Escobar (1915, p. 48), uno de los agrónomos más destacados del periodo porfirista, dice que Molina conocía a fondo nuestro problema agrario y que había escrito «un precioso libro» donde proponía el derecho de reversión sobre la propiedad particular, cosa que el autor considera de mucha utilidad.

Pero también su visión tiene eco en el extranjero. Robert Bruce Brinsmade (1916a), ingeniero de minas nacido en Nueva York en 1871 y residente en México desde 1911, publica en Nueva York en 1916 un trabajo donde habla de los problemas agrarios mexicanos. Allí argumenta lo pernicioso del sistema de latifundio, la opresión del peón, el acaparamiento de la tierra por los hacendados en vísperas de la Revolución y lo injusto de los impuestos que benefician a los grandes hacendados y lastiman al pequeño propietario (1916a, p. 11). En el mismo año publica un trabajo más amplio en México, donde desarrolla estas ideas de Molina (1916a). Las ideas de Molina no sólo se expanden a través de Brinsmade, sino que autores norteamericanos como Gruening (1928), Tannenbaum (1929) y McBride (1953) también coinciden con la visión de la hacienda de Molina. Por ello E. Gruening (1928, p. 132), al describir la hacienda mexicana, repite la visión de Molina Enríquez de que la hacienda no es negocio sino una institución feudal, y luego los otros autores, que analizamos en seguida, marcan una nueva etapa donde se impone la concepción liberal de la hacienda ineficiente. En Europa, el primer autor que trata estos asuntos, aunque sin citar a Molina, es J. H. Retinger, quien publica en Londres en 1926 su Tierra Mexicana, donde también vehicula la idea de la hacienda como latifundio, de la opresión del sistema de peonaje y de los cuantiosos beneficios a unos cuantos amigos de P. Díaz (Retinger, 1926, pp. 65-71).

En efecto, en tercer lugar con la Revolución mexicana se impone la concepción liberal y entre 1930 y 1960 los estudiosos del campo mexica-

13 He aquí la cita: «en ciertas zonas de la república y principalmente en la zona correspondiente a la Mesa central, todos los ejidos se encuentran constituyendo parte integrante de las fincas circunvecinas; en la actualidad, pueblos como Jonacatepec, como Jojutla; pero para que he de citar Morelos? Citaré el Distrito Federal: pueblos como San Juan Ixtayopan, como Mixquic, como Tláhuac, como el mismo Chalco, se encuentran absolutamente circunscritos dentro de la barreras de la población, y en condiciones de vida tales, que jamás el mas cretino de los monarcas españoles o de los virreyes de la Nueva España se le habría ocurrido que un pueblo pudiese vivir en esta forma» (Cabrera, 1913, p. 16). 
no señalan, en forma contundente, que la hacienda mexicana está en la base de la Revolución por los grandes defectos que tenia. Así lo indican los importantes trabajos de Tannenbaum (1929), McBride (1953) y Chevalier (1956). El primero señala que la hacienda era una institución colonialista que tiene éxito por incorporar espacios, hombres y mercados con tácticas como el despojo de los pueblos, el endeudamiento de los trabajadores, el pago con fichas y el cultivo con poco riesgo. De su obra surge la idea de que un puñado de hacendados eran propietarios de la mayor parte del territorio mexicano (Tannenbaum, 1952, p. 18). Luego McBride (1953) desarrolla las tesis de Molina Enríquez, considerando al hacendado más como un terrateniente que como un agricultor, más como un propietario absentista que como un ranchero y más preocupado por la hacienda como propiedad hereditaria que como posibilidad económica (McBride, 1953, p. 29). Finalmente, F. Chevalier coincide también con esta visión de la hacienda cuando señala que las villas libres fueron absorbidas por los latifundios, que desde el siglo XVII la autoridad y el poder estaban en manos de los grandes propietarios y que los hacendados se preocupaban muy poco por las «viles ganancias» (Chevalier, 1956, pp. 242270).

Estas tesis se desarrollan en un contexto fértil para criticar a la hacienda, en un momento en el cual México vivía una época de auge, el llamado milagro mexicano, asociado a la puesta en práctica de una economía donde la hacienda por fin había desaparecido. En materia agraria se habían repartido, sólo en el periodo cardenista, de 1934 a 1940, más de diecisiete millones de hectáreas, es decir, más que todos sus antecesores juntos (Gutelman, 1977, p. 109). El viejo sueño de A. Molina Enríquez, quien frente a un México diverso en razas, en lenguas, en costumbres, proponía basar el nacionalismo en un país de propietarios, parecía estar al alcance con esta reforma agraria. El milagro económico asociado a la reforma agraria hacia creíble la leyenda negra de la hacienda ineficiente. Por ello E. Gruening (1928, p. 132), al describir la hacienda mexicana, repite la visión de Molina Enríquez de que la hacienda no es negocio sino una institución feudal.

Al terminar este periodo de crecimiento agrario, al final de los sesenta, esta visión comenzó a ser matizada. Revisar el pasado mexicano no era tarea fácil. Los trabajos de Chevalier (1956), Tannenbaum (1929) y McBride (1953) se habían convertido en clásicos. Surgen, entonces, dis- 
tintas tendencias que hemos clasificado, con muchas precauciones, de acuerdo a su aproximación al estudio de la hacienda, en funcionalistas, paternalistas, marxistas y economicistas, que en lo esencial subrayan el atraso en el campo motivado por la ineficiencia de la hacienda. ${ }^{14}$

Los historiadores, por su parte, reaccionaron de distintas formas frente a esta situación que subraya el atraso en el campo y su corolario, la revolución: aumentando el número de variables explicativas del movimiento revolucionario, desplazando las causas del atraso a los factores institucionales, aumentando el peso del factor político, y ubicando el problema campesino en el marco regional. La historia regional mostró la debilidad del análisis de Molina Enríquez.

En efecto, en el cambio de siglo aparecen una serie de estudios regionales que muestran que las tesis de Molina Enríquez de la hacienda ineficiente son más una representación ideológica, motivada por el debate entre liberales y conservadores, que una argumentación basada en un estudio acucioso del campo mexicano (Tortolero, 1995, Miller, 1997 y Kourí, 2002).

En suma, la tesis de Molina Enríquez y su hacienda ineficiente permea la historia agraria mexicana y tarda casi un siglo en ser modificada; ${ }^{15}$ de ahí nuestra segunda preocupación, de cómo un argumento tan inexacto se convierte en algo verdadero, en mito. Aquí la explicación no es nada fácil, ya que la fuerza del argumento está enraizada en la Revolución. Con su argumento Molina estaba situándose como un ideólogo de la Revolución y su reforma agraria. Primero, había mostrado la pertinencia de su análisis al anunciar una posible revolución desde 1909, es decir, era un profeta desarmado, y segundo, había desarrollado el argumento agrarista.

En efecto, el autor es un profeta cuando plantea que lo que quisiera hacer en la zona de los cereales era la obra de la Revolución francesa, que desamortiza los bienes del clero y los de la nobleza, anunciando que «es

14 Tortolero (2003).

15 Todavía al final del siglo Xx, A. Warman hace un balance del campo mexicano y de sus cambios entre 1900 y el 2000, y su visión de la hacienda coincide en mucho con las tesis de Molina Enríquez (Warman, 2001, p. 16). 
necesario hacerla y se hará por los medios pacíficos que indicamos, o por una revolución que mas o menos tarde tendrá que venir» (Molina, [1909] 1979, p. 199). Pero no sólo en este punto mira adelante. También en asuntos tan relevantes como el reparto agrario y el aumento poblacional, el autor establece que, si todo el territorio útil que abarca la zona de los cereales se pusiera en cultivo, entonces la producción y la población ascenderían hasta alcanzar proporciones colosales (Molina, [1909] 1979, p. 174). Allí se esta enraizando la fuerza de Molina. Su representación erudita, cientificista, darwinista sintoniza con un sector social que se hará el beneficiario de las políticas de la división de la hacienda y del reparto agrario. Su obra, entonces, se convierte en la ideología del reparto agrario y allí adquiere la fuerza que trasciende el análisis histórico que sumariamente hemos presentado.

En efecto, si definimos el mito como una creencia ampliamente sostenida sobre un individuo, grupo, institución, sociedad o proceso histórico que combina los hechos y la fantasía en un estereotipo que oscurece la realidad, y además admitimos que entre los historiadores un mito es con frecuencia un modelo simplificado de un fenómeno mucho mas complejo, en el cual uno o dos aspectos se resaltan hasta el grado de sustituir el todo, entonces podemos resolver la aparente contradicción en su representación de la hacienda basada en una demostración endeble (Cuello, 1988, p. 186). El sociólogo mexiquense, en realidad, está cristalizando en un argumento contundente, "la hacienda no es negocio», ideas que se venían gestando desde hacía mucho tiempo, que nos remiten a Jovellanos, a Abad y Queipo, y que adquieren una enorme fuerza como representación del ideal de una sociedad emergente de rancheros, de pueblos desposeídos de tierras y recursos comunales, de peones; en suma, de un enorme sector social rural que veía como la hacienda no era un negocio para ellos, pero sí para los 847 propietarios registrados erróneamente en el censo de 1910.

Si el mito tiene la función de generalizar y sintetizar modelos conceptuales sin preocuparse demasiado por el rigor científico de la investigación, entonces encontramos que Molina Enríquez había construido un modelo de hacienda demasiado simple en relación con su acercamiento a los grupos sociales, a las formas de propiedad, a las prácticas del crédito, pero que, visto en la arquitectura erudita de su obra, donde el darwinismo y el positivismo dan una fundamentación científica a su representación, 
entonces entendemos por qué pronto se convierte en mito. ${ }^{16}$ Tiene tres ingredientes principales. En primer lugar, es una representación que forma parte de una argumentación científica. En segundo, beneficia a un amplio sector social que ve como la Revolución destruye el orden establecido de la hacienda mexicana ineficiente, inmensa y ociosa; esta hacienda que la revolución destruye, aunque sea lentamente, servirá como parteaguas para que tanto los gobernantes como sus representados se unifiquen en una ideología agrarista que permea todo el siglo XX mexicano y que es piedra de toque de una política incluyente, de bienestar social, opuesta entonces a la política de amigos y de beneficios empresariales del porfirismo. Finalmente, muy pronto es legitimada por la argumentación persuasiva, por la prueba académica de brillantes intelectuales como Tannenbaum, McBride, Chevalier y tantos otros. Con esto el círculo se cierra. El mito adquiere una fuerza enorme que sólo lentamente comienza a ser erosionada. ${ }^{17}$ Ésta es, pues, a mi juicio, la explicación de la enorme fuerza del modelo de hacienda de Molina, que no sólo se reduce a este tema, sino que también, como otras de sus generalizaciones relativas a la comunidad indígena o a la irrigación, encuentra ahora, en la práctica de los estudios regionales, un laboratorio de prueba que incomoda muy a menudo a la práctica de la síntesis y la generalización basada en una insuficiente prueba empírica. Analicemos, pues, cómo los estudios regionales han servido para erosionar el mito.

\section{La reforma agraria y la gran propiedad: el caso de Chalco}

La estructura agraria de Chalco estaba dominada por la gran propiedad, la hacienda, que tenía dominio pleno sobre tierras y mercados. Junto con ella conviven, en forma complementaria, los pueblos y los ranchos. En efecto, el espacio productivo de esta región estaba dominado por la hacienda, que se había apropiado de los recursos mas importantes, como lo eran

16 Para Cuello, un mito histórico por lo común es producto de la necesidad de hacer extensas generalizaciones, es resultado de sintetizar modelos conceptuales de sociedades históricas sobre la base de investigaciones inadecuadas (Cuello, 1988, p. 186).

17 La historia regional ha sido responsable de esta lenta erosión de algunos mitos. Para ello pueden verse los trabajos citados de Tortolero (1995), Miller (1997) y Kourí (2002). 
las tierras planas cercanas a las vías de comunicación y a los caudales de agua e insertas en áreas con abundante fuerza de trabajo. Los ranchos, en cambio, ocupaban las tierras marginales, a menudo eran espacios arrendados por la hacienda a sus aparceros con el fin de volverlos productivos, tenerlos ocupados y formar clientelas, elemento básico en las sociedades de Antiguo Régimen. Los pueblos, por su parte, habían sufrido la expansión de las haciendas y, a pesar de encontrarse en tierras apropiadas para la práctica de una agricultura intensiva, no contaban con tierras suficientes y complementaban su economía con el trabajo en la gran propiedad.

Si en el ámbito nacional hacia 1910 existen 8431 haciendas, 48635 ranchos y 11310 pueblos, ${ }^{18}$ en Chalco, un distrito agrícola que apenas se extendía sobre unos $1900 \mathrm{~km}^{2}$ en la parte oriental de la cuenca de México, encontramos alrededor de 30 haciendas y 15 ranchos que ocupan las mejores tierras del distrito, extendiéndose sobre la mitad de la superficie de éste y dejando a los cincuenta y cinco pueblos territorios pequeños y en ocasiones faltos de agua y alejados de las vías de comunicación (mapa 1).

La élite de hacendados de Chalco estaba compuesta por familias como la de los hermanos Noriega, propietarios de varias haciendas en la región. Estos personajes habían nacido en Colombres (España) y dejan la Península en 1866. Ínigo tenía 14 años, Benito 16 y Remigio 19 cuando embarcaron de Cádiz a La Habana. En 1868 los encontramos ya en México trabajando en la tienda de su tío, Íñigo Noriega Mendoza, dedicada a la importación de vinos y licores finos, conservas y «otros efectos extranjeros». En 1874 los hermanos aparecen ya como propietarios de la tienda La Mariscala y de la fábrica de cigarros El Borrego. Quizá su paso por Cuba abrió el interés de los hermanos por convertirse en fabricantes de cigarros y "los peritos aseguraban que los cigarros del Borrego podían rivalizar con los mejores de La Habana». ${ }^{19}$ A partir de esta base comercial y empresarial se vinculan a la sociedad asturiana y desde 1886 hasta 1898 utilizan cuatro estrategias para consolidar su fortuna: primero, forman la Sociedad Mercantil Remigio Noriega y Hermano; segundo, continúan en la fabricación

18 Tortolero (2003), p. 130. Hacia 1877 existían también unas 6937 comunidades (González Navarro, 1986, p. 364).

19 El Monitor Republicano, 29 de noviembre de 1876, p. 3. 
MAPA 1

HACIENDAS Y RANCHOS EN CHALCO (FIN DEL SIGLO XIX): INTENTO DE RECONSTRUCCIÓN DE LOS LÍMITES DE PROPIEDAD Y POBLACIÓN

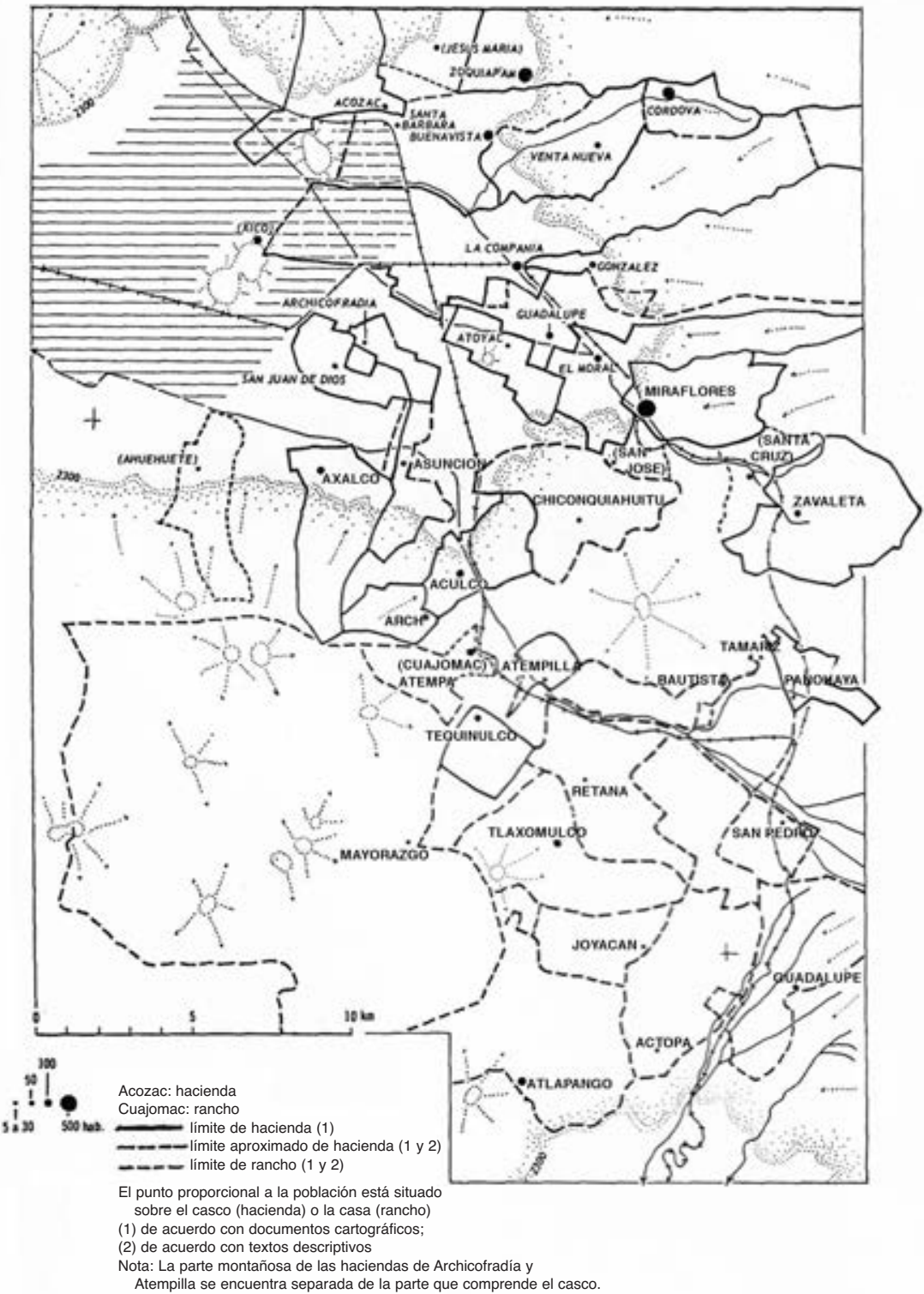


de tabacos; tercero, compran la herencia de su tío Manuel Mendoza Cortina; y finalmente, agrandan su capital con la cesión de derechos. ${ }^{20}$

Sin duda todas estas estrategias rindieron frutos, pero quizá la más importante fue la de vincularse con el tío Manuel Mendoza Cortina, prominente hacendado de Morelos, quien muere sin tener descendientes y de cuya fortuma los hermanos Noriega se convierten en herederos a través de prácticas legales poco claras. Sus bienes ascendían a casi 3 millones de pesos invertidos en una mina y hacienda de beneficio en el estado de Guerrero, otra en el estado de Morelos y bienes raíces en México y España.

De estas propiedades, la más importante era sin duda la hacienda de Coahuistla, finca azucarera en la cual Mendoza Cortina había construido una enorme fortuna. A mediados del siglo XIX sólo había unas cuantas haciendas en Morelos que habían modernizado su sistema de fabricación de azúcar y Coahuistla era una de ellas. Diversas fuentes nos dan cuenta de la importancia de la hacienda, pero una de ellas es muy clara. Los informes de viajeros, como el de C. Bertie, quien en 1886 describe la hacienda como un verdadero castillo fortificado que valía veinticinco millones de francos. ${ }^{21} \mathrm{El}$ valor de esta hacienda era la producción de azúcar que enviaba a través de los canales navegables que surcaban el distrito de Chalco a Ciudad de México.

Quizá por ello los Noriega vuelven su mirada a Chalco. En efecto, el corredor natural del comercio del azúcar seguía los canales navegables de Chalco, y por ello no es extraño encontrar que los hermanos Noriega compran prácticamente la mitad norte del distrito. Allí la hacienda de La Compañía era estratégica, ya que tenía un embarcadero por donde podían circular los productos de Tierra Caliente. Los hermanos Noriega compran esta hacienda en 1888 y también las de Zoquiapan (1886), Río Frío (1897), Ixtlahuacan (1897), San Juan de Dios (1898) y los ranchos de Xico (1888), Córdova (1888), San Isidro (1890) y Venta Nueva (1898). ${ }^{22}$

Con estas compras, realizadas entre 1886 y 1897, los Noriega se convierten en los hacendados mas importantes de la región. En 1897, por ejemplo, forman la Negociación Agrícola de Xico y Anexas, S. A. La sociedad tenía dos objetivos: la explotación agrícola e industrial de las fincas rústicas

20 Martínez Moctezuma (2001), p. 19.

21 Bertie (1886), p. 124.

22 Martínez Moctezuma (1996), p. 187. 
denominadas Xico y La Compañía y explotar la concesión presidencial que les había sido otorgada desde abril de 1895 para conducir por medio de un canal las aguas depositadas en el lago de Chalco, haciendo a la vez el drenaje y la desecación de los terrenos para usos agrícolas e industriales. ${ }^{23}$

Los Noriega llevan a cabo una revolución agrícola en la región de los volcanes. Así la he conceptualizado por su semejanza con la inglesa, que se caracteriza por el cambio en los sistemas de cultivo, en los sistemas de propiedad y en las actitudes empresariales; los Noriega introducen estos cambios en Chalco en forma vertiginosa al finalizar el siglo XIX.

En efecto, en los sistemas de cultivo los Noriega introducen toda una serie de innovaciones en sus haciendas. La Compañía, por ejemplo, en 1897 tiene 198 arados, 4 desterronadoras, 4 rastras y 29 rastrillos, 11 sembradoras y 26 cultivadoras. Tenían 3 máquinas trilladoras y 3 aventadoras de trigo. Esto nos da una idea de los cambios en las técnicas de cultivo, que son aún mas evidentes cuando sabemos que en el cambio de siglo hacen venir a sus haciendas a Mariano Gajón, arboricultor zaragozano, para ocupar la dirección técnica de cultivos y arbolados de la hacienda La Compañía. Allí el señor Gajón introduce un campo de selección de simientes, cien mil árboles frutales «todos importados de Europa, Francia y España principalmente», más de cien mil árboles forestales, forrajes y hortalizas.

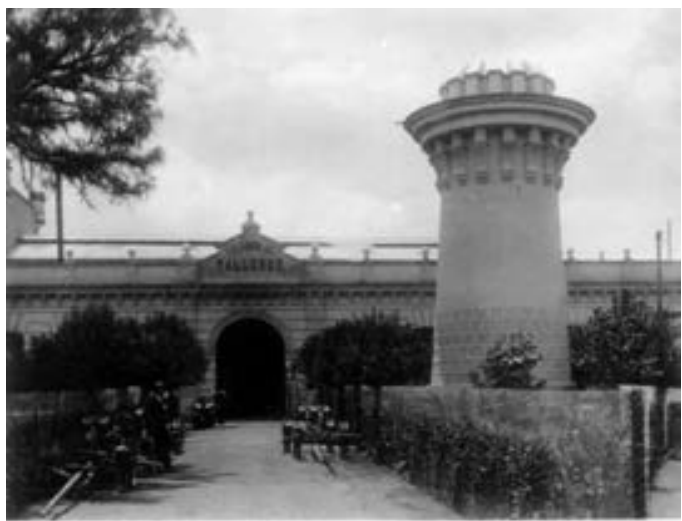

Talleres de la hacienda de Yico hacia 1898. Foto cortesía de L. Martínez y J. L. Solana.

23 Martínez Moctezuma (2001), p. 44. Para la desecación, Tortolero (1997). 
Los cambios en los sistemas de propiedad tienen que ver esencialmente con la privatización del lago de Chalco. Este lago era usufructuado por los habitantes de los pueblos ribereños, quienes señalaban que desde "tiempo inmemorial» sus pobladores se beneficiaban de sus aguas para irrigar sus tierras y construir chinampas, además de comer peces y fauna acuática del lago. Los tules les servían para construir sus casas y fabricar sillas y petates para dormir. La centralidad del lago en la economía campesina era evidente. ${ }^{24}$ Los Noriega aprovechan la concesión para beneficiarse de las aguas del lago dictada por Porfirio Díaz en 1895 y declaran todas las tierras desecadas como propiedad privada de la Negociación Agrícola de Xico. La propiedad de las aguas y canales, antes comunal, se convierte al finalizar el siglo en propiedad de una empresa.

Si bien el Gobierno porfirista había hecho esfuerzos notables en materia de derechos de propiedad de aguas y tierras, dictando leyes como las de desamortización de 1856 o las de aguas de 1888, existían muchas aristas por donde los empresarios podían burlar tales leyes. ${ }^{25}$ Una de ellas era el enorme poder de negociación que tenían con el presidente Díaz. En un régimen que privilegiaba la amistad y los lazos clientelares, la ley podía estar supeditada a la influencia de las élites. ${ }^{26}$ Los hermanos Noriega se convierten en propietarios privados de las aguas aun cuando, bajo la legislación, estas aguas debían ser propiedad federal porque por el vientre del lago corrían una multitud de canales navegables y uno de ellos, el Canal Nacional, había sido construido por la federación para facilitar el tráfico de mercancías entre Ciudad de México y su entorno agrario. Luego, ellos mismos explotan el tráfico por canales, inaugurando un servicio de vapores en 1890. El sobrante, pues, de las aguas de los lagos, desviadas en su mayor parte hacia el vecino lago de Texcoco, es explotado por los Noriega, como también todas las tierras, extremadamente fértiles, que liberan los antiguos humedales. Aquí vale la pena mencionar la enorme catástro-

24 Tortolero (coord.) (1999).

25 En 1856 es abolida la propiedad corporativa y la Constitución de 1857, en su artículo 27 , reitera la desamortización y establece el derecho de propiedad individual. Además se promulgan una serie de leyes relativas a la colonización y propiedad de tierras. En asuntos de aguas, las leyes de 1888 impulsan una federalización de las aguas quitando paulatinamente la propiedad a los actores locales, como haciendas, pueblos, ranchos, etc.

26 Para esto, véase Molina ([1909] 1979), Guerra (1988) y Bortz y Haber (2002). 
fe ecológica que significa desviar varios millones de litros de agua dulce del lago de Chalco hacia las aguas salinas del de Texcoco. ${ }^{27}$

Todo esto no hubiera sido posible sin un cambio en la mentalidad, que, lejos de ser la mentalidad tradicional del hacendado retratada por Molina Enríquez y otros, en los casos que nos ocupan se trata de hacendados dispuestos a la inversión, conocedores de la legislación en materia de aguas, enterados del crecimiento poblacional de ciudades y centros de consumo como las minas, practicantes de sistemas de administración y contabilidad semejantes a los negocios industriales; en suma, interesados en hacer rendir productivamente sus haciendas. ${ }^{28}$ Lo cual no está reñido con una ambición de prestigio que se observa en la construcción de soberbios palacios en sus respectivas haciendas.

Sin embargo, en el centro de sus preocupaciones está el mercado. Si hacia 1890, antes de los trabajos de desecación, la propiedad explotaba 500 cargas de maíz, 60 de trigo, 120 cabezas de vacuno y 300 de lanar, luego de la gran transformación se avanzan cifras de producción de 200000 cargas de maíz para fines de siglo, los cuales sabemos que se cumplen, ya que los reportes de A. Genin, miembro del consejo de administración de la Sociedad Financiera para la Industria en México, que

27 Según Ramon Iglesias, el lecho del lago albergaba 233860100 metros cúbicos de agua en 1902 (Niederberger, 1987, p. 81). Si sabemos que esta cantidad era mayor que la que contenían las presas que abastecían de agua potable a ciudades enteras como San Luis Potosí, entonces se puede ver con mayor claridad la enorme catastrófe causada por los Noriega (Camacho, en Birrichaga, 2006). Al respecto conviene señalar los atinados comentarios de D. Gallego, quien, al analizar la relación entre empresas, ambiente y sociedad, señala que «una empresa que se sitúa en un contexto ambiental y social dado con muy alta capacidad de imponer los objetivos de la propiedad sobre las demás personas y grupos implicados en el proceso productivo puede provocar graves efectos ambientales y sociales en su entorno, ya sea socavando el capital ambiental o humano o dificultando la realización de algunas potencialidades de la sociedad y de la naturaleza en la que se inserta» (Gallego, 2006, p. 21).

28 En este sentido, me fue muy útil discutir mi trabajo con A. Presedo, quien muestra como la hidalguía acomodada gallega en el siglo XIX daba gran importancia a sus archivos, tenía administradores encargados de poner en práctica sus órdenes y mantenía un intercambio epistolar con sus subordinados. En el caso de Chalco, esta situación es particularmente cierta para personajes como los Noriega, los Solórzano y la familia Riva Palacio, quienes guardan sus archivos en perfecto orden y cuyos libros de contabilidad nos permiten hacer el análisis de la rentabilidad de sus haciendas de forma parecida a la mostrada por J. M. Lana en su trabajo discutido en Salamanca y en Lana (2006). 
había hecho importantes préstamos a Xico, establece que la Negociación vende 38000 pesos en leche, 14000 en pulque, 130000 en trigo y alfalfa y un 1230000 en maíz, total 1412000 pesos en $1908 .^{29}$

Para hacer frente a esta demanda siguen una estrategia: transforman sus negociaciones familiares en sociedades anónimas, se asocian con capitalistas extranjeros y banqueros nacionales, logran integrar economías de escala donde la diversificación de las inversiones es un punto importante y, finalmente, gozan del favor de las autoridades políticas para instrumentar su proyecto empresarial. ${ }^{30}$ Este proyecto está en la base de la construcción de enormes fortunas; en 1912 la fortuna de Íñigo Noriega se evaluaba en 7696740,46 pesos y sus inversiones no se limitaban al centro de México, sino que se habían extendido al norte, donde habían formado una compañía agrícola, denominada La Sauteña, a la urbanización de terrenos, a la explotación de líneas férreas y establecimientos industriales y así sucesivamente. ${ }^{31}$

Sin embargo, todos estos proyectos se vienen abajo con la Revolución de 1910-1917. Con la Revolución zapatista las haciendas de Noriega son invadidas en mayo de 1913, sus edificios son quemados y se destruyen las plantaciones. Sus bienes son incautados por la Dirección General de Bienes Intervenidos y es esta institución quien se encarga de negociar con los revolucionarios, que pedían el fraccionamiento y reparto de las haciendas y la creación de ejidos. Así se escribe entonces la disolución de este enorme patrimonio. La Revolución se encarga, a través de las leyes de 1915 y 1917, de dar las bases para la destrucción de las grandes haciendas. Noriega abandona el país y regresa sólo para morir en 1920 en la casa de su hija en Ciudad de México.

En efecto, la ley de 6 de enero de 1915, formulada por Luis Cabrera para dar una base social al carrancismo, preveía el proporcionar tierras a los pueblos, ya fuese por dotación o por restitución. La restitución se hacía

29 Genin (1910) y AHPARIBAS, 610 FOM.221.326, México, 28 de agosto de 1914 , carta de Auguste Genin.

30 Tortolero (2002) y (2004).

31 En este sentido, también es útil remitir al trabajo de Presedo incluido en este volumen, quien, al responder quiénes eran los miembros de la hidalguía gallega en el siglo XIX, nos muestra algunos rasgos compartidos por la élite de propietarios de nuestra región: los ingresos excepcionales, la exitosa reproducción social a través del matrimonio, el tren de vida ostentoso y el ethos aristocrático. 
cuando los pueblos demostraban que habían perdido sus tierras por efecto de la ley de 25 de junio de 1856 . En el caso de que no pudieran exhibir títulos de propiedad, se les dotaría de las tierras y aguas que necesitasen. Entonces, era un problema de crucial importancia el demostrar con títulos - y mapas en caso de existir — la extensión de los pueblos para que una Comisión Nacional Agraria se encargara de emitir el fallo respectivo de restitución o dotación. ${ }^{32}$

Luego, la Constitución de 1917, en su artículo 27, establece la formación de ejidos para beneficiar a los habitantes de los pueblos que no tenían tierras. ${ }^{33}$ Con esta política los habitantes de Chalco se lanzan a los tribunales para encauzar por la vía legal sus demandas agrarias y el panorama se transforma radicalmente allí. La poderosa hacienda cede su lugar a la agricultura campesina practicada en los ejidos de los pueblos.

El cuadro 1 nos muestra que entre 1921 y 1956 los pueblos de Chalco se apoderan, por dotación y ampliación, de 45678 hectáreas, lo que muestra la transformación de la región. Con la Revolución asistimos a la desintegración de la hacienda y de sus proyectos innovadores y, en cambio, el paisaje agrario ahora aparece dominado por los pueblos y sus ejidos. Los pueblos se convierten en propietarios de sus tierras y una nueva organización y distribución del espacio es ahora favorable a las comunidades. En Chalco el reparto comienza en 1921, con la restitución de 232 hectáreas de tierras de temporal al pueblo de San Mateo Huitzilzingo. Entre 1921 y 1934 se distribuyen entre los pueblos 39423 hectáreas, es decir, la mayor parte del reparto agrario. Durante el periodo cardenista sólo se distribuyen 11571 hectáreas y de 1941 a 1956 sólo se entregan 2348. De estas tierras, la mayor parte (27757) se clasifican como tierras de temporal, cultivos que dependen de las lluvias, y sólo 437 hectáreas de riego. ${ }^{34}$

32 Tannenbaum (1952).

33 El artículo 27 expresa que las tierras y aguas comprendidas dentro del territorio nacional pertenecen originariamente a la nación, la cual tiene el derecho de transmitir su dominio a los particulares, constituyendo la propiedad privada. Establece que las expropiaciones de tierras y aguas se harían por causa de utilidad pública y mediante indemnización. Se restituirían tierras, bosques y aguas usurpadas a las poblaciones como consecuencia de la Ley Lerdo de 1856 y, en caso de que no procediese esta vía, a los pueblos faltos de tierras se les dotaría de ejidos.

34 El resto se clasifica en tierras de monte y pasto (23100 ha), agostadero (2237) e incultivables y eriazas (481). 
CUADRO 1

DISTRIBUCIÓN DE TIERRAS ENTRE LAS COMUNIDADES DE CHALCO, 1921-1956

\begin{tabular}{|l|c|c|c|c|c|r|r|r|r|}
\hline Periodo & Com. & Confirmación & Com. & Restitución & Com. & Dotación & Com. & Ampliación & Totales \\
\hline $1921-1934$ & 1 & 2684 & 2 & 4980 & 47 & 31381 & 1 & 378 & 39423 \\
$1935-1940$ & & & & & 10 & 2631 & 23 & 8940 & 11571 \\
$1941-1956$ & & & & & & & 4 & 2348 & 2348 \\
$1921-1956$ & 1 & 2684 & 2 & 4980 & 57 & 34012 & 28 & 11666 & 53342 \\
\hline
\end{tabular}

FUENTE: AHEM, CAM.

La otrora omnipresente hacienda a mediados del siglo XX ha disminuido su presencia en el espacio de Chalco-Amecameca, y esto es un enorme cambio. El siguiente mapa expresa, como ningún discurso lo haría, lo que fue la Revolución en Chalco: una nueva distribución de los espacios donde la hacienda sufre ahora los embates de los pueblos. Aquí vemos que la distribución de tierras es más equilibrada: los bienes comunales representan el $27,3 \%$ de la propiedad, los ejidos el $26,6 \%$, la pequeña propiedad el $13,1 \%$, la superficie federal el 12,6\% y las haciendas el 15,9\%. ${ }^{35}$ Si Andrés Molina Enríquez había señalado con razón que la hacienda que no tiene todo sufre apuros y para tenerlo todo era necesario ensanchar la propiedad (Molina, [1909] 1979, p. 167), entonces en este momento la hacienda estaba en apuros (mapa 2).

Esto es particularmente cierto en Chalco, donde las haciendas de los hermanos Noriega son incautadas por el Gobierno federal y luego fraccionadas entre los habitantes de los pueblos o administradas por políticos revolucionarios como Plutarco Elías Calles o Luis N. Morones; pero también en la vecina región de Morelos, donde los Noriega poseían hacia 1880 su hacienda de Coahuistla.

35 Éste fue un cambio importante, pero no suficiente. En efecto, como bien lo señala D. Gallego analizando el pensamiento de D. North, acumular unos a costa de otros afectaría negativamente a los otros y al conjunto de la sociedad, y es según North una de las principales razones que explican la persistencia del atraso en algunas sociedades. Esta nueva distribución de la tierra en Chalco genera una sociedad con menos contrastes, pero para que una reforma agraria sea exitosa es necesario no sólo entregar la tierra, sino reorientar la política gubernamental en factores como los señalados por Carmona y Simpson (2006, p. 3): investigación, precios, educación, riego, crédito y organización. 
MAPA 2

LA REGIÓN DE CHALCO HACIA 1925. RECONSTRUCCIÓN DE LOS LÍMITES DE LAS PROPIEDADES EN EL NORTE DESPUÉS DE LA REVOLUCIÓN

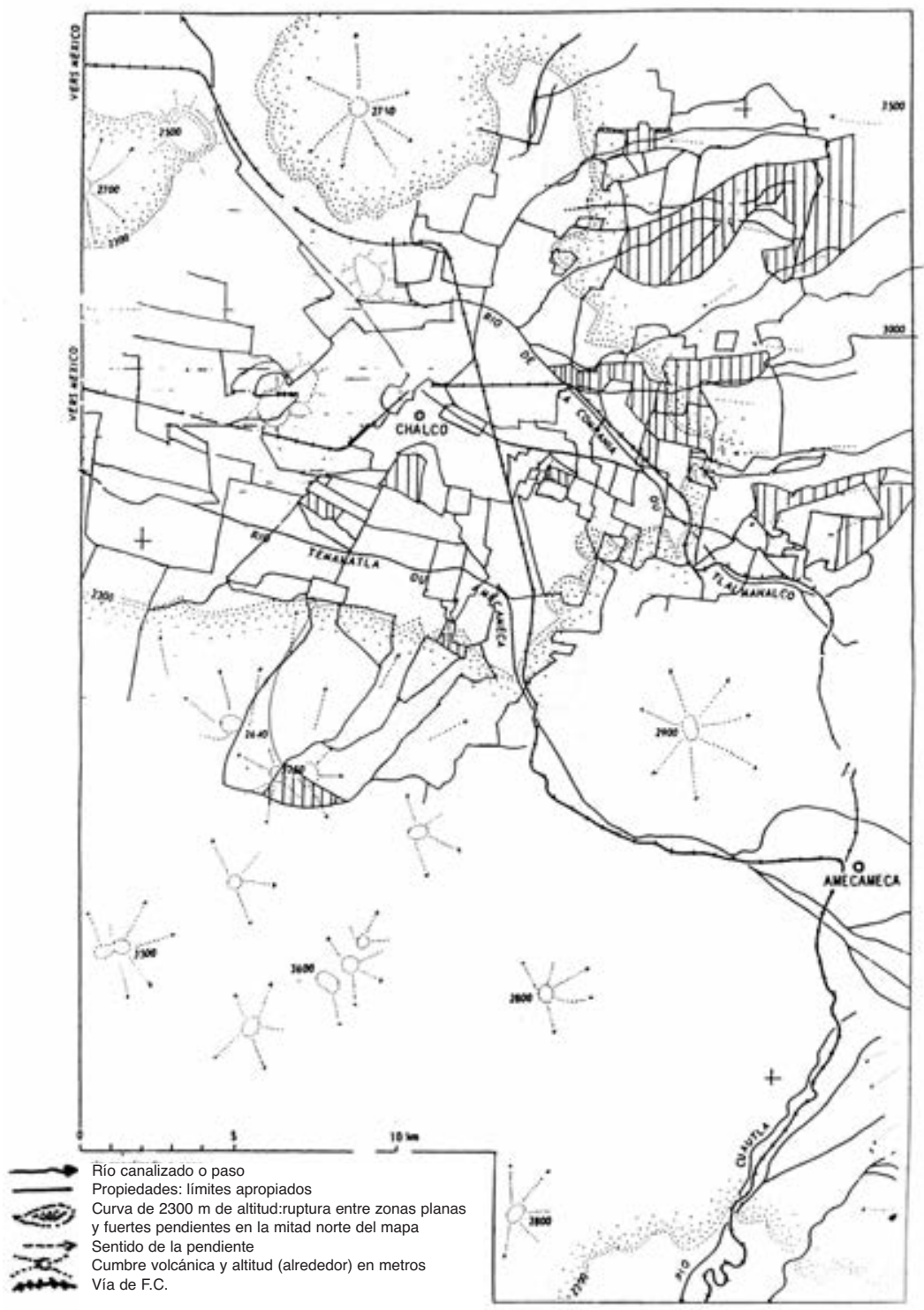


En Morelos, la estructura agraria durante el porfiriato mostraba también un predominio aplastante de las haciendas. En 1912 estas haciendas se extienden sobre el $63 \%$ de la superficie territorial del estado, ocupando las mejores tierras, aptas para el cultivo, sobre todo las irrigadas. Los ranchos, en su mayoría, son parte integrante de las haciendas y ocupan las tierras marginales y periféricas. Los pueblos sólo ocupaban el $25 \%$ de la superficie del estado y más de la mitad de ellos se situaban en la franja montañosa de la región norte, donde era muy difícil acceder al agua puesto que, en un espacio de algunos kilómetros, la pendiente de la zona descendía de 3000 a 1600 metros.

Aquí los Noriega habían vendido su hacienda de Coahuistla a Joaquín Araoz al despuntar el siglo, y quizá con buen tino, porque el primer pueblo que recibe tierras como consecuencia del reparto agrario en Morelos es Anenecuilco, la tierra de Zapata, a costa de haciendas como Coahuistla. En 1920 recibe 600 hectáreas y luego, en abril de 1923, 700 más que eran antiguamente tierras de Coahuistla y de Hospital. En 1936 Anenecuilco poseía 4105 hectáreas, que representaban la superficie de una hacienda de la región.

En conjunto, en el estado de Morelos, a partir de 1922 se practica una reforma agraria que en unos cuantos años, entre 1922 y 1929, beneficia a 25668 ejidatarios entregándoles 208522 hectáreas. El objetivo era convertir la lucha armada en una lucha ante los tribunales, desmantelando las haciendas para dotar a los habitantes de los pueblos. La casi totalidad del espacio hacendario se distribuye entre los pobladores morelenses. Las superficies ejidales representan el $64 \%$ del espacio cultivado en 1930 y alcanzan el $80 \%$ en 1940, cuando el reparto cardenista ha completado la transformación espacial de la región. Aquí el reparto es mas rápido y profundo que a escala nacional, puesto que la talla media de tierras distribuidas a los ejidatarios es de 9,3 hectáreas.

Las haciendas, por su parte, se restituyen a sus antiguos dueños en 1919, pero en condiciones deplorables. Los edificios, ingenios, canales de irrigación y maquinaria son parcial o totalmente destruidos por efecto de la Revolución. De 39 haciendas registradas en 1910, once años después no hay más que 5 que se registran en los censos como tales, 21 cambian su estatus convirtiéndose en villas, congregaciones o rancherías y once han desaparecido. En 1940 sólo tres haciendas sobreviven a la Revolución y a la reforma agraria: Santa Clara, Tenango y Cuachichinola. 
El esplendor de la hacienda morelense, visto en dos indicadores, la producción y la riqueza, cambia drásticamente con la Revolución. En efecto, Morelos produce en 1870 la cantidad de 9912 toneladas de azúcar, en 1889 son 20615 y en 1908 se alcanza la enorme cifra de $52230 .{ }^{36}$ La innovación tecnológica había sentado sus reales en Morelos y la había convertido en una de las regiones azucareras más productivas del mundo. ${ }^{37} \mathrm{La}$ élite azucarera explota esta riqueza, como la familia Amor, con sus haciendas de San Gabriel, San Ignacio y Michapa, extendidas sobre unas 36495 hectáreas, la familia Araoz, propietaria de Coahuixtla y Treinta, con 21607 hectáreas, los Pasquel, con sus haciendas de Miacatlán y Cocoyotla. Esta élite ya ha sido retratada por J. Womack, ${ }^{38}$ pero nuevos datos nos muestran como algunos hacendados de Morelos, como Jorge Carmona, propietario de Chiconcuac, San Gaspar y San Vicente, se daban el lujo de vivir en uno de los mejores barrios de París, gracias en buena medida a la fortuna generada por sus haciendas. En efecto, Carmona parte a París en compañía de su esposa Dolores Arriaga en 1876 y vive allí hasta finalizar el siglo. Su fortuna le permitía vivir en París, en el número 5 de la avenida Hoche, donde complacía a la aristocracia parisina con grandes fiestas. ${ }^{39}$ Se trata, en suma, de una élite terrateniente cosmopolita para quien la hacienda es un gran negocio.

Sin embargo, con la Revolución encontramos que en 1927 sólo cinco ingenios funcionan y en 1930 la producción de azúcar apenas alcanza 15500 toneladas. La Revolución significó, entonces, la ruina del sistema de la hacienda azucarera. La elección de Cárdenas en 1934 impulsa una forma de organización cooperativa para hacer producir los ingenios. Se crea un organismo

36 Ruiz (1937), pp. 134 y 271.

37 Díez (1919, p. 14) menciona que hacia 1910 Morelos era la tercera región más productora de azúcar por kilómetro cuadrado. Detrás de Hawai, con 56332 kilos, Puerto Rico, con 31315, luego Morelos, con 10635 , lo que la ubica delante de Java (10504) y Cuba (10 010).

38 Womack (1972), p. 48, anota que, hacia 1908, 17 propietarios de fincas azucareras controlaban mas del $25 \%$ de la superficie del estado, la mayor parte de las tierras de cultivo y de casi todas sus tierras buenas.

39 Bertie menciona que esto distingue a Carmona de los otros notables mexicanos en Francia, el "savoir-vivre». En sus palabras, «Malgré ses riches haciendas de San Gaspar et San Vicente, où il a aussi une grande raffinerie de sucres, fonctionnant avec les excellents appareils de Séraphin frères, M. Georges Carmona préfére le voisinage du Parc Monceau et des Champs-Elysées au chaos de montagnes, aux fourrés de palmiers, à la savane et aux forêts vierges» (Bertie, 1886, p. 149). Para una semblanza de Jorge Carmona, véase Paz (1888) y Canales (2001). 
encargado de la gestión financiera de los gastos agrícolas, de la regulación y el aprovechamiento del mercado interno y de la comercialización (UNPASA, Unión Nacional de Productores de Azúcar, S. A.), y se crean complejos industriales azucareros, como el Ingenio Emiliano Zapata en Zacatepec. Esto constituye un primer paso para la toma de control por el Estado del sector agroindustrial azucarero a través del origen del financiamiento y la gestión.

¿Podemos generalizar que la reforma agraria había destruido la mayor parte de las grandes fortunas construidas por los hacendados porfiristas, como sucedió en Chalco y en Morelos? La respuesta es negativa hasta por lo menos el final de la década de los treinta, cuando sólo se habían distribuido el $4 \%$ del total de tierras cultivables en el país como resultado de la reforma agraria. ${ }^{40}$ Por lo mismo, el presidente Calles, figura máxima del periodo, declaraba que la reforma agraria había sido un fracaso y que era necesario terminar con la distribución de tierras. ${ }^{41}$

Dos elementos son importantes para explicar por qué en Chalco y en Morelos la reforma agraria es tan rápida, violenta y diferente a otras zonas del país. El primero es la fuerza del zapatismo, que irrumpe prácticamente en toda esta zona. ${ }^{42}$ Los soldados zapatistas sólo estaban dispuestos a cambiar los fusiles por tierras. El segundo es la existencia de una élite de hacendados de origen español. Si la Revolución mexicana fue una lucha contra la hacienda, en el fondo no lo era contra todas las haciendas, sino particu-

40 Esta situación es compartida por diferentes países donde se hace una reforma agraria. El trabajo de Mónica Blanco incluido en este volumen muestra que para la provincia de Buenos Aires el discurso revolucionario es radical, sin hacerse efectivo en la práctica. La reforma agraria no es inmediata, las grandes fortunas permanecen a salvo y los grandes propietarios aprovechan la división de los reformadores (algunos radicales, otros productivistas, etc.) para permanecer a salvo. Por lo anterior, no es extraño encontrar cifras como las que hallamos en el trabajo de V. Bretón, también incluido en este volumen, donde muestra que las asignaciones habían beneficiado al 74,5\% del campesinado en Bolivia hasta 1977, al 43\% en México hasta 1970 y al 30\% en Perú hasta 1982.

41 Haber, Razo y Maurer (2003), p. 287.

42 En México la fuerza de la Revolución le da una dinámica interna al reparto de tierras que la hace distinta a otras reformas agrarias. Si en otros países latinoamericanos el análisis de la relación entre reforma agraria y contexto externo (los modelos económicos, el consenso de Washington, las ideas de la CEPAL) es útil para entender el reparto, como nos lo muestra el trabajo incluido en este volumen de V. Bretón, en México la dinámica interna que hemos analizado (los ideólogos como Molina Enríquez y los grupos revolucionarios) le imprime un carácter propio. 
larmente contra los hacendados originarios de la Península Ibérica. ${ }^{43}$ Por esto no es extraño observar en el cuadro 2, que la reforma agraria casi no toca estados como Nayarit, Puebla, Quintana Roo, Tabasco, Tlaxcala, Colima, Chiapas, el Distrito Federal, Baja California y Aguascalientes.

CUADRO 2

DOTACIÓN DE TIERRAS POR ENTIDAD, 1900-1940 (MILES DE HECTÁREAS)

\begin{tabular}{|l|c|c|r|r|r|l|}
\hline Entidad & $1900-1914$ & $\%$ & $1915-1934$ & $\%$ & $1935-1940$ & \multicolumn{1}{c|}{$\%$} \\
\hline Aguascalientes & 204 & & 77824 & 0,7 & 121971 & 0,64 \\
Baja California & & & & & 169234 & \multicolumn{1}{c|}{0,9} \\
Baja California Sur & & & 24694 & 0,22 & 24964 & 0,13 \\
Campeche & & & 270044 & 2,46 & 1472103 & 7,83 \\
Coahuila & 89993 & 46,27 & 309087 & 2,81 & 1051053 & 5,59 \\
Colima & & & 24533 & 0,22 & 100683 & 0,53 \\
Chiapas & & & 2244 & 0,02 & 30247 & 0,16 \\
Chihuahua & 774 & 0,3 & 1945414 & 17,72 & 1281225 & 6,82 \\
Distrito Federal & & & 23674 & 0,21 & 6762 & 0,03 \\
Durango & 23611 & 12,13 & 847011 & 7,71 & 1394661 & 7,42 \\
Guanajuato & 981 & 0,5 & 224992 & 2,04 & 636533 & 3,38 \\
Guerrero & & & 509966 & 4,64 & 569203 & 3,02 \\
Hidalgo & 739 & 0,3 & 473746 & 4,31 & 266051 & 1,41 \\
Jalisco & 8585 & 4,41 & 359391 & 3,27 & 1020173 & 5,43 \\
México & 5233 & 2,69 & 521542 & 4,75 & 341083 & 1,81 \\
Michoacán & 10209 & 5,24 & 308017 & 2,8 & 1074750 & 5,72 \\
Morelos & & & 225949 & 2,05 & 66951 & 0,35 \\
Nayarit & & & 130097 & 1,18 & 448956 & 2,38 \\
Nuevo León & 4326 & 2,22 & 160480 & 1,46 & 674125 & 3,58 \\
Oaxaca & 3712 & 1,9 & 163987 & 1,49 & 597866 & 3,18 \\
Puebla & 5122 & 2,63 & 63098 & 0,57 & 389821 & 2,07 \\
Querétaro & 200 & 0,1 & 131864 & 1,2 & 291264 & 1,55 \\
Quintana Roo & 2635 & 1,35 & 14973 & 0,13 & 433614 & 2,3 \\
San Luis Potosí & 4370 & 2,24 & 935863 & 8,52 & 1752461 & 9,32 \\
Sinaloa & 7319 & 3,76 & 187728 & 1,71 & 619105 & 3,29 \\
Sonora & & & & & & \\
Tabasco & 2635 & 1,35 & 28970 & 0,26 & 460257 & 2,44 \\
Tamaulipas & 1787 & 0,91 & 204509 & 1,86 & 537476 & 2,86 \\
Tlaxcala & 700 & 0,35 & 88706 & 0,8 & 98589 & 0,52 \\
Veracruz & 4,21 & 552115 & 5,03 & 516750 & 2,75 \\
Yucatán & 0,35 & 734000 & 6,68 & 520900 & 2,77 \\
Zacatecas & 4,4 & 784321 & 7,14 & 927073 & 4,93 \\
No especificada & 2 & 647304 & 5,89 & 890227 & 4,73 \\
Total & 194495 & 100 & & 100 & 18786131 & 100 \\
\hline
\end{tabular}

FUENTE: EHM (1990), p. 19.

43 Francisco Villa, por ejemplo, no toca las haciendas de propietarios norteamericanos, ni tampoco las de la familia Madero (Katz, 1998, p. 413). 
En forma general, la hacienda quedó a salvo hasta por lo menos 1930. ${ }^{44}$ Esto se explica por varias razones. La primera es que en algunos estados se pone en práctica el modelo villista de administrar las haciendas confiscadas por soldados revolucionarios. Esto es particularmente cierto bajo el control carrancista de Sonora, pero también en Durango, Zacatecas y en menor medida en San Luis Potosí. ${ }^{45}$ En segundo lugar, los generales revolucionarios se alían con los antiguos propietarios, ya que a cambio de otorgar protección reciben importantes cantidades de dinero, ${ }^{46}$ cuando no se convierten ellos mismos en propietarios de haciendas. ${ }^{47}$ En tercer lugar, para no desmantelar el aparato productivo en una época de inestabilidad, fue necesario no fraccionar las grandes propiedades. Al parecer, el campo mexicano responde a la demanda de los mercados internos y externos durante el periodo revolucionario y esto se debe, en buena parte, a la alianza entre militares y antiguos propietarios para no desmantelar la hacienda. ${ }^{48}$

Estos factores inciden en la timidez del reparto, por lo que no será sino durante la presidencia de Lázaro Cárdenas (1934-1940) cuando se incremente en forma notable. Hasta 1935, la superficie afectada por la reforma agraria era de 10,8 millones de hectáreas, de las cuales 2,8 millones correspondían a tierras cultivadas, repartidas entre 545000 familias,

44 El censo de 1930 muestra que el $83 \%$ de la tierra cultivable estaba en poder de explotaciones de más de mil hectáreas. Estas explotaciones eran propiedad del 1,5\% de cultivadores. Un $12 \%$ adicional de la tierra se concentraba en explotaciones de 101 a 1000 hectáreas (Haber, Razo y Maurer, 2003, p. 313).

45 Haber, Razo y Maurer (2003), p. 301.

46 Gruening (1928), p. 319.

47 Villa mismo se convierte en propietario de la hacienda de Canutillo; A. Obregón se convierte en exportador de garbanzos y gran propietario en Sonora; P. E. Calles se convierte en propietario de fincas azucareras en El Mante. Hasta figuras de menor talla, como el general Guadalupe Sánchez, de Veracruz, adquiere fincas azucareras en Córdoba, Jalapa y Orizaba.

48 Ésta es la posición de Haber, Razo y Maurer (2003, p. 349), basada en las evidencias de las exportaciones de productos agrícolas a los Estados Unidos. México incrementa sus exportaciones de café, plátano, vegetales de temporada, y por primera vez es un exportador neto de azúcar y algodón. Sólo el henequén sufre menoscabo, pero no por problemas de los hacendados yucatecos, sino por la competencia asiática y africana. El maíz, frijol y productos de consumo interno tampoco parecen tener grandes alteraciones. No hay importaciones masivas de estos productos de los Estados Unidos, en cambio en frijol México es un exportador neto. 
es decir, 5 hectáreas de promedio por familia. ${ }^{49}$ Con Cárdenas, el reparto asciende a más de 17 millones de hectáreas, entregadas a 814537 campesinos de los ejidos. El sueño de A. Molina Enríquez de construir un nacionalismo a partir de la propiedad de la tierra parecía al alcance de la mano. Su huella, entonces, es indeleble. Los derechos de propiedad cambian, entonces. Si las comunidades, para Molina, no tenían ninguna idea de la propiedad durante el porfiriato, a partir de la Revolución, y para sustentar sus demandas de tierras, la noción de propiedad se convierte en un elemento central.

\section{Comentarios finales}

La imprecisión de los derechos de propiedad durante el porfiriato es un elemento que obstaculiza el desarrollo económico de México. Su falta de especificación origina una gran acumulación de tierras y aguas por parte de los grandes propietarios. En este periodo el Gobierno hace intentos notables por definir con claridad estos derechos. Se toman medidas para privatizar la propiedad a través de políticas como la de deslindes de terrenos baldíos. Una quinta parte del territorio mexicano se convierte así en propiedad de grandes compañías. El costo social de esta gran concentración de la tierra es enorme, a juzgar por una de las revoluciones mas violentas del siglo XX, que sacude a México hacia 1911.

La política porfirista en materia de derechos de propiedad consistía en especificar las leyes para garantizar la propiedad privada, pero en negociar la aplicación de estas leyes. A los pueblos, por ejemplo, no se les tocan sus formas de organización comunal. De hecho, una de las bases de la larga vida del régimen porfirista fue la no aplicación de las leyes desamortizadoras a los pueblos. Si a los hacendados y a los grandes propietarios se les dan condiciones favorables para garantizar sus derechos de propiedad, esto genera una violenta crítica por parte de uno de los intelectuales mas importantes del siglo XX mexicano. Andrés Molina Enríquez observa esta situación de ventaja y oportunidad para la gran hacienda y detrimento para las otras formas de propiedad. Por

49 AHCL, DEEF, 73437.2, México, 1934. 
ello reacciona haciendo el diagnóstico del campo mexicano, donde la hacienda no es negocio.

Nada menos científico en su demostración, y a la vez nada más certero. La hacienda es un gran negocio para los notables del campo, como los Noriega, los Amor, los Araoz o los Carmona, pero también es cierto que los desequilibrios que generaba hacían extremadamente difícil la coexistencia de distintos actores del mundo rural. Los rancheros, por ejemplo, a menudo avecindados en tierras marginales de la hacienda, no tienen en su mayoría títulos de propiedad y dependen de acuerdos que establecen con los hacendados. Los habitantes de los pueblos, por su parte, deberían transformar sus propiedades comunales en privadas por efecto de la ley de 1856. La práctica, por contra, nos muestra que pocas comunidades lo logran al finalizar el siglo, lo que incide en una imprecisión sobre los derechos de propiedad. ${ }^{50}$

Frente a esta imprecisión, la hacienda emerge como la única explotación con títulos de propiedad y capacidad de negociación; por ello su colonialismo, que se expresa en el dominio de tierras, mercados y capitales. Este enorme poder es excluyente. Si los campesinos y rancheros participan en los trabajos de la hacienda, en cambio en la toma de decisiones es el hacendado quien emerge con el poder y el señorío del cual habla Molina. Nada mejor que la frase de los habitantes de Chalco cuando describen a Í. Noriega diciendo que era el «gran terrateniente que no nos dejaba pasar por sus fincas». ${ }^{51}$

La Revolución es una consecuencia de este desequilibrio, como también la reforma agraria, que sólo poco a poco erosiona el poder de los antiguos propietarios, inaugurando una nueva forma de tenencia de la tierra

50 Según F. Schenk (1991), por ejemplo, al finalizar el siglo se había repartido una parte mínima de los terrenos comunales en Sultepec y Toluca (Schenk, 1991, p. 264). Salinas (1993), por su parte, menciona que todavía en 1871 el gobernador del estado de México incitaba a los pueblos y autoridades municipales a practicar la repartición de terrenos comunales infructuosamente. Menegus (1995, p. 68) menciona que Ocoyoacac en 1890 no había cambiado mucho en las condiciones de propiedad de la tierra ni en la forma de cultivarla que existían en 1845. En el estado de Michoacán la situación era semejante (Knowlton, 1995, pp. 126-129). De las pocas excepciones que conocemos, es el caso de los vainilleros de Papantla (Kourí, 2004).

51 AHEM, CAM, 1921-1925, vol. 161.E.III-A-1, f. 13. 
donde el ejido se convierte en una piedra angular de la política. ${ }^{52}$ Esta reforma reequilibra la capacidad de negociación de los actores. La sociedad bipolar porfirista, compuesta por hacendados y peones, tiende a transformarse en otra donde el ejido, la pequeña propiedad, los bienes comunales y federales están en la base de una recomposición social y de una nueva capacidad de negociación de los actores, ahora agrupados en centrales campesinas y organizaciones ejidales.

Siglas

AHCL Archivo Histórico del Crédit Lyonnais (París).

AHEM, CAM Archivo Histórico del Estado de México, Comisión Agraria Mixta.

AHPARIBAS Archivo Histórico de la Banque de Paris et du Pays Bas (Francia).

EHM Estadísticas Históricas de México.

52 Hasta 1992 los ejidatarios eran usufructuarios de una propiedad de la nación que sólo se transmitía por herencia o decisión ejecutiva. La reforma del 92 otorga a ejidos y comunidades propiedad sobre la tierra. El ejido estaba compuesto por las tierras explotadas por los ejidatarios, el terreno donde se establecía la comunidad y pastos y leñas necesarios para la reproducción del campesinado. En 1991 es la base de la llamada propiedad social, que se extiende sobre 103,3 millones de hectáreas, es decir, el 59\% de la propiedad rústica del país. La propiedad privada, tierras irrigables de 50 a 100 ha, ocupa 71,7 millones de ha, es decir, el $41 \%$ de la propiedad. Hay 2,5 ejidatarios por cada propietario particular y cada ejidatario o comunero tiene en promedio 29,3 ha, frente a 50,8 de cada propietario privado (Warman, 2001, p. 77). 


\section{4. ¿GRANDES HACENDADOS O PEQUEÑOS AGRICULTORES? DEBATES Y RESULTADOS DE LA LEY DE TIERRAS DE 1876 EN LA PROVINCIA DE BUENOS AIRES (ARGENTINA)}

\section{Marta Valencia}

(Consejo Nacional de Investigaciones Científicas y Técnicas [CONICET], Centro de Estudios Histórico Rurales, Universidad Nacional de La Plata)

\section{Introducción}

Los grandes hacendados y los pequeños agricultores estuvieron presentes en la sociedad rioplatense desde los tiempos coloniales. ${ }^{1}$ La tensión entre favorecer a unos u otros atravesó casi todas las discusiones sobre el avance de la frontera productiva y la entrega de la tierra pública desde la creación del virreinato del Río de la Plata, a fines de la década de 1770, hasta el cierre de la frontera bélica con las tribus aborígenes un siglo después.

Con el reforzamiento del aparato administrativo de los Borbones en América a partir de la instalación del virrey en Buenos Aires, el litoral de

1 Para una revisión historiográfica, cf. Garavaglia y Gelman (1998) y Fradkin y Gel$\operatorname{man}(2004)$. 
los ríos cobró preeminencia sobre las regiones del interior, iniciándose una oleada pobladora que a partir de la instalación de fuertes sobre el río Salado logró expandir el hinterland del puerto, redefiniendo los límites con el mundo aborigen. La economía del nuevo virreinato se basaba en la exportación de plata del Alto Perú y, en menor medida, en la exportación de cueros. En los años que siguieron a la independencia se inició un proceso de fragmentación política en el que las luchas internas durante más de cincuenta años reflejaron las dificultades para la aceptación general de un modelo de organización estatal que contuviera los intereses de todos, salvo en el interregno del gobierno de Rosas, que a lo largo de diecisiete años consecutivos mantuvo la unión de las provincias imponiendo la paz desde Buenos Aires, que continuó ampliando su territorio en una complicada trama de relaciones con los indios que oscilaba entre la represión y la persuasión, según lo permitiera la disponibilidad de tropas en medio de las luchas intestinas y la propia dinámica de los cambios de liderazgo en las tribus de la pampa. ${ }^{2}$ En estas décadas la región se vinculó a los mercados internacionales a partir del comercio libre, apoyándose en la exportación de productos pecuarios, especialmente los provenientes de las tierras bonaerenses. ${ }^{3}$

Con la derrota del régimen rosista comenzó a organizarse el país a partir de la Constitución de 1853, aunque Buenos Aires se había marginado del proceso de integración que unió a las provincias del interior y el litoral en la Confederación Argentina. La inseguridad se adueñó nuevamente de la frontera y los aborígenes, pacíficos por espacio de bastante tiempo, volvieron a invadir las estancias, alcanzando el norte de la provincia. A partir de 1858 se estableció una línea que delimitaba el territorio controlado por el Gobierno, renovándose en los círculos políticos la inquietud por encontrar una solución definitiva al problema de la frontera. Al mismo tiempo, se consiguió la unidad política con la inclusión de Buenos Aires mediante la aceptación de la Constitución reformada en 1860 y con la consecuente nacionalización de las rentas aduaneras. Se crearon nuevas condiciones para la articulación de los intereses de los sectores dominantes del interior con el circuito económico que mantenía

2 Barba (1962a), (1962b) y (1962c) y Ratto (2003).

3 Amaral (1998). 
como eje el puerto de Buenos Aires y continuando la exportación de cueros, carne salada y sebo, mientras se iniciaba una febril incorporación de la producción lanar.

A fines de la década de 1870 la última etapa de la incorporación de tierras la protagonizaron Adolfo Alsina y Julio Roca, quien avanzó en forma definitiva sobre los dominios de los aborígenes, alcanzando hasta el río Negro. ${ }^{4} \mathrm{Al}$ calor de las nuevas oportunidades generadas por la revolución tecnológica europea y el constante aumento de la demanda de materias primas, la producción de lana alcanzó sus cifras más altas, se tendieron las primeras líneas férreas, con el aporte de las inversiones británicas, la incorporación de los inmigrantes europeos al mercado laboral y la utilización extensiva de la tierra con la continua expansión de la frontera. ${ }^{5}$

Este trabajo gira en torno a las discusiones y resultados del marco legal que rigió durante ochenta años en Buenos Aires sobre las tierras que se iban conquistando e incorporando a la estructura productiva. Se analiza la formación de grandes predios en el periodo 1820-1900 y los límites rigurosos que impuso la ley sancionada en 1876, después de intensos debates, para promover la subdivisión de la propiedad a través de la oferta de lotes cuya superficie contrastaba con la estipulada por la legislación que la precedió. Se ubica esta medida legal dentro del contexto de otros dos intentos de reformar la política de tierras: las donaciones de «suertes de estancias» en 1832 y la creación de centros agrícolas en 1887. Se observará el papel de las instituciones estatales, su influencia sobre los derechos de propiedad y sobre la actividad económica, poniendo el acento en su escasa organización debido a la situación embrionaria del estado provincial, que les dificultó diseñar un eficiente aparato de control para garantizar la aplicación de las normas. ${ }^{6}$ Para ello se exponen las políticas sobre tierras públicas implementadas en la provincia de Buenos Aires desde 1810 hasta fines del siglo, teniendo en cuenta que la superficie ocupada en ese lapso pasó de 2 a 31 millones de hectáreas.

\footnotetext{
4 Heras y Barba (1962) y Barba (1976).

5 Amaral (2001), Barba (1995) y Sabato (1989).

6 Amaral (1998), pp. 146-156.
} 


\section{La legislación de tierras públicas en la provincia de Buenos Aires y la estructura de las tenencias}

En los años posteriores a la independencia, el espacio ocupado y poblado en la provincia abarcaba desde la zona costera al río de la Plata hasta la frontera natural que constituía el río Salado, sobre la que se encontraba la línea de fortines. Allí se habían radicado los antiguos pobladores, quienes durante los primeros veinte años del siglo XIX, con cierta lentitud, fueron perfeccionando los títulos de propiedad mediante la utilización de los sistemas coloniales de venta y moderada composición, además de las donaciones del Directorio entre los años 1818 y 1822. Al mismo tiempo, ocupantes sin títulos poblaban las tierras baldías, problema que preocupó a los sucesivos gobiernos hasta prácticamente fines de siglo.

A partir de 1820 las políticas implementadas desde el Gobierno provincial se basaron en dos sistemas, donaciones - condicionadas e incondicionadas-y enfiteusis. ${ }^{7}$ En 1821 se suspendieron las denuncias y entregas de títulos de propiedad, porque las tierras se constituyeron en garantía de la deuda pública; al año siguiente se instauró el contrato enfitéutico para explotarlas, mediante el cual se transfirieron alrededor de siete millones de hectáreas hasta 1840 , ubicándose la mayor cantidad de contratos al sur del río Salado. En la década de 1830 también se acentuó la apropiación plena a través de donaciones condicionadas (que obligaban a poblar con ganado, edificar y plantar árboles) e incondicionadas (en pago de servicios al Estado en la lucha contra los indios y de la fidelidad política al gobernador Rosas). Entre las primeras se encuentra el reparto gratuito de «suertes de estancias» (2025 hectáreas), ${ }^{8}$ pensado para aplicarse a lo largo de la frontera interior de la provincia con el objetivo de contribuir a su defensa, pero que en la realidad sólo se concretó en Azul. En este caso, aunque investigaciones anteriores señalaron la tardía escrituración de las suertes y las escasas personas que lo lograron, ${ }^{9}$ se está explorando la hipótesis referida a la coexistencia, durante el rosismo, de una estructura agra-

7 Infesta (2003).

8 La suerte de estancia era una porción de tierra que, según los cálculos de la época, permitía cubrir las necesidades de reproducción de una familia que poblara la campaña de Buenos Aires dedicada a la cría de ganado vacuno (Garavaglia, 1999a).

9 Infesta (1994). 
ria latifundista con la pequeña y mediana tenencia rural. ${ }^{10}$ Las nuevas investigaciones permiten aseverar que durante la época de Rosas las políticas de tierras realizadas tuvieron una intencionalidad bifronte: las donaciones de suertes habrían favorecido a los pequeños y medianos propietarios, mientras que los sectores más acomodados pudieron sacar mejor provecho de la enfiteusis y las ventas posteriores. La intención del Estado mediante las donaciones de suertes fue la de contribuir al poblamiento local en una zona de frontera, porque fueron apropiadas y puestas en producción sin necesidad de una retribución monetaria. ${ }^{11}$

Con respecto a las donaciones incondicionadas, entre 1834 y 1852 se entregaron por combates contra los indios. Este tipo de premios era común en la época porque el erario no contaba con fondos para pagar esos servicios. Los certificados entraron en el circuito de intercambios de derechos de posesión, de modo que los inversores podían montar una estancia comprando estos papeles a sus titulares. Diferentes en su esencia fueron los premios a la fidelidad al gobernador Juan Manuel de Rosas, quien en plena dictadura los otorgó a aquellas personas que se habían mantenido a su lado en los momentos difíciles del alzamiento en su contra de $1839 .{ }^{12}$ Estos boletos o certificados sirvieron para acceder a la propiedad de las tierras en enfiteusis porque el gobernador los habilitó como único medio posible para adquirirlas. ${ }^{13}$

En 1836 se sancionó la Ley de Ventas de Tierras Públicas y la mayor parte de la concedida en enfiteusis fue adquirida por los mismos usufructuarios. A partir del año 1840, sólo se registraron algunas pocas escrituras. La enfiteusis había cesado virtualmente al impedirse la renovación de los contratos en la mejor zona de la provincia; no obstante, tanto los favorecidos por premios como muchos ex enfiteutas quedaron con trámites inconclusos al suspenderse las transacciones, al igual que los derechos de los perseguidos políticos pendientes de resolución, dado que en la década

10 Lanteri (2002) y (2004).

11 Lanteri (2005).

12 La llamada "Revolución del Sur» fue un levantamiento armado de un grupo de terratenientes que se oponían a la política económica de Rosas. Una reciente revisión del tema, en Gelman (2002).

13 Infesta y Valencia (1987). 
de 1840 gran cantidad de enemigos del régimen rosista debieron exiliarse por temor a perder su vida y la mayoría de ellos tenían intereses vinculados con las tierras públicas. ${ }^{14}$

Después de la caída de Rosas en 1852 subsistieron problemas políticos que impidieron la unidad del país durante más de una década. Sin embargo, en esos años se inició una nueva etapa en la que se operaron sucesivas transformaciones relacionadas estrechamente con los cambios producidos en las economías metropolitanas, donde el incremento en la producción de manufacturas incidió en la búsqueda de nuevos mercados y de proveedores de materias primas para sus industrias, de manera que Buenos Aires, a través de la lana, se vinculó muy fuertemente al mercado internacional. El negocio amistoso con los indios que había practicado Rosas se terminó con su derrota en la batalla de Caseros y se produjo un retroceso en la frontera porque las luchas provinciales obligaron a desproteger los fuertes fronterizos con los aborígenes; éstos realizaron numerosas incursiones que forzaron al abandono de los campos, reduciéndose significativamente la extensión de la provincia, por lo que a partir de 1857 se buscó ampliar el espacio ocupado implantando el sistema de arriendo público en lugar de la enfiteusis. ${ }^{15}$ Para esto era necesario clarificar derechos que habían quedado pendientes de la etapa anterior: múltiples reclamos efectuados por los ex enfiteutas, los embargados, los exiliados con trámites incompletos y los ocupantes sin títulos. En el texto legal promulgado se admitió la posibilidad de fijar los contratos por un periodo más corto que el que había regido para la enfiteusis: las tierras se otorgarían por el término de ocho años, reservándose el Estado la potestad de venderlas en el ínterin, en cuyo caso tendría derecho de preferencia el arrendatario; se estipularon un precio máximo y uno mínimo para las tierras arrendadas dentro de la frontera, y más allá de este límite se exceptuó el pago, pero a cambio de ciertas condiciones de población. Esta legislación debía permitir, además, la incorporación de tierras a la estructura productiva sin lesionar los derechos de los ocupantes que desde décadas atrás se encontraban radicados sin títulos.

14 Infesta (2003) y Valencia (2005).

15 Durante el rosismo se había aplicado una política de entrega de raciones alimenticias, yeguas, tabaco y alcohol a las tribus indígenas que se avinieran a mantener la tranquilidad en la frontera. Cf. Ratto (1994) y (1998) y Bechis (1998). 
El sistema de arriendo, establecido por la ley de 1857, hizo posible tanto la regularización de las situaciones de los tenedores precarios de la tierra pública como la ampliación de la zona productiva, pues hasta 1876 se firmaron contratos por alrededor de cinco millones de hectáreas - la mayor cantidad situadas fuera de la frontera- para una superficie ocupada en la provincia que previamente a esta disposición legal era de once millones. Esta ley, previendo la concentración de tierras en pocas manos, fijó límites para su obtención. Los autores clásicos estimaron que su aplicación había posibilitado la formación de latifundios. La estructura de las tenencias en arriendo mostró, contrariamente a lo afirmado, que la Ley de Arrendamientos no promovió la acumulación de la tierra en pocas manos en la misma medida que la enfiteusis. ${ }^{16}$

Entre 1864 y 1878 se sancionaron normas legales por las cuales se decidió la venta de las tierras arrendadas a los particulares. Se había señalado que la implementación del sistema de arriendo permitió, en parte, la regularización de las situaciones de los tenedores precarios de la tierra pública. Las transferencias a manos privadas completaron dicho ordenamiento, poniendo fin —o por lo menos límites más rigurosos - a los ocupantes sin títulos, que permanecían usufructuándolas amparados, en algunos casos, en derechos de origen dudoso, en litigios de larga data signados por una tramitación lenta y deficiente o, simplemente, en la posibilidad de eludir todo control oficial en una campaña donde la organización institucional era todavía débil, las municipalidades no estaban organizadas en todos los partidos y, si lo estaban, no funcionaban del todo bien. ${ }^{17}$ La justicia de paz tomaba todas las decisiones obrando como delegada del poder central. ${ }^{18}$

16 Valencia (2005), pp. 94-95.

17 La organización político-administrativa de la campaña bonaerense, que estaba dividida en distritos denominados "partidos», se basó en una ley de 16 de octubre de 1854, que establecía que el régimen económico y administrativo estaría a cargo de una municipalidad compuesta por el juez de paz y cuatro propietarios vecinos. Los cuatro municipales eran electos por el voto de todos los vecinos de la localidad y el juez de paz era nombrado por el poder ejecutivo provincial de una terna propuesta por la municipalidad. Heras (1949) y Barba (1976).

18 Los juzgados de paz fueron organizados en 1821 después de la supresión de los cabildos en la provincia de Buenos Aires. Las atribuciones de los jueces de paz eran muy amplias, tanto que el juez se convirtió en el nexo entre las autoridades locales y los poderes provinciales, a la vez que se vinculaba con los pares de cada partido. Reunía en su persona las funciones legislativas, ejecutivas y judiciales, que fueron variando a través del tiempo por los cambios en la organización política de la campaña y de la ciudad. Garavaglia (1999b) y (1999c). 
Más aún, se registraron muchas acusaciones sobre el rol de los jueces de paz, dado que tenían amplios poderes en lo referente al cumplimiento de muchas de las pautas de la legislación terrera. Fueron los encargados de extender los certificados de población exigidos en cada norma legal dictada para corroborar que efectivamente las parcelas estaban con ganados y edificaciones, porque era bastante común que se obtuvieran tierras sin otro motivo que esperar su valorización, sin ocuparse de fundar establecimientos productivos. En los periódicos y en los debates se escucharon muchas voces denunciando a los jueces por extender certificados falsos. La campaña de Buenos Aires, tan extensa y dilatada, con sus fronteras siempre en riesgo, era muy difícil de vigilar o inspeccionar y las autoridades residentes en la capital delegaban el control, en buena parte, en estas autoridades locales. ${ }^{19}$

La ley sancionada en 1864 estipuló que los arrendatarios podrían solicitar la compra estableciendo un mismo plazo para todos los ocupantes y tomando como referencia los precios para las tierras públicas fijados por un decreto de 1862 en moneda corriente, los cuales, expresados en oro dos años después, se habían reducido levemente. El precio de la tierra pública en el interior del Salado subió vertiginosamente entre 1857 y 1862, duplicando su valor. En el exterior del Salado, después de un incremento entre 1859 y 1862, bajó constantemente para todas las zonas hasta $1871 .{ }^{20} \mathrm{En}$ realidad, las diferencias entre las leyes de ventas sancionadas en este periodo se encontraron básicamente en el precio fijado a la tierra, los plazos otorgados a los adquirentes y las posibilidades de concentración de la tierra que consintieron. La aplicación de esta norma legal encontró varios obstáculos, en primer lugar porque saturó el mercado al ofrecer en venta una gran cantidad de tierras. Por otro lado, los arrendatarios públicos, aun los que habían suscripto sus contratos recientemente, debían presentarse a comprar, pero los alquileres bajos contrastaban con el alto precio estipulado para la venta; en consecuencia, se concretaron muy pocas operaciones porque los arrendatarios de Buenos Aires consideraron exagerados los precios estipulados y pidieron la suspensión de la medida.

La oferta de tierras de 1864 se enmarcaba en los prolegómenos de la crisis de sobreproducción lanera desatada en 1866 a raíz de la pérdida del

19 Banzato y Valencia (2005).

20 Valencia (2005), p. 106. 
mercado estadounidense y del excedente en Amberes, destinos privilegiados de la lana argentina, que coronaron la sucesión de dificultades que afectaron a este sector. ${ }^{21}$ Los estancieros con intereses en este rubro y que aumentaron su patrimonio o lo crearon con los arrendamientos públicos, fundaron la Sociedad Rural Argentina, institución que los representaba en su relación con el Estado. ${ }^{22}$ La composición de la entidad era heterogénea, pues sus integrantes, además de propietarios rurales, eran políticos destacados que ocuparon altos cargos en el poder ejecutivo o legislativo, financistas, comerciantes y empresarios. La Sociedad Rural Argentina estableció conexiones con el poder legislativo provincial durante la etapa fundacional mediante la actuación de sus miembros más relevantes. Entre 1866 y 1871 treinta y dos ruralistas formaron parte de la Cámara de Diputados y dieciséis fueron electos para el Senado, más tarde aumentaron su participación. La vanguardia de la Sociedad Rural consideraba al poder legislativo como un ámbito muy preciado; así lo expresaban en Anales, su publicación institucional periódica, en la que exhortaban a secundar la acción del Gobierno mediante la sanción de leyes que interesaban a todos los terratenientes. ${ }^{23}$

En 1866, dos años después de otorgadas sucesivas prórrogas para la aplicación de la ley, comenzó la discusión de otro proyecto de venta que involucraba a las mismas tierras. Este debate se dio en medio de la crisis que afectaba precisamente a los productores rurales dedicados al ovino y que eran, a su vez, arrendatarios públicos. En enero de 1867 el Gobierno dispuso la venta de las parcelas del interior de la línea de frontera, que fueron divididas en diferentes secciones. Los precios estipulados se relacionaron con su calidad y ubicación. Los arrendatarios tenían que comprar los campos dentro de los noventa días a partir del vencimiento de los contratos. Así, se transfirieron al dominio privado alrededor de 1700000 hectáreas. El porcentaje más alto de los adquirentes fueron los arrendatarios públicos, pero también el Estado accedió a vender a una cantidad de personas que ofrecían pagar los alquileres atrasados desde el momento en que habían iniciado su trámite. Además se enajenaron predios en pública

\footnotetext{
21 Sabato (1989).

22 Martínez Nogueira (1988), p. 295.

23 Valencia (2005).
} 
subasta y a los subarrendatarios. La multiplicidad de alternativas aceptadas evidencia que predominó el criterio oficial de transferir las tierras a manos privadas, tratando de resolver todas las cuestiones relacionadas con la discusión de derechos de ocupación. Si se analiza la estructura de tenencias formada después de esta venta, no se advierte que haya habido concentración de la propiedad.

Para agosto de 1871 se sancionó la ley de ventas de tierras arrendadas fuera de la frontera. Esta medida legal complementaba la anterior, aunque la decisión se basó en que era necesario recaudar fondos para hacer frente a los diversos compromisos contraídos por la provincia. También en ésta se dividió el territorio en secciones, de acuerdo con la calidad y ubicación, aunque el precio estipulado fue sensiblemente más bajo que en las otras ofertas. Los arrendatarios podían adquirir los predios que ocupaban en una superficie que no excediera las 16200 hectáreas y en plazos bastante cómodos. Para lograr estas ventajas, precios relativos más bajos y planes de pago accesibles, actuaron activamente en la legislatura de Buenos Aires los representantes más importantes de la Sociedad Rural Argentina. Su presidente y miembros conspicuos eran legisladores en los momentos en que se discutían estas leyes.

El total de la tierra vendida a partir de la sanción de la ley de 1871 fue de alrededor de cuatro millones de hectáreas, predominando las transacciones efectuadas por los arrendatarios públicos, aunque, como en el caso de la aplicación de la ley anterior, se resolvieron por vía de excepción las cuestiones suscitadas por los poseedores o concesionarios que tenían sus trámites terminados, y también se reconocieron como válidas las transferencias de derechos aunque no se encontraran protocolizadas. La localización de estas ventas se realizó en mayor medida en el noroeste y sur de la provincia, en tierras lindantes con el dominio de los indios. La estructura de tenencias formada en este caso permitió advertir una mayor concentración de la propiedad si se la compara con la delineada como consecuencia de la aplicación del arriendo y la venta de 1867, aunque menor que la producida por la venta de 1836 . No obstante, en la legislatura de Buenos Aires se denunciaron abusos en cuanto a la formación de grandes propiedades por la adquisición de superficies mayores que las que la ley autorizó. Para ello, los adquirentes contaron con la complacencia de los jueces de paz, que certificaron condiciones de población y otros requisitos que posibilitaron tales maniobras. La legislación terrera les señaló a estas 
autoridades un papel decisivo, porque eran las encargadas de fiscalizar el cumplimiento de un aspecto sustancial para acreditar el derecho de preferencia tanto para el arriendo como para la compra: que las tierras estuviesen efectivamente ocupadas, incluyendo edificaciones para vivir y ganado en cantidad suficiente para justificar la puesta en producción. Esta exigencia legal muchas veces no fue cumplida, porque los jueces extendían, para favorecer a unos y otros, certificaciones falsas.

Las tierras que no se vendieron por las leyes de 1867 y 1871 fueron incluidas en el proyecto de 1876, aunque tratando de promover la subdivisión de la propiedad. La base de dicha propuesta fue la oferta en pequeños lotes de 100 hectáreas, estableciendo topes máximos que evitaban la concentración. En esta oportunidad se enfrentaron concepciones opuestas, respecto de la política de tierras, entre ministros y legisladores que a su vez eran miembros de la Sociedad Rural. Roy Hora estudió especialmente la gestión de la corporación desde su etapa fundacional y hasta el siglo XX, señalando que, pese a que los empresarios rurales y el Estado tenían intereses y visiones de largo plazo en gran medida coincidentes, fundamentalmente para impulsar la expansión de la economía agraria en un marco institucional liberal, la existencia de distintos puntos de fricción entre ellos resulta un rasgo que no debe subestimarse. ${ }^{24}$

En 1878 se reiteró la oferta de tierras debido al poco éxito de la anterior; en este caso predominó la idea de no limitar la concentración de la propiedad. Se vendieron alrededor de tres millones de hectáreas. Los compradores lo hicieron en zonas reservadas por la ley de 1871, y con la aplicación de esta norma legal terminó el proceso de transferencia de las tierras arrendadas a los particulares. El 5 de octubre de 1878 el Parlamento nacional aprobó una ley que dispuso la incorporación definitiva e inmediata del territorio ocupado por los indios mediante una campaña militar cuyo costo se financió a través de un empréstito interno garantizado por las tierras a conquistar. Cada acción suscripta equivalía a 2500 hectáreas, enajenándose en manos de un mismo propietario un mínimo de $10000 \mathrm{y}$ un máximo de 30000 . En la provincia de Buenos Aires quedaba para ser distribuida la zona del oeste, que se dividió en cuatro secciones. En estos cuatro millones y medio de hectáreas que pasaron a los particulares se for-

24 Hora (2002), p. 16. 
maron grandes propiedades, algunos de los antiguos terratenientes adquirieron estas tierras y trasladaron allí sus planteles de ganado ovino. ${ }^{25}$

En 1887 se sancionó la Ley de Centros Agrícolas, destinada a fomentar los cultivos de cereales y a convertir en propietarios a los pequeños agricultores, tomando como base 2700 hectáreas que rodeaban las estaciones de ferrocarril y que estuvieran alejadas unos 100 kilómetros de la capital. Estos centros podrían formarse mediante expropiación o por iniciativa de los dueños de los campos. Así se expresó una especialista en el tema al evaluar los resultados de la aplicación de dicha legislación, producto de la política liberal positivista llevada adelante por los hombres de la generación del 80: «es una de las pocas disposiciones legales del siglo para la provincia de Buenos Aires — sin olvidar la Ley General de Tierras de 1876con tan altos objetivos, aunque difíciles de concretar en la práctica». ${ }^{26}$ Algunos factores coincidieron para que los resultados de esta medida legal fueran poco exitosos: problemas burocráticos, un proceso especulativo en torno a las tierras a partir de 1888 que desembocará en la crisis de 1890, etc.; así, sólo unos pocos centros dejaron saldos positivos.

A partir de la aplicación de las distintas leyes mencionadas se examina la estructura de la propiedad partiendo de aquellas medidas legales que promovieron la concentración. La historiografía sobre el tema ha denunciado la formación de latifundios sin hacer distinción espacio-temporal alguna. ${ }^{27}$ Sin embargo, cabe consignar que entre 1820 y 1840 la estructura de la propiedad formada por las donaciones del Directorio, los premios y la enfiteusis manifestó una marcada concentración de la propiedad, que fue disminuyendo con los arriendos y luego aumentó algo con las ventas de 1871. Las ventas de 1878 y las derivadas de la incorporación a la estructura productiva después de la campaña de Roca marcaron otra etapa de acumulación hasta fines del siglo, aunque todavía no se ha hecho una evaluación definitiva, si bien la mera observación de los registros gráficos

25 En la década de 1970, el equipo de trabajo dirigido por Enrique Mariano Barba trató la cuestión de la Campaña al Desierto y la distribución de tierras (Barba, 1975, 1977a y 1977b, y Barba et ál., 1974); Silvia Mallo (1979) realizó una puesta al día del tema en un contexto temporal más amplio; en tanto que los últimos trabajos de Susana Bandieri (2005) retoman el problema de la tierra para la Patagonia.

26 Girbal-Blacha (1980), p. 156.

27 Oddone (1967). 
revela grandes predios. Cabe señalar, sin embargo, dentro de este proceso la presencia de los pequeños y medianos adquirentes: con la enfiteusis, en 1827 , el $50 \%$ de las personas ( $8 \%$ de la tierra total) optó por tenencias de entre 1 y 5400 hectáreas, y en la venta de 1836 se ha señalado que los terrenos de dicho tamaño fueron comprados en proporciones significativas. ${ }^{28}$ En tanto que en los arriendos un $26 \%$ de las personas (7\% de la tierra total) escogió superficies de entre 1 y 2700 hectáreas, mientras que en 1871 un $18 \%$ de los particulares compraron el $5 \%$ de la tierra en parcelas inferiores a las 2700 hectáreas. $^{29}$

\section{Ganadería versus agricultura en los debates parlamentarios de la nación y la provincia}

El presidente Nicolás Avellaneda envió al Congreso nacional un proyecto en 1875 que se discutió durante dos periodos parlamentarios. Se disponía la exploración y subdivisión de las tierras de los territorios nacionales, practicando las mensuras de las tierras aptas para la colonización:

[...] la división básica, denominada sección, sería un cuadrado de 20 kilómetros de lado, dividido en cuatrocientos lotes. En cada sección se reservarían tierras destinadas a formar un pueblo, cuyas características eran detalladas. Todo debía ser mensurado y amojonado. Luego, por el Departamento de Inmigración se enviaban las familias, las cien primeras recibían gratis un lote de cien hectáreas, la tierra restante se enajenaba a plazos, a \$2 la hectárea no pudiendo reunirse más de cuatro lotes en una persona. ${ }^{30}$

En este proyecto se plasmaba el pensamiento del presidente, escrito y publicado en 1865 en su tesis doctoral sobre las tierras públicas. Decía entonces: «sóbranos tierra, fáltanos trabajo y capital [...] elementos que hemos de importar de afuera». Reconocía el legado intelectual de Adam Smith y se apoyaba en Jovellanos para argumentar a favor de que el Estado se desprendiera de los terrenos baldíos. La condición para que un pueblo fuera "próspero" era que la tierra se poblara y cultivara. Atacó lo que consideraba el efecto de una «supersticiosa codicia» que llevaba a los

\footnotetext{
28 Infesta (2003), pp. 71 y 134.

29 Valencia (2005), pp. 92 y 150-153.

30 Heras (1962), p. 248.
} 
gobiernos a retener la propiedad de la tierra baldía suponiendo que tenía un valor en sí misma. Siguiendo a Bastiat, argumentó que la tierra valía en tanto fuera trabajada y se invirtiera en ella un determinado capital. Avellaneda deseaba para lo que consideraba el desierto argentino el mismo horizonte que alcanzaron los Estados Unidos, la misma expansión, el mismo sistema de adquirir la tierra. Se preguntaba:

¿Por qué el sentimiento del hogar, el culto doméstico, ese amor que incrusta la vida del hombre con la piedra y con el árbol, con la sombra del bosque, con la plegaria de la tarde y la sonrisa del niño, cielo viviente que el hombre lleva en su corazón, y sobre el que le basta replegarse en las horas de fatiga y en los días de inquietud, para sentirse mecido por el murmullo de un mundo de felicidades; por qué, decimos, este sentimiento santo que multiplica y difunde la vida, se encuentra desenvuelto en el pueblo angloamericano con una intensidad, con una fuerza, con una universalidad desconocidas hasta hoy en la historia del género humano?

Y respondía: porque todos son propietarios, de manera tal que el hogar era el resultado y la glorificación de la propiedad. El padre que trabaja para obtener y defender la propiedad, la madre que engendra y cuida de la prole. Siguiendo entonces la experiencia internacional, proponía la venta directa como sistema más conveniente. ${ }^{31}$

Coincidiendo con la sanción en la esfera nacional de la llamada Ley Avellaneda de 1876, cuyo objetivo fue facilitar el acceso a la tierra a los agricultores y a los inmigrantes, comenzó a discutirse en la provincia de Buenos Aires un proyecto similar en lo relacionado con la subdivisión de la propiedad de las tierras públicas que se habían reservado y aún quedaban en arrendamiento. El proyecto fue enviado a la legislatura provincial durante el gobierno de Carlos Casares, un hacendado que también se dedicó a la política y que ocupó importantes cargos antes de llegar al poder ejecutivo de la provincia. ${ }^{32}$ La Convención Constituyente que se llevó a cabo en 1873 había señalado la necesidad de dictar una ley general de tierras que impulsara la inmigración y la colonización. ${ }^{33}$ El proyecto enviado al Senado provincial en septiembre de 1875 contenía ciertas similitudes con el nacional en lo relacionado con la mensura de las tierras, que se haría por secciones, divididas en lotes de 100 hectáreas, y ninguna persona o

\footnotetext{
31 Avellaneda (1915).

32 Heras (1962).

33 Barba (1976), p. 41.
} 
sociedad podría comprar en cada sección más de 800 hectáreas, ni se vendería menos de un lote. El poder ejecutivo podría limitar a un solo lote el derecho a la compra en los terrenos que estuvieran en condiciones de ser destinados a la agricultura. También se determinó que las personas que compraran por medios fraudulentos más extensión de tierra que la permitida, perderían el dinero y las parcelas.

Sobre un número total de dieciocho senadores provinciales, trece eran afiliados a la Sociedad Rural Argentina: Luis Sáenz Peña, que presidió la cámara en su carácter de vicegobernador, Torcuato de Alvear, Jacinto Arauz, Álvaro Barros, Manuel Gaché, Manuel J. de Guerrico, Luis A. Huergo, Alfredo Lahitte, Ventura Martínez, José Zoilo Miguens, José Miguel Núñez, Jorge Stegman y Carlos Urioste; también se agrega que el gobernador Casares y el ministro Rufino Varela eran integrantes de la corporación recientemente fundada. ${ }^{34}$ No obstante su pertenencia, manifestaron posiciones disímiles a la hora del debate. Huergo y Urioste formaron parte de la Comisión de Hacienda, sugiriendo reformas tendentes a morigerar las pautas del ejecutivo en cuanto a las cantidades de tierras que podía acumular cada comprador, "y la Comisión cree que estando estos terrenos situados en la frontera a grandes distancias de los centros de población, sin vías de comunicación no se pueden destinar a la agricultura», ${ }^{35}$ estimando que se debían aumentar las superficies de las parcelas ofrecidas. Por otro lado, Barros se opuso abiertamente a

34 Carlos Casares fue gobernador de la provincia entre 1875 y 1878 , director y presidente del Banco de la Provincia en varios periodos y adquirente de tierras del estado. Rufino Varela se destacó en el periodismo y la política, y Carlos Casares lo designó ministro de Hacienda en 1875. Luis Sáenz Peña fue legislador en Buenos Aires, diputado nacional, vicegobernador en Buenos Aires durante el gobierno de Casares, presidente del Banco de la Provincia y de la Municipalidad de Buenos Aires y, finalmente, presidente de la República. Torcuato de Alvear fue el primer intendente de la ciudad de Buenos Aires, donde realizó grandes planes de transformación urbana. Álvaro Barros, militar y funcionario público, combatió a los indios, escribió un libro sobre fronteras y territorios federales (Barros, 1957) y ocupó los cargos de diputado y gobernador de Buenos Aires. Manuel J. Guerrico, un importante terrateniente y empresario, también fue diputado y senador. Luis A. Huergo, ingeniero, realizó numerosas obras públicas y fue ministro de ese ramo en la provincia de Buenos Aires. Los restantes mencionados arriba fueron terratenientes y productores en la provincia. Cf. Cutolo (1969).

35 Diario de Sesiones de la Cámara de Senadores de la Provincia de Buenos Aires (en adelante, DSCSPBA), 7 de septiembre de 1875, p. 575. 
fomentar el desarrollo de la agricultura haciendo de esta industria nuestra fuente principal de producción es un propósito definido y manifestado en el proyecto de ley [...] Suprimir la ganadería para dar camino a la agricultura si no es un propósito determinado en él, se ve con la limitación dada a la propiedad de la tierra. ${ }^{36}$

A su vez, otros ruralistas apoyaron la propuesta del Ejecutivo: «la tierra no está entre nosotros al alcance de los agricultores. Es por esto que la agricultura no existe como debe existir», ${ }^{37}$ decía Torcuato de Alvear; en cuanto a Manuel Gaché, se presentó como agricultor, diciendo que representaba a la sección más agrícola de la provincia, integrada por los partidos de Chivilcoy, Chacabuco, Junín, Bragado y 25 de Mayo, ${ }^{38}$ agregando que

hasta hoy los ganaderos han logrado hacer triunfar sus opiniones, siempre que se ha tratado de la venta de la tierra pública esta se ha hecho en grandes áreas, y yo pregunto ¿qué resultado se ha obtenido, que bienes ha reportado al país? Pena me da decirlo, los beneficios que se han conseguido son la reproducción de los ganados mayores en la Provincia y la despoblación de la campaña. ${ }^{39}$

Rufino Varela, ministro de Hacienda, le refutó a Álvaro Barros, reeditando un antiguo enfrentamiento en el mismo sentido entre los integrantes de la Sociedad Rural. Aunque en distinta circunstancia, los argumentos esgrimidos por uno y otro fueron similares. Barros sugería seguir con el modelo de la gran propiedad apta para la actividad ganadera, que era predominante en la economía bonaerense, en tanto Varela defendía la subdivisión de la propiedad para dedicarla a la agricultura:

No es para las grandes fortunas, no es para los grandes capitalistas que debemos hacer leyes de tierras, y repito una frase que he tenido que decir otra vez: el estanciero no debe vender la tierra como especulación [...] nosotros debemos buscar al hombre de pequeño capital. ${ }^{40}$

36 Ibídem, p. 581.

37 Ibídem, p. 591.

38 Los partidos aludidos están ubicados en la región noroeste de la provincia de Buenos Aires. Entre ellos, Chivilcoy era uno de los distritos especializados en la agricultura. Cf. Birabent (1941). La historiografía debe aún un estudio exhaustivo sobre esta jurisdicción y los resultados de las políticas aplicadas en ella. Pese a lo expuesto por los legisladores, en los otros lugares mencionados predominaba todavía la ganadería, aunque las aspiraciones estaban dirigidas a incentivar la producción agrícola mediante distintos proyectos. En ese sentido, fue notorio el fracaso de algunos pobladores de Bragado en su intento de lograr la subdivisión de las tierras públicas para que quedaran al alcance de los agricultores. Cf. Valencia (1999).

39 DSCSPBA, p. 616.

40 Ibídem, p. 663. 
Pese a que la Sociedad Rural tenía a muchos de sus integrantes en el Senado, presentó una nota en la cámara firmada por su presidente y su secretario, José María Jurado y Julio Lacroze respectivamente, ${ }^{41}$ oponiéndose a la subdivisión de la propiedad y proponiendo que los lotes tuviesen como mínimo 1350 hectáreas y como máximo 8099, concediendo a cada comprador la cantidad de tierra que pudiera pagar al contado. Esto significaba una gran ventaja para los que contaban con mayores capitales. ${ }^{42}$

En la Cámara de Diputados el proyecto fue rechazado en la primera votación en general y, luego de la intervención de los ministros Rufino Varela y Aristóbulo del Valle, fue reconsiderado y aprobado: «una ley de esta importancia no se puede rechazar en general sin haber antes discutido», ${ }^{43}$ y agregó el ministro de hacienda Varela:

Se dice en apoyo a la oposición a esta ley que el indio invade la tierra que queremos vender. Que sea así, pero yo pregunto ¿cómo nos defenderemos, que barrera opondremos a sus irrupciones? El desierto? No, el desierto es su elemento; dejárselo libre sería conspirar a nuestra ruina [...] necesitamos poblar para reducir al salvaje [...] necesitamos población y civilización es lo que ha de producir al país la ley que presenta el Poder Ejecutivo. Se nos dice que vamos a vender una tierra que tiene el salvaje, que la domina, que vamos a vender una tierra para que el poblador que vaya a habitarla pierda a sus hijos y a su familia. No, esto no puede ser invocado como un argumento para rechazar el proyecto, se rechaza porque no se consagra el derecho de adquirir toda la extensión que los intereses privados anhelan [...] porque el proyecto de ley sólo autoriza la venta de la tierra en áreas de tres cuartos de legua cuando hay partidarios de que se vendan áreas de tres y seis leguas. ${ }^{44}$

Estos argumentos esbozados recogían el pensamiento, entre otros, de Domingo Faustino Sarmiento en su libro Facundo. Civilización y Barbarie, vida de Juan Facundo Quiroga, que fue publicado en 1845 en Chile, donde se encontraba exiliado a raíz de la persecución política durante la dictadura

41 José María Jurado fue una figura prominente dentro de la Sociedad Rural, ocupó los cargos de presidente y vicepresidente durante varios periodos y actuó también como vocal. En la esfera pública fue diputado y senador, director del Banco Hipotecario Nacional y de la Provincia de Buenos Aires. Realizó transacciones con tierras públicas logrando adquirir 21295 ha en los partidos de General Alvear y Tapalqué. Julio Lacroze también formó parte de las comisiones directivas de la sociedad como presidente y secretario. Cf. Cutolo (1969).

42 DSCSPBA, p. 684.

43 Diario de Sesiones de la Cámara de Diputados de la Provincia de Buenos Aires, 17 de julio de 1876 , p. 347.

44 Ibídem, pp. 349-350. 
rosista. ${ }^{45}$ En uno de sus capítulos describió el espacio argentino, dedicándose a señalar sus características, muy distintas entre sí, pero con un denominador común cuantitativo, la inmensidad, y otro cualitativo, el desierto:

La inmensa extensión del país, que está en sus extremos / extremo sur del continente americano/ es enteramente despoblada, y ríos navegables posee que no han surcado aún el débil barquichuelo. El mal que aqueja a la República Argentina es la extensión: el desierto la rodea por todas partes, y se le insinúa en las entrañas; la soledad, el despoblado sin una habitación humana, son, por lo general, los límites incuestionables entre unas y otras provincias. Allí la inmensidad por todas partes: inmensa la llanura, inmensos los bosques, inmensos los ríos, el horizonte siempre incierto, siempre confundiéndose con la tierra [...] Al sur y al norte, acéchanla los salvajes, que aguardan las noches de luna para caer, cual enjambre de hienas, sobre los ganados que pacen en los campos y sobre las indefensas poblaciones. ${ }^{46}$

El remedio para poblar, tanto para Sarmiento como para Juan Bautista Alberdi, era la inmigración europea, privilegiando la actividad industrial sobre la agricultura y ésta sobre la ganadería. ${ }^{47}$

\section{La agricultura impregna el debate y la ganadería triunfa en los hechos}

Las tierras que no se vendieron con ocasión de las ofertas anteriores fueron objeto de una nueva ley sancionada el 5 de noviembre de 1876. La mensura se haría por secciones, que a su vez se dividirían en lotes de 200 hectáreas. En cada sección se reservaban lotes para la traza de los pueblos y ejidos, tal como se disponía en la ley de 1867. Las condiciones de venta estipulaban precios escalonados según la cantidad de tierra a adquirir y prohibían expresamente que ninguna persona o sociedad pudiera comprar en una misma sección más de 5400 hectáreas, o que se vendiera menos de un cuarto de lote.

45 Domingo Faustino Sarmiento, incansable en su lucha por mejorar la educación pública, fue maestro, militar, periodista, escritor, diplomático, ocupó una gran cantidad de cargos públicos y organizó el Departamento de Escuelas; senador, ministro de gobierno de la provincia de Buenos Aires, gobernador de la provincia de San Juan, presidente de la República Argentina entre 1868 y 1874. Juan Bautista Alberdi, abogado, escritor de importantes trabajos jurídicos y literarios, autor de las Bases para la Organización Política de la Confederación Argentina. Como Sarmiento, tuvo que exiliarse durante la dictadura rosista, eligiendo como destino Montevideo. Cf. Cutolo (1969).

46 Sarmiento (1965), p. 26.

47 Halperín Donghi (1987), p. 202. 
En el artículo $4 .^{\circ}$ se estipulaba que en caso de «concurrencia a la compra será preferido el que solicite menor extensión». ${ }^{48} \mathrm{El}$ precio se pagaría una sexta parte al contado y el resto en cinco anualidades. Al pagar al contado se efectuaba una rebaja del $7 \%$ anual. Se mantuvo preferencia por los ocupantes (a quienes se denominó "poseedores»), tal como lo expresaron las leyes de ventas anteriores, pues podrían comprar hasta cinco mil hectáreas siempre que, con seis meses de anterioridad a la sanción de esta ley, hubiesen tenido en el campo que ocupaban mil quinientas cabezas de ganado mayor o seis mil de ganado menor como mínimo, y se presentaran dentro de los noventa días de su sanción. Los pobladores con menor cantidad de ganado tenían derecho a la preferencia para conseguir una fracción proporcional, según las bases consignadas en el inciso anterior.

Las personas que compraran por medios fraudulentos más extensión de tierra que la permitida por esta ley en cada sección, perderían el precio total de la tierra y ésta volvería a venderse por cuenta del Estado. Todo individuo o sociedad que comprara tierra pública y no la poblara dentro de los dos años siguientes perdería su derecho a ella y la sexta parte del importe del terreno. Por cada 50 hectáreas debían invertir, como mínimo, un capital de mil pesos de moneda corriente en habitaciones y cultivos de tierras o ganados. Se penalizaba expresamente la presentación de certificados falsos sobre el cumplimiento de las condiciones de población, que se obtenían y utilizaban frecuentemente.

Por el artículo 20 se otorgaba un plazo de seis meses a partir de la sanción de la ley para que se presentaran a comprar los ocupantes de tierras públicas cuya existencia fuera desconocida para el Departamento de Ingenieros tanto en el interior como en el exterior de la frontera. A los que no se presentaran, se los penalizaba cobrando el arrendamiento por el tiempo de la ocupación o vendiendo sus tierras al mejor postor. Los decretos reglamentarios designaron a los agrimensores encargados de practicar las mensuras y levantar los planos de los terrenos, marcando ríos, arroyos, sierras y demás accidentes del terreno.

Como se ha podido observar, el proyecto inicial subdividía las secciones en lotes de 100 hectáreas y la aprobación definitiva los elevó a 200. También reconocía los derechos de los ocupantes o poseedores de tierras públicas comprendidos en leyes anteriores y, en este caso, se facilitaba la

48 Muzlera (1895), p. 334. 
venta de parcelas más extensas que las dispuestas para los nuevos adquirentes. Las escrituras asentadas en los protocolos de los escribanos públicos de gobierno a partir de la sanción de la ley sólo suman 33 registros, que no aluden a la citada subdivisión de las tierras en secciones y lotes de 200 hectáreas salvo en un caso, que fue producto de una venta realizada por remate después de un litigio por mejores derechos.

\begin{tabular}{|l|c|l|}
\hline Apellido y nombre & Hectáreas & Partido \\
\hline Carballo, Gregorio, y Carlos Wrigth & 2699 & 9 de Julio \\
Diehl, Julio & 5399 & 9 de Julio \\
Dudignac, Ezequiel & 2799 & 9 de Julio \\
Fages, José & 5399 & 9 de Julio \\
Peluffo, Vicente & 2699 & 9 de Julio \\
Silva, Mariano & 2024 & Azul \\
Sintas, Juan & 329 & Chivilcoy \\
Muñoz, Celestino & 6074 & Juárez \\
Videla, Jacinto & 8099 & Juárez \\
Martínez, Carolina L. de [1] & 8099 & Juárez \\
Belaustegui, Melchor & 650 & Las Flores \\
Bordeau, Carlos & 808 & Lincoln \\
Cardinal, Noel & 1818 & Lincoln \\
Henestrosa, Pedro & 4049 & Lincoln \\
Rivera, Manuel & 2429 & Lincoln \\
Rueda, Manuel & 2429 & Lincoln \\
Saves, Juan & 808 & Lincoln \\
Martínez, Juan C. & 1821 & Lincoln (remate) \\
Lafuente, Santos & 2908 & Lobería \\
Zepeda, Francisco & 167 & Magdalena \\
Corvalán, Saturnino y Víctor & 3396 & Necochea \\
Deferrari, Luis & 3196 & Necochea \\
Gómez, Manuel & 521 & Necochea \\
Gómez, Manuel & 799 & Necochea \\
Gómez, Manuel G. & 2799 & Necochea \\
Lupo, Francisco & 661 & Necochea \\
Gómez, Gaspar & 4724 & Rauch \\
Larrecy, Juan & 724 & Rojas \\
Logegaray, Luis & 200 & Rojas \\
Piñeiro González, Manuel & 168 & Rojas \\
Saavedra, Luis M., y Luis C. Saavedra & 2600 & Rojas \\
Sierra, Adolfo & 2818 & Rojas \\
Moreno, José & 197 & Rojas \\
\hline
\end{tabular}

[1] Se trataba de la viuda del general Martínez, un arrendatario público de 16200 ha. en el partido de Azul, en cuyas tierras se encontraban propietarios de las suertes de estancias donadas en 1832; después de un largo pleito, le vendieron las 8100 ha. 
MAPA 1

MAPA DE LA PROVINCIA DE BUENOS AIRES 1858-1880

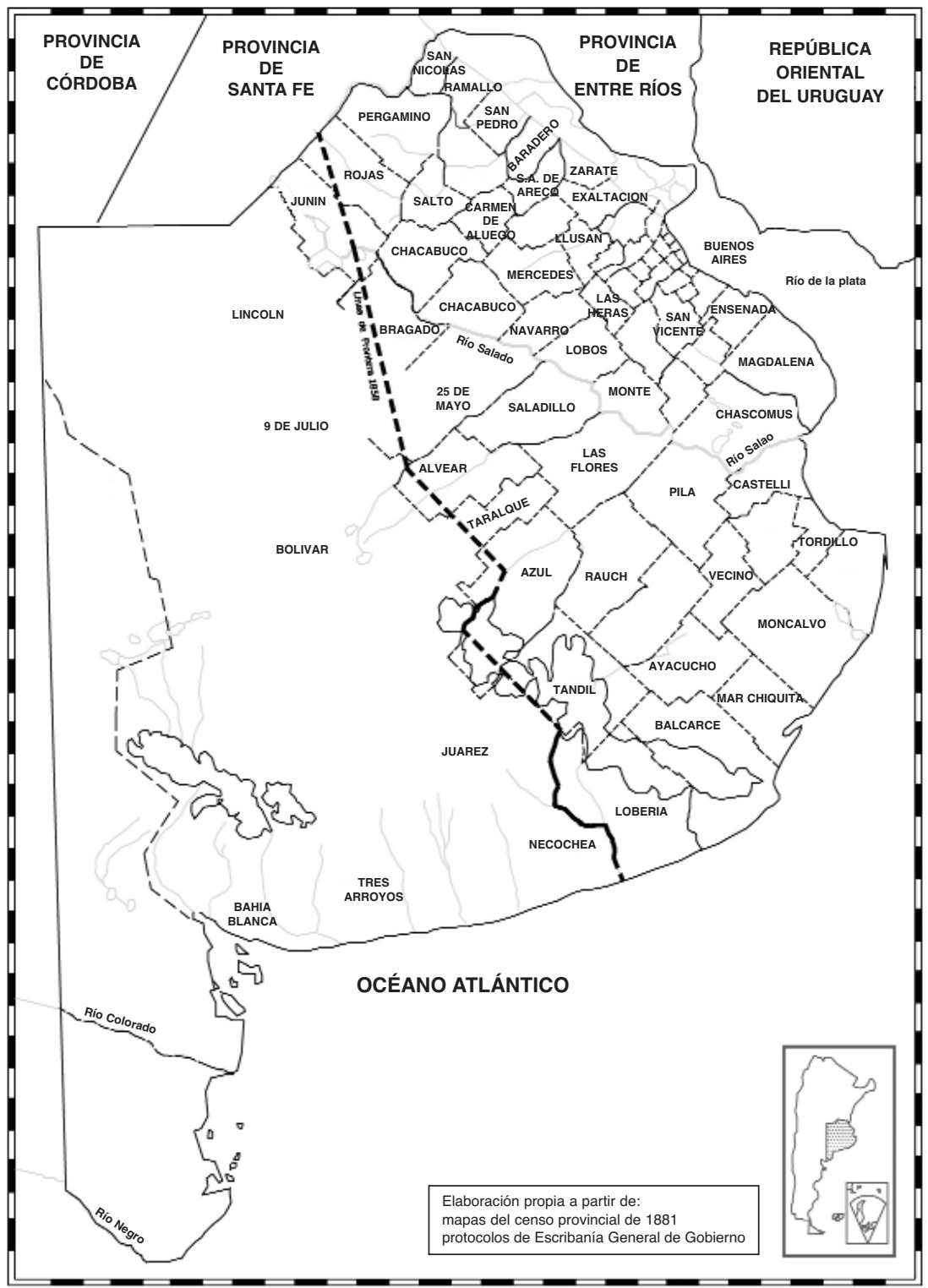


Como se podrá apreciar, estas escrituraciones en su gran mayoría no responden a la división propuesta en el proyecto, ni a las condiciones estipuladas en el texto de la ley. Así, el Gobierno expresó que, preocupado por los magros resultados obtenidos en cuanto a la venta dispuesta en 1876 , dos años más tarde envió un proyecto de ley que permitía la escrituración de superficies más extensas. Como en la legislatura se encontraban algunos representantes que habían intervenido en los debates de 1875, entre ellos Manuel Gaché, resulta interesante tener en cuenta su punto de vista:

[...] yo abogué por la subdivisión de la propiedad de la tierra y estoy lejos de arrepentirme [...] se dice ahora que los resultados de la ley de 1876 son negativos, que la ley es mala. Yo digo no es mala la ley, los resultados que ha dado no son negativos, porque ella no ha dado resultado ninguno porque ella no ha estado en vigencia un solo instante, no se ha cumplido absolutamente ninguna de sus partes.

Sostuvo Gaché que las tierras no se habían mensurado:

[...] el señor senador decía que las tierras estaban medidas y yo decía que no. No están mensuradas, porque si bien fueron mensuradas en su extensión total, no están de ninguna manera subdivididas con arreglo a la ley de 1876. Así es que ninguno de ellos sabía donde se le iba a ubicar la tierra. Diría que las ideas del Senado hoy son contrarias a las del año '76 y que las grandes áreas de la estancia pampeana, diré así, si se me permite la expresión, han de triunfar. ${ }^{49}$

Resulta interesante el argumento vertido por el senador Gaché, porque se ve reflejado en las escrituras públicas. Seguramente la división en lotes de 200 hectáreas, por su trabajosa ejecución, se demoró más de la cuenta; así que en 1877 y 1878 todavía no estaba terminada, impidiendo de ese modo la pronta puesta en vigencia de la ley. Sí se advierte, en algunas escrituras notariales correspondientes a ventas en 1879 por la siguiente ley de 1878, que se alude a la venta de «110 lotes de 200 has o 32 lotes de 200 has la mayoría en el partido de Bolívar».50

Si se tiene en cuenta el balance realizado por Noemí Girbal-Blacha sobre la creación de los centros agrícolas en 1887, se pueden advertir las similitudes con lo sucedido en la discusión del proyecto y la posterior aplicación de la ley de 1876 . Así como se opuso a ésta, una década más tarde

49 DSCSPBA, 24 de octubre de 1878, p. 1017.

50 Escribanía General de Gobierno, Protocolos notariales, 1879, f. 302 y 414. 
la Sociedad Rural Argentina estuvo en contra de los centros agrícolas, temiendo que se aplicara el derecho de expropiación de las tierras particulares. Además, en el momento de cumplir con las disposiciones de la ley de 1876 se encontraron una serie de problemas institucionales y económicos: la subdivisión de las secciones en lotes era un requisito de difícil cumplimiento porque demoraba mucho tiempo, era muy gravoso y generaba numerosas dificultades de índole técnica y administrativa. El estado provincial no contaba con la infraestructura necesaria para llevar adelante y fiscalizar un procedimiento tan complejo en el espacio y en el tiempo. Aunque ésta no fue la única causa de su fracaso, el contexto socioeconómico de la campaña de Buenos Aires tampoco favorecía la virtud de estos proyectos. El pequeño agricultor hubiera necesitado, además, crédito, buenos transportes y una política estatal eficiente. De forma similar, como señaló Girbal-Blacha, la «desorganización administrativa bonaerense» impidió la implementación satisfactoria de los centros agrícolas, que era ciertamente compleja, ${ }^{51}$ y conspiró contra las mejores intenciones de los proyectistas: falta de protección a la agricultura en la esfera política provincial, infraestructura inadecuada, caminos insuficientes, debilidad institucional para hacer cumplir la ley, etcétera. En definitiva, un número muy escaso de ellos pudo superar las dificultades y mostrar buenos resultados.

\section{Reflexiones finales: la realidad se impuso a los argumentos del debate}

En este trabajo se ha recorrido, en primer lugar, todo el camino seguido por la legislación de tierras públicas aplicada en la provincia de Buenos desde 1820 hasta fines de siglo. Los aborígenes dominaban la mayor parte del territorio, incursionando en las estancias y provocando incertidumbre y grandes pérdidas económicas y humanas. Sin duda, el siglo XIX fue el de la conquista y ocupación de ese espacio, pues casi 30 millones de hectáreas fueron primero arrebatadas a los indios y luego, ya en manos del Estado, transferidas en uso o en propiedad a los particulares por diferentes sistemas. Se ha señalado que la acumulación de tierras en pocas manos ocurrió

51 Girbal-Blacha (1980), p. 157. 
en distintas etapas. La historiografía sobre el tema ha denunciado la formación de latifundios sin hacer distinción espacio-temporal alguna, pero la realidad fue más variada. Cabe consignar que desde 1820 hasta fines de siglo se encuentra que la estructura de las tenencias formada luego de las donaciones del Directorio, los premios y la enfiteusis manifiesta concentración de la propiedad, que disminuye con los arriendos y aumenta algo con las ventas de 1871. Las ventas de 1878 y las derivadas de la incorporación a la estructura productiva después de la campaña de Roca, marcaron otra etapa de acumulación hasta fines del siglo, aunque esta concentración coexistió con la importante presencia de pequeños y medianos usufructuarios o propietarios.

La tensión entre fomentar la pequeña propiedad agrícola o la ganadería extensiva recorre las discusiones y las políticas de todo el siglo. En primer lugar, y sujeto a revisión después de los últimos estudios, la entrega de suertes de estancias en el arroyo Azul en 1832, la ley de tierras de 1876 y la creación de centros agrícolas de 1887, aunque con diferencias entre sí bastante marcadas, fueron algunos de los intentos durante el siglo XIX de generar desde el Estado una distribución que contemplara y acentuara los diversos matices que recorrían la campaña de Buenos Aires, que contenía, además de terratenientes, ocupantes y propietarios de predios pequeños o medianos que labraban y criaban sus ganados. En ese escenario se inscribió el reparto de suertes de estancias en 1832 durante el gobierno rosista. Mediante las donaciones de las suertes y las ventas de 1836, el Estado generó una política dual de beneficio a dos grupos bien diferenciados. Por un lado, el de sectores sociales con tradición colonial en la campaña rioplatense, los pequeños y medianos productores y los propietarios rurales que se beneficiaron de la política de las donaciones. Y por el otro, el de sectores socioeconómicos consolidados en la campaña, que pudieron acceder a la propiedad legal de sus explotaciones enfiteuticas y que a su vez estaban estrechamente enraizados en el poder provincial. Según las últimas interpretaciones, Juan Manuel de Rosas atendió a ambos vértices de la economía rural en la década de 1830: a los grandes propietarios que respaldaban su gestión y a los pequeños y medianos que formaban parte de una realidad incontrastable en el ámbito rural.

Sin embargo, en la época de la organización nacional, estadistas, proyectistas y políticos de mucha gravitación tenían una imagen estereotipa- 
da de la campaña, describiendo el desierto como el mal que aquejaba al país; no sólo señalaron los problemas, sino que plantearon soluciones. Juan Bautista Alberdi, Domingo Faustino Sarmiento y Nicolás Avellane$\mathrm{da}$, entre otros, fueron publicistas de nota, pero además plasmaron sus pensamientos al ocupar los cargos públicos más altos, como la presidencia de la República, o al sentar las bases de nuestra Constitución Nacional. Había muchas tierras que, aunque estaban en otras manos, una vez conquistadas no tenían valor en sí mismas sin el agregado del capital y la mano de obra. La inmigración masiva y las inversiones externas llenaron estos requisitos después de lograda la organización nacional.

En 1876, el gobernador Casares propuso la única ley general de ventas de tierras públicas que planteó la subdivisión de la propiedad en lotes de 200 hectáreas marcando límites rigurosos a la acumulación. En el ámbito legislativo se advirtió la firme oposición que provocó, aunque fue expuesta en consonancia con lo discutido también en 1875 en el orden nacional, fruto de la inspiración del presidente Avellaneda. El texto inicial elevado a las cámaras por el poder ejecutivo tuvo algunos cambios con respecto a la superficie de los lotes y se contemplaron los derechos de los poseedores, que podían acceder a mayor cantidad de tierra que la estipulada para los nuevos adquirentes. En el curso de los debates se revelaron las diferencias existentes en el seno de la Sociedad Rural Argentina, la corporación de los hacendados fundada en 1866, porque muchos de sus miembros integraban el Senado en la oportunidad del tratamiento del proyecto enviado por Carlos Casares, que también era socio de la entidad, lo mismo que Rufino Varela, ministro de Hacienda que reiteró sus argumentos esbozados en 1869 en defensa de la agricultura.

En 1887 se sancionó la Ley de Centros Agrícolas, destinada a fomentar los cultivos de cereales y a convertir en propietarios a los pequeños agricultores, considerada, junto con la ley antes mencionada, como una de las pocas disposiciones legales del siglo para la provincia de Buenos Aires con el objetivo de incentivar la agricultura, aunque fue difícil de concretar en la práctica. Algunos factores coincidieron para que los resultados de esta medida legal fueran poco exitosos: problemas burocráticos y un proceso especulativo en torno a las tierras a partir de 1888 que desembocará en la crisis de 1890 . 
En los tres proyectos hubo un denominador común a la hora de la factibilidad; las dificultades para implementar los propósitos; en Azul sólo se escrituraron muy pocas suertes y muy tardíamente, en 1860. La implementación de la ley de 1876 fue muy dificultosa porque había que subdividir enormes extensiones de tierras en lotes de 200 hectáreas, lo que implicaba enormes costos y dificultades técnicas y administrativas. El balance sobre los centros agrícolas arrojó resultados similares: impedimentos burocráticos, intereses contrapuestos. La Sociedad Rural Argentina exhibió visiones antagónicas en los debates de subdivisión de la propiedad de las tierras públicas, interviniendo para mostrar sus argumentos. Éste es un rasgo interesante de la corporación que se encontraba recientemente fundada, que ha sido advertido como singular.

La ley de 1876 tuvo una aplicación muy escasa, como se deduce de la consulta de los protocolos notariales, quizá por las características de la campaña de Buenos Aires, con sus instituciones débiles, que hacían difícil la instrumentación de una medida legal tan compleja. Por otro lado, era casi imposible ejercer el control desde los organismos públicos para que las pequeñas parcelas de tierras fueran escrituradas con cierta rapidez, quedando de ese modo en manos de productores agrícolas. Nicolás Avellaneda había planteado la necesidad del acceso fácil a la tierra tal como se hacía en otros países, pero en nuestras circunstancias el escenario era muy complejo. Las oficinas públicas situadas en la ciudad trabajaban con lentitud, siendo ineficaces para acompañar un proceso de parcelamiento que debía llevarse a cabo en lugares cercanos a la frontera, donde el acecho de los indígenas mantenía en vilo a los pobladores dado que en la década de 1870 sus incursiones fueron cada vez más frecuentes y violentas. Factores como la lejanía de la capital y de los mercados, con pocos centros poblados a su alrededor, muy malos caminos, con el ferrocarril en una etapa inicial y el crédito escaso, conspiraron contra la radicación de los pequeños agricultores. 


\title{
15. LA REFORMA AGRARIA EN LA PROVINCIA DE BUENOS AIRES (ARGENTINA): LEGISLACIÓN, DISCURSO POLÍTICO Y PRÁCTICA LEGISLATIVA DURANTE LOS GOBIERNOS PERONISTAS (1946-1955)
}

\author{
Mónica Blanco \\ (Consejo Nacional de Investigaciones Científicas y Técnicas \\ [CONICET], Universidad Nacional del Centro \\ de la Provincia de Buenos Aires)
}

Comparado con otros casos latinoamericanos, el camino de la reforma agraria ha seguido en Argentina un derrotero peculiar. El proceso de transformaciones en la estructura de tenencia de la tierra, que tuvo su momento más significativo entre las décadas de 1940 y 1960, no estuvo precedido de grandes movilizaciones campesinas al estilo de las que impulsaron las reformas agrarias de México y Bolivia — por mencionar los casos más paradigmáticos-, ni de una presión social sobre la tierra como la que caracterizó las migraciones campesinas en Brasil. Si bien la distribución de la propiedad poseía un carácter fuertemente desigual, ${ }^{1}$ ésta se negociaba libremente en el mercado y constituía el horizonte futuro que esperaban concretar los productores sin tierra, quienes eran fundamentalmente arrendatarios.

1 Cárcano (1972) y Gallo (1984). 
MAPA 1

ZONAS PRODUCTIVAS DE LA PROVINCIA DE BUENOS AIRES

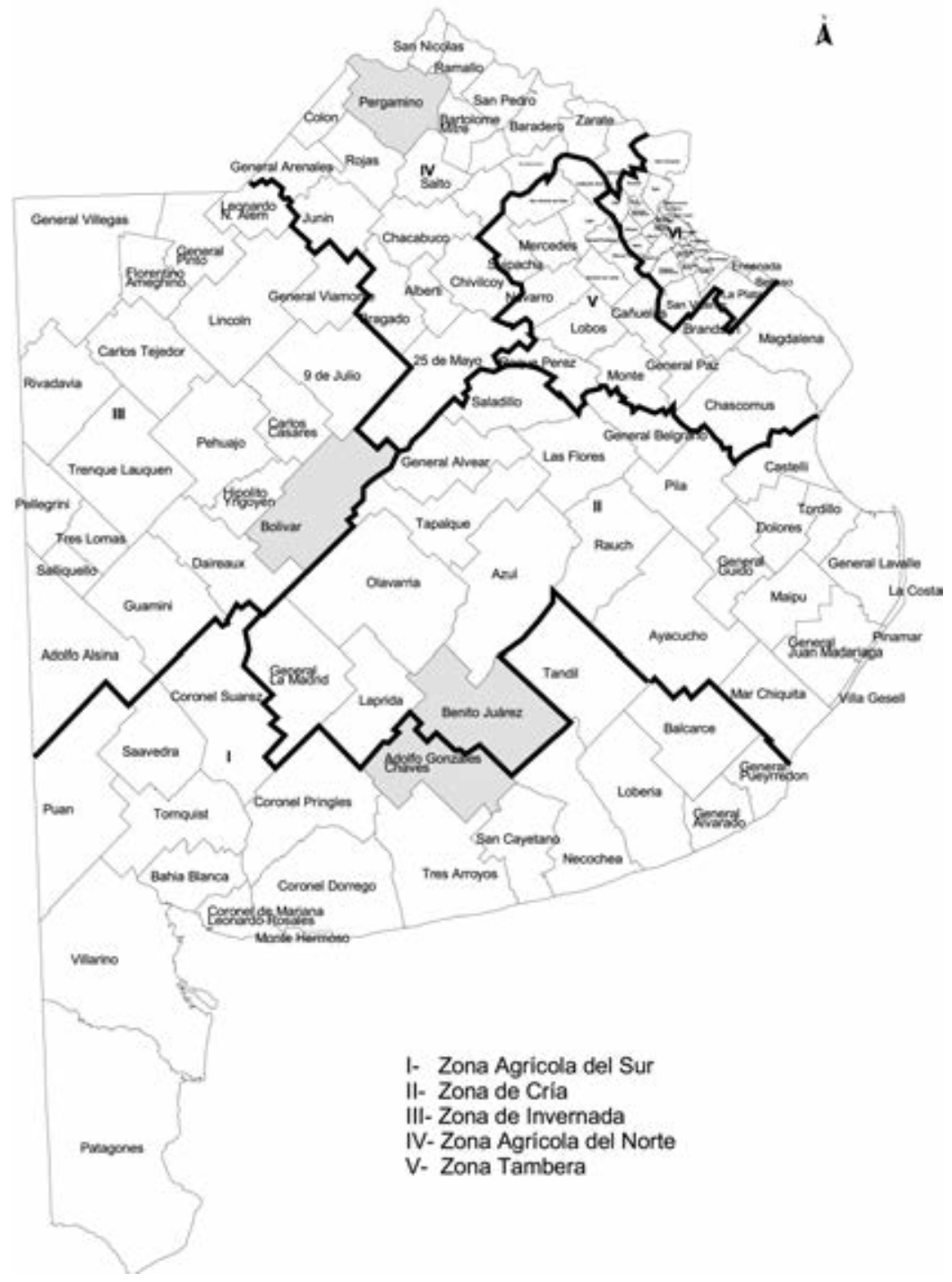

FUENTE: Elaboración propia a partir de la regionalización aportada por Daniel Slutzky (1968). 
No obstante este menor nivel comparativo de conflictividad, sí existía desde principios del siglo XX cierta inquietud social en demanda de mejores condiciones contractuales y leyes específicas que ampararan a los arrendatarios. Tales reclamos, que en principio sólo recibieron respuestas coyunturales, tendieron a exacerbarse en los momentos en que las crisis externas, fundamentalmente la crisis económica de 1929 y la Segunda Guerra Mundial, contribuyeron a deteriorar la rentabilidad agropecuaria. ${ }^{2}$

El trabajo propuesto procura mostrar las características adoptadas, hacia mediados del siglo XX, por la reforma agraria en la provincia de Buenos Aires. ${ }^{3}$ Proceso que respondió a demandas largamente demoradas y que no se implementó a través de una ley formal de reforma, sino que derivó en la sanción y aplicación de una legislación de colonización y de arrendamientos rurales que buscaba responder a una emergencia que se estimaba coyuntural. El carácter revolucionario que se ha intentado dar a este proceso derivó de un discurso político que enfatizaba el cambio, pero que no se tradujo en una práctica igualmente innovadora, sino que presentó importantes continuidades con respecto a periodos previos.

\section{Apropiación, producción y legislación}

La concentración de la propiedad de la tierra fue, sin duda, una de las características distintivas del proceso de expansión agropecuaria iniciado hacia fines del siglo XIX. Los inmigrantes ultramarinos, atraídos por las nuevas oportunidades laborales que la región pampeana ofrecía, encontra-

2 Estos dos procesos internacionales tuvieron un impacto directo en el modelo económico sustentado en las exportaciones primarias. Se tradujeron en claros obstáculos a la comercialización de granos y cereales como consecuencia de las políticas proteccionistas adoptadas por los mercados consumidores durante la crisis, y en el alto costo de los fletes y seguros marítimos y la escasa disponibilidad de bodegas, en el contexto de guerra. En ambos momentos, el efecto más visible fue la caída de los precios de exportación y, por lo tanto, la reducción de la capacidad de importación. Gerchunoff y Llach (1998) y Rapoport (2003).

3 Elegimos la provincia de Buenos Aires porque creemos que, por su tipología productiva y de tenencia de la tierra, es un área suficientemente representativa de toda la región pampeana, ya que en ella se encuentran representadas las distintas zonas productivas características de esta región: cría, invernada, agricultura y producción mixta. Gómez et ál. (1991) y Slutzky (1968). Véase mapa 1. 
ron a su arribo que gran parte de la tierra productiva había sido tempranamente distribuida merced a ventas, donaciones o premios por servicios militares. ${ }^{4}$ La posibilidad de acceder a la tierra propia fue una alternativa que sólo permaneció abierta en algunos espacios del sur bonaerense, de más tardía ocupación. En tanto, el arrendamiento o el trabajo como peón asalariado fueron los medios más frecuentes de inserción en el ámbito rural, a veces como camino para arribar a la propiedad y otras como tránsito para radicarse finalmente en las ciudades. De este modo, la presión sobre la tierra fue acentuándose, máxime después de la década de 1920, cuando llegó a su fin, en la provincia de Buenos Aires, la ocupación de todo el espacio productivo. ${ }^{5}$ Se exacerbaban así las contradicciones del sistema, poniendo la "cuestión agraria» en la agenda de discusión política y confrontación social. ${ }^{6}$

En una economía profundamente inserta en el mercado mundial, sus derroteros no le fueron ajenos. La fuerte caída e inestabilidad de precios, así como la disminución de la demanda de cereales que provocara la Primera Guerra Mundial, se tradujeron, en el interior de la región pampeana, en crisis agraria, social y económica. Los terratenientes redoblaron exigencias sobre sus arrendatarios y éstos reaccionaron negándose a sembrar sus campos. Una inédita modalidad de protesta entre los chacareros pampeanos, la huelga, se hizo frecuente y reiterada desde 1912 (Grito de Alcorta $)^{7}$ hasta fines de los años 20.

Si bien las primeras respuestas legales llegaron a partir de la década de 1920 (ley 11170/21 y ley 11627/32), la lenta y dificultosa aplicación de la normativa mantuvo el problema latente. Fue recién hacia los años 1930 y 1940 cuando, en el contexto de una nueva crisis, adquirieron particular relevancia las políticas públicas orientadas a incrementar la producción y la estabilidad de la población rural a través de medidas distributivas de la

4 Infesta y Valencia (1987).

5 Cárcano (1972), Gallo (1984), Girbal-Blacha (1980) y Álvarez y Zeberio (1991).

6 Girbal-Blacha (1988), Arcondo (1980), Reguera (1993) y Solberg (1975).

7 Conflicto con fuerte participación de los sectores arrendatarios que se originó en la zona productora de maíz del norte de la provincia de Buenos Aires y sur de Santa Fe; planteaba entre sus principales demandas la rebaja de los cánones de arrendamiento y mayores libertades en las contrataciones. Véase Arcondo (1980). 
propiedad. ${ }^{8}$ Este periodo coincidió con un momento particular de nuestra historia económica y política: un cambio de rumbo en la conducción de la economía que se remonta a los primeros años de la década de 1940 y marca el paso de una economía con marcadas pautas liberales a otra de claro carácter intervencionista; y el ascenso del peronismo al poder en 1946. Desde el Gobierno militar surgido en junio de 1943, el coronel Juan Domingo Perón había comenzado a ejercer un creciente protagonismo político que, teniendo como carta de presentación un proyecto orientado a contener el conflicto social e impulsar el desarrollo industrial, derivó en su acceso a la presidencia de la nación en 1946. Se constituyó así un movimiento político de base popular y nacional que culminó teniendo un fuerte impacto en la vida política y social argentina. La inclusión social y política de los sectores obreros, la promoción de la industria nacional, la ampliación del mercado interno a través de medidas económicas distributivas y el énfasis puesto en la justicia social fueron algunos de los parámetros que definieron el nuevo modelo.?

Los cambios en política agraria tuvieron que ver, una vez más, con una coyuntura internacional muy particular: la guerra mundial, las dificultades para colocar nuestra producción agrícola en los mercados tradicionales y el boicot norteamericano, primero; las perspectivas más promisorias que abría la posguerra, luego. Ello determinó, en líneas generales, una mayor protección hacia el pequeño productor (propietario o no), que atravesaba críticos momentos durante la guerra, a fin de que fuera el pilar sobre el cual responder a las crecientes demandas de alimentos que, se especulaba, abriría la posguerra.

En este rumbo y con tales objetivos, fue perfilándose una nueva legislación que, en primer lugar, apuntó a asegurar una mayor estabilidad a los arrendatarios y que, a partir de la llegada de Perón al Gobierno y durante los primeros años en él, incorporó medidas tendentes a estimular la fragmentación y venta de los grandes latifundios. La sanción de nuevas leyes de arrendamiento, expropiación, colonización y créditos rurales, así como de incrementos impositivos a los grandes latifundios, estuvo acompañada

8 Tecuanhuey Sandoval (1988). (2003).

9 Gerchunoff y Llach (1998), Altamirano (2001), Romero (2001) y Rapoport 
de una fuerte prédica política abanderada de eslóganes tales como «La tierra para el que la trabaja», "La tierra no debe ser un bien de renta sino de producción", "Que no haya argentinos excesivamente ricos ni argentinos excesivamente pobres», ${ }^{10}$ entre otros, los cuales, ya enarbolados desde 1918 por la Federación Agraria Argentina, ${ }^{11}$ adquirían un renovado y particular impulso al constituir parte del discurso político de un Gobierno con amplia base popular y con sesgos revolucionarios.

La primera disposición legal en este sentido data de 1942, fecha en que fueron sancionadas la ley 12771 y su decreto reglamentario 136321 , que prorrogaban los contratos de arrendamiento por un plazo no mayor de 3 años, a pedido del locatario, y reajustaban sus precios en caso de que alguna de las partes lo solicitase. Esta ley constituyó, así, el antecedente inmediato del decreto 14001 , que, sancionado en 1943, disponía la rebaja de un $20 \%$ sobre todos los arrendamientos agrícolas (respecto de los precios vigentes al $1 .^{\circ}$ de julio de 1940), derogaba la disposición que impedía destinar a la producción ganadera parte de la superficie arrendada, prorrogaba nuevamente los contratos y determinaba la suspensión de todos los juicios de desalojo. Establecía, asimismo, la obligatoriedad de celebrar contratos escritos ante escribano público o juez de paz, al tiempo que corroboraba la defensa de los derechos del arrendatario contemplados por disposiciones anteriores.

El peronismo retomó y profundizó esta política (ley 12842/46, $12995 / 47$ y 13198/48), enmarcándola en un discurso fuertemente orientado hacia la reforma agraria, y, si bien fue poco lo que avanzó en este sentido, sancionó en 1948 la ley 13246 de arrendamientos y aparcerías rurales, a través de la cual se procuraba perfeccionar los mecanismos que hacían a la protección de los derechos de los arrendatarios, poniendo particular énfasis en la función social de la propiedad. Los arrendatarios adquirieron, de este modo, una estabilidad de ocho años

10 Declaraciones del coronel Juan Perón en conferencia de prensa el 17 de noviembre de 1944, en El campo recuperado por Perón 1944-52, Buenos Aires, Presidencia de la Nación, Subsecretaria de Informaciones, 1952; Juan D. Perón, Asi era arrojado el colono de sus tierras, Buenos Aires, Presidencia de la Nación, Subsecretaria de Informaciones, s.a.

11 Institución organizada por los chacareros de la pampa húmeda en defensa de sus intereses en el contexto de movilización rural de 1912. Grela (1958), Arcondo (1980) y Bonaudo y Godoy (1985). 
en las parcelas que arrendaban. Se prohibía el subarriendo, se elevaba el porcentaje de indemnizaciones por mejoras, se facultaba al Banco de la Nación para conceder créditos a los arrendatarios hasta el $100 \%$ del valor requerido para construcción de mejoras o adquisición de los predios que ocupaban y se creaban, asimismo, cámaras paritarias de conciliación y arbitraje obligatorio, integradas por representantes de propietarios y arrendatarios, a fin de que intervinieran en los litigios suscitados entre las partes. ${ }^{12}$

Paralelamente se implementó una importante política de colonización a través del Instituto Autárquico de Colonización, creado en 1936 (ley 4418), el establecimiento de impuestos adicionales a las propiedades rurales mayores de 10000 hectáreas (ley 4834 de 1942) y la incorporación de la provincia al régimen de la ley 12636 de Consejo Agrario Nacional, también en 1942. Hacia 1948, el impulso colonizador se vio revitalizado con la sanción de la Ley General de Expropiaciones 13264 , que, al agilizar notablemente el trámite de expropiaciones, estimulaba la labor de colonización que se venía implementando sobre la base de la ley 12636 de 1940 y reforzaba aún más las expectativas en cuanto a la implementación de la reforma agraria propuesta durante la campaña electoral. ${ }^{13}$ Una vez mas, en la provincia de Buenos Aires se creaba el Instituto Autárquico de Colonización (ley 5286), con el objetivo primordial de adquirir, colonizar y vender predios rurales con tierras aptas para la producción agropecuaria. ${ }^{14}$ Esta nueva ley de colonización demostró ser ampliamente superadora de su antecesora, por cuanto, si bien se conferían nuevamente las actividades colonizadoras a un organismo especialmente creado para ello, el Instituto Autárquico de Colonización de la provincia de Buenos Aires, se lo investía ahora con nuevas y más amplias atribuciones, que evidenciaban el mayor compromiso con la causa agraria al contemplar aspectos sociales antes desatendidos. Un extenso enunciado de funciones marcaba el mayor interés en la asisten-

12 Lattuada (1986).

13 Lattuada (1986), p. 135.

14 Anales de Legislación Argentina, Ley Orgánica de la Colonización 5286, 1948, tomo II, p. 1063. Cabe destacar que, si bien el Instituto Autárquico de Colonización se creó originariamente en 1936, en 1945 fue reemplazado por la Dirección General de Colonización, y vuelto a crear en 1948 . 
cia técnica, económica y social de los colonos. Se autorizaba al instituto a convenir planes de colonización con el Banco de la Provincia de Buenos Aires, asesorar con sus organismos técnicos los intentos de colonización privada, ensayar nuevas formas de colonización que apuntaban a solucionar el problema social del peón rural o del pequeño propietario, y facilitar la asistencia técnica y material necesaria para promover el progreso y mejoramiento cultural, económico, social y moral de los colonos. Este último aspecto incluía desde el impulso a la arborización, mejoramiento agrícola y ganadero, organización del seguro agrícola o del sistema cooperativo y promoción de industrias rurales transformadoras, hasta la distribución de becas para los hijos de los colonos que desearan ingresar a las escuelas agrícolas oficiales, o la fundación de escuelas agrícolas en las mismas colonias. He allí presente el interés en arraigar a los productores en el medio rural, frenando así el creciente proceso de migraciones. Por otra parte, la nueva composición del Directorio permite observar un mayor grado de autonomía respecto de los intereses de la burguesía agraria, incluyendo, en su reemplazo, a los mismos representantes de los colonos, a pesar de la explícita oposición de la Sociedad Rural Argentina. ${ }^{15}$

Este conjunto de disposiciones contribuyó a alimentar entre arrendatarios y aparceros la esperanza de convertirse en propietarios, en tanto para el gobierno fue el medio que le permitió trasladar el peso del financiamiento del crecimiento industrial de las espaldas de los arrendatarios a las de los terratenientes arrendadores. ${ }^{16}$ Los gobiernos posteriores a la caída del peronismo, imposibilitados para pasar repentinamente del régimen de emergencia a otro de libre contratación por los trastornos sociales que ello generaría, continuaron legislando prórrogas y controles en los cánones, pero con el

$15 \mathrm{Al}$ ser consultada sobre los proyectos de modificación de la ley de colonización 4418, la Sociedad Rural Argentina (entidad representativa de los intereses de grandes propietarios y productores rurales) había manifestado claramente su desacuerdo con la incorporación de los colonos al directorio del ente colonizador. Aducía para ello que tal medida no daba resultados positivos, pues implicaba distraer al colono de sus tareas específicas e involucrarlo en la toma de decisiones para las cuales no estaba capacitado. Véase "Régimen de colonización en la provincia de Buenos Aires", Anales de la SRA, abril de 1947, pp. 177-193.

16 Flichman (1977), p. 112. 
explícito objetivo de concluir paulatinamente con ellos. ${ }^{17}$ En este sentido se orientaron sucesivos planes de transformación agraria (decreto-ley 2187/55; ley 14451/58; decreto-ley 4403/63; ley 16883/66), tendentes a estimular las ventas entre propietarios y arrendatarios procurando facilitar la recuperación de sus predios a los primeros y la adquisición de la propiedad entre los segundos. Finalmente, la ley 17253 de 1967 disolvió las cámaras paritarias y culminó definitivamente con las prórrogas vigentes, poniendo con ello fin a la denominada "emergencia agraria» y procurando concluir con el proceso de fraccionamiento de la propiedad rural. ${ }^{18}$

En la provincia de Buenos Aires, dada la importancia del agro en su estructura productiva, la implementación de la «reforma del agro» ocupó un rol central en el discurso político y en la confrontación partidaria. Los debates originados en ambas cámaras legislativas se convirtieron en reflejo de las distintas opiniones e intereses suscitados y nos permiten analizar las oposiciones generadas entre las distintas formaciones partidarias durante los gobiernos peronistas (1946-1955). Desvelan también las contradicciones del mismo peronismo, que, apremiado por la crisis de fines de la década de 1940, se vio obligado a replantear el rumbo económico y poner mayor énfasis en el incremento de la producción, otorgando mayores seguridades a los grandes propietarios rurales para que colaborasen en ese proceso y traicionando su compromiso inicial con la reforma agraria.

\section{La legislatura bonaerense en la reforma del agro}

La discusión parlamentaria en el ámbito de la legislatura bonaerense refleja los fallidos intentos de aplicación de leyes de expropiación y colonización. Los acalorados debates dejaron ver las contradicciones dentro del mismo partido gobernante entre quienes habían adquirido un compromi-

17 A la caída del peronismo, ocurrida el 16 de septiembre de 1955 como consecuencia de un golpe militar, siguieron una serie de gobiernos marcados por la confrontación y la inestabilidad política. El país se vio inmerso en una lucha entre modelos enfrentados por la pervivencia o no del peronismo. La proscripción política de un movimiento que era percibido como representativo de los sectores populares restó capacidad de diálogo y, por lo tanto, de convivencia política sobre un marco genuinamente democrático. La sucesión de gobiernos militares y otros semidemocráticos y la creciente escalada de violencia fueron, entonces, la constante de los siguientes treinta años. Romero (2001) y Altamirano (2001).

18 Lazzaro (2004). 
so real con la causa agraria y aquellos que sólo la utilizaban como parte de una propaganda demagógica.

El seguimiento de los proyectos de leyes de expropiación y colonización presentados y debatidos durante las dos gobernaciones peronistas bonaerenses, la de Domingo Mercante (1946-1952) y la de Vicente Aloé (1953-1955), guarda estrecha relación con los cambios observados en el discurso oficial en el ámbito nacional respecto de la aplicación de una reforma en el sistema de tenencia de la tierra. No obstante, si bien se observa un cambio importante hacia 1949 respecto a la cantidad de proyectos presentados y a la caducidad de los debatidos desde $1946,{ }^{19}$ la transformación más significativa se produjo hacia 1953, directamente vinculada al alejamiento del mercantismo del poder político provincial. Precisamente el gobierno de Mercante persistió en su compromiso con la causa agraria, aun cuando ésta había dejado de ocupar, hacia 1949, un lugar central en el discurso político nacional. ${ }^{20}$

Entre 1946 y 1951, una importante cantidad de proyectos sobre expropiación y colonización (60 aproximadamente) fueron presentados y debatidos en las cámaras legislativas bonaerenses. Todos estaban referidos a propiedades entre 1000 y 38000 hectáreas, ubicadas en distintos partidos de la provincia. Desde un punto de vista regional, se veían afectados sobre todo los partidos de la zona de invernada, siguiendo en orden de importancia la zona de cría y la zona agrícola del sur. En la zona agrícola del norte, la cantidad de proyectos presentados fue considerablemente menor, y ninguno se plasmó finalmente en ley. En esto se puede ver una directa correlación con las zonas productivas de propiedades rurales tradi-

19 Se destina al «archivo por caducidad», de acuerdo con el artículo 94 de la Constitución provincial y 93 del reglamento de las cámaras legislativas, todo proyecto que no fuese votado definitivamente en el periodo de sesiones en que se presente o en el siguiente (Reglamento de la Honorable Cámara de Diputados de la Provincia de Buenos Aires, La Plata, 1947).

20 Como gobernador de la provincia de Buenos Aires, Domingo Mercante asumió un particular compromiso con la "reforma del agro», convirtiéndose en el referente político de la implementación de la colonización en la provincia más allá de los límites impuestos por el Gobierno nacional a partir de 1949. Éstas, entre otras actitudes analizadas, marcaron un estilo político propio que nos ha inducido a hablar de "mercantismo» para referirnos al protagonismo del gobernador, quien integró una segunda línea dentro del peronismo y fue alejado de la escena política al intensificarse la conducción personalista dentro del movimiento, a partir de 1950-1952. Blanco (2001a) y Blanco (2004a). 
cionalmente más extensas, vinculadas a la producción ganadera. La mayor parte de los proyectos correspondieron al periodo 1947-1949, es decir, al momento de mayor auge del discurso oficial respecto a la reforma agraria, y provinieron mayoritariamente del bloque peronista. Para principios de 1949, la mayoría de ellos pasó al archivo por caducidad y con posterioridad a 1951 ya no se presentaron nuevos proyectos.

El análisis abordado nos ha permitido comprobar una escasa correlación entre "propuesta" y "acción" respecto a la implementación de la política agraria, aun dentro de una misma formación partidaria. El mismo partido político que planteaba la reforma era luego el que entorpecía su implementación, fundamentalmente cuando las propuestas de cambio agrario condicionaban la propiedad privada de la tierra. De modo que el entorpecimiento en la aplicación de las propuestas innovadoras no fue producto exclusivamente de la oposición política, sino de las contradicciones dentro del mismo partido gobernante.

\section{a) El discurso agrario en los proyectos legislativos}

Muchas de las características propias del discurso populista del peronismo están presentes en el discurso agrario elaborado por los sectores oficialistas en el Parlamento bonaerense: la irreconciliable oposición entre pueblo y oligarquía, en este caso identificada con los sectores latifundistas «expoliadores» del trabajo de arrendatarios y asalariados rurales, y el rol central del Estado como único interlocutor válido o bien como árbitro en los conflictos sociales. Así como Perón y el peronismo procuraron, a través del discurso populista, hacer públicas las esperanzas y las expectativas de los trabajadores urbanos, sus valores, sus códigos, de la misma forma buscaron llegar a los sectores rurales más desprotegidos. Homogeneizando y simplificando las demandas del sector, aspiraban a satisfacer sus postergados anhelos, identificando el latifundio y el sistema económico social a él vinculado como la principal causa del atraso y de la crisis del agro.

Fueron precisamente estas características discursivas las que sustentaron los proyectos de expropiación y colonización presentados, sobre todo por el oficialismo, en ambas cámaras legislativas de la provincia. A pesar de la aparente homogeneidad, es interesante destacar cierta disparidad no sólo en la fundamentación, sino en el mismo espíritu que inspiraba los proyectos. Junto a aquellos que evidenciaban un cuidadoso estu- 
dio técnico, productivo y social respecto de la necesidad de expropiar con fines de colonización, se observaban otros excesivamente ambiguos y generales en sus apreciaciones y demandas. Estos últimos, claramente sujetos al discurso oficial, se presentaban tan sólo como una enunciación de principios. Muchos lugares comunes y escasas formulaciones concretas, como las que fundamentaban un impreciso proyecto de expropiación de 5000 hectáreas en Ayacucho, en el sudeste de la provincia de Buenos Aires, donde se planteaba la necesidad de colonizar "por su gran beneficio colectivo, ya que tiende a combatir el latifundio, de alarmantes proporciones en nuestra provincia». ${ }^{21}$ Se ponía énfasis en los perjuicios sociales y económicos de tan injusta distribución de un recurso vital para la producción, cuya concentración traía «aparejada una injusta retribución a los sacrificios que sobrellevan esos modestos labradores que fomentan con su trabajo la grandeza de la Nación». ${ }^{22}$ Y se destacaba la responsabilidad histórica de los gobiernos anteriores en la perduración de tan inequitativa situación, aduciendo que "jamás ninguno de los gobiernos de la oligarquía veló por su bienestar, ni reconoció tampoco, ese derecho innato que tiene cada hombre dentro de un régimen democrático como el nuestro: el de ser dueño de un instrumento de trabajo, en este caso, la tierra», ${ }^{23}$ pero no había una propuesta concreta de expropiación sobre un determinado campo que por su extensión, organización de la producción, condiciones de sus arrendatarios, etcétera, debiera ser afectado por la legislación. Más bien se acentuaba el nuevo rumbo del Gobierno en política agraria, en contraste con el accionar de los gobiernos previos. Se destacaban, en función de ello, las grandes dimensiones de las propiedades agrarias y la idílica y desdichada imagen de los arrendatarios rurales, eternamente marginados en su capacidad de acumulación. Por otra parte, era muy frecuente en los discursos legislativos la referencia a los arrendatarios como los únicos y verdaderos productores que habrían contribuido al cultivo y mejoramiento de los campos en la región pampeana, generalizan-

21 Diario de Sesiones de la Cámara de Diputados, Proyecto de ley por el que se autoriza la expropiación de tierras para colonización en Ayacucho, diputado Alberto Ochandio (UCR-JR), 30 de octubre de 1947. [N. del E.: en ésta y en las siguientes citas, la cursiva, de mano de la autora.]

22 Ibíd.

23 Ibíd. 
do y simplificando de este modo una realidad mucho más heterogénea. El contraste estereotipado entre bueno y malo, justo e injusto atravesaba, sin matices, muchos de los fundamentos legislativos de estos primeros años. Tal es el caso de campos propiedad de la familia Zuberbuller en el partido de Saavedra, donde durante más de 30 años estuvieron radicados "un grupo de colonos que expusieron durante una vida al sacrificio todas sus energías, mejorando las tierras y formando una población de hombres de trabajo que se han formado las ilusiones de que "la tierra es para quien la trabaja" ". ${ }^{24}$ Tales expectativas se habrían visto frustradas por el perjudicial y, en apariencia, inexorable avance de la gran propiedad, respecto de lo cual, continuaba el legislador, «se han visto desposeídos de esas aspiraciones, dado que, esos campos donde han trabajado toda una vida, depositando todas sus esperanzas en la adquisición de una parcela de tierra que les pudiera garantizar el derecho de propiedad, se ha desvirtuado mediante la compra en bloque de las mencionadas tierras, por parte de un Sr. hacendado, propietario a la vez de una estancia de inmensa dimensión en el partido de Guaminí». ${ }^{25}$

Múltiples razones de carácter económico y social impulsaron la elaboración de tales proyectos. La inestabilidad de los contratos de arrendamiento, que en la coyuntura de crisis agrícola y reconversión hacia la ganadería provocaba una fuerte expulsión de productores rurales no propietarios, contribuyendo a intensificar el despoblamiento rural y la concentración de la población en las áreas urbanas, constituía uno de los argumentos o problemas mencionados con mayor frecuencia.

Otra inquietud siempre presente era el estancamiento del desarrollo económico y social de las zonas ocupadas por grandes latifundios, muchas de ellas factibles de ser explotadas en pequeñas extensiones dedicadas a la producción agrícola, o bien necesarias para la ampliación de los pequeños poblados existentes. Tal es el caso de un campo de importante potencial agrícola en el partido de Alberti:

24 Diario de Sesiones de la Cámara de Diputados, Proyecto de ley autorizando la expropiación del campo "La Casilla», situado en el partido de Puan y Saavedra, para adjudicarlo al Instituto Autárquico de Colonización, diputado Alberto López Claro (UCR-JR) 26 de junio de 1946, La Plata.

25 Ibíd. 
[...] hasta el presente, en manos de un sólo propietario y son trabajadas por numerosos colonos desde hace mucho tiempo —algunos más de 35 años- en condiciones de arrendatarios. Tal situación mantiene hoy a esos trabajadores en la misma condición que cuando se iniciaron ya que, a pesar de los años de dedicación y de sacrificios, no cuentan con más capital que su trabajo. ${ }^{26}$

La imposibilidad de acceso a la propiedad estaría generando la expulsión de las familias campesinas y, en consecuencia, el despoblamiento del medio rural. La existencia de grandes latifundios explotados con una mentalidad rentística, la constitución de sociedades anónimas con el propósito de evitar la normal subdivisión de la propiedad, la insuficiencia del sistema de arrendamientos para garantizar la estabilidad de los productores agrarios y la falta de una política estatal más intervencionista, se mencionaban repetidamente como los principales factores promotores de este proceso. ${ }^{27}$

Para evitar y frenar los efectos negativos de esta evolución se planteaba, entonces, entregar la tierra en propiedad a los agricultores y generar, al mismo tiempo, las condiciones para que pudieran iniciar un proceso de acumulación. La necesidad de implementar un sistema de pagos acorde a las posibilidades del pequeño productor fue precisamente una de las perspectivas en la que avanzó el oficialismo al sancionar la nueva ley de colonización en 1948, procurando superar los artilugios de leyes anteriores que «bajo la apariencia de resolver el problema agrario, hacían prácticamente imposible que el labrador adquiriese en propiedad la tierra que trabajaba, pues con habilidad maliciosa se estableció en la ley de colonización, entre otras, la cláusula que obliga al comprador de una pequeña propiedad a entregar al contado, en el acto de la compra, el $10 \%$ del precio total. Bien sabían los que tal exigencia incluyeron, que el $10 \%$ del precio total representaba una suma inasequible para el colono y en consecuencia práctica-

26 Diario de Sesiones de la Cámara de Diputados, Proyecto de ley para la formación y colonización de Palantelen, partido de Alberti, diputado Leandro Cerizola (laborista), 15 de octubre de 1947.

27 En referencia al mismo caso anterior, se destacaba que la localidad rural de Palantelen «es una estación en la que ningún habitante de la zona puede adquirir un lote de tierra en la que levantar su hogar. No hay en ella pequeños propietarios, y el núcleo que constituye el poblado de la misma esta compuesto por unas pocas viviendas humildes, miserables casi, levantadas en tierras alquiladas o prestadas, propiedad, como dije, de un sólo dueño que impide por este hecho y por la razón de no querer vender lotes pequeños para edificar, el afianzamiento de los pobladores, la formación y desarrollo de un centro poblado» (ibíd.). 
mente la mayor parte de ellos no podían comprar»; en consecuencia, se disponía en la nueva coyuntura que «El principio justo para la subdivisión de la tierra se sintetiza en el pago de la pequeña propiedad adquirida sin exigir la entrega de ninguna suma al contado», ${ }^{28}$ con lo cual se procuraba poner fin a las injustas condiciones previas.

\section{b) Contradicciones entre el discurso político y la práctica legislativa}

De modo que entre 1946 y 1949 los discursos legislativos procedentes tanto de la bancada peronista como de la radical se mostraron favorables a la implementación de una política de colonización que permitiera el acceso de pequeños y medianos productores a la propiedad de la tierra. Sin embargo, los proyectos presentados y debatidos difícilmente se convertían en ley o, si lograban hacerlo, encontraban fuertes dificultades para su puesta en práctica. Esto motivó una dura crítica por parte de algunos senadores autores de proyectos, poniendo en evidencia la disparidad de criterios no sólo entre los bloques mayoritarios (radicales — UCR - ${ }^{29}$ y peronistas - PP-), ${ }^{30}$ sino en su interior, donde no siempre primaba el mismo compromiso con la causa agraria.

Entre las leyes cuya implementación se vio largamente postergada cabe mencionar la ley 5101, de ensanche del ejido de Lincoln, partido del noroeste de la provincia, ubicado dentro de los que definimos como zona de invernada. Esta ley establecía la expropiación de tierras para colonización en una extensión de 25800 hectáreas, afectando a unos 25 propietarios. El proyecto, originado en julio de 1946 por iniciativa de senadores radicales, planteaba la necesidad de resolver mediante la expropiación los problemas de despoblamiento, pobreza e inequidad social generados por la inadecuada distribución de la tierra y la expansión de empresas ganaderas sobre tierras de las colonias agrícolas. ${ }^{31}$

28 Diario de Sesiones de la Cámara de Diputados, Proyecto de ley por el que se dispone la expropiación de tierras para colonización en Coronel Mon y ampliación del ejido de Villa Ortiz, partido de Alberti, diputado Leandro Cerizola (Partido Peronista), 6 de junio de 1947, La Plata.

29 Unión Cívica Radical.

30 Partido Peronista.

31 Diario de Sesiones de la Cámara de Senadores, $7 .^{a}$ sesión ordinaria, 18 de julio de 1946, La Plata. 
El debate que tuvo lugar en el Senado provincial el 24 de octubre de 1947 con motivo de avanzar en el cumplimiento de esta ley, es representativo de las dificultades que atravesó la implementación de la «reforma del agro». En dicha oportunidad, el mismo autor del proyecto, el senador Federico Cané, pedía que se le permitiera tratar sobre tablas ${ }^{32}$ un pedido de informe al poder ejecutivo sobre las condiciones en que se encontraba la aplicación de la ley 5101, votada en el periodo anterior. Demandas de este tipo no inquietaban sólo a la oposición, sino también a algunos legisladores oficialistas que denunciaban dilaciones semejantes en proyectos de expropiación de grandes latifundios. En este sentido se expresaba el senador Eduardo Carvajal (PP) al exigir que se tratasen todos los casos de expropiaciones juntos antes de terminar las sesiones de prórroga, pues, siendo él uno de los primeros legisladores que había presentado un proyecto de expropiación, se encontraba aún sin despacho de comisión, a pesar de contar con informe técnico favorable y afectar, en total concordancia con el discurso oficial, «a una de las familias reconocidas como latifundistas en la provincia de Buenos Aires: me refiero a la familia Anchorena». ${ }^{33}$

La intervención del senador Luis Quijano permite observar la reticencia dominante en la UCR respecto a acompañar al oficialismo en esta reforma, al aclarar que la Comisión de Presupuesto de la que formaba parte había adoptado como norma no despachar proyectos sin ver antes cómo se encontraban los inmuebles que se querían expropiar, o comprobar que el propietario no estuviese de acuerdo en hacer subdivisión privada. ${ }^{34}$ El senador Carvajal enfatizaba que las comisiones contaban con los informes técnicos correspondientes, a lo que Cané agregaba que con su proceder la comisión estaba poniendo en duda los informes presentados por los senadores.

Se estaría así frente a un sector dentro de esta misma formación política que, sin declararse contrario al proceso de reforma de la tenencia de la tierra,

32 Un proyecto es tratado sobre tablas cuando es votado por los legisladores presentes sin ser girado a la comisión pertinente para su evaluación.

33 Diario de Sesiones de la Cámara de Senadores de la Provincia de Buenos Aires, 8. ${ }^{\text {a }}$ sesión de prórroga, 24 de octubre de 1947, La Plata, t. II, p. 2250.

34 «a Comisión tiene criterio formado: necesita, por lo menos, concurrir al lugar, ver el campo a expropiar, establecer si procede la expropiación y estimo, a pesar de lo que acaba de exponer mi compañero de sector, el Sr. Senador Cané, que esta resolución no importa una falta de consideración hacia los senadores autores de proyectos» (ibíd.). 
articulaba mecanismos capaces de dilatar la evolución del proceso, favoreciendo con ello los intereses de la burguesía agraria. Concretamente se evidenciaba ello al plantear la necesidad de revisar las situaciones catastrales, pues, se argumentaba, habría casos en que ya la herencia había determinado subdivisiones de las propiedades que los proyectos respectivos no advertían. Generaban así la posibilidad de mantenerlos al margen de eventuales expropiaciones, aun cuando en la práctica muchas de estas propiedades continuaban funcionando como una misma unidad productiva. Esta misma voluntad, reticente a alterar significativamente los patrones de tenencia vigentes, se observaba en el impulso a la subdivisión privada como paso previo a la expropiación, con lo cual se incrementaban las posibilidades de negociar mejores precios y condiciones de pago por parte de los propietarios, o aun ganar tiempo para poner tales propiedades a resguardo de eventuales expropiaciones.

El bloque peronista hacía una dura crítica al bloque opositor acusándolo de dilatar la aprobación de los proyectos de expropiación con cláusulas como las de la Comisión de Presupuesto, o simplemente no tratando los proyectos en las reuniones de comisión. ${ }^{35} \mathrm{Al}$ parecer, la intervención del oficialismo hizo girar la discusión poniendo en evidencia la aparente dilación en el tratamiento de los proyectos de expropiación por parte del partido opositor y eludiendo con ello el debate sobre el tema planteado inicialmente: la implementación de leyes ya sancionadas. Era esta ambivalente política agraria del peronismo la que intentaba poner en evidencia el senador Cané al enfatizar la lentitud en la puesta en práctica de una ley de expropiación. Procuraba con ello presionar para que se arbitraran los medios capaces de agilizar y simplificar el proceso, al tiempo que denunciaba la presión —al parecer exitosa - de los sectores afectados para impedir la sanción de la ley. ${ }^{36}$

Podemos observar, entonces, una marcada ambigüedad discursiva en ambos bloques políticos. Aparentemente, los dos estarían comprometidos con la causa de la reforma en el sistema de tenencia, pero sin llegar con

35 El debate derivó en una acusación del senador Carvajal a la Comisión de Legislación General, y concretamente a la representación radical en ella, de que dilataba la firma del proyecto por él presentado aun cuando contaba con despacho técnico favorable.

36 Menciona el caso concreto de la Sociedad Rural Argentina, que acusa a esta ley de afectar gravemente a unidades económicas eficientemente explotadas. 
ello a hacerla efectiva, dados los obstáculos que mutuamente se imponían. Mientras que el oficialismo demandaba a la oposición acelerar la aprobación de proyectos de ley, ésta lo acusaba de no poner en práctica las leyes ya aprobadas. En conclusión, la reforma del agro se mantenía radicalizada en el ámbito del discurso, sin hacerse efectiva en la práctica.

La ambigüedad entre discurso y práctica fue aún más evidente a partir del cambio de coyuntura económica hacia fines de los años cuarenta, y una vez más los nuevos debates suscitados por la aplicación de la ley 5101 lo pusieron en evidencia.

En la sesión del 10 de agosto de 1949 se daba entrada y destino en la Comisión de Agricultura, Ganadería e Industria al proyecto de ley del diputado Mario Martínez (PP), modificatorio de la ley 5101, con pedido de preferente atención y pronto despacho, así como de colaboración por parte de la oposición, dada su importancia no sólo para la provincia, sino para el país. Proponía la expropiación de menor cantidad de propiedades, aunque en mayores extensiones, con un total semejante al establecido por la ley, es decir, 25478 hectáreas. En concordancia con el renovado discurso oficial, apuntaba a detener la expropiación de los establecimientos ganaderos trabajados «racionalmente» y expropiar, sí, los dedicados a la producción agrícola y los latifundios no trabajados por sus propietarios o trabajados deficientemente. En tal sentido afirmaba el diputado Martínez que «si bien debemos mantener inflexible el principio de que "la tierra ha de ser para quien la trabaja" $[. .$.$] no debe hallar aplicación en aquellas tierras que, aunque extensas,$ se encuentren [...] en producción dirigida y explotada por sus propios dueños». Advertía, entonces, sobre los inconvenientes económicos que ello generaría, puesto que «el desmembramiento de algunos importantes establecimientos ganaderos en plena producción y progreso conduciría: a) A la posibilidad de provocar su liquidación, [...], con evidente perjuicio general para la economía del país; b) A la posibilidad de que la provincia pueda verse obligada a extender la expropiación a la totalidad de esos establecimientos afectados, en los casos en que los mismos no puedan subsistir sobre la superficie remanente». ${ }^{37}$ Era evidente el cambio en el discurso oficial en relación con la colonización en un contexto económico más crítico que el existente

37 Diario de Sesiones de la Cámara de Diputados, $13 .^{\text {a }}$ sesión ordinaria, 10 de agosto de 1949, La Plata, t. II, pp. 1275 y 1382. 
en 1946, y donde se volvía necesario priorizar los requerimientos económicos y la necesidad de producir saldos exportables, con independencia de los postulados agraristas de la primera hora. ${ }^{38}$

Al día siguiente de este elocuente reclamo, se expidió la Comisión de Agricultura, Ganadería e Industria y el proyecto fue aprobado sobre tablas. Justificaba su posición y se hacía eco del «ambiguo discurso oficial» de la época, que mantenía los alegatos a favor de la «distribución equitativa de la tierra a sus verdaderos trabajadores», pero esta vez matizados con ribetes marcadamente conservadores. Así, el diputado informante, Rodolfo Arce (PP), destacaba que, tras haberse "considerado este proyecto [...] con verdadero interés y especial preocupación...», la comisión ha considerado necesario "procurar soluciones integrales [...], máxime si se tienen en cuenta que nuestra riqueza agrícola-ganadera, [...], constituye el pilar más firme sobre el que descansa nuestra economía»; y si bien reconoce que "La ley n. ${ }^{\circ}$ 5101 [...] del año 1946 [...], se inspiró en sanos propósitos sociales y económicos, al procurar la estabilización del trabajador y su familia, mediante la posesión de la tierra que trabajan [...] acrecentamiento de la producción [...] subdivisión de los grandes latifundios», ha contribuido a provocar «numerosos reclamos por parte de los afectados», con lo cual «Del estudio consciente y sereno de la mismas, como así también de las consideraciones [...] de los informes técnicos producidos por el Instituto Autárquico de Colonización, se desprenden una serie de conclusiones que movieron al autor de este proyecto a establecer la necesidad de una reforma inmediata de la ley», ya que las expropiaciones establecidas «afectan a establecimientos ganaderos bien organizados, en plena producción». ${ }^{39}$

Era clara y reiterada la referencia a los cambios en la concepción de la expropiación que el discurso oficial adoptaba en un contexto económico más crítico que el existente en 1946, donde el reclamo de reforma agraria

38 «Desde la promulgación de aquella ley (9 de noviembre de 1946), se han producido en el país nuevos hechos [...] Acaba de firmarse un nuevo tratado de comercio con Gran Bretaña, por el que nuestro país se compromete a venderle 46900000 de libras esterlinas en carne y sus derivados [...] el saldo exportable en la Argentina no es muy grande en la actualidad, por lo que en este caso cabe muy adecuadamente la consigna de producir» (ibíd.).

39 Diario de Sesiones de la Cámara de Diputados, 10 de agosto de 1949, La Plata, t. II, p. 1275. 
perdía vigencia ante la inminente necesidad de incrementar la producción, ${ }^{40}$ ya que, en vista del convenio de comercio firmado con Gran Bretaña para exportar carnes, «Se hace, pues, absolutamente necesario mantener y aún estimular las actividades de los establecimientos ganaderos del tipo a que se ha hecho referencia». ${ }^{41}$ Esto planteaba a los legisladores oficialistas la necesidad de avanzar más lentamente en materia de «reforma agraria», priorizando, en cambio, las necesidades económicas más inminentes de la economía en su conjunto. Y nos permite entender la nueva concepción del latifundio, y hasta su justificación por parte de quienes habían sido sus propios detractores: "Debemos también considerar este proyecto, Sr. presidente, como un homenaje a los hombres que poblaron nuestros campos en épocas en que eran desiertos, a establecimientos de nombradía, a establecimientos tradicionales, a establecimientos ganaderos que han hecho que la Argentina ocupe un lugar sin par en el mercado mundial de la carne». ${ }^{42}$ La antes «defenestrada» burguesía agraria, acusada reiteradamente desde el discurso peronista de explotadora y opuesta a los intereses generales, pasaba a ser reivindicada desde aquel mismo lugar político por ser la que había puesto las tierras en producción, y por mantener con éstas no sólo un vínculo económico, sino también afectivo: «Estos hombres del campo merecen nuestra consideración, en el sentido de que no se vean privados, no solamente de un bien de subsistencia, sino también de un patrimonio al que necesariamente están unidos por el afecto que le profesan como resultado de la labor de muchos lustros». ${ }^{43}$

Si bien la UCR expresó su desacuerdo con la forma en que se había tratado el proyecto de ley en discusión, no pudo evitar, dado su carácter minoritario, que ésta se convirtiera en ley. Sin embargo, denunció explícitamente el «desmedido» interés del oficialismo en la aprobación del proyecto, así como ciertas desprolijidades en su presentación y tratamiento. En ese sentido explicaba el diputado Harrington la razón por la cual no llevaba su firma

40 «El concepto doctrinario de que la tierra debe ser para quien la trabaja y no un bien de renta, no debe aplicarse a aquellas explotaciones que desde tiempo atrás son dirigidas por sus verdaderos propietarios, en las que los tres factores de la producción: tierra, trabajo y capital, se hallan en máxima ventaja y acuerdan el logro de una producción altamente racionalizada» (ibíd.).

41 Ibíd.

42 Ibíd.

43 Ibíd. 
el despacho de la Comisión de Ganadería e Industria: «no es para oponernos al proyecto, pero la verdad es que el mismo tuvo entrada en la sesión de ayer. Se reunió, tengo entendido, esta mañana la Comisión de Ganadería e Industrias, no obstante haber sesionado la Honorable Cámara hasta las 4 de la mañana de hoy, y ya tiene entrada para ser tratado sobre tablas. Nosotros hemos conocido en las bancas, hace un momento, el proyecto. Esa es la razón por la cual la minoría de la Comisión no ha podido suscribirlo [...] Yo creía, Sr. Presidente, que dada la importancia de este asunto [...] que esta situación sería tratada conjuntamente con unos 15 o 20 expedientes sobre expropiación que [...], se tratarían en presencia del Sr. Ministro del ramo a fin de conocer su opinión con respecto a estas expropiaciones». ${ }^{44}$

Esta y otras leyes ${ }^{45}$ sancionadas a partir de proyectos originados en el bloque de la UCR nos permiten comprobar la existencia de una voluntad política compartida por los dos bloques mayoritarios respecto a la necesidad de modificar los patrones de tenencia de la tierra, en gran medida obstaculizada por las mismas confrontaciones en el interior de cada formación partidaria, sensibles, por supuesto, a las presiones ejercidas por los sectores económicos afectados. Tales condicionamientos habrían resultado más exitosos hacia fines de la década de 1940, en estrecha relación con el deterioro de la situación económica. En el caso de los proyectos de ley originados en el radicalismo, ello derivó en su caducidad después de demorados tratamientos. Los surgidos en el seno mismo del oficialismo corrieron mejor suerte $y$, en general, fueron implementados a partir de decretos del poder ejecutivo, reforzando con ello una «aparente» correspondencia entre discurso y prácti-

44 Diario de Sesiones de la Cámara de Diputados, $14 .^{a}$ sesión ordinaria, 11 de agosto de 1949, La Plata, t. II, pp. 1423-1444. El proyecto modificatorio de la ley 5101 fue aprobado y sancionado como ley 5452 el 26 de agosto de 1949. Dicha ley afectaba a un total de 25478 hectáreas, sobre las cuales se implementaron cuatro colonias, quedando sin expropiarse 5700 hectáreas.

45 Una situación semejante se planteó en el caso de la ley 5110 de ampliación del ejido de General Alvear, que, sancionada en noviembre de 1946, planteaba expropiar 9240 hectáreas (Diario de Sesiones de la Cámara de Senadores de la Provincia de Buenos Aires, senador José Antonio Isleño, 18 de julio de 1946, La Plata, t. 1, pp. 376 y 377); o en los de las leyes 4013 y 3736 de expropiación de 7250 hectáreas en General Pinto (Diario de Sesiones de la Cámara de Diputados, 1948, La Plata, t. II, p. 1848), que, al ser reiteradamente postergada su implementación, dan lugar a situaciones muy irregulares de venta de tierras afectadas por procesos de colonización (Blanco, 2001b). 
ca en una coyuntura electoral clave como la de $1949^{46}$ y destacando el rol protagónico del gobernador Mercante en la implementación de la reforma.

A partir de 1953, ya bajo la conducción política de Vicente Aloé y con un nuevo elenco legislativo, el cambio en el discurso oficial fue mucho más marcado. La adhesión a la política del Gobierno nacional era clara y explícita. Durante la sesión del 16 de julio de 1953, el Senado aprobaba sobre tablas el despacho de la Comisión de Asuntos Agrarios e Industrias, adhiriéndose a la política de reforma agraria que propiciaba el presidente Perón. El peronismo justificaba el cambio de rumbo en la política agraria como parte de una nueva estrategia de la «revolución» que, a través de un ritmo más pausado, tendía a compatibilizar crecimiento de la productividad con justicia social para los trabajadores del agro. Las expropiaciones continuarían, pero no afectando a tierras privadas, sino a las fiscales; el centro del discurso se ponía en la tierra improductiva y no en la gran propiedad; al tiempo que se destacaba al minifundio como un problema aún mayor que el latifundio. ${ }^{47}$

46 Los dispares criterios políticos que comenzaron a distanciar al poder ejecutivo nacional y al provincial se pusieron en evidencia por ejemplo, en el momento de reformar el artículo 77 de la Constitución Nacional, referido a la reelección del presidente y vicepresidente, o en el momento de aplicar la sexta cláusula transitoria sancionada por la Asamblea Constituyente, en la cual se habilitaba a los gobernadores provinciales, elegidos por cuatro años, para prorrogar por dos años sus mandatos a fin de equipararlos con el Gobierno nacional. Así, aun cuando la reelección fue aprobada e incluida en el artículo 78 de la nueva Constitución Nacional, la de la provincia no siguió el mismo criterio, estableciendo en cambio la no reelegibilidad sucesiva de los futuros gobernantes. Con ello Mercante se autoanulaba para un nuevo periodo de gobierno en la provincia, pero al mismo tiempo establecía una forma distinta de conducción política y se comenzaba a presentar como un posible rival a la presidencia. Precisamente, no aceptó la prolongación automática de su mandato hasta 1952 sin antes consultar la voluntad del pueblo, que lo había elegido sólo hasta mayo de 1950, y someterse nuevamente a su decisión por medio de elecciones que legitimaran la prolongación de sus funciones. Actitud que puede leerse como una medida plebiscitaria que le permitiría poner en evidencia su propio poder político en el interior del peronismo y habilitarse como un postulante a la presidencia (Blanco, 2001a).

47 «En mi carácter de Presidente de la Comisión de Asuntos Agrarios —expresaba el senador oficialista José Ladaga Rosito- - [... tengo el alto honor de informar, en nombre de la mayoría, el proyecto de Declaración presentado por el bloque peronista, en virtud del cual el Honorable Senado declara su total adhesión y absoluta solidaridad con el plan de reforma agraria propugnado por el Excelentísimo señor Presidente de la Nación, General Juan Perón, así como los fundamentos expuestos en su discurso del día 11 de junio último, pronunciado en el Teatro Colon de la Ciudad de Buenos Aires ante representantes del agro. [...] Con el Plan de Reforma Agraria de Perón se cambia el antiguo sistema de explotación, no como lo quieren los comunistas sino en forma atenuada. [...] Perón cree que la solución 
Ilustrativo de este cambio en el discurso oficial es también el siguiente diálogo, entre representantes de los bloques políticos mayoritarios, donde se ponía en evidencia el accionar de la tradicional burguesía agraria, camuflada en forma de sociedades anónimas, y el consentimiento del oficialismo, que había modificado la prioridad antes otorgada a la «igualdad social» por la necesidad de incrementar la productividad, con independencia de la equidad en la distribución de los beneficios:

SR. Pérez Vélez (UCR)— - [...] Además, se invoca el art. 38 de la Constitución Nacional, donde se afirma que la economía y la sociedad privadas son bienes en función social, manteniendo la estructura actual de las posesiones terratenientes en poder de las fuertes Sociedad Anónimas.

SR. Guadalupe (PP) - Pero esas Sociedades Anónimas de las que tanto habla el Senador ¿Trabajan o no esas tierras?

SR. PÉrez Vélez- Sí, las trabajan.

SR. Guadalupe- Entonces ello va en beneficio del país.

SR. PÉREZ VéLEZ - Pero está en contra de la ley de colonización. La función social a que se hace referencia en cualquier reforma agraria, no justifica la explotación exitosa sino el mayor número de trabajadores afincados a la tierra en el concepto de unidad económica. ${ }^{48}$

El radicalismo criticaba esta nueva política como claudicante ante los intereses de monopolios extranjeros y nacionales que actuaban a través de las sociedades anónimas; insistía en la necesidad de ahondar el proceso de colonización, poniendo la tierra en manos de los que la trabajaban; y denunciaba el directo compromiso del gobernador de la provincia, Vicente Aloé, en la implementación de la nueva política agraria diseñada a nivel nacional. ${ }^{49}$ Sin embargo, tales denuncias no pasaron del discurso, ya que no se tradujeron en la presentación de nuevos proyectos de leyes.

no es la supresión de la propiedad sino la supresión del abuso de la propiedad. Por ello, con este ordenamiento social que se encarará se va a la tranquilización del agro argentino, y habremos obtenido así un objetivo que no ha conseguido nadie en el mundo» (Diario de Sesiones de la Cámara de Senadores, 16 de julio de 1953, La Plata, t. I, p. 316).

48 Ibíd.

49 Así se expresaba el senador radical Falup: «Tal política zigzagueante frente a las fuerzas de la oligarquía tuvo su confirmación seis días después. El Señor gobernador de la provincia afirmó en Olavarría —el 14 de junio- que "Siguiendo indicaciones precisas del Presidente de la Nación ha de respetar, garantizar y apuntalar decididamente esos establecimientos (se refiere a los establecimientos ganaderos mejor montados y más ricos, según sus propias palabras) pues no solamente son orgullo de sus propietarios, sino que son orgullo de toda la ganadería nacional" [...]. La oligarquía, hasta ayer vilipendiada, tiene ya a buen resguardo sus privilegios» (ibíd.). 
3. Cambios en la tenencia de la tierra.

El impacto de la legislación

Ahora bien, mas allá de esta discusión parlamentaria, que marca los intereses de una época, cabe preguntarse qué impacto concreto tuvo la nueva legislación sobre el sistema de tenencia de la tierra. ¿Contribuyó a generar una distribución más equitativa de la propiedad rural? De ser así, ¿bajo qué modalidades se implementó y qué incidencia tuvo el proceso de colonización? ${ }^{50}$ Sin duda no son éstas cuestiones que encuentren una fácil y, sobre todo, corta respuesta aplicable a todo el espacio pampeano. De todos modos, procuraremos acercar algunos datos que nos permitan aproximarnos a la problemática.

El análisis comparativo de los censos agropecuarios del periodo (1937, 1947 y 1960) nos muestra una progresiva disminución del arrendamiento como forma de tenencia de la tierra, que guarda una más o menos estrecha relación con el incremento en la cantidad de explotaciones en propiedad. Para 1937, el $65 \%$ de las explotaciones estaban en arrendamiento, frente a un $30 \%$ en propiedad. Una leve modificación se registra diez años más tarde, que lleva los porcentajes a 50 y $31 \%$ respectivamente. Este censo, de 1947, mide también la cantidad de hectáreas afectadas para cada modalidad de explotación: un $43 \%$ en arrenda-

CUADRO 1

EVOLUCIÓN DEL SISTEMA DE TENENCIA DE LA TIERRA

EN LA PROVINCIA DE BUENOS AIRES (1937-1960)

\begin{tabular}{|l|cc|rc|rc|rc|}
\hline & \multicolumn{2}{|c}{1937} & \multicolumn{1}{c|}{1947} & \multicolumn{1}{c|}{1960} \\
\cline { 2 - 9 } & Explot. & $\%$ & \multicolumn{1}{|c|}{ Explot. } & $\%$ & Hect. & $\%$ & \multicolumn{1}{c|}{ Hect. } & $\%$ \\
\hline Propiedad & 33552 & 30,88 & 38484 & 31,42 & 9957740 & 35,18 & 16407947 & 61,55 \\
Arrendamiento & 70887 & 65,24 & 61386 & 50,11 & 12406081 & 43,83 & 7200787 & 27,01 \\
Total & 108649 & 100,0 & 122480 & 100,0 & 28301605 & 100,0 & 26654091 & 100,0 \\
\hline
\end{tabular}

FUENTE: Elaboración propia a partir de los censos nacionales agropecuarios de 1937, 1947 y 1960 ,

50 Es pertinente aclarar que, en el contexto de mediados del siglo XX, entendemos por colonización la subdivisión de grandes propiedades y su redistribución (fundamentalmente por venta) con el propósito de su puesta en producción bajo formas intensivas, susceptibles de admitir un mayor número de productores. 
miento y un $35 \%$ en propiedad. Aquí es donde podemos extrapolar para comparar los dos censos terminales de nuestra serie, ya que el censo de 1960 mide también hectáreas y muestra una tendencia contrapuesta a la de 1937: un $27 \%$ de hectáreas en arrendamiento frente a un $61 \%$ en propiedad. ${ }^{51}$

Tal cambio en el sistema de tenencia se corrobora y reafirma a partir del análisis comparativo de los planos catastrales de 1940 y 1958 realizados para algunos partidos de la provincia ${ }^{52}$ (ver cuadro 2). Allí es posible observar un notable incremento en la cantidad de propietarios, que oscila entre 25 y $47 \%$ y se traduce en una disminución de las hectáreas medias, tendencia derivada de la disminución de las propiedades mayores de 5000 hectáreas y del incremento de las que se encuentran entre las 500 y las 2000 .

CUADRO 2

EVOLUCIÓN DE PROPIETARIOS Y HECTÁREAS OCUPADAS (1940-1958)

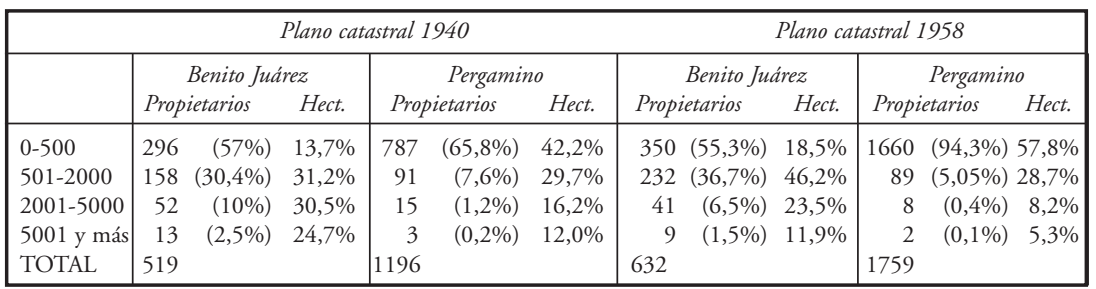

FUENTE: Elaboración propia a partir de los planos catastrales de 1940 y 1958 correspondientes a Benito Juárez y Pergamino.

51 Como se ve en el cuadro 1, sólo el censo de 1947 mide cantidad de explotaciones y hectáreas, en tanto el de 1937 mide sólo explotaciones y el de 1960, sólo hectáreas, con lo cual el de 1947 oficia de nexo a efecto de poder comparar ambas variables.

52 Véase Mónica Blanco (2001b). Allí hemos abordado un estudio regional comparativo, representativo de la productividad bonaerense, con el propósito de evaluar el impacto de la legislación agraria sobre el sistema de tenencia de la tierra, analizando hasta qué punto estas leyes fueron ejecutadas y cuáles fueron los efectos concretos sobre la realidad que legisló. Para cumplir con tales objetivos, hemos centrado el análisis en cuatro partidos de la provincia de Buenos Aires ubicados en distintas áreas productivas: Benito Juárez, en la zona de cría; González Cháves, dentro de la zona agrícola del sur; Bolívar, perteneciente a la zona de invernada; y Pergamino, comprendido dentro de la zona agrícola del norte. 
En líneas generales, hemos podido comprobar que la subdivisión de las propiedades mayores de 2001 hectáreas fue producto de la venta o la herencia decididas por grandes propietarios en respuesta a la peculiar situación generada por la legislación sobre arrendamientos, así como por la incertidumbre que el discurso antilatifundista del peronismo suscitaba, pero también a la posibilidad de hacerse con dinero en efectivo para invertir en otras actividades que la existencia de créditos hipotecarios generaba. ${ }^{53}$ De este modo se subdividieron y salieron a la venta hacia fines de los años 40 propiedades pertenecientes a miembros clásicos de la burguesía pampeana, como Ortiz Basualdo, Anchorena, González Guerrico y Alzaga Unzué, entre otros, que habían sido trabajadas en arrendamiento al menos desde los años 30. Tal es el caso de la propiedad de Rómulo Ayerza (9405 hectáreas) en el sur de la provincia de Buenos Aires, que se subdividió y vendió en su totalidad entre los 24 arrendatarios de la sucesión de María Jacobé de Ayerza, en parcelas muy dispares por su extensión, que oscilaban entre 90 y 1400 hectáreas, poniendo en evidencia los diversos niveles de acumulación de los arrendatarios adquirentes. Si bien Rómulo Ayerza no aparecía como arrendador en los contratos, su propiedad había sido trabajada como una misma explotación con la de María Helena Jacobé de Ayerza, su esposa, propietaria de 9924 hectáreas linderas. Las entrevistas orales ${ }^{54}$ nos han permitido conocer que la propiedad de Rómulo Ayerza se fragmentó por iniciativa de los mismos propietarios, quienes, habiendo conseguido un crédito del Banco de la Nación, ofrecieron en 1952 estos campos en venta a los mismos arrendatarios. Una empresa consignataria local fue la que tramitó todas las subdivisiones y las adjudicaciones de los créditos, los cuales fueron otorgados con un plazo de 15 años, a pagar al $5 \%$ las primeras 10 anualidades y al $10 \%$ las cinco restantes, y con un interés anual del $4 \%$. Si bien no mediaba en este caso una amenaza concreta de expropiación, era claro que dar tierras en arrendamiento a tan bajos precios como los vigentes había dejado de ser rentable, más aún cuando las perspectivas de rever-

53 Los principales bancos oficiales con injerencia en la provincia (Banco de la Nación Argentina y Banco de la Provincia de Buenos Aires) orientaron algunas de sus líneas crediticias a facilitar el acceso de los arrendatarios a la propiedad de la tierra. Mediante la hipoteca del predio adquirido se obtenía una financiación que oscilaba entre el 40 y el $100 \%$ del valor de la propiedad, con planes de pago de entre 15 y 30 años. Para mayores detalles, véase Blanco $(2004 b)$. Para ampliar el análisis de la política crediticia del peronismo, véase Girbal-Blacha (1998).

54 Entrevista a Hernán Sarramone y a Aníbal Bianchi, arrendatarios. 
sión de tal situación en el corto plazo parecían ser poco viables, a lo que se sumaba la siempre vigente propaganda favorable a una "reforma agraria». Algunos grupos terratenientes como los Ayerza-Jacobé, con propiedades en sucesión, habrían preferido vender y derivar sus capitales hacia otros ramos de la producción, a ensayar alternativas tales como la constitución de sociedades agropecuarias, entre otras. La propiedad de María Helena Jacobé de Ayerza también se fragmentó, en un $59 \%$ por herencia entre los hijos de la propietaria y el resto por venta. Si bien quienes compraron parte de este campo $^{55}$ no figuraban en los contratos como arrendatarios en la propiedad que adquirieron, sí lo eran en otras parcelas y el crédito oficial fue la vía de acceso a la propiedad.

Semejante fue la estrategia seguida por María Josefina Riglos de Alzaga con al menos dos grandes propiedades ubicadas en distintos partidos de la provincia (Pergamino y González Cháves). Para 1948 solicitó un crédito al Banco de la Provincia de Buenos Aires por $934000 \mathrm{~m} \$ \mathrm{n}^{56}$ con garantía hipotecaria sobre su propiedad de 2389 hectáreas en Pergamino, con el objeto de ofrecer facilidades a quienes resultaran compradores de los 25 lotes en que la propiedad salía a la venta, de acuerdo a un plan de 29 años y medio. ${ }^{57}$ Esta última tenía la particularidad de haber sido trabajada como colonia agrícola desde los años treinta y fue la misma propietaria la que gestionó, en 1948, un crédito hipotecario en el banco provincial a fin de facilitar su subdivisión y venta. Esta subdivisión coincidió con la venta que la misma propietaria habría realizado un año más tarde de un campo de 5008 hectáreas en el partido de González Cháves. Trabajado por admi-

55 Uzandizaga Hermanos (1354 hectáreas), José Carlos Jorda (1031 hectáreas), Manuel y Aurelio de la Hoz (797 hectáreas) y Ricardo Donovan (725 hectáreas).

56 Peso moneda nacional. Unidad monetaria argentina vigente desde el 5 de noviembre de 1881 al $1 .^{\circ}$ de enero de 1970 .

57 «Visto el pedido formulado por María Josefina Riglos y Alzaga y considerando que el préstamo que solicita es con el objeto de ofrecer facilidades a los que resulten compradores de los lotes n.o 1 al 25 inclusive, que integran una fracción de campo [...], cuartel XX, con una superficie total [...] de 2389 hectáreas [...] cuyos lotes se subastaran próximamente; se resuelve establecer el monto máximo de los prestamos a que podrán acogerse los posibles interesados dentro del planes de 29 años y 6 meses, llenando las formalidades de práctica» (acta del directorio del Banco de la Provincia de Buenos Aires, sección crédito hipotecario, 16-VII-48). La resolución se refiere a una de las líneas crediticias especiales otorgadas por el banco a los grandes propietarios que decidieran parcelar y vender sus propiedades, ofreciendo facilidades a los adquirentes como un amplio plazo de reembolso y un bajo interés anual. 
nistración con sólo dos o tres arrendatarios, ${ }^{58}$ fue vendido en su totalidad en octubre de 1949, dividido en 19 lotes. La venta, a cargo de una casa consignataria de la ciudad de Buenos Aires (Pedro Duhalde y Cía.), se anunció libre de ocupantes en lotes de 125 a 600 hectáreas, con bases definidas como «bajas» (entre 350 y $450 \mathrm{~m} \$ \mathrm{n}$ ). Se destacaba la buena ubicación del campo (sobre la ruta nacional $n .^{\circ} 3$ y muy próximo a la ciudad cabecera del partido), con tierras de buena aptitud tanto para ganadería como para agricultura, que incluso admitían la producción de papas. ${ }^{59}$ Quince nuevos propietarios adquirieron el campo a un promedio de $680 \mathrm{~m} \$ \mathrm{n}$ la hectárea, lo cual resultó superior a las bases iniciales. ${ }^{60}$ Cabe destacar, finalmente, que esta propiedad también había sido parte de un proyecto de expropiación y colonización hacia 1947.

Volviendo al impacto del proceso de colonización, es necesario destacar que, no obstante el particular énfasis puesto en la colonización agrícola en la provincia de Buenos Aires durante los gobiernos peronistas, es ésta una política que, aunque con características diferentes, se remonta a la década de 1930. El proceso de colonización en esta provincia se encuentra, como ya dijimos, asociado a la labor desempeñada por el Instituto Autárquico de Colonización, creado en 1936 por la ley n. ${ }^{\circ} 4418$. En los años siguientes se sucedieron distintas normas legales con la común finalidad de afincar en el medio rural a los productores directos no propietarios, pero que difirieron en cuanto a la forma e intensidad con que tal objetivo procuró cumplirse. En virtud de la aplicación de esta normativa, entre 1937 y 1972 se constituyeron en la provincia de Buenos Aires 60 colonias, lo que permitió el afincamiento de 3071 colonos que ocuparon en calidad de nuevos propietarios 630982 hectáreas, es decir, un 2\% de la superficie total de la provincia $\left(305000 \mathrm{~km}^{2}\right)$.

A fin de comprender la importancia y singularidad de la política de colonización durante los gobiernos peronistas, hemos procurado analizarla en una perspectiva de largo plazo, a fin de entender sus antecedentes así como sus proyecciones posteriores a 1955. Con este objetivo hemos divi-

58 Fundamentación del proyecto de expropiación presentado por el senador Eduardo Carvajal (Diario de Sesiones de la Cámara de Senadores de la Provincia de Buenos Aires, 13-V-48, t. I, pp. 172-173).

59 Diario Tribuna, 12-IX-49, Benito Juárez.

60 Diario Tribuna, 31-X-49, Benito Juárez. 
dido el accionar de los organismos bonaerenses de colonización en cuatro periodos: una etapa previa al peronismo (1936-1945), el gobierno de Domingo Mercante (1946-1952), el gobierno de Carlos Aloé y la etapa post-peronista (desde 1956 en adelante).

Si agrupamos la información según la fecha en que las distintas colonias fueron adquiridas, observamos que el $66 \%$ (419520 hectáreas) de la superficie se concentró en el periodo previo al ascenso del peronismo al gobierno de la provincia; el $20 \%$ correspondió al gobierno de Mercante y el $12 \%$ restante fue posterior a la caída del peronismo (cuadros 3 y 4 y gráfico 1). Sin embargo, el 72,6\% (304713 hectáreas) de la superficie afectada durante el periodo previo a 1946 correspondió a campos fiscales, en tanto que la superficie expropiada sólo representó un 3,4\% (el 15,4\% restante corresponde a compra directa); esto sobredimensiona la importancia del proceso de colonización de este primer periodo en cuanto a su impacto sobre el proceso de desconcentración de la propiedad rural ${ }^{61}$ (cuadro 5 y gráfico 4). De modo que, si consideramos sólo aquellas tierras adquiridas por compra o expropiación, el total se reduce a 114807 hectáreas, cifra que no supera la cantidad de hectáreas adquiridas en cada uno de los periodos posteriores.

CUADRO 3

TIERRAS ADQUIRIDAS PARA COLONIZACIÓN EN LA PROVINCIA DE BUENOS AIRES

\begin{tabular}{|l|r|r|r|r|}
\hline \multirow{2}{*}{ Fecha adquisición } & \multicolumn{2}{|c|}{ Hectáreas } & \multicolumn{2}{c|}{ Colonias } \\
\cline { 2 - 5 } & Cant. & $\%$ & Cant. & $\%$ \\
\hline $1936-1945$ & 419520 & 66,4 & 20 & 33,3 \\
$1946-1952$ & 129698 & 20,5 & 26 & 43,3 \\
$1953-1955$ & 102 & 0,01 & 1 & 1,6 \\
$1956-1969$ & 81662 & 12,9 & 13 & 21,6 \\
Total & 630982 & 100 & 60 & 100 \\
\hline
\end{tabular}

FUENTE: Carpetas de Colonias de la Dirección de colonización de la provincia.

61 Cabe aclarar que la colonización de tierras fiscales se constituye en uno de los principales postulados de las entidades representativas de los grandes propietarios, que, como la Sociedad Rural Argentina, pretendían evitar la confrontación directa con el Estado y aportar soluciones al problema agrario que pusieran sus intereses a buen resguardo. Así, en un contexto de total ocupación de la frontera productiva, argumentaban acerca de la conveniencia de "poblar los inmensos latifundios que todavía posee el Estado, en distintas regiones del país, y dejar al Código Civil [...], al progreso y al tiempo, el resto de la obra» («Colonización oficial», Anales de la Sociedad Rural Argentina, t. II, septiembre de 1945, p. 698). 
CUADRO 4

COLONIAS CONSTITUIDAS EN LA PROVINCIA DE BUENOS AIRES

\begin{tabular}{|l|cc|cc|cc|}
\hline \multirow{2}{*}{ Fecha adjudic. } & \multicolumn{2}{|c|}{ Hectáreas } & \multicolumn{2}{c|}{ Colonias } & \multicolumn{2}{c|}{ Lotes adjudicados } \\
\cline { 2 - 7 } & Cant. & $\%$ & Cant. & $\%$ & Cant. & $\%$ \\
\hline $1936-1945$ & 78092 & 12,3 & 9 & 15 & 443 & 14,4 \\
$1946-1952$ & 106069 & 16,8 & 19 & 31,6 & 862 & 28 \\
$1953-1955$ & 345560 & 54,7 & 15 & 25 & 902 & 29,3 \\
$1956-1969$ & 101261 & 16 & 17 & 28,3 & 864 & 28,1 \\
Total & 630982 & 100 & 60 & 100 & 3071 & 100 \\
\hline
\end{tabular}

FUENTE: Carpetas de Colonias de la Dirección de Colonización de la provincia.

\section{GRÁFICO 1}

COLONIZACIÓN EN LA PROVINCIA DE BUENOS AIRES. INSTITUTO AUTÁRQUICO

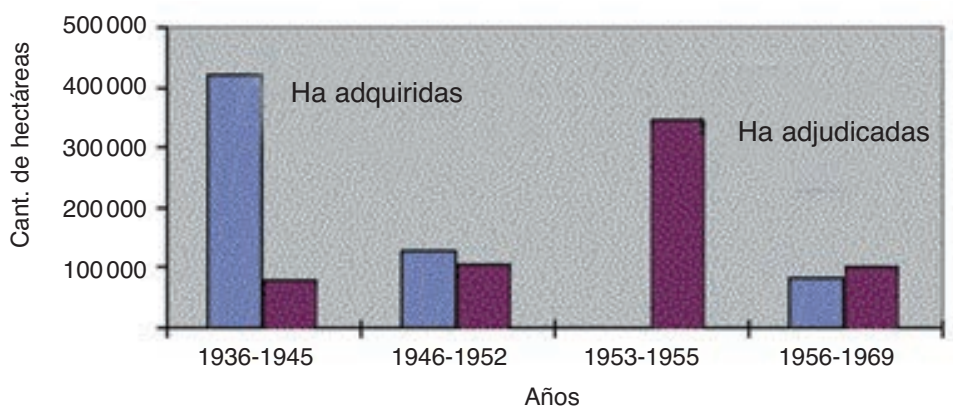

FUENTE: Carpetas de Colonias de la Dirección de Colonización de la provincia de Buenos Aires.

\section{CUADRO 5}

TIERRAS ADQUIRIDAS PARA COLONIZACIÓN EN LA PROVINCIA DE BUENOS AIRES

\begin{tabular}{|l|r|r|r|r|r|}
\hline \multirow{2}{*}{ Fecha adquisición } & \multicolumn{4}{|c|}{ Forma de adquisición } & \multirow{2}{*}{ Cant. hectáreas } \\
\cline { 2 - 5 } & \multicolumn{1}{|c|}{$S P$} & \multicolumn{1}{c|}{ CD } & EXPR. & CF & \\
\hline $1936-1945$ & 35456 & 64997 & 14354 & 304713 & 419520 \\
$1946-1952$ & & 25480 & 104218 & & 129698 \\
$1953-1955$ & 102 & & & & 102 \\
$1956-1969$ & & 3993 & 77669 & & 81662 \\
Total & 35558 & 94470 & 196241 & 304713 & 630982 \\
\hline
\end{tabular}

FUENTE: Carpetas de Colonias de la Dirección de Colonización de la provincia de Buenos Aires. 


\section{GRÁFICO 2}

COLONIZACIÓN EN LA PROVINCIA DE BUENOS AIRES.

TIERRRAS ADQUIRIDAS POR EL INSTITUTO AUTÁRQUICO

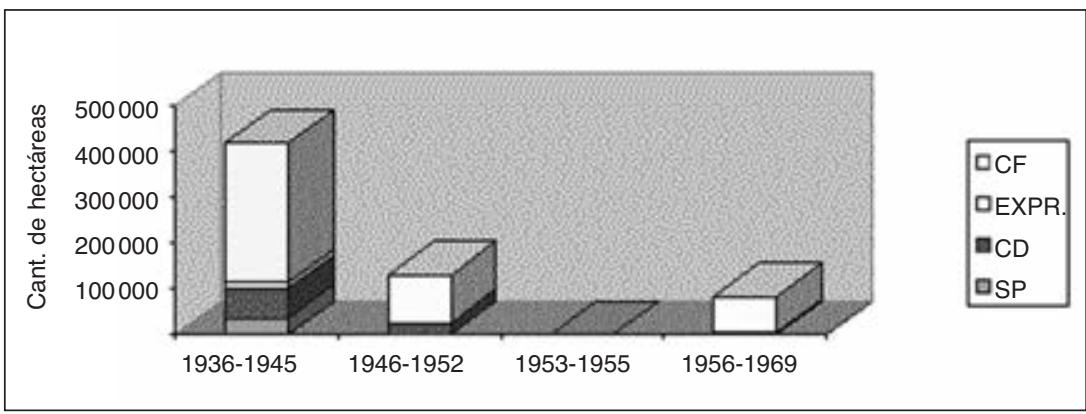

FUENTE: Carpetas de Colonias de la Dirección de Colonización de la provincia de Buenos Aires.

La adjudicación de las colonias ha demandado plazos variables que oscilaron entre el año y, en los casos más extremos, los 20 años (cuadro 6 y gráfico 3). Sin embargo, el $58 \%$ de los casos correspondieron a adjudicaciones que no superaron los cinco años de demora. Un particular dinamismo se evidenció durante el periodo peronista, pero también en el periodo 1958-1962. Si analizamos la cantidad de hectáreas adjudicadas en cada etapa, la tendencia es bastante diferente a la resultante según la fecha de adquisición. Así, mientras durante el gobierno de Aloé no se registraron nuevas adquisiciones de tierras con fines de colonización, sí se adjudicó el 62,9\% (345218 hectáreas) del total de hectáreas que el instituto había adquirido desde el inicio de su accionar (549218), lo cual representa el $54,7 \%$ para la totalidad del periodo analizado. Durante este gobierno se culminó con la casi totalidad de los procesos de colonización en marcha desde periodos anteriores: 3 colonias adquiridas en 1942, y las 12 restantes correspondientes al gobierno de Mercante. Sin embargo, nuevamente lo que más incrementó el proceso de adjudicaciones fue la implementación de 3 colonias en Patagones, en campos fiscales de escasa productividad. ${ }^{62}$ Éstas totalizaban 292583 hectáreas, sin lo cual las

62 Su colonización había generado una temprana discusión e intervención de la Sociedad Rural Argentina, la cual cuestionaba la conveniencia de colonizarlas en tanto requerían costosas obras de riego para ponerlas en producción («Instituto Autárquico de Colonización de la Provincia de Buenos Aires. Consideraciones formuladas por el ingenie- 
adjudicaciones más importantes del periodo sumarían 52977 hectáreas, es decir, sólo un 49,9\% de la superficie adjudicada durante el gobierno de Mercante (106069 hectáreas). Como en otros aspectos de la obra de gobierno de Aloé, muchas realizaciones se limitaron sólo a la implementación de obras impulsadas e iniciadas durante el gobierno de Mercante, aunque no se recordara su protagonismo, como parte de la estrategia de descrédito que llevó adelante la nueva conducción provincial. ${ }^{63}$

CUADRO 6

PLAZOS EN LA IMPLEMENTACIÓN DE LAS COLONIAS

\begin{tabular}{|l|c|c|}
\hline \multirow{2}{*}{ Plazos } & \multicolumn{2}{|c|}{ Colonias } \\
\cline { 2 - 3 } & \multicolumn{2}{|c|}{ Cant. } \\
\hline Hasta 1 año & 13 & 21,6 \\
Hasta 5 años & 35 & 58,3 \\
Hasta 10 años & 6 & 10 \\
Hasta 15 años & 3 & 5 \\
Más de 15 años & 3 & 5 \\
Total & 60 & 100 \\
\hline
\end{tabular}

FUENTE: Carpetas de Colonias de la Dirección de Colonización de la provincia de Buenos Aires.

GRÁFICO 3

PLAZOS EN LA IMPLEMENTACIÓN DE LAS COLONIAS

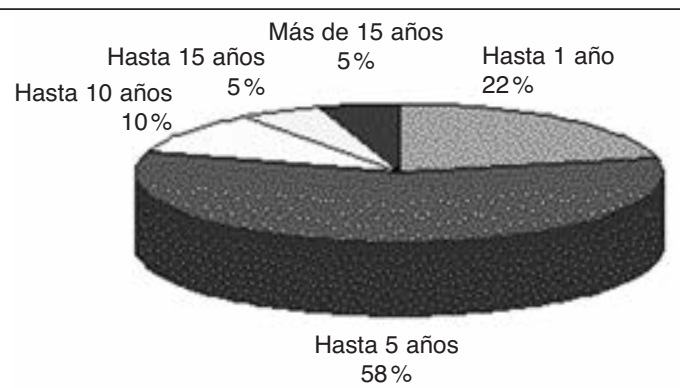

FUENTE: Carpetas de Colonias de la Dirección de Colonización de la provincia de Buenos Aires.

ro José María Bustillo en Agosto de 1942 al ministro de Obras Públicas de la provincia», Anales de la Sociedad Rural Argentina, t. I, pp. 279-289, abril de 1943). Sin embargo, años mas tarde, cuando la amenaza de expropiación se volvió mas concreta para los grandes propietarios, fue la misma entidad la que comenzó a insistir en la necesidad de colonizar las tierras del Estado para poner las suyas a buen resguardo.

63 Mercante (1995), pp. 108 y 160. 
Durante el periodo posterior a la destitución del peronismo, se produjo también un significativo proceso de colonización, concentrado fundamentalmente en 1958-1962, época correspondiente al Gobierno nacional de Arturo Frondizi. Se adquirieron, hasta 1969, 81662 hectáreas, distribuidas en 13 campos, y se adjudicaron 17 colonias, con un total de 101261 hectáreas hasta 1972. Un análisis mas desagregado pone en evidencia con más claridad la importancia del periodo 1958-1962, en que se adquirió el $92,4 \%$ de las hectáreas (75486) y se adjudicó el 55,4\% (56 147), entre las que se incluían dos colonias adquiridas en 1945 y 1949 , respectivamente.

De modo que los momentos más significativos en la implementación de la colonización en la provincia se correspondieron con aquellos donde el discurso favorable a la reforma agraria estuvo más presente, esto es, el gobierno de Mercante (1946-1952) y el gobierno de Oscar Alende durante la conducción nacional de Arturo Frondizi (1958-1962). No sólo es importante destacar en ambos periodos la cantidad de colonias y hectáreas adquiridas y adjudicadas, sino también la forma en que éstas pasaron a manos del Instituto de Colonización. En los dos momentos se destacó la expropiación como vía de adquisición: 104218 hectáreas (80,3\%) y 19 colonias, en el primer periodo, y 75486 hectáreas y 8 colonias, en el segundo. En tanto que para la etapa previa a 1946 el 72,6\% de las tierras en colonización correspondió a campos fiscales, y la expropiación sólo implicó la afectación de 14354 hectáreas, es decir, un 3,4\% de la superficie total.

Lo que más llama nuestra atención al analizar las expropiaciones implementadas a lo largo del periodo peronista es que no se correspondieron con los proyectos de leyes presentados por las cámaras legislativas, sino que 18 sobre un total de 19 casos de expropiaciones fueron por decretos impulsados directamente por el poder ejecutivo provincial, concretamente en el periodo en que éste fue ocupado por Domingo Mercante. De los 18 propietarios expropiados en este periodo, al menos ocho estarían vinculados a las tradicionales familias de la burguesía agraria pampeana: Casimiro Polledo, Pedro Alchourrón Castaño, Pedro Inchauspe, Jorge Lavalle Cobos, Félix Viñales Alzaga, Luis y Jorge Bemberg, Raúl y Leonor Martínez de Hoz, Sara Gutiérrez de Seré. Descendientes de familias ganaderas, vinculadas a la gran propiedad rural en la provincia de Buenos Aires desde el siglo anterior; miembros de la Sociedad Rural Argentina y de 
diversas asociaciones de criadores (Hereford, Shorthon, etcétera) donde habían incluso ocupado cargos directivos; algunos con intereses en el ámbito industrial: los Bemberg en la maltería, los Alchourrón en la producción de fertilizantes. ${ }^{64}$ Sin embargo, no se estaba afectando a los miembros más prestigiosos e influyentes dentro de este grupo social. Paradójicamente, éstos son los nombres que figuran en los frustrados proyectos de expropiación que tuvieron origen en las cámaras legislativas bonaerenses: Rosa Anchorena de Fernández, ${ }^{65}$ Alejandro Estrugamou, ${ }^{66}$ Glorialdo Fernández, ${ }^{67}$ Carlos Arias ${ }^{68}$ o Emilio de Alzaga. ${ }^{69}$

Aun cuando el año 1949 marcó un cambio de rumbo en la «política agraria» del peronismo, fue éste el momento en que desde el poder ejecutivo provincial se firmaron la mayor parte de los decretos de expropiación. Sin duda, y a pesar de la crisis económica cada vez más tangible, éste fue un año peculiar desde el punto de vista político: reformada la Constitución Nacional, Mercante se había embarcado en una nueva contienda electoral a fin de legitimar la prolongación de su gobierno en la provincia por dos años más. La política agraria se orientó en este sentido procurando marcar una sutil diferencia con la conducción nacional, que había suspendido las expropiaciones, para reforzar con ello su poder político, sobre todo entre los sectores de arrendatarios rurales del interior de la provincia. Es evidente que en este rumbo marchó la acción colonizadora: hacer efectivo desde el mismo poder ejecutivo provincial leyes largamente demoradas en los ámbitos legislativos. Lo cual, por otra parte, no dejó de ser un

64 Newton (1972).

65 Un proyecto de expropiación presentado en la segunda sesión extraordinaria de la Cámara de Senadores, el 27 de noviembre de 1946, proponía expropiar 21968 hectáreas en Benito Juárez. Aprobado por dos tercios de los votos, el 1. ${ }^{\circ}$ de julio de 1948 pasó a la Cámara de Diputados, donde quedó sin tratamiento durante un año, por lo cual se produjo su pase al archivo por caducidad en 1950. Véase Mónica Blanco (2004a).

66 Un proyecto originado en la Cámara de Senadores proponía la expropiación de 7400 ha en Bolívar.

67 El senador Eduardo Carvajal presentó, en mayo de 1948, un proyecto para expropiar la estancia «El Carmen», de 17390 ha, ubicada en el partido de Coronel Dorrego.

68 En la Cámara de Diputados tuvo origen el proyecto por el que se proponía expropiarle 5500 hectáreas en Pehuajó. Frustrado el intento durante la conducción peronista, finalmente este campo se expropió y colonizó en 1958.

69 Un proyecto de expropiación sobre 4100 hectáreas en González Cháves fue presentado y debatido en la Cámara de Senadores durante el año 1948. 
certero golpe de gracia contra la oposición radical, ya que algunas de las expropiaciones entonces implementadas por decreto habían sido proyectos legislativos presentados por diputados y senadores radicales, que aun con media sanción habían caducado en las cámaras revisoras como consecuencia de la oposición del oficialismo a acelerar su tratamiento.

\section{Conclusiones}

Una reforma agraria no formal que adquiere renovado impulso durante la particular coyuntura económica y política de los años cuarenta y que procura responder a una latente conflictividad social presente desde los años 20, caracterizó las transformaciones en el sistema de tenencia de la tierra en la región pampeana argentina hacia mediados del siglo XX.

El propósito de detener el proceso de migraciones reteniendo a los productores en sus predios, en la medida en que se los consideraba pilares para responder a la creciente demanda de alimentos que abriría la posguerra, orientó la sanción de una peculiar legislación sobre arrendamientos, colonización y expropiaciones desde fines de los años 30. Retomada por el peronismo en el marco de un discurso marcadamente antilatifundista, encontró su clímax hacia 1949, cuando las crecientes exigencias de saldos exportables tornaron imperioso otorgar mayor seguridad a quienes disponían de capitales para invertir en la producción, es decir, los grandes propietarios.

De modo que esta política, en apariencia revolucionaria, mostró más continuidades que rupturas con los periodos previos, en la medida en que, haciendo hincapié en lo retórico, retomaba y reforzaba disposiciones anteriores sobre arrendamientos y colonización, evitando con ello adoptar medidas de fondo que promovieran una real subdivisión de las grandes propiedades. A pesar del fuerte énfasis discursivo del Gobierno, el impacto fue indirecto y, más que impulsado por el proceso compulsivo de expropiación y colonización, fue consecuencia de la voluntad de vender de los propietarios, inducida por la decreciente rentabilidad de los arrendamientos.

El clima de época, el compromiso formal o real de los legisladores con la causa agraria, así como su disciplinamiento y verticalidad respecto de la conducción política nacional, quedaron reflejados en las discusiones par- 
lamentarias. El énfasis originario en la promoción del reparto agrario mutó sensiblemente hacia fines de la década de 1940, dado el interés prioritario que adquirió el incremento de los saldos exportables. De modo que la «reforma del agro», planteada como uno de los postulados básicos del peronismo antes de su acceso al poder, no siguió un ritmo lineal, sino que se vio afectada y detenida por los cambios en la coyuntura económica y quizás también por la voluntad política de quienes debían ejecutarla. No obstante ello, tuvo en la provincia de Buenos Aires un más largo aliento, dada su vinculación con la sutil confrontación política en el interior del peronismo. De todos modos, la elocuencia de la retórica discursiva contrastó claramente con una práctica mucho más cauta en lo que a la afectación de los grandes capitales agropecuarios se refiere. Fue en este sentido en el que la subdivisión de la propiedad rural no afectó a los intereses mas poderosos dentro de la provincia, e involucró en cambio a miembros marginales de la burguesía agraria pampeana, sectores cercanos, en algunos casos, a la oposición política. 


\section{MÁS ALLÁ DE LA «NUEVA RURALIDAD»: REPENSAR LA REFORMA AGRARIA EN AMÉRICA LATINA}

Victor Bretón Solo de Zaldivar

(Universitat de Lleida)

En los últimos años, son numerosas las voces que están llamando la atención sobre las implicaciones de la globalización en el mundo rural. Implicaciones que tienen que ver con la misma redefinición de la noción de «ruralidad» y, naturalmente, con los desafíos que suponen y las sinergias que desatan —en casos como los de América Latina- en el seno de una agricultura familiar sometida a un alargamiento sin precedentes de su hinterland. Recientemente, Luciano Martínez ha señalado en este sentido como la economía campesina ha dejado de ser parte de «una sociedad eminentemente local para pasar a pertenecer a un espacio más amplio que pertenece a la dimensión mezo o regional y se encuentra en proceso de vincularse con la dimensión más macro o global». Es ahí donde se puede hablar de glocalidad, pues "el nivel local ya no es autosuficiente», en tanto inserto «en una dinámica más larga, más amplia, determinada por dinámicas externas que ejercen una situación de dominación estructural sobre la primera». ${ }^{1}$ En realidad, ese proceso de glocalización viene de lejos, y en su conformación ha jugado un rol protagónico el aparato del

1 Martínez Valle (2004), p. 3. 
desarrollo - desde las financieras multilaterales hasta las organizaciones no gubernamentales (ONG) y las agencias ministeriales estatales-, por la tenacidad de sus intervenciones en aras de la modernización y la adecuación de los campesinos a los parámetros de las economías emergentes: si en los sesenta y setenta se insistía en la indispensabilidad de su integración en las estructuras económicas nacionales, de los ochenta en adelante se priorizará, en el mejor de los casos, la búsqueda de vías de inserción en un escenario global cada vez más interconectado y desprotegido.

Durante décadas, "reforma agraria» fue una expresión mágica en ese mundo del desarrollo. Eran los años del industrialismo cepalino, cuando se aseguraba por activa y por pasiva que la transformación profunda de las estructuras agrarias constituía una condición sine qua non del despegue económico (muy al estilo rostowiano), pues facilitaría la capitalización y adecuación del campesinado a la coyuntura expansiva y reforzaría colateralmente la cohesión de unas sociedades inmersas en un proceso de construcción nacional en muchos casos hoy todavía inconcluso. Tras el colapso de ese modelo y el advenimiento del neoliberalismo como nuevo dogma de fe, la reforma agraria se esfumó de la arena política, pasando a ser considerada como un tema obsoleto e inviable en el contexto de la globalización. A tenor de estas consideraciones, en estas páginas quiero sugerir algunas líneas de reflexión, más allá de las interpretaciones convencionales, sobre los efectos nunca previstos de las medidas reformistas - en el ámbito de la redefinición de los actores sociales en regiones de alta densidad indígena, por ejemplo, ${ }^{2}$ y la Sierra ecuatoriana es buena muestra de ello—3 y llamar la atención sobre la reaparición actual (aún tímida) de la

2 Las demandas étnicas, de hecho, han solido emerger asociadas a formas de protesta social (Fox y Starn, 1997) y, en la particular tesitura latinoamericana de los noventa, de fuerte contenido anti-neoliberal. Así al menos ha sucedido en Chiapas (Tejera Gaona, 1996 y Díaz-Polanco, 1997), en el Chapare boliviano (Viola, 2000), en el altiplano occidental de Guatemala (Palenzuela, 1999 y Hale, 2003) o en los Andes ecuatorianos (Zamosc, 1994).

3 Voy a hacer alusión especial a la trayectoria seguida por la reforma y las estructuras agrarias de la República del Ecuador, y eso por varias razones. La primera y principal, desde la óptica de quien escribe estas líneas, es que ése es el escenario en que se circunscribe su investigación empírica (Bretón, 1997 y 2001). La segunda tiene que ver con la representatividad del caso ecuatoriano dentro del marco general de la región: Ecuador es, desde el punto de vista de su historia económica — en su territorio se han ensayado todos y cada 
reforma agraria en la agenda de las organizaciones sociales (con mayor o menor fuerza, según el caso) y su regreso a la palestra del debate académico - en buena hora-, al tiempo que instituciones como el Banco Mundial parecen revisar su ideario al respecto. Subrayo, en suma, la importancia de releer la reforma agraria treinta años después: releerla en toda su complejidad histórica como una herramienta de comprensión de la realidad; y releerla también como parte de un camino de búsqueda de alternativas para los pequeños productores rurales glocalizados.

\section{La era de la reforma agraria en América Latina: ¿historia de un fracaso?}

La apuesta en favor de la inducción de reformas agrarias como pilar de una estrategia general de desarrollo industrialista hacia adentro, reiterada sin solución de continuidad para la América Latina del tercer cuarto del siglo pasado por los grandes organismos internacionales, debe ser entendida en el marco de las teorías económicas al uso sobre la modernización de los países dependientes. ${ }^{4}$ La reforma, se argumentaba, constituía un requisito institucional previo de cara a estimular dicha modernización. A través de la reasignación del factor tierra habrían de mejorar los índices de producción agraria, condición necesaria para acelerar el crecimiento económico: «la nueva fuerza de trabajo urbana debe ser alimentada, las impor-

uno de los grandes modelos de desarrollo implementados en la América Latina contemporánea, desde el modelo liberal agroexportador hasta los planes de ajuste neoliberales, pasando por el desarrollismo endógeno- , un ejemplo de la trayectoria seguida a lo largo del siglo XX por las economías latinoamericanas; constituye, además, un caso emblemático de la transformación experimentada en Mesoamérica y en la región andina de los viejos movimientos campesinos en nuevas plataformas organizativas de acción colectiva, hoy articuladas alrededor de la identidad étnica.

4 La cuestión de la tierra, que ya había sensibilizado a la región a causa de las experiencias de México (especialmente durante el cardenismo) y, con posterioridad, de Bolivia (1952) y Guatemala (1952), se reavivó con la Revolución cubana, con el agravamiento de las tensiones en el medio rural y con la presión que la Administración norteamericana ejerció a fin de instrumentar medidas que conjurasen el peligro revolucionario. De ahí la inusitada promulgación de leyes reformistas durante ese periodo: no en vano, la reforma agraria era, por aquel entonces, una "condición indispensable para contar con la ayuda económica de los Estados Unidos e inclusive de los organismos financieros internacionales» (Chonchol, 1996), p. 266. 
taciones de alimentos deben mantenerse bajas, y las exportaciones deben aumentar para financiar las inversiones de capital desde el exterior». ${ }^{5} \mathrm{La}$ reforma posibilitaría así equilibrar la distribución de los ingresos, elevando los niveles de consumo de las masas campesinas, dinamizando el mercado interno y aportando vías de integración a los sectores más excluidos del tejido social a través de su conversión en propietarios agrícolas, aspecto éste especialmente relevante en aquellos países con elevados porcentajes de población indígena y campesina económicamente marginal.

Las transformaciones agrarias de esa época, sin embargo, no solieron estar a la altura de las expectativas sociales despertadas. Más todavía: muchas veces las reformas contribuyeron más bien a estabilizar y reforzar - $\mathrm{o}$ en su caso redefinir - las estructuras asimétricas preexistentes. Bien fuera por la timidez de las iniciativas redistributivas, bien por su deliberada tergiversación o bien por la puesta en funcionamiento de verdaderas contrarreformas agrarias tras avances más o menos significativos hacia la equidad (es el caso de Guatemala a partir de 1954 o el de Chile tras el golpe de 1973), el caso es que el sector no reformado de la agricultura mantuvo en términos generales las mejores tierras y acaparó la mayor parte de los servicios (como crédito, infraestructura o riegos) destinados al agro. Los cambios inducidos, pues, no siempre incrementaron el consumo ni el mercado interno, y el vigoroso desarrollo de las grandes unidades capitalizadas terminó limitando las perspectivas económicas de un subsector campesino nuevamente relegado. Podría afirmarse en trazo grueso que las reformas sirvieron para adecuar las estructuras agrarias a los requerimientos del desarrollismo periférico del momento: eso significó liquidar las relaciones de producción precarias (pre-capitalistas, en la literatura de la época), consolidar mercados de trabajo típicamente capitalistas, fomentar la mercantilización de las economías campesinas y facilitar la generalización selectiva del paquete tecnológico de la Revolución verde. ${ }^{6}$ Actuaron, paradójicamente, como correa de transmisión de lo que, con mucho acierto, Jacques Chonchol (1996) califica como la «modernización conservadora y excluyente» de los sistemas agrarios latinoamericanos.

5 Barraclough (1965), p. 138.

6 Ver Dorner (1992) y Kay (1998). 
TABLA 1

SUPERFICIE ASIGNADA Y UNIDADES DE PRODUCCIÓN DOMÉSTICA BENEFICIADAS POR LA REFORMA AGRARIA EN ALGUNOS PAÍSES DE AMÉRICA LATINA (en \%)

\begin{tabular}{|l|c|r|r|}
\hline & $\begin{array}{c}\text { Superficie } \\
\text { agroforestal } \\
\text { afectada }\end{array}$ & $\begin{array}{c}\text { Familias } \\
\text { asentadas }\end{array}$ & $\begin{array}{c}\text { UPD rurales } \\
\text { beneficiadas }\end{array}$ \\
\hline Bolivia & 83,4 & 74,5 (hasta 1977) & $78,9(1953-1975)$ \\
Chile & 10,2 & 9,2 (hasta 1982) & $20,0(1962-1973)$ \\
Costa Rica & 7,1 & 5,4 (hasta 1980) & $13,5(1961-1979)$ \\
Ecuador & 9,0 & 10,4 (hasta 1983) & $9,1(1964-1976)$ \\
México & 43,4 & 42,9 (datos 1970) & $52,4(1917-1980)$ \\
Panamá & 21,9 & 13,3 (datos 1977) & $2,7(1963-1969)$ \\
Perú & 39,3 & 30,4 (hasta 1982) & $21,3(1967-1979)$ \\
Rep. Dominicana & 14,0 & 8,5 (datos 1983) & $19,2(1962-1986)$ \\
Venezuela & 19,3 & 30,6 (hasta 1979) & $25,4(1959-1975)$ \\
\hline
\end{tabular}

FUENTE: Elaborado a partir de Meyer (1989), Thiesenhusen (ed.) (1989), El-Ghonemy (1990) y Dorner (1992).

Con todo, más allá de sus limitaciones y de las críticas que les son imputables, la era reformista sí estimuló en conjunto la estabilidad de la agricultura familiar, ya que supuso un «avance» del campesinado en términos de superficie y presencia social. ${ }^{7}$ A pesar de que la casuística es muy amplia, es recurrente la constatación (por otra parte lógica) de una relación directa entre la magnitud de las incautaciones y el volumen de población beneficiado por los repartos (tabla 1). Así, en Bolivia, donde la reforma alcanzó entre 1953 y 1977 al 83,4\% de la superficie agrícola y forestal del país, se asignó tierra al 74,5\% del campesinado. De igual manera, México y Perú, con un monto de tierras reformadas sobre el $40 \%$ del total, dotaron respectivamente al $43 \%$ (hasta 1970) y al $30 \%$ (hasta 1982) de sus explotaciones familiares. ${ }^{8}$ Mucha tierra redistribuida, por otra parte,

7 Ortega (1986).

8 Las diferencias que se observan entre la tercera y la cuarta columna de la tabla 1 se explican porque aluden a realidades no siempre comparables entre sí. En el primer caso (columna 3), los datos se refieren al porcentaje de unidades que recibieron tierras, mientras que en el segundo (columna 4), aluden al volumen de unidades de producción domésticas (UPD) que se vieron de algún modo (y no exclusivamente a través de la dotación de parcelas) beneficiadas por las reformas (crédito, infraestructuras, regadíos, etc.). Los años de estimación, además, también justifican en parte los cambios. Piénsese, por ejemplo, que en procesos como el de Chile no es lo mismo trabajar con las cifras del periodo anterior a 1973 que globalmente con las resultantes del giro experimentado por la política agraria a partir de esa fecha. 
no significa necesariamente buena tierra, puesto que el epígrafe de «superficie agrícola y forestal» incluye, junto a terrenos ciertamente feraces, no se sabe qué porcentaje de bosques y de extensiones marginales o sencillamente incultivables: de ahí los límites de las reformas en lo que atañe a la reducción de la pobreza rural. Las medidas de reparto, además, no solieron verse acompañadas de apoyos complementarios que permitieran reorganizar adecuadamente la pequeña producción agropecuaria. ${ }^{9}$

Piénsese que, en otro orden de cosas, las tierras redistribuidas solían ser inembargables e inalienables (al menos formalmente) y que, en casos emblemáticos como los de México o Bolivia, la reforma plasmaba un cierto pacto entre el Estado y las organizaciones campesinas; pacto que coadyuvó a mantener un tenue clima de paz social en el medio rural o, cuando menos, facilitó encauzar hacia andariveles manejables la conflictividad desatada alrededor de la lucha por la tierra. También debe hacerse la lectura contraria, en el sentido de que el incumplimiento de ese pacto por parte del Estado ha generado a menudo un agudizamiento de las contradicciones y no pocos estallidos violentos. ${ }^{10} \mathrm{La}$ fiebre reformista alentó con frecuencia el fomento de redes clientelares, aumentando la presencia gubernamental en el agro y, a través de ella, dificultando la unidad de acción del campesinado. Las familias beneficiarias — ha señalado Grindle-, «se convirtieron en una clientela estable y dependiente de las agencias de reforma agraria, de unos específicos partidos políticos y del mismo Estado». ${ }^{11}$ De este modo, las reformas fueron útiles para las élites nacionales: prueba de ello es su permanencia legal e institucional hasta entrados los noventa como una parte del aparato estatal. ${ }^{12}$

9 Márquez (1983), pp. 32-33.

10 Cf. Kay (2001).

11 Grindle (1986), p. 160.

12 En el caso ecuatoriano, la reforma agraria desarrollada al amparo de las leyes de 1964 y 1973 redundó en una ampliación de la superficie agropecuaria del país del orden de cuatro millones de hectáreas hasta 1984. Esa ampliación sirvió para aliviar la presión sobre la tierra en la Sierra y se fundamentó en el desmonte y posterior colonización de la costa noroccidental y de algunas partes de la Amazonía: de hecho, el porcentaje de entregas del Instituto Ecuatoriano de Reforma Agraria y Colonización (IERAC) en régimen de reforma agraria stricto sensu no llegó al $30 \%$ de las adjudicaciones (estimaciones para la década de 1980), cuyos casi dos tercios (el 71,5\%) procedían de la ocupación del trópico y subtrópico. Si a eso añadimos que el tamaño promedio de los lotes era considerablemente más grande en los territorios colonizados (habitualmente por encima de las 30 hectáreas) 
TABLA 2

POBREZA, INDIGENCIA Y SUBNUTRICIÓN EN EL MEDIO RURAL DE AMÉRICA LATINA Y EL CARIBE, 1970-2002

\begin{tabular}{|c|c|c|c|}
\hline & $\begin{array}{c}\text { Magnitud de la } \\
\text { pobreza (\%) }\end{array}$ & $\begin{array}{c}\text { Magnitud } \\
\text { de la indigencia (\%) }\end{array}$ & $\begin{array}{c}\text { Millones } \\
\text { de personas subnutridas }\end{array}$ \\
\hline 1970 & 62,0 & 34,0 & 55,4 \\
1980 & 59,9 & 32,7 & 46,2 \\
1990 & 65,4 & 40,4 & 59,6 \\
2002 & 61,8 & 37,9 & 53,1 \\
\hline
\end{tabular}

FUENTE: CEPAL (1996) y (2004) y Dirección Estadística de la FAO (<http://www.fao.org>).

Las estimaciones sobre pobreza, indigencia y prevalencia de la subnutrición no dejan lugar a dudas, y marcan con claridad los límites de la vía reformista tal como se ensayó en América Latina (tabla 2). Según datos de la CEPAL, ${ }^{13}$ en 1970 , en pleno proceso reformista en la mayor parte de los países de la región, el $62 \%$ de los hogares rurales estaba bajo la línea de la pobreza, y el $34 \%$, de la indigencia. Eso se traducía en un volumen de población subnutrida del orden de los 55,4 millones de personas. Diez años después, la magnitud de la pobreza rural había descendido tímidamente al 59,9\% y la de la indigencia estaba en el 32,7\%, en parte como consecuencia del impacto, moderado (pero positivo) para una porción del campesinado, de las reformas y en parte también como efecto del fuerte éxodo rural estimulado por la industrialización y la expansión del paquete tecnológico de la Revolución verde. ${ }^{14}$ En consonancia con ello, la sub-

que en las antiguas haciendas redistribuidas (pocas veces superaban las 15-16 hectáreas), salta a la vista la estrechez de la reforma desde la óptica de la redistribución real de la propiedad y la riqueza (Chiriboga, 1987 y Barsky, 1988). El IERAC desmovilizó al campesinado a través del fomento de la colonización y del acceso a la propiedad de los precaristas serranos; aceleró los procesos de disolución y posterior redistribución de aquellas haciendas incapaces, por las razones que fuera, de adecuarse a las necesidades modernizantes impuestas por la coyuntura; pero garantizó la reconversión sobre las mejores tierras de buena parte de las antiguas haciendas andinas en unidades capitalizadas y orientadas al mercado urbano interior o a la exportación.

13 Acrónimo de la Comisión Económica para América Latina y el Caribe. Este organismo define la pobreza como aquella situación en que los hogares disponen de ingresos inferiores al doble del costo de una canasta básica de alimentos. La indigencia, por su parte, se refiere a cuando ingresan menos del costo de una canasta básica de alimentos.

14 Sobre la persistencia de la pobreza rural a partir de 1990, resulta muy sugerente el trabajo de Kay (2005). 
nutrición cayó en ese decenio hasta los 46,2 millones. De ahí en adelante, los ajustes estructurales de corte neoliberal y la apertura comercial y financiera estimulada por el Consenso de Washington no van a hacer más que estabilizar el número de personas hambrientas en los niveles de los años sesenta, dejando el porcentaje de pobres e indigentes como en los albores de los ochenta. En esa coyuntura, los límites de las reformas ensayadas, el camino hacia la articulación de grandes espacios económicos y la consolidación de modelos de crecimiento netamente neoliberales, enterraron este tipo de medidas reformistas dentro del cajón de sastre de lo obsoleto y no viable en los nuevos escenarios de la globalización.

\section{De la obsolescencia del reparto a la «nueva ruralidad»}

La praxis neoliberal se concretó en la región a través de la puesta en funcionamiento de tres grandes líneas de actuación, en lo que al sector agropecuario y a las áreas rurales se refiere: la liberalización y la desregulación de mercados de productos e insumos antaño protegidos; la liberalización del mercado de tierras - lo que supuso el fin del mencionado pacto del Estado con el campesinado-; y la substitución paulatina y definitiva del paradigma de la reforma agraria por el del desarrollo rural integral (DRI). Dicha substitución, más trascendente de lo que pudiera parecer a simple vista, implicó el abandono de la pretensión de una transformación global y estructural del sector agrario en aras de una intervención parcial y circunscrita a determinados grupos de productores (se privilegió el trabajo con campesinos viables o potencialmente viables, excluyendo de facto a los más pobres), abriendo de esta manera una puerta a la posibilidad de privatizar y externalizar las intervenciones en materia de desarrollo en un escenario general de repliegue del Estado. Esto es al menos lo que se desprende de un somero análisis de lo que ha significado la práctica del desarrollo en el medio rural durante las últimas dos décadas del siglo XX; una práctica marcada por grandes tendencias que, en mi opinión, pueden sintetizarse de la siguiente manera:

a) El abandono del tema - hasta entonces prioritario- de la distribución de la tierra. En nombre del desarrollo rural, y asumiendo tácitamente el fin del ciclo reformista, casi todas las intervenciones han terminado eludiendo esta cuestión: los proyectos DRI, pione- 
ros de la nueva coyuntura, ni siquiera lo mencionaban, pues lo consideraban (por activa o por pasiva) como un asunto desfasado $\mathrm{y}$ anticuado.

b) La proliferación de nuevos agentes, muchos de ellos de carácter privado (ONG), que van a ser los responsables de implementar los proyectos concretos y substantivos sobre el territorio, llenando el vacío dejado por los poderes públicos, actuando como eslabones intermedios de la "cadena de la ayuda" y consolidando nuevas formas de cooptación y clientelismo. ${ }^{15}$

c) Una enorme dispersión y fragmentación paradigmática, pues hay tantos paradigmas de intervención como agentes interviniendo. $\mathrm{Ni}$ que decir tiene que esta situación ha generado ingentes problemas de competencia entre las agencias de desarrollo, de yuxtaposición de iniciativas y de incapacidad, en última instancia, para negociar una mínima agenda común de prioridades que atender.

d) Relacionado con lo anterior, una sucesión y caótica convivencia de «modas» y «vaivenes» en las conceptualizaciones de lo que «debe ser» el desarrollo rural. Modas y vaivenes — desde el etnodesarrollo o desarrollo con identidad hasta el capital social, la sostenibilidad, la descentralización o el enfoque de género- que, al tiempo que fragmentan la realidad social, impiden acometer algunos de los problemas (irresueltos) que condicionan el devenir de las áreas rurales (y urbanas). ${ }^{16}$

e) De la mano de las políticas neoliberales se ha incrementado la brecha de la exclusión y la pobreza; fenómeno que tiene mucho que ver con la permanencia de problemas estructurales - y el de la inequitativa distribución de la tierra es uno de ellos- que, además de alimentar numerosas espirales de violencia, sitúan a los pequeños productores en una posición desventajosa frente a los desafíos impuestos por la globalización neoliberal y uno de sus corolarios, la desestatalización (traducida en este ámbito en la ausencia de políticas agrarias estatales).

15 Ver Sogge (2004) y Bretón (2002).

16 Ver Fine, Lapavitsas y Pincus (eds.) (2001). Circunscritos al ámbito del Ecuador, resultan de interés, para cada uno de los diferentes temas, las aportaciones de Martínez Valle (1999) y (2003), Bretón (2005) y Cuvi, Ferraro y Martínez (2000), entre otras. 
Ante esta situación, y muy en consonancia con el espíritu del Postconsenso de Washington y su énfasis en explorar las vías para conseguir un «ajuste con rostro humano», en los últimos años se está consolidando lo que podría ser el preludio de un paradigma interpretativo de esa nueva ruralidad: el desarrollo rural territorial. Se trata de una concepción que, partiendo de la consideración de los desafíos que la globalización impone a las respectivas estructuras agrarias locales y regionales, y asumiendo la evidencia de la glocalidad como característica definitoria de ese escenario a nivel microsocial, recoge algunas de las aportaciones teóricas más significativas y recientes — de las modas, en definitiva - a fin de intentar brindar una imagen articulada, poliédrica y holística de la compleja y mudable realidad rural latinoamericana. Es en ese contexto donde el tema de la reforma agraria ha sido "desempolvado" y traído nuevamente a la palestra del debate académico y político, hecho en sí mismo significativo y remarcable.

Son ya abundantes, en efecto, los documentos —oficiales u oficiosos- en que se reconoce explícitamente el fracaso de muchas de las medidas tomadas bajo el palio del Consenso de Washington, puesto que han incrementado la distribución asimétrica de la riqueza y la renta, limitando en última instancia las posibilidades de crecimiento del conjunto de la región. ${ }^{17}$ En esa polarización asimétrica, la cuestión de la tierra ocupa todavía un lugar central, pues los procesos de reconcentración han sido de tal magnitud en la última década ${ }^{18}$ que en muchos países — y el Ecuador es uno de ellos- los índices de Gini de la propiedad se sitúan ya en valores próximos o incluso superiores a los existentes antes del inicio de las reformas agrarias. Con todo, y aun reconociendo que el problema de las reformas «clásicas» es la forma en que se llevaron a cabo o el hecho de que quedaran inconclusas - aspecto éste que marca un punto y aparte en relación con las tesis del "fracaso» y la obsolescencia dominantes hasta hace bien poco-, se continúa insistiendo en que debe ser el mercado quien debe reasignar el factor tierra. Es decir, que la nueva economía ins-

17 Banco Mundial (2002).

18 Desde la puesta en marcha de las «contrarreformas» neoliberales (México en 1992, Perú en 1993, Ecuador en 1994, Bolivia en 1996), que en teoría iban a dinamizar los mercados de tierras, incentivar la inversión de capital privado en el sector y mejorar su situación relativa de cara a su competitividad en un mundo cada vez menos regulado desde los estados nacionales. 
titucional parece empeñada en circunscribir el problema al funcionamiento irregular de los mercados, enfatizando la necesidad del fortalecimiento de las instancias de intermediación únicamente como mecanismo capaz de corregir dicha anomalía.

Un buen ejemplo de esta postura oficialista lo encontramos en las reflexiones de Frank Vogelgesan, de la CEPAL, autor que plantea que, dado que el medio rural se caracteriza por la presencia de mercados imperfectos, información asimétrica e incertidumbre —obsérvese la huella sui géneris de Stiglitz-y que, además, «el comportamiento económico está generalmente guiado por la lógica de la unidad campesina, que difiere marcadamente de la manera en que opera la agricultura convencional» (¿regreso, en plena glocalización, a planteamientos idealizados de corte chayanoviano?), resulta que «ningún régimen de derechos de propiedad [puede ser] universalmente válido», de donde se desprende que "las complejidades de los mercados de tierras rurales tienen que ser consideradas en el diseño de políticas efectivas», cosa que no había sucedido en el proceso de aplicación de un mismo modelo de reforma de la reforma (contrarreforma neoliberal) a contextos significativamente heterogéneos. De ahí — concluye este autor- la pertinencia de un enfoque neoinstitucional. ${ }^{19}$ Siguiendo otra línea argumental (aunque convergente con la anterior), hay quienes responsabilizan del fracaso de las medidas liberalizadoras a su carácter contradictorio y parcial. Es el caso de Arturo Warman, uno de los artífices del controvertido giro de la política agraria mexicana a inicios de los noventa; giro que - vía reforma constitucional— sirvió de punto de referencia, entre otros, a los países andinos. Para Warman, el modelo «quedó a medio camino entre la inercia y la reforma», puesto que «el aparato institucional y su burocracia no han seguido el ritmo de las nuevas normas legales ni se han adaptado al espíritu de la reforma». ${ }^{20}$ Tanto desde el prisma de un organismo internacional (Vogelgesang) como desde el de quien tuvo responsabilidades de gestión (Warman), el caso es que nunca se cuestiona la bondad intrínseca de las medidas neoliberales, sino, en todo caso, el cómo se ha intentado llevarlas adelante y el peso de las inercias heredadas.

19 Vogelgesang (1998), p. 20.

20 Warman (2003), p. 94. 


\section{La necesidad de repensar la reforma agraria y el papel del Estado}

Desde el punto de vista de la hipotética inclusión de los campesinos pobres desahuciados en nombre de la competitividad, algunos analistas llaman la atención sobre la necesidad de impulsar, dadas las circunstancias, una nueva legislación sobre la tenencia de la tierra; de redefinir el papel de los poderes públicos, abogando por un «rol proactivo del Estado, sobre todo en la política de precios y la protección del mercado interno»; ${ }^{21}$ y de consolidar, como consecuencia de todo ello, mercados agrícolas regionales (a cuyo afianzamiento deberían contribuir los procesos de integración tipo Mercosur o Pacto Andino). Repensar la reforma agraria y el Estado en la coyuntura actual se nos antoja, así, una tarea pertinente y necesaria de cara al diseño de posibles líneas de actuación en el futuro. Una tarea, por otra parte, que bien pudiera articularse alrededor de varios grandes ejes temáticos:

Primer eje. La revisión de lo que significó el proceso reformista desde la perspectiva de las transformaciones sociales y políticas de la América Latina contemporánea. Decimos esto porque la inmensa mayoría de la literatura disponible sobre el tema se limita a realizar balances de las variables estrictamente económico-productivas - labor por otra parte ineludible como punto de partida interpretativo-, aunque la reforma agraria fue mucho más allá de todo eso. De alguna manera - y parafraseando lo afirmado por Rodrigo Montoya (1992) para el caso peruano-, es como si las reformas agrarias hubieran roto un dique enorme - en el mundo andino, el de la dominación hacendataria secular-, provocando un desembalse inmenso, inconmensurable, cuyas consecuencias de todo orden - políticas, culturales, sociales, simbólicas, pero también económicas - todavía no hemos aprehendido en toda su magnitud y complejidad.

Segundo eje. Un tema básico, en este sentido, es el del devenir de los «nuevos movimientos sociales» que, surgidos en los intersticios de la ruralidad, difícilmente son interpretables sin tener en consideración la significación profunda de las reformas agrarias y la dinámica que éstas acarrea-

21 Martínez Valle (2004), p. 9. 
ron en la intermediación del Estado con los campesinos. ${ }^{22}$ Un ejemplo emblemático lo encontramos justamente en la articulación del movimiento indígena de los Andes ecuatorianos, referente donde los haya en la literatura especializada del resurgir de la indianidad en América Latina. Los procesos allí desencadenados a partir del desmoronamiento del régimen gamonal, de la eliminación de las relaciones de producción precarias - que encontraban en los huasipungos su máxima expresión— ${ }^{23} \mathrm{y}$ del establecimiento de un nuevo marco de relaciones con el Estado, marcaron definitivamente un antes y un después que está en la base de la extensa redefinición de los campesinos como indígenas, así como de la consolidación de un sólido andamiaje organizativo en el medio rural; ${ }^{24}$ andamiaje en cuyo fortalecimiento jugaron a posteriori (ya en los años ochenta y noventa) un rol fundamental las agencias de desarrollo estatales y privadas, y que hasta el día de hoy es, para éstas, objeto preferido de experimentación de las más sofisticadas modas en materia de intervención socioeconómica sobre la realidad indígeno-campesina. ${ }^{25}$

Tercer eje. Siguiendo con esta línea argumental, resulta indispensable analizar y explicar por qué en la inmensa mayoría de esas plataformas organizativas no se aborda de manera clara, explícita y prioritaria el tema de la reforma agraria. ${ }^{26}$ Es evidente que por debajo de las demandas de carácter estrictamente étnico e identitario subyacen reividicaciones que tienen que ver con el carácter rural de una parte importante de las bases

22 Veltmeyer (1997) y Petras y Veltmeyer (2003).

23 La histórica hegemonía social y económica de las haciendas explica la pervivencia, hasta la década de los años sesenta, de todo un amplio abanico de vínculos precarios entre las economías campesinas serranas y los hacendados. Esos vínculos, el más importante de los cuales era el huasipungo, se fundamentaban en la obtención de rentas por parte de los terratenientes a cambio de permitir el acceso en precario de los campesinos a la tierra.

24 Guerrero (1993) y (2000).

25 Estoy pensando por ejemplo en el Proyecto de Desarrollo de los Pueblos Indígenas y Negros del Ecuador (PRODEPINE), auspiciado por el Banco Mundial y que de 1998 a 2004 constituyó el intento más ambicioso a escala continental de aplicación sobre el terreno de las nociones de capital social y de etnodesarrollo (Bretón, 2005).

26 Una notable excepción a esta tendencia es, sin duda, el Movimiento de los Sin Tierra brasileño. El giro experimentado por el Estado boliviano tras la llegada a la presidencia de la República del carismático líder Evo Morales, por su parte, puede marcar un parteaguas en la mencionada línea discursiva, muy presente (a veces dominante) entre sectores remarcables de las dirigencias indígenas al menos desde la segunda mitad de la década de 1990. 
sociales que dan soporte y aliento a esos movimientos. Pero resulta cuando menos sorprendente que, ante los importantes procesos de reconcentración de la tierra experimentados en los últimos años, esta cuestión no haya trascendido (más allá de un modesto segundo plano) a la articulación de los discursos y a la publicitación de éstos de cara a la intermediación con las agencias de desarrollo. No deja de ser chocante esta situación si tomamos en consideración, en perspectiva temporal, lo importante que fueron las propias reformas agrarias como hito que rompió con una situación y abrió las puertas a la consolidación de nuevas y potentes formas de aglutinar la acción colectiva del campesinado.

Cuarto eje. ¿'Tiene alguna relación la predilección mostrada por el aparato institucional del desarrollo por privilegiar la etnicidad como elemento de discriminación positiva a la hora de canalizar sus intervenciones en el medio rural con la mencionada subordinación del discurso campesinistaclasista por parte de los nuevos actores indígenas? En trabajos anteriores ${ }^{27}$ hemos tenido ocasión de constatar, para los Andes ecuatorianos, la correlación existente entre el volumen de los proyectos (e inversiones) y la presencia de contingentes de población indígena, fenómeno que está naturalmente relacionado con el vigor y la capacidad de movilización mostrada por las organizaciones étnicas. Ahí queda, por ejemplo, la apuesta de organismos como el Banco Mundial a favor de los pueblos y nacionalidades indígenas; apuesta que puede ser interpretada en términos del proyecto cultural —que sí existe- del neoliberalismo: como certeramente recuerda Willem Assies ${ }^{28}$ este último trasciende en América Latina a las políticas económicas stricto sensu, englobando medidas como el reconocimiento (incluso constitucional) de algunos derechos culturales de las minorías étnicas - aquellos que no ponen en entredicho el núcleo duro del patrón de acumulación-y el rechazo más o menos explícito del resto. ${ }^{29}$ Optar, como se ha hecho, por la vía proyectista (esto es, por circunscribir el quehacer de las agencias de desarrollo — de todas ellas, públicas y privadasa las intervenciones concretas y substantivas - los proyectos convencionales, con todas sus limitaciones de alcance social y espacial-, dejando de

\footnotetext{
27 Bretón (2001) y (2002).

28 Assies (2000), p. 10.

29 Cf. Hale (2003).
} 
lado el abordaje de cuestiones como la transformación de las estructuras económicas y de poder) se mostró funcional con la asunción — por parte de todos, de los donantes y de los beneficiarios de las inversiones- de determinadas demandas de carácter étnico e identitario (en sí mismas importantes, aunque insuficientes desde el punto de vista de la pobreza rural), al tiempo que facilitó el archivo paralelo de reivindicaciones económicas más profundas.

Quinto eje. La revisión histórica del papel que jugó el Estado en el ciclo reformisma es, por lo dicho anteriormente, fundamental. Cómo entender la reforma agraria desde el punto de vista de la presencia del Estado y los poderes públicos en las áreas rurales (qué significó en el pasado y qué podría llegar a significar —si es que ello es posible - en los deseables escenarios de la integración regional); qué sentido tiene en el discurso y las demandas de los movimientos sociales y qué potencialidades tendría desde la óptica de generar procesos reales de distribución de la renta y de mejora de las condiciones de vida de los sectores más desprotegidos del medio campesino. Lejos de reivindicar sin más una reedición de los modelos obsoletos del pasado, es menester abrir una línea de reflexión sobre cómo tiene que plantearse una nueva reforma agraria que, asumiendo los desafíos que comporta la globalización neoliberal, permita contrarrestar el discurso neoinstitucional en que se fundamenta la aproximación al tema del Banco Mundial y otros organismos.

\section{Algunas reflexiones finales}

Estas inquietudes, desde luego, no son nuevas. Tal como lo han ido planteando autores como Plaza (1995), Rosenthal (1994), o Murmis (1994), por citar algunos de los más conocidos, se trataría de buscar vías de salida para las masas de excluidos de la nueva modernización del agro latinoamericano; salidas que pasan por estrategias de viabilización de las explotaciones familiares en el contexto del neoliberalismo. Son interesantes en esta línea las propuestas (escasamente atendidas, dicho sea de paso) articuladas por la misma CEPAL en los primeros años noventa (1990 y 1993) en torno a la transformación productiva con equidad. Ahí la comisión se inclinaba ya a incorporar parte de los enfoques procedentes de la orientación neoliberal (la inevitabilidad de la globalización y todo lo que ello 
comporta) e intentar encajarla en un paradigma preocupado por los sectores sociales desprotegidos. Este planteamiento de corte neoestructuralista suponía una cierta revalorización de la actuación estatal como garante del achicamiento de la brecha social, a la vez que apostaba por un mercado interno capaz de incentivar el crecimiento y por la puesta en marcha de medidas redistributivas del ingreso, aunque moderadas y restringidas a los más necesitados. El énfasis puesto en no salir del ámbito de lo políticamente correcto (que acostumbra a identificarse sencillamente con lo posible) advierte, sin embargo, del riesgo de este tipo de proposiciones. Es cierto que su clave de bóveda es la noción de que los productores marginales pueden ser incorporados al proceso de desarrollo siempre y cuando existan condiciones favorables a su participación y a que esa participación se canalice en actividades viables. ${ }^{30}$ No es menos cierto, sin embargo, que la solución con mayúsculas para estos excluidos implica la satisfacción de demandas de más hondo calado. ${ }^{31}$ Es indispensable retomar con seriedad la oferta de oportunidades en el medio rural; tema que pasa, se quiera ver o no, por la candente cuestión del acceso a la tierra.

Además de indispensable, la tarea es urgente, habida cuenta del escenario de relaciones de poder en que se desenvuelven estos procesos. Retóricas aparte, y más allá de lo que pueda implicar la profundización de la vía mercantilista priorizada por el establishment financiero en nombre de una nueva reforma agraria para el mundo en desarrollo, lo cierto es que los subsidios agrícolas previstos en los Estados Unidos para el periodo 20032009 serán superiores en un $80 \%$ a la media del intervalo 1996-2002, y que un promedio del $54 \%$ del precio de los productores de la Unión Europea está todavía respaldado por las ayudas gubernamentales. ${ }^{32} \mathrm{Si}$ a eso añadimos el impacto que previsiblemente tendría —en caso de culminar el actual proceso negociador bilateral entre los Estados Unidos y cada país - la paulatina consolidación de facto de una gran área de libre comercio en las Américas hegemonizada por los Estados Unidos, el panorama se ensombrece en términos de (in)seguridad alimentaria, en términos de

30 Sunkel (1993).

31 Veltmeyer y O’Malley (eds.) (2001).

32 Jordán (2003), p. 34. 
dependencia y, por supuesto, en términos de descomposición social y económica de buena parte de las áreas rurales de América Latina. ${ }^{33}$

Paralelamente, sin embargo, hasta la FAO reconoce que «la lucha por eliminar el hambre [...] se ganará o se perderá en las zonas rurales, pues es allí donde vive la mayoría de las personas hambrientas del mundo». ${ }^{34}$ Eso debiera implicar prestar atención a las prácticas consuetudinarias de producción y distribución de alimentos; unas prácticas que los teóricos de la agroecología reconocen como sostenibles y biodiversas y que, durante dilatados periodos de su historia, han demostrado ser mucho más eficientes desde el punto de vista del abasto alimentario local que las alternativas modernas impulsadas sin descanso por el aparato del desarrollo. ${ }^{35}$ También debiera implicar, por supuesto, ofrecer un espacio dentro de los mercados

33 Chiriboga (2004), p. 13, pronosticaba para Ecuador un efecto neutro del acuerdo de libre comercio (TLC) en los productores de exportación de banano, cacao y café; un efecto beneficioso en rubros como flores y algunos otros cultivos tropicales; un efecto previsiblemente perjudicial en especies que, pese a tener ventajas comparativas (caso de la palma aceitera), «están sujetos a restricciones impuestas [...] por la presión de los productores de soya americanos"; y un efecto desastroso en ítems "donde hay un gran número de productores y donde se emplean miles de ecuatorianos, hombres y mujeres, como el arroz, la leche y la carne, los pollos, el maíz o la papa». "Estos se han beneficiado hasta ahora del sistema arancelario, de acuerdos de absorción de cosechas y de restricciones de diverso tipo a la importación. ¿Pueden estos productores competir en el contexto actual, si se eliminan tales sistemas? ¡La respuesta es decididamente No! Sus costos son más altos que el de los competidores americanos, aún sin considerar los enormes subsidios que ellos reciben; no tienen un sistema de apoyo tecnológico significativo y varios costos de producción están muy por arriba». Paradojas de la vida, el mismo Chiriboga terminó siendo el responsable de la delegación ecuatoriana en las negociaciones del TLC; negociaciones que en este momento (mayo de 2006) se encuentran paralizadas como respuesta de la Administración estadounidense a la rescisión de las concesiones petroleras por parte del Gobierno ecuatoriano a la compañía Oxy.

34 FAO (2005), p. 4.

35 Ver Toledo (1993), Altieri (1995) y Yurjevic (1997), entre otros muchos. Igualmente hay que fijarse en las estrategias desplegadas por los actores sociales ante el envite de la globalización neoliberal. Resulta interesante el ejemplo que brindan los campesinos del valle peruano de Lares (Cuzco), estudiados por Martí Sanz (2005). Se trata de comunidades mercantilizadas, ubicadas durante décadas en los parámetros desarrollistas de la Revolución verde, que en los últimos años han consolidado una sólida red de mercados de trueque (los chalayplasa) como respuesta a la expulsión del mercado monetario convencional a que el ajuste estructural de principios de los noventa (el fujishock) las condenó. Al parecer, los resultados, desde el punto de vista de complementar la dieta aprovechando los recursos locales y el manejo de la microverticalidad andina, no son nada desdeñables. 
locales y regionales (entendiendo la región en un sentido amplio) a los productores rurales. Los ejemplos de como todo eso está siendo desbaratado por la apertura comercial y su corolario, el empobrecimiento masivo de la población, son numerosos y están bien documentados. ${ }^{36}$ Esto comportaría - y ahí queda eso - recuperar el sentido de la política y su capacidad de encauzar los efectos concentradores de las fuerzas del mercado, poner sobre el tapete la cuestión del rol que debe desempeñar el Estado y, con él, reconducir e impulsar los procesos de integración regional. El relanzamiento de estos últimos en América Latina - la Comunidad Andina de Naciones es, hoy por hoy, más virtual que real y las dificultades por las que atraviesa el Mercosur prácticamente lo neutralizan como bloquepodría brindar la oportunidad de negociar con mayor fuerza y capacidad de maniobra en el escenario internacional, de llevar a cabo las medidas de carácter estructural ineludibles (reforma agraria incluida) y de consolidar unos mercados internos donde los pequeños productores locales tengan un lugar al sol. La articulación de esos espacios económicos regionales y supranacionales (a modo de contrahegemonía territorial, si se quiere), con la consiguiente redefinición del papel de los poderes públicos —el rol proactivo del Estado a que alude Luciano Martínez - y, sobre la base de éste, la puesta en marcha de medidas que garanticen el acceso de los pequeños productores a los medios de producción, al capital, a la información y a los mercados glocales son, pues, aspectos que convendría considerar seriamente si no se quiere alcanzar el escenario de «tierra arrasada» a que parece conducir el actual modelo imperante.

36 Uno de los casos más dramáticos quizás sea el del Ecuador, país que dio un paso decisivo en esa dirección cuando dolarizó plenamente su economía a partir de enero de 2000. Las consecuencias de la dolarización sobre las explotaciones campesinas (productoras de alimentos básicos para el consumo de los sectores populares) han sido hasta el momento demoledoras. La quiebra de muchas de ellas - especialmente las de aquéllas adaptadas a la Revolución verde e integradas en el mercado nacional- por el incremento en el precio de los insumos y por la invasión de los mercados locales de productos básicos procedentes de los países limítrofes (no dolarizados), está redundando en un notable empobrecimiento de la dieta en el medio rural, además de en una crisis profunda en términos de alternativas y expectativas de futuro. 


\section{REFORMA AGRARIA, DESARROLLO RURAL Y AGRICULTURA SOSTENIBLE EN AMÉRICA LATINA BAJO EL CONTEXTO DE LA GLOBALIZACIÓN Elisa Botella Rodríguez (Universidad de Salamanca)}

\section{Introducción}

Desarrollo es fundamentalmente un proceso de cambio. Parte primordial de ese cambio es el incremento de la productividad y la intensidad de la agricultura, de la gente moviéndose del sector agropecuario al sector secundario y servicios, y del campo a las ciudades. Una tenencia de la tierra segura [...] cuyos derechos de propiedad son muy a menudo ignorados, es un prerrequisito para ello. ${ }^{1}$

En todo el mundo los más pobres entre los pobres son los campesinos sin tierra de las zonas rurales, seguidos muy de cerca por los pequeños agricultores que poseen parcelas de mala calidad o demasiado pequeñas para la subsistencia. A su vez, los suelos de mayor calidad se han concentrado en grandes propiedades pertenecientes generalmente a multinacionales o grandes propietarios (muchas veces absentistas) y reservadas a una agricultura intensiva de monocultivo, destinada a la exportación, mecanizada y altamente dependiente de insumos químicos.

1 Stern, en Deininger (2003), p. 6. 
Este artículo trata de examinar el significado y actual importancia del desarrollo agrario y rural en América Latina, los procesos de reforma agraria -durante mucho tiempo relegados a un segundo plano en las agendas y políticas de desarrollo de los gobiernos latinoamericanos- y subrayar la necesidad de un cambio de concepción en las agendas de desarrollo de la región.

Con este objetivo, el punto 1 abordará el impacto que la globalización ha tenido en el agro latinoamericano. Es decir, las oportunidades y amenazas que ésta representa a la hora de elaborar políticas de desarrollo agrario y rural en la región, así como la existencia de dos modelos de producción agraria en conflicto: el modelo dominante versus un paradigma alternativo. El punto 2 introducirá el problema de la tierra en América Latina y cómo este ha ido dando forma a la actual situación agraria y rural de la región a través de las diferentes etapas de crecimiento desarrolladas durante el siglo XX.

En tercer lugar, se abordará la importancia del desarrollo agrario y la redistribución de tierras en los procesos de industrialización de las economías en vías de desarrollo. Para ello se compararán las reformas agrarias llevadas a cabo en algunos de los nuevos países industrializados del este asiático con las numerosas reformas fallidas implementadas en el siglo XX en América Latina.

En la sección 4 se estudia el papel del Estado en los procesos de reforma agraria, explicando como éste ha ido variando y adquiriendo un nuevo rol a finales del siglo XX en América Latina.

Por último, en el punto 5, nos situaremos en el contexto de la globalización, para tratar de entender cómo se comprende bajo este marco a partir de los 90, el desarrollo rural y la reforma agraria. Se establecerán dos estudios de casos muy diferentes, en los que la reforma agraria ha sido un elemento muy importante en el proceso de desarrollo económico. Por un lado, se introducirá el caso de Brasil, donde el principal impulsor del proceso de reforma agraria ha sido el MST y su ideología basada en la agroecología. Por otro lado, se abordará el ejemplo de la redistribución de la tierra en Cuba y la emergencia de un modelo de agricultura sostenible como respuesta a la profunda crisis económica de los 90, desarrollado a escala nacional y sin precedentes en la historia de la humanidad. 
Este artículo concluye con algunas lecciones, recomendaciones y desafíos que se deben tener en cuenta no sólo a la hora de desarrollar políticas agrarias en América Latina, sino también en muchos países desarrollados.

\section{La globalización y la agricultura: Oportunidades y amenazas}

El enemigo es el modelo, y la meta de las protestas es la «mudança do modelo», ó la transición de modelo. ${ }^{2}$

En el contexto actual de la globalización nos encontramos con una situación muy crítica en las zonas rurales de la mayoría de los países de América Latina. La Vía Campesina sostiene que nos enfrentamos a un conflicto histórico entre dos modelos económicos, sociales y culturales de desarrollo en el mundo rural. Por un lado, observamos un modelo dominante lleno de externalidades negativas, basado en el monocultivo de exportación y una alta dependencia de maquinaria y agroquímicos. Por otro lado, encontramos un modelo alternativo conocido como «soberanía alimentaria».3

La tabla 1 expuesta a continuación incluye las ventajas y desventajas de ambos modelos. En primer lugar, se describen las características del modelo dominante de producción agraria, resultado de la Revolución verde. Un sistema altamente dependiente de maquinaria, mano de obra empleada, fertilizantes químicos y con una productividad de la tierra decreciente en el medio y largo plazo, así como un negativo impacto medioambiental y social sobre los pequeños productores locales, entre otros aspectos. Un modelo que ha sido estimulado a partir de los años 90

2 Stédile (1998), en MST (2006), p. 1.

3 Vía Campesina (2005): la Vía Campesina es un movimiento internacional que coordina organizaciones campesinas, pequeños y medianos productores, mujeres rurales, comunidades indígenas, gente sin tierra, jóvenes rurales y trabajadores agrícolas emigrantes. Es un movimiento autónomo, plural, independiente, sin ninguna afiliación política, económica o de otro tipo, formado por organizaciones que vienen de 56 países de Asia, África, Europa y el continente americano. 
por la liberalización comercial desarrollada a nivel internacional (rondas de la OMC) y la nueva ola de integración económica al estilo del TLC o NAFTA (Tratado de Libre Comercio de América del Norte) entre países subdesarrollados, como México, y economías muy desarrolladas, como Canadá o Estados Unidos.

En segundo lugar, surge un paradigma alternativo denominado soberanía alimentaria, basado en el acceso a la tierra, los mercados locales, precios justos, la agroecología y la seguridad alimentaria. Se trata de incentivar la producción local lo suficiente para que cada persona de las áreas rurales tenga acceso seguro y diario a la alimentación, sin necesidad de recurrir a la importación, a través de acuerdos de libre comercio, de productos alimenticios más baratos y de peor calidad de otros países, como los Estados Unidos, con el consiguiente impacto negativo sobre los pequeños agricultores locales.

A su vez, los beneficios de la agricultura familiar en la que se basa la soberanía alimentaria van más allá de la mera esfera económica. Mientras que las grandes explotaciones de tipo industrial imponen un estricto sistema de producción centrado exclusivamente en la eficiencia económica (privada en general, de las multinacionales), las explotaciones familiares promueven prácticas más diversificadas, respetando la biodiversidad e incentivando valiosos servicios al ecosistema y al resto de la sociedad. Al mismo tiempo, el compromiso de los miembros de la familia de conservar la fertilidad del suelo tiene un interés implícito en la sostenibilidad a largo plazo, intergeneracional, muy difícil de conseguir en las explotaciones a gran escala. ${ }^{4}$ Adicionalmente, un enfoque alternativo basado en la agroecología muestra menos dependencia de tecnología importada, incentivando la participación y rescate del conocimiento campesino, la difusión de tecnología local "de agricultor a agricultor», así como el entendimiento entre academia, campesinos y el Estado, a través de una progresiva descentralización de las políticas agrarias y la creación de un capital social ecológico autóctono. Los campesinos son los que mejor conocen sus necesidades y potencialidades, y por ello deben tener un papel clave en el diseño de las políticas de desarrollo agrario y rural (ver tabla 1 ).

4 Rosset (2005) y Vía Campesina (2005). 
TABLA 1

MODELO DOMINANTE VERSUS UN PARADIGMA AGROECOLÓGICO

\begin{tabular}{|c|c|c|}
\hline Caracteristicas & Modelo convencional & $\begin{array}{l}\text { Sistema agroecologico: paradig- } \\
\text { ma de la soberanía alimentaria }\end{array}$ \\
\hline $\begin{array}{l}\text { Principal objetivo } \\
\text { Significado de la agricultura } \\
\text { Impacto socioeconómico }\end{array}$ & $\begin{array}{l}\text { Maximizar la producción } \\
\text { Un negocio }\end{array}$ & $\begin{array}{l}\text { Optimizar la producción } \\
\text { Sostenibilidad: económica, } \\
\text { social y medioambiental }\end{array}$ \\
\hline $\begin{array}{l}\text { Externalidades } \\
\text { Ventaja comparativa } \\
\text { Dependencia de insumos } \\
\text { químicos (petróleo) } \\
\text { Productividad de la tierra } \\
\text { Producción (cultivada) } \\
\text { Estabilidad de la producción } \\
\text { Espacio para el mercado local } \\
\text { Autonomía } \\
\text { Calidad de los alimentos } \\
\text { Acceso a la tierra }\end{array}$ & $\begin{array}{l}\text { Negativas } \\
\text { Estática } \\
\text { Alta } \\
\text { Baja /media } \\
\text { Alta } \\
\text { Alta } \\
\text { Bajo o nulo } \\
\text { Baja } \\
\text { Muy baja } \\
\text { Limitado y concentrado } \\
\text { en grandes explotaciones } \\
\text { de monocultivo a gran escala } \\
\text { Realmente dañino }\end{array}$ & $\begin{array}{l}\text { Positivas } \\
\text { Dinámica } \\
\text { Baja } \\
\text { Alta } \\
\text { Baja /media } \\
\text { Baja /media } \\
\text { Alto } \\
\text { Alta } \\
\text { Sana } \\
\text { Elevado: pequeña explotación } \\
\text { familiar } \\
\text { Positivo, respetuoso }\end{array}$ \\
\hline $\begin{array}{l}\text { Sostenibilidad } \\
\text { Diversidad } \\
\text { Recuperación } \\
\text { Desplazamiento humano del } \\
\text { proceso medioambiental } \\
\text { Impacto tecnológico }\end{array}$ & $\begin{array}{l}\text { Baja } \\
\text { Baja } \\
\text { Baja } \\
\text { Alto }\end{array}$ & $\begin{array}{l}\text { Alta } \\
\text { Media /alta } \\
\text { Media } \\
\text { Medio/bajo }\end{array}$ \\
\hline $\begin{array}{l}\text { Generación de tecnología } \\
\text { Diseño de la investigación } \\
\text { Dependencia de insumos } \\
\text { humanos externos }\end{array}$ & $\begin{array}{l}\text { Desde arriba, importada } \\
\text { Agronomía convencional } \\
\text { Alta }\end{array}$ & $\begin{array}{l}\text { Participativa y local: el campe- } \\
\text { sino primero. } \\
\text { Investigación participativa } \\
\text { media }\end{array}$ \\
\hline
\end{tabular}

FUENTE: Rosset (2005) y Gliessman (2000).

En definitiva, la globalización plantea la elección entre un modelo dominante muy productivo en el corto plazo, con síntomas claros de agotamiento y numerosos problemas sociales añadidos para la gran mayoría rural de los países subdesarrollados, y un modelo alternativo basado en una agricultura sostenible que hace el mejor uso de los recursos y servicios naturales, del conocimiento y las habilidades de los campesinos, así como 
de la capacidad colectiva de las personas para trabajar de manera conjunta y resolver problemas de administración comunal. ${ }^{5}$

\section{El problema de la tierra en América Latina}

La agricultura no es la obra de un capricho, ni el resultado de una concepción a priori. Tiene su fundamento en las bases mismas de la sociedad en que radica, nace y se desenvuelve al compás de las instituciones que la presiden: con ellas crece y medra, con ellas se estanca y decae. ${ }^{6}$

América Latina posee la distribución más desigual de la tierra de todo el mundo y la permanencia de la dualidad minifundio-latifundio ha sido una característica sin resolver a lo largo de su historia.

El problema de la tierra en América Latina tiene raíces muy profundas. Tras la conquista, América Latina se vislumbró como un lugar en el que hacer dinero rápido y volver a casa. ${ }^{7}$ Posteriormente, ni en la etapa de crecimiento basada en la exportación de productos primarios, ni en el periodo de industrialización por sustitución de importaciones ni con las políticas de ajuste estructural de los 80 se pudo redistribuir la tierra de manera equitativa, y el dualismo minifundio-latifundio caracterizó la estructura agraria de la región, llegando incluso a persistir en la actualidad.

Numerosas evidencias empíricas han demostrado que sin acceso a la tierra es imposible reducir la pobreza rural en cualquier lugar del mundo; porque cuando la mayoría de la gente no tiene acceso a los recursos productivos, el resto de políticas posibles son prácticamente irrelevantes. Es precisamente la redistribución de la tierra, por tanto, el punto de partida de un camino alternativo de desarrollo en América Latina. ${ }^{8}$ En particular, la discusión principal en el agro latinoamericano ha estado siempre relacionada con la concentración del recurso en grandes propiedades (latifundio-

5 Pretty (2002), p. 4.

6 Conde de Pozos Dulce (1866), en Machado (2006).

7 Roberts y Thanos (2003).

8 Rosset (2005). 
minifundio), el fenómeno de una demanda por la tierra insatisfecha y un sector amplio de productores rurales sin derechos formalizados de dominio.

En general, la falta de una definición clara de los derechos de propiedad sobre la tierra, la existencia de numerosas tierras ociosas, muchas veces en manos de grandes propietarios absentistas, la falta de unos registros de propiedad fiables y la actuación de un Estado muchas veces capturado por intereses sociopolíticos, relegaron a un segundo plano el desarrollo agrario durante la mayor parte del siglo XX.

Como consecuencia, tuvimos que esperar hasta finales de los 90 para poder ampliar la agenda del desarrollo con más instrumentos y objetivos más amplios, bajo lo que Stiglitz propone como el Postconsenso de Washington. Una revisada agenda de desarrollo que acentúa el importante rol del Estado y las instituciones en la promoción de un desarrollo equitativo y sostenible. Es entonces cuando la reforma agraria y el problema de la tierra vuelven a tener cabida en las agendas de desarrollo. ${ }^{9}$ Hasta ese momento, el Banco Mundial, la FAO o incluso la mayoría de los gobiernos latinoamericanos habían relegado la reforma agraria a un segundo plano. Sin embargo, a finales del siglo XX estas organizaciones internacionales terminan dándose cuenta de la importancia de incentivar unos programas de reforma agraria más complejos, que incluyan a los beneficiarios últimos, los pequeños campesinos, de una manera coherente. De este modo, la reforma agraria debe propiciar condiciones que permitan a los campesinos el acceso a créditos, precios justos, la tierra y los mercados locales. Incentivando así las ventajas comparativas dinámicas no estáticas de los países, y una estrategia integral de desarrollo agrario y rural de largo plazo en América Latina.

En este sentido, las experiencias del este asiático y sus procesos de reforma agraria llevados a cabo tras la Segunda Guerra Mundial dejan ideas muy esclarecedoras para América Latina, demostrando que la reforma agraria va más allá del simple reparto de tierras. La reforma agraria también implica la creación de las condiciones necesarias para garantizar el éxito de la agricultura familiar, el primer paso hacia un modelo diferente de desarrollo.

9 Stiglitz (1998). 


\section{La importancia del desarrollo agrario: algunas lecciones del Este Asiático para América Latina}

Para lograr un grado de industrialización consistente, un país tendrá que resolver las dificultades asociadas con la generación, transferencia y uso de los excedentes agrarios, principalmente en los primeros pasos del desarrollo industrial. ${ }^{10}$

Tradicionalmente el papel de la agricultura en el proceso de desarrollo económico ha sido relegado a un segundo plano. Si analizamos la historia económica de los países del Primer Mundo, vemos como el desarrollo económico era visto como una transformación estructural rápida requerida por la economía, para pasar de un modelo basado predominantemente en la agricultura a una sociedad más compleja, moderna, industrial y de servicios. El papel principal de la agricultura, por tanto, era proporcionar suficiente comida y mano de obra baratas para desarrollar el sector industrial. ${ }^{11}$

Tras la Segunda Guerra Mundial, una serie de países del este asiático pusieron en práctica diferentes programas de reforma agraria exitosos que sentaron las bases de sus posteriores procesos de industrialización. Por ello, una comparación entre las reformas agrarias llevadas a cabo en América Latina y las del este asiático tras la Segunda Guerra Mundial, a pesar de ser bastante complicada, nos puede llevar a conclusiones interesantes. Sin embargo, antes debemos advertir el diferente contexto social, político y económico de ambas regiones (ver tabla 2), así como señalar que América Latina, a pesar de ser una región primordialmente agraria, continuamente relegó a un segundo plano el desarrollo de su sector primario y, por consiguiente, la diversificación e integración de la agricultura y la industria como pasos iniciales de desarrollo.

Una de las diferencias más significativas entre ambas regiones está claramente asociada con la programación temporal de puesta en práctica de la reforma agraria. En Corea del Sur y Taiwán, por ejemplo, las reformas agrarias fueron el punto de partida de la industrialización, con-

10 Kay (2002), p. 40.

11 Todaro (2003). 
TABLA 2

\section{LAS REFORMAS AGRARIAS DEL ESTE ASIÁTICO FRENTE A AMÉRICA LATINA}

\begin{tabular}{|c|c|c|}
\hline & Este asiático & América latina \\
\hline $\begin{array}{l}\text { Importancia del sector } \\
\text { agrario }\end{array}$ & $\begin{array}{l}\text { Media: variando entre países (por ejemplo, } \\
\text { Hong Kong o Singapur no tienen apenas } \\
\text { sector agrario). }\end{array}$ & $\begin{array}{l}\text { Muy alta: es la fuente principal de } \\
\text { riqueza. }\end{array}$ \\
\hline $\begin{array}{l}\text { Programación temporal } \\
\text { de la reforma agraria }\end{array}$ & $\begin{array}{l}\text { La reforma agraria se llevó a cabo antes de } \\
\text { cualquier intento significativo de indus- } \\
\text { trialización. }\end{array}$ & $\begin{array}{l}\text { Sucesivas fases, casi siempre falli- } \\
\text { das, y después de muchos intentos } \\
\text { de industrialización. }\end{array}$ \\
\hline $\begin{array}{l}\text { Diversificación agraria e } \\
\text { integración agricultura- } \\
\text { industria. }\end{array}$ & $\begin{array}{l}\text { El sector primario fue la fuente de acumu- } \\
\text { lación principal para la industria, suminis- } \\
\text { trando mano de obra abundante y barata. }\end{array}$ & $\begin{array}{l}\text { Nunca se entendió la reforma } \\
\text { agraria como un mecanismo para } \\
\text { exprimir la agricultura. }\end{array}$ \\
\hline $\begin{array}{l}\text { Concentración de la pro- } \\
\text { piedad de la tierra }\end{array}$ & $\begin{array}{l}\text { No era realmente elevada, predominando } \\
\text { la explotación familiar (minifundio). }\end{array}$ & $\begin{array}{l}\text { Extrema: latifundio y grandes } \\
\text { plantaciones de monocultivo des- } \\
\text { tinadas a la exportación. }\end{array}$ \\
\hline $\begin{array}{l}\text { El papel de los grandes } \\
\text { propietarios }\end{array}$ & $\begin{array}{l}\text { Intermedio: el Estado dio los incentivos } \\
\text { necesarios para llegar a un acuerdo entre } \\
\text { propietarios y arrendatarios. La clase de } \\
\text { grandes propietarios fue eliminada del } \\
\text { poder en el momento de implantar la } \\
\text { reforma agraria. }\end{array}$ & $\begin{array}{l}\text { Elevado y muy poderoso: absen- } \\
\text { tismo, aparcería, etc. Siempre blo- } \\
\text { quearon o retrasaron cualquier } \\
\text { intento de redistribuir la tierra. }\end{array}$ \\
\hline $\begin{array}{l}\text { El rol de los movimientos } \\
\text { de campesinos }\end{array}$ & $\begin{array}{l}\text { Como resultado de los acuerdos mencio- } \\
\text { nados entre campesinos y la oligarquía } \\
\text { rural, nunca fueron relevantes. }\end{array}$ & $\begin{array}{l}\text { Los movimientos campesinos han } \\
\text { sido esenciales para llevar a cabo } \\
\text { la reforma agraria (Brasil y el } \\
\text { MST). }\end{array}$ \\
\hline El papel del Estado & $\begin{array}{l}\text { Elevado: un Estado desarrollista que ace- } \\
\text { leró el ritmo de crecimiento, con una } \\
\text { visión coherente del desarrollo económi- } \\
\text { co. }^{12} \\
\text { Developmental state con una autonomía } \\
\text { integrada con las distintas clases socia- } \\
\text { les. }{ }^{13}\end{array}$ & $\begin{array}{l}\text { Elevado pero ineficiente: a veces, } \\
\text { un Estado 'capturado' (ISI) por } \\
\text { los intereses de la elite rural o los } \\
\text { capitales extranjeros; a veces, un } \\
\text { Estado intermedio. }\end{array}$ \\
\hline $\begin{array}{l}\text { Principales razones para } \\
\text { llevar a cabo la reforma } \\
\text { agraria }\end{array}$ & $\begin{array}{l}\text { Políticas mucho más que económicas o } \\
\text { sociales: la presión de los Estados Unidos } \\
\text { ante la amenaza socialista. }\end{array}$ & $\begin{array}{l}\text { Razones políticas y conflictos } \\
\text { sociales, pero nunca motivos eco- } \\
\text { nómicos: presión social de los sin } \\
\text { tierra, las invasiones de tierras, la } \\
\text { pobreza rural, etc. }\end{array}$ \\
\hline Resultados & $\begin{array}{l}\text { Exitosas: en términos económicos y socia- } \\
\text { les. Mayor equidad social, creación de } \\
\text { unos mercados domésticos, alto desarrollo } \\
\text { de capital humano, etc. Integración entre } \\
\text { agricultura e industria }\end{array}$ & $\begin{array}{l}\text { En general, los procesos de reforma } \\
\text { agraria fueron fallidos tanto desde } \\
\text { el punto de vista económico como } \\
\text { social y político; con diferente } \\
\text { magnitud según los países. }\end{array}$ \\
\hline
\end{tabular}

FUENTE: Elaboración propia, 2006.

12 Dietz (1992).

13 Evans (1995). 
virtiéndose en uno de los factores clave del sucesivo proceso de industrialización.

Por otro lado, mientras que en América Latina la concentración de la tenencia de la tierra era extrema (caracterizada por la dualidad latifundio-minifundio), en el este asiático la agricultura familiar era el modelo predominante, y el problema rural al que se enfrentaba la región era la gran cantidad de pequeños agricultores. Además, el papel de los propietarios absentitas en América Latina siempre apareció como un problema pendiente de resolver. ${ }^{14}$

También es relevante destacar que ni en América Latina ni en el este asiático las reformas agrarias se llevaron a cabo por motivos de eficiencia económica, aumento de la competitividad y autonomía de sus beneficiarios, los pequeños campesinos. En América Latina, las revueltas sociales de la gran masa de campesinos sin tierra o de subsistencia forzaron a los gobiernos a implementar las reformas. Las ocupaciones y movilizaciones campesinas fueron pautas comunes en el proceso de lucha por la tierra en la región, ya que el Estado y las instituciones agrarias no propiciaron las soluciones demandadas durante muchas décadas. Por el contrario, en Corea del Sur o Taiwán fue la presión política de los Estados Unidos la que llevo a la implementación de reformas agrarias. Se estableció una especie de consenso entre los intereses del Estado, los grandes propietarios de tierra y la presión externa de los Estados Unidos para implementar unos programas de reforma agraria coherentes, entregando la tierra a los campesinos.

Por último, el Estado, a pesar de ser intervencionista en ambas regiones, tuvo un comportamiento muy diferente en el diseño de las políticas agrarias. En América Latina, una fracasada intervención estatal durante el periodo ISI relegó el sector agrario a un papel secundario en aras del desarrollo industrial y urbano. Por el contrario, los gobiernos de muchos de los nuevos países industrializados del este asiático trataron de acelerar el ritmo de crecimiento económico a través de una consistente política intervencionista, generando una coherente integración entre los diferentes sectores de la economía. La pregunta ya no era cuánto debía intervenir el Estado en la economía, sino más bien qué tipo de Estado debía existir: developmental state, teniendo éste como una de sus principales funciones la redistribución

14 Cardoso y Helwege (1990). 
de la tierra siempre que fuera necesario. ${ }^{15}$ Un Estado con una visión desarrollista en el este asiático, con una visión lógica del crecimiento económico, mientras que en América Latina el Estado, a pesar de ser intervencionista, a menudo demostró ser cautivo de los intereses específicos de determinadas clases sociales, normalmente los grandes propietarios rurales, con gran influjo político y social en la región, así como las grandes multinacionales extranjeras, principalmente estadounidenses. ${ }^{16}$ De esta manera, el Estado desarrollador de Corea del Sur, Taiwán o Japón permanece en claro contraste con el estado intermedio de América Latina. Un Estado capaz de encontrar bolsillos de eficiencia en la promoción de la industria, pero relegando en general a un segundo plano la agricultura, e incapaz durante mucho tiempo de promover la equitativa distribución de la tierra como el paso previo de cualquier intento de desarrollo económico. ${ }^{17}$

La comparación recogida en la tabla 2 en ningún momento trata de sugerir que las políticas agrarias implementadas en el este asiático deban ser replicadas ciegamente en otras regiones. Lo que por el contrario trata de transmitir, tal y como recientemente han señalado los expertos del desarrollo económico, es que la desigual distribución de recursos impide el crecimiento económico. ${ }^{18}$ Sobhan, por ejemplo, ha argumentado que debemos distinguir entre reformas agrarias transformadoras y «otras reformas agrarias». En la mayoría de las reformas agrarias, aquellos que realmente terminaron recibiendo las mejores parcelas eran en términos generales los que finalmente se encontraban en una situación mejor. Sin embargo, existen ejemplos de reformas agrarias que han sido el elemento clave para permitir a naciones enteras un cambio en sus sendas de desarrollo. En estos casos, las naciones han pasado de una espiral excluyente hacia abajo de pobreza y degradación medioambiental a una espiral creciente de mejoras amplias en los estándares de vida, creando fuertes mercados internos que originan un desarrollo económico más dinámico e inclusivo. ${ }^{19}$ Éstos son precisamente los casos del este asiático, Corea del Sur o Taiwán, reformas agrarias transformadoras que debemos tener en cuenta a la hora de elaborar las agendas y políticas de desarrollo agrario y rural en América Latina.

15 Rapley (1996).

16 Dietz (1992).

17 Evans (1995).

18 Solimano (2000).

19 Sobhan (1993). 


\section{Evolución de la reforma agraria en América latina (1900- 2006): el papel del Estado y los derechos de propiedad}

En todos y cada uno de los casos de América Latina donde tuvieron lugar reformas agrarias que beneficiaron de manera significativa a los pobres de las zonas rurales, el Estado jugó un papel decisivo [...] Desafortunadamente en todos y cada uno de los casos en los que se negó o deformó el objetivo de la reforma agraria, también el Estado jugó un papel crítico. ${ }^{20}$

Los gobiernos juegan un papel esencial en los procesos de reforma agraria; deben intervenir activamente dando el apoyo legal y reglamentario necesario para fortalecer los derechos de propiedad de los pobres, reduciendo así los elevados costes de transacción e información que caracterizan el mercado agropecuario.

Teniendo en cuenta los ejemplos mencionados de reformas agrarias del sudeste asiático, el tipo de Estado apropiado sería aquél capaz de diseñar una política agraria eficaz que fomente la inversión, aumentando la productividad y, a su vez, el poder de participación de los pobres en las oportunidades económicas de la sociedad: un Estado desarrollador. ${ }^{21}$ Por el contrario, el Estado latinoamericano, caracterizado en ocasiones como «intermedio», a veces sí fue capaz de actuar de manera autónoma y combinar los diferentes intereses de distintos grupos sociales y multinacionales extranjeras para promover políticas económicas eficaces. Por ejemplo, el Estado brasileño, durante el periodo de ISI, fue capaz de encontrar «bolsillos de eficiencia" y vincularse a los intereses de las multinacionales y la oligarquía nacional para desarrollar un elevado nivel de industrialización en el país. Sin embargo, estos bolsillos de eficiencia desarrollados en el sector secundario, en general, relegaron el sector agrario a un segundo plano. ${ }^{22}$

Habitualmente se distinguen tres oleadas de reformas agrarias en América Latina a lo largo del siglo XX, en las que el papel del Estado ha ido variando y adaptándose a las diferentes corrientes de pensamiento dominantes, como veremos a continuación (ver tabla 3).

\footnotetext{
20 Barraclough (1999), en Rosset (2005), p. 8.

21 Stern, en Deininger (2003).

22 Evans (1979).
} 
En primer lugar, y hasta los años 80 , tuvo lugar un conjunto de reformas agrarias basado en la importante disponibilidad de factores de producción, entre ellos la tierra. Se implementaron programas clásicos de reforma agraria, generalmente promovidos por causas políticas y sociales, pero nunca por motivos de eficiencia económica y necesidad previa de desarrollar el agro latinoamericano.

Este tipo de reformas agrarias anteriores a los 80, que en principio se reivindicaron como un acto de justicia social, fueron transformándose poco a poco, para entenderse como un factor de desarrollo y un acto de planificación. Sin embargo, esta transformación llevó su tiempo. La célula de producción debía adaptarse al plano económico del momento, entendiéndose desde dos puntos de vista.

En primer lugar, la reforma agraria debía establecer unidades de producción que favorecieran el mejor empleo de los medios humanos y técnicos, para así poder asegurar la máxima rentabilidad de la tierra y de los hombres. En segundo lugar, en el ámbito de la economía global, se debía proceder a una reforma de las estructuras agrarias que asegurase un equilibrio mayor entre los diferentes sectores económicos. ${ }^{23}$ Este binomio no consiguió entenderse y los intereses políticos del Estado, muchas veces cautivo de los caprichos de una élite rural muy poderosa o del influjo de capitales extranjeros, imposibilitaron el éxito de las reformas. Ante la impotencia de los gobiernos latinoamericanos, al no poder resolver los problemas agrarios, comenzaron a intervenir los organismos internacionales. La FAO organizó la primera conferencia mundial sobre la reforma agraria en Roma en 1966; sin embargo, la máxima influencia conseguida por este organismo internacional fue la de mera consejera de los estados, sin poder llegar a soluciones concretas.

A partir de los años 80 se produce un cambio radical en el contexto de la reforma agraria. La revolución de las ideas neoclásicas que empezó a ganar peso en el pensamiento económico internacional, así como el ascenso de determinados gobiernos de corte conservador a finales de los $70 \mathrm{y}$ principios de los 80 , promovieron campañas políticas basadas en la libera-

23 Le Coz (1975). 
lización económica y comercial, viendo el mercado como el único actor económico capaz de asignar los recursos de manera eficiente. En particular, los numerosos fallos de los programas de redistribución de la tierra llevados a cabo en América Latina durante las etapas anteriores trasladan el interés a los mecanismos de mercado como posible solución al acceso más libre al factor tierra, apareciendo los programas de ajuste y apertura promovidos por el Banco Mundial y el Fondo Monetario Internacional.

Sin embargo, la mayoría de los países de la región no contaban con la compleja red institucional necesaria para el correcto funcionamiento del sistema. Se llevaron a cabo reformas de libre mercado sin realizar simultáneamente los cambios correspondientes en las instituciones sociales y políticas necesarias para paliar los complejos fallos del mercado agrario. Muchos países del Tercer Mundo en general, y de América Latina en particular, presentaban un mundo rural carente de registros fiables de tierra o derechos formalizados de dominio, así como unos contratos agrarios caracterizados por unos altísimos costes de información y transacción para los pequeños campesinos o empleados agrarios sin tierra. Los programas de reforma agraria, por tanto, implementados a finales de los 80 y principios de los 90 que siguieron las pautas neoliberales, creando mercados rurales de tierra basados en la libre oferta y demanda, profundizaron la desigualdad rural. Aquellos que adquirieron las tierras fueron, como en el caso brasileño, nuevamente los grandes propietarios o multinacionales con suficiente poder y capacidad adquisitiva.

Como respuesta a estos fallos de los mercados de tierras y la profundización de la desigualdad agraria y rural, emerge la tercera oleada reformas agrarias, a finales de los 90. Los nuevos programas de redistribución de tierras se centraron en combatir las carencias subyacentes del periodo anterior. Es decir, en la importancia de la institucionalidad y el papel crucial del predominio de la ley y de su aplicación equitativa. Es la corriente en la que se basan la mayor parte de las reformas agrarias que se están llevando a cabo en América Latina en la actualidad. ${ }^{24}$ Ahora el Estado pasa

24 BID (1998). Equitable Enforcement: para conseguir la formación del mercado, las políticas de ajuste macroeconómicas, las leyes para permitir la libre transmisión de la tierra o el desarrollo de programas de registro de tierras no son suficientes sin la existencia de las instituciones básicas. 
a ser un actor clave en las políticas de desarrollo agrario y rural, el encargado de proveer de ciertos bienes públicos relacionados con la administración de tierras, asegurando así el marco jurídico, legal e institucional formal necesario para definir los derechos de propiedad.

Importancia de los derechos de propiedad sobre la tierra

La tierra es un componente clave de la riqueza de cualquier nación. Históricamente todas las civilizaciones han gastado considerable tiempo en la definición de los derechos de tenencia sobre la tierra, creando instituciones para administrarla.

En los países en vías de desarrollo, como América Latina, la mayor parte de la tierra se destina a la agricultura, constituyendo un pilar clave del sustento económico. Unos derechos de propiedad de la tierra seguros suponen, de esta forma, la base para la subsistencia familiar, permitiendo a los propietarios rurales invertir para incrementar la productividad, acumulando y transfiriendo la riqueza entre generaciones y sectores económicos. La posibilidad de usar los derechos sobre la tierra como aval para pedir créditos ayuda a crear un clima de inversión más fuerte y los derechos sobre la tierra se convierten, entonces, en una condición previa para el surgimiento y la operatividad de mercados financieros. Los derechos de propiedad sobre la tierra, por tanto, son piedras angulares para el funcionamiento de las economías modernas. ${ }^{25}$

Sin embargo, una cuestión relevante que emerge con la tercera oleada de reformas agrarias ha sido: ¿por qué se les solía prestar tan poca atención a los derechos de propiedad durante las dos oleadas anteriores, si son tan relevantes?

Lo que se observa a través de la experiencia latinoamericana es la generalización de unos derechos de propiedad definidos como los de los países occidentales: exclusivos, transferibles, enajenables y exigibles. Es la ideología de un modelo, el anglosajón, que encaja en todos. Sin embargo, cuando hablamos de países en vías de desarrollo la situación es muy diferente. La atención insuficiente que se ha prestado a los dere-

25 Deininger (2003). 
chos de propiedad a lo largo del siglo XX es una de las principales causas de que muchas de las reformas agrarias realizadas en el pasado con fines distributivos hayan llevado a resultados poco exitosos y, al mismo tiempo, no hayan entendido la reforma agraria como un concepto mucho más amplio que el simple reparto de tierras. Porque la reforma agraria es un proceso que debe ir acompañado de una compleja red institucional y una constante intervención estatal que vele por unos derechos de propiedad seguros adaptados a las condiciones de cada país. ${ }^{26}$ En definitiva, al impedir que los países en vías de desarrollo adopten las políticas e instituciones que los propios países del Primer Mundo utilizaron en sus fases de desarrollo, estamos intentando "retirar la escalera" a través de la cual han trepado hasta alcanzar la cima del desarrollo económico. ${ }^{27}$

A continuación, la tabla 3 resume las tres etapas mencionadas de reformas agrarias desarrolladas a lo largo del siglo XX y que continúan desarrollándose en la actualidad. En ella se analiza el papel del Estado, el mercado, las instituciones, principalmente los derechos de propiedad, la sociedad civil y el resultado general que han tenido en América Latina.

En definitiva, la tabla 3 demuestra como a partir de lo que Stiglitz acuña como el Postconsenso de Washington, a finales de los 90, las reformas agrarias han vuelto a tener cabida en los debates de política económica y agendas de desarrollo como elementos clave para el desarrollo económico. El informe del Banco Mundial de 2003 es un buen ejemplo de ello, demostrando como el diseño de políticas de tierra para promover el crecimiento económico y la disminución de la pobreza necesita unir la idea de un proceso de mercado espontáneo y evolutivo, y el diseño institucional premeditado; dos conceptos que se necesitan el uno al otro y se complementan, por lo que deberían trabajar simbióticamente en el proceso de desarrollo económico. ${ }^{28}$

\footnotetext{
26 BID (1998).

27 Chang (2004).

28 Deininger (2003) y Stiglitz (1998).
} 
TABLA 3

LA REFORMA AGRARIA EN AMÉRICA LATINA (1900-2006)

\begin{tabular}{|c|c|c|c|}
\hline & $\begin{array}{l}\text { Programas clásicos de } \\
\text { reforma agraria } \\
1900-1980\end{array}$ & $\begin{array}{c}\text { Programas de reforma agraria } \\
\text { de corte neoliberal } \\
1980-1998\end{array}$ & $\begin{array}{c}\text { Renovada atención a las } \\
\text { reformas agrarias } \\
\text { y el desarrollo rural } \\
1998-2006\end{array}$ \\
\hline $\begin{array}{l}\text { El papel del } \\
\text { Estado }\end{array}$ & $\begin{array}{l}\text { Importante, movido por } \\
\text { reivindicaciones sociales } \\
\text { y políticas. Nunca mos- } \\
\text { tró un verdadero interés } \\
\text { en la reforma agraria. }\end{array}$ & $\begin{array}{l}\text { Perjudicial: resultados negati- } \\
\text { vos de un Estado intermedio, } \\
\text { a veces capturado bajo ISI. }\end{array}$ & $\begin{array}{l}\text { Esencial: promover programas } \\
\text { coherentes de reforma agraria en } \\
\text { un contexto institucional adap- } \\
\text { tado a las circunstancias de los } \\
\text { países. }\end{array}$ \\
\hline $\begin{array}{l}\text { El papel del } \\
\text { mercado }\end{array}$ & No era un asunto. & $\begin{array}{l}\text { Es el mejor mecanismo para la } \\
\text { asignación eficiente de recur- } \\
\text { sos: la tierra. }\end{array}$ & $\begin{array}{l}\text { Esencial pero apoyado por el } \\
\text { Estado para generar una asigna- } \\
\text { ción eficiente y segura de la tie- } \\
\text { rra, disminuir los elevados costes } \\
\text { de información y transacción del } \\
\text { mercado agrario. }\end{array}$ \\
\hline $\begin{array}{l}\text { El rol de los } \\
\text { movimientos } \\
\text { campesinos }\end{array}$ & $\begin{array}{l}\text { Muy importante. Princi- } \\
\text { pales promotores de la } \\
\text { reforma agraria. No bus- } \\
\text { caron la eficiente asigna- } \\
\text { ción de los recursos, sim- } \\
\text { plemente el acceso a la } \\
\text { tierra que desde la época } \\
\text { colonial llevaban deman- } \\
\text { dando. }\end{array}$ & $\begin{array}{l}\text { Seguían demandando sus } \\
\text { derechos sobre la tierra, pero } \\
\text { el mercado los relegó a un } \\
\text { segundo plano, centrándose } \\
\text { en un conjunto de objetivos } \\
\text { muy estrechos y unos instru- } \\
\text { mentos muy limitados. }\end{array}$ & $\begin{array}{l}\text { Gran y renovada importancia: } \\
\text { MST en Brasil, Vía Campesina, } \\
\text { etc. }\end{array}$ \\
\hline $\begin{array}{l}\text { Instituciones: } \\
\text { derechos de } \\
\text { propiedad }\end{array}$ & $\begin{array}{l}\text { No estaban correctamen- } \\
\text { te definidos: permanen- } \\
\text { cia de reglas formales e } \\
\text { informales de la época } \\
\text { colonial y carencia de } \\
\text { registros fiables de tierras. }\end{array}$ & $\begin{array}{l}\text { Exportar las instituciones, } \\
\text { reglas formales e informales } \\
\text { de los países desarrollados a } \\
\text { los países en vías de desarro- } \\
\text { llo. }\end{array}$ & $\begin{array}{l}\text { No hay un modelo premedita- } \\
\text { do. Simplemente unos derechos } \\
\text { de propiedad bien definidos } \\
\text { para paliar los fallos del mercado } \\
\text { agrario teniendo en cuenta las } \\
\text { especificidades de cada país. }\end{array}$ \\
\hline $\begin{array}{l}\text { El rol de las } \\
\text { organizaciones } \\
\text { internacionales: } \\
\text { BID, FAO o el } \\
\text { Banco Mundial }\end{array}$ & $\begin{array}{l}\text { Inicial pero secundario: } \\
\text { la FAO sólo actuó como } \\
\text { mero consejero de los } \\
\text { estados. }\end{array}$ & $\begin{array}{l}\text { Basadas en la ideología neoli- } \\
\text { beral: Consenso de Washing- } \\
\text { ton. }\end{array}$ & $\begin{array}{l}\text { FAO, Banco Mundial y BID: } \\
\text { renovada atención sobre los pro- } \\
\text { blemas de la tierra. El Estado y el } \\
\text { mercado deben trabajar simultá- } \\
\text { neamente teniendo en cuenta las } \\
\text { características específicas de cada } \\
\text { país. }\end{array}$ \\
\hline $\begin{array}{l}\text { Desarrollo } \\
\text { agrario y rural }\end{array}$ & $\begin{array}{l}\text { Exceptuando el caso de } \\
\text { Cuba, el resto no alteró } \\
\text { significativamente la } \\
\text { desigual y dual estructura } \\
\text { agraria. }\end{array}$ & $\begin{array}{l}\text { La búsqueda de la eficiencia } \\
\text { económica, la falta de unos } \\
\text { derechos de propiedad claros } \\
\text { y unas instituciones apropia- } \\
\text { das originaron una asignación } \\
\text { ineficiente de la tierra y la } \\
\text { profundización de la desigual- } \\
\text { dad y dualidad rural. }\end{array}$ & $\begin{array}{l}\text { Se necesita experimentación y } \\
\text { búsqueda de alternativas, pero } \\
\text { por lo menos hemos aprendido } \\
\text { que las instituciones y políticas } \\
\text { que funcionan en las economías } \\
\text { del Primer Mundo o en el este } \\
\text { asiático no tienen por qué hacer- } \\
\text { lo en los países del Tercer } \\
\text { Mundo. }\end{array}$ \\
\hline
\end{tabular}

FUENTE: Elaboración propia, 2006. 


\section{Reforma agraria y desarrollo rural sostenible en América Latina bajo el contexto de la globalización}

La renovada importancia de las políticas agrarias para el crecimiento y la reducción de la pobreza en las agendas y debates de desarrollo en América Latina, se ilustrará en este apartado a través de dos alternativas de desarrollo agrario y rural surgidas a finales de los 90, en pleno contexto de la globalización, y en las que una reforma agraria previa ha sido el elemento fundamental.

Primero se introducirá el caso de Brasil, caracterizado por el predominio de la agricultura familiar, que ha demostrado ser más eficiente que las grandes explotaciones de monocultivo a gran escala del país; así como la implementación de la reforma agraria desde mediados de los 90, promovida principalmente por el MST (Movimiento de los Trabajadores Rurales sin Tierra). Desde su creación en los 80, el MST ha estado presionando al Gobierno brasileño para la implementación de una estrategia seria de reforma agraria, requisito indispensable para el desarrollo agrario y rural brasileño.

En segundo lugar, se explorará el caso de Cuba, que, tras la puesta en práctica de tres leyes de reforma agraria desde el triunfo de la Revolución en 1959, ha desarrollado un modelo agrario alternativo como respuesta a la crisis económica de los 90. Modelo alternativo del que se puede aprender a escala global observando atentamente tanto sus errores como sus éxitos.

\subsection{El caso del MST en Brasil: positiva interacción entre agroecología y reforma agraria}

Si vamos a desarrollar una agricultura y unos sistemas alimentarios sostenibles, entonces necesitaremos desarrollar nuevas formas de organización social y educación ecológica [...] para construir relaciones basadas en la confianza, mecanismos recíprocos, normas comunes y reglas, así como nuevas formas de conexión, que por tanto ayudarán en el desarrollo y la difusión de una mayor educación sobre la tierra y la naturaleza. ${ }^{29}$

29 Pretty (2002), pp. 168-169. 
Brasil es precisamente un buen ejemplo de los numerosos intentos fallidos de reforma agraria llevados a cabo durante el siglo XX en América Latina. Contando con uno de los índices más altos de concentración de la propiedad de la tierra del mundo, Brasil se caracteriza por un alto número de campesinos sin tierra y una larga demanda política de reforma agraria.

El desarrollo de la agricultura brasileña, tanto bajo el modelo de crecimiento basado en la exportación de materias primas como en la etapa de ISI, privilegió el latifundio. Un latifundio extremadamente excluyente, del que se beneficiaron a largo del siglo XX una minoría de oligarquías rurales que se aliaron con el capital industrial, comercial y financiero. Esta alianza, que bajo la etapa de ISI promovió importantes bolsillos de eficiencia en la industrialización y urbanización del país, relegó a un segundo plano el desarrollo agrario y rural brasileño, incentivando pautas como el absentismo y la permanencia de un contexto generalizado de indefinición de los derechos de propiedad sobre la tierra. La mayoría de la población rural fue, como resultado, marginada en ineficientes parcelas de cultivo y, en los peores casos, formando parte de los sin tierra del país. ${ }^{30}$ Como respuesta inicial a la extrema exclusión social campesina y la proliferación de los sin tierra, el gobierno brasileño creó en 1964 el Instituto Nacional de Colonización y Reforma Agraria (INCRA), que distribuyó 10 millones de hectáreas entre 300000 familias y colonizó unos 14 millones de hectáreas destinadas a 75000 familias beneficiarias en los primeros 30 años de su existencia. ${ }^{31}$

Sin embargo, un giro de 180 grados se produjo a partir de 1984, cuando Brasil comenzó la liberalización de las políticas agrarias, suprimiéndose los subsidios y disminuyendo sensiblemente el volumen de crédito a disposición de los grandes productores. Los pequeños y medianos agricultores no se retiraron de la producción y se aventuraron a pedir más crédito. Mientras tanto, los grandes productores abandonaron el sector o comenzaron a utilizar más sus propios recursos, al haber perdido el trato favorable, por parte del Gobierno y las instituciones agrarias, del que durante muchos

30 Durante los últimos 25 años, más de 30 millones de campesinos tuvieron que abandonar el campo, mientras que 4,8 millones de familias que viven en áreas rurales no tienen tierra.

31 Deininger (2003). 
años habían disfrutado. Se observa, por tanto, un giro en la política agraria brasileña hacia la agricultura familiar, siendo ésta la que expresaba mayores ventajas comparativas, dinámicas, en un país donde el capital es escaso, mientras que la tierra y la mano de obra son abundantes y, por tanto, aprovechadas por la agricultura familiar de forma más intensiva.

A partir de 1995, con el gobierno de Cardoso, muchas más familias se beneficiaron de la reforma agraria gracias a la mayor disponibilidad de fondos y al aumento de la presión del MST, que tras la masacre del Eldorado de Carajás en 1996, donde murieron 19 trabajadores sin tierra, hizo insostenible la situación. A partir de 1995, unas 584000 familias recibieron un total de 18,7 millones de hectáreas de tierra. A su vez, y en parte como respuesta a las políticas de ajuste macroeconómico y la progresiva eliminación de la protección agraria, que disminuyó los precios de la tierra, el coste de acceso a ésta por familia pasó a ser casi la mitad entre 1995 y 2000. Teniendo en cuenta que la Constitución brasileña prohíbe la expropiación de tierras por debajo de un tamaño mínimo, así como la larga tradición de pequeños y medianos campesinos del agro brasileño, el Gobierno inició un modelo de redistribución de la tierra basado en comunidades de asentamientos de pequeños agricultores, donde las familias reciben recursos financieros de apoyo a la inversión de tierra adquirida a través de negociaciones voluntarias. El programa fue bastante controvertido políticamente, y su impacto no ha sido todavía propiamente evaluado, pero algunos de los programas piloto, como experiencia preliminar, parecen indicar que donde el programa fue correctamente dirigido a los pobres y su implementación contó con la participación activa del MST, se adquirió la tierra a precios bajos, significativamente menores que los de mercado, expandiéndose así la cantidad de beneficiarios de la tierra y mejorando el bienestar de las familias participantes. ${ }^{32}$

El desafío para el gobierno de Lula a partir de 2003 ha sido garantizar la continuidad de una reforma agraria competitiva para sus beneficiarios dentro de un marco político que busque el desarrollo en las zonas rurales y la actuación y presión constantes del MST. ${ }^{33}$

32 Deininger (2003).

33 Ibíd. 
Precisamente la actuación firme del MST es lo realmente relevante del caso de Brasil; sin su presión y lucha persistente por la tierra, nunca se hubiera llegado a implementar una verdadera reforma agraria. Muchas veces las reformas agrarias, aunque sí repartieron la tierra antes de los 80 , no contaron con una estrategia integral de desarrollo agrario y rural a largo plazo. Por ello, los miembros del MST han estado nadando a contracorriente gracias tan sólo a su poder de organización.

A su vez, el MST es un buen ejemplo de las positivas interacciones entre medio ambiente y desarrollo a través de la puesta en práctica de la agroecología. Es el movimiento social más grande de América Latina, contando con unos 1,5 millones de campesinos sin tierra organizados en 23 de los 27 estados de Brasil. Se creó en los años 80 y desde entonces ha ocupado, a través de acciones generalmente pacíficas, tierras ociosas donde se han establecido cooperativas de explotación agropecuaria, han construido viviendas, escuelas y centros de salud, promoviendo la conservación de las culturas y prácticas indígenas, la sostenibilidad medioambiental y la equidad de género. El MST también ha conseguido títulos de propiedad de la tierra para más de 250000 familias en 1600 asentamientos, y a su vez 200000 familias acampadas en tierras de latifundios ociosos están actualmente esperando un decreto gubernamental que reconozca sus derechos de propiedad sobre la tierra. Ellos basan sus ocupaciones en la Constitución brasileña, que especifica que la tierra que permanezca ociosa e improductiva debe y puede ser usada con amplios fines sociales.

El éxito del MST se basa, por tanto, en su habilidad para organizar y educar. Sus miembros no sólo han conseguido arreglárselas para asegurar la tierra, y por consiguiente la seguridad alimentaria para sus respectivas familias, sino que también están tratando de aplicar un modelo socioeconómico sostenible que proporcione una alternativa concreta al modelo de producción industrial que predomina en la agricultura mundial actual. El MST trata de promover y extender el uso de prácticas agroecológicas a través de la puesta en marcha de campañas, cartilhas o recetas para un modelo de agricultura alternativo y la agroecología como un paradigma alternativo. ${ }^{34}$

$34 \operatorname{MST}(2001)$. 
GRÁFICO 1

MST: AGROECOLOGÍA Y DESARROLLO A TRAVÉS DEL ACCESO A LA TIERRA

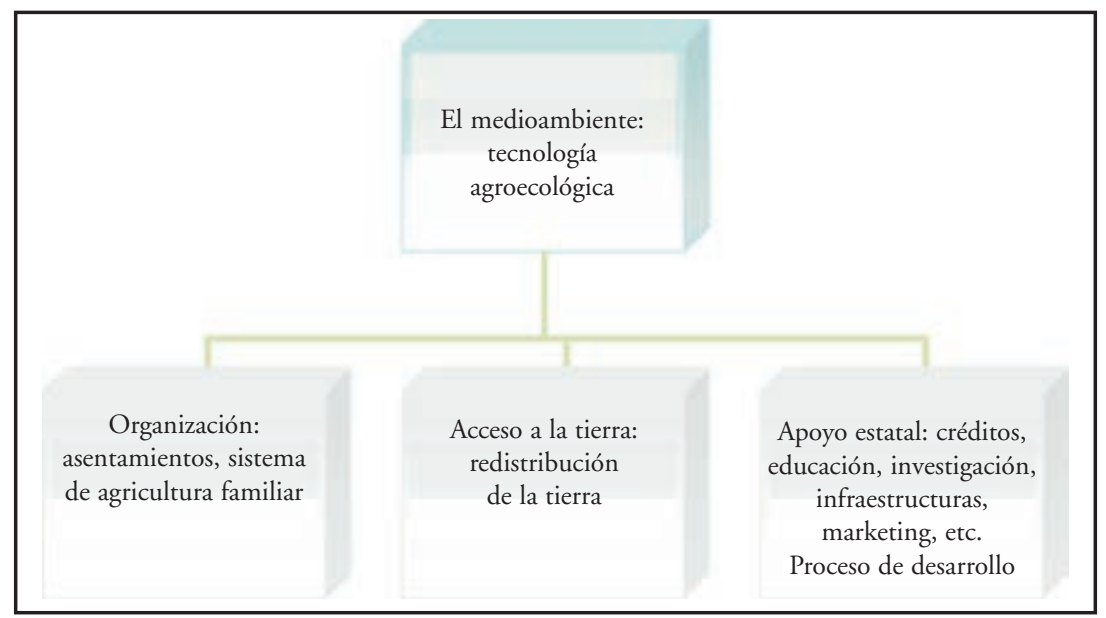

FUENTE: Rosset (2005).

En definitiva, el MST (ver gráfico 1) está demostrando como, a través de la aplicación de prácticas agroecológicas, la organización en asentamientos de agricultura familiar y el acceso a la tierra, la relación entre medioambiente y desarrollo económico a nivel local y regional se ve altamente beneficiada por las economías de explotación familiar, así como la vida y prosperidad en las poblaciones rurales. Tal y como ha demostrado la propia historia del agro brasileño, las economías rurales basadas en pequeñas explotaciones familiares relativamente equitativas pueden servir de motor para un desarrollo económico más amplio a nivel nacional. En ese sentido, las experiencias ya mencionadas de Corea del Sur o Taiwán han demostrado el importante papel que desempeña una distribución equitativa de la tierra en la promoción del desarrollo económico. Estas exitosas experiencias del sudeste asiático fueron incentivadas al principio por los mercados locales internos desarrollados en las zonas rurales, tal y como está haciendo el MST, mucho antes de la aparición del modelo de crecimiento destinado a la exportación que más tarde lanzó estas economías a competir en el mercado internacional. ${ }^{35}$

35 Rosset (2005). 


\subsection{El modelo de agricultura sostenible en Cuba en el contexto de la globalización}

Un experimento que el mundo debería estar observando atentamente. ${ }^{36}$

El modelo cubano de agricultura sostenible iniciado en los años 90 es el primer ejemplo de conversión agraria desarrollado a escala nacional en la historia. La alternativa cubana fue resultado de varias leyes de reforma agraria (1959, 1963 y 1993), el desarrollo de tecnología sostenible y la transformación de un sistema convencional de producción en prácticas sostenibles basadas en principios agroecológicos.

La agricultura cubana anterior a 1959 se caracterizaba por la presencia de grandes latifundios de caña de azúcar en manos de capital extranjero, predominantemente estadounidense, destinados a la explotación y cultivados por mano de obra campesina empleada. Las características de predominancia de pequeños campesinos familiares, el no excesivo tamaño de las explotaciones y la integración entre ganadería y agricultura que caracterizaban el agro cubano durante el periodo colonial, ya en 1929 habían desaparecido por completo, dando lugar a grandes desequilibrios y desigualdad social entre el mundo rural agrario y un mundo urbano que empezaba a apostar por una rápida conversión industrial.

Todos estos problemas sociales fueron alimentando la Revolución cubana que el 1 de enero de 1959 triunfó en la isla. Precisamente una de las primeras medidas del Gobierno revolucionario fueron las dos leyes de reforma agraria, llevadas a cabo en el 59 y el 63, respectivamente. El Estado revolucionario, de esta manera, expropiaba la mayor parte de las tierras destinadas al monocultivo azucarero, en manos de multinacionales estadounidenses, pasando a ser propiedad del Estado. Tierra que el gobierno cubano, a su vez, fue entregando a los campesinos bajo distintas formas de propiedad, permaneciendo aun así el 70\% de ella bajo empresas estatales, cultivadas por campesinos asalariados.

Durante la etapa socialista, y gracias a su integración en el CAME (Consejo de Ayuda Mutua Económica), Cuba consiguió exportar su azúcar a la URSS y los países del este, a precios muy elevados que a su vez le

36 Rosset y Benjamin (1994), p. 7. 
permitían importar grandes cantidades de petróleo, fertilizantes químicos y productos alimenticios en unas condiciones muy favorables. Esto permitió el desarrollo en la isla de un tipo de agricultura a imitación del modelo soviético, basada en los principios de la Revolución verde, así como la explotación a gran escala (gigantismo) de latifundios mucho mayores que los de la época prerrevolucionaria. Cuba adoptó un patrón de desarrollo dependiente de la URSS y los países del este, en la agricultura en particular y en toda la economía en general. Estas condiciones comerciales tan beneficiosas para Cuba, a su vez, propiciaban la reexportación de petróleo e insumos químicos, obteniendo más divisas para alimentar la economía. Sin embargo, este mecanismo tan beneficioso era al mismo tiempo extremadamente dependiente de los países del CAME. En particular, la agricultura cubana era, además de dependiente, muy intensiva, por lo que a mediados de los 80 comenzaba a mostrar síntomas de agotamiento, disminución constante de los rendimientos de la tierra por hectárea y una notable degradación medioambiental.

Tras la caída del bloque socialista en el este de Europa (1989-1990), Cuba se vio inmersa en una profunda crisis. La isla se vio sumergida en una urgente búsqueda de soluciones que obligaron a la reestructuración de la economía. Cuba perdió el $85 \%$ de su comercio exterior, experimentó una reducción del $53 \%$ de las importaciones de petróleo que afectó no sólo a la disponibilidad de combustible, sino también a la eliminación de las divisas que Cuba obtenía al exportar sus excedentes petroleros. ${ }^{37} \mathrm{Al}$ mismo tiempo, las importaciones de trigo y otros granos destinados al consumo animal también cayeron drásticamente, más de un $50 \%$, mientras que la disponibilidad de otros productos alimentarios disminuyó aún más. ${ }^{38}$

El momento crítico llegó en 1993, con la crisis alimentaria que obligó al país a buscar alternativas que pudieran producir el doble de la cantidad de comida con sólo la mitad de los insumos agrarios disponibles con anterioridad. ${ }^{39}$ El Gobierno declara el «periodo especial» a través del cual se introdujeron diferentes medidas de reestructuración económica, social y política para afrontar la dura depresión económica. Particularmente, la

\footnotetext{
37 Murphy (1999).

38 Rosset y Benjamin (1994).

39 Funes Monzote (2006).
} 
agricultura cubana llevó a cabo una transformación, aunque necesaria, muy positiva, que la llevó hacia un modelo de agricultura sostenible. Progresivamente, un número considerable de campesinos y ganaderos abandonaron el sistema convencional de producción, altamente dependiente de petroquímicos y maquinaria, y comenzaron a producir sus alimentos de manera ecológica.

Afortunadamente, Cuba no estaba totalmente desprovista de elementos para combatir la depresión económica. El Gobierno revolucionario siempre había subrayado la necesidad del capital humano en el proceso de desarrollo económico. Por lo tanto, la isla contaba con numeroso personal cualificado, académicos e investigadores, que desde mediados de los 80 , conscientes del agotamiento del modelo de agricultura convencional, desarrollaron una combinación de agricultura tradicional, tecnología moderna y conocimiento técnico. También se crearon instituciones de investigación para mejorar las técnicas de gestión de la tierra, la aplicación de fertilizantes de origen animal, la vuelta a la tracción animal en lugar de la maquinaria pesada, etcétera. Estas innovaciones permitieron el desarrollo de la agricultura urbana, que, junto a muchas pequeñas y medianas explotaciones rurales basadas en la producción ecológica, se convirtió en una fuente importante de oferta de alimentos de la isla. ${ }^{40}$

A continuación, el gráfico 2 resume los elementos clave que hicieron posible semejante transición en Cuba para paliar la crítica situación alimenticia de los $90 .{ }^{41}$

El factor principal fue el acceso a la tierra de la mayoría de los campesinos y gentes rurales. La segunda ley de redistribución de la tierra, de 1963, dividió las granjas estatales en pequeñas propiedades; las cooperativas y las unidades de producción individual fueron posibles gracias a la expropiación de los antiguos propietarios de la tierra, que ya había tenido lugar al inicio de la revolución.

A pesar de ser un factor exógeno negativo, la protección frente al dumping en el mercado internacional, resultado del embargo comercial llevado a cabo por los Estados Unidos, fue una condición positiva, promo-

40 Rosset y Benjamin (1994).

41 Funes (2002). 


\section{GRÁFICO 2}

CLAVES DE LA TRANSICIÓN CUBANA DE UN MODELO DE PRODUCCIÓN

DOMINANTE HACIA UN MODELO ALTERNATIVO BASADO

EN LA AGROECOLOGÍA EN LOS 90

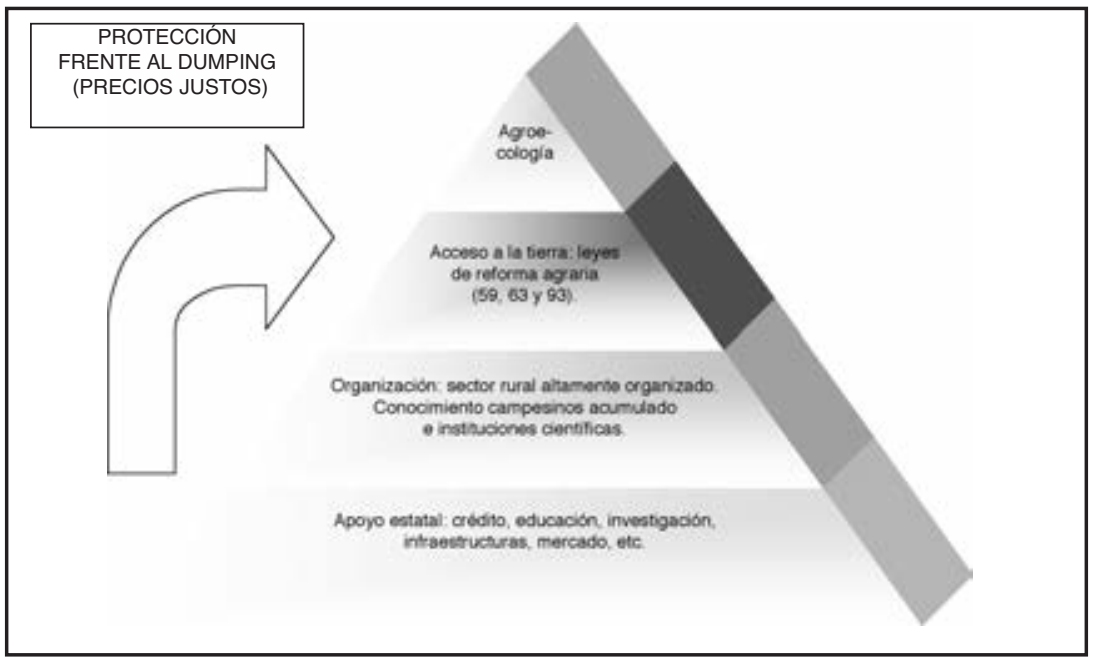

FUENTE: Rosset (2005).

viendo precios más altos para los campesinos y proporcionándoles la viabilidad económica e incentivos necesarios para que la agricultura autóctona cubana pudiera afrontar la dura situación económica.

Los otros factores clave fueron el activo interés del Estado en el proceso de transición, reflejado a través de su apoyo financiero (créditos), la investigación o la ampliación del sistema educativo, entre otros factores. Adicionalmente, Cuba contaba con un sector rural altamente organizado y estructurado que permitió una rápida transformación. Por último, la existencia de una tecnología agroecológica autóctona (proveniente tanto del conocimiento campesino acumulado como de las instituciones de investigación) ayudó a paliar la dependencia y no disponibilidad de insumos importados. ${ }^{42}$

42 Funes (2002). 
En definitiva, todos estos factores llevaron a Cuba a desarrollar un modelo de agricultura sostenible sin precedentes en la historia de la humanidad. Un modelo que en la actualidad, a pesar de tener muchas dificultades inherentes al propio sistema agrario cubano, ha obtenido resultados muy positivos avalados por más de diez años de experiencia. Resultados como la agricultura urbana, el consenso entre el Estado, la academia y los campesinos en el desarrollo de un modelo agrario alternativo y la creación de estrategias de desarrollo agrario participativas basadas en el conocimiento campesino local, entre otros factores, han demostrado como una alternativa que en principio apareció como necesaria para afrontar la crisis de los 90 finalmente ha demostrado estar llena de lecciones y pautas ricas en conocimiento. Experiencias que debemos observar atentamente para el desarrollo agrario y rural no sólo en los países del Tercer Mundo, sino también en el primero.

\section{Conclusión. Desarrollo agrario y rural: Elementos clave para el desarrollo económico de América Latina}

No existe una propuesta "única» para las políticas agrarias [...] Adaptarse a las condiciones locales e involucrar a todos los interesados resulta esencial para el diseño y la implementación de políticas agrarias eficaces. ${ }^{43}$

Las políticas de la tierra son la base de los conflictos sociales en países tan diversos como Camboya, Zimbabwe o Brasil. Una distribución de la tierra extremadamente desigual, así como una ineficiente distribución de la propiedad de la tierra en muchos países en desarrollo, fueron en la mayoría de los casos el resultado de relaciones de poder establecidas o políticas distorsionadas, más que la consecuencia de las fuerzas del mercado. En muchos de los intentos de reforma agraria llevados a cabo en América Latina, uno no podía esperar que los mercados por sí mismos llevasen a cabo la asignación eficiente de la tierra, requerida para maximizar la eficiencia y el bienestar social. 
Las experiencias posteriores a la Segunda Guerra Mundial del sudeste asiático han demostrado que la reforma agraria puede de manera significativa mejorar el bienestar social y la productividad, estableciendo una positiva integración horizontal entre el sector primario y el resto de la economía. Sin embargo, la larga historia de la reforma agraria en América Latina ha sido en la mayoría de los casos (Bolivia, Guatemala, Perú o México) el resultado de luchas políticas para el restablecimiento de territorios ancestrales y derechos políticos. Muchas iniciativas se vieron incentivadas por el clima político de los años 60 , que veían al pequeño agricultor familiar como una pieza clave para combatir el comunismo; tal fue el caso de Brasil, Venezuela o Chile. Incluso, en ocasiones, las reformas agrarias tuvieron un propósito antifeudal explícito, con el objetivo de terminar de una vez por todas con las relaciones laborales basadas en la servidumbre.

En general, casi todas las reformas agrarias latinoamericanas llevadas a cabo durante el siglo XX han estado basadas en el mero acceso a la tierra, sin pretender el objetivo más amplio de aumentar el bienestar familiar y la competitividad de los beneficiarios. Por ello, los resultados conseguidos para combatir la pobreza rural y promover el crecimiento han sido muy pobres, permaneciendo como un desafío futuro en la región. Parece que era más simple, en el corto plazo, dar el acceso a la tierra que diseñar unos programas coherentes de reforma agraria basados en el incremento de la productividad y competitividad de los beneficiarios. Muchos de los verdaderos programas de reforma agraria, por lo tanto, permanecieron incompletos en América Latina; inclusive muchas veces fueron improvisados a posteriori, sin ser entendidos como parte esencial de una estrategia de desarrollo rural sostenible a largo plazo, teniendo nefastas consecuencias para el pequeño campesino. ${ }^{44}$

A su vez, la naturaleza política de los programas de reforma agraria implementados en América Latina obvió algunas de las iniciativas con posibilidades de obtener mejoras significativas en la productividad y el bienestar familiar, como en el caso brasileño. Los gobiernos latinoamericanos, por lo general, demostraron durante casi todo un siglo ser incapaces de llevar a cabo una reforma agraria real. Sólo a finales del siglo XX y principios

44 Deininger (2003). 
del XXI fuertes campañas políticas de movimientos sociales, como el MST en Brasil, o nuevos gobiernos de corte populista, como en Venezuela o Bolivia, parecen haber comenzado la lucha por una reforma agraria real.

Por consiguiente, parece que en América Latina la confusión entre los fines u objetivos del desarrollo económico y los medios para lograrlo fue una pauta común en todas y cada una de las etapas de crecimiento vividas en la región a lo largo del siglo XX. Nunca se logró involucrar a la sociedad civil y los campesinos en las políticas agrarias, y éstos continuaron siendo vistos como meros destinatarios pasivos de los frutos de elaborados programas de desarrollo, como el Consenso de Washington. ${ }^{45}$ Tuvimos que esperar a la emergencia del denominado Postconsenso de Washington para entender la necesidad de más instrumentos y objetivos más amplios en la búsqueda de un desarrollo equitativo sostenible. ${ }^{46}$ Entre esos objetivos más amplios, tanto los economistas del desarrollo como los organismos internacionales han incluido finalmente el desarrollo agrario, el acceso a la tierra y la sostenibilidad medioambiental; claves de cualquier estrategia integral de desarrollo económico con una perspectiva de largo plazo. Adicionalmente, se ha reconocido que el Estado debe intervenir e intentar trabajar simbióticamente con el mercado para lograr el objetivo de un desarrollo agrario y rural sostenible, definiendo y fortaleciendo los derechos de propiedad de los más pobres, eliminando las barreras a las transacciones de tierra e involucrando a la sociedad civil de una manera significativa; teniendo en cuenta, eso sí, las específicas características de cada país.

En particular, las pautas seguidas por Brasil o Cuba, basadas en la experimentación y la conexión entre los diferentes actores de la política económica, pueden ser buenos ejemplos donde mirar. En la práctica, tanto la experiencia del MST en Brasil como el modelo alternativo surgido en Cuba en los 90 demuestran que se ha avanzado mucho hacia la autosuficiencia en estas regiones. Éste es un logro significativo que debemos observar atentamente, particularmente a la luz del fallo de la comunidad mundial y los estados en conseguir el menos ambicioso de los objetivos de desarrollo del milenio: reducir en un $50 \%$ el número de personas sin acce-

\footnotetext{
45 Sen (1999).

46 Stiglitz (1998).
} 
so a la comida en las naciones en vías de desarrollo. ${ }^{47}$ En los actuales debates de seguridad alimentaria, generalmente se argumenta que un país no puede alimentar a su propia población sin pesticidas ni fertilizantes químicos; sin embargo, parece que el acceso a la tierra y los mercados locales, junto con las prácticas agroecológicas, podrían conseguir este objetivo de seguridad nacional. También se suele argumentar la necesidad de la eficiencia de la producción a gran escala para producir suficientes alimentos. Sin embargo, en Cuba encontramos pequeños productores y agricultores urbanos en la vanguardia del proceso de recuperación de la depresión económica de los 90, que sin maquinaria e insumos químicos han demostrado ser más eficientes que las unidades de producción a gran escala.

Paralelamente, la alternativa alimentaria agroecológica desarrollada en Cuba o Brasil parece por el momento funcionar, al menos para la producción local o en experimentos piloto. La agricultura sostenible debe afrontar, por tanto, el reto de extenderse a la producción a gran escala. Para ello los proyectos piloto, los asentamientos del MST o la iniciativa de la agricultura urbana cubana pueden ser la fuente generadora de soluciones adaptadas a las condiciones locales, contando siempre con una cuidadosa evaluación e integrando a todos los agentes sociales pertinentes.

Muchas críticas temen que la agricultura sostenible, en el caso de Cuba, termine cuando el dinero (divisas) o los petroquímicos vuelvan a estar disponibles en la isla, una vez superada la crisis. Sin embargo, en Brasil, un país con acceso a petroquímicos, los asentamientos del MST demuestran como en el largo plazo los sistemas agroecológicos poseen unos niveles más estables de producción total por unidad de área que las explotaciones intensivas con tecnología e insumos químicos de Revolución verde. ${ }^{48}$

Es verdad que la historia, geografía, sistema y clima político tanto de Cuba como de Brasil son muy diferentes y específicos, poniendo de esta forma en tela de juicio la viabilidad a largo plazo de un modelo alternativo. Sin embargo, tanto en Cuba como en Brasil los pequeños campesinos están desarrollando pautas de agricultura sostenible para paliar sus crisis

47 Wright (2005).

48 Altieri (1997). 
rurales. Sus historias ofrecen por tanto una lección coherente sobre las políticas de autosuficiencia y la producción alternativa, así como métodos que podrían ser muy útiles para otros países no sólo del Tercer Mundo, sino también del primero, ya que el desarrollo rural sostenible, el agotamiento de las reservas petrolíferas y otros recursos no renovables, o la necesidad de alimentos sanos y naturales, son problemas que afectan a toda la comunidad internacional.

En particular, en los países del Tercer Mundo se debe decidir de una vez por todas, dentro las políticas de desarrollo agrario y rural, si es o no el sector agrario donde se debe librar la batalla por un desarrollo económico integral a largo plazo. La mayoría de los países en vías de desarrollo cuentan con un sector agrario y rural en condiciones muy pobres; por ello, si el desarrollo va a tener lugar, tendrá que incluir a las zonas rurales de forma general, y al sector agrario de manera particular. ${ }^{49}$

Países como Bolivia o Venzuela, que en la actualidad están luchando para resolver sus propias crisis alimentarias y rurales, podrían extraer interesantes lecciones de los casos de Cuba y Brasil. ${ }^{50}$ En Venezuela, a pesar de que Chávez ha demostrado un compromiso serio para resolver la crisis rural y la puesta en práctica de una reforma agraria real, los intereses de los grandes propietarios absentistas y funcionarios, los efectos negativos del dumping sobre las importaciones masivas de alimentos y la relativa falta de organización campesina como un sujeto activo en la reivindicación y puesta en marcha de la reforma agraria, mantienen el proceso paralizado. En Bolivia, el nuevo gobierno de Evo Morales emprende la reforma agraria tras numerosos y costosos intentos que endeudaron al país y nunca consiguieron regularizar el derecho propietario de los campesinos e indígenas. El nuevo Gobierno está reanudando una reforma agraria que se inició el 2 de agosto de 1953 y que nunca llegó a los llanos orientales, mientras que los intereses de la oligarquía rural que se gestaron en su interior no permitieron una equitativa distribución de la tierra. ${ }^{51}$

49 Todaro (2003).

50 Rosset (2005).

51 Instituto Nacional de Reforma Agraria, Bolivia (2006). 



\section{BIBLIOGRAFÍA}

AbAd de Subirà y de CASADES, José Calasanz de (1842), Expediente instruido ante el M.I.S. Gefe Superior Político de la Provincia de Lérida, sobre la formación de un pantano en la villa de Abella para el riego de las tierras de dicha población, de las de San Roman, de Bastus y otras, Barcelona, Imprenta de José Torner.

ABAD y QueIPO, Manuel (1986), En favor del campo / Gaspar de Jovellanos, Manuel Abad y Queipo, Antonio de San Miguel y otros, introd., sel. y n. de Heriberto Moreno García, [México, D.F.], Secretaría de Educación Pública.

Abraham, A., y J. P. Platteau (2002), "Participatory Development in the Presence of Endogenous Community Imperfections», Journal of Development Studies, vol. 39, n. ${ }^{\circ}$, pp. 104-136.

Acemoglu, D. (2003), "Why not a Political Coase Theorem? Social Conflict, Commitment and Politics», Journal of Comparative Economics, vol. 31, 4, pp. 620-652.

- S. Johnson y J. Robinson (2004), "Institutions as the Fundamental Cause of Long Run Growth", en National Bureau of Economic Research, Working Paper 10481.

Acta del Directorio del Banco de la Provincia de Buenos Aires, Sección Crédito Hipotecario.

Acuña Rubio, Carlos (2000), "Títulos nobiliarios de los hijos de Galicia», Boletín de Estudios de Genealogía, Heráldica y Nobiliaria de Galicia, 1, pp. 37-50.

Albert i Corp, Esteve (1987), Don Guillem d'Areny i de Plandolit, Baró de Senaller $i$ de Gramenet, M. Iltre. Sr. Sindic de les Valls d'Andorra, Andorra la Vieja, Edicions Andorra.

AlberTí, Antònia (2002), La formació de la burgesia mallorquina i la seva implicació en les transformacions econòmiques dels segles XIX $i$ XX, memoria de investigación presentada en la Fundación Ignasi Villalonga.

AlCAIDE, Julio (2003), Evolución económica de las regiones y provincias españolas en el siglo XX, Madrid, Fundación Banco Bilbao Vizcaya Argentaria. 
Almansa, Rosa María (2005), Familia, tierra y poder en la Córdoba de la Restauración. Bases económicas, poder politico y actuación social de algunos miembros de su élite, Córdoba, Servicio de Publicaciones de la Universidad de Córdoba.

Alonso, José A. (2005), «Equidad y crecimiento: una relación en disputa», Estudios de Economía Politica, n. ${ }^{\circ} 1$ (enero), pp. 9-36.

AlOnSO PeÑA, Manuel (1933), «Estudios previos para la implantación de la Reforma Agraria en la provincia de Cáceres», en Archivo IRYDA, Fondo Reforma Agraria, legajo 0.3.

Alston, Lee J., y Joseph P. FerRie (1993), «Paternalism in Agricultural Labor Contracts in the U.S. South: Implications for the Growth of the Welfare State», American Economic Review, vol. 83, n. ${ }^{\circ} 4$, pp. 852-876.

Altamirano, Carlos (2001), Bajo el signo de las masas (1943-73), Buenos Aires, Ariel.

Altieri, Miguel Á. (1995), «El "estado del arte” de la agroecología y su contribución al desarrollo rural en América Latina», en Alfredo Cadenas (ed.), Agricultura y desarrollo sostenible, Madrid, Ministerio de Agricultura, pp. 151-203.

- (1999), «Applying Agroecology to Enhance the Productivity of Peasant Farming Systems in Latin America», Environment, Development and Sustainability, vol. 1, pp. 197-217.

ÁlvarEZ, Norberto, y Blanca ZeBerio (1991), «Los inmigrantes y la tierra. Labradores europeos en la región sur de la campaña bonaerense (Argentina) a principios del siglo XX», Estudios Migratorios Latinoamericanos, año 6, n. ${ }^{\circ} 17$. Amaral, Samuel (1998), The Rise of Capitalism on the Pampas, Nueva York, Cambridge University Press.

- (2001), «Producción agropecuaria, 1810-1850», en Academia Nacional de la Historia, Nueva Historia de la Nación Argentina, Buenos Aires, Planeta, vol. 6, pp. 41-64.

- y Marta Valencia (1999), Argentina, el país nuevo, La Plata, Universidad Nacional de la Plata [EUNLP].

Anales de legislación Argentina (1920-1970).

ARCONDO, Aníbal (1980), «El conflicto agrario argentino de 1912. Ensayo de interpretación», Desarrollo Económico, n. ${ }^{\circ} 79$.

ARIzCORRETA, M. (1849), Comunicación dirigida a los propietarios de fincas rusticas del estado de Mexico y Acta de la junta celebrada en 6 de agosto con motivo de la circular del 18 de julio, México, Imprenta de Ignacio Cumplido.

Aróstegui, Julio, y Juan Andrés Blanco (1995), «Historia contemporánea de Castilla y León», en A. García Simón (ed.), Historia de una Cultura. I. Castilla y León en la Historia de España, Valladolid, Junta de Castilla y León, pp. 417-517.

Artiaga RegO, Aurora (1984), "La renta foral en Galicia a finales del siglo XIX», Agricultura y Sociedad, n. ${ }^{\circ}$ 30, pp. 207-237. 
Artola, Miguel, et ál. (1978), El latifundio. Propiedad y explotación, siglos XIX y $X X$, Madrid, Ministerio de Agricultura, Pesca y Alimentación.

Assies, Willem (2000), «Indigenous Peoples and Reform of the State in Latin America», en Willem Assies, Gemma Van Der Haar y André Hoekema (eds.), The Challenge of Diversity. Indigenous Peoples and Reform of the State in Latin America, Amsterdam, Thela Thesis, pp. 3-21.

Atienza Hernández, Ignacio (1987), Aristocracia, poder y riqueza en la España Moderna: la casa de Osuna, siglos XV-XIX, Madrid, Siglo XXI.

- y Rafael Mata Olmo (1986), "La quiebra de la Casa de Osuna», Moneda y Crédito, n. ${ }^{\circ} 176$, pp. 71-95.

Avellaneda, Nicolás (1915), Estudio sobre las leyes de tierras públicas, Buenos Aires, La Facultad.

Ayala EsPino, José (1999), Instituciones y Economía. Una introducción al neoinstitucionalismo económico, México, Fondo de Cultura Económica.

BANCO DE LA NACIÓN ARgENTINA, Memoria y Balance general correspondiente al periodo 1940-53.

Banco Mundial (2002), Llegando a los pobres de las zonas rurales. Estrategia de Desarrollo Rural para América Latina y el Caribe, Washington, Departamento de Desarrollo Ambiental y Socialmente Sostenible, Banco Mundial.

BANDIERI, Susana (2005), «Del discurso poblador a la praxis latifundista: La distribución de la tierra pública en la Patagonia», Mundo Agrario, 2. ${ }^{\circ}$ semestre, n. ${ }^{\circ} 11$ [edición electrónica en <www.mundoagrario.unlp.edu.ar>].

BANERJEe, Abhijit V. (1999), "Prospects and Strategies for Land Reform», en B. Pleskovik y Joseph E. Stiglitz, Annual World Bank Conference on Development Economics, Washington.

BANZATO, Guillermo (2005), La expansión de la frontera bonaerense. Posesión y propiedad de la tierra en Chascomuis, Ranchos y Monte, Bernal (Argentina), Universidad Nacional de Quilmes.

- y Marta Valencia (2005), «Tierra y poder en la Provincia de Buenos Aires: 1820-1880», Anuario del IEHS, Tandil, n. ${ }^{\circ} 20$, pp. 211-238.

BARBA, Enrique M. (1962a), «El primer gobierno de Rosas. Gobierno de Balcarce, Viamonte y Maza», en Ricardo Levene (dir.), Historia de la Nación Argentina, Buenos Aires, El Ateneo, 3. ${ }^{\mathrm{a}}$ ed., vol. 7, 2. ${ }^{\mathrm{a}}$ sección, cap. 1, pp. 9-84.

- (1962b), «Formación de la tiranía», en Ricardo Levene (dir.), Historia de la Nación Argentina, Buenos Aires, El Ateneo, 3. a edición, vol. 7, 2. ${ }^{a}$ sección, cap. 2, pp. 84-129.

- (1962c), "Las reacciones contra Rosas», en Ricardo Levene (dir.), Historia de la Nación Argentina, Buenos Aires, El Ateneo, 3. ${ }^{\mathrm{a}}$ ed., vol. 7, 2. ${ }^{\mathrm{a}}$ sección, cap. 9, pp. 331-445.

- (1975), «La Campaña al Desierto y el problema de la tierra: la ley de premios militares de 1885", en Segundo Congreso de Historia Argentina y 
Regional, Buenos Aires, Academia Nacional de la Historia, vol. 3, pp. 145-183.

BARBA, Enrique M. (1977a), «La conquista del desierto y la distribución de la tierra. Las leyes de 5 y 16 de octubre de 1878», en Tercer Congreso de Historia Argentina y Regional, Buenos Aires, Academia Nacional de la Historia, pp. 65-76.

- (1977b), «La campaña al desierto y la distribución de la tierra en virtud de la ley de 5 de octubre de 1878 y su aplicación en Córdoba y Territorios Nacionales», en Tercer Congreso de Historia Argentina y Regional, Buenos Aires, Academia Nacional de la Historia, pp. 226-228.

- et. ál. (1974), «La Campaña al Desierto y el problema de la tierra: la ley de 1878 y su aplicación en la provincia de Buenos Aires», en Segundo Congreso de Historia de los Pueblos de la Provincia de Buenos Aires, La Plata, Archivo Histórico de la Provincia de Buenos Aires, pp. 225-254.

BARBA, Fernando (1976), Los Autonomistas del 70, Buenos Aires, Pleamar.

- (1995), Frontera ganadera y guerra con el indio, La Plata, Universidad Nacional de La Plata [EUNLP].

BARDAHN, Pranab (1989), «The New Institutional Economics and Development Theory: A Brief Critical Assesment», World Development, n. ${ }^{\circ}$ 17, vol. 9, pp. 1389-1395.

- (2001a), «Distributive Conflicts, Collective Action, and Institutional Economics», en Meier y Stiglitz (eds.) (2001), pp. 269-295.

- (2001b), «Institutions, Reforms, and Agricultural Performance», en Kostas Stamoulis, Food, Agriculture, and Rural Development, Food and Agriculture Organization [FAO].

BARDají, Alfonso (1933), «Tercera Ponencia de la Asamblea Económica Agraria», Economía Española (marzo), pp. 123-130.

BARRAClOUGH, Salomon (1965), "¿Qué es una reforma agraria?», en O. Delgado (ed.), Reformas agrarias en la América Latina, México, Fondo de Cultura Económica, pp. 127-145.

- (1999), Land reform in developing countries: the role of state and other actors, Ginebra, UNRISD (Discussion Paper, n. ${ }^{\circ} 101$ ).

Barreiro Fernández, Xosé Ramón (1991), A Sociedade Galega Contemporánea. Tradición e Modernidade, La Coruña, Hércules.

Barreiro Mallón, Baudilio (1978), La jurisdicción de Xallas en el siglo XVIII: Población, sociedad y economía, Santiago de Compostela, Universidade de Santiago de Compostela, 2. ${ }^{a}$ ed.

- (1990), «El dominio de la familia Porras y la evolución de las rentas agrarias en la Tierra de Santiago", Obradoiro de Historia Moderna. Homenaje al Prof. Antonio Eiras Roel, pp. 25-45.

BARros, Álvaro (1957), Fronteras y territorios federales de las pampas del sur, Buenos Aires, Hachette. 
BARSKY, Osvaldo (1988), La reforma agraria ecuatoriana, Quito, Corporación Editora Nacional.

- y Jorge Gelman (2001), Historia del agro argentino. Desde la Conquista hasta fines del siglo XX, Buenos Aires, Mondadori.

- y Julio DJENDEREdjian (2003), La expansión ganadera hasta 1895, Buenos Aires, Universidad de Belgrano y Siglo XXI.

BASAVE, Agustín (2001), Con la revolución a cuestas/Andrés Molina Enríquez, México, Fondo de Cultura Económica.

BATES, Robert (1997), Open Economy Politics: The Politics and Economics of the International Coffee Market, Princeton, Princeton University Press.

BaZ Vicente, María Jesús (1995), «Endeudamiento y desvinculación de los mayorazgos de la casa de Alba en la España liberal», en Antiguo régimen y liberalismo: homenaje a Miguel Artola, Madrid, Alianza Editorial, vol. 2 (Economía y Sociedad), pp. 25-41.

- (1996a), Señorío y propiedad foral de la alta nobleza en Galicia, (siglos XVI-XX): La Casa de Alba, Madrid, Ministerio de Agricultura, Pesca y Alimentación.

- (1996b), «La pervivencia del régimen foral en la Galicia del siglo XIX vista a través de un grande absentista. La Casa de Alba», en Lourenzo Fernández Prieto y Xesús Balboa López (eds.), La sociedad en la España Contemporánea. Mercado y patrimonio, Sada, O Castro, pp. 107-119.

BECHIS, Martha (1998), "Fuerzas indígenas en la política criolla del siglo XIX», en Noemí Goldman y Ricardo Salvatore (comps.), Caudillismos rioplatenses, Buenos Aires, Editorial Universitaria de Buenos Aires [EUDEBA], pp. 293317.

BERNAL, Antonio Miguel (1985), «La llamada crisis finisecular (1872-1919)», en José Luis García Delgado (ed.), La España de la Restauración, Madrid, Siglo XXI

- (1988), Economía e historia de los latifundios, Madrid, Espasa-Calpe.

Bernstein, H. (2004), «Changing before our very eyes: Agrarian questions and the politics of land in Capitalism Today», Journal of Agrarian Change, vol. 4, núms. 1 y 2, pp. 190-225.

BERRY, Albert (2002), «iColombia encontró por fin una reforma agraria que funcione?», Revista de Economía Institucional, n. ${ }^{\circ}$ 6, pp. 25-70.

Berry, R. Albert, y William R. Cline (1979), Agrarian Structure and Productivity in Developing Countries, Baltimore y Londres, The Johns Hopkins University Press.

Bertie, C. (1886), Un parisien au Mexique, París, E. Dentu.

BHADURI, Amit ([1983] 1987), La estructura económica de la agricultura atrasada, México, Fondo de Cultura Económica.

- (1998), «Eficiencia económica e instituciones agrarias», Historia Agraria, n. ${ }^{\circ}$ 15 , pp. $15-25$. 
Biagioli, Giuliana (2003), "Les contrats dans l'historiographie italienne de la période contemporaine», en Gérard Béaur, Mathieu Arnoux y Anne VaretVitu (eds.), Exploiter la terre. Les contrats agraires de l'Antiquité à nos jours. Actes du Colloque de Caen (10-13 septembre 1997), Rennes, Association d'Histoire des Sociétés Rurales, pp. 63-84.

BID [Banco Interamericano de Desarrollo] (1998), Informe técnico. Perspectivas sobre mercados de tierras rurales en América Latina, Departamento de Desarrollo Sostenible, División de Medio Ambiente.

Binswanger, H. P. (1984), Agricultural Mechanization: A Comparative Historical Perspective, Washington (World Bank Staff Working Papers, n. ${ }^{\circ}$ 673).

Birabent, Mauricio (1941), Chivilcoy. La región y las chacras, La Plata, Archivo Histórico de la Provincia de Buenos Aires.

BiSSON, Jean (1969), "Origen y decadencia de la gran propiedad en Mallorca», Boletín de la Cámara Oficial de Comercio, Industria y Navegación de Palma de Mallorca, n. ${ }^{\circ}$ 665, pp. 161-188

- (1977), La terre et l'homme aux Iles Baléares, Aix-en-Provence, Edisud.

BlanCo, Mónica (2001a), «Peronismo, Mercantismo y Política Agraria en la provincia de Buenos Aires (1946-55)», Mundo Agrario, n. ${ }^{\circ} 2$.

- (2001b), Planificación estatal, política agraria y tenencia de la tierra en la provincia de Buenos Aires (1940-60). Una aproximación regional, tesis doctoral inédita, Universidad Nacional de La Plata.

- (2004a), "Colonización y Reforma Agraria en la provincia de Buenos Aires. Cambios y continuidades en las políticas agrarias peronistas», en Guido Galafassi (comp.), El Campo Diverso. Enfoques y perspectivas de la Argentina agraria del siglo XX, Quilmes (Argentina), Universidad Nacional de Quilmes.

- (2004b), «Tierras, créditos y subdivisión de la propiedad rural en el sudeste bonaerense (1940-60)», en Anuario N.o 4, Córdoba (Argentina), Centro de Estudios Históricos «Prof. Carlos S. A. Segretti».

- y M. ${ }^{a}$ Eugenia ROMERO (2000), Tres siglos de economía novohispana, 15211821, México, Universidad Nacional Autónoma de México [UNAM].

Boletín de la Agrupación de Propietarios de Fincas Rústicas (1932), n. ${ }^{\circ} 10$ (octubre), «Editorial».

BONALES, Jacinto (1999), «Les muntanyes en venda. La desamortització de terres comunals a la Conca de Tremp, 1855-1931», Diari de Ponent.

- (2000), «L'accés a la terra a la Catalunya alodial pagesa i comunitària. El Prepirineu occidental», Recerques, n. ${ }^{\circ} 41$, pp. 31-58.

- (2003), Comunidad rural y economía de mercado en la Conca de Tremp (siglos XVIII-XIX). Cambio económico y éxodo rural, tesis doctoral, Universitat de Lleida.

- (2004a), «Estructuració de l'espai i construcció del paisatge a la Catalunya nord-occidental. L'exemple de la Feixa al Pallars Jussà», en Enric Vicedo Rius 
(ed.), Medi, Territori i història. Les transformacions territorials en el món rural català occidental, Lérida, Pagès, pp. 165-188.

BONALES, Jacinto (2004b), La construcció dels limits parroquials a Andorra, El cas d'Ordino-La Massana, Ordino, en prensa.

BonaUdo, Marta, y Cristina Godoy (1985), «Una corporación y su inserción en el proyecto agroexportador: la Federación Agraria Argentina (1912-1033)», Anuario, n. ${ }^{\circ} 11$.

Borrero FernÁNDEZ, Mercedes (2003), La organización del trabajo. De la explotación de la tierra a las relaciones laborales en el campo andaluz (siglos XIII-XVI), Sevilla, Universidad de Sevilla.

Bortz, J., y S. Haber (2002), The Mexican economy, 1870-1930. Essays on the economic history of institutions, revolution and growth, Stanford, Stanford University Press.

Bretón, Víctor (1994), ¿La Tierra para quien la trabaja? Reforma Agraria, desarrollo rural y crisis del campesinado en América Latina (1950-1990), Lérida, Universitat de Lleida.

- (1997), Capitalismo, reforma agraria y organización comunal en los Andes. Una introducción al caso ecuatoriano, Lérida, Universitat de Lleida.

- (2001), Cooperación al desarrollo y demandas étnicas en los Andes ecuatorianos. Ensayos sobre indigenismo, desarrollo rural y neoindigenismo, Quito, Facultad Latinoamericana de Ciencias Sociales [FLACSO] y Universitat de Lleida.

- (2002), "Cooperación al desarrollo, capital social y neo-indigenismo en los Andes ecuatorianos", European Review of Latin American and Caribbean Studies / Revista Europea de Estudios Latinoamericanos y del Caribe, n. ${ }^{\circ}$ 73, pp. 43-63.

- (2005), Capital social y etnodesarrollo en los Andes, Quito, Centro Andino de Acción Popular.

BREY, Gérard, y Roland Forgues (1976), «Algunas rebeliones campesinas en la literatura española: Mano negra, Jerez, Casas Viejas y Yeste», en José Luis García Delgado (ed.) La cuestión agraria en la España contemporánea, Madrid, Edicusa, pp. 329-361.

BRINES BlaSCO, Joan (1979), «Aportació a l'estudi de la desvinculació al País Valencià», Estudis d'Història Contemporània del País Valencià, n. ${ }^{\circ}$ 1, pp. 227253.

Bringas GutiérReZ, Miguel Ángel (2000), La productividad de los factores en la agricultura española (1752-1935), Madrid, Banco de España, Servicio de Estudios de Historia Económica.

BRINGUÉ, Josep M. (1995), Comunitats i béns comunals al Pallars Sobirà, segles XVXVIII, tesis doctoral, Universitat Pompeu Fabra.

BRINSMADE, Robert B. (1916), El latifundismo mexicano, su origen y su remedio, México, Imprenta de la Secretaría de Fomento. 
Brook, T., y G. Blue (eds.) (1999), China and Historical Capitalism. Genealogies of Sinological Knowledge, Cambridge, Cambridge University Press.

Bugallal, Gabino (1917), Pleito sobre la nulidad de la testamentaría de la excelentísima señora condesa de Bornos, Madrid, Imprenta Gráfica Excelsior.

Bulmer-Thomas, Victor (1998), La historia económica de América Latina desde la independencia, México, Fondo de Cultura Económica.

BUlNES, Francisco (1916), El latifundismo mexicano, su origen y su remedio, obra que contiene proyectos practicos para libertar a Mexico o a cualquiera otra nación del azote del monopolio privado, prologo del sr. Ing. José Covarrubias, tr. del inglés por Ignacio Flores Iñiguez, México, Imprenta de la Secretaría de Fomento.

- (1920), El verdadero Diaz y la revolución, México, La Editorial Hispanomexicana.

CABALlERO, Gonzalo (2004), «Instituciones e historia económica: enfoques y teorías institucionales», Revista de Economía Institucional, vol. 6, n. ${ }^{\circ}$ 10, pp. 135-157.

Cabo Villaverde, Miguel (1995), Alén do latifundio: Galicia e a Reforma Agraria da II República, tesis doctoral, Universidade de Santiago de Compostela.

Cabral Chamorro, Antonio (2000), Renovación tecnológica y mecanización de la agricultura en Cádiz, 1850-1932, Cádiz, Servicio de Publicaciones de la Universidad de Cádiz.

CABRERA, Luis (1913), Reconstitución de los ejidos de los pueblos como medio de suprimir el esclavismo del jornalero mexicano, México, Tip. F. Soria.

Calatayud, Salvador, Jesús Millán y María Cruz Romeo (1997), «El ideal del propietario agrícola y estabilidad de la sociedad de clases. Discurso y gestión de la nobleza valenciana del siglo XIX", en VIII Congreso de Historia Agraria. Salamanca, 28-30 de mayo de 1997, Preactas, Salamanca, Sociedad Española de Historia Agraria y Universidad de Salamanca, pp. 335-348.

- Jesús Millán y María Cruz Romeo (2000), «El rentismo nobiliario en la agricultura valenciana en el siglo XIX», Revista de Historia Económica, vol. 1, n. ${ }^{\circ} 18$, pp. 79-107.

- Jesús Millán y María Cruz Romeo (2002), «Les múltiples cares de la renda: propietaris i arrendataris al País Valencià», Estudis d'Historia Agrària, n. ${ }^{\circ} 15$, pp. 57-86.

CAMPS I ARBOIX, Joaquim de (1965), Les cases pairals catalanes, Barcelona, Destino.

CANales, Claudia (2001), El poeta, el marqués y el asesino. Historia de un caso judicial, México, Era.

CANUT, Basilio (1865), Memoria sobre los medios de promover el incremento de la riqueza agricola y pecuaria de Mallorca atendidos los recursos y las condiciones de su territorio, Palma de Mallorca, Imprenta de Felipe Guasp. 
CARASA, Pedro (dir.) (1997), Elites castellanas de la Restauración. Diccionario biográfico de Parlamentarios castellanos y leoneses (1876-1923), Salamanca, Junta de Castilla y León, vol. I.

CÁRCANO, Miguel Ángel (1972), Evolución histórica del régimen de la tierra pública, 1810-1916, Buenos Aires, EUDEBA.

Cardoso, Eliana, y Ann Helwege (1990), Latin America's Economy: Diversity, Trends and Conflict, Cambridge (Estados Unidos), Massachusetts Institute of Technology Press.

CARMONA Pidal, Juan (1991), El comportamiento económico de la nobleza española en el siglo XIX: la Casa de Alcañices, 1790-1910, tesis doctoral, Universidad Complutense de Madrid.

- (1995), "Las estrategias económicas de la vieja aristocracia española y el cambio agrario en el siglo XIX», Revista de Historia Económica, n. ${ }^{\circ}$ 1, pp. 6792.

- (2001), La aristocracia terrateniente y el cambio agrario en España en el siglo XIX: la Casa de Alcañices, 1790-1910, Valladolid, Junta de Castilla y León.

- (2006), «Sharecropping and livestock specialization in France, 1830-1930», Continuity and Change, n. ${ }^{\circ}$, en prensa.

- y James Simpson (2003), El laberinto de la agricultura española. Instituciones, contratos y organización entre 1850 y 1936, Zaragoza, Prensas Universitarias de Zaragoza.

CARREÑo Díaz, Juan María (2004), «De la gestión a la revolución (1931-1936)», en Manuel Redero San Román (ed.), La Unión General de Trabajadores en Castilla y León (1888-1998). Historia de un compromiso social, Salamanca, Universidad de Salamanca, pp. 159-252.

Carreras, Albert, y Xavier Tafunell (2004), Historia económica de la España contemporánea, Barcelona, Crítica.

CARRIÓN, Pascual ([1932] 1975), Los latifundios en España, Barcelona, Ariel.

- (1973), La Reforma Agraria de la Segunda Republica, Barcelona, Ariel.

Cascón, José (1934), Agricultura española, Madrid, Dirección General de Agricultura.

CASTAÑO, José Félix (2003), "Teoría económica e institucionalismo», Revista de Economía Institucional, n. ${ }^{\circ}$ 9, pp. 213-227.

CASTRO, Fidel (1992), Discurso pronunciado en la Conferencia de Naciones Unidas sobre Medio Ambiente y Desarrollo, Río de Janeiro.

CatalÁ SANZ, Jorge Antonio (1995), Rentas y patrimonios de la nobleza valenciana en el siglo XVIII, Madrid, Siglo XXI.

Cela Conde, Camilo (1979), Capitalismo y campesinado en la isla de Mallorca, Madrid, Siglo XXI.

CEPAL [Comisión Económica para América Latina y el Caribe] (1990), Transformación productiva con equidad. La tarea prioritaria del desarrollo de Amé- 
rica Latina y el Caribe en los años noventa, Santiago de Chile, Organización de las Naciones Unidas.

CEPAL (1993), Población, equidad y transformación productiva, Santiago de Chile, Organización de las Naciones Unidas.

- (1996), Anuario estadístico de América Latina y el Caribe, Santiago de Chile, Comisión Económica para América Latina.

- (2004), Anuario estadístico de América Latina y el Caribe, Santiago de Chile, Comisión Económica para América Latina.

Cerrato Mateos, Felisa (2000), Monasterios femeninos de Córdoba. Patrimonio, rentas y gestión económica a fines del Antiguo Régimen, Córdoba, Universidad de Córdoba.

ChAng, Ha-Joon (2004), Retirar la escalera. La estrategia del desarrollo en perspectiva histórica, Madrid, Catarata.

Chevalier, François (1956), La formación de los grandes latifundios en México, México, Fondo de Cultura Económica.

Chiriboga, Manuel (1987), «La Reforma Agraria y la modernización en América Latina: nuevos actores, nuevos contenidos», en Coloquio Las Sociedades Rurales Hoy, México, mimeografiado.

- (2004), «Posibles efectos del TLC sobre el sector agropecuario del Ecuador», en Proyecto CESA Comercialización, Monitoreo TCL, Quito, CESA y COSUDE.

Chonchol, Jacques (1996), Sistemas agrarios en América Latina. De la etapa prehispánica a la modernización conservadora, Santiago de Chile, Fondo de Cultura Económica.

Clavero, Bartolomé (1974), Mayorazgo: propiedad feudal en Castilla: 1369-1836, Madrid, Siglo XXI.

COASE, R. H. ([1937] 1994), "La naturaleza de la empresa», en La empresa, el mercado y la ley, Madrid, Alianza Editorial, pp. 33-49.

- ([1960] 1994), «El problema del coste social», en La empresa, el mercado y la ley, Madrid, Alianza Editorial, pp. 121-164.

Cово Romero, Francisco (1999), Conflicto rural y violencia politica. El largo camino hacia la Dictadura, Jaén, 1917-1950, Baeza, Universidad de Jaén.

- (2003), De campesinos a electores, Madrid, Biblioteca Nueva.

Colin, Jean-Philippe (ed.) (2003), Figures du métayage. Étude comparée de contrats agraires au Mexique, París, Institut de Recherche pour le Développement.

Congost, Rosa (1983), "Las listas de los mayores contribuyentes de 1875», Agricultura y Sociedad, n. ${ }^{\circ} 27$, pp. 289-375.

- et ál. (1997), «La evolución del contrato de masovería (Gerona, ss. XVXVIII)", en VIII Congreso de Historia Agraria. Salamanca, 28-30 de mayo de 1997, Preactas, Salamanca, Sociedad Española de Historia Agraria y Universidad de Salamanca, pp. 277-294. 
Córdova, Arnaldo (1979), «El pensamiento social y político de Andrés Molina Enríquez», en Molina Enríquez ([1909] 1979), pp. 9-67.

CORONAS VIDA, Luis Javier (1994), La economía agraria de las tierras de Jaén (1500-1650), Granada, Universidad de Granada y Ayuntamiento de Jaén.

Corrionero, F. (1986), «El Censo de campesinos: la jerarquización del proletariado rural», Studia Historica, vol. IV, pp. 181-203.

Cortada Reus, Francisco (1950), Geografía económica de Cataluña, Barcelona, Miguel Arimany.

Crespo, Horacio, et. ál. (1992), Historia del azúcar en México, México, Unión Nacional de Productores de Azúcar y Fondo de Cultura Económica.

Creus, G. (1911), "La propiedad rústica en Mallorca», Boletín de la Cámara Agrícola Balear, n. ${ }^{\circ}$ 14, pp. 210-213.

Cuello, José (1988), «El mito de la hacienda colonial en el norte de México», en Arij Ouweneel y Cristina Torales (comps.), Empresarios, indios y estado. Perfil de la economía mexicana (siglo XVIII), Ámsterdam, Centro de Estudios y Documentación Latinoamericanos, pp. 186-205.

Cutolo, Vicente Osvaldo (1969), Nuevo diccionario biográfico argentino (17501930), Buenos Aires, Elche.

Cuvi, María, Emilia Ferraro y Alexandra MarTínez (2000), Discursos sobre género y ruralidad en el Ecuador. La década de 1990, Quito, Consejo Nacional de las Mujeres.

DEININGER, Klaus (2003), Land policy for growth and poverty reduction: a policy research report, Washington, World Bank y Oxford, Oxford University Press.

- y Gershon FeDER (2001), «Land institutions and land markets», en B. L. Gardner y G. C. Rausser (eds.), Handbook of Agricultural Economics, Ámsterdam y Nueva York, Elsevier, vol. 1, pp. 288-331.

DemÉlas, Marie-Danielle, y Nadine VIVIER (dirs.) (2003), Les propriétés collectives face aux attaques libérales (1750-1914). Europe Occidentale et Amérique Latine, Rennes, Presses Universitaites de Rennes, 2003.

Diario de Sesiones de la Cámara de Diputados de la Provincia de Buenos Aires, años 1876 y 1878 y período 1946-1955 (La Plata).

Diario de Sesiones de la Cámara de Senadores de la Provincia de Buenos Aires, año 1875 y período 1946-1955 (La Plata).

Diario Tribuna, 1946-1955 (Benito Juárez).

DíAz-PolanCO, Héctor (1997), La rebelión zapatista y la autonomía, México, Siglo XXI.

DietZ, J. (1992), "Overcoming Underdevelopment: What Has Been Learned from the East Asian and Latin American Experience?», Journal of Economic Issues, vol. XXVI, n. ${ }^{\circ}$ 2, pp. 373-383.

DíEz, D. (1919), El cultivo e industria de la caña de azúcar, Memorias de la Asociación de Ingenieros y Arquitectos de México. 
Dirección de Colonización, Ministerio de Asuntos Agrarios, Carpetas 1 a 80, 1937-1972.

Direccion General de Agricultura, Industria y Comercio (1891), Avance estadístico sobre el cultivo cereal y de leguminosas asociadas en España, formado por la Junta Consultiva Agronómica, 1890, Quinquenio 1886 a 1890, ambos inclusive, Madrid, 3 vols.

- (1892), La ganadería en España: avance sobre la riqueza pecuaria en 1891, Madrid, Junta Consultiva Agronómica.

Dirección General de Trabajo (1931), Estadística de salarios y jornadas de trabajo referidas al periodo 1914-1930, Madrid.

DOMíngUeZ CASTRO, Luis (1992a), Viños, viñas e xentes do Ribeiro. Economía e patrimonio familiar, 1810-1952, Vigo, Xerais.

- (1992b), «Análisis económico de una explotación agraria fidalga a finales del Antiguo Régimen", Minius, n. ${ }^{\circ}$ 1, pp. 95-186.

- (1996), «Las tierras vinculares orensanas a finales del Antiguo Régimen: origen y formas de explotación», en Lourenzo Fernández Prieto y Xesús Balboa López (eds.), La sociedad rural en la España contemporánea. Mercado y patrimonio, Sada, O Castro, pp. 121-137.

DOMínGUEZ MARTín, Rafael (1993), "Caracterizando al campesinado y a la economía campesina: Pluriactividad y dependencia del mercado como nuevos atributos de la campesinidad", Agricultura y Sociedad, n. ${ }^{\circ} 66$.

- (2002), «Desigualdades sociales y crecimiento económico regional en España a largo plazo», Revista de Historia Industrial, n. ${ }^{\circ} 22$, pp. 177-196.

DomíngueZ Nicolau, José Manuel (1995), Estudio de las repercusiones de las leyes desvinculadoras sobre un patrimonio concreto: Montis (marqués de la Bastida), trabajo mecanografiado presentado en el Departamento de Ciencias Históricas y Teoría de las Artes de la Universitat de Les Illes Balears.

DORNER, Peter (1974), Reforma agraria y desarrollo económico, Madrid, Alianza Editorial.

- (1992), Latin American Land Reforms in Theory and Practice. A Retrospective Analysis, Madison, The University of Wisconsin Press.

DovRING, Folke (1956), Land and labor in Europe, 1900-1950, La Haya, Mouton.

DraIN, Michel (1977), Les campagnes de la province de Seville: espace agricole et société rurale, Lille, Université de Lille.

DyeR, Granham (2004), «Redistributive Land Reform: No April Rose. The Poverty of Berry and Cline and GKI on the Inverse Relationship", Journal of Agrarian Change, 4-1-2, pp. 45-72.

EGGERTSSON, Thráinn ([1990] 1995), El comportamiento económico de las instituciones, Madrid, Alianza Editorial.

EHM [Estadísticas Históricas de México]. 
EIRAS ROEL, Antonio (1972), «El régimen subforal y la clase hidalga intermediaria», introd. a María del Carmen Quintáns Vázquez, El dominio de San Martin Pinario ante la desamortización, Santiago de Compostela, Universidade de Santiago de Compostela, pp. 10-12.

- (1984), «Las élites urbanas de una ciudad tradicional: Santiago de Compostela a mediados del siglo XVIII», en La Documentación Notarial y la Historia. Actas del II Coloquio de Metodología Histórica Aplicada, Santiago de Compostela, Universidade de Santiago de Compostela, vol. I, pp. 117-139.

El-Ghonemy, Mohamad Riad (1990), The Political Economy of Rural Poverty. The Case for Land Reform, Londres, Routledge.

ERdozÁin, M. a Pilar, y Fernando Mikelarena (1996), "Algunas consideraciones acerca de la evolución de la población rural en España en el siglo XIX», Noticiario de Historia Agraria, n. ${ }^{\circ}$ 12, pp. 91-118.

Erias MartíneZ, Alfredo (1996), "Fidalgos das Mariñas. Os Leis de Lema e Mondoi», Anuario Brigantino, n. ${ }^{\circ}$ 19, pp. 129-170.

Escobar, Rómulo (1896), "Las Tiendas de Raya», El Agricultor Mexicano, vol. I, n. 3 y 4 .

- (1915), El problema agrario, México, Imp. Juárez.

Escribanía general del Gobierno de la Provincia de Buenos Aires, Protocolos notariales, años 1876-1887.

EsPejo, Zoilo (1900), Costumbres de derecho y economía rural, Madrid.

ESPINOSA, Francisco (2006), La reforma agraria del Frente Popular en la provincia de Badajoz. Los origenes de la guerra civil, tesis doctoral, Universidad de Sevilla.

Estalella, Helena (1984), La propietat de la terra a les comarques gironines, Gerona, Col.legi Universitari de Girona.

Evans, Peter (1979), Dependent Development. The Alliance of Multinational, State and Local Capital in Brazil, Princeton, Princeton University Press.

- (1995), Embedded Autonomy. States and Industrial Transformation, Princeton, Princeton University Press.

FAO [Food and Agriculture Organization] (2005), El estado de la inseguridad alimentaria en el mundo 2005. La erradicación del hambre en el mundo: clave para la consecución de los Objetivos de desarrollo del Milenio, Roma, Food and Agriculture Organization.

- e INCRA [Instituto Nacional de Colonização e Reforma Agrária] (1999), The Agrarian Reform and the Globalization of the Economy: Brazil's Case. Project of Technical Operation, Brasilia.

FERRER I ALÓs, Llorenç (1995), «Estructures agràries catalanes: observacions sobre la seva diversitat en el segle XVIII», en El món rural cátala a l'època de la revolució liberal, Lérida, Universitat de Lleida, pp. 13-51.

Ferrer Rodríguez, Amparo, y Arturo González Arcas (1996), Las medidas de tierra en Andalucía según las Respuestas Generales del Catastro de Ense- 
nada, Madrid, Centro de Gestión Catastral y Cooperación Tributaria y Tabapress.

Fine, Ben, Costas Lapavitsas y Jonathan Pincus (eds.) (2001), Development Policy in the Twenty-first Century, Londres, Routledge.

FLICHMAN, Guillermo (1977), La renta del suelo y el desarrollo agrario argentino, Madrid, Siglo XXI.

FlorenCio PUnTAS, Antonio (1994), Empresariado agrícola y cambio económico, 1880-1936 (organización y estrategia de la patronal sevillana en los inicios de la modernización), Sevilla, Diputación Provincial de Sevilla.

- (2001), «Mercado de trabajo y reformismo agrario en Andalucía en el primer tercio del s. XX», en C. Arenas Posadas, A. Florencio Puntas y J. Pons Pons (eds.), Trabajo y relaciones laborales en la España contemporánea, Sevilla, Mergablum, pp. 209-224.

- (2004), Ingenieros agrónomos, cambio institucional e innovación tecnológica de la agricultura andaluza contemporánea, Sevilla, Junta de Andalucía, Consejería de Agricultura y Pesca.

Florescano, Enrique (1969), Precios del maíz y crisis agrícolas en México, México, Colegio de México.

- (1991), El nuevo pasado mexicano, México, Cal y Arena.

- (coord.) (1979), Ensayos sobre el desarrollo económico de México y América Latina, México, Fondo de Cultura Económica.

FONTAINE, Laurence (1990), «Solidarités familiales et logiques migratoires en pays de montagne à l'époque moderne», Annales E.S.C., n. ${ }^{\circ}$ 6, pp. 1433-1450.

- (1994), «Espaces, usages et dynamiques de la dette dans les hautes vallées dauphinoises (XVIIe-XVIIIe siècles)», Annales. Histoire, Sciences Sociales, n. ${ }^{0} 6$, pp. 1375-1391.

FOX, Richard G., y Orin STARN (eds.) (1997), Between Resistance and Revolution: Cultural Politics and Social Protest, New Brunswick, Rutgers University Press.

FradKIN, Raúl, y Jorge GELMAN (2002): «La rebelión de los estancieros. Algunas reflexiones en torno a los Libres del Sur de 1839", Entrepasados, Buenos Aires, n. ${ }^{\circ} 22$, pp. 113-144.

- (2004), «Recorridos y desfíos de una historiografía. Escalas de observación y fuentes en la historia rural rioplatense», en Beatriz Bragoni (ed.), Microanálisis. Ensayos de historiografia argentina, Buenos Aires, Prometeo, pp. 31-54.

- (2005): «Estado, tierra y poblamiento en la campaña sur de Buenos Aires durante la época de Rosas. La frontera del Arroyo Azul», Anuario de Estudios Americanos, n. ${ }^{\circ}$ 62, vol. 2, Escuela de Estudios Hispano-Americanos, CSIC, Sevilla, julio-diciembre, pp. 251-283.

Frankema, Ewout (2006), The Colonial Origins of Inequality: Exploring the Causes and Consequences of Land Distribution, Research Memorandum GD-81, 
Groningen Growth and Development Centre, <http://econpapers.repec. org/paper/dgrrugggd/gd-81.htm>.

Funes MONZOTE, Fernando (2002), «The organic farming movement in Cuba», en F. Funes, L. García, M. Bourque, N. Pérez y P. Rosset, Sustainable agriculture and resistance: Transforming food production in Cuba, Oakland, Food First Books, pp. 1-26.

Funes Monzote, Fernando (2006), Towards sustainable agriculture in Cuba. [Inédito.]

Furubotn, R. G., y R. Richter (2005), Institutions and Economic Theory. The Contribution of the New Institutional Economics, Michigan, The University of Michigan Press, 2. ${ }^{\mathrm{a}}$ ed.

Gallego, Domingo (1993), «Pautas regionales de cambio técnico en el sector agrario español (1900-1930)», Cuadernos aragoneses de economía, 2. ápoca, vol. 3, n. ${ }^{\circ}$ 2, pp. 241-276.

Gallo, Ezequiel (1984), La Pampa Gringa, Buenos Aires, Sudamericana.

Gamero Rojas, Mercedes (1993a), El mercado de la tierra en Sevilla en el siglo XVIII, Sevilla, Universidad de Sevilla y Diputación Provincial de Sevilla.

- (1993b), «Nobleza y desvinculación en la Sevilla de fines del Antiguo Régimen», en E. Sarasa Sánchez y E. Serrano Martín (eds.), Señorio y feudalismo en la Península Ibérica, Zaragoza, Institución «Fernando el Católico», vol. 4, pp. 337-349.

- Rafael Mata Olmo y María Dolores Muñoz Dueñas (1997), «El arrendamiento como estrategia patrimonial en la gestión de los cortijos de la Campiña de Córdoba», en VII congreso de Historia Agraria, Salamanca, 28-30 de mayo de 1997, Salamanca, Universidad de Salamanca, pp. 403-417.

Garavaglia, Juan Carlos (1999a), Pastores y labradores de Buenos Aires, Buenos Aires, Instituto de Estudios Históricos y Sociales y Ediciones de la Flor y Universidad Pablo de Olavide.

- (1999b), «Paz, orden y trabajo en la campaña: la justicia rural y los juzgados de paz en Buenos Aires, 1830-1852», en Garavaglia (1999d), pp. 57-88.

- (1999c), «La justicia rural en Buenos Aires durante la primera mitad del siglo XIX (Estructuras, funciones y poderes locales)», en Garavaglia (1999d), pp. 89-122.

- (1999d), Poder, conflicto y relaciones sociales. El río de la Plata, XVIII-XIX, Rosario, Homo Sapiens.

- (2003), «Capitalismo agrario en la frontera. Buenos Aires y la región pampeana en el siglo XIX», Historia Agraria, n. ${ }^{\circ} 29$, pp. 105-121.

- y Jorge GELMAN (1998), «Mucha tierra y poca gente: un nuevo balance historiográfico de la historia rural rioplatense (1750-1850)», Historia Agraria, n. ${ }^{\circ} 15$, pp. $29-50$. 
GARCÍA LOMBARDERO, Jaime (1973), La agricultura y el estancamiento económico de Galicia en la España del Antiguo Régimen, Madrid, Siglo XXI.

GarCía MonTORO, Cristóbal (1978), Málaga en los comienzos de la industrialización: Manuel Agustín Heredia, 1786-1846, Córdoba.

García Pozuelo, Rosa María (2001), Propiedad y Concejo. Venta de Bienes Municipales en Córdoba (1808-1854), Córdoba, Universidad de Córdoba.

García Romero, Antonio (1933), "La ganadería en Extremadura», Boletín del Instituto de Reforma Agraria, n. ${ }^{\circ}$ 10, pp. 147-152.

García SANZ, Ángel (1978), «La agonía de La Mesta y el hundimiento de las exportaciones laneras: un capítulo de la crisis del Antiguo Régimen en España", Agricultura y Sociedad, n. ${ }^{\circ}$ 6, pp. 283-356.

- (1983), «Las tribulaciones de un noble castellano en la crisis del Antiguo Régimen: Don Luis de Conteras y Escobar y Escobar, V marqués de Lozoya (1779-1838)», en G. Anes, L. Á. Rojo y P. Tedde (eds.), Historia Económica y pensamiento social, Madrid, Alianza Editorial.

- (1985), "Crisis de la agricultura tradicional y revolución liberal (18061850)», en García Sanz y Garrabou (eds.) (1985), vol. 1, pp. 7-99.

- (1995), «Explotación y renta en una dehesa salmantina durante el siglo XIX: Miguel Muñoz, 1802-1895», en V. Cabero et ál. (eds.) (1995), El medio rural español: Cultura, paisaje y naturaleza, Salamanca, Universidad de Salamanca.

- (1999), "Lana de Segovia para los telares de Cataluña en el siglo XIX: Un aspecto de la formación del mercado nacional», en A. Carreras, P. Pascual, D. Reher y C. Sudrià (eds.), La industrialización y el desarrollo económico de España, Barcelona, Universitat de Barcelona, vol. II, pp. 1006-1024.

- y Ramón Garrabou (eds.) (1985), Historia agraria de la España contemporánea, 3 vols., Barcelona, Crítica.

García Tato, Isidro (1999), Vilanova, Outarelo y San Francisco Blanco. Monografia histórica de una comarca gallega, Barco de Valedorras, Instituto de Estudios Valdeorreses.

- (2001), La casa de Outarelo de Valdeorras. Formación y desarrollo de su patrimonio (siglos XIV-XX), Santiago de Compostela, Trevinca.

GARRABOU, Ramón (1985), «La crisis agraria española de finales del siglo XIX: una etapa del desarrollo del capitalismo», en Historia agraria de la España contemporánea: expansión y crisis (1850-1900), Barcelona, Crítica, pp. 477-542.

- (2000), «La organización del trabajo en el mundo rural y sus evoluciones históricas. Época contemporánea», Historia Agraria, n. ${ }^{\circ} 20$, pp. 25-38.

- (coord.) (1992), Propiedad y explotación campesina en la España contemporánea, Madrid, Ministerio de Agricultura.

- (ed.) (1988), La crisis agraria de fines del siglo XIX, Barcelona, Crítica.

- y Xavier Cussó (2004), "La transició nutricional a la Catalunya contemporània: una primera aproximació», Recerques: Història, Economia i Cultura, n. ${ }^{\circ} 47-48$, pp. 51-80. 
GarRabou, Ramón y Manuel GonZÁlez Molina (2006), Presentación a «Balances y flujos energéticos y sistemas agrarios», Historia Agraria, n. ${ }^{\circ}$ 40, pp. 429-435.

- Pere Pascual, Josep Pujol Andreu y Enric Saguer (1995), «Potencialidad productiva y rendimientos cerealícolas en la agricultura catalana contemporánea (1820-1935)», Noticiario de Historia Agraria, n.o 10, pp. 89-130.

- Jordi Planas (1997), «La aparcería y la gestión de la gran propiedad territorial en la Cataluña contemporánea», en VIII Congreso de Historia Agraria. Salamanca, 28-30 de mayo de 1997, Preactas, Salamanca, Sociedad Española de Historia Agraria y Universidad de Salamanca, pp. 379-402.

- Jordi Planas y Enric SAguer (2001a), Un capitalisme impossible? La gestió de la gran propietat agrària a la Catalunya contemporània, Vic, Eumo.

- Jordi Planas y Enric SAGUeR (2001b), "Sharecropping and management of large rural estates in contemporary Catalonia», Journal of Peasant Studies, vol. 28, n. ${ }^{\circ} 3$, pp. 89-108.

- Jordi Planas y Enric SAGUeR (2002), «Administradores, procuradores y apoderados. Una aproximación a las formas de gestión de la gran propiedad agraria en la Cataluña contemporánea», en Robledo Hernández y Casado Alonso (eds.) (2002), pp. 301-322.

GARRIDO, Luis (1990), Riqueza y tragedia social. Historia de la clase obrera en la provincia de Jaén (1820-1939), Jaén, Diputación Provincial de Jaén.

GARRIDO, Samuel (2003), «La força de la cooperació. El cooperativisme agrari espanyol al començament del segle XX», en Sindicalisme i món rural a Catalunya, 1900-1975, Gerona, CCG Edicions, Associació d'Història Rural de les Comarques Gironines y Universitat de Girona, pp. 11-48.

GARRIER, G. (1979), «Las nuevas agriculturas», en P. Léon, Historia económica y social del mundo. 4. La dominación del capitalismo, 1840-1914, Madrid, Zero-Zyx, pp. 402-458.

GASTÓN AGUAS, José Miguel (1997), «Coyuntura económica y conflictividad social: la Azucarera de Marcilla (1900-1936)», Gerónimo de Uztariz, n. ${ }^{\circ} 13$, pp. 57-82.

Gelman, Jorge (1998), «El mundo rural en transición», en Noemí Goldman (dir.), Nueva Historia Argentina, Buenos Aires, Sudamericana, vol. 3, pp. 71-101.

- (2002), «La rebelion de los estancieros. Algunas reflexiones en torno a los Libres del Sur de 1839», Entrepasados, n. ${ }^{\circ} 22$, pp. 113-144.

- (2005), «Derechos de propiedad, crecimiento económico y desigualdad en la Región Pampeana, siglos XVIII y XIX», Historia Agraria, n. ${ }^{\circ} 37$, pp. 465-488.

Genin, Auguste (1910), Notes sur le Mexique 1908, México.

Georgescu-Roegen, Nicholas ([1971] 1996), La ley de la entropía y el proceso económico, Madrid, Fundación Argentaria. 
GerChunoff, Pablo, y Lucas Llach (1998), El ciclo de la ilusión y el desencanto, Buenos Aires, Ariel.

Gibson, Clark C., John Williams y Elinor Ostrom (2005), «Local Enforcement and Better Forests», World Development, vol. 33, n. ${ }^{\circ} 2$, pp. 273-284.

Girbal-Blacha, Noemí (1980), Los centros agrícolas en la provincia de Buenos Aires, Buenos Aires, Fundación para la Educación, la Ciencia y la Cultura [FECYC].

- (1988), Estado, chacareros y terratenientes (1916-1930), Buenos Aires, Centro Editor de América Latina.

- (1998), "Estado, campo e crédito na Argentina Peronista: confrontação pública, acordos privados (1946-55)», en Sônia Mendonça y Márcia Motta (eds.), Nação e poder: as dimensões da história, Niterói (Río de Janeiro), Editora da Universidade Federal Fluminense.

Gliessman, Stephen (2000), Agroecology, Ecological Processes in Sustainable Agriculture, Boca Ratón, Lewis.

Gómez, Pedro, et ál. (1991), «Delimitación y caracterización de la región pampeana», en Osvaldo Barsky (ed.), El desarrollo agropecuario pampeano, Buenos Aires, Grupo Editor Latinoamericano.

GonZÁlEZ DE Molina, Manuel (1996), «Nota preliminar», a J. M. Naredo, La evolución de la agricultura española (1940-1990), Granada, Universidad de Granada.

- (2001), "Condicionamientos ambientales del crecimiento agrario español (siglos XIX y XX)», en Pujol, González de Molina, Fernández Prieto, Gallego y Garrabou (2001), pp. 43-94.

- (2003), «Nota preliminar» a J. M. Naredo, La evolución de la agricultura en España (1940-1990), Granada, Universidad de Granada.

- (ed.) (2000), La historia de Andalucía a debate, Barcelona, Anthropos.

- (ed.) (2002), La Historia de Andalucía a debate. II. El campo andaluz, Barcelona, Diputación de Granada y Anthropos.

- y E. Sevilla Guzmán (ed.) (2000), La Historia de Andalucía a debate. 1. Campesinos y jornaleros, Barcelona, Diputación Provincial de Granada y Anthropos.

GONZÁlEZ NAVARRO, Moisés (1986), «Falacias, calumnias y descubrimientos del Mediterráneo", Historia Mexicana, n. ${ }^{\circ} 36$, pp. 363-367.

Goody, Jacques (2005), Capitalismo y modernidad: el gran debate, Barcelona, Crítica. Gracia Guillén, José Antonio (2001), La industria azucarera y el sector remolachero en Navarra. Un siglo de historia, Pamplona, Gobierno de Navarra.

Grela, Plácido (1958), El grito de Alcorta. Historia de la rebelión campesina de 1912, Rosario, Tierra Nueva.

Griffin, Keith, Azizur Rahman Khan y Amy ICKOwITZ (2002), «Poverty and the distribution of land", Journal of Agrarian Change, 2-1, pp. 279-330. 
Grindle, Merilee S. (1986), State and Countryside. Development Policy and Agrarian Politics in Latin America, Baltimore, The Johns Hopkins University Press.

Gruening, Ernest H. (1928), Mexico and its heritage, Nueva York, The Century Co. Grupo de Estudios de Historia Rural [GEHR] (1983), «Evolución de la superficie cultivada de cereales y leguminosas en España, 1886-1935», Agricultura y Sociedad, n. ${ }^{\circ}$ 29, pp. 285-325.

- (1994), «Más allá de la "propiedad perfecta”. El proceso de privatización de los montes públicos españoles (1859-1926)», Noticiario de Historia Agraria, n. ${ }^{\circ} 8$.

Grupo de Historia Social Agraria Andaluza (1997), «El arrendamiento como estrategia patrimonial en la gestión de los cortijos de la campiña de Córdoba (ss. XVI-XX)", en VIII Congreso de Historia Agraria. Salamanca, 2830 de mayo de 1997, Preactas, Salamanca, Sociedad Española de Historia Agraria y Universidad de Salamanca, pp. 403-417.

Guerra, François-Xavier (1988), México: del antiguo régimen a la revolución, México, Fondo de Cultura Económica.

GuERRERO, Andrés (1993), «La desintegración de la administración étnica en el Ecuador. De sujetos-indios a ciudadanos-étnicos: de la manifestación de 1961 al levantamiento indígena de 1990», en Sismo étnico en el Ecuador, Quito, Centro de Investigación de los Movimientos Sociales de Ecuador y Abya-Yala, pp. 91-112.

- (2000), «El levantamiento indígena nacional de 1994: discurso y representación política (Ecuador)», Boletín Americanista, año L, n. ${ }^{\circ}$ 50, pp. 124-151.

GUSTAFSON, Bo (1998), «Problemes metodològics de la història econòmica institucional», Recerques, n. ${ }^{\circ} 36$, pp. 7-34.

Gutelman, Michel (1977), Capitalismo y reforma agraria en México, México, Era. Haber, Stephen H., Noel Maurer y Armando Razo (2003), The politics of property rights, Cambridge, Cambridge University Press.

HABSBURG-LOREna, Luis Salvador (1982-1993), Las Baleares por la palabra y el grabado, Palma de Mallorca, Caja de Ahorros de Baleares «Sa Nostra», vol. 10.

Hale, Charles R. (2003), «Does Multiculturalism Menace? Governance, Cultural Rights and the Politics of Identity in Guatemala», Journal of Latin American Studies, vol. 34, pp. 485-524.

HALPERín Donghi, Tulio (1969), «La expansión ganadera en la campaña de Buenos Aires (1810-1852)», en Torcuato Di Tella y Tulio Halperín Donghi (eds.), Los fragmentos del poder, Buenos Aires, Jorge Álvarez, pp. 21-73.

- (1985), José Hernández y sus mundos, Buenos Aires, Sudamericana.

- (1987), "¿Para qué la inmigración? Ideología y política inmigratoria en la Argentina (1810-1914)», en El espejo de la historia, Buenos Aires, Sudamericana, pp. 189-238. 
Hayami, Yujiro, y Vernon M. RutTan (1989), Desarrollo agrícola. Una perspectiva internacional, México, FCE.

- y Keijiro OTsuka (1993), The Economics of contract Choice. An Agrarian Perspective, Oxford, Clarendon Press.

HERAs, Carlos (1949), «Antecedentes sobre la instalación de las municipalidades en la Provincia de Buenos Aires (1852-1854)», Trabajos y Comunicaciones, n. ${ }^{\circ} 1$, pp. $75-107$.

- (1962), «Presidencia de Avellaneda», en Academia Nacional de la Historia, Historia Argentina Contemporánea, Buenos Aires, El Ateneo, vol. 1, pp. 149-268.

- y Enrique M. BARBA (1962), «Relaciones entre la Confederación y el Estado de Buenos Aires (1854-1858)», en Ricardo Levene (dir.), Historia de la Nación Argentina, Buenos Aires, El Ateneo, 3. a ed., vol. 8, cap. 5, pp. 173-246.

Hermida REVILlas, Carlos (1988), Economía agraria y agitaciones campesinas en Castilla la Vieja y León: 1900-1936, tesis doctoral, Universidad Complutense de Madrid.

Hirschman, Albert O. ([1970] 1977), Salida, voz y lealtad, México, Fondo de Cultura Económica.

Hobson, John M. (2006), Los orígenes orientales de la civilización de Occidente, Barcelona, Crítica.

Hodgson, Geoffrey M. ([1993] 1995), Economía y evolución. Revitalización de la Economía, Madrid, Colegio de Economistas de Madrid y Celeste Ediciones.

- (1999), Evolution and Institutions, Cheltenham, Edwar Elgar.

Hoff, Karla, y Joseph E. Stiglitz (2001), «Modern Economic Theory and Development», en Meier y Stiglitz (eds.) (2001), pp. 389-459.

Hora, Roy (2002), Los terratenientes de la pampa argentina, Buenos Aires, Siglo XXI.

Hoyos SAINZ, Luis de (1950), "Análisis por partidos judiciales del acrecentamiento de la población de España», Revista Internacional de Sociología, n. ${ }^{\circ} 29$, pp. 99-128.

- (1952), La densidad de la población y el acrecentamiento en España, Madrid, Consejo Superior de Investigaciones Científicas.

<http://www.agroecology.org> (agosto de 2006).

$<$ http://www.inra.gov.bo> (agosto de 2006).

$<$ http://www.cnr.berkeley.edu/ agroeco3/principles_and_strategies.html> (agosto de 2006).

$<$ http://www.mstbrazil.org> (agosto de 2006).

IgLESIAS BlANCO, Atanasio Santos (2004), A Casa de Xunqueiras nos séculos XVII e XIX. Contribución ó estudio das economías fidalgas, Valga, Ayuntamiento de Valga.

InFESTA, María Elena (1994), "Propiedad rural en la frontera. Azul 1839», en Enrique M. Barba In Memoriam, Buenos Aires, Academia Nacional de la Historia, pp. 269-287. 
INFESTA, María Elena (2003), La pampa criolla. Usufructo y apropiación privada de tierras públicas en Buenos Aires, 1820-1850, La Plata, Archivo Histórico de la Provincia de Buenos Aires.

- y Marta Valencia (1987), «Tierras, Premios y donaciones. Buenos Aires 1830-1860", Anuario IEHS, n. ${ }^{\circ} 2$, pp. 177-213.

- Marta Valencia (1991), "Los criterios legales en la revisión de la política rosista de tierras públicas. Buenos Aires, 1852-1864», Investigaciones y Ensayos, n. ${ }^{\circ} 41$, pp. 407-421.

instituto de Reforma Agraria, Servicio Provincial de Cáceres (1935), Memoria.

Instituto DE REFORMas Sociales (1921), Subarriendos y arrendamientos colectivos de fincas rústicas, Madrid.

THE InTERNATIONAL InSTITUTE OF AgRiculture (1931), The International Yearbook of Agricultural Statistics, Roma.

IRIARTE GONII, Iñaki (1998), «La pervivencia de bienes comunales y la teoría de los derechos de propiedad: algunas reflexiones desde el caso navarro", Historia Agraria, n.o 15.

- y José M. LANA (2006), "The "concurrence" and "hierarchization" of rights to property: The case of public lands in Spain", en XIV International Economic History Congress, Sesión 21, Helsinki, 21-25 de agosto, en prensa.

Irwin, D. A. (1996), Against the tide. An intellectual history of free trade, Princeton y Chichester, Princeton University Press.

JANVRY, Alain de, et ál. (2001), "The changing role of the State in Latin American land reforms», en Alain de Janvry, Gustavo Gordillo, Jean-Philippe Platteau y Elisabeth Sadoulet (eds.), Access to Land: Rural Poverty and Public Action, Nueva York, Oxford University Press.

JORDAN, Fausto (2003), "Reforma agraria en Ecuador», ponencia presentada al Seminario Internacional Resultados y perspectivas de las reformas agrarias y los Movimientos indígenas y campesinos en América Latina, La Paz, Universidad Mayor de San Andrés, en prensa.

JovellanOS, Gaspar Melchor de (1986), En favor del campo / Gaspar de Jovellanos, Manuel Abad y Queipo, Antonio de San Miguel y otros, introd., sel. y n. de Heriberto Moreno García, [México, D.F.], Secretaría de Educación Pública.

Jover, Gabriel (1996), Desenvolupament econòmic i societat rural a Mallorca: feudalisme, latifundi i pagesia, 1500-1800, tesis doctoral, Universitat de Barcelona.

- (1998), «Endeudamiento, inversión y nobleza terrateniente. Mallorca, 1650-1750», comunicación presentada en el Seminario sobre crédito urbano y consumo en la Europa preindustrial (1650-1850) (3 y 4 de diciembre), Universitat de Barcelona. 
Jover, Gabriel (1999), «Crisi agrària i endeutament nobiliari. La casa Gual-Despuig, Mallorca 1650-1750», Randa, n. ${ }^{\circ} 42$, pp. 11-46.

- (2002), «Ingresos y estrategias patrimoniales de la nobleza durante la crisis del seiscientos, Mallorca, 1600-1750», en Robledo Hernández y Casado Alonso (eds.) (2002), pp. 99-130.

- Antònia Morey (2003), «Les possessions mallorquines: una modalitat d'organització de l'espai agrari i l'explotació del treball», en Rosa Congost, Gabriel Jover y Giuliana Biagioli (eds.), L'organització de l'espai rural a l'Europa mediterrània: massos, possessions, poderi, Gerona, CCG, pp. 127-238.

Junta General de Estadística (1868), Censo de la ganadería de España, según el recuento verificado en 24 de septiembre de 1865 por la —, Madrid.

KaTZ, F. (1998), The life and times of Pancho Villa, Stanford, Stanford University Press. KAY, Cristóbal (1998), «¿El fin de la reforma agraria en América Latina? El legado de la reforma agraria y el asunto no resuelto de la tierra», Revista Mexicana de Sociología, vol. 60, n. ${ }^{\circ}$ 4, pp. 61-98.

- (2001), «Estructura agraria, conflicto y violencia en la sociedad rural de América Latina», Revista Mexicana de Sociología, vol. 63, n. ${ }^{\circ}$, pp. 159-195.

- (2002), "Why East Asia overtook Latin America: agrarian reform, industrialization and development», Third Word Quarterly, vol. 23, n. ${ }^{\circ}$ 6, pp. 1073-1102.

- (2005), «Reflections on Rural Poverty in Latin America», The European Journal of Development Research, vol. 17, n. ${ }^{\circ}$ 2, pp. 317-346.

KNOWLTON, Robert J. (1995), «El ejido mexicano en el siglo XIX», en Margarita Menegus Bornemann, Problemas agrarios y propiedad en Mexico, siglos XVIII y $X I X$, México, D.F.

KNUDSEN, C. (1993), «Modeling rationality, institutions and processess in economic theory», en U. Maki, C. Knudsen y B. Gustafsson, Rationality, Institutions, and Economic Methodology, Londres, Routledge.

Koning, N. (1994), The failure of agrarian capitalism. Agrarian politics in the United Kingdom, Germany, the Netherlands and the USA, 1846-1919, Londres, Routledge.

Kourí, E. (2000), «La vainilla de Papantla: agricultura, comercio y sociedad rural», Signos, n. ${ }^{\circ} 3$.

- (2002), «Interpretating the expropriation of Indian Pueblo Lands in Porfirian Mexico. The unexamined legacies of Andres Molina Enriquez», Hispanic American Historical Review, vol. 82, n. ${ }^{\circ}$ 1, pp. 69-117.

- (2004), A pueblo divided: bussines, property and community in Papantla, México, Stanford, Stanford University Press.

Krugman, Paul (1992), Geografia y comercio, Barcelona, Bosch.

Ladero Quesada, Miguel Ángel (1999), Andalucía a fines de la Edad Media. Estructuras, valores, sucesos, Cádiz, Universidad de Cádiz. 


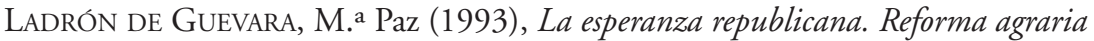
y conflicto campesino en la provincia de Ciudad-Real (1931-1936), Ciudad Real, Diputación de Ciudad Real.

Lana Berasain, José Miguel (1997), Cambio agrario y relaciones de propiedad en el sur de Navarra, 1800-1936, tesis doctoral, Universidad de Zaragoza.

- (1999a), «Desequilibrios hídricos y transformaciones del regadío en la Navarra seca, 1841-1936», en R. Garrabou y J. M. Naredo (eds.) (1999), El agua en los sistemas agrarios. Una perspectiva histórica, Madrid, Visor-Argentaria, pp. 365-390.

- (1999b), El sector agrario navarro (1785-1935). Cultivo, ganadería, propiedad $y$ mercados, Pamplona.

- (2002), «Afanes y recompensas del cuitado señor don José María Magallón y Armendáriz o la remodelación de un patrimonio aristocrático en el siglo XIX», en Robledo Hernández y Casado Alonso (eds.) (2002), pp. 131-164.

- (2003), "Hacienda y gobierno del linaje en el "nuevo orden de cosas". La gestión patrimonial de los marqueses de San Adrián durante el siglo XIX", Revista de Historia Económica, n. ${ }^{\circ}$ 21, vol. 1, pp. 79-112.

- (2007), «El poder de compra de jornaleros y criados. Salarios reales y mercados de trabajo en la Navarra rural, 1782-1936», Investigaciones de Historia Económica, n. ${ }^{\circ}$ 7, pp. 37-68.

LANDES, David S. ([1998] 1999), La riqueza y la pobreza de las naciones, Barcelona, Crítica.

LANTERI, María Sol (2002), «Pobladores y donatarios en una zona de la frontera sur durante el rosismo. El arroyo Azul durante la primera mitad del siglo XIX», Quinto Sol, n. ${ }^{\circ}$ 6, pp. 11-42.

- (2004), "Colonizando la frontera: acceso y tenencia de la tierra en la campaña sur bonaerense en la primera mitad del siglo XIX. El arroyo Azul durante el rosismo", en Jornada Académica "Acceso y tenencia de la tierra en Argentina y América Latina. Desde los tiempos coloniales a la actualidad", Córdoba (Argentina), Centro de Estudios Históricos «Profesor Carlos S. A. Segreti», en prensa.

- (2005), «Estado, tierra y poblamiento en la campaña sur de Buenos Aires durante la época de Rosas. La frontera del Arroyo Azul», Anuario de Estudios Americanos, vol. 62, n. ${ }^{\circ} 2$ (julio-diciembre), pp. 251-283.

LATTUADA, Mario (1986), La politica agraria peronista (1943-83), Buenos Aires, Centro Editor de América Latina.

LAZZARO, Silvia (2004), «La política agraria de la autodenominada Revolución Argentina», en Guido Galafassi (comp.) (2004), El campo diverso, Quilmes, Universidad Nacional de Quilmes.

LE CoZ, Jean (1975), Las reformas agrarias, de Zapata a Mao Tsé-tung y la FAO, Barcelona, Ariel. 
Leirós de la Peña, Paz (1986), La casa de Fontefiz. (Contribución al estudio de la hidalguia gallega), memoria de licenciatura, Universidade de Santiago de Compostela.

- (1993), "La casa de Fontefiz», Boletín Avriense, n. ${ }^{\circ}$ XXII, pp. 197-237.

LEVY, Hermann (1911), Large and small holdings. A study of English agricultural economics, Cambridge, Cambridge University Press.

Lievanais, Patrick (2001), Peuplement et évolution agraire au Morelos (Mexique), París, L’Harmattan.

Llopis, Enrique, y Santiago Zapata (2001), «El "Sur del Sur”. Extremadura en la era de la industrialización», en Luis Germán, Enrique Llopis, Jordi Maluquer y Santiago Zapata (eds.), Historia económica regional de España. Siglos XIX y XX, Barcelona, Crítica.

López, Esteve, Joan Peruga y C. Tudel (1988), L'Andorra del segle XIX. (De la Nova Reforma a la Revolució del 1881), Andorra la Vieja.

LÓPEZ, Santiago, y Ricardo Robledo (2004), «El administrador de los antiguos patrimonios agrarios según la teoría de la agencia», Información Comercial Española, n. ${ }^{\circ}$ 812, pp. 105-124.

- y Jesús María VAldaliso (1999), «Economía, biología y evolución. Algunas reflexiones sobre la economía evolutiva y la importancia de la historia», Anthropos, n. ${ }^{\circ} 182$, pp. 30-41.

López Estudillo, Antonio (1996), «Evolución de los procesos de fertilización tradicional en Córdoba», en Ramón Garrabou y José Manuel Naredo (eds.), La fertilización en los sistemas agrarios. Una perspectiva histórica, Madrid, Argentaria-Visor, pp. 171-210.

- (2002), "Crisis finisecular, transformaciones agrarias y atraso económico. Andalucía 1870-1930», en González de Molina (ed.) (2002), pp. 137-178

- (2005), «La Mesa Capitular de la Catedral de Córdoba y la gestión de su patrimonio rústico", en VIII Congreso de la Asociación Española de Historia Económica, Santiago de Compostela, 13 al 16 de septiembre, en prensa.

LÓPEZ MARTÍNEZ, Antonio Luis (1997), «La empresa agraria monástica en Andalucía. Gestión de las explotaciones agrarias de la Orden Cartuja (siglos XVXIX)", Hispania, LVII/2, n. ${ }^{\circ} 196$, pp. 709-729.

- (2001), «La ganadería en la Baja Andalucía, siglos XV-XX», documento de trabajo de la Universidad de Sevilla.

- (2002), Ganaderías de lidia y ganaderos. Historia y economía de los toros de lidia en España, Sevilla.

López MarTínez, Mario (1995), Orden público y luchas agrarias en Andalucía, Madrid, Libertarias.

- y R. Gil Bracero (1997), Caciques contra socialistas, Granada, Diputación de Granada. 
López Ontiveros, Antonio (1974), Emigración, propiedad y paisaje agrario en la Campiña de Córdoba, Barcelona, Ariel.

- (1990), Córdoba 1752. Según las Respuestas Generales del Catastro de Ensenada, Madrid, Centro de Gestión Catastral y Cooperación Tributaria.

- y Rafael Mata Olmo (1993), Propiedad de la tierra y reforma agraria en Córdoba (1932-1936), Córdoba, Universidad de Córdoba.

LÓPEZ RodríGueZ, Pilar (1985), Campesinos y propietarios: la redención de foros en la provincia de Lugo durante la I República, Lugo, Diputación Provincial de Lugo.

LunA, Pablo (2002), «Sociedad, reforma y propiedad: el liberalismo de Manuel Abad y Queipo, fines del siglo XVIII-comienzos del siglo XIX», Secuencia, n. ${ }^{\circ}$ 52, pp. 153-179.

- (2006), Propriété, Dominium et Lumières hispaniques, des deux côtés de l'Atlantique: seconde moitié du XVIII siècle. [Copia mecanoescrita.]

Machado, Hilda (2006), entrevista con —- Universidad de Matanzas (1 de junio).

MadOZ, Pascual (1986), Diccionario geográfico-estadístico-histórico de Navarra, Valladolid, ed. facs. extr.

Majuelo, Emilio (1986), La Segunda República en Navarra. Conflictividad agraria en la Ribera tudelana 1931-1936, Pamplona, Pamiela.

- (1989), Lucha de clases en Navarra (1931-1936), Pamplona, Gobierno de Navarra.

MALEFAKIS, Edward ([1971] 1982), Reforma agraria y revolución campesina en la España del siglo XX, Barcelona, Ariel.

- (1978), "Análisis de la Reforma Agraria durante la II República», Agricultura y Sociedad, n. ${ }^{\circ}$ 7, pp. 35-51.

Malenbaum, Wilfred (1953), The world wheat economy 1885-1939, Cambridge, Harvard Economic Studies.

Mallo, Silvia (1979), "Quién se quedó con el desierto», Todo es Historia, n. ${ }^{\circ} 144$, pp. 86-91.

MALUQUER DE MOTES, Carlos J. (1983), La fundación como persona jurídica en la codificación civil: de vinculación a persona (estudio de un proceso), Barcelona, Publicacions i Edicions de la Universitat de Barcelona.

MANDEVILLE, Bernard ([1729] 1982), La fábula de las abejas o Los vicios privados hacen la prosperidad pública, nota preliminar de F. B. Kaye, México, Fondo de Cultura Económica.

MANera, Carles (1995), Desarrollo económico y actitudes empresariales en la Mallorca contemporánea, 1730-1930: rasgos económicos esenciales de una sociedad pre-turística, Madrid, Fundación Empresa Pública.

- (1999), "Cambio agrario y desarrollo industrial no fabril en la isla de Mallorca, 1830-1930», Revista de Historia Económica, n. ${ }^{\circ} 2$, pp. 371-410. 
Marcos del Olmo, M. a Concepción (1995), Voluntad popular y urnas. Elecciones en Castilla y León durante la Restauración y la Segunda República (1907-1936), pról. de Celso Almuiña, Valladolid, Universidad de Valladolid.

Márquez, Viviane Brachet de (1983), Ciencia, tecnología y empleo en el desarrollo rural de América Latina, México, El Colegio de México.

MARTí SANZ, Neus (2005), La multidimensionalidad de los sistemas locales de alimentación en los Andes peruanos: los chalayplasa del Valle de Lares (Cusco), tesis doctoral, Universitat Autònoma de Barcelona.

MARTín, José Luis (dir.) (1997), Documentos sobre la reforma agraria en los Archivos del IRYDA, introd. y est. de R. Robledo, Madrid, Universidad Nacional de Educación a Distancia.

Martínez Alier, Juan (1971), Labourers and Landowners in Southern Spain, Londres, Allen \& Unwin.

Martínez Moctezuma, Lucía (1996), D’Espagne au Mexique. Iñigo Noriega Lasso, un entrepreneur dans la vallée de Mexico (1868-1919), tesis doctoral, Université de Paris X-Nanterre.

- y Alejandro Tortolero (2000), «Du local au global. Le chemin de fer dans le bassin de Mexico à l'epoque du porfiriat (1880-1911)», Cahiers des Amériques Latines.

- y Alejandro TorTolero (2001), Iñigo Noriega Laso. Un emporio empresarial. Inmigración y crecimiento económico (1868-1913), México, UAM-Itzapalapa (Cuadernos de Historia Empresarial).

MarTínez Nogueira, Roberto (1988), «Las organizaciones corporativas del sector agropecuario", en Osvaldo Barsky (comp.), La agricultura pampeana, problemas y perspectivas, Buenos Aires, Centro de Investigaciones Sociales sobre el Estado y la Administración, pp. 295-322.

MARTíneZ RuIZ, José Ignacio (2000), Trilladoras y tractores. Energía, tecnología e industria en la mecanización de la agricultura española (1862-1995), Sevilla, Universitat de Barcelona y Universidad de Sevilla.

Martínez VAlle, Luciano (1999), «La nueva ruralidad en el Ecuador», Íconos, n. ${ }^{\circ}$, pp. $12-26$.

— (2003), "Capital social y desarrollo rural», Íconos, n. ${ }^{\circ}$ 16, pp. 73-83.

- (2004), "Los límites de la agricultura campesina en la nueva ruralidad», ponencia presentada al XXV International Congress of the Latin American Studies Association, Las Vegas, en prensa.

Mata Olmo, Rafael (1987), Pequeña y gran propiedad agraria en la depresión del Guadalquivir, Madrid, Ministerio de Agricultura, Pesca y Alimentación.

Matas Balaguer, Josep (1991), "Aproximació als conflictes agraris a les comarques gironines durant la II República», en La II República, 60 anys 
després, Gerona, Quaderns del Cercle d'Estudis Històrics i Socials, pp. 19-37.

Mateos Rodríguez, Miguel Ángel (1988), La República en Zamora. Comportamientos y actitudes de una sociedad tradicional. Elecciones y partidos (1931-1936), Zamora, Instituto de Estudios Zamoranos «Florián de Ocampo», vol. I.

MAurice, Jacques (1990), El anarquismo andaluz. Campesinos y sindicalistas, 1868-1936, Barcelona, Crítica.

McBRIDE, George McCutchen (1923), The land systems of Mexico, Nueva York, American Geographical Society.

- (1953), «Los sistemas de propiedad rural en México», en Problemas agrícolas e industriales de México, México.

MeIER, Gerald, y Joseph E. STiglitz (eds.) (2001), Frontiers of Development Economics, Nueva York, World Bank y Oxford University Press.

Menegus, M. (1995), Problemas agrarios y propiedad en México, siglos XVIII y XIX, México, El Colegio de México.

Mercante, Domingo (1995), Mercante: el corazón de Perón, Buenos Aires, Ediciones de la Flor.

Meyer, Carrie A. (1989), Land Reform in Latin America: The Dominican Case, Nueva York, Praeger.

Migués Rodríguez, Vítor Manuel (2002a), As terras, as pousas e os vinculeiros. A fidalguía galega na Época Moderna, Sada, O Castro.

- (2002b), Os arquivos privados e a nobreza: Un apuntamento histórico-arquivístico. O caso galego a través do fondo do Marquesado de "San Martín" de Ombreiro [ARG], La Coruña, Xunta de Galicia.

MikelarenA, Fernando (1995), «Algunas consideraciones acerca de las cifras de activos agrarios de los censos de población españoles del periodo 1877 1981», en VII Congreso de Historia Agraria. Baeza.

Miller, Simon (1997), Formación de clase y transición agraria en México, México, Universidad Iberoamericana.

Ministerio de Hacienda (1931), Memoria de la gestión de la Dirección General de propiedades y contribución territorial durante el año de 1928, Madrid.

Ministerio de Trabajo y Previsión Social (1932), Labor realizada desde la proclamación de la República hasta el 8 de septiembre de 1932, Madrid, Imprenta de los Sucesores de Rivadeneyra.

MiÑo, Manuel (comp.) (1991), Haciendas, pueblos y comunidades, México, Consejo Nacional para la Cultura y las Artes.

Mir, P. Miguel (1898), La condesa de Bornos, Madrid, Imprenta de San Francisco de Sales.

Mirabet, Magda (1989), Els Pallarès de Talarn: petita noblesa rural, Lérida, Ajuntament de Talarn.

Molina EnRíQueZ, A. ([1909] 1979), Los grandes problemas nacionales, México, Era. 
Moll, Isabel, y Jaume SUAU (1979), "Senyors i pagesos a Mallorca (17181860/70)», Estudis d'Història Agrària, n.o 2, pp. 95-191.

- Antònia AlberTí y Antònia MOREY (1993), «Tierra de fideicomisos: las consecuencias de la ley de desvinculaciones en Mallorca (1768-1865)», Áreas, n. ${ }^{\circ} 15$, pp. $13-31$.

MonTAN̂́s, Enrique (2000), «Los movimientos campesinos andaluces entre 1874 y 1930: un balance historiográfico", en González de Molina (ed.) (2000), pp. 79-101.

MonToya, Rodrigo (1992), Al borde del naufragio. Democracia, violencia y problema étnico en el Perú, Lima, SUR Casa de Estudios del Socialismo.

Moreno LAZARO, Javier (1994), «Burguesía y crecimiento económico en Castilla la Vieja en el siglo XIX. Los Pombo: Una historia empresarial», Anales de Estudios Económicos y Empresariales, vol. 9, pp. 333-356.

- (1995), «Protección arancelaria, distorsiones de mercado y beneficios extraordinarios: La producción de harinas en Castilla la Vieja, 1820-1841», Revista de Historia Económica, vol. 2, pp. 227-250.

- (1998), La industria harinera en Castilla la Vieja y León, 1778-1913, tesis doctoral, Universidad de Valladolid.

- (2006), «Los niveles de vida en la España atrasada entre 1800 y 1936. El caso de Palencia, 1900-1936», Investigaciones de Historia Económica, pp. 9-50.

Moreno Sebastián, Atilana (1993), Conflictos jurídicos en la abolición de los señoríos de la grandeza en Zamora. Prestaciones subsistentes hasta la Reforma Agraria de la II República, Zamora, Imprenta Espacio.

MOREY, Antònia (1998), «El mercat de la propietat nobiliària a Mallorca entre la crisi de l'antic règim i la consolidació de l'estat liberal», Estudis d'Història Económica, n. ${ }^{\circ} 15$, pp. 93-114.

- (1999a), Noblesa i desvinculació a Mallorca als segles XVIII $i$ XIX: les repercussions de la legislació desvinculadora sobre els patrimonis nobiliaris, Palma de Mallorca, Universitat de les Illes Balears y Abadia de Montserrat.

- (1999b), «La participació de la noblesa mallorquina en el procés desvinculador (1768-1862)», Recerques, n. ${ }^{\circ} 38$, pp. 87-112.

- (1999c), «Reformes liberals i pervivència del sistema latifundista a Mallorca", Randa, n. ${ }^{\circ} 42$, pp. 47-79.

Movimento dos TrabalHadores Rurais Sem Terra [MST] (2001), Os Empreendimentos Sociais do MST, manuscrito.

MoYa UlLDEMOLINS, José María (1978), «Aspectos económicos de la mesa capitular del cabildo catedral de Córdoba», en Actas del I Congreso de Historia de Andalucía, diciembre 1976. Andalucía Moderna (siglos XVI-XVII), Córdoba, Publicaciones del Monte de Piedad y Caja de Ahorros de Córdoba, vol. II, pp. 243-254.

Muñoz DueÑAs, María Dolores (1984), «Diezmos de la Hacienda Real. La administración de exentos en Córdoba (1796-1820)», IFIGEA, Revista de la 
Sección de Geografía e Historia. Facultad de Filosofía y Letras, Universidad de Córdoba, n. ${ }^{\circ}$ 1, pp. 117-130.

Muñoz Dueñas, María Dolores (1988), El diezmo en el obispado de Córdoba (1750-1845), Córdoba, Publicaciones del Monte de Piedad y Caja de Ahorros de Córdoba.

- Rafael Mata Olmo y Mercedes Gamero Rojas (2003), "L'exploitation des grands domaines dans la Campiña de Cordue (XVI Gérard Béaur, Mathieu Arnoux y Anne Varet-Vitu (eds.), Exploiter la terre. Les contrats agraires de l'Antiquité à nos jours. Actes du Colloque de Caen (10-13 septembre 1997), Rennes, Association d'Histoire des Sociétés Rurales.

Murmis, Miguel (1994), «Incluidos y excluidos en la reestructuración del agro latinoamericano", Debate Agrario, n. ${ }^{\circ}$ 18, pp. 101-133.

MurPHY, Catherine (1999), "Cultivating Havana: Urban Agriculture and Food Security in the Years of Crisis», Food First Development Report, n. ${ }^{\circ} 12$.

Muzlera, Joaquín (1895), Tierras Públicas. Recopilación de leyes decretos y resoluciones de la Provincia de Buenos Aires sobre tierras públicas. 1810-1895, La Plata, Isidro Solá Sanz.

NABLI, Mustapha K., y Jeffrey B. Nugent (1989), «The New Institutional Economics and Its Applicability to Development», World Development, vol. 17, n. ${ }^{\circ}$ 9, pp. 1333-1347.

NARANJO RAMíreZ, José (1995), «Peculiar organización agraria de un señorío en la Campiña de Córdoba: Fernán Núñez», en Actas del II Congreso de Historia de Andalucía. Córdoba, 1991. Andalucía Moderna (II), Córdoba, Publicaciones de la Consejería de Cultura de la Junta de Andalucía y Obra Social y Cultural Cajasur, pp. 139-149.

NAREDO, José Manuel, y Manuel GonZALEZ De Molina (2002), «Reforma agraria y desarollo económico en la Andalucía del siglo XX», en M. González de Molina (ed.) (2002).

Negre y Pastell, Pelayo (1921), Evolución del régimen de propiedad en Cataluña, singularmente en la provincia de Gerona, La Bisbal, Jovés impresor.

- (1925), «Del notable informe elaborat pel Doctor D. Pelai Negre sobre el nostre sistema contractual agrari...", Butlletí de la Federació Sindical Agrària, n. ${ }^{\circ} 75$, pp. $1-8$.

NEWTON, Jorge (1972), Diccionario biográfico del campo argentino, Buenos Aires.

Niederberger, Christine (1987), Paléopaysages et archéologie pré-urbaine du bassin de Mexico (Mexique), México, Centro de Estudios Mexicanos y Centroamericanos.

Nieto Cumplido, Manuel (1979), "El "Libro de diezmos de donadíos" de la Catedral de Córdoba», Cuaderno de Estudios Medievales, Universidad de Granada, n. ${ }^{\circ}$ IV-V, pp. 125-162. 
NorTH, Douglass C. ([1990] 1993), Instituciones, cambio institucional y desempeño económico, México, Fondo de Cultura Económica.

- (2001), «Needed: A Theory of Change», en Meier y Stiglitz (eds.) (2001), p. 491.

- (2005), Understanding the Process of Economic Change, Princeton y Oxford, Princeton University Press.

- y Robert Paul Thomas (1973), The rise of the Western World: a new economic history, Cambridge Cambridge University Press.

Noticias sobre la Cabaña de Bornos recogidas con ocasión de mandar las lanas de sus ganados merinos a la Exposición de París de 1878, Madrid, Viuda e hijos de Aguado, 1878.

O’Brien, Patrick K., y Leandro Prados De la Escosura (1992), "Agricultural productivity and European industrialization, 1890-1980», Economic History Review, n. ${ }^{\circ} \mathrm{XLV}$, vol. 3, pp. 514-536.

Oddone, Jacinto (1967), La burguesía terrateniente argentina, Buenos Aires, Libera. OfFer, Avner (1991), The First World War: an agrarian interpretation, Oxford, Clarendon Press.

Olmstead, Alan L., y Paul W. Rhode (2002), «The Red Queen and the Hard Reds: Productivity Growth in American Wheat, 1800-1940», en National Bureau of Economic Research, Working Paper 8863.

Olson, Mancur ([1982] 1986), Auge y decadencia de las naciones. Crecimiento económico, estagflación y rigidez social, Barcelona, Ariel.

- ([2000] 2001), Poder y prosperidad. La superación de las dictaduras comunistas y capitalistas, Madrid, Siglo XXI.

OrozCo, Luis Wistano (1911), La cuestion agraria, Guadalajara, Tip. regional.

Ortega, Emiliano (1986), Agricultura campesina en América Latina y el Caribe, Santiago de Chile, División Agrícola Conjunta CEPAL/FAO.

Ostrom, E. (1990), Governing the commons: The evolution of institutions for collective action, Nueva York, Cambridge University Press.

Palenzuela, Pablo (1999), «Etnicidad y modelos de auto-organización económica en el occidente de Guatemala», en Kees Koonings y Patricio Silva (eds.), Construcciones étnicas y dinámica sociocultural en América Latina, Quito, Abya-Yala, pp. 53-75.

Parejo, Antonio (1990), Málaga y los Larios, Málaga, Arguval.

PARÉs GANYET, Quirze (2001), La despoblació rural i les masies del Collsacabra, Barcelona, Fundació Salvador Vives i Casajoana.

Parias SÁINZ De Rozas, María (1989), El mercado de la tierra sevillana en el siglo XIX, Sevilla, Universidad de Sevilla y Diputación Provincial de Sevilla.

- (1991), «La pervivencia de las estrategias vinculares en las transmisiones testamentarias de la segunda mitad del siglo XIX», en Saavedra Fernández y Villares Paz (eds.) (1991), vol. 1, pp. 39-61. 
Pascual, Aina (1997), Casa i estament social en la ruralia mallorquina. L'exemple de Binissalem als segles XVIII-XIX, Benisalem, Ajuntament de Binissalem.

Pascual, Pere (2000), Els Torello. Una família igualadina d'advocats i propietaris. Un estudi sobre la crisi de l'agricultura tradicional (1841-1930), Barcelona, Fundació Vives i Casajuana, vol. II.

Pastor, Reyna, et ál. (1999), Transacciones sin mercado: Instituciones, Propiedady redes sociales en la Galicia monástica, Madrid, Consejo Superior de Investigaciones Científicas.

PAZ, Ireneo (1888), Los hombres prominentes de México, México, Imprenta y Litografía de La Patria.

Peña Novo, Luis (1932), «Informe sobre la situación de las provincias de Badajoz y Cáceres», Archivo General de la Guerra Civil (Salamanca), Sección Político-Social, Madrid, legajo 695.

Peñarrubia, Isabel (2001), L'origen de la Caixa de Balears. Els projectes d'una burgesia modernitzadora (1882), Palma de Mallorca, Documenta Balear.

Pérez García, José Manuel (1979), Un modelo de sociedad rural de Antiguo Régimen en la Galicia costera: la Península del Salnés (Jurisdicción de La Lanzada), Santiago de Compostela, Universidade de Santiago de Compostela.

- (1998), Mapa triguero de Andalucía, Sevilla, Consejería de Agricultura y Pesca de la Junta de Andalucía.

Pérez PicAzo, María Teresa (1990), El mayorazgo en la historia económica de la región murciana: expansión, crisis y abolición (s. XVIII-XIX), Madrid, Ministerio de Agricultura, Pesca y Alimentación.

- (1991), «Riqueza territorial y cambio agrícola en la Murcia del siglo XIX. Aproximación al estudio de una contabilidad privada (circa 1800-1902)», Agricultura y Sociedad, n. 0 61, pp. 39-95.

- y Miguel Ấngel Pérez De PerCeval (2004), «El mercado de la tierra en Murcia, 1836-1862», Historia Agraria, n. ${ }^{\circ} 32$, pp. 57-84.

PÉrez Yruela, Manuel (1979), La conflictividad campesina en la provincia de Córdoba (1931-1936), Madrid, Ministerio de Agricultura, Pesca y Alimentación.

Perón, Juan D. (s.a.), Así era arrojado el colono de sus tierras, Buenos Aires, Presidencia de la Nación, Subsecretaria de Informaciones.

- (1952), El campo recuperado por Perón 1944-52, Buenos Aires, Presidencia de la Nación, Subsecretaria de Informaciones.

Perren, R. (1970), "The Landlord and Agricultural Transformation, 18701900", Agricultural History Review, vol. 18, n.o 1, pp. 36-46.

Petras, James, y Henry Veltmeyer (2003), «The Peasantry and the State in Latin America: A Troubled Past, an Uncertain Future», en T. Brass (ed.), Latin American Peasants, Londres, Frank Cass, pp. 41-82. 
Pinilla, Vicente (2004), «Sobre la agricultura y el crecimiento económico en España (1800-1935)», Historia Agraria, n. ${ }^{\circ} 34$, pp. 137-162.

PIORE, Michael J., y Charles F. SABEL ([1984] 1990), La segunda ruptura industrial, Madrid, Alianza Editorial.

Planas MaResma, Jordi (1994a), «Agrarisme i gestió de la propietat al primer terç del segle XX. Un exemple significatiu: Jaume Maspons i Camarasa (1872-1934)", Estudis d'Història Agrària, n. ${ }^{\circ}$ 10, pp. 63-69.

- (1994b), Catalanisme i agrarisme. Jaume Maspons i Camarasa (1872-1934), escrits politics, Vic, Eumo.

- (1996), «La contabilidad del patrimonio Maspons (Vallés Oriental, 19131945): uso del suelo, formas de tenencia y evolución de la renta», en Lourenzo Fernández Prieto y Xesus Balboa (eds.), La sociedad rural en la España contemporánea. Mercado y patrimonio, La Coruña, Ediciós do Castro, pp. 183-200.

- (2003), «Cooperativismo y difusión del cambio técnico en la agricultura. La contribución de las cámaras agrícolas (Cataluña 1890-1930)», Historia Agraria, n. ${ }^{\circ} 30$, pp. 87-117.

- (2004a), «Cooperativisme i associacionisme agraris a Catalunya: els propietaris rurals i l'organització dels interessos agraris al primer terç del segle XX», Butlletí de la Societat Catalana d'Estudis Històrics, n. ${ }^{\circ}$ 15, pp. 205-216.

- (2004b), «La Lliga de Productors del Principat de Catalunya i els interessos agraris (1894-1898)», Recerques, n. ${ }^{\circ}$ 47-48, pp. 155-186.

- (2006), Els propietaris i l'associacionisme agrari a Catalunya (1890-1936), Gerona, Documenta Universitaria, Associació d'Història Rural de les Comarques Gironines y Universitat de Girona.

PlAZA, Orlando (1995), "Desarrollo rural y desarrollo micro-regional», en Desarrollo rural en los Andes, Quito, Centro Andino de Acción Popular, pp. 115122.

PONSOT, Pierre (1981), Etudes sur le dix-neuvième siècle espagnol, Córdoba, Instituto de Historia de Andalucía.

- (1986), Atlas de historia económica de la Baja Andalucía (Siglos XVI-XIX), Sevilla, Editoriales Andaluzas Unidas.

Poujade, Patrice (1998), Une vallée frontière dans le Grand Siècle. Le Val d'Aran entre deux monarchies, Aspet, PyréGraph.

Pozas PovedA, Lázaro (1995), "Consecuencias financieras de una crisis de subsistencias. El caso de Córdoba en 1734", en Actas del II Congreso de Historia de Andalucía. Córdoba, 1991. Historia Moderna (II), Córdoba, Publicaciones de la Consejería de Cultura de la Junta de Andalucía y Obra Social y Cultural Cajasur.

- (2001), Ciudades castellanas y monarquía hispánica. La aportación municipal al gasto del Estado, Córdoba, Universidad de Córdoba. 
Prados, Leandro, e Isabel SANZ-Villarroya (2004), «Derechos de propiedad y atraso económico en Argentina: una perspectiva histórica», en Actas de las XIX Jornadas de Historia Económica, San Martin de los Andes (Argentina).

Presedo Garazo, Antonio (1995), «El dominio de Rubianes en el siglo XIX: Composición del mayorazgo y desvinculación", Cuadernos de Estudios Gallegos, n. ${ }^{\circ}$ XLII, pp. 69-94.

- (1999), "O luxo na fidalguía galega a través do exemplo da Casa-Torre de Raíndo, 1798-1800», en Luis Alonso Girgado (coord.), Homenaxe ó profesor Manuel Quintáns, Santiago de Compostela, Follas Novas, pp. 183-207.

- (2001), Dueños y señores de casas, torres y pazos, 1500-1900. (Contribución al estudio de la fidalguía gallega), tesis doctoral, Universidade de Santiago de Compostela, 2 vols.

- (2003a), «Estudiantes de condición nobiliaria en la Universidad de Santiago de Compostela (siglos XVII y XVIII): Aproximación a su perfil sociológico», Hispania, n. ${ }^{\circ}$ 215, pp. 907-968.

- (2003b), «A cultura material nun pazo lugués a comezos do século XVII: a Casa de Noceda en As Nogais», Boletín do Museo Provincial de Lugo, n. ${ }^{\circ} \mathrm{XI} / 2$, pp. 71-92.

- (2004a), «El ascenso de la pequeña nobleza provincial gallega bajo la Casa de Austria», en Alfredo Alvar Ezquerra, Jaime Contreras Contreras y José Ignacio Ruiz Rodríguez (eds.), Política y cultura en la Época Moderna (Cambios dinásticos. Milenarismos, mesianismos y utopias), Madrid, Universidad de Alcalá, pp. 125-133.

- (2004b), «Los patrimonios de la elite nobiliaria de la ciudad de Santiago de Compostela ante la ley desvinculadota de 1841», en Josep Fontana: Història i projecte social. Reconeixement a una trajectòria, Barcelona, Crítica, vol. 1, pp. 667-693.

- (2004c), «Patrimonio y administración privada en la hidalguía gallega durante el Antiguo Régimen a través del ejemplo de la Casa de Noceda», Estudis d'Història Agrària, n. ${ }^{\circ} 17$, pp. 719-728.

- (2005a), A fidalguía galega ante a crise do Antigo Réxime, 1812-1868, Santa Comba, 3C3.

- (2005b), «La nobleza provincial gallega ante la crisis del Antiguo Régimen: una visión panorámica», Hidalguía, n. ${ }^{\circ}$ 308, pp. 15-35.

- Antonio Bernárdez Sobreira y Miguel Cabo Villaverde (1999), «Rentistas y foreros: Evolución de la renta agraria en la Galicia oriental, 18281922», Minius, n. ${ }^{\circ}$ 7, pp. 127-151.

Pretty, Jules (2002), Agri-Culture. Reconnecting People, Land and Nature, Londres, Earthscan.

El Progreso Agricola y Pecuario, Madrid. 
PUJOL ANDREU, Josep (1988), Les transformacions del sector agrari català entre la crisi finisecular y la guerra civil, tesis doctoral, Universitat Autònoma de Barcelona.

- Josep (1998a), «La difusión de los abonos minerales y químicos hasta 1936: el caso español en el contexto europeo», Historia Agraria, n. ${ }^{\circ}$ 15, pp. 143-182.

- (1998b), "Las innovaciones biológicas en la agricultura española antes de 1936: el caso del trigo", Agricultura y Sociedad, n.o 86, pp. 163-182.

- (1998c), «Especialització i canvi tècnic en l'expansió del sector ramader català», Recerques, n. ${ }^{\circ}$ 37, pp. 31-55.

- (1999), "Trabajo asalariado y actividad agraria en Can Codorniu: un caso excepcional de la explotación del viñedo catalán durante el primer tercio del siglo XX", en Albert Carreras et ál. (eds.), Doctor Jordi Nadal. La industrialització i el desenvolupament econòmic d'Espanya, Barcelona, Universitat de Barcelona, vol. I, pp. 479-506.

- M. González de Molina, L. Fernández Prieto, D. Gallego y R. GARRABOU (2001), El pozo de todos los males. Sobre el atraso en la agricultura española contemporánea, Barcelona, Crítica.

PUjOL JUNCA, Rafael (1977), "Acció Social Agrària de les terres gironines (1)», Revista de Girona, n. ${ }^{\circ}$ 81, pp. 305-313.

- y Josep Clara Resplandis (1978), "Acció Social Agrària de les terres gironines (2)», Revista de Girona, n. ${ }^{\circ}$ 84, pp. 247-254.

Pulido Bueno, Ildefonso (1982), "Un aspecto de la historia rural: los arrendamientos de la tierra de sembradura. El caso de la comarca onubense en el siglo XVII», Archivo Hispalense, n. ${ }^{\circ}$ 200, pp. 5-34.

- (1988), La tierra de Huelva en el Antiguo Régimen 1600-1750. Un análisis socioeconómico comarcal, Huelva, Diputación Provincial de Huelva.

PutZel, James (1998), Land Reform and Rural Poverty: Thinking About Lessons from Asia for Sub-Saharan Africa, Londres, LSE Development Studies Institute (Working Paper Series) [consultado en <http//www.lse.ac.uk/Depts /destin>]. Rabasa, Emilio ([1920] 1986), La evolución histórica de México, México, Lib. Vda. Ch. Bouret.

Rapley, John (1996), Understanding Development. Theory and Practice in the Third World, Boulder (Estados Unidos), Lynne Rienner.

Rapoport, Mario (2003), Historia económica, política y social de la Argentina (1880-2000), Buenos Aires, Macchi.

RATTO, Silvia (1994), «Indios amigos e indios aliados, orígenes del negocio político en la provincia de Buenos Aires (1829-1832)», Cuadernos del Instituto Ravignani, n. ${ }^{\circ} 5$.

- (1998), «¿Finanzas públicas o negocios privados? El sistema de racionamiento del negocio pacífico de indios en la época de Rosas», en Noemí Goldman y Ricardo Salvatore (comps.), Caudillismos rioplatenses, Buenos Aires, Editorial Universitaria de Buenos Aires, pp. 241-265. 
RATTO, Silvia (2003), La frontera bonaerense (1810-1828): espacio, negociación y convivencia, La Plata, Archivo Histórico de la Provincia de Buenos Aires.

Reglamento de la Honorable Cámara de Diputados de la Provincia de Buenos Aires, La Plata, 1947.

Reguera, Andrea (1993), «Arrendamientos y forma de acceso a la producción en el sur bonaerense: el caso de una estancia del partido de Necochea, primera mitad del siglo XX», en Raúl Mandrini y Andrea Reguera (comps.), Huellas en la tierra, Tandil (Argentina), Instituto de Estudios Históricos y Sociales y Universidad Nacional del Centro de la Provincia de Buenos Aires.

Reher, David-Sven, M. ${ }^{a}$ Nieves Pombo y Beatriz Nogueras (1993), España a la luz del censo de 1887, Madrid, Instituto Nacional de Estadística.

Requena Gallego, Manuel (1983), Los sucesos de Yeste (mayo 1936), Albacete, Instituto de Estudios Albacetenses (Consejo Superior de Investigaciones Científicas), 1983.

Respuesta de algunos propietarios de fincas rusticas a la manifestacion que ha hecho al publico el Sr. Lic. Mariano Arizcorreta, México, Ignacio Cumplido, 1849.

Retinger, J. H. (1926), Tierra mexicana. The study of land and agriculture in modern and ancient Mexico, Londres, Noel Douglas.

Rey Castelao, Ofelia (1998), A Galicia clásica e barroca, Vigo, Galaxia.

RIESCO ROCHE, Sergio (2005), La lucha por la tierra: reformismo agrario y cuestión yuntera en la provincia de Cáceres (1907-1940), tesis doctoral, Universidad Complutense de Madrid.

Roberts, J. Timmons, y Nikki Demetria Thanos (2003), Trouble in Paradis, Londres, Routledge.

Robledo Hernández, R. (1984), La renta de la tierra en Castilla la Vieja y León (1836-1913), Madrid, Servicio de Estudios del Banco de España.

- (1987), «Un Grande de España en apuros. Las rentas del marqués de Cerralbo en 1840", Revista Internacional de Sociología, n. ${ }^{\circ} 45$, pp. 106-123.

- (1988), "Crisis agraria y éxodo rural: emigración española a Ultramar, 18801920», en Garrabou (ed.) (1988), pp. 212-245.

- (1991), «El crédito y los privilegiados durante la crisis del Antiguo Régimen", en Bartolomé Yun (coord.), Estudios sobre capitalismo agrario, crédito e industria en Castilla (siglos XIX y XX), Valladolid, Junta de Castilla y León, Consejería de Cultura y Bienestar Social, pp. 237-265.

- (1993), Economistas y reformadores españoles: La cuestión agraria (17601935), Madrid, Ministerio de Agricultura, Pesca y Alimentación.

- (1996), «Política y reforma agraria: de la Restauración a la II República (1868/74-1939)», en Ángel García Sanz y Jesús Sanz Fernández (coords.), Reformas y politicas agrarias en la historia de España, Madrid, Ministerio de Agricultura, Pesca y Alimentación, pp. 247-349. 
Robledo Hernández, R. (1999), «La liquidación del patrimonio de los PatiñoSentmenat (1910): ¿eutanasia del rentista?», en Albert Carreras et ál. (eds.), La industrialització i el desenvolupament econòmic d'Espanya, Barcelona, Universitat de Barcelona, vol. 1, pp. 541-558.

- (2004), "Discursos sobre la reforma agraria, siglos XIX-XX», Estudis d'Història Agrària. Homenatge al Dr. Emili Giralt, n. ${ }^{\circ}$ 17, pp. 789-812.

- y Luis Enrique EsPINOZA (1999), «La Reforma agraria en la II República: el proceso de asentamiento de comunidades de campesinos en la provincia de Salamanca», en S. De Dios, J. Infante, R. Robledo y E. Torijano (coords.), Historia de la propiedad en España, siglos XV-XX, Madrid, Centro de Estudios Registrales, pp. 403-440.

- e Hilario CASAdO AlONSO (2002), Fortuna y negocios: Formación y gestión de los grandes patrimonios, siglos $X V-X X$, Valladolid, Universidad de Valladolid.

RoDRIGÁÑEZ, Celedonio (1886), La vida del campo: memoria premiada con accésit por la Real Academia de Ciencias Morales y Políticas en el concurso ordinario de 1885, Madrid.

Rodríguez Galdo, M. ${ }^{a}$ Xosé, y Fausto Dopico (1981), Crisis agrarias y crecimiento económico en Galicia en el siglo XIX, Sada, O Castro.

RodriK, Dani (2002), "After Neoliberalism, What?», en $<\mathrm{http} / \mathrm{ksghome}$.harvard.edu/ drodrik/After\%20Neoliberalism.pdf>.

Romero, Luis Alberto (2001), Breve Historia contemporánea de la Argentina, Buenos Aires, Fondo de Cultura Económica.

Roncaglia, Alejandro (2006), La riqueza de las ideas. Una historia del pensamiento económico, Zaragoza, Prensas Universitarias de Zaragoza.

Rosenthal, Gert (1994), «Reflexiones sobre el pensamiento económico de la Comisión Económica para América Latina y el Caribe (CEPAL)», Pensamiento Iberoamericano, n. ${ }^{\circ}$ 24-25, pp. 9-18.

Rosselló Verger, Vicenç Maria (1981), "Canvis de propietat i parcel-lacions al camp mallorquí entre els segles XIX i XX», Randa, n. ${ }^{\circ}$ 12, pp. 19-60.

Rosset, Peter (2005), «Moving Forward: Agrarian Reform and Food Sovereignty», Land Research Action Network (LRAN) y Center for the Study of Rural Change in Mexico (CECCAM), en <http//www.landaction.org>.

- y Medea Benjamin (1994), The Greening of the Revolution: Cuba's Experiment with Organic Agriculture, Melbourne, Ocean Press.

Rubia Alejos, Francisco (2004), «El palacio señorial de Liñares en las últimas centurias", Deza. Anuario de Estudios e Investigación, n. ${ }^{\circ}$ 6, pp. 177-230.

RUIZ CASTILLO-BASALA, José (1983), Funcionario republicano de reforma agraria y otros testimonios, Madrid, Biblioteca Nueva.

RUIZ DE VeLASCO, Felipe (1937), Historia y evoluciones del cultivo de la caña y de la industria azucarera en México hasta el año 1910, México, Cultura. 
Runge, C. Ford, y Edi Defrancesco (2006), «Exclusion, Inclusion, and Enclosure: Historical Commons and Modern Intellectual Property», World Development, vol. 34, n. ${ }^{\circ}$ 10, pp. 1713-1727.

SaAVEdra FernándeZ, Pegerto (1997), "Formación, consolidación e influencia social e cultural da fidalguía, ss. XVI-XVIII", en Galicia faiu dous mil anos. $O$ feito diferencial galego. I, Historia, Santiago de Compostela, Museo do Pobo Galego, pp. 123-156.

- (1998), "A vida cotiá da fidalguía pacega», en Un percorrido pola Galicia cotiá, Santiago de Compostela, Asociación Galega de Historiadores, pp. 373-396.

- (2003), «La vida cotidiana en los pazos gallegos: entre la Literatura y la Historia», Pedralbes. Revista d'Història Moderna, n.o 23, pp. 285-316.

- y Ramón Villares Paz (1985), "Galicia en el Antiguo Régimen: la fortaleza de una sociedad tradicional», en Roberto Fernández (ed.), España en el siglo XVIII. Homenaje a Pierre Vilar, Barcelona, Crítica, pp. 434-504.

- y Ramón Villares Paz (eds.) (1991), Señores y campesinos en la Península Ibérica, siglos XVIII-XX, Barcelona, Crítica y Santiago de Compostela, Consello de Cultura Galega, 2 vols.

Sabato, Hilda (1989), Capitalismo y ganadería en Buenos Aires: la fiebre del lanar 1850-1890, Buenos Aires, Sudamericana.

SAGUER, Enric (1996), «La consolidació de la propietat pagesa a Catalunya (el Baix Empordà, 1850-1940)», tesis doctoral, Universitat de Girona.

- (1998), «Estímulos y obstáculos al avance de la propiedad campesina (el Baix Empordà, 1860-1940)», Revista de Historia Económica, año XVI, n.o 3, pp. 677-706.

- (2000), "Treballar a pagès, 1930-1936. Alguns retalls», Revista de Girona, n. ${ }^{\circ} 202$, pp. 80-84.

- (2001), «Els Negre i Pastell. Notes sobre els orígens d'un gran patrimoni agrari», en Roser Julià y Marisa Roig (eds.), Gent de Castelló. La seva vida $i$ la seva obra, Castelló de Ampurias, Ajuntament de Castelló d'Empúries, pp. 163-172.

- (coord.) (2005), Els últims hereus: història oral dels propietaris rurals gironins, 1930-2000, Barcelona, Generalitat de Catalunya, Departament de Cultura.

- y Javier TeBAR (1991), «Pelai Negre: Un hisendat gironí i la qüestió agrària», Revista de Girona, n. ${ }^{\circ}$ 144, pp. 67-71.

SALAS, Pere (1997), El poder i els poderosos a les viles de Mallorca (1868-1898), Palma de Mallorca, Documenta Balear.

Salas, Vicente (1996), Economía de la empresa. Decisiones y organización, Barcelona, Ariel.

SALINAS, M. del C. (1993), Transformación o permanencia del gobierno municipal. Estado de México, 1856-1880, tesis doctoral, El Colegio de México. 
SANLlehy, M.a Àngels (1996), Comunitats, veïns $i$ arrendataris a la Val d'Aran (s. XVII-XVIII): dels usos comunals a la dependencia económica, tesis doctoral, Universitat de Barcelona.

SANTAMARÍA Y TOUS, Victorino (1902), Derecho consuetudinario y economía popular de las provincias de Tarragona y Barcelona con indicaciones de las de Gerona y Lérida, Madrid, Imprenta del Asilo de Huérfanos del Sagrado Corazón de Jesús [existe una reed. de 2005, publicada por el Institut d'Estudis Penedesencs].

SANTOS, Rui (2004), «Economic sociology of the modern latifundium. Economic institutions and social change in Southern Portugal, 17th-19th centuries", Sociología, Problemas e Prácticas, n. ${ }^{\circ} 45$, pp. 23-52.

SAnZ SANCHO, Iluminado (1995), Geografía del Obispado de Córdoba en la Baja Edad Media, Madrid, Universidad Autónoma de Madrid y Polifemo.

- (2000), «El cabildo catedralicio de Córdoba en la Edad Media», En la España Medieval, n. ${ }^{\circ} 23$, pp. 189-264.

Sarmiento, Domingo Faustino (1965), Facundo, Buenos Aires, Estrada.

SATORRAS, Francisco (1878), Informe sobre el estado de la agricultura en la provincia de las Baleares, Palma de Mallorca, Imprenta de Pedro José Gelabert.

- (1887), Memoria sobre el estado de la agricultura en la provincia de Baleares, documento inédito sin foliación.

SCHENK, Frank (1991), «Haciendas y ranchos en Sultepec», en Miño (comp.) (1991), pp. 230-269.

Sen, Amartya (1999), Development as Freedom, Nueva York, Random House.

SePÚlVEda Losa, Rosa María (2003), «La primavera conflictiva de 1936 en Albacete», Pasado y Memoria: Revista de Historia Contemporánea, n. ${ }^{\circ}$ 2, pp. 221240.

Serrano García, Rafael (1992), "Repercusiones de "La Gloriosa” en el campo castellano-leonés (1868-1869)», Investigaciones Históricas, n. ${ }^{\circ}$ 12, pp. $177-$ 191.

- (2002), "La casa de Gor y sus administradores en Salamanca y Ciudad Rodrigo, 1860-1910», en Ricardo Robledo e Hilario Casado Alonso (2002), pp. 323-350.

SHADLE, S. (1994), Andres Molina Enriquez: Mexican land reformer of the revolutionary era, Tucson, University of Arizona Press.

Sieferle, Rolf Peter (2001), "Qué es la historia ecológica», en M. González de Molina y J. Martínez Alier (eds.), Naturaleza transformada, Barcelona, Icaria, pp. 31-54.

SiMPSON, James (1987), «La elección técnica en el cultivo triguero y atraso de la agricultura española a finales del siglo XIX", Revista de Historia Económica, año v, n. ${ }^{\circ}$ 2, pp. 271-299. 
Simpson, James (1992), «Technical Change, Labour Absorption and Living Standards in Rural Andalusia, 1886-1936», Agricultural History, vol. 66, n. ${ }^{\circ} 3$, pp. 1-24.

- (1995), Spanish agriculture. The long Siesta, 1765-1965, Cambridge, Cambridge University Press. [Trad., esp., La agricultura española (1765-1965): la larga siesta, Madrid, Alianza Editorial, 1997.]

- (1997), "Did tariffs stifle Spanish agriculture before 1936?», European Review of Economic History, n. ${ }^{\circ}$ 1, pp. 65-87.

SLuTZKY, Daniel (1968), «Aspectos sociales del desarrollo rural en la Pampa Húmeda", Desarrollo Económico, n. 29.

SMITH, Adam ([1776] 1988), Investigación sobe la naturaleza y causas de la riqueza de las naciones, Vilasar de Mar (Barcelona), Oikos Tau.

SobHan, Rehman (1993), Agrarian Reform and Social Transformation: Preconditions for Development, Londres, Zed Books.

Sobrado Correa, Hortensio (2001), Las Tierras de Lugo en la Edad Moderna. Economía campesina, familia y herencia, 1550-1860, La Coruña, Fundación Pedro Barrié de la Maza.

SogGe, David (2004), Dar y tomar. ¿Qué sucede con la ayuda internacional?, Barcelona, Icaria.

SOLBERG, Carl (1975), «Descontento rural y política agraria en la Argentina, 1912-30», en Marcos Giménez Zapiola (ed.), El régimen oligárquico. Materiales para el estudio de la realidad argentina (hasta 1930), Buenos Aires, Amorrortu.

- (1987), The Prairies and the Pampas. Agrarian Policy in Canada and Argentina, 1880-1930, Stanford, Stanford University Press.

Solimano, Andrés (2000), "Beyond Unequal Development: An Overview», en Andres Solimano, Eduardo Aninat y Nancy Birdsall (eds.), Distributive Justice and Economic Development: The Case of Chile and Developing Countries, Ann Arbor, University of Michigan Press.

STIGLITZ, Joseph E. (1998), "More instruments and broader goals: moving toward a post-Washington Consensus», Conferencia Anual Wider, Helsinki (enero), reimpreso en Ha-Joon Chang (ed.) (2001), The Rebel Within, Londres, Wimbledon, cap. 1, pp. 17-56.

SUAU PUIG, Jaume (1988), «Els patrimonis nobiliaris mallorquins al darrer quart del segle XVIII i primeres dècades del segle XIX», Estudis d'Història Agrària, n. ${ }^{\circ}$, pp. $139-160$.

- (1991a), «Estudio sobre la renta de la tierra. Mallorca, 1750-1860», en Saavedra y Villares Paz (eds.) (1991), vol. 1, pp. 117-137.

- (1991b), El món rural mallorquí, Barcelona, Curial.

SuMPSI, José María (1978), «Estudio de la transformación del cultivo al tercio al de año y vez en la campiña de Andalucía", Agricultura y Sociedad, n. ${ }^{\circ}$ 6, pp. 31-70. 
Sunkel, Osvaldo (1993), Development from Within: Toward a Neostructuralist Approach for Latina America, Boulder, Lynne Rienner.

Suñol i Molina, Santiago (1989), El catastro de rústica en las tierras de Lleida, Madrid, Subdirección General de Estudios y Estadística.

Tannenbaum, F. (1929), The mexican agrarian revolution, Nueva York, McMillan. [Trad. esp., Problemas agrícolas e industriales de México, 1952.]

Tecuanhuey Sandoval, Alicia (1988), La revolución de 1943: politicas y conflictos rurales, Buenos Aires, Centro Editor de América Latina.

Tejera GaOna, Héctor (1996), «Las causas del conflicto en Chiapas», en Hubert C. de Grammont y Héctor Tejera Gaona (eds.), La sociedad rural mexicana frente al nuevo milenio. Volumen IV. Los nuevos actores sociales y procesos politicos en el campo, México, Plaza y Valdés, Universidad Autónoma Metropolitana, Universidad Nacional Autónoma de México, Instituto Nacional de Antropología e Historia, pp. 299-332.

TelLo, Enric (1983), «La producció cerealícola a les petites explotacions pageses des Pla de Mallorca (1850-51)», Estudis d'Història Agrària, n. o 4, pp. 167-194.

- (1997), "Los usos de la enfiteusis en la Cataluña "Nueva" y la Cataluña "Vieja" (siglos XVIII-XIX)", en VIII Congreso de Historia Agraria. Salamanca, 28-30 de mayo de 1997, Preactas, Salamanca, Sociedad Española de Historia Agraria y Universidad de Salamanca, pp. 525-538.

- (2005), La historia cuenta. Del crecimiento económico al desarrollo humano sostenible, Barcelona, Nous Horizons y El Viejo Topo.

Thaize-CHALliER, Marie Christine (2003), «Redevances rurales et rentes informationnelles en France de la fin de l'époque médiévale au XVIII siècle», en Arnoux Béaur, Gérard, Mathieu y Anne Varet-Vitu (eds.), Exploiter la terre. Les contrats agraires de l'Antiquité à nos jours. Actes du Colloque de Caen (10-13 septembre 1997), Rennes, Association d'Histoire des Sociétés Rurales, pp. 45-62.

Thiesenhusen, William (ed.) (1989), Searching for Agrarian Reform in Latin America, Cambridge, Unwin Hyman y Cambridge University Press.

Thompson, Edward P. (1995), Costumbres en común, Barcelona, Crítica.

ThOrp, Rose Mary (1998), Progress, Poverty and Exclusion: an Economic History of Latin America in the 20th century, Washington, Inter-American Development Bank.

Toboso, Fernando, y Raúl Compés (2003), «Nuevas orientaciones en el ámbito de la Nueva Economía Institucional. La incorporación de los aspectos distributivos", El Trimestre Económico, n. ${ }^{\circ} 280$.

Todaro, Michael (2003), Economic Development, Essex, Addison Wesley Longman, 8. ${ }^{\mathrm{a}}$ ed.

TOLEDO, Víctor M. (1993), «La racionalidad ecológica de la producción campesina», en Eduardo Sevilla Guzmán y Manuel González de Molina (eds.), Ecología, campesinado e historia, Madrid, Las Ediciones de la Piqueta, pp. 197-218. 
TORIJANo PÉrez, Eugenia (2000), Los nuevos propietarios de Ledesma, 1752-1900. De la propiedad territorial feudal a la propiedad territorial capitalista, Salamanca, Diputación de Salamanca.

TORTOLERO, Alejandro (1995), De la coa a la máquina de vapor: actividad agrícola e innovación tecnológica en las haciendas de la región central de México, 1880-1914, México, Siglo XXI.

- (1997), «Les hommes et les ressources naturelles dans le bassin de Mexico. L'innovation technologique et son impact dans un milieu rural: Chalco (18901925)», Annales. Histoire, Sciences Sociales, año 52, n. ${ }^{\circ}$ 5, pp. 1085-1114.

- (2000), «¿Revolución agrícola en el valle de México?: El caso de Iñigo Noriega Laso», en Daniel Hiernaux y Alicia Lindón (coords.) La construcción social de un territorio emergente. El valle de Chalco, México, El Colegio Mexiquense, pp. 113-132.

- (2002), «Agricultura y modernización: la desecación de los lagos en el México porfirista», en XIII Congreso Internacional de Historia Económica. Buenos Aires, 22 al 26 de julio, en prensa.

- (2003), "Crecimiento y atraso: la vía mexicana hacia el capitalismo agrario (1856-1920)", Historia Agraria, n. ${ }^{\circ} 29$, pp. 123-152.

- (2004), «Transforming the central Mexican waterscape: lake drainage and consequences during the Porfiriato", en Christian Brannstrom (ed.), Territories, commodities and knwoledges. Latin American environmental history: nineteenth and twentieth centuries, Londres.

- (coord.) (1999), La agricultura mexicana. Crecimiento e innovaciones, México, I. Mora, Colimch, El Colegio de México y Universidad Nacional Autónoma de México.

Tutino, John (1986), From Insurrection to Revolution in Mexico. Social bases of agrarian violence. 1750-1940, Princeton, Princeton University Press.

- (1990), "Cambio social agrario y rebelión campesina en el México decimonónico: el caso de Chalco», en Friedrich Katz (comp.) (1990), Revuelta, rebelión y revolución, México, Era, pp. 99-134.

- (1998), «The revolution in Mexican independence: insurgency and the renegotiation of property, production, and patriarchy in the Bajio, 1800-1855", Hispanic American Historical Review, vol. 78, n. ${ }^{\circ} 3$, pp. 367-418.

United States Department of Agriculture (1932), Fifteenth Census of the United Status: 1930, Agriculture, Washington D.C., vol. IV.

VAamonde Gamo, Adoración (1995), «El archivo de los Vaamonde en la Casa de Ouces», Anuario Brigantino, n. ${ }^{\circ} 18$, pp. 77-82.

VAlDAliso, Jesús María, y Santiago López GarCía (2000), Historia económica de la empresa, Barcelona, Crítica.

VALENCIA, Marta (1999), «Conflictos por la ocupación y propiedad legal de la tierra en Bragado, 1850-1870», en Prof. Carlos S. A. Segreti. In Memoriam, Cór- 
doba (Argentina), Centro de Estudios Históricos «Prof. Carlos S. A. Segretti», pp. 207-217.

Valencia, Marta (2005), Tierras públicas-tierras privadas, Buenos Aires, 18521876, La Plata, Universidad Nacional de La Plata.

VAN Young, E. (1992), La crisis del orden colonial. Estructura agraria y rebeliones populares de la Nueva España 1750-1821, México, Alianza Editorial.

- (2001), The other rebellion. Popular violence, ideology and the struggle for mexican independence, 1810-1821, Stanford, Stanford University Press.

VAQUero LASTRES, Berta María (1986), "La hidalguía de Betanzos en el siglo XVIII: la familia y la vivienda», Anuario Brigantino, n. ${ }^{\circ}$ 9, pp. 53-62.

VARA, Óscar, Jorge TURMo y Ángel RODRíGUEZ (2005), «Las raíces intelectuales de la economía evolutiva», Revista de Historia Económica, año 23, n. ${ }^{\circ}$ 1, pp. 177-186.

Vázquez Bertomeu, Mercedes (2004), "Escritura y sociedad en la Galicia moderna: reflexiones a propósito del archivo de la casa de Mirapeixe», Estudios Mindonienses, n. ${ }^{\circ}$ 20, pp. 893-915.

VÁZQUEZ LESMES, Rafael (1987), Córdoba y su cabildo catedralicio en la modernidad, Córdoba, Publicaciones del Monte de Piedad y Caja de Ahorros de Córdoba.

- (1993), «Episcopado y Guerra de la Independencia en Córdoba», Boletín de la Real Academia de Córdoba, de Ciencias, Bellas Letras, y Nobles Artes, n. ${ }^{\circ} 125$, pp. 131-142.

Veiga Alonso, Xosé Ramón (1999), O conde de Pallares e o seu tempo, 18281908. Aproximación ó activismo das elites na Galicia decimonónica, Lugo, Diputación Provincial de Lugo.

Veltmeyer, Henry (1997), «New social movements in Latin America: The dynamics of class and Identity», The Journal of Peasant Studies, vol. 25, n. ${ }^{\circ} 1$, pp. 139-169.

- y Anthony O’Malley (eds.) (2001), Trascending Neoliberalism. CommunityBased Development in Latin America, Bloomfield, Kumarian Press.

Vía CamPesina (2005), WTO in Crisis: Groups Offer Alternative Plan to Protect People's Food Sovereignty, en <http://www.peoplesfoodsovereignty.org/statements.html>.

VidAl BENDiTO, Tomás (1979), "Exode rural i problemàtica demoespacial a Catalunya (1860-1970)», Estudis d'Història Agrària, n.o 2, pp. 193-206.

VILLADA, José Vicente (1893), Memoria que el gobernador constitucional del Estado de México Gral. J. V. Villada presenta a la XV Legislatura durante el cuatrienio de 1889 a 1893, Toluca, Of. Tip. del Gob. de la Escuela de Artes y Oficios.

Villares PaZ, Ramón (1982), La propiedad de la tierra en Galicia, 1500-1936, Madrid, Siglo XXI. 
VILLARES PAZ, Ramón (1999), "La nobleza gallega en los siglos XVI al XIX: La hegemonía de la hidalguía de pazo», en María del Carmen Iglesias (dir.), Nobleza y sociedad en la España Moderna, Oviedo, Nobel, vol. 3, pp. 31-62.

Viola, Andreu (2000), "iKawsachun coca, Wañuchun gringos!». Colonización, cultivos de coca y sindicalismo campesino en el trópico de Cochabamba (Bolivia), tesis doctoral, Universitat de Barcelona.

Virto IbÁÑEZ, Juan José (2002), Tierra y nobleza en Navarra (1850-1936), Pamplona, Gobierno de Navarra.

Viveiro Mogo, Prudencio (2004), Política, eleccións e fidalgos. O réxime do estatuto real na provincia de Lugo, 1834-1836, Sada, O Castro.

Vogelgesang, Frank (1998), «After Land Reform, The Market?», Land Reform / Réforme Agraire / Reforma Agraria, n. ${ }^{\circ}$ 1, pp. 20-34.

Walter, Juan Carlos (1970), La conquista del desierto, Buenos Aires, Editorial Universitaria de Buenos Aires.

WARMAN, Arturo (2001), El campo mexicano en el siglo XX, México, Fondo de Cultura Económica.

- (2003), «La reforma agraria mexicana: una visión de largo plazo», Land Reform / Réforme Agraire / Reforma Agraria, n. ${ }^{\circ}$ 2, pp. 84-94.

Wolf, Eric (1969), Peasant wars of the twentieth century, Nueva York, Harper \& Row.

- (1976), Las luchas campesinas del siglo XX, Madrid, Siglo XXI.

Womack, John (1969), Zapata y la revolución mexicana, México, Siglo XXI.

World Bank (1993), The East Asian Miracle: Economic Growth and Public Policy, Oxford, Oxford University Press y The World Bank Group.

Wright, Julia (2005), ;Falta Petroleo! Cuba's experiences in the transformation to a more ecological agriculture and impact on food security, tesis doctoral, Wageningen University.

Wrigley, E. A. ([1988] 1993), Cambio, continuidad y azar. Carácter de la Revolución industrial inglesa, Barcelona, Crítica.

Yun Casalilla, Bartolomé (1987), Sobre la transición al capitalismo en Castilla. Economía y sociedad en Tierra de Campos (1500-1830), Salamanca, Junta de Castilla y León.

YURJEVIC, Andrés (1997), «Agroecología y desarrollo rural sustentable», en Luciano Martínez Valle (ed.), El desarrollo sostenible en el medio rural, Quito, Facultad Latinoamericana de Ciencias Sociales, pp. 13-30.

ZamosC, Leon (1994), "Agrarian Protest and the Indian Movement in Highland Ecuador", Latin American Research Review, vol. 21, n. ${ }^{\circ} 3$, pp. 37-69.

ZAPATA, Santiago (1986), La producción agraria de Extremadura y Andalucía Occidental, 1875-1935, tesis doctoral, Universidad Complutense de Madrid.

ZINK, Anne (1997), Clochers et Troupeaux. Les communautés rurales des Landes et du Sud-Ouest avant la Révolution, Burdeos, Presses Universitaires de Bordeaux. 



\section{ÍNDICE}

Introducción: Tiempo, instituciones y reformas

Ricardo Robledo y Santiago López ............................................ 7

I. GRANDES PATRIMONIOS

1. Las empresas y los derechos de propiedad. Propuestas desde la economía institucional

Domingo Gallego Martínez

2. El arrendamiento de latifundios a partes de frutos: contratos y gestión patrimonial del cabildo de la catedral de Córdoba (1700-1840).

Antonio López Estudillo

3. Cambios hacendísticos y de gestión en los patrimonios de la hidalguía acomodada gallega en el siglo XIX Antonio Presedo Garazo

4. La legislación desvinculadora: una oportunidad para racionalizar la gestión de los patrimonios nobiliarios mallorquines y retrasar su desmembración Antònia Morey Tous

5. Estrategias de gestión patrimonial ante los cambios institucionales en el Pirineo catalán (siglos XIX-XX)

Jacinto Bonales 
6. Administración y rentas del patrimonio rústico del estado de Bornos, 1814-1924

Javier Moreno Lázaro

7. ¿Condenado al absentismo? La administración del conde de Zaldívar en Cortes de Navarra (1859-1935)

José Miguel Gastón Aguas y José Miguel Lana Berasain

8. El declive de una casa aristocrática en Castilla la Vieja y León: las administraciones de los Alburquerque en la primera mitad del siglo XX

Rafael Serrano García

9. La Acción Social en casa. Gestión patrimonial de un dirigente sindical (Pelayo Negre y Pastell, 1924-1936)

Enric Saguer

10. Estructura social del campo español: El Censo de Campesinos (1932-1936). Primeros resultados (I)

Luis E. Espinoza, Ricardo Robledo, M. ${ }^{a}$ Pilar Brel y Julio Villar.....

11. Economías de escala, organización de patrimonios y obstáculos a una reforma agraria. Andalucía, 1880-1936 Juan Carmona y James Simpson

12. La intensificación de cultivos durante la reforma agraria de la Segunda República: ¿alternativa o complemento? Sergio Riesco

13. La gran propiedad y sus transformaciones con la reforma agraria en México Alejandro Tortolero 
14. ¿Grandes hacendados o pequeños agricultores? Debates y resultados de la Ley de Tierras de 1876 en la provincia de Buenos Aires (Argentina)

Marta Valencia

15. La reforma agraria en la provincia de Buenos Aires (Argentina): Legislación, discurso político y práctica legislativa durante los gobiernos peronistas (1946-1955)

Mónica Blanco

16. Más allá de la «nueva ruralidad»: repensar la reforma agraria en América Latina

Victor Bretón Solo de Zaldivar

17. Reforma agraria, desarrollo rural y agricultura sostenible en América Latina bajo el contexto de la globalización Elisa Botella Rodríguez 

Este libro se terminó de imprimir en los talleres gráficos de Linea 2015, S.L., de Zaragoza, en mayo de 2007

206 


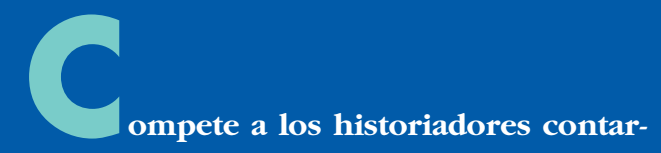

nos la íntima relación que existe en las sociedades entre la búsqueda del interés particular y la redistribución de la riqueza, entre eficiencia y equidad. Es la dicotomía esencial de la economía en la que vivimos desde que nació el capitalismo. Éste permitió que los individuos pudieran tomar sus propias decisiones, también trajo al Estado regulador y más o menos intervencionista. La puja por defender los intereses particulares vino acompañada desde el primer momento de leyes para moderarlos, y fue en los conflictos con el principal de los bienes, la tierra, donde se fraguaron todas nuestras cuitas, todos los conceptos sobre los que se asientan nuestras instituciones. Este libro apunta al corazón mismo del capitalismo, a la naturaleza intima en la que se fraguaron sus instituciones. Todo lo que hoy discutimos al respecto de cualquier bien o servicio ya fue discutido hace siglos, de una u otra forma, cuando peleamos por la tierra. La tierra, su apropiación, su reparto y su administración son el reflejo de nuestra manera de relacionarnos. Aún hoy, cuando parece que la información y el conocimiento son la materia a repartirse, nos encontramos que la lucha por la tierra sigue siendo el asunto económico y social por excelencia de muchos países. Conocer y preguntarse por la historia de la gestión de los patrimonios y por las reformas agrarias que fueron y son es tocar la materia de la que están hechos los sueños del capitalismo.

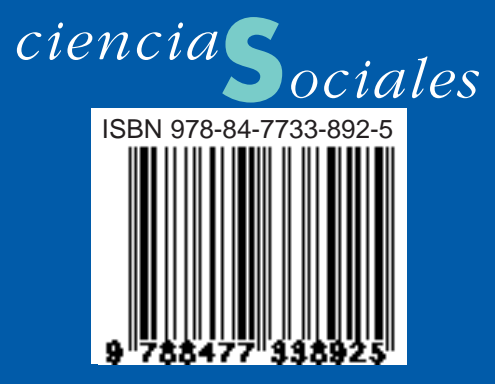

